Pontifícia Universidade $C_{\text {atólica }}$

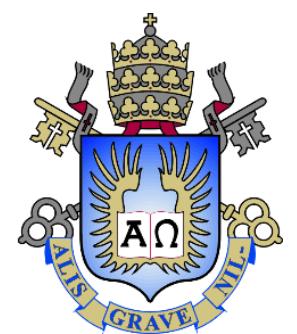

Jefferson Grijo Brasil

\begin{abstract}
A missão na Igreja do Evangelho Quadrangular em relação com a teologia da missão em Comblin
\end{abstract}

Tese de Doutorado

Tese apresentada como requisito parcial para obtenção do grau de Doutor pelo Programa de Pós-graduação em Teologia do Departamento de Teologia da PUC-Rio.

Orientador: Profa. Maria Teresa de Freitas Cardoso

Rio de Janeiro

Novembro de 2020 


\section{A missão na Igreja do Evangelho Quadrangular em relação com a teologia da missão em Comblin}

\section{Tese de Doutorado}

Tese apresentada como requisito parcial para obtenção do grau de Doutor pelo Programa de Pós-graduação em Teologia do Departamento de Teologia da PUC-Rio. Aprovada pela Comissão Examinadora abaixo.

Profa. Maria Teresa de Freitas Cardoso

Orientador

Departamento de Teologia da PUC-Rio.

Prof. Abimar Oliveira de Moraes Departamento de Teologia da PUC-Rio.

Prof. Luís Côrrea Lima Departamento de Teologia da PUC-Rio.

Prof. Bruno da Silveira Albuquerque Prefeitura Municipal de Itatiaia.

Prof. David Mesquiati de Oliveira

Faculdade Unida de Vitória. 
Todos os direitos reservados. É proibida a reprodução total ou parcial do trabalho sem a autorização da universidade, do autor e do orientador.

\section{Jefferson Grijo Brasil}

Estudou no (ITQ) Instituto Teológico Quadrangular em (Cariacica/ES), 2008. Graduou-se em teologia na Faculdade Unida (FUV) (Vitória/ES), em 2014. Concluiu o Mestrado em Ciências das Religiões na Faculdade Unida (FUV) (Vitória/ES), em 2016. Concluiu o Doutorado em Teologia na PUC-Rio, em 2020. Leciona no ITQ Instituto Teológico Quadrangular de Vitória/ES. É professor de Ensino Religioso Prefeitura Municipal de Viana/Serra - ES.

Ficha Catalográfica

Brasil, Jefferson Grijo

A missão na Igreja do Evangelho Quadrangular em relação com a teologia da missão em Comblin / Jefferson Grijo Brasil ; orientador: Maria Teresa de Freitas Cardoso. - 2020.

393 f. ; $30 \mathrm{~cm}$

Tese (doutorado)-Pontifícia Universidade Católica do Rio de Janeiro, Departamento de Teologia, 2020.

Inclui bibliografia

1. Teologia - Teses. 2. Igreja do Evangelho Quadrangular. 3. Missão. 4. Pentecostalismo. 5. José Comblin. 6. Diálogo ecumênico. I. Cardoso, Maria Teresa de Freitas. II. Pontifícia Universidade Católica do Rio de Janeiro. Departamento de Teologia. III. Título.

CDD: 200 
Para minha família, por ter dado total apoio,

Dedico este trabalho, com amor. 


\section{Agradecimentos}

A minha orientadora Professora Maria Teresa de Freitas Cardoso pelo estímulo e parceria para a realização deste trabalho.

Ao CNPq e à PUC-Rio, pelos auxílios concedidos, sem os quais este trabalho não poderia ter sido realizado.

Aos meus amigos David Mesquiati de Oliveira, Wanderley Pereira da Rosa.

Ao Pr. Josué Bengtson por todo apoio e atenção, Pra. Elizabeth Pereira de Souza diretora do ITQ de Vitória/ES.

Aos meus amigos Pr. Roberto Lima e Pr. Rodrigo Pio da IEQ de Universal por todo apoio, paciência e compreensão. Pra. Vanúzia Andrade da IEQ Viana por todo apoio. Ao amigo Missionário Adilson Francisco pelo incentivo de sempre.

Aos meus pais, pela educação e exemplo.

À minha professora Ademildes Sá (In memorian) pelo importante legado dentro da teologia quadrangular.

Aos meus colegas da PUC-Rio.

Aos professores que participaram da Comissão examinadora.

A todos os professores e funcionários do Departamento pelos ensinamentos e pela ajuda.

À minha esposa, Poliana, por toda compreensão.

A todos os amigos e familiares que de uma forma ou de outra me estimularam ou me ajudaram.

A Deus seja a glória.

"O presente trabalho foi realizado com apoio da Coordenação de Aperfeiçoamento de Pessoal de Nível Superior - Brasil (CAPES) - Código de Financiamento 001 


\section{Resumo}

Brasil, Jefferson Grijo; Freitas Cardoso, Maria Teresa de. A missão na Igreja do Evangelho Quadrangular em relação com a teologia da missão em Comblin. Rio de Janeiro, 2020. 393p. Tese de Doutorado Departamento de Teologia, Pontifícia Universidade Católica do Rio de Janeiro.

A pesquisa está ligada ao Programa de Pós-Graduação em Teologia da PUC-Rio na área de Teologia Sistemático-Pastoral, linha de pesquisa: Religião e Modernidade; e ligada ao projeto de pesquisa Temas sobre a Igreja e os Diálogos. $\mathrm{O}$ início do século $\mathrm{XX}$ apresentou ao mundo o atual movimento pentecostal, que se expandiu consideravelmente no cristianismo, e sua maneira de atuação missionária tem despertado a atenção de muitos pesquisadores. Nesta tese é analisada a missão da Igreja do Evangelho Quadrangular, que integra o movimento, tanto no tocante à sua participação histórica quanto na teologia. A pesquisa buscou um teólogo que discutisse temas pneumatológicos e da teologia da missão, encontrando em José Comblin um interessante referencial teórico para compor um diálogo sobre a missão e o Espírito Santo. Esse proeminente teólogo, além de ocupar-se dos temas pertinentes à missão dessa denominação, também atuou como missionário, refletindo a partir do agir. Propõe-se aqui o diálogo ecumênico, por se tratar de uma prática pentecostal em diálogo com um expoente da teologia católica. A hipótese da pesquisa é que o crescimento da IEQ no Brasil está relacionado à sua missão pelos leigos . A missão, para a IEQ, inicia-se com uma evangelização de anúncio taumatúrgico, pela cura dos indivíduos. Vemos que para Comblin a missão tem um caráter de libertação do ser humano. Nesse ponto as duas noções de missão podem dialogar. Observa-se que na atualidade a reflexão da IEQ está se abrindo da cura do indivíduo para ter também o cuidado com o ser humano e tudo que diz respeito à vida, como a ecologia e as diferenças sociais.

\section{Palavras-chave}

Igreja do Evangelho Quadrangular; missão; pentecostalismo; José Comblin; diálogo ecumênico; leigos. 


\section{Abstract}

Brasil, Jefferson Grijo; Freitas Cardoso, Maria Teresa de. The mission in the Foursquare Church in relation to the Theology of the mission in Comblin. Rio de Janeiro, 2020. 393p. Doctoral Thesis - Department of Theology, PUC -Pontifical Catholic University of Rio de Janeiro.

The research is linked to the Graduate Program in Theology at PUC-Rio in the area of Systematic-Pastoral Theology, line of research: Religion and Modernity; and linked to the research project Themes on the Church and the Dialogues. The beginning of the 20th Century introduced to the world the current pentecostal movement, which it expanded considerably in Christianity, and its way of missionary work has awakened the attention of many researchers. In this thesis is analyzed the mission of the Foursquare Church, which integrates the movement, both in terms of its historical participation and in Theology. The research sought a theologian who discussed pneumatological themes and the mission Theology, finding in José Comblin an interesting theoretical reference to compose a dialogue about the mission and the Holy Spirit. This prominent theologian, in addition to deal with relevant themes to the mission of that denomination, also served as a missionary, reflecting from the act itself. It's proposed here the ecumenical dialogue, as it is a pentecostal practice in dialogue with an exponent of the Catholic Theology. The hypothesis research is that the growth of the Foursquare Church in Brazil is related to its mission by the laypeople. The mission for the Foursquare Church begins with an evangelization of thaumaturgical proclamation, for the healing of individuals. We see that for Comblin, the mission has a liberation character of the human being. At this point, the two notions of mission can dialogue. It is observed that nowadays the reflection of Foursquare Church is opening up from the healing of the individual to also have the care of the human being and everything that concerns to life, such as Ecology and social differences.

\section{Keywords}

Foursquare Church; mission; pentecostalism; José Comblin; ecumenical dialogue; laypeople. 


\section{Sumário}

1 Introdução

2 A missão na Igreja do Evangelho Quadrangular

2.1. A Igreja do Evangelho Quadrangular entre os pentecostais clássicos

2.1.1. Considerações sobre as igrejas pentecostais

2.1.2. Das Tendas à Igreja do Evangelho Quadrangular

2.1.3. A Cruzada Nacional de Evangelização e o pós-pentecostalismo

2.2. A Igreja do Evangelho Quadrangular em sua história e em sua missão

2.2.1 Histórico das origens e missão da Igreja do Evangelho

Quadrangular

2.2.2. O conceito e a prática da missão na Igreja do Evangelho

Quadrangular

2.2.3. Os estatutos e a visão geral da fé, do culto e da prática da Igreja do Evangelho Quadrangular

3 A missão na perspectiva de José Comblin

3.1. Linhas gerais da teologia de José Comblin

3.1.1. Perfil do teólogo Comblin

3.1.2. Alguns precedentes da teologia de Comblin

3.1.3. Estudos gerais sobre Comblin

3.2 A teologia da missão em Comblin

3.2.1. Conceito e prática da missão em Comblin

3.2.3. Discussões sobre a missão em Comblin

4 Relações entre os estudos e sugestões pastorais

4.1.1. Pontos em comum no conceito e nos métodos para a missão

4.1.2. Diferenças principais no conceito e nos métodos para a missão

4.1.3. Sucessos e limites da prática missionária da Igreja Quadrangular à luz da Teologia

4.2.1. Contribuições da Igreja do Evangelho Quadrangular para o enriquecimento da reflexão e prática da missão segundo a perspectiva apontada por Comblin 
4.2.2. Contribuições para enriquecimento da perspectiva da Igreja do Evangelho Quadrangular à luz de Comblin e outras sugestões no contexto do diálogo entre pentecostais e católicos

4.2.3. Contribuições da tese para a pastoral missionária de todos os cristãos, em especial, a missão dos leigos

5 Conclusão

6 Referências bibliográficas 


\section{Lista de Siglas e Abreviaturas}

IEQ - Igreja do Evangelho Quadrangular

CND - Cruzada Nacional de Evangelização

CNBB - Conferência Nacional dos Bispos do Brasil

CEBs - comunidades eclesiais de base

ITER - Instituto de Teologia do Recife

CFM - Centros de Formação Missionária

EFM - Escola de Formação Missionária 


\section{1 \\ Introdução}

O tema da tese é a missão da Igreja Evangelho Quadrangular em relação com a teologia da missão de Comblin. O objetivo geral é verificar a missão da IEQ em relação com Comblin. A tese apresenta a IEQ e sua tradição. Estuda Comblin, nos pontos que se relacionam com o tema de estudo, e faz aproximações, diferenças. Observa a importância da missão, da pneumatologia e da ação dos leigos em comunidades. Observa pontos de diálogo e a novidade da reflexão da IEQ sobre a missão hoje.

A igreja do Evangelho Quadrangular (IEQ) é uma das maiores igrejas pentecostais do Brasil e do mundo. Porém seu grande crescimento em adeptos e templos pelo Brasil não foi acompanhado, na mesma proporção, da reflexão e da pesquisa teológica. Quando os termos pentecostalismo ou pentecostais são utilizados no Brasil, passam pela história e legado da IEQ em solo brasileiro. O estudo e reflexões surgiram, entretanto ainda existe certa lacuna na pesquisa pentecostal, inclusive sobre a Igreja do Evangelho Quadrangular, pois esta ainda não ganhou tanto destaque se comparada a outras denominações pentecostais.

O autor da tese é membro da Igreja do Evangelho Quadrangular, e em sua percepção a denominação é contribuinte do pentecostalismo brasileiro. Entretanto, no campo da pesquisa teológica, ainda se sente falta de pesquisas sobre a IEQ. Assim, o trabalho contará com a contribuição de um nativo da denominação, fato que introduz não só uma pesquisa sobre a IEQ na reflexão teológica, mas também um pesquisador pertencente à igreja. Assim, a fé, a teologia e a história da IEQ no Brasil somam à área da pesquisa acadêmica.

A originalidade da tese está em fazer dialogar ecumenicamente parte da teologia pentecostal e prática missionária da Igreja do Evangelho Quadrangular com parte da teologia sistemático-pastoral católica, de maneira aberta e direta. Também é o tributo a um grande missionário que devotou muitos anos à evangelização do Brasil, o padre Comblin, que, dedicado aos cristãos leigos na América Latina, contribuiu para uma Igreja mais fraterna. A tese vem contribuir com a missão e o trabalho relevante que a Igreja do Evangelho Quadrangular vem 
executando no Brasil com sua forma de fazer missão; indo e executando através do leigo.

Na metodologia da pesquisa, o método geral foi um trabalho realizado sobre pesquisas bibliográficas, análises, comparações e verificações de pontos teológicos para uma contribuição para a missão da IEQ, junto com ideias de Comblin. A pesquisa reuniu material publicado e divulgado e material adquirido diretamente junto à IEQ, de seus trabalhos internos, como do Instituto Teológico Quandrangular. Utilizou estatutos da Igreja, declaração de fé, biografia da fundadora, e outros materiais sobre a IEQ. Sobre Comblin, consulta de obras do autor e artigos e teses e dissertações a respeito da teologia de Comblin. A pesquisa utilizou outros artigos teológicos relacionados com os temas estudados.

Neste primeiro capítulo, de Introdução, apresentamos o tema, objeto, método e roteiro da explanação. Apresentamos a seguir o que se pesquisa nos capítulos de desenvolvimento do trabalho.

No segundo capítulo, mapeia-se a origem e a história da Igreja do Evangelho Quadrangular, operação essencial, dado que a denominação tornou-se uma das mais importantes no pentecostalismo. $\mathrm{O}$ esclarecimento quanto à história dessa igreja visa detectar seus primeiros passos, desde sua fundação, nos Estados Unidos, por Aimee Semple McPherson, e todo o contexto dessa fundação.

Mas é ainda mais importante para esta pesquisa compreender o processo inicial de atuação da Igreja do Evangelho Quadrangular no Brasil. Embora a denominação sempre seja citada em pesquisas sobre o pentecostalismo e sua pluralidade no Brasil, o que se mostra muitas vezes é um repetido e breve panorama, destacando-se a escassez de fontes sobre sua origem no Brasil. Obras relevantes, como a de Júlio O Rosa, historiador da Igreja do Evangelho Quadrangular no Brasil, de 1977, abrange os primeiros 25 anos da igreja no país. Desde então, não se investiu mais em publicações em torno da denominação por iniciativa interna. Rosa foi pastor quadrangular e ocupou vários cargos durante o trabalho pastoral, ajudando a estruturar a igreja no Brasil. Daí a importância de sua obra para o primeiro capítulo deste estudo. Outras contribuições, como da própria fundadora Aimee Semple McPherson, também embasam essa primeira parte, mostrando a biografia da fundadora, suas inspirações, a revelação da doutrina quadrangular e sua relação com o pentecostalismo em geral. 
O segundo capítulo divide-se em duas partes, a primeira analisando a missão da Igreja do Evangelho Quadrangular. A primeira seção tem como escopo a contextualização da Igreja do Evangelho Quadrangular entre os pentecostais clássicos, e se estrutura em três subtítulos: Considerações sobre as igrejas pentecostais; Das tendas à Igreja do Evangelho Quadrangular; e A Cruzada Nacional de Evangelização e o pós-pentecostalismo.

A primeira seção do capítulo situa a Igreja do Evangelho Quadrangular entre os pentecostais clássicos, inexistindo consenso entre os pesquisadores quanto à pertença dessa denominação a esse grupo, mas esta tese seguirá o entendimento de que a denominação faz parte do pentecostalismo clássico. A problemática justifica-se por sua chegada aproximadamente 40 anos após a instalação dos primeiros grupos pentecostais no Brasil, as Assembleias de Deus, em 1911, e a Congregação Cristã no Brasil, em 1910. Os missionários que fundaram a Igreja do Evangelho Quadrangular no Brasil, Harold Edwin Williams e Jésus Hermírio Vasquez, chegaram em 1946, mas somente em 1951, na então Igreja Evangélica do Brasil, em São João da Boa Vista, em São Paulo, o pastor Williams fundou a Igreja Quadrangular. Essa distância em relação às primeiras igrejas consideradas clássicas tem sido pauta de divergência, e alguns pesquisadores, por esse fator, a situam entre os neoclássicos.

No primeiro subtítulo fazem-se algumas considerações sobre as igrejas pentecostais, o que ajuda a integrar o pentecostalismo quadrangular e esclarecer um pouco mais sobre seus antecedentes e o cenário das bases que a enquadram no movimento. Também é importante destacar a importância da Igreja do Evangelho Quadrangular para o pentecostalismo brasileiro e suas contribuições, bem como o que a difere das demais denominações pentecostais já instaladas no Brasil antes de sua chegada. E sua contribuição ao protestantismo brasileiro em geral marca uma mudança no cenário religioso da época, quando a população está em plena migração para as grandes cidades.

Até esse momento o pentecostalismo brasileiro não era de massa, mas a partir de novos elementos inseridos pelos quadrangulares, a exemplo das campanhas em lugares abertos, do uso de instrumentos musicais até então ausentes dos cultos no Brasil e talvez do elemento mais importante, que alterou a estrutura do movimento no Brasil, a cura divina, centralidade do pentecostalismo quadrangular. 
No segundo subtítulo, busca-se compreender a primeira década dos quadrangulares no Brasil, desde sua chegada, com Harold Edwin Williams e Jésus Hermírio Vasquez, seguindo-se a fundação da Igreja Evangélica do Brasil, em 1951, e logo em seguida, a partir de 1953, o surgimento da Cruzada Nacional de Evangelização, instalada em tendas de cura divina, até sua transformação em Igreja do Evangelho Quadrangular, em 1958.

As tendas de cura divina não foram exclusividade dos quadrangulares, mas foi o movimento ecumênico liderado por Harold Edwin Williams, missionário de doutrina quadrangular, que resultou na Igreja do Evangelho Quadrangular como em outras, a exemplo da Igreja O Brasil para Cristo, cujo fundador, Manoel de Mello, também integrou a Cruzada Nacional de Evangelização. Por isso, dissociar a CNE da IEQ é essencial para a clara compreensão desse período inicial da igreja no Brasil, pois se popularizou a impressão de ambas eram sinônimas.

O terceiro subtítulo refere-se à relação entre a Cruzada Nacional de Evangelização e o pós-pentecostalismo - ou mais conhecido como neopentencostalismo. Muitos pesquisadores consideram a Quadrangular como precursora desse movimento no Brasil, por sua ênfase nas campanhas de cura divina. É bem aceito que o neopentecostalismo seja subsequente aos trabalhos iniciais tanto da CNE como da IEQ. Entretanto, parece que esse movimento muito se distanciou do pentecostalismo e de suas origens, bem como sua teologia, e alguns pensadores do pentecostalismo brasileiro tratam esse movimento como pós-pentecostalismo.

A partir da segunda seção do segundo capítulo, a tese concentra-se na Igreja do Evangelho Quadrangular em si, em sua história e em sua missão. Essa segunda parte estrutura-se em três subtítulos: Histórico das origens e missão da Igreja do Evangelho Quadrangular; O conceito e a prática da missão na Igreja do Evangelho Quadrangular; e Os estatutos e a visão geral da fé, do culto e da prática da Igreja do Evangelho Quadrangular.

Nessa segunda seção o primeiro subtítulo recupera a história inicial da denominação a partir do movimento pentecostal do início do século XX e da atuação de McPherson desde sua infância, passando por seu envolvimento com o pentecostalismo norte-americano e suas primeiras atividades no pentecostalismo, bem como sua aproximação com a doutrina de cura divina e as primeiras experiências com o Espírito Santo. Esse período também abrange sua experiência 
como missionária na China, a morte de seu primeiro esposo durante a missão naquele país, o nascimento da primeira filha e seu retorno aos Estados Unidos, com o segundo casamento e o nascimento do segundo filho. Durante o segundo casamento a fundadora passou por diversas internações que quase a levaram à morte, e após uma dessas experiências ela decidiu deixar a função de esposa e dona de casa, separar-se do segundo marido e iniciar uma vida de missão, respondendo ao seu chamado. Por isso essa parte tem por título O histórico das origens e a missão da Igreja do Evangelho Quadrangular.

O segundo subtítulo da seção dois do segundo capítulo busca compreender o conceito e a prática da missão na Igreja do Evangelho Quadrangular. Para isso, analisar-se-ão os passos iniciais de Aimee como pregadora do evangelho em campanhas de avivamento nos Estados Unidos, de maneira ecumênica, em várias denominações, a utilização de tendas em suas campanhas de avivamento e suas contínuas experiências com a cura divina, até a revelação da visão quadrangular a partir do texto bíblico de Ezequiel durante uma campanha de avivamento em que havia pastores e leigos de várias denominações. A partir dessa visão é que se constroem a doutrina quadrangular e o nome da denominação. Essa parte do trabalho encerra-se com a inauguração da sede internacional do Angelus Temple, em $1^{\circ}$ de janeiro de 1923, em Los Angeles, Califórnia.

A terceira parte da segunda seção do segundo capítulo conclui-se com o aprofundamento nos estatutos e na visão geral da fé, do culto e da prática da Igreja do Evangelho Quadrangular. Essa parte visa perceber a relação da Igreja do Evangelho Quadrangular brasileira com a International Church of the Foursquare Gospel, com o intuito de compreender sua estrutura organizacional, com base na análise do estatuto da igreja brasileira, de sua declaração de fé e da percepção geral da fé dos quadrangulares, além das bases e do significado da doutrina quadrangular e de sua estrutura.

O terceiro capítulo tem por título A missão na perspectiva de Comblin e se divide em duas seções: a primeira trata das linhas gerais da teologia de José Comblin; a segunda analisa a teologia da missão segundo Comblin.

A primeira seção do capítulo três é estruturada em três subtítulos: O perfil do teólogo Comblin; Alguns precedentes de Comblin; e Estudos gerais sobre Comblin. Propõe-se, assim, o estudo do autor como missionário, desde a formação na Europa até a chegada ao Brasil, e do desenvolvimento de sua 
teologia e missão no território brasileiro e na América Latina, tendo em vista que grande parte da vida ele passou no Nordeste brasileiro. Busca-se, também, nessa etapa, investigar possíveis antecedentes de Comblin e apontar os estudos empreendidos a partir de sua teologia.

A primeira seção do terceiro capítulo busca mapear o perfil do teólogo Comblin, que chega a São Paulo em 1958, concidentemente na época do movimento da Cruzada Nacional de Evangelização no mesmo estado, no início da denominação Igreja do Evangelho Quadrangular, depois de seus fundadores terem liderado o movimento das tendas de cura divina. Foi a partir desse mesmo ano que a denominação se definiu como Igreja do Evangelho Quadrangular. Essa etapa do trabalho está focada nas origens do teólogo, ainda na Bélgica, no histórico de sua formação e vocação e na sua opção pela América Latina. Essa primeira parte descreve a instalação de Comblin no Brasil, sua caminhada por outros países da América Latina e o estabelecimento de sua missão e teologia no Nordeste brasileiro, até sua morte nessa região. Ainda nessa parte se mostra Comblin como teólogo da esteira do Concílio Vaticano II e que as percepções propostas no Concílio muito se refletiram em sua teologia e prática.

Nessa segunda seção, intitulada como "Alguns precedentes da teologia de Comblin", percorreremos o caminho que inspirou sua teologia e sua prática como teólogo e missionário, pela grande relevância da compreensão das bases que fizeram de Comblin o teólogo e missionário coerente com sua opção de vida em missão. A tese tem por hipótese que um dos grandes influenciadores da pneumatologia combliniana é o teólogo dominicano francês Yves Congar, que antecedeu Comblin e muito escreveu sobre o tema, sendo possível notar nos escritos pnematológicos de Comblin certa influência congariana. Foi o exemplo missionário do Padre José Antonio Maria Ibiapina que inspirou Comblin a viver em missão entre o povo nordestino. Ainda entre possíveis influências da formação desse autor, também figuram seu grande incentivador Dom Hélder Câmara, com quem Comblin colaborou em vários projetos.

$\mathrm{Na}$ terceira parte dessa primeira seção a reflexão se concentrará nos estudos gerais sobre Comblin, no fôlego proveniente do Concílio Vaticano II e em tentativas comblininas de tentar contribuir com as novas perspectivas propostas, abrangendo sua reflexão teológica e diversas tentativas de práticas missionárias envolvendo a participação em vários movimentos. Destaca-se nessa parte da tese 
seu engajamento nas CEBs, como também no ITER - Instituto de Teologia do Recife, com a elaboração da Teologia da Enxada. Ainda compõem essa etapa do estudo seu exílio durante a repressão militar, o acolhimento no Chile e o poesterior retorno ao Brasil.

A segunda seção do terceiro capítulo concentra-se no estudo da teologia da missão em Comblin e se subdivide em: $\mathrm{O}$ conceito e a prática da missão em Comblin; A missão leiga ou dos cristãos em geral; e Discussões da missão em Comblin.

A primeira parte, assim, adota o ponto de vista de que a missiologia combliniana está associada à sua pneumatologia, e nessa etapa da pesquisa recorrer-se-á a publicações peneumatológicas comblinianas e se discutirá a questão que marca seu posicionamento pneumatológico e o relacionamento deste com a cristologia a partir de comparações com a igreja oriental, que acusa a teologia e a igreja ocidental de priorizar o evento Cristo em detrimento do evento Pentecostes. $\mathrm{O}$ esclarecimento resultante será relevante para o conceito de missão combliniano, explicitando-se o parecer de Comblin, para quem a missão ora em curso é a do Espírito, o que se mostra essencial ao diálogo com a missão quadrangular.

A segunda parte da segunda seção do mesmo capítulo trabalhará a missão leiga ou dos cristãos em geral. A percepção da atuação do leigo e dos cristãos em geral manifestada por Comblin também se relaciona com a atuação do Espírito, que proporciona a todos a contribuição na missão, e nesse sentido a noção combliniana de participação leiga se aproxima da percepção do pentecostalismo quadrangular. Entretanto em Comblin o agir do Espírito liga-se à concretização, ou seja, envolve todos os cristãos para ações visíveis.

A terceira parte da segunda seção do terceiro capítulo busca se inteirar das discussões da missão sob o ponto de vista desse autor, envolvendo sua decisão de assumir uma ação evangelizadora a partir do leigo na força do Espírito. Nesse ponto da pesquisa o teólogo Comblin avança para uma perspectiva de missão que atribui ao Espírito o protagonismo de todo o curso da atual missão. O autor aponta para o preparo dos novos missionários leigos, formando os Centros de Formação Missionária, forma de capacitar os missionários, pois na percepção combliniana o poder do Espírito está associado à concretude. Dessa maneira, Comblin estava sempre em movimento, buscando alternativas à prática missionária. 
No capítulo quatro propõe-se uma aproximação entre a missão da Igreja do Evangelho Quadrangular e Comblin, delimitada à sua pneumatologia e à teologia da missão. O quarto capítulo da tese tem por tema as relações entre os estudos e as sugestões pastorais, dividindo-se em duas seções, a primeira buscando aproximações com o conceito de missão, a segunda contribuindo com sugestões para aprofundamentos posteriores.

A primeira seção do quarto capítulo trata de pontos em comum no conceito e nos métodos para a missão, de diferenças principais no conceito e nos métodos para a missão e sucessos, e limites da prática missionária da Igreja do Evangelho Quadrangular à luz da teologia.

Na primeira parte da seção um do quarto capítulo detectam-se os pontos em comum no conceito e nos métodos para a missão entre as partes evolvidas na tese. O caminho proposto nessa altura da pesquisa passa pelos textos comblinianos que citam o movimento pentecostal e sua atuação. Comblin não se refere diretamente à Igreja do Evangelho Quadrangular, mas trata constantemente do pentecostalismo, do qual faz parte a denominação em estudo. Ainda nessa parte do estudo demonstra-se que os quadrangulares têm Comblin como referência bibliográfica em sua apostila do curso de preparação de pastores, quando o assunto é relacionado à missão, o que o torna um ponto em comum. Essa parte do trabalho compreende que, ao tratar em geral do pentecostalismo, sem menção a denominações, Comblin abarca o pentecostalismo da Quadrangular, o que encaminha um possível diálogo entre as partes. O autor retratava em suas considerações o sucesso do movimento e o mostrava como desafio.

A segunda parte da primeira seção do quarto capítulo descreve as principais diferenças de conceito e de métodos entre quadrangulares e Comblin, no que tange à missão. Para o autor, o movimento pentecostal obteve uma dinâmica na atuação missionária, percebendo-se, nessa parte da pesquisa, que tanto quadrangulares quanto Comblin criticam a atuação missionária de suas próprias estruturas. Os quadrangulares, assim, deparam-se com a limitação de sua prática missionária, por não conseguirem preencher as lacunas da sociedade. Ao contrário, Comblin critica o modelo de missão julgado por ele coerente (o modelo das CEBs), pois, para ele, faltava uma mística na atuação do modelo. O encaminhamento desse tópico segue a hipótese de que os diagnósticos de quadrangulares e de Comblin revelam dois extremos em ambas as práticas 
missionárias: por um lado o pentecostalismo priorizou as questões espirituais, faltando-lhe, no entanto, engajamento social, enquanto o modelo apresentado por Comblin aponta a ausência de uma forte espiritualidade, priorizando o engajamento social. A tese propõe o somatório desses dois caminhos.

A terceira parte da primeira seção do quarto capítulo analisa os sucessos e limites da prática missionária da Igreja Quadrangular à luz da teologia, estudando a prática da missão quadrangular, diretamente associada à atuação do Espírito. A pesquisa observará, a partir da percepção combliniana, a prática missionária quadrangular, segundo a qual o poder do Espírito possibilita a taumaturgia. Essa parte da pesquisa se concentra na recuperação teológica da taumaturgia, para a IEQ, com olhos voltados para o problema da doença.

A segunda seção do capítulo quatro dedica-se ao estudo de contribuições da Igreja do Evangelho Quadrangular ao enriquecimento da reflexão e da prática da missão, segundo a perspectiva de Comblin, com possíveis fomentos ao enriquecimento da perspectiva dessa denominação à luz do autor e de outras sugestões para o diálogo entre pentecostais e católicos, além de subsídios à pastoral missionária de todos os cristãos, em especial, leigos.

A primeira parte da segunda seção do capítulo quatro terá como centro as contribuições da Igreja do Evangelho Quadrangular para o enriquecimento da reflexão e da prática da missão, segundo Comblin. A partir do modelo da Cruzada Nacional de Evangelização, essencial ao crescimento da Igreja do Evangelho Quadrangular, essa parte da pesquisa seguirá o entendimento de que a missão nas tendas foi relevante, mas o que proporcionou maior dinâmica ao crescimento e estabelecimento da missão quadrangular foi a centralidade de sua mensagem, com forte ênfase na pneumatologia, em especial na taumaturgia que regia as campanhas nas tendas itinerantes de cura divina. Será demonstrado que essa evangelização por meio de tendas não é mais viável, sendo possível, no entanto, recuperar a mensagem das tendas mediante a proposta da evangelização dos grupos pequenos ou células. Comblin também dedicou-se ao trato da instalação de grupos pequenos, no seu caso, o termo "casas de igrejas", capaz de aproximar as partes.

No segundo tópico da segunda seção serão propostas contribuições ao enriquecimento da perspectiva da Igreja do Evangelho Quadrangular à luz de Comblin e feitas sugestões no contexto do diálogo entre pentecostais e católicos. 
De passagem pelo novo paradigma da missão nessa etapa, recorrer-se-á à reflexão de David Bosch sobre a missão transformadora, que se modifica enquanto se concretiza. A reflexão sobre temas atuais como inculturação, contextualização e missio Dei, ensaiar-se-á ainda a possibilidade de diálogo ecumênico - que não pressupõe uniformidade - como sugestão de caminho de missionário a Quadrangular.

É preciso esclarecer que o conceito de ecumenismo no pentecostalismo não é o do meio eclesiástico, nem do acadêmico, mas do popular. Na verdade o termo poderia ser cooperação de pentecostais ou ajuntamento de denominações pentecostais com objetivos bem próximos. A pesquisa compreende tais diferenças e reconhece que esse caminho para o ecumenismo mais abrangente necessita ser construído. Entretanto, o ecumenismo pode ser visto na pesquisa, em sua primeira abordagem, referente ao período inicial da CNE no Brasil, com a cooperação entre pentecostais no movimento de evangelização. Um segundo momento aparece nas sugestões para a missão da IEQ, de modo que a pesquisa propõe um diálogo mais aberto e respeitoso com outras taxonomias de ecumenismo. A nossa tese avança propondo novos passos de diálogo ecumênico entre aspectos da missão da Igreja do Evangelho Quadrangular e aspecto da teologia missionária e libertadora do católico José Comblin. O final desta tese aponta para a possibilidade de aumentar o diálogo, porque a evangelização e os cuidados necessários no mundo são temas para todas as igrejas.

No terceiro e último subtítulo do capítulo quarto, são propostas contribuições à pastoral missionária de todos os cristãos, em especial, dos leigos. Busca-se contribuir com a missão de todos os cristãos e propor um caminho de missão que passe pelo sucesso da fase inicial da Igreja do Evangelho Quadrangular no Brasil e pela teologia da missão e do Espírito de Comblin, que muito contribuiu para a reflexão sobre os temas aqui tratados. Somando ambas as frentes, a última parte da pesquisa aponta para o futuro da missão, que passa pela atuação leiga na força do Espírito, em atendimento à pluralidade das culturas na sociedade, dado que somente o leigo, integrante das transformações sociais, poderá comunicar a missão, tornando desnecessária a inculturação.

A missão da IEQ segue o caminho da libertação, cuja fase introdutória no Brasil destaca-se pela forte evangelização taumatúrgica em sua mensagem. Depois de mais de meio século da chegada da IEQ no Brasil, outros temas 
libertadores ganham espaço em sua pauta missionária. Durante a pesquisa notouse que o tema da cura avançou para outras esferas da vida, juntando-se à sua integralidade. A isso se soma a preocupação com a ecologia e as injustiças sociais que degradam a vida. A cura também pode ser prevenção, daí estar diretamente associada ao cuidado. O cuidado como missão encontra espaço na IEQ, e esta pesquisa insere uma das maiores denominações do pentecostalismo mundial em temas contemporâneos e urgentes. A IEQ pode ser a maior igreja pentecostal do Brasil, cuja administração não está centrada em diversas convenções, a exemplo das Assembleias de Deus, que são múltiplas associações. O ministério da IEQ tem convenção única no Brasil, ou seja, trata-se de um único ministério em todo o país. A tese busca mostrar seu tributo histórico ao pentecostalismo brasileiro, como sua relevância na atualidade e sua possível contribuição com temas que desafiam a missão no presente.

A produção desta pesquisa encontrou em sua última fase, desde o início de 2020 até a defesa, em novembro, o cenário de pandemia da Covid-19. A pesquisa já estava avançada quando a pandemia se instalou, mas sofreu atrasos com a quarentena, sendo que a ultima etapa era a mais importante do trabalho. Assim, as restrições não permitiram algumas ações importantes, como novas visitas a bibliotecas, encontros com grupos de pesquisas, exposições em congressos e seminários, o que muito contribuiria no crescimento da investigação, mediante os aportes dos demais pesquisadores. Em contraposição, tentamos seguir debates acadêmicos online. O contexto também envolveu muitas dimensões de problemas sociais e de pandemia, que além de restringir o trabalho bastante para o ambiente virtual, provocou incerteza e preocupação. O terceiro desenvolvimento da tese, depois da pesquisa ter feito a descrição da Igreja do Evangelho Quadrangular e buscado pontos de contatos com a teologia de Comblin, constitui parte final que pode servir ao um novo desenvolvimento da Igreja do Evangelho Quadrangular. Esse novo desenvolvimento acentua elementos como: missão, atividade de cura, atuação dos leigos, e outros, que no contexto de pandemia podem se tornar mais desafiadores para Igreja do Evangelho Quadrangular e para o seu diálogo com outras Igrejas e colaboração com o mundo. De fato a Igreja do Evangelho Quadrangular, como as outras igrejas, não pode prometer o milagre da cura da pandemia, mas pode junto com as outras, em certo sentido de ecumenismo, dialogar e trabalhar junto para aumentar os cuidados em favor dos enfermos, da 
sociedade e do mundo. A dimensão de cura poderia ser entendida mais como todo trabalho de dedicação e cuidado das pessoas. Assim no contexto da pandemia a tese aponta na ultima parte na direção de ajudar a superar a pandemia através do cuidado para todos. 


\section{A missão na Igreja do Evangelho Quadrangular}

Este capítulo objetiva descrever a missão da Igreja do Evangelho Quadrangular, e para tanto se proporá o aprofundamento a partir dos principais acontecimentos de sua história, inclusive sua origem. Assim, este capítulo se concentrará na recuperação de fatos relevantes para a compreensão da denominação. Já de início, será traçado um panorama da sua situação entre os pentecostais clássicos, tecendo considerações sobre as igrejas pentecostais e a origem do movimento. O capítulo ainda mostrará a fase inicial da instalação da IEQ no Brasil, abrangendo uma fase iniciada com a chegada dos primeiros missionários e suas tentativas de estabelecimento entre os brasileiros.

Esse período se estende da fundação da Igreja Evangélica do Brasil, passando pelo movimento Cruzada Nacional de Evangelização, até a institucionalização da Igreja do Evangelho Quadrangular. Também será estudada a relação da Cruzada Nacional de Evangelização com o pós-pentecostalismo, grupo que muito cresceu no Brasil e incorporou elementos por meio da Cruzada Nacional de Evangelização no Brasil. O capítulo resgata o histórico das origens e a missão da Quadrangular desde antecedentes da fundadora, Aimee Semple McPherson, e o processo que levou à fundação de uma nova denominação pentecostal e do seu envolvimento com o pentecostalismo e suas experiências. Isto associa-se ao conceito e à prática da missão na IEQ, pois a fundadora norteou os quadrangulares em sua ação missionária. Ainda neste capítulo buscaremos compreender as doutrinas cardeais da denominação, analisando sua declaração de fé e seus estatutos.

\section{1.}

\section{A Igreja do Evangelho Quadrangular entre os pentecostais clássicos}

Esta parte da pesquisa buscará situar a IEQ entre os pentecostais clássicos e sua relação com o movimento, dadas as contradições entre os conceitos de pentecostais clássicos, neoclássicos, neopentecostais e pós-pentecostalismo. A pesquisa seguirá o entendimento de que a Igreja do Evangelho Quadrangular 
situa-se entre os clássicos, talvez se estendendo aos neoclássicos em sua instauração no Brasil.

\subsection{1.}

\section{Considerações sobre as igrejas pentecostais}

O movimento pentecostal que surgiu no protestantismo, na sua forma originaria ajudou hoje no protestantismo ajudou na continuidade da expansão do cristianismo. Quando se previa o distanciamento das pessoas das religiões, o movimento pentecostal, surgido no início do século XX, parece ter sido a resposta contra tais predições. Matos informa: "o moderno movimento pentecostal é considerado por muitos estudiosos o fenômeno mais revolucionário da história do cristianismo no século 20, e talvez um dos mais marcantes de toda a história da igreja". ${ }^{1}$ Nesta parte inicial da pesquisa, estudaremos esse fenômeno. Porém, perguntamos antes: o que exatamente é o pentecostalismo ou movimento pentecostal, hoje muito popular e de grande proliferação, com pluralidade no interior do próprio movimento?

Matos assegura que "em relativamente poucas décadas, as igrejas pentecostais reuniram uma imensa quantidade de pessoas em praticamente todos os continentes". São muitas as denominações que se intitulam pentecostais, entretanto concentraremos esta pesquisa no pentecostalismo da Igreja do Evangelho Quadrangular, ${ }^{3}$ e a partir desse recorte, investigaremos a missão nessa igreja. Porém, neste momento, é necessário situar a Igreja do Evangelho Quadrangular entre os pentecostais em geral. Maçaneiro acrescenta: "os pentecostais clássicos se veem diretamente vinculados à experiência de Pentecostes referida no Novo Testamento (At 2), a qual eles acreditam terem provado de maneira nova em etapas significativas da história de suas

\footnotetext{
${ }^{1}$ MATOS, Alderi Souza de. O Movimento Pentecostal: reflexões a propósito do seu primeiro centenário. Fides Reformata XI, No 2, p. 23-50, 2006, p. 24.

${ }^{2}$ MATOS, A. S., O Movimento Pentecostal, p. 24.

3 A IEQ no Brasil conta com 1.808 .389 membros, constituindo-se como uma das maiores denominações do pentecostalismo brasileiro, conforme os dados do IBGE - Censo de 2010. Tabela 137 - População residente, por religião. Brasil ano 2010: Religião - Evangélica de origem pentecostal - Igreja do Evangelho Quadrangular: 1.808.389 Fonte: IBGE - Censo Demográfico. Disponível em: < https://sidra.ibge.gov.br/tabela/137\#resultado15273 >. Acesso em: 7 nov. 2020.
} 
Comunidades, desde o século XVIII". " É necessário considerar alguns fatores, denominações e acontecimentos que construíram a história do movimento pentecostal, pois é exatamente a partir de tais elementos que nasce a Igreja do Evangelho Quadrangular, objeto desta investigação. Duffield e Cleave esclarecem:

Não se trata de sectarismos nem de serviço em causa própria que qualquer pentecostal observe o fato, agora histórico, de que o reavivamento usado por Deus para introduzir esta sucessão de reavivamentos leva o nome, extraído da inauguração da própria igreja - Pentecostes. No início deste século, primeiro em Topeka Kansas, e depois na Rua Azusa, em Los Angeles, Califórnia, a manifestação do Espírito Santo resultou num despertamento que continua a afetar ainda hoje a igreja em toda parte. O que Deus fez através de Lutero, ao recuperar a mensagem da salvação, e através de Wesley, ao recobrar a mensagem da vida santa e serviço, Ele o fez mediante o primeiro reavivamento pentecostal, quando recuperou a dinâmica do poder dos dons do Espírito Santo para a igreja. A partir desta época, acumulou-se a evidência sobre o fato de o crescimento do evangelismo resultar de uma resposta mais ampla e fervorosa ao Espírito e suas obras, à medida que os crentes em todo o lugar se dispõem a receber estes derramamentos periódicos do céu. ${ }^{5}$

Amostras de momentos de tendências mais centralizadas nas experiências espirituais fazem parte desse tipo de cristianismo pentecostal. Afirma Matos: "nas décadas de 1730 e 1740, a ocorrência do Primeiro Grande Despertamento trouxe revitalização às igrejas protestantes, mas, ao mesmo tempo, produziu um tipo diferente de cristianismo, mais emocional". ${ }^{6}$ Durante algum tempo, os grupos que buscavam essa prática estavam associados ao protestantismo. Santos informa:

O pentecostalismo ou pentecostismo é uma religião protestante, nascida do protestantismo, no começo deste século. Considera a crença no Espírito Santo como a crença maior, em torno da qual giram as outras crenças e as práticas religiosas. O nome vem de Pentecoste, festa religiosa dos judeus, dia em que o Espírito Santo desceu sobre os apóstolos e começou o cristianismo. Por isso, o centro do pentecostalismo é o batismo no Espírito Santo, que não é um rito como o batismo com água, e sim uma presença toda especial do Espírito Santo, que tem como sinal exterior proferir algumas palavras estranhas. ${ }^{7}$

\footnotetext{
${ }^{4}$ MAÇANEIRO, Marcial. Uma aproximação ao diálogo internacional católico-pentecostal. Revista de Cultura Teológica 13 Ano XXI, No 82, p. 11-31.Jul/Dez. 2013. p. 16.

${ }^{5}$ DUFFIELD, P. Guy; CLEAVE, Nathaniel. M. Van. Fundamentos da teologia pentecostal. Vol I. São Paulo: Quadrangular, 1991, p. 4.

${ }^{6}$ MATOS, A. S., O Movimento Pentecostal, p. 27.

${ }^{7}$ SANTOS, Valdevino Rodrigues dos. Tempos de exaltação: um estudo sobre a música e a glossolalia na Igreja do Evangelho Quadrangular. São Paulo: Annablume, 2002, p. 15.
} 
As raízes do pentecostalismo remontam ao início do protestantismo. As pesquisas em torno do tema demonstram que as primeiras manifestações ocorrem na Europa. Matos ressalta: "os estudiosos têm adotado diferentes abordagens na busca de compreender a gênese do pentecostalismo". 8 As bases argumentais iniciais se davam em torno da necessidade de maior compreensão dos textos sagrados, em concordância com Espírito, ao qual toda a estrutura que envolve o pentecostalismo está associada. É Santos quem afirma:

A primeira manifestação desse "protestantismo do Espírito" teve início no século XVI, como o Anabatismo na Alemanha e na Suíça. Foi através dos menonitas, ramo anabatista fundado por Menno Simons, em 1536, que reafirmava a necessidade do recebimento direto da inspiração do Espírito Santo, iluminando os fiéis para que compreendessem os textos bíblicos. ${ }^{9}$

Sobre a maior evocação dos relatos bíblicos que apresentavam manifestações do Espírito, Maçaneiro esclarece: “em termos simples, trata-se de um reavivar, nos dias de hoje, os carismas e frutos manifestos no período da pregação apostólica e nas primitivas comunidades cristãs". ${ }^{10} \mathrm{O}$ moderno movimento pentecostal contextualiza sua prática missionária, associando-se diretamente ao período bíblico. Isso proporciona ao pentecostalismo a aproximação com as práticas das primeiras comunidades. Maçaneiro diz: "é sob a hermenêutica bíblico-espiritual mencionada acima que se consolidou a doutrina do 'batismo no Espírito Santo', como evento central das experiências de 'avivamento", 11

O movimento introduz em suas reuniões essa característica que marca o início, da forma e identidade a esse modelo de cristianismo. Destacam-se nessa fase alguns grupos que tinham no seu seguimento litúrgico manifestações incomuns nas reuniões da época. Santos assegura: "originalmente, denominados Children of light ou Friends, os seguidores de Fox passaram a ser designados pelo nome de quakers (tremedores), devido aos tremores de que eram acometidos os fiéis em suas reuniões, quando se sentiam iluminados pelo Espírito Santo (os "quakerismos" não penetraram no Brasil)". ${ }^{12}$ Assim se percebe que a

\footnotetext{
${ }^{8}$ MATOS, A. S., O Movimento Pentecostal, p. 27.

${ }^{9}$ SANTOS, V. R., Tempos de exaltação, p. 15.

${ }^{10}$ MAÇANEIRO, M., Uma aproximação ao diálogo internacional católico-pentecostal, p. 18.

${ }^{11}$ MAÇANEIRO, M., Uma aproximação ao diálogo internacional católico-pentecostal, p. 18.

${ }^{12}$ SANTOS, V. R., Tempos de exaltação, p. 16.
} 
personificação presente nas reuniões pentecostais insere-se no movimento desde que apareceram os primeiros grupos com tais características. Lopes assegura: "em primeiro lugar, é necessário rememorar que o pentecostalismo caracteriza-se pela crença na atualidade dos carismas bíblicos, mormente os neotestamentários". ${ }^{13}$ São muitos os momentos, na história do protestantismo, de surgimento de grupos com traços similares aos do movimento pentecostal atual. Lopes continua: "tal crença fundamenta-se na narrativa do livro dos Atos dos Apóstolos por ocasião do intermédio entre a ascensão de Cristo e o cumprimento da promessa da chegada do Paracleto". 14 É relevante destacar, nesta pesquisa, os primeiros momentos do pentecostalismo nos Estados Unidos. Santos esclarece:

As manifestações de caráter iluminista revestiam-se de novo teor entre os grupos religiosos que começaram a surgir nos Estados Unidos, a partir do século XVII. O pastor congregacional Jonathan Edwards iniciou em 1734 suas pregações de reavivamento nos Estados da Nova Inglaterra. Pregando um tipo de cristianismo baseado na comunhão direta entre Deus e a alma humana, esse movimento e outros subsequentes provocaram extremo emocionalismo entre os participantes, que chegavam a ter reações físicas violentas, tanto de medo como de alegria. ${ }^{15}$

O pentecostalismo brasileiro está diretamente enraizado nessa perspectiva de reações corporais. Isso mostra que as primeiras aparições desse tipo de cristianismo estabeleceu o modelo que chegou ao Brasil. A gênese do pentecostalismo brasileiro associa-se à história do movimento pentecostal dos EUA. Aleixo afirma: "no final do século XIX, surgiam em pequenas comunidades religiosas no Tennessee e na Carolina do Norte os primeiros movimentos que pregavam a renovação doutrinária e espiritual do protestantismo histórico, por exemplo, o movimento reavivalista Latter Rain Movement" ${ }^{16}$

Ao relembrar os passos do movimento pentecostal a partir do recorte de acontecimentos dos EUA, recorremos à declaração de Santos: "em fins do século XIX, surgiu no Tennessee e na Carolina do Norte o Latter Rain Movement. Os seguidores desse movimento, baseando-se na profecia bíblica de J1 2, 28-32, acreditavam que o fenômeno da glossolalia determinava a era nova do

13 LOPES, Marcelo. Pentecostalismo no Brasil e a cura divina: um olhar histórico e fenomenológico. Sacrilegens, Juiz de Fora, v. 11, n. 1, p. 89-110, jan-jun/2014, p. 94.

${ }^{14}$ LOPES, M., Pentecostalismo no Brasil e a cura divina, p. 94.

${ }^{15}$ SANTOS, V. R., Tempos de exaltação, p. 16.

${ }^{16}$ ALEIXO, Vitor Corrêa. "Deus Faz, o Templo dos Anjos Mostra": perfil eclesial e adesão religiosa na Igreja do Evangelho Quadrangular em Belo Horizonte. Dissertação de Mestrado. UFMG. Belo Horizonte, 2014, p. 23. 
cristianismo, sendo o sinal que anunciava a segunda vinda de Cristo". ${ }^{17}$ É a partir desse momento que se identifica a proximidade direta com as raízes mais próximas do pentecostalismo do início do século $\mathrm{XX}$, que chegaria também ao Brasil. Aleixo destaca que o movimento foi: "fruto da cisão de grupos batistas e metodistas, que enfatizavam o dom de línguas (glossolalia), a operação de milagres e a segunda vinda de Cristo (milenismo) - princípios fundamentais que permaneceram no escopo teológico das denominações pentecostais ao longo dos anos". 18

A história do pentecostalismo está marcada por continuidade e descontinuidade, pois os grupos dissidentes, embora se emancipem, conservam certa continuidade. A multiplicação e a pluralidade do movimento parece constituir o pentecostalismo. É Santos quem Informa as origens dos grupos pentecostais no Brasil:

Partindo de cisões oriundas do Latter Rain Movement, surgiram alguns ramos holiness e pentecostais, merecendo citação, entre estes últimos, os grupos que se instalaram posteriormente no Brasil: Assembléia de Deus e a Igreja do Evangelho Quadrangular. ${ }^{19}$

Os antecedentes do pentecostalismo norte-americano sempre foram marcados pela fragmentação dentro do próprio movimento. Os antecedentes do marco inicial do movimento pentecostal de Azusa encontram-se também associados a Charles Fox Parham, precursor de William Joseph Seymour, conforme Matos diz: "no ano de 1900, um pregador metodista influenciado pelo movimento de santidade, Charles Fox Parham (1873-1929), criou um instituto bíblico na cidade de Topeka, Estado do Kansas, na região central dos Estados Unidos". ${ }^{20}$

A importância de Parham para o movimento que antecede Azusa configurase pelo conceito por ele popularizado, do qual acreditava ser o falar em línguas a evidência do Batismo. Matos acrescenta é um distintivo do movimento pentecostal: "a novidade na teologia de Parham é que ele foi o primeiro a considerar o 'falar em línguas' como a evidência inicial do batismo no Espírito Santo. Foi essa característica que se tornou a marca distintiva do movimento

\footnotetext{
${ }^{17}$ SANTOS, V. R., Tempos de exaltação, p. 16.

${ }^{18}$ ALEIXO, V. C., "Deus Faz, o Templo dos Anjos Mostra", p. 23.

${ }^{19}$ SANTOS, V. R., Tempos de exaltação, p. 16.

${ }^{20}$ MATOS, A. S., O movimento pentecostal, p. 30.
} 
pentecostal". ${ }^{21}$ A maior parte do pentecostalismo dos EUA estabelece o conceito de Parham, o falar em línguas torna-se aceito e popular no meio pentecostal e torna-se algo a ser alcançado pelos adeptos. Além de propor o conceito de evidência do batismo no Espírito Santo como o falar em línguas, Parham participou da formação de William Joseph Seymour. Matos informa:

Em 1905, Charles Parham mudou-se para o Texas e iniciou uma escola bíblica em Houston. Um dos estudantes atraídos por essa escola foi um ex-garçom negro e pregador holiness, William Joseph Seymour (1870-1922). Era o período da discriminação racial no sul dos Estados Unidos e Parham era simpatizante desse sistema. Seymour assistia às aulas sentado em uma cadeira no corredor ao lado da sala. $^{22}$

A questão social dos EUA nessa época, aí inclusa a segregação racial, atingia todas as esferas da vida humana, inclusive a religiosa. Assim como Matos, citado acima, Oliveira diz: "Seymour foi aluno de Parham em 1905 numa escola bíblica em Houston no Texas. Porém devido ao racismo vigente à época, assistia às aulas numa cadeira colocada no corredor, do lado de fora da sala". ${ }^{23} \mathrm{~A}$ insistência de Seymour seria recompensada, pois ele é o nome mais aceito entre os pesquisadores do pentecostalismo. Seu nome tornou-se o marco do pentecostalismo moderno de Azusa.

O movimento pentecostal do início do XX iniciado a partir de Azusa, em Los Angeles, e propagado no Brasil e em tantos outros lugares, foi responsável pelo grande crescimento do cristianismo no último século. Oliveira informa: "o moderno movimento pentecostal tem sua origem no histórico avivamento de Azusa Street em Los Angeles - CA, no início do século XX, entre os anos de 1906 e 1915. Era uma época em que a segregação racial afetava largamente a nação norte-americana". ${ }^{24}$ Mesmo em momentos adversos, o pentecostalismo encontrou seu caminho. Sua modalidade apresentada nas sociedades contemporâneas cresceu em uma época de incertezas e conflitos, em que os EUA sempre estiveram ativos. Wulfhorst diz:

\footnotetext{
${ }^{21}$ MATOS, A. S., O movimento pentecostal, p. 30.

${ }^{22}$ MATOS, A. S, O movimento pentecostal, p. 31.

${ }^{23}$ OLIVEIRA, Myckon Alves de. Pentecostais: história, contexto e caminhos para teologizar. Integratio, v. 1, n. 2, jul. - dez. p. 67-77. 2016.p. 69.

${ }^{24}$ OLIVEIRA, M. A., Pentecostais, p. 68.
} 
Lá o pentecostalismo surgiu em 1906 a partir do assim chamado "movimento de santidade". Esse movimento, fortemente influenciado pelo conceito de Wesley acerca da perfeição humana, acentuava que se deve diferenciar a santidade da justificação e que a santidade é uma segunda obra da graça de Deus. O núcleo mais forte era a Escola Bíblica de Topeka, onde se defendia que o falar em línguas era um sinal que acompanhava o Batismo do Espírito Santo. ${ }^{25}$

Muitos eventos cooperaram para a explosão do movimento pentecostal, mas a maioria dos estudiosos do pentecostalismo aponta para a mesma direção quanto à deflagração de sua vertente instalada no Brasil. Santos continua: "mas o ponto do movimento pentecostal, que hoje atinge vários continentes, foi em 1906, numa velha igreja metodista de Azusa Street, em Los Angeles, Estados Unidos. O interior daquele velho templo abrigava evangélicos, majoritariamente negros, que, em orações prolongadas pela noite adentro buscavam a santificação do Espírito". ${ }^{26} \mathrm{O}$ marco inicial do pentecostalismo traz em si elementos dignos de análise. Certos traços tornaram-se marca do movimento em todo o mundo. Destacam-se as orações prolongadas em uma igreja considerada refúgio para alguns cristãos.

É importante destacar as afinidades entre a cultura negra e o pentecostalismo no contexto brasileiro, que aproximou ambos. E como Macedo diz: "o pentecostalismo brasileiro reinterpretou e incorporou algumas de suas práticas e crenças". ${ }^{27}$ As raízes do pentecostalismo norte-americano demonstram contribuição e influência da cultura negra. Macedo continua:

Do ponto de vista histórico, indiscutivelmente o Pentecostalismo carrega heranças culturais africanas. Além do fato do pastor que fundou o Pentecostalismo nos EUA ser descendente de africanos, William J. Seymour, o movimento primeiramente se consolidou entre os afro-norte-americanos. ${ }^{28}$

Não é que o pentecostalismo norte-americano seja predominantemente produto da cultura negra, como reconhece Macedo: “o pentecostalismo nos EUA também encontrou alguns adeptos da etnia branca, como demonstra a atuação do pastor Charles F. Parham, mas permaneceu segregado do resto da sociedade norte-americana, enquanto entre os afro-americanos se expandiu e se

\footnotetext{
${ }^{25}$ WULFHORST, Ingo. O pentecostalismo no Brasil. Estudos Teológicos, 35 (l) p. 7-20, 1995, p. 7.

${ }^{26}$ SANTOS, V. R., Tempos de exaltação, p. 16.

${ }^{27}$ MACEDO, E. U. Pentecostalismo e religiosidade brasileira, p. 118.

${ }^{28}$ MACEDO, E. U. Pentecostalismo e religiosidade brasileira, p. 119.
} 
consolidou". ${ }^{29} \mathrm{O}$ pentecostalismo nos EUA cresceu e se pluralizou, e a Igreja do Evangelho Quadrangular, objeto deste estudo, inserida nesse contexto, acompanhou essa expansão pentecostal: "todavia, denominações pentecostais diversas foram surgindo nos EUA, diferente das fundadas por Seymour e Parham. A mais expressiva é a 'Assembly of God', a que mais cresceu e se tornou uma das maiores do gênero no mundo". ${ }^{30}$ Macedo, explicando o pentecostalismo brasileiro, diz que muitas de suas características têm afinidade com a cultura afrobrasileira:

\begin{abstract}
Contrário a algumas doutrinas do Protestantismo tradicional, o Pentecostalismo brasileiro, embora tendo raízes protestantes, incorporou a crença em entidades sobrenaturais em práticas de possessões espirituais e na solução de problemas cotidianos através da magia, demonstrando a influência afro-brasileira. A glossolalia, a cura divina e a possessão espiritual nas denominações pentecostais brasileiras acabam permitindo ao adepto expressar mais livremente suas frustrações e anseios, solucionando seus problemas cotidianos e combatendo espíritos malignos que ameaçam sua vida. ${ }^{31}$
\end{abstract}

Segundo o autor, o pentecostalismo encarnou a dor e a luta de grande parte da população brasileira, por isso tem crescido em determinada parcela da sociedade:

Com isso, o Pentecostalismo adaptou sua oferta à demanda dos adeptos, demonstrando uma atitude prática no meio sócio-religioso. Adapta-se à crença de acordo com os anseios e frustrações da população circundante, buscando solucionar seus problemas cotidianos, atestando influências religiosas afrobrasileiras. ${ }^{32}$

Essa mensagem provedora, contida em ramificações do pentecostalismo, encontrou audiência na religiosidade brasileira: "foi essa plasticidade e flexibilidade do Pentecostalismo, entre outros fatores, incorporando práticas e ritos da religiosidade brasileira, e sua praticidade ao oferecer soluções de problemas cotidianos da população que favoreceu seu crescimento e popularização". ${ }^{33}$ Em seu diagnóstico, Macedo define as bases do pentecostalismo brasileiro e alerta para a questão da intolerância de ramos mais extremistas dessa corrente:

\footnotetext{
${ }^{29}$ MACEDO, E. U. Pentecostalismo e religiosidade brasileira, p. 119.

${ }^{30}$ MACEDO, E. U. Pentecostalismo e religiosidade brasileira, p. 119.

${ }^{31}$ MACEDO, E. U. Pentecostalismo e religiosidade brasileira, p. 120.

${ }^{32}$ MACEDO, E. U. Pentecostalismo e religiosidade brasileira, p. 121.

${ }^{33}$ MACEDO, E. U. Pentecostalismo e religiosidade brasileira, p. 124.
} 
Enfim, o Pentecostalismo, carregando influências do Metodismo e Pietismo e de crenças afro-brasileiras, cresceu e se popularizou mesclando-se com as características religiosas da sociedade brasileira, sincretizando-se. Apesar do sincretismo observado na religiosidade popular brasileira há séculos, o Pentecostalismo no Brasil apresenta, todavia, algumas características de intolerância e imposição sobre outras religiões. ${ }^{34}$

É preciso reconhecer elementos contidos no discurso de variações do pentecostalismo brasileiro traços de intolerância, principalmente quanto às religiões de matrizes africanas. Entretanto, como já foi comentado nesta pesquisa, existe um ramo autônomo, alicerçado no pentecostalismo considerado clássico, que se emancipou e se distanciou, tanto teologicamente quanto do ponto de vista doutrinário, da doutrina pentecostal. Muitos desses grupos estão nas grandes mídias e são denominados de "Neopentecostais", mas nesta pesquisa utiliza-se o termo "Pós-pentecostalismo" para se referir a eles, por sua grande diferença em relação do pentecostalismo clássico. A mensagem pós-pentecostalista é mais agressiva e intolerante, como observa Macedo: "a demonização de espíritos africanos e a rejeição da idolatria da Igreja Católica aos santos são suas manifestações mais marcantes". ${ }^{35}$ A preocupação apontada pelo autor, de fato, é constatada em discursos de intolerância, tanto no pentecostalismo clássico quanto no pós-pentecostalismo, mas tal comportamento não assume caráter geral, pela predominância das marcas de afinidade:

\begin{abstract}
A ironia nesse caso reside no fato de que o Pentecostalismo incorporou influências religiosas afro-brasileiras e católicas, tais como transe espiritual, curas divinas por meio de rezas e atos simbólicos como a "imposição das mãos", como fazia Jesus entre os doentes. Ao mesmo tempo os pentecostais incorporam elementos dessas religiões e transformam elementos delas em inimigos máximos, como materializações do mal. ${ }^{36}$
\end{abstract}

Percebe-se a constante presença da cultura negra no pentecostalismo, desde suas primeiras manifestações nos EUA até a sua instalação no Brasil, mesmo nos dias atuais. Cabe ao pentecostalismo resistir profeticamente à injustiça sofrida estruturalmente pela cultura negra. $\mathrm{O}$ pentecostalismo tem grande presença entre a população negra e é o segmento do cristianismo que mais cresceu em números de adeptos nas últimas décadas. Talvez a realidade resida no silêncio ou ausência do

\footnotetext{
${ }^{34}$ MACEDO, E. U. Pentecostalismo e religiosidade brasileira, p. 124.

${ }^{35}$ MACEDO, E. U. Pentecostalismo e religiosidade brasileira, p. 124-125.

${ }^{36}$ MACEDO, E. U. Pentecostalismo e religiosidade brasileira, p.125.
} 
tema na pauta e no itinerário profético do pentecostal brasileiro no trato do assunto. Essa omissão diante do sofrimento e da opressão vem sendo praticada durante séculos, e parece que o pentecostalismo está em débito com a cultura e a população negras, necessitando urgentemente criar caminhos de reparação dessa atitude.

A igreja do Evangelho Quadragular como igreja pentecostal pode seguir o caminho do Evagelho, do acolhimento das culturas, e de uma missão que respeite a todos e valorize o dialogo na busca e permacecendo fiel ao Evangelho.

Nesse contexto, não se poderia desconsiderar que as primeiras manifestações da glossolalia do atual movimento pentecostal iniciado no templo metodista de Azusa foi experimentada por negros. É Santos relata: “e quem primeiro falou em línguas estranhas, foi um negro". ${ }^{37} \mathrm{O}$ autor se referia à expressão "falar em linguas", do Novo Testamento (Atos 2). É uma prática que os pentecostais pretendem realizar nos seus cultos. $\mathrm{O}$ fato do inicio desta prática ter sido ligado a uma contribuição da cultura negra gerou especulação, na imprensa norte americana, como também mostrou Santos. Entretanto, o movimento pentecostal sempre esteve associado às margens da população, e sua expansão se dá, em grande parte, pela parcela mais frágil da sociedade. Logo, todo tipo de notícia começa a ser associada ao movimento. Wulfhorst destaca o papel fundamental de Seymour:

Em 1906 o pregador negro W. J. Seymour foi pregar na igreja negra da evangelista Nelly Terry, em Los Angeles sobre Atos 2.4. Pregou que, além da justificação e santificação, Deus teria uma terceira bênção, ou seja, o Batismo do Espírito Santo. A evangelista ficou escandalizada e expulsou o pregador Seymour da sua igreja. Ele não desistiu, e realizava reuniões de oração na Rua Azusa, 312, onde, no dia 6 de abril de 1906, um menino negro de 6 anos falou em línguas, seguido por outros. Nascia o pentecostalismo entre os negros. ${ }^{38}$

Nas constantes reuniões de avivamento, de grande público, era muito comum o fluxo de pessoas interessadas em compreender a novidade que se propagava, caracterizada a princípio por trabalhos de caráter ecumênico entre os grupos do movimento, trabalhos esses que se concentravam na figura dos líderes. Wulfhorst Continua: "numa das reuniões pentecostais de Seymour o pastor batista W. H. Durham, de Chicago, estava presente e também falou em línguas. Então

\footnotetext{
${ }^{37}$ SANTOS, V. R., Tempos de exaltação, p. 17.

${ }^{38}$ WULFHORST, I., O pentecostalismo no Brasil, p. 7.
} 
levou essa experiência para a sua Igreja em Chicago". ${ }^{39}$ Apesar das diferenças em relação às práticas das igrejas históricas protestantes, sua teologia caminha na mesma direção, construindo sua percepção de missão a partir do entendimento da salvação, como afirma Santos: "do mesmo modo que as igrejas históricas evangélicas, [o pentecostalismo] é salvacionista, não pelas obras mas pela graça, por meio da fé". 40

O encontro do pastor Durham com a mensagem pentecostal de Seymour e sua experiência em falar em línguas foi determinante na formação da matriz do pentecostalismo brasileiro, pois exatamente em Chicago os líderes das igrejas do pentecostalismo clássico brasileiro tiveram suas experiências com o movimento. Wulfhorst diz: "reencontramos essa doutrina no pentecostalismo brasileiro, pois na Igreja de Durham, em Chicago, encontramos o núcleo comum a partir do qual se formariam 'as três vertentes do pentecostalismo brasileiro': a Assembléia de Deus, a Congregação Cristã do Brasil e a Igreja Evangélica Quadrangular no Brasil". ${ }^{41}$ A influência do pastor Durham sobre o pentecostalismo brasileiro é constatada nas denominações pentecostais clássicas.

$\mathrm{O}$ movimento chega ao Brasil no início do século $\mathrm{XX}$, trazendo consigo todas as características e a identidade ostentadas nos Estados Unidos. Os primeiros grupos fixados entre o povo brasileiro são inicialmente datados por Santos: "entre 1910 e 1950, a presença pentecostal no Brasil, foi discreta."42 Durante esse tempo o movimento em terras brasileiras permaneceu marginal, não se destacando como nos Estados Unidos. Campos destaca: "entre 1910 e 1911 chegaram ao Brasil os primeiros pregadores do pentecostalismo. Dois suecos, imigrantes nos EUA, e Luis Francescon, um italiano também imigrante nos EUA, todos vindos de Chicago, receberam revelações atribuídas a Deus para iniciar o movimento pentecostal no Brasil". ${ }^{43} \mathrm{O}$ movimento ganhava força aos poucos entre os protestantes, mas havia muito preconceito quanto à glossolalia, que era o elemento de destaque dos primeiros grupos instalados no Brasil, que alguns especialistas tentam distinguir. Santos diz: "o pentecostalismo brasileiro pode ser

\footnotetext{
${ }^{39}$ WULFHORST, I., O pentecostalismo no Brasil, p. 8.

${ }^{40}$ SANTOS, V. R., Tempos de exaltação, p. 17.

${ }^{41}$ WULFHORST, I. O pentecostalismo no Brasil, p. 8.

${ }^{42}$ SANTOS, V. R., Tempos de exaltação, p. 18.

${ }^{43}$ CAMPOS, Leonildo Silveira. Pentecostalismo e protestantismo "histórico" no Brasil: um século de conflitos, assimilação e mudanças. Horizonte, Belo Horizonte, v. 9, n. 22, p. 504-533, jul./set. 2011, p. 510.
} 
compreendido como a história de três ondas de implantação de igrejas". ${ }^{44}$ Seguindo essa teoria, os primeiros grupos estariam inseridos na chamada primeira onda, considerada a mais tímida. O movimento pentecostal inserido no Brasil é associado à expansão da missão do movimento iniciado em Azusa. É Santos quem destaca:

O pentecostalismo no Brasil está ligado de modo direto ao movimento de Los Angeles (EUA). Um italiano emigrado para os Estados Unidos, chamado Luigi Francescon, era membro da igreja Presbiteriana italiana em Chicago, e, influenciado pelo pastor batista W. H. Durham, a cujas reuniões comparecia, afirmou ter recebido o dom de línguas em 25 de agosto de 1907. Por revelação, segundo ele, viajou para América do Sul a fim de trazer a nova mensagem. Em São Paulo, fundou em 1910, entre a colônia italiana, a atual segunda maior igreja pentecostal do Brasil, a Congregação Cristã no Brasil. ${ }^{45}$

Os primeiros missionários pentecostais anunciam um modelo de protestantismo, que, embora novo para os brasileiros, foi indubitavelmente bem recebido. $\mathrm{O}$ crescimento não foi expressivo no início, mas o cenário desbravado pelos primeiros missionários pentecostais em terras brasileiras estabeleceu um marco religioso inédito no Brasil. Campos acentua: "o crescimento das duas denominações pentecostais pioneiras, a princípio foi lenta". ${ }^{46} \mathrm{O}$ campo foi preparado pelos missionários vindos de Chicago e o processo de contextualização foi acontecendo a partir dos primeiros pentecostais, proporcionando a inculturação do pentecostalismo. Destaca-se nessa fase inicial, segundo Santos: "um sueco de nome Daniel Berg era membro da igreja batista de W. H. Durham e de lá veio para o Brasil como missionário. Após provocar cisão numa igreja batista em Belém do Pará, fundou, junto com o seu compatriota, o pastor batista Gunnar Vigren, as Assembléias de Deus, em 1911".47

As Assembleias de Deus nascem no Brasil a partir desse fato, enfrentando conflitos pelas características pentecostais dos missionários, que enfatizavam o batismo no Espírito Santo e as manifestações de glossolalia, o que provocou a cisão e a consequente expulsão dos missionários e de outros simpatizantes do pentecostalismo. Aleixo assegura: “contudo, em 1911, os dois missionários e treze fiéis foram expulsos da igreja batista sob a acusação de que pregavam no templo e

\footnotetext{
${ }^{44}$ SANTOS, V. R., Tempos de exaltação, p. 18.

${ }^{45}$ SANTOS, V. R., Tempos de exaltação, p. 19.

${ }^{46}$ CAMPOS, L. S., Pentecostalismo e protestantismo "histórico" no Brasil, p. 510.

${ }^{47}$ SANTOS, V. R., Tempos de exaltação, p. 19.
} 
em cultos domiciliares a glossolalia e a operação de milagres, preceitos doutrinários dissonantes da teologia batista tradicional". ${ }^{48}$ Assim nasce a maior denominação pentecostal do Brasil, que, desde a fundação, desempenhou papel de destaque no protestantismo brasileiro. Sobre seu início, Aleixo destaca: "da separação desse pequeno grupo surgiria uma das mais proeminentes precursoras do pentecostalismo no país, inicialmente chamada Missão da Fé Apostólica, nome inspirado no movimento de Charles Fox Parham, sendo renomeada para Assembleia de Deus (AD) em 1914". ${ }^{49}$

A origem do pentecostalismo brasileiro passa pelo reverendo W.H. Durham, dada a influência do seu modelo de trabalho sobre os missionários e denominações aqui estabelecidos, inclusive os fundadores das três primeiras denominações pentecostais brasileiras: Luigi Francescon, da Congregação Cristã; Daniel Berg e Adolph Gunnar Vingren, das Assembleias de Deus; e Aimee Semple McPheson, da Igreja do Evangelho Quadrangular. Santos destaca: “em 1907, uma jovem metodista canadense, Aimeé Semple McPerson, converteu-se pela pregação de Robert Semple, missionário pentecostal (parece que vindo de Chigago). Ano seguinte, teve uma experiência de cura divina com o próprio reverendo W. H. Durham, que já havia influenciado Daniel Berg e Luigi Francescon". ${ }^{50}$ Assim, a entrada do movimento pentecostal no Brasil acontece de forma múltipla, mas com traços comuns importantes entre as primeiras denominações pentecostais brasileiras e o pentecostalismo de Chicago.

A pesquisa concentra-se, a partir deste ponto, na Igreja do Evangelho Quadrangular. Segundo Dias: “a Igreja do Evangelho Quadrangular é uma das mais importantes denominações pentecostais no Brasil". ${ }^{51}$ As manifestações do pentecostalismo na Igreja do Evangelho Quadrangular se dão desde a fundação. Para Santos:

Inspirando-se em profecia de Ezequiel, Aimeé escolhe a denominação de Evangelho Quadrangular para sua obra, significando, segundo expresso em "declaração de fé" da Igreja do Evangelho Quadrangular, a dimensão da missão de Cristo entre os homens como salvador, batizador, médico, e rei que voltará. Aimeé,

\footnotetext{
${ }^{48}$ ALEIXO, V. C., "Deus Faz, o Templo dos Anjos Mostra", p. 25.

${ }^{49}$ ALEIXO, V. C., "Deus faz, o templo dos anjos mostra", p. 25.

${ }^{50}$ SANTOS, V. R., Tempos de exaltação, p. 19.

${ }^{51}$ DIAS, Agemir de Carvalho. A implantação da Igreja do Evangelho Quadrangular em Curitiba: a evangelização através de tendas. Anais eletrônicos. Congresso de Teologia da PUC/PR. Curitiba, 2009 , p. 80 .
} 
após servir como missionária na China, voltou aos Estados Unidos e fundou na mesma cidade de Los Angeles, onde se deram as primeiras manifestações pentecostais, a Igreja do Evangelho Quadrangular. ${ }^{52}$

A chegada da Igreja do Evangelho Quadrangular no Brasil acontece por intermédio de um movimento denominado de cura divina. Segundo Tureck: "quarenta anos depois de haver chegado o movimento pentecostal no Brasil, e depois de ter sido um instrumento poderoso nas mãos de Deus, parecia que algo ainda faltava. Quase a totalidade dos brasileiros estava por ser evangelizada ainda, e jamais o seria somente dentro dos templos". ${ }^{53}$ Estudiosos do pentecostalismo brasileiro atribuem a essa denominação forte contribuição na propagação do movimento pentecostal no Brasil, como Santos:

O movimento de cura divina promovido pela Cruzada Nacional de Evangelização abalou o Brasil protestante, envolvendo numerosos pastores e líderes leigos de outras denominações. Como resultado surgiram outras igrejas pentecostais, como a Igreja evangélica pentecostal "O Brasil para Cristo", a Igreja de Cristo Pentecostal, a Igreja Evangélica do Avivamento Bíblico, etc. Assim como foi a gênese de todo o movimento de cura divina, que pendura até hoje. ${ }^{54}$

O Brasil pentecostal, antes da chegada da Igreja do Evangelho Quadrangular, não era muito popular. Mendonça informa: “a explosão pentecostal teve como ponto de partida o movimento de 'tendas de cura divina', promovido pela chamada Cruzada Nacional de Evangelização que alcançou o país todo" ${ }^{55}$ A partir do movimento de cura divina, considerado novidade no meio pentecostal brasileiro da época, propaga-se o movimento pentecostal por todo o país. Santos afirma: "a Igreja do Evangelho Quadrangular foi o estopim da segunda onda pentecostal. Das seis grandes igrejas pentecostais brasileiras, é a única de origem realmente norte-americana. E mesmo assim, foi fundada nos Estados Unidos por uma canadense" ${ }^{56}$ Essa igreja destaca-se a partir de suas campanhas de cura divina, concentrando muitas pessoas em tendas de lona já no seu início no Brasil. Santos lembra: "a implantação no Brasil se dá alguns anos depois da morte de

\footnotetext{
${ }_{52}^{52}$ SANTOS, V. R., Tempos de exaltação, p. 19-20.

${ }^{53}$ TURECK, Andre. Cuidando da comunicação em família: uma reflexão sobre a interação entre cônjuges na primeira igreja do Evangelho Quadrangular em Curitiba. Dissertação de Mestrado. Escola Superior de Teologia. São Leopoldo, 2009, p. 19.

${ }^{54}$ SANTOS, V. R., Tempos de exaltação, p. 20.

${ }^{55}$ MENDONÇA, Antonio Gouvêa. O protestantismo no Brasil e suas encruzilhadas. Revista USP, São Paulo, n. 67, p. 48-67, set/nov., 2005, p. 61.

${ }^{56}$ SANTOS, V. R., Tempos de exaltação, p. 23.
} 
Aimeé" ${ }^{57}$ A missão da Igreja do Evangelho Quadrangular assume proporções internacionais ainda com sua fundadora, mas chega ao Brasil mediante outros líderes.

Rosa (1977), historiador da Igreja do Evangelho Quadrangular no Brasil, é quem melhor retrata a chegada e os marcos históricos da igreja. Em O Evangelho Quadrangular no Brasil, ele relata os 25 anos iniciais da denominação no Brasil. Essa fonte, provavelmente a mais respeitada no que se refere à primeira fase da IEQ brasileira, começa com o histórico dos seus fundadores. Rosa destaca: "no dia 27 de novembro de 1913, nascia na cidade de Hollywood, Estados Unidos, uma criança que Deus usaria mais tarde como pregador do evangelho na América do Sul. Warold Edwim Williams era o nome dessa criança". ${ }^{58}$ Esse missionário enviado ao Brasil recebeu seu preparo teológico na Igreja do Evangelho Quadrangular dos Estados Unidos. Rosa assim refere o seu desenvolvimento: “em sua cidade, estudou no 'Hollywood High School' e no seminário 'L.I.F.E.' da Igreja do Evangelho Quadrangular Internacional, em Los Angeles, concluindo seus estudos de teologia em 1940". 59

Depois de formado, Williams trabalhou durante anos ajudando a liderança da IEQ nos Estados Unidos, cumprindo diversas tarefas, mas já queria ser missionário em outro país. Scotti ressalta: "Harold Edwin Williams também, a exemplo de nossa fundadora, venceu todos os obstáculos e tentativas de barrar seu propósito de pregar a Palavra de Deus a outras nações". ${ }^{60}$ Harold Williams, buscando uma possível missão no exterior, oficializa sua intenção ao órgão responsável pela missão internacional da Quadrangular. Rosa diz: "tratou de informar ao secretário de missões da Igreja Quadrangular a sua decisão de partir para o estrangeiro. Um ano depois, o seu pedido era atendido, quando foi convidado para assumir a direção de uma escola da Igreja Quadrangular na Bolívia". 61

Harold Williams foi à Bolívia desenvolver um trabalho específico em uma escola do país, porém seu trabalho missionário lá não foi bem sucedido. Conforme Scotti: "ele foi para a Bolívia como missionário da IEQ americana, mas Deus o

\footnotetext{
${ }^{57}$ SANTOS, V. R., Tempos de exaltação, p. 24.

${ }^{58}$ ROSA, Júlio O. O evangelho quadrangular no Brasil. Belo Horizonte: Betânia, 1977, p. 248.

${ }^{59}$ ROSA, O evangelho quadrangular no Brasil, p. 248.

${ }^{60}$ SCOTTI, Ignez T. R. Quadrangular: há 65 anos sendo a luz que resplandece neste mundo! São Paulo: Quadrangular, 2016, p. 6.

${ }^{61}$ ROSA, J. O., O evangelho quadrangular no Brasil, p. 248.
} 
direcionou ao Brasil”. ${ }^{62}$ Uma senhora, responsável pela escola, tentou impedir o trabalho de Williams no cargo. Scotti afirma que ele "permaneceu um ano na Bolívia, tentando desenvolver de alguma forma seu trabalho missionário". ${ }^{6}$

O estabelecimento dessa denominação no Brasil não foi orquestrado pela direção da igreja norte-americana, mas deveu-se a uma série de eventos que fugiram ao controle da liderança. Rosa demarca essa série: "enquanto isso, outro fato havia acontecido em $1^{\circ}$ de abril de 1937, na cidade de Lima, no Peru. Um jovem peruano de nome Hermírio Vasquez ingressava na Escola Bíblica da Assembleia de Deus, a fim de seguir carreira ministerial, para a qual fora chamado por Deus. Hermírio nasceu na cidade de Huaillacayn, no Peru" ${ }^{64}$ Esse jovem, que se preparava para o trabalho missionário de raiz assembleiana, buscava ser missionário, orando com vistas ao seu objetivo, e mais tarde se dirigindo à Bolívia. Rosa lembra:

\begin{abstract}
Hermírio, enquanto estudava e ajudava um pastor lá em Lima, orava para que Deus lhe mostrasse onde deveria abrir uma obra. Mais tarde, sentiu a direção de Deus de ir para a Bolívia. Assim, a 7 de janeiro de 1940, juntamente com um outro seu colega de estudos, iniciava uma obra missionária na cidade de Trinidad, na Bolívia, onde permaneceu até 1946. Andou mais um pouco, e chegou à fronteira da Bolívia com o Brasil, entrando em Porto Velho, já no Brasil. Alei entrou em contato com muitos brasileiros, percebendo logo a grande receptividade destes ao Evangelho. ${ }^{65}$
\end{abstract}

A história da missão quadrangular brasileira passa pelo decisivo encontro entre Williams e Vasquez. Santos de Paula trata da continuação do pentecostalismo: "foi durante os anos 1950 que chegou ao Brasil, com a implantação da Igreja do Evangelho Quadrangular (IEQ), em 1951, um novo tipo de pentecostalismo, denominado de pentecostalismo neoclássico". ${ }^{66} \mathrm{~A}$ IEQ, portanto, é introduzida no Brasil pelo trabalho de dois missionários, um de tradição quadrangular e outro de tradição assembleiana. Rosa esclarece: "em Trinidad, em 1945, Hermírio já havia entrado em contato, pela primeira vez, com o pastor Williams, que lá desenvolvia o seu trabalho missionário". ${ }^{67} \mathrm{O}$ trabalho não crescia como Harold esperava e seu encontro com o missionário peruano

\footnotetext{
${ }^{62}$ SCOTTI, I. T., Quadrangular, p. 6.

${ }^{63}$ ROSA, J. O., O evangelho quadrangular no Brasil, p. 248.

${ }^{64}$ ROSA, J. O., O evangelho quadrangular no Brasil, p. 248-249.

${ }^{65}$ ROSA, J. O., O evangelho quadrangular no Brasil, p. 249-250.

${ }^{66}$ PAULA, Vitor Aparecido Santos de. Religião e política no Vale do Paranapanema: a Igreja do Evangelho Quadrangular em Assis-SP (1996-2008). Dissertação de Mestrado. ASSIS, 2012. p. 30.

${ }^{67}$ ROSA, J. O., O evangelho quadrangular no Brasil, p. 250.
} 
Hermírio o inspirou a desenvolver seu trabalho no Brasil. Mas como ele havia sido comissionado por sua igreja para atuar na Bolívia, deveria regressar aos Estados Unidos para obter a autorização de sua liderança para representar a Quadrangular em outro país. Rosa assegura:

Naquela hora difícil, em que devia tomar uma decisão capaz de mudar toda a sua vida e de sua família, e que até certo ponto parecia uma atitude de rebeldia contra seus superiores eclesiásticos, o encontro com Hermírio Vasquez foi a melhor coisa que lhe acontecera. A palavra de estímulo daquele pastor peruano, calmo, com aquela voz grave, e melhor conhecedor dos hábitos e costumes latino-americanos, infundiram novo ânimo em Harold Williams. E a decisão foi tomada: viriam para o Brasil, mesmo com o risco de entrar em conflito com seus superiores. ${ }^{68}$

A aliança estabelecida entre os dois missionários, essencial para o ingresso e progresso da missão pentecostal no Brasil, deixa clara a possibilidade de diálogo ecumênico entre pentecostais. Sobre a mensagem quadrangular no Brasil, Dias assegura: "foi trazida ao Brasil no ano de 1946 pelos missionários Harold Edwin Williams e Jésus Hermírio Vasquez". ${ }^{69}$ Rosa também afirma: "entraram o Brasil, pelo porto de Guarajamirim, em maio de 1946, fronteira do Brasil com a Bolívia". ${ }^{70}$ Os dois missionários romperam a fronteira das diferenças geográficas e iniciaram a peregrinação em terras brasileiras até encontrarem o lugar certo para a propagação da missão pentecostal, e tendo como meta as grandes cidades do país, desembarcaram em São Paulo. Rosa lembra: "de Santos, chegando na capital paulista, sentiram que não era a vontade de Deus que ficassem na capital; seguiram então para Poços de Caldas, em Minas Gerais". ${ }^{71}$ Os pentecostais buscam esse tipo de percepção a fim de sustentar decisões consideradas diretivas de Deus, mas Minas Gerais ainda não era o lugar. Assim, voltaram a São Paulo. Rosa diz: "mudando-se para São João da Boa Vista, cidade paulistana, o pastor Williams fundou a Igreja Quadrangular naquela cidade, no ano de 1951, sob o nome de 'Igreja Evangélica do Brasil'", 72

A instalação de Williams no Brasil ainda não contava com o apoio da Quadrangular dos Estados Unidos. Scotti diz: “junto com o missionário Jesus Hermírio Vasquez Ramos, fundou a ‘Igreja Evangélica do Brasil', em São João da

\footnotetext{
${ }^{68}$ ROSA, J. O., O evangelho quadrangular no Brasil, p. 250.

${ }^{69}$ DIAS, A. C., A implantação da Igreja do Evangelho Quadrangular em Curitiba, p. 80.

${ }^{70}$ ROSA, J. O., O evangelho quadrangular no Brasil, p. 250.

${ }^{71}$ ROSA, J. O., O evangelho quadrangular no Brasil, p. 250.

${ }^{72}$ ROSA, J. O., O evangelho quadrangular no Brasil, p. 250-251.
} 
Boa Vista, no ano de $1950 "{ }^{73}$ Independente e autônoma, a primeira igreja fundada por Williams no Brasil, antes de um concerto entre ele e a liderança norte-americana, é denominada Igreja Evangélica do Brasil. Scotti continua: "este foi o nome dado por ele naquele primeiro momento, mas em 1958, a Igreja passou a ter o nome que lhe era devido: Igreja do Evangelho Quadrangular". ${ }^{74}$ Paula assegura: "sua ligação com a igreja internacional foi assegurada, ficando a esta a prerrogativa de indicar o presidente da Igreja do Evangelho Quadrangular no Brasil, situação essa que perdurou até meados da década de 1980 " ${ }^{75}$ Os dois primeiros anos de trabalho em São João da Boa Vista serviram de base para o amadurecimento e o planejamento da estratégia missionária a ser praticada no Brasil.

\subsection{2.}

\section{Das Tendas à Igreja do Evangelho Quadrangular}

Depois de algum tempo em São João da Boa Vista, o movimento rumou para a capital, fato decisivo para o desenvolvimento do trabalho. Lopes ressalta: "mas o trabalho ficou restrito àquela cidade por dois anos. Seu desenvolvimento deu-se somente a partir de 1953, quando, a convite de Williams, o pregador de cura divina Raymond Boatright iniciou campanhas de cura divina com as famosas tendas de lona aos moldes de Aimee, sua precursora" ${ }^{76}$ A história inicial da IEQ no Brasil é resultado da tradição religiosa do missionário Harold Williams, ainda que este não estivesse em missão pela Igreja Quadrangular, apenas reproduzindo sua prática missionária. Lopes afirma: “dessas campanhas surgiria a Cruzada Nacional de Evangelização". ${ }^{77}$ grande movimento ecumênico de alguns protestantes e pentecostais da década de 1950.

A IEQ introduziu no campo religioso brasileiro um elemento pouco conhecido até a época. Mendonça diz: “a novidade era a nova ênfase na cura

\footnotetext{
${ }^{73}$ SCOTTI, I. T., Quadrangular, p. 6.

${ }^{74}$ SCOTTI, I. T., Quadrangular, p. 6.

${ }^{75}$ PAULA, V. A. S., Religião e política no Vale do Paranapanema, p. 52.

${ }^{76}$ LOPES, Marcelo. O legado de uma pioneira: Aimee Semple McPherson, a cura divina e seus desdobramentos no subcampo religioso pentecostal brasileiro. Plura, Revista de Estudos de Religião, ISSN 2179-0019, vol. 6, nº 1, p. 74-99, 2015, p. 86-86.

${ }^{77}$ LOPES, M.,O legado de uma pioneira, p. 85-86.
} 
divina". ${ }^{78}$ A chamada cura divina, comum nos Estados Unidos, era praticada pela própria fundadora da IEQ, que desenvolveu grande parte de sua ação missionária com base nesse princípio, mas no Brasil essa era novidade, apesar da presença dos primeiros pentecostais durante décadas. Por isso alguns estudiosos classificam a IEQ como pertencente à segunda onda do pentecostalismo inserida no Brasil, dada a sua chegada ao Brasil aproximadamente quarenta anos depois dos primeiros pentecostais. Para Mendonça, "muitos pastores e leigos dessas igrejas, influenciados pela nova prática religiosa, vieram a fundar várias igrejas no mesmo estilo". ${ }^{79}$

Sobre a ação missionária praticada pela IEQ nos primeiros anos em terras brasileiras, Rosa destaca: “o estranho movimento da cura divina em São Paulo. Das inúmeras manchetes nos jornais paulistanos naquele ano de 1953, nos primeiros dias de março, esta era uma: 'É A Repetição dos Milagres de Cristo' cegos enxergando e paralíticos andando" ${ }^{80} \mathrm{O}$ fenômeno era considerado estranho, pela novidade, mas ganhou evidência na região.

A Igreja do Evangelho Quadrangular no Brasil tem como grande marca a evocação de cura do corpo físico, eixo temático de sua pregação e exposição aos brasileiros. Assim, aos poucos, o movimento foi ganhando identidade e ficou conhecido, segundo Rosa, como "Movimento da Cura Divina". Mais tarde, esse movimento passou a chamar-se Cruzada Nacional de Evangelização". ${ }^{81}$ título inspirado pelo seu crescimento em escala tão notável que alcançou todo o território brasileiro. O nome também era vinculado à intenção inicial de não se estabelecer em templos, mas levar a cabo campanhas de reavivamento nos moldes desenvolvidos nos Estados Unidos pela IEQ e outras denominações do movimento pentecostal. Rosa lembra: "o local dos acontecimentos era um templo evangélico Presbiteriano Independente no número 1140 da Rua Barão de Jaguara, no bairro do Cambuci". ${ }^{82}$

A Igreja Presbiteriana Independente contribuiu grandemente com a instalação da IEQ no Brasil e foram seus templos que abrigaram as primeiras campanhas de cura divina da Cruzada Nacional de Evangelização, primeiro nome do movimento quadrangular brasileiro. Rosa continua: "na fachada do templo,

\footnotetext{
${ }^{78}$ MENDONÇA, A. G., O protestantismo no Brasil e suas encruzilhadas, p. 61.

${ }^{79}$ MENDONÇA, A. G., O protestantismo no Brasil e suas encruzilhadas, p. 61.

${ }^{80}$ ROSA, J. O., O evangelho quadrangular no Brasil, p. 15.

${ }^{81}$ ROSA, J. O., O evangelho quadrangular no Brasil, p. 15.

${ }^{82}$ ROSA, J. O., O evangelho quadrangular no Brasil, p. 15.
} 
uma grande faixa de pano fora pendurada. Nessa faixa lia-se o seguinte: 'Alerta, Povo do Cambuci - Cura Divina Pela Oração - Todos São Bem-Vindos - Entrada Franca.' Constava também o nome do conferencista americano, Raymond Boatright, horário e datas das reuniões". ${ }^{83}$

O missionário Harold Williams havia convidado seu amigo, que empreendia campanhas de reavivamento nos Estados Unidos. Nessa etapa inicial os missionários utilizavam tudo daquilo que cooperava para o andamento da missão. Mendonça destaca: "foi um movimento religioso tipicamente urbano que começou em São Paulo em 1953" ${ }^{84}$ Percebe-se, assim, que a IEQ brasileira, nos primeiros anos, por meio dos missionários fundadores, exercitavam grande diálogo e práticas ecumênicas com outras denominações. Sobre o pastor presbiteriano responsável por acolher o movimento de cura divina em sua igreja, Rosa diz: "tratava-se do Rev. Silas Dias, pastor daquela igreja, que corajosamente abrira as portas para os missionários americanos da "cura divina"" ${ }^{85}$

A inovação proposta era bastante ousada: "tal atitude naqueles dias era uma temeridade e requeria coragem. Certos pontos doutrinários dos missionários americanos entravam em choque com as doutrinas presbiterianas". 86 Mesmo diante do risco, o diálogo continuou, juntamente com a campanha de reavivamento, e o trabalho evangelístico foi preparado no templo da Igreja Presbiteriana Independente, de forma, aliás, bem diferente da tradição presbiteriana. Dias pontua: “a IEQ foi a maior e mais impactante denominação da segunda onda do protestantismo brasileiro. Isso ocorreu por causa da sua atuação nos centros urbanos, alcançando pessoas das mais variadas condições socioeconômicas e culturais". ${ }^{87}$

A experiência pentecostal brasileira até então não havia se deparado com campanhas do modelo apresentado pelo convidado estadunidense. Rosa diz: "de acordo com as informações colhidas aqui e ali, Raymond Boatright, aparentando uns 35 anos de idade, fora um artista de cinema. Nos filmes de 'Far west' fazia papéis de 'cowboy', sendo um astro de destaque no seu tempo". ${ }^{88}$ A preparação e o domínio artístico de missionários muito ajudou na comunicação com o público

\footnotetext{
${ }^{83}$ ROSA, J. O., O evangelho quadrangular no Brasil, p. 15-16.

${ }^{84}$ MENDONÇA, A. G., O protestantismo no Brasil e suas encruzilhadas, p. 61.

${ }^{85}$ ROSA, J. O., O evangelho quadrangular no Brasil, p. 16.

${ }^{86}$ ROSA, J. O., O evangelho quadrangular no Brasil, p. 16.

${ }^{87}$ DIAS, A. C., A Implantação da Igreja do evangelho quadrangular em Curitiba, p. 80-81.

${ }^{88}$ ROSA, J. O., O evangelho quadrangular no Brasil, p. 17.
} 
brasileiro, pois suas campanhas nos Estados Unidos eram bem sucedidas, alojadas em lonas, exatamente como a fundadora da IEQ utilizou no início de suas campanhas, que culminou com a revelação do Evangelho Quadrangular. Rosa continua: "em suas campanhas evangelísticas realizadas nas enormes tendas de lona, feitas especialmente para esse trabalho, 'Slim", ${ }^{89}$ As experiências missionárias na IEQ tinham variados modos de apresentação, mas sem dúvida o que mais caracteriza a missão quadrangular são suas campanhas de reavivamento, com a proclamação da cura divina e o batismo com o Espírito Santo. Mendonça acrescenta: "ao lado da cura divina, como complemento, vinha o exorcismo de demônios". ${ }^{90}$ Os missionários da IEQ desenvolviam esse trabalho em vários lugares. Rosa afirma: "no ano de 1950, o pastor Raymond havia visitado a cidade de São João da Boa Vista, no estado de São Paulo, onde realizou uma campanha evangelística, cujos resultados foram milagres ainda testemunhados três anos depois". ${ }^{91}$ Tal relato mostra que, pelo menos três anos antes de as campanhas ganharem força, já havia tentativas em São Paulo.

A fundação da IEQ no Brasil não teria tanto êxito na fase inicial se não fosse o protagonismo do missionário Raymond, conferencista que melhor se comunicou com o povo brasileiro. Dias destaca: "enfatizou a cura divina nos seus cultos, se diferenciando do pentecostalismo da primeira onda que enfatizava a glossolalia". ${ }^{92}$ Abrindo o caminho para a missão da IEQ em terras brasileiras, sua maneira de evangelizar foi muito bem recebida pela cultura local. Rosa continua:

\begin{abstract}
Analisando a evolução desta Cruzada através destes anos, bem como o incomparável reavivamento espiritual que envolveu o Brasil em decorrência do movimento de 'cura divina', não podemos deixar de pensar naquele ano de 1950. Tornou-se claro que Deus já preparava as coisas para os acontecimentos que se seguiriam. ${ }^{93}$

É necessário lembrar mais uma vez que o objetivo inicial dos primeiros missionários eram as campanhas de reavivamento. Mendonça assegura: "a cruzada atingiu as igrejas tradicionais, bem como as pentecostais clássicas". ${ }^{94}$ Vários grupos adeririam mais tarde à Cruzada, graças às proporções alcançadas
\end{abstract}

\footnotetext{
${ }^{89}$ ROSA, J. O., O evangelho quadrangular no Brasil, p. 17.

${ }^{90}$ MENDONÇA, A. G., O protestantismo no Brasil e suas encruzilhadas, p. 61.

${ }^{91}$ ROSA, J. O., O evangelho quadrangular no Brasil, p. 17.

${ }^{92}$ DIAS, A. C., A implantação da Igreja do Evangelho Quadrangular em Curitiba, p. 81.

${ }^{93}$ ROSA, J. O., O evangelho quadrangular no Brasil, p. 19.

${ }^{94}$ MENDONÇA, A. G., O protestantismo no Brasil e suas encruzilhadas, p. 61.
} 
pelo movimento de cura divina, cujo responsável foi o missionário Raymond. Rosa diz: "esse homem seria usado por Deus três anos mais tarde, dando início ao mais espantoso e estranho movimento na capital paulista, O Movimento da Cura Divina". ${ }^{95}$ A sequência descrita por Rosa mostra claramente que a IEQ no Brasil só conquista espaço depois da chegada do missionário Raymond, com suas campanhas de cura divina. Essas campanhas foram organizadas pelos fundadores da IEQ no Brasil Harold Williams e Hermírio Vasquez. Rosa assegura: “o 'show' prosseguia. Digo 'show', porque uma extraordinária novidade musical fora introduzida num culto religioso aqui no Brasil; o uso de uma guitarra elétrica, tocada com muita habilidade pelo pastor Raymond, enquanto cantava corinhos religiosos". ${ }^{96}$ A IEQ foi responsável por uma renovação na liturgia pentecostal no Brasil: a introdução de instrumentos elétricos nas reuniões era mais um elemento de inovação no cenário religioso local, destacando-se, mais uma vez, a importância do missionário Raymond na história do pentecostalismo brasileiro. Segundo Dias, a IEQ "utilizou instrumentos de comunicação de massa, principalmente o rádio. Ela inovou com a ordenação das mulheres a cargos ministeriais". ${ }^{97}$ Tudo era muito novo no Brasil e tais inovações causavam grande impacto. É Rosa quem assegura: "sinceramente, eu nunca antes ouvira uma mensagem evangelística naquele estilo. Era o estilo dos apóstolos de Cristo, mas numa apresentação mais moderna ou atualizada". ${ }^{98}$ A partir de então inicia-se o que seria conhecido como a segunda fase do pentecostalismo no Brasil, depois da chegada das primeiras denominações pentecostais, no início do século XX. Este é o momento de grande disseminação no Brasil. ${ }^{99}$ Rosa detalha bem esse momento de grande disseminação no Brasil, pois vivenciou essa fase do pentecostalismo brasileiro:

\footnotetext{
${ }^{95}$ ROSA, J. O., O evangelho quadrangular no Brasil, p. 19.

${ }^{96}$ ROSA, J. O., O evangelho quadrangular no Brasil, p. 19.

${ }^{97}$ DIAS, A. C., A implantação da Igreja do evangelho quadrangular em Curitiba, p. 80-81.

${ }^{98}$ ROSA, J. O., O evangelho quadrangular no Brasil, p. 20.

${ }^{99}$ A IEQ difere de outras denominações do pentecostalismo, a exemplo das Assembleias de Deus, quanto à ordenação de mulheres. É destaque em sua atuação missionária a presença e atuação da liderança feminina. A IEQ já nasce com essa tradição, por ter sido fundada por uma mulher; daí a inexistência de dificuldades internas sobre a temática. Tais questionamentos sobre a ordenação de mulheres têm sido ponto constante da pauta de outras denominações pentecostais. Dessa maneira, a discussão desse tema, no caso da IEQ, pode ser proposta para reflexão e diversas formas de ação. $\mathrm{Na}$ IEQ as mulheres exercem cargos de liderança sem restrição ou impedimento de hierarquia. As mulheres na IEQ ocupam diversos cargos dentro da organização, que variam da liderança de regiões e estados até o pastoreio, entre outras funções de destaque.
} 
Naquela noite, o missionário americano orou por muita gente. E o que realmente aconteceu, jamais vi antes; cegos voltaram para suas casas vendo, surdos ouviram, endemoniados foram libertos e centenas de pessoas viriam a testemunhar nos dias que seguiram a cura de enfermidades internas, mesmo as mais graves e desenganadas pela medicina. Eu mesmo fui curado, pela oração daquele homem de Deus, de deficiências no pulmão esquerdo, em consequência de uma pleuresia. ${ }^{100}$

Algo diferente começava acontecer no estado de São Paulo, como enfatiza Mendonça: "na verdade, a Cruzada Nacional de Evangelização foi a origem dos neopentecostais". ${ }^{101}$ De fato, o movimento de cura divina no Brasil foi decisivo para redesenhar o cenário religioso brasileiro, marcando a gênese das igrejas neopentecostais. Rosa afirma: "eu não sabia meio que ninguém ali suspeitava, nem mesmo os dirigentes dessa campanha, que chegara para todo o povo brasileiro, oprimido e cansado de buscar alívio para seus males físicos e espirituais, a verdadeira hora dos milagres e da libertação. E mais do que isso". ${ }^{102}$ Foi um tempo de unidade.

Certo detalhe muito relevante na historia do pentecostalismo brasileiro é digno de nota. Tureck diz: "nos anos de 1950, era mais que evidente a grande fome e sede espiritual. Grupos avivados oravam buscando mais poder e um reavivamento nacional. As reuniões aconteciam numa sala alugada, no terceiro andar de um prédio à Rua Líbero Badaró, região oeste do centro velho de São Paulo". ${ }^{103}$ Podemos chamar esse movimento de oração ecumênica, congregando religiosos de várias denominações protestantes que oravam por um avivamento no Brasil. Tureck diz: "o local se tornou conhecido como "irmãos de fogo". ${ }^{104}$ Esse grupo reunia pastores e muitos leigos, que por anos oraram juntos. Rosa afirma:

Ninguém imaginava que naquele $1^{\circ}$ de março de 1953, naquele templo da Rua Barão de Jaguara, acontecia a resposta de Deus às orações de um grupo de pessoas, pastores e leigos de diversas denominações, que clamaram durante cinco anos por um grande avivamento espiritual no Brasil. ${ }^{105}$

\footnotetext{
${ }^{100}$ ROSA, J. O., O evangelho quadrangular no Brasil, p. 23.

${ }^{101}$ MENDONÇA, A. G., O protestantismo no Brasil e suas encruzilhadas, p. 61.

${ }^{102}$ ROSA, J. O., O evangelho quadrangular no Brasil, p. 24.

103 TURECK, A., Cuidando da comunicação em família, p. 20.

104 TURECK, A., Cuidando da comunicação em família, p. 20.

${ }^{105}$ ROSA, J. O., O evangelho quadrangular no Brasil, p. 24.
} 
Entre os pentecostais é comum o entendimento de que o movimento interdenominacional Cruzada Nacional de Evangelização seria a resposta das orações por avivamento no Brasil. Bellotti destaca:

A vinda da Cruzada teria sido, de acordo com a tradição evangélica fartamente reconstruída como parte da memória religiosa militante, o atendimento às orações por avivamento feitas por evangélicos desde meados da década de 1940 em São Paulo. ${ }^{106}$

O movimento era uma proposta de evangelização interdenominacional.

É preciso destacar a presença de leigos - elemento ontológico na propagação pentecostal - nesse movimento que antecede a segunda onda do pentecostalismo no Brasil. Além disso, também molda sua forma missionária e sua presença, sempre alinhando o movimento pentecostal com o povo por intermédio da comunicação. Rosa relata: "terminada esta campanha em São Paulo, o Pastor Raymond seguiu para o interior, Assis e Botucatu, permanecendo uma semana em cada dessas cidades". ${ }^{107}$ No decorrer das campanhas, os testemunhos de curas se repetiam pelas cidades onde o missionário evangelizava, numa peregrinação por diversas urbes paulistas. Lopes destaca: “objetivamente, a Cruzada começou, no princípio da década de cinquenta, seus trabalhos numa Igreja Presbiteriana Independente". ${ }^{108}$ Rosa também destaca o papel estruturante da Igreja Presbiteriana Independente: "cumprida sua missão, retornou a São Paulo, onde já estava programando uma outra campanha no templo da terceira Igreja Presbiteriana Independente, localizada à Rua Joli, 508, no Braz. Essa campanha durou de 29 de março a 4 de abril do mesmo ano de 1953". ${ }^{109}$ Mais uma vez destaca-se a importância da Igreja Presbiteriana Independente na estruturação da Igreja do Evangelho Quadrangular no Brasil, o que mostra claramente o espírito ecumênico que assegurava o sucesso do movimento: de um lado, um grupo de pastores e leigos de diversas denominações; e de outro lado, uma denominação com princípios divergentes do movimento em análise, abrindo seus templos para esses trabalhos.

\footnotetext{
${ }^{106}$ BELLOTTI, Karina Kosicki. Delas é o reino dos céus: mídia evangélica infantil na cultura pósmoderna do Brasil (anos 1950 a 2000). Tese de Doutorado. Campinas, SP, 2007, p. 74.

${ }^{107}$ ROSA, J. O., O evangelho quadrangular no Brasil, p. 27.

${ }^{108}$ LOPES, M., O legado de uma pioneira, p. 89.

${ }^{109}$ ROSA, J. O., O evangelho quadrangular no Brasil, p. 27.
} 
Pode-se denominar a segunda fase do pentecostalismo brasileiro de ecumênica. É Rosa quem informa: “dezenas de pastores e obreiros de diversas denominações evangélicas tinham sido autorizados pelos missionários americanos a efetuar a imposição das mãos sobre os enfermos, em nome de Cristo". ${ }^{110} \mathrm{O}$ trabalho pentecostal desenvolvido nessa fase parece manter o diálogo com o diferente, resultando em aproximação e crescente força do movimento. Esse gesto de imposição de mãos, autorizado pelos missionários americanos aos pastores e obreiros brasileiros, abriu caminho para um nova prática religiosa no Brasil, como retrata Rosa: "concluída a campanha no Braz, o pastor Raymond realizou a sua terceira campanha em São Paulo, no templo do avivamento Bíblico, à Av. Henry Janot, em Vila Mazzei. Nessa igreja havia uma vantagem; criam basicamente nas mesmas doutrinas da Igreja do Evangelho Quadrangular, o que contribuiria favoravelmente para o derramamento das bênçãos". ${ }^{111}$ Essa primeira etapa termina com as campanhas nos templos de diversas denominações. É Bellotti quem informa: "muitos simpatizantes e obreiros da Cruzada eram de diversas igrejas, em especial, da Igreja Presbiteriana Independente, Metodista, Batista e Assembléia de Deus". ${ }^{112}$ Fica evidente, assim, que a origem da Cruzada Nacional de Evangelização foi ecumênica.

A fase inicial da IEQ no Brasil foi marcada pelo movimento denominado Cruzada Nacional de Evangelização. O termo, nada novo no cristianismo, remete primeiramente ao período medieval. Walker destaca: "as Cruzadas estão entre os fenômenos mais notáveis da Idade Média". ${ }^{113}$ É importante destacar que o termo está associado a guerras, disputas e conquistas, pois a Cruzada foi o empreendimento em torno da Terra Santa e marcou um longo período de disputas entre cristãos e muçulmanos que incendiou as relações entre as duas religiões, como lembra González:

De todas as tentativas de reconquistar com armas o território conquistado pelos mulçumanos, a mais notável foi a das Cruzadas, ainda que nem tanto pelos seus resultados diretos, que foram efêmeros, como pela permanência de seus ideais ao longo dos séculos, e sobretudo por seu indelével impacto nas relações entre cristãos e mulçumanos. ${ }^{114}$

\footnotetext{
${ }^{110}$ ROSA, J. O., O evangelho quadrangular no Brasil, p. 28.

${ }^{111}$ ROSA, J. O., O evangelho quadrangular no Brasil, p. 28.

${ }^{112}$ BELLOTTI, K. K., Delas é o reino dos céus, p. 74.

${ }^{113}$ WALKER, Wiliston. História da Igreja Cristã. São Paulo: ASTE, 2006, p. 327.

${ }^{114}$ L. GONZÁLEZ, J. História do movimento missionário, p. 136.
} 
As impressões negativas que marcam a ideia das Cruzadas fazem parte da herança desse período histórico, que envolvia disputa territorial, anexando violência e imposição, como relata Walker: "o amor pela aventura, a esperança por pilhagens, o desejo de aquisições territoriais e o ódio religioso sem dúvida moveram os cruzados com impulsos bastante mundanos". 115 As Cruzadas tiveram início com Urbano: "Urbano assim combinou a antiga ideia de peregrinação à Terra Santa com a ideia mais recente de guerra santa contra os infiéis". ${ }^{116}$ Essa mensagem de guerra resultou em duplicidade, já que "o cruzado era simultaneamente peregrino e soldado." ${ }^{\prime 17} \mathrm{O}$ apelo de Urbano foi respondido pelo povo: "a mensagem de Urbano encontrou resposta imediata e entusiástica. Os cronistas relataram que seu anúncio da cruzada ao povo reunido fora de Clermont foi saudado com um grande brado de Deus lo volt: Deus quer isso!" ${ }^{118}$ A manipulação do discurso sobre a vontade de Deus somou-se a outros acontecimentos que se processavam desde 1095, como explica González:

Muitos outros incidentes e tendências da época constituíram o pano de fundo das Cruzadas. De forma geral tem-se como ponto de partida desse novo fenômeno o chamado, na cidade de Clermont, do Papa Urbano II para que um exército cristão marchasse até o Oriente a fim de arrebatar dos muçulmanos os santos lugares: "Digo aos presentes; faço-o dizer aos ausentes: Cristo manda". Esse eloquente chamado aconteceu no ano de $1095 .{ }^{119}$

Foram vários os empreendimentos de Cruzadas, quase sempre marcados por violência e intolerância: "houve primeiro uma série de Cruzadas populares nas quais as multidões sem organização, nem outro propósito senão chegar a Jerusalém, partiram para o Oriente. No caminho, cometeram arbitrariedades contra a população local, e em particular contra os Judeus". ${ }^{120}$ As armas tornaramse componentes das Cruzadas na tentativa de retomada do território sob domínio muçulmano: "no entanto, a cristandade ficou convencida de que era possível reconquistar o território perdido para o poderio mulçumano com força das

\footnotetext{
${ }^{115}$ WALKER, Wiliston. História da Igreja Cristã. São Paulo: ASTE, 2006, p. 328.

${ }^{116}$ WALKER, Wiliston. História da Igreja Cristã. São Paulo: ASTE, 2006, p. 329.

${ }^{117}$ WALKER, Wiliston. História da Igreja Cristã. São Paulo: ASTE, 2006, p. 329.

${ }^{118}$ WALKER, Wiliston. História da Igreja Cristã. São Paulo: ASTE, 2006, p. 329.

${ }^{119}$ L. GONZÁLEZ, J. História do movimento missionário, p. 136.

${ }^{120}$ L. GONZÁLEZ, J. História do movimento missionário, p. 137.
} 
armas". ${ }^{121}$ Para os estudiosos, as Cruzadas não alcançaram seus objetivos, mas inflamaram ainda mais um ódio religioso, como lembra González:

Por outro lado, como meio de expansão do cristianismo em território muçulmano, as Cruzadas fracassaram redondamente. Todos os estados estabelecidos no Oriente pelas Cruzadas sucumbiram ante o poder do Islã". Tampouco se alcançou a conversão dos mulçumanos; pelo contrário, o ódio destes para com o cristianismo se fez mais violento. ${ }^{122}$

Walker concorda com o insucesso dos propósitos das Cruzadas: “consideradas à luz do seu propósito original, as Cruzadas foram um fracasso. Elas não realizaram nenhuma conquista permanente na Terra Santa; não retardaram o avanço do Islã". ${ }^{123}$ Segundo González, a memória e a história das Cruzadas continuam refletindo nas relações entre cristãos e muçulmanos: "até o dia de hoje, a memória das Cruzadas continua inflamando as relações entre muçulmanos e cristãos". 124

Um ligeiro resgate das origens históricas das Cruzadas no cristianismo revela que o termo está sempre associado à disputa territorial ou religiosa. Cabe aqui o questionamento da vinculação desse período histórico com a denominação do primeiro movimento missionário dos quadrangulares no Brasil, já que a conotação herdada dos registros históricos parece impeditiva do diálogo religioso e do ecumenismo.

Entretanto, essa vinculação não parece ser o propósito da IEQ, pois, como já mencionado, a $\mathrm{CNE}$ era um movimento que reunia várias denominações protestantes, mostrando-se aberta ao diálogo e à cooperação. Talvez o uso do termo objetive reforçar a ideia de peregrinação e de fé cristã. Por fim, o termo Cruzada foi abandonado pela Quadrangular. A história da IEQ também mostra, durante o período de evangelização em tendas, a utilização do termo "Tenda de Jesus", em contraste com a concepção de "Cruzada". Entre os pentecostais é comum dar nomes específicos às campanhas de evangelização.

A segunda fase da Igreja do Evangelho Quadrangular no Brasil disseminar as tendas de lona como palco das missões. Esse modelo também havia sido

\footnotetext{
${ }^{121}$ L. GONZÁLEZ, J. História do movimento missionário, p. 138.

${ }^{122}$ L. GONZÁLEZ, J. História do movimento missionário, p. 139.

${ }^{123}$ WALKER, Wiliston. História da Igreja Cristã. São Paulo: ASTE, 2006, p. 335.

${ }^{124}$ L. GONZÁLEZ, J. História do movimento missionário, p. 139.
} 
utilizado pela fundadora, nos Estados Unidos. No Brasil também era chamado de circo de lona, conforme Rosa:

Tais tendas eram muito parecidas com aquelas usadas para circos, apenas mais simples e com menos equipamentos, de montagem e desmontagem mais fácil. Esta tinha capacidade para umas três mil pessoas; na verdade, uma capela ambulante. Fora obtida como doação pelo pastor Raymond, de um grupo de americanos. Tanto para mim, como para os populares que por ali passavam, aquilo parecia mesmo um circo. Essa era provavelmente a primeira ideia que ocorria, no primeiro instante, às pessoas que viam a tenda pela primeira vez. Pelo menos eu nunca tinha visto aqui no Brasil reuniões religiosas em "circos". Era uma coisa inteiramente fora de série! As pessoas paravam, certamente, para ler na enorme placa o nome do "circo" e a programação. Entretanto, eram surpreendidas pelos dizeres: "Cruzada Nacional de Evangelização", que pela primeira vez se usava no Brasil. ${ }^{125}$

A Igreja do Evangelho Quadrangular no Brasil primeiramente ficou conhecida como Cruzada. Bellotti diz: "a divulgação das sessões nas tendas era feita pela distribuição de folhetos evangelísticos, cartazes espalhados pela cidade, propaganda em jornais e programas de rádio". ${ }^{126}$ As tendas de evangelização eram itinerantes, indo de cidade em cidade e proporcionando muitas experiências. $\mathrm{O}$ movimento contava com diversos meios de divulgação, e por ser novidade, atraía reportagens, como refere Bellotti: "além disso, as reuniões atraíam a curiosidade da imprensa, o que ajudava a divulgar indiretamente o trabalho por meio de reportagens". ${ }^{127}$ As tendas também oportunizaram o contato direto com o povo, o que muito ajudou na propagação da propagação da Cruzada. Rosa afirma: "os missionários não poderiam parar, mas deviam mudar a tenda para outro lado da cidade. E o bairro escolhido foi de Água Branca, num terreno amplo". ${ }^{128}$ O início do trabalho nas tendas no estado de São Paulo fez crescer notavelmente o movimento e as campanhas conferiram mais identidade ao movimento, pela maior liberdade de exposição da doutrina.

A pregação da cura divina, pela autenticidade, vinha se tornando marca da Cruzada Nacional de Evangelização. Rosa acrescenta: "um fato novo vinha alegrar a todos quantos se empenhavam na continuidade da obra: alguns pastores e evangelistas brasileiros estavam também tendo a oportunidade de pregar e orar pelos enfermos naquela tenda, e o povo aceitava com a mesma fé e

\footnotetext{
${ }^{125}$ ROSA, J. O., O evangelho quadrangular no Brasil, p. 30.

${ }^{126}$ BELLOTTI, K. K., Delas é o reino dos céus, p. 74.

${ }^{127}$ BELLOTTI, K. K., Delas é o reino dos céus, p. 74.

${ }^{128}$ ROSA, J. O., O evangelho quadrangular no Brasil, p. 32.
} 
sinceridade". ${ }^{129}$ Essa prática missionária ainda não é totalmente denominacional, mas ecumênica, dispondo, no início, de vários atores de outras denominações, criando um movimento dinâmico a partir da liderança dos missionários da Cruzada. Bellotti acrecenta: "com a atuação da Cruzada Nacional de Evangelização em um período de intensa urbanização e industrialização, o pentecostalismo voltou-se para as massas e assumiu a preocupação em fazer a diferença na vida das pessoas e do país por meio de uma estratégia empresarial". ${ }^{130}$ Essa atuação ganharia novos agentes nas próximas décadas.

O início da institucionalização do movimento se deu naturalmente no decorrer da missão. O movimento era bastante carismático e atraía a simpatia do povo, mas pelo seu caráter itinerante, o trabalho era descontinuado. Rosa diz: "o Rev. Williams, o homem que Deus separara como instrumento para execução do seu plano, tomara uma decisão: fundaria a primeira igreja da Cruzada em São Paulo". ${ }^{131}$ Assim os simpatizantes poderiam ser assistidos pela mesma doutrina difundida pela Cruzada. Essa decisão ajudou na expansão do movimento a outras partes, possibilitando maior organização. Rosa continua: "da Cruzada em São Paulo explodiria o chamado movimento da cura divina no sul, centro, norte e nordeste do país, desencadeando uma onda de reavivamento espiritual". ${ }^{132}$ A partir da estruturação da instituição, o movimento avança por várias partes do país. O modelo de evangelização apresentado pela Cruzada adaptou-se muito bem à cultura brasileira a forma litúrgica desenvolvida em suas tendas parecia aproximar mais o povo dos missionários, dando também protagonismo aos leigos. Rosa afirma:

Entretanto, esse estilo diferente e desconhecido do público, estilo todo espontâneo na realização dos cultos, e que levava o público a uma participação intensa e envolvente no louvor e adoração a Deus, viria a constituir um fator importante para a atração das massas humanas aos templos. ${ }^{133}$

O envolvimento e a adesão do público ao movimento estão diretamente vinculados à forma de fazer missão da Quadrangular e dos pentecostais em geral, pois esse seguimento está centrado na experiência do povo leigo. Para Dias, a IEQ

\footnotetext{
${ }^{129}$ ROSA, J. O., O evangelho quadrangular no Brasil, p. 33.

${ }^{130}$ BELLOTTI, K. K., Delas é o reino dos céus, p. 72.

${ }^{131}$ ROSA, J. O., O evangelho quadrangular no Brasil, p. 33.

132 ROSA, J. O., O evangelho quadrangular no Brasil, p. 34.

${ }^{133}$ ROSA, J. O., O evangelho quadrangular no Brasil, p. 35.
} 
"proporcionou uma maior participação dos membros, inclusive com a possibilidade da ordenação ministerial, não exigindo uma preparação teológica formal para exercer um cargo na instituição". ${ }^{134}$ Assim esse segmento se sente coparticipante e propulsiona o crescimento numérico dos pentecostais no Brasil. Mas ainda sobre as características das reuniões, Rosa observa: "outra diferença que notei foi no cântico de muitos hinos e corinhos com melodias e letras fáceis de o público aprender, sendo alguns em ritmos rápidos". ${ }^{135}$ A linguagem comum ou popular de fácil aceitação é essencial no trabalho missionário, e isso os pentecostais perceberam muito bem. Os acontecimentos nessa segunda fase do pentecostalismo brasileiro apresentam definitivamente o movimento ao povo brasileiro. Bellotti também identifica a simplicidade da liturgia: "outro aspecto foi o formato do culto, mais informal, espontâneo, com grande participação dos presentes, que cantavam hinos e corinhos com letras fáceis de acompanhar". ${ }^{136}$

A vertente popular do protestantismo encontra solo fértil entre os brasileiros, como lembra Rosa: "eu nada sabia sobre as doutrinas do batismo com o Espírito Santo, do poder de Cristo para curar enfermidades hoje e sempre, da sua segunda vinda e, pasmem vocês, nunca me fora ensinado como ganhar almas". ${ }^{137}$ Nota-se claramente, portanto, a agressividade missionária do movimento, buscando proporcionar uma experiência pessoal com o Espírito e o doutrinamento na perspectiva de "ganhar almas", termo utilizado no movimento pentecostal para a evangelização. Lopes esclarece: "assim, a IEQ se expandiu no Brasil, inicialmente, não com a doutrina Quadrangular - ortodoxa propriamente dita, já consolidada nos EUA, mas através da hipertrofia da cura divina". ${ }^{138}$

A cura divina assumia o protagonismo do movimento, constituindo elemento ontológico nesse tipo de pentecostalismo dos anos 1950. Essa plataforma pentecostal resultaria em novos modelos de denominações pósCruzada. Lopes informa: "é ressaltado, assim, o papel protagônico exercido pela cura divina no processo de implantação da IEQ no Brasil, muito embora

\footnotetext{
${ }^{134}$ DIAS, A. C, A implantação da Igreja do Evangelho Quadrangular em Curitiba, p. 80-81.

${ }^{135}$ ROSA, J. O., O evangelho quadrangular no Brasil, p. 35.

${ }^{136}$ BELLOTTI, K. K., Delas é o reino dos céus, p. 74.

${ }^{137}$ ROSA, J. O., O evangelho quadrangular no Brasil, p. 39.

${ }^{138}$ LOPES, M., O legado de uma pioneira, p. 86.
} 
atualmente a prática da cura não seja mais rotina". ${ }^{139}$ A cura caracterizou o pentecostalismo do período da Cruzada.

Como já dito, os líderes do movimento de cura divina da Cruzada Nacional de Evangelização não tinham por meta inicial a abertura de templos. A ideia original centrava-se nas campanhas de reavivamento pela cura divina e na propagação do batismo com o Espírito Santo. Rosa é quem assegura: “o projeto inicial do movimento da cura divina não previa a organização de mais uma seita religiosa, nem instalação de novas igrejas. $\mathrm{O}$ objetivo específico era apenas evangelizar as massas, deixando às seitas já estabelecidas a assistência aos novos convertidos". ${ }^{140}$ A chegada da Igreja do Evangelho Quadrangular muito se assemelha à sua fundação nos Estados Unidos, pois sua fundadora Aimee Semple McPherson também não pretendia abrir igrejas e assim trabalhou durante anos na evangelização. Somente pela visão do Evangelho Quadrangular é que ela compreende que deveria fundar uma denominação.

Obedecendo a esse plano de evangelização, os missionários fazem planos, como avalia Rosa: "Para atingir esse alvo, a evangelização das massas a curto prazo em todo o território nacional, é que seriam utilizadas as tendas de lona". ${ }^{141}$ A dinâmica e a praticidade dos templos de lona possibilitavam o fácil deslocamento e as viagens itinerantes, que já havia funcionado na historia da IEQ nos Estados Unidos. Os missionários norte-americanos sabiam bem o que almejavam, como detalha Rosa: "cada tenda funcionaria como uma espécie de capela ambulante, permanecendo perto de 30 a 60 dias em cada lugar". ${ }^{142}$ Esse tempo, segundo os missionários, era suficiente para a efetivação das campanhas e assim as pessoas evangelizadas seriam direcionadas para as denominações já estabelecidas nas cidades por onde as tendas passassem. Rosa lembra:

O Rev. Williams, que na verdade liderava o movimento, entusiasmado com a ideia e apoiado pelos outros missionários, convocou diversas denominações e seitas evangélicas, pentecostais e não pentecostais, enviando cartas a seus pastores, convidando-os para uma reunião informal. Nessa reunião, o Rev. Williams pretendia fazer uma lista de todas as igrejas que estivessem dispostas a receber os novos convertidos, dando a estes os endereços das mesmas, conforme o bairro onde residissem. Então os novos convertidos passariam a frequentar essas igrejas, cada qual em seu bairro. Dessa forma, pensavam o Rev. Williams e os demais

\footnotetext{
${ }^{139}$ LOPES, M.,O legado de uma pioneira, p. 86.

${ }^{140}$ ROSA, J. O., O evangelho quadrangular no Brasil, p. 40.

${ }^{141}$ ROSA, J. O., O evangelho quadrangular no Brasil, p. 40.

${ }^{142}$ ROSA, J. O., O evangelho quadrangular no Brasil, p. 40.
} 
missionários, os novos convertidos não ficariam abandonados e sem assistência espiritual. [...] Pelo menos, segundo fui informado, a maioria dos pastores convidados não deu a mínima atenção ao convite; não compareceram à referida reunião. ${ }^{143}$

Existiram, de fato, ecumenismo e diálogo durante a instituição da Igreja do Evangelho Quadrangular no Brasil. Mas, como descrito por Rosa, não houve esforço dos convidados do Rev. Williams em aderir ao movimento em cooperação. Entretanto, diante da falta de apoio das denominações convidadas para recepcionar os evangelizados nas campanhas, esse líder percebeu a necessidade de criar igrejas por onde passassem as tendas. Bandini destaca: "em 1953, promovem uma campanha de curas chamada "Cruzada Nacional de Evangelização", e no ano seguinte Williams funda a Igreja da Cruzada, reestruturada em 1955 como a Igreja do Evangelho Quadrangular". ${ }^{144} \mathrm{O}$ processo de institucionalização dessa igreja no Brasil acontece gradualmente, até que ela se torne denominação. Rosa diz: "por outro lado, somente alguns meses mais tarde compreendeu-se que, pelo menos na Capital, não seria possível prosseguir com as campanhas evangelísticas, sem a organização de igrejas da própria Cruzada". ${ }^{145}$

A realidade da capital fez o pastor líder da Cruzada Harold Williams compreender que era hora de estabelecer os templos, pois não haveria continuidade das doutrinas se isso não se efetivasse. Oliveira destaca: "esse movimento cresceu rapidamente, chamando a atenção de outros pastores pentecostais ou não que se uniram à Cruzada". ${ }^{146}$ A questão determinaria o futuro do movimento pentecostal da segunda fase no Brasil, como detalha Oliveira: "Assim, no início de 1954, o pastor Williams organizava a primeira igreja da Cruzada em São Paulo. Conseguira alugar um velho prédio situado na Rua Brigadeiro Galvão, 723, na Barra Funda". ${ }^{147}$ A partir da primeira experiência, o Rev. Williams animou-se a abrir novos templos da Cruzada, e nessa perspectiva estabeleceu metas para capital paulista. Rosa lembra-se: “o entusiasmo tomou conta de todos, quando o Conselho Nacional de Diretores planejou em 1955 a

\footnotetext{
${ }^{143}$ ROSA, J. O., O evangelho quadrangular no Brasil, p. 40.

${ }^{144}$ BANDINI, Claudirene. Ministério feminino na Igreja do Evangelho Quadrangular: autonomia além do espaço religioso Notas de uma pesquisa. Actas dos ateliers do $\mathrm{V}^{\mathbf{o}}$ Congresso Português de Sociologia Sociedades Contemporâneas: Reflexividade e Acção Atelier: Género. p. 42-46, 2004, p. 42-43.

${ }^{145}$ ROSA, J. O., O evangelho quadrangular no Brasil, p. 41.

146 OLIVEIRA, M. A., Pentecostais: história, contexto e caminhos para teologizar. p. 71.

${ }^{147}$ ROSA, J. O., O evangelho quadrangular no Brasil, p. 42.
} 
formação de 200 igrejas e congregações na capital paulistana. Isso seria feito, circulando tendas em todos os bairros". ${ }^{148}$ Nota-se a mudança na visão da Cruzada, dos trabalhos em templos de outras denominações protestantes às campanhas nas tendas de lona, seguindo-se o estabelecimento dos templos, como refere Rosa: "contudo, de início foram inauguradas cerca de 30 congregações na capital, usando-se tendas ou salões, das quais resultaram boas igrejas". ${ }^{149}$ Esse objetivo levou a Cruzada a estruturar-se em São Paulo, algo essencial na sequência do desenvolvimento, conforme detalha Rosa:

A igreja da Barra Funda crescia de maneira incrível, e a mudança de local tornarase uma necessidade premente. Assim, em 1957 foi adquirido o terreno com mais de mil metros quadrados, sito à Praça Olavo Bilac 90, onde hoje se localiza o templo próprio da sede da Igreja do Evangelho Quadrangular. Entretanto, somente no ano de 1968 , mais precisamente a 7 de abril, seria inaugurado. ${ }^{150}$

A história da Igreja do Evangelho Quadrangular no Brasil é construída a partir de muitas tentativas que não pareciam claras. O movimento era novo em muitos aspectos, mas faltavam-lhe uniformidade e identidade. Bitun relata: "anos depois teria seu nome mudado para Igreja do Evangelho Quadrangular, a 'cura divina' foi introduzida eficazmente". ${ }^{151}$ Assim, a identidade da Igreja do Evangelho Quadrangular no Brasil surge a partir de variadas experiências e tentativas. A denominação não nasce definida, mas é uma extensão da matriz norte-americana, percebendo-se essa evolução mesmo no nome inicial: ainda não era Quadrangular, passando a se denominar Igreja do Evangelho Quadrangular mais tarde, depois do entendimento do Rev. Harold Williams, com sua liderança inspirada na igreja estadunidense, já que ele não havia sido enviado como missionário ao Brasil, e sim à Bolívia, necessitando, mais tarde, reatar os laços com sua liderança. Rosa diz: "a 'Igreja do Evangelho Quadrangular' dava os seus primeiros passos no Brasil. Tudo ainda era improvisado. Denominava-se, então, 'Igreja Evangélica do Brasil', sendo seu departamento evangelístico a 'Cruzada Nacional de Evangelização"”. ${ }^{152}$ Mariano destaca o pioneirismo: “a Igreja do

\footnotetext{
${ }^{148}$ ROSA, J. O., O evangelho quadrangular no Brasil, p. 42.

${ }^{149}$ ROSA, J. O., O evangelho quadrangular no Brasil, p. 42.

${ }^{150}$ ROSA, J. O., O evangelho quadrangular no Brasil, p. 43.

${ }^{151}$ BITUN, Ricardo. A "remasterização" do movimento pentecostal Igreja Mundial do Poder de Deus. Ciberteologia - Revista de Teologia \& Cultura - Ano III, n. 23, p. 19-31. Maio/Junho 2009, p. 21.

${ }^{152}$ ROSA, J. O., O evangelho quadrangular no Brasil, p. 44.
} 
Evangelho Quadrangular foi a primeira igreja pentecostal a fundar um instituto teológico no Brasil, em 1957". ${ }^{153}$ Aos poucos, sua identidade formava-se dentro do campo religioso brasileiro.

A história da Igreja do Evangelho Quadrangular no Brasil constrói-se a partir de fatos incomuns nas organizações religiosas. Como exemplo, o primeiro presidente da instituição foi outro pastor, e não o missionário responsável, porque questões legais impediam que estrangeiros ocupassem a presidência, conforme detalha Rosa: "na ocasião, o Dr. Syr Martins, cirurgião-dentista que tinha vindo da Igreja Presbiteriana Independente de Santo André, era o presidente; o Rev. Harold Williams, o vice-presidente". ${ }^{154}$ Dessa maneira o movimento pentecostal da Igreja do Evangelho Quadrangular no Brasil é liderado pelo Rev. Harold Williams, mas sob a presidência legal do Dr. Syr Martins. As campanhas continuavam nas tendas, cuja estrutura é descrita por Rosa:

\begin{abstract}
Uma tenda para cerca de duas mil pessoas requer: dois mastros de cinco metros, sustentados em pé por três cordas cada um, amarradas em estaca firmemente cravadas no solo; vinte guarda-polos (paus de quase quatro metros que sustentavam a lona no centro); sessenta paus laterais de dois metros e meio mais ou menos, que sustentam a lona nos lados; perto de sessenta estacas de madeira de lei com um metro e vinte centímetros cada, com um anel de ferro no cabeçote; essas estacas são cravadas a golpes de marreta de dez quilos, até oitenta centímetros no solo, no mesmo alinhamento dos paus laterais. Para cobrir essa área, é necessária uma lona dividida em três partes; o lençol central, que é a parte maior e fica entre os dois mastros, e as pontas redondas. Depois de ligadas estas três partes por meio de cordas finas, são suspensas por meio de roldanas (carretilhas de ferro) afixadas nos mastros; em seguida ela é amarrada por cordas às estacas e depois retesada pelos guarda-polos e paus laterais. Além disso, há a instalação elétrica, os bancos para acomodar pelo menos mil pessoas. Muitos outros acessórios são necessários para equipar uma boa tenda. ${ }^{155}$
\end{abstract}

A evangelização em tendas seguiu seu plano original de buscar sistematicamente um trabalho ecumênico entre as igrejas protestantes. Paula afirma: “a grande inovação trazida pelo pentecostalismo neoclássico se deu principalmente no campo teológico, ao pregar uma mensagem centrada na cura divina". ${ }^{156} \mathrm{O}$ diálogo e o esforço da primeira liderança da IEQ brasileira de evangelizar pelo diálogo e pela cooperação precisam ser analisados. Rosa afirma:

\footnotetext{
${ }^{153}$ MARIANO, Ricardo. Crescimento pentecostal no Brasil: fatores internos. Revista de Estudos da Religião. Dezembro / ISSN 1677-1222 / pp. 68-95, 2008, p. 82.

${ }^{154}$ ROSA, J. O., O evangelho quadrangular no Brasil, p. 44.

${ }^{155}$ ROSA, J. O., O evangelho quadrangular no Brasil, p. 47.

${ }^{156}$ PAULA, V. A. S., Religião e política no Vale do Paranapanema, p. 30.
} 
"as normas dos dirigentes da Cruzada naqueles primeiros tempos eram que as tendas fariam apenas trabalhos de evangelização, durante cerca de sessenta dias em cada cidade". ${ }^{157}$ Não se pretendia, nessa fase, construir templos e seguir o caminho convencional das demais organizações religiosas. Bandini destaca: "na década de 1950 houve a transição de um cristianismo rural para um cristianismo preponderantemente urbano". ${ }^{158}$ Os missionários da Cruzada entendiam que seu trabalho estava restrito à evangelização, com resultados já bem positivos. Entretanto, a continuação do trabalho com todos os evangelizados ficaria a cargo das demais denominações que aceitassem o diálogo e a cooperação. Aleixo esclarece: "nessa fase inicial de campanhas missionárias, a coesão institucional não era o interesse proeminente, mas sim a evangelização e as conversões. Com isso, muitas igrejas foram fundadas com a CNE, durante as décadas de 1950 e 1960". ${ }^{159}$ A liderança da Cruzada tinha a clara visão de manter o programa missionário de alcance nacional em proporções interdenominacionais. Rosa continua: "os novos convertidos deveriam procurar outras igrejas evangélicas para receberem assistência espiritual. Obedeci a essas diretrizes nas campanhas de Sorocaba, Campinas e Piracicaba. Mas, logo em seguida, os dirigentes sentiram essa necessidade da fundação de igrejas após cada campanha". ${ }^{160}$ Rosa, além de registrar a primeira fase da IEQ no Brasil, fazia parte da Cruzada, tendo vivenciado cada etapa na experiência pentecostal. Primeiro como espectador, quando experimentou a cura divina, segundo seu próprio relato. $\mathrm{E}$ subsequentemente, como pastor, e mais tarde, participante da liderança nacional. Ele continua: "em Limeira houve pequenas perseguições da parte de pessoas inconformadas com os sucessos da Cruzada, perseguições que não chegaram a impedir o crescimento do trabalho. É bem verdade que mãos criminosas atearam fogo na tenda. Conseguiram queimá-la". ${ }^{161}$ A novidade oferecida pela Cruzada também provocou descontentamento em alguns indivíduos que não aceitavam o movimento, bem como suas práticas.

A partir do momento em que a Cruzada decide seguir o caminho missionário como instituição, reconhecendo a necessidade de organização de seu

\footnotetext{
${ }^{157}$ ROSA, J. O., O evangelho quadrangular no Brasil, p. 50.

${ }^{158}$ BANDINI, Claudirene Aparecida de Paula. Religião e política: a participação política dos pentecostais nas eleições de 2002. Dissertação de Mestrado. UFSCAR. São Carlos, 2003, p. 20.

${ }^{159}$ ALEIXO, V. C., Deus faz, o templo dos anjos mostra, p. 47.

${ }^{160}$ ROSA, J. O., O evangelho quadrangular no Brasil, p. 50-51.

${ }^{161}$ ROSA, J. O., O evangelho quadrangular no Brasil, p. 57.
} 
trabalho, ela constitui um quadro de obreiros para as muitas tarefas da evangelização, como explica Rosa: "contudo naqueles dias, a Cruzada, por necessidade, credenciava todos os obreiros que demonstrassem o mínimo de fé, disposição e sinceridade para sair ao campo". ${ }^{162}$ A formação dos obreiros na Cruzada no início era bem simples, sem tantos pré-requisitos. a fé e a coragem eram a base para evangelizar, e o processo de formação se dava na prática. Parece ser essa uma das características do sucesso inicial, pois a simplificação e a participação do leigo como agente de missão levam a Cruzada à sua expansão por todo o território brasileiro. Aleixo assegura: "a cruzada nacional inauguraria uma nova forma de se viver a prédica cristã, uma maneira pouco ortodoxa de interpretar os textos bíblicos e de se relacionar com o Espírito Santo". ${ }^{163}$ O processo simplificado obtinha a comunicação com o povo, e os novos convertidos logo participavam da evangelização. Rosa ilustra com um desses casos:

O moço alto e magro só podia ser o pastor Jayme. Agora estava ele exatamente na cidade-berço da IEQ no Brasil, São João da Boa Vista. Sim, a Cruzada havia praticamente nascido ali. Contudo, a igreja que lá existia era muito pequena, fraca e cheia de problemas. O CND achou por bem que uma tenda fosse instalada naquela cidade, onde nunca fora uma tenda, e o evangelista seria o pastor Jayme. ${ }^{164}$

O pastor Jayme foi um dos pioneiros, de nome bem popular na história da IEQ brasileira, que começou em São João da Boa Vista, quando os pastores Williams e Hemírio Vazquez fundaram a Igreja Evangélica do Brasil. Após a chegada do missionário Raymond, as campanhas de curas divina passaram a se concentrar em outros lugares, como nos templos da Igreja Presbiteriana Independente. Rosa diz: "ali fora o berço da Cruzada no Brasil, mas na ocasião a igreja, muito enfraquecida devido a uma série de problemas, contava apenas com um pequeno grupo de membros mais antigos". ${ }^{165}$ Os fatos mostram que a fundação da IEQ em São João da Boa Vista foi no modelo convencional abriu se uma igreja, entretanto sua liderança dedicou-se ao trabalho missionário idealizando o movimento de cura divina o fato é que o movimento denominava-se de Cruzada Nacional de Evangelização e não de Igreja Evangélica do Brasil como se registrava a IEQ. O protagonismo exercido pelos missionários da Cruzada faz

\footnotetext{
${ }^{162}$ ROSA, J., O Evangelho Quadrangular no Brasil, p. 63.

${ }^{163}$ ALEIXO, V. C., "Deus Faz, o Templo dos Anjos Mostra”, p. 48.

${ }^{164}$ ROSA, J. O., O Evangelho Quadrangular no Brasil, p. 64.

${ }^{165}$ ROSA, J. O., O Evangelho Quadrangular no Brasil, p. 66.
} 
da cura divina publica. Bitun comenta: "porém, torná-lo consumível para grande parte da população, propagando-o através dos meios de comunicação de massa, assim como a tarefa de exercitá-lo em locais públicos, isso sim foi inovador". ${ }^{166} \mathrm{O}$ movimento Cruzada Nacional de Evangelização cresceu e a igreja fundada pelos missionários Harold Williams e Hermírio Vasquez passou a ser conhecido como Cruzada. Rosa continua: "o pastor Jayme havia recebido a igreja do pastor Hermírio Vasquez, peruano, o qual estivera sempre acompanhando o pastor Williams". ${ }^{167}$ Com a expansão do movimento da Cruzada o pastor Hermírio Vasquez acompanhava o pastor Harold Williams na estruturação do movimento. O trabalho ganhou grande proporção na capital. "Mas seu crescimento espantoso foi verificado quando avançou para a cidade de São Paulo". ${ }^{168}$ O pastor Jayme revitalizou o trabalho em São João da Boa Vista, por sua excelente atuação.

Em Araraquara o movimento de cura divina foi perseguido e os missionários, acusados de prática ilegal de medicina. Rosa lembra: "acusaram os missionários de estarem perturbando a cidade, porque estavam reunindo muita gente. Mas no processo instaurado mais tarde, foram acusados de curandeirismo e exercício de medicina ilegal". ${ }^{169} \mathrm{O}$ movimento atraía a atenção da população e o povo se reunia para conferir os acontecimentos, daí também a acusação de tumultuar a cidade, o que causou a prisão dos missionários.

\subsection{3. \\ A Cruzada Nacional de Evangelização e o pós-pentecostalismo}

O movimento rompeu os limites do estado de São Paulo e chegou ao Paraná. Rosa diz: "no ano de 1955, no dia 28 de maio. Dia muito frio e garoento, pois o inverno em Curitiba havia chegado mais cedo naquele ano. Nessa data, estava sendo inaugurada a primeira tenda de lona para evangelização no Estado do Paraná" ${ }^{170}$ As tendas chegam a outro estado brasileiro e o plano de evangelização assume escala nacional, alcançando aos poucos o objetivo expresso no nome do

\footnotetext{
${ }^{166}$ BITUN, R. A., "remasterização" do movimento pentecostal Igreja Mundial do Poder de Deus, p. 22.

${ }^{167}$ ROSA, J. O., O Evangelho Quadrangular no Brasil, p. 66.

${ }^{168}$ IV Simpósio do GT História das Religiões e Religiosidades - ANPUH/ Regional Sul (Santa Catarina, Paraná e Rio Grande do Sul) "Religiões, Religiosidades e Patrimônio Cultural" 14, 15 e 16 DE OUTUBRO DE 2015, p. 353.

${ }^{169}$ ROSA, J. O., O evangelho quadrangular no Brasil, p. 68.

${ }^{170}$ ROSA, J. O., O evangelho quadrangular no Brasil, p. 84.
} 
movimento: Cruzada Nacional de Evangelização. A chegada a Curitiba deve-se mais uma vez ao papel fundamental da Igreja Presbiteriana Independente, denominação determinante para a história da IEQ no Brasil. Rosa diz: "o Rev. Williams tinha sido convidado a visitar em Curitiba a família do pastor Mariano de Castro, que fazia parte de um grupo dissidente da Igreja Presbiteriana Independente da Vila Parolim". ${ }^{171}$ Espectadores do movimento de cura divina criaram a expectativa de levá-lo a Curitiba, abrindo a possibilidade da expansão para o Paraná.

Os participantes da Igreja Presbiteriana Independente eram simpatizantes do movimento de cura divina da Cruzada e assim, o diálogo foi proposto, com acertos para tendo sido feitos para a chegada da Cruzada Nacional de Evangelização a Curitiba. Rosa diz: "alguns desses irmãos tinham visto e participado do movimento da cura divina em São Paulo; desde então, desejavam ardentemente que a Cruzada fosse levada a Curitiba". ${ }^{172}$ Assim se iniciava o movimento de cura divina no Paraná. "Além desses fatores, com um culto mais 'alegre', a IEQ inovou no uso das famosas tendas de lona em um movimento conhecimento como Cruzada Nacional de Evangelização". ${ }^{173}$

Os eventos em Curitiba não difeririam grandemente dos de São Paulo, mas a novidade da evangelização em tendas, com cura divina, resultou em certo desconforto de parte da população, com discordâncias e interpretações negativas do movimento, o que resultou na prisão dos missionários. Rosa afirma: "após explicarmos para o delegado o que realmente fazíamos, ele nos disse que não estava perseguindo a religião, mas queria esclarecimentos sobre o que fazíamos, devido às denúncias". ${ }^{174} \mathrm{O}$ estranhamento não impediu a propagação e a expansão da Cruzada, que continuou a se reunir. As dificuldades em Curitiba, segundo Rosa, foram criadas principalmente por alguns religiosos indispostos ao diálogo com o que lhes parecia diferente, e detentores de meios de comunicação de massa. Para o autor, "outro jornal que nos trouxe também alguns problemas foi a 'Gazeta do Povo', publicando artigos autorizados pela Igreja Católica Romana, contra a Cruzada". 175

\footnotetext{
${ }^{171}$ ROSA, J. O., O evangelho quadrangular no Brasil, p. 86.

${ }^{172}$ ROSA, J. O., O evangelho quadrangular no Brasil, p. 87.

${ }^{173}$ IV Simpósio do GT História das Religiões e Religiosidades, p. 355.

${ }^{174}$ ROSA, J. O., O evangelho quadrangular no Brasil, p. 92.

${ }^{175}$ ROSA, J. O., O evangelho quadrangular no Brasil, p. 93.
} 
Tratava-se de uma tentava de impedir o povo de ser enganado por um movimento pouco difundido na época, com práticas religiosas pouco conhecidas no Brasil até aquele momento. Rosa continua: "na 'Gazeta do Povo', na Coluna Católica, foi publicado um artigo intitulado 'A Religião, Clínica de Doentes"”. ${ }^{176}$ Essas publicações acabam por afirmar o modelo missionário desenvolvido pela Cruzada, que propagava a doutrina da cura divina pelo país, e essa era a preocupação dos religiosos.

Como lembra Aleixo, "o 'pentecostalismo das tendas de lona' teria realizado uma espécie de aggiornamento pentecostal, um processo de abertura dos templos à modernidade, de liberalização dos perfis eclesiais e de democratização dos bens de salvação". ${ }^{177} \mathrm{E}$ as tentativas de depreciação, servindo-se das mídias, continuavam em Curitiba. É Rosa quem assegura: "no Diário do Paraná de 18/8/55, saía numa entrevista intitulada: 'Esse Movimento é Falso, Charlatão e Irreverente', declarações de um pastor presbiteriano, inclusive procurando desmoralizar a pessoa de Aimée Semple Marcpherson". ${ }^{178}$ Percebe-se pela publicação certa rejeição dessas doutrinas mesmo no seio do protestantismo. A situação ficou muito séria em Curitiba, a ponto de alguns pastores protestantes ingressarem com uma representação contra o movimento de cura divina da Cruzada, afirmando que a denominação não fazia parte do povo evangélico, como refere Rosa:

\begin{abstract}
No seu desespero, um grupo de pastores chegou a publicar neste mesmo jornal uma declaração por eles assinada, que é a seguinte: “As Igrejas Evangélicas de Curitiba, representadas pelos pastores abaixo-assinados, informam ao mui digno povo paranaense que o movimento religioso denominado "Cruzada Nacional de Evangelização" ou "Tenda de Jesus" não faz parte das comunidades evangélicas referidas, e propaga doutrinas e práticas que aberram dos princípios fundamentais da palavra de Deus". Assinado... - Por uma questão de ética, deixo de mencionar os nomes constantes das assinaturas, cuja relação está em meu poder. Durante todo o mês de agosto, o Diário do Paraná foi um ferrenho inimigo da obra. Coincidiu que essa campanha anticura divina visava mais diretamente à pessoa do evangelista em evidência na ocasião, Manoel de Melo. Foram feitas reportagens e fotografias em várias edições, mas todas visando sempre a desmoralização da obra e dos pregadores. ${ }^{179}$
\end{abstract}

\footnotetext{
${ }^{176}$ ROSA, J. O., O evangelho quadrangular no Brasil, p. 93.

${ }^{177}$ ALEIXO, V. C., "Deus faz, o templo dos anjos mostra", p. 48.

${ }^{178}$ ROSA, J. O., O evangelho quadrangular no Brasil, p. 93.

${ }^{179}$ ROSA, J. O., O evangelho quadrangular no Brasil, p. 94-95.
} 
Em Curitiba, o movimento, também ficou conhecido como Tenda de Jesus. E seus opositores continuavam intentando alguma maneira de depreciar o movimento, que conquistava cada vez mais adeptos. Aleixo esclarece que tais situações deviam-se em parte à publicidade dos cultos: "por um lado, o evangelismo de massa tornaria públicos os milagres de cura divina, as pregações emocionadas, as possessões espirituais e os rituais de exorcismo realizados, até então, a portas cerradas pelos pentecostais clássicos". ${ }^{180}$

O movimento também avançou para outras cidades do Paraná, como lembra Rosa: “em 1958, o pastor Mariano de Castro iniciava uma obra na segunda principal cidade do Estado do Paraná, a cidade de Ponta Grossa. Em 16 de outubro de 1962, assumiu a direção daquele trabalho o pastor Moacyr José da Silva, que com sua família viera da Igreja Batista para a Cruzada, por intermédio do pastor Ismael do Lago". ${ }^{181}$ O desenvolvimento da Cruzada no Paraná foi possível pelo fluxo migratório proveniente de outras denominações protestantes, o que muito facilitava o trabalho, pois esses migrantes já conheciam as cidades e suas culturas, a elas adaptando a evangelização da Cruzada. Paula assegura: "a chegada dos missionários da International Church of the Foursquare Gospel ao Brasil na década de 1950 e a posterior fundação da Igreja do Evangelho Quadrangular (IEQ) são apontados pelos pesquisadores do movimento pentecostal no Brasil como um marco importante no desenvolvimento deste movimento religioso". ${ }^{182}$ Abriam-se novas perspectivas pós-Cruzada.

A evangelização no sul do país continuou avançando, chegando a Santa Catarina. Relata Rosa: "na cidade de Joinvile, lá pelo ano de 1956, a obra da Cruzada foi implantada também pelo incansável pastor Mariano de Castro. Em Florianópolis, a Cruzada começou diferente". ${ }^{183}$ Havia o templo de uma missão, cujo pastor, por algum motivo, decidiu doar à Cruzada. Isso tornou o início da Cruzada em Santa Catarina diferente do método usual, em tendas. Rosa informa, a respeito do pastor: "assim propôs passar a obra para a Cruzada, doando o patrimônio também". ${ }^{184} \mathrm{O}$ trabalho se inicia de maneira atípica da praticada: "Na ocasião, o pastor Silas França ajudou a fundar a igreja na Ilha, pregando 30 dias

\footnotetext{
${ }^{180}$ ALEIXO, V. C., "Deus Faz, o Templo dos Anjos Mostra, p. 49.

${ }^{181}$ ROSA, J. O., O evangelho quadrangular no Brasil, p. 104.

${ }^{182}$ PAULA, V. A. S., Religião e política no Vale do Paranapanema, p. 49.

${ }^{183}$ ROSA, J. O., O evangelho quadrangular no Brasil, p. 105.

${ }^{184}$ ROSA, J. O., O evangelho quadrangular no Brasil, p. 105.
} 
numa tenda de lona". ${ }^{185}$ O progresso no estado seguiu o caminho natural da Cruzada, com a evangelização em tendas. "As tendas foram importantes porque se tornaram um tipo de igreja volante que favorecia o deslocamento por vários espaços do ambiente urbano". ${ }^{186}$

A Cruzada se expande mais, chegando ao Rio Grande do Sul. Rosa assim refere a obra no estado gaúcho: "lá pelo ano de 1959, chegava a Passo Fundo, no Rio Grande do Sul. O pastor Emil iniciava o seu ministério na Cruzada. Mais tarde entregou também a obra de Passo Fundo ao pastor Eurípedes Batista, que havia terminado o seu curso no IBQ". ${ }^{187} \mathrm{O}$ trabalho processou-se timidamente, sem grandes movimentos, como em outras cidades. A tentativa de chegar à capital no mesmo ano não obteve sucesso, dada a cisão do missionário responsável pelo trabalho em Porto Alegre com a Cruzada. Rosa lembra-se da conduta desse missionário: "organizou uma nova denominação, registrou novos estatutos, e assumiu a liderança dessa obra em Porto Alegre". ${ }^{188}$

Por causa desse episódio a Cruzada não se estabeleceu naquela época na capital gaúcha. O trabalho continuou no interior, mas Porto Alegre só conheceria a Cruzada dez anos mais tarde, como atesta Rosa: "somente em 1970 a obra seria realmente aberta em Porto Alegre". ${ }^{189}$ Essa reabertura seria empreendida por um dos maiores nomes da história da Cruzada, o missionário Mário de Oliveira. Paula diz: "a mensagem religiosa apresentada pelos missionários norte-americanos, centrada na cura divina, se distanciava dos modelos até então correntes no protestantismo e pentecostalismo clássico". ${ }^{190}$ A nova apresentação do pentecostalismo alcança outros estados.

A chegada ao Rio de Janeiro foi marcada pelo convite de um general do Exército, que ajudou nos primeiros passos da Cruzada no estado. Na cidade do Rio de Janeiro era muito difícil a evangelização, por causa do ritmo da grande cidade, que não proporcionava muitas perspectivas. Ainda assim, era um sonho do Rev. Harold Williams levar a obra à capital do estado, como detalha Rosa:

\footnotetext{
${ }^{185}$ ROSA, J. O., O evangelho quadrangular no Brasil, p. 106.

${ }^{186}$ IV Simpósio do GT História das Religiões e Religiosidades, p. 355.

${ }^{187}$ ROSA, J. O., O evangelho quadrangular no Brasil, p. 106.

${ }^{188}$ ROSA, J. O., O evangelho quadrangular no Brasil, p. 107.

${ }^{189}$ ROSA, J. O., O evangelho quadrangular no Brasil, p. 107.

${ }^{190}$ PAULA, V. A. S., Religião e política no Vale do Paranapanema, p. 52.
} 
Uma pessoa enferma, da família de um certo general do Exército, havia recebido cura mediante as orações do pastor Williams, na tenda da Água Branca, em São Paulo. Maravilhados com as bênçãos recebidas, o general e sua família se tornaram grandes amigos da Cruzada. Com a ajuda desse general e sua esposa, foi alugado um terreno em pleno centro do Rio, na Praça da Bandeira, onde uma grande tenda foi armada em 1956. Naquele local foi iniciado o movimento de cura divina para os cariocas. Durante o pouco tempo em que a tenda foi mantida ali, algumas centenas de pessoas ouviram a mensagem Quadrangular. A obra não chegou a estourar, como se esperava. Através do pastor Francisco Rodrigues Suhett e sua esposa, D. Maria Suhett, que vieram conhecer a Cruzada ali na tenda da Praça da Bandeira, e que residiam em Bangu, preparou-se a montagem da tenda naquela cidade. $\mathrm{O}$ pastor Suhett dava os primeiros passos como obreiro da Cruzada. ${ }^{191}$

Mesmo com a ajuda desse general, os missionários perceberam a dificuldade de manutenção da tenda no centro da cidade, decidindo buscar alternativa para o rumo da obra no Rio de Janeiro. Rosa continua: "no ano de 1956, uma tenda já funcionava num outro bairro do Rio, o bairro de Vaz Lobo. Tinha sido montada pelo pastor Joaquim Pedro dos Santos, que viera da Igreja Metodista. Sendo muito dinâmico e bom evangelista, o pastor Joaquim alcançava certo sucesso". ${ }^{192}$ Esse trabalho deu novo ânimo à continuidade da obra no estado, com a condução da tenda a outras localidades.

Os missionários percebiam que a Cruzada não conseguia repetir no Rio de Janeiro o mesmo sucesso alcançado em São Paulo. "Nas tendas de lona o uso de aparelhos eletrônicos foi uma constante, com o emprego de guitarras elétricas, contrabaixos e baterias visando o acompanhamento de cânticos inovando a liturgia evangélica". ${ }^{193}$ À custa de muito trabalho, a Cruzada conseguiu se estabelecer no estado do Rio de Janeiro. O Rio sempre se mostrou um desafio à inovação missionária, como destaca Rosa: “a obra em Campo Grande e Bangu marcou realmente a implantação definitiva da Cruzada no Rio. Em seguida foi armada uma pequena tenda na cidade de Santa Cruz. Não demorou muito, e a Cruzada penetrava no Estado do Rio, em Nova Iguaçu, Nilópolis, Caxias, Ilha do Governador, etc". ${ }^{194}$ Segundo os missionários, um dos empecilhos ao crescimento do movimento pentecostal na época no Rio de Janeiro era a evangelização radical de alguns pentecostais, o que afastava o povo carioca do movimento, como relata Rosa:

\footnotetext{
${ }^{191}$ ROSA, J. O., O evangelho quadrangular no Brasil, p. 108.

192 ROSA, J. O., O evangelho quadrangular no Brasil, p. 109.

${ }_{193}$ IV Simpósio do GT História das Religiões e Religiosidades, p. 355.

${ }^{194}$ ROSA, J. O., O evangelho quadrangular no Brasil, p. 110.
} 
No Rio de Janeiro, havia muita prevenção do povo contra os crentes e contra a Bíblia, embora o carioca seja de bons sentimentos e hospitaleiro. Essa prevenção já vinha de longe. Qual a razão? Provavelmente, devido ao estilo de evangelização, tanto dos pentecostais como dos demais evangélicos, estilo muito egregístico e muito limitado, que não chegava a atingir as massas. Apenas uns poucos eram ganhos para Cristo e outros apenas para as seitas ou denominações. Mas, a grande massa de povo recebia efeitos negativos desse tipo de evangelização; isto é, a evangelização que acusa o próximo de pecador, que o ameaça sistematicamente com o fogo do inferno, e que já no primeiro encontro, critica os costumes, critica o vestuário e utiliza uma porção de impertinências, etc. ${ }^{195}$

A evangelização pentecostal encontrava grande desafio no Rio de Janeiro, o lugar mais progressista e multicultural da época no Brasil. Essa cultura tão aberta não favorecia, em termos gerais, a missão pentecostal, que privava seus adeptos de algumas comodidades do cotidiano, algo rejeitado pelo carioca. Rosa lembra, a título de ilustração:

Na tenda em Vaz Lobo, certa noite, isso nos dias de carnaval - e o carnaval no Rio é pra valer - em plena reunião, alguns elementos, fantasiados e mascarados, entraram pulando e dançando e cantando; mas, ao perceberem que se tratava de uma reunião religiosa, ficaram quietos e ouviram a pregação sem mais perturbações. ${ }^{196}$

Era esse o cenário diante dos missionários, mas a Cruzada aos poucos foi encontrando espaço e estabelecendo suas primeiras obras no Rio, construindo seus templos e dando sequência aos trabalhos. Rosa continua: "as primeiras obras que tiveram seus templos construídos foram Campo Grande e Bangu". ${ }^{197}$ Assim a Cruzada chega ao Rio de Janeiro, mesmo sem os resultados esperados pela liderança. Zwetsch reflete sobre o poder de integração social do pentecostalismo em geral: "além desse aspecto sociológico, que o pentecostalismo resolve com a presença poderosa do Espírito Santo acessível às pessoas individuais, mediante a participação nos ritos e nos custos desses ritos, este tipo de igreja soube se inserir no mundo mágico-religioso que caracteriza a sociedade brasileira". ${ }^{198}$ Isso também se aplica à Cruzada, constituinte do pentecostalismo.

Ainda no mesmo ano, a Cruzada chegava a Minas Gerais, iniciando o trabalho de evangelização em Juiz de Fora. A tenda anunciava a cura divina, o

\footnotetext{
${ }^{195}$ ROSA, J. O., O evangelho quadrangular no Brasil, p. 112-113.

${ }^{196}$ ROSA, J. O., O evangelho quadrangular no Brasil, p. 113.

${ }^{197}$ ROSA, J., O evangelho quadrangular no Brasil, p. 115.

198 ZWETSCH, Roberto Ervino. Missão como com-paixão: por uma teologia da missão em perspectiva latino-americana. Tese de Doutorado. São Leopoldo, 2007, p. 249.
} 
trabalho recebeu bastante audiência e as notícias de curas na tenda se propagaram pela cidade. Rosa se lembra:

Na cidade de Juiz de Fora, a notícia se espalhara de que paralíticos andavam, cegos tornavam a ver, endemoniados eram libertados pelas orações de um missionário. Falava-se que isso tudo estava acontecendo numa tenda de lona, que mais parecia um circo, instalada na Praça Alfredo Lage. Realmente, naquela tenda, isto em setembro de 1956, pregava um missionário escurinho, o pastor Joaquim Pedro dos Santos, que Viera do Rio de Janeiro. ${ }^{199}$

Diante do crescimento e aceitação do movimento de cura divina da Cruzada em Juiz de Fora, alguns opositores levantaram-se contra o movimento, mas as campanhas continuaram, mesmo sob perseguição. A situação chegou a tal ponto que a tenda sofreu um atentado, como especifica Rosa: "a tenda foi incendiada por dois rapazes, que utilizaram gasolina para cometer o crime". ${ }^{200}$ A obra continuou na cidade e, alguns anos mais tarde, receberia o apoio do trabalho do missionário Mário de Oliveira. “A IEQ se configurou como uma igreja do evangelismo dinâmico, movimentando tendas e fundando novas igrejas gigantescas, direcionando a sua corrente doutrinária à cura divina". ${ }^{201}$

A Cruzada avançou até outra cidade mineira, Poços de Caldas, como narra Rosa: "na famosa cidade turística de Poços de Caldas, em princípios de 1958, o público, ao ligar os seus rádios, certo dia, sintonizando a poderosa Rádio Cultura, começou a ouvir um novo programa intitulado 'Visita ao seu Lar', naquela época, já padronizado em toda a Cruzada". ${ }^{202} \mathrm{O}$ rádio nessa cidade foi muito útil, facilitando o contato do público com os missionários e proporcionando maior divulgação das campanhas.

A Cruzada completa sua expansão pelo Sudeste, chegando a Vitória, Espírito Santo. A boa recepção dos capixabas coroou de grande êxito as campanhas iniciais. Rosa refere: "a obra da Cruzada em Vitória foi iniciada de 1958 para 1959, numa grande tenda de lona armada na Esplanada Capixaba. Diversos pregadores ajudaram na evangelização, entre eles o pastor Williams e o

\footnotetext{
${ }^{199}$ ROSA, J. O., O evangelho quadrangular no Brasil, p. 116.

${ }^{200}$ ROSA, J. O., O evangelho quadrangular no Brasil, p. 116.

${ }^{201}$ DINIZ, Priscila Ribeiro Jeronimo. A Construção do Conceito de Identidade: a Partir da Análise Realizada na Igreja do Evangelho Quadrangular, em Juazeiro do Norte. Ciências da Religião História e Sociedade, v. 11, n. 2, p. 115-137. 2013, p. 122.

${ }^{202}$ ROSA, J. O., O evangelho quadrangular no Brasil, p. 117.
} 
pastor Geraldino dos Santos". ${ }^{203}$ Os missionários seguiram o plano da Cruzada de ficar de 30 a 60 dias na cidade e estabelecer a obra. A denominação adquiriu um terreno para a construção do primeiro templo da Cruzada no Espírito Santo, que, infelizmente, se localizava num morro, carecendo de nivelamento para o início da construção. Sobre esse trabalho, afirma Rosa: "naquele dia, exatamente 13 de outubro de 1960, grande número de pessoas entre homens e mulheres e até crianças, trabalhavam duramente transportando pedras para carregar os quatro caminhões ali estacionados". 204

O trabalho para terraplenar o terreno construção foi executado pelos simpatizantes e adeptos do movimento, e todos ajudavam como podiam. Havia muito a fazer naquele terreno tão acidentado, como detalha Rosa: "nada menos do que o desmonte de uma grande pedreira, para o nivelamento de uma área no terreno de 2.631 metros quadrados, adquirido pela Cruzada em Vitória, capital do Estado do Espírito Santo". ${ }^{205} \mathrm{O}$ trabalho na tenda estava muito precário pelo estado de conservação da tenda, ainda considerando sua instalação à beira-mar, onde os ventos e a maresia constantes geravam desconforto ao público. Rosa assegura:

\begin{abstract}
A tenda de lona onde se iniciara a obra estava apodrecida. Milhares de pessoas lotavam aquela tenda diariamente; mas na sua maioria era um povo muito pobre. Aqueles irmãos que trabalhavam no desmonte daquele morro faziam-no com alegria, sob a liderança do pastor Abrahão Alves de Oliveira, superintendente da região do Espírito Santo. [...] Ainda no seu pastorado, a obra se expandiu por vários municípios próximos, tais como: Morro da Penha, Maruípe, Barreiros, Ilha do Príncipe, Jardim América, Alto Lage, Alto da Boa Vista, Ibes, Bairro da Glória, Vila Velha, Morro do Quadro, etc. ${ }^{206}$
\end{abstract}

A construção do templo começou no dia 13 de outubro de 1960, quando um acidente ocasionou a morte do pastor Abrahão, responsável pela Cruzada no Espírito Santo. É Rosa quem assegura: "lá estava ele, por volta das 16 horas, ao lado de um dos operários ao pé daquele morro, quando inesperadamente uma barreira deslizou, sem que houvesse tempo para o pastor Abrahão e o operário escaparem". ${ }^{207}$ A perda do líder, em pleno exercício de evangelização com resultados muito positivos, muito abalou a Cruzada em todo o Brasil. Uma

\footnotetext{
${ }^{203}$ ROSA, J. O., O evangelho quadrangular no Brasil, p. 121.

${ }^{204}$ ROSA, J. O., O evangelho quadrangular no Brasil, p. 120.

${ }^{205}$ ROSA, J. O., O evangelho quadrangular no Brasil, p. 120.

${ }^{206}$ ROSA, J. O., O evangelho quadrangular no Brasil, p. 121.

${ }^{207}$ ROSA, J. O., O evangelho quadrangular no Brasil, p. 121.
} 
multidão acompanhou o cortejo até o cemitério. A obra iniciada pelo pastor Abrahão continuou crescendo entre os capixabas e diversos templos foram construídos em várias cidades.

Em 1959 a Cruzada chegou aos estados de Mato Grosso, Goiás e Amazonas. Pedde destaca: "no final da década de 1960, as barracas de cura divina já haviam alcançado as regiões Sudeste, Sul e Centro-Oeste". ${ }^{208}$ A Cruzada alcançava sua intenção inicial de expansão por todo o país.

A história da "Cruzada", nome popular pelo qual ficou conhecida a Igreja do Evangelho Quadrangular no Brasil, tem como um dos grandes nomes o missionário Mário de Oliveira, que desempenhou papel fundamental no desenvolvimento da denominação no Brasil. Sobre seu início como missionário da Cruzada, Rosa diz: "isto aconteceu na noite de 26 de março de 1956, na cidade de Assis, no interior de São Paulo. Mario de Oliveira, que estreava naquela noite como missionário, tinha pouco mais de 19 anos e a aparência de um menino". ${ }^{209}$ Depois de sua estreia diante do público de Assis, com resultados considerados satisfatórios pela liderança da Cruzada, ele foi comissionado a Porto Alegre, onde a Cruzada ainda não conseguira se estabelecer. Segundo Rosa: "a primeira reunião do Missionário Mario em Porto Alegre aconteceu no dia 22 de janeiro de 1970, com a surpreendente frequência de cerca de sete mil pessoas. Porto Alegre sempre fora o grande objetivo da Cruzada no Sul, desde o início da obra no Brasil". ${ }^{210} \mathrm{O}$ sucesso do trabalho em Porto Alegre pôs esse missionário em destaque na Cruzada, por ser essa cidade um objetivo bem antigo do movimento. Mais tarde ele também seria enviado a Belo Horizonte.

A IEQ foi a precursora de estratégias de evangelização mais bem exploradas, no futuro, por outras denominações. Lima informa: “de acordo com os principais pesquisadores do pentecostalismo brasileiro dessa época, apesar de os missionários americanos da Cruzada terem implantado o movimento de cura divina e incentivado o uso do rádio pelos pentecostais brasileiros". ${ }^{211}$ Foram as

\footnotetext{
${ }^{208}$ PEDDE, Valdir. A inserção dos pentecostais na política: uma ameaça à democracia? História Unisinos. Vol. $13 \mathrm{~N}^{\circ} 3$ - p. 285-296. Set /dez, 2009, p. 289.

${ }^{209}$ ROSA, J. O., O evangelho quadrangular no Brasil, p. 145.

${ }^{210}$ ROSA, J. O., O evangelho quadrangular no Brasil, p. 202.

${ }^{211}$ LIMA, José Hélio de. Manoel de Mello: expoente na radiodifusão religiosa ao anonimato na historiografia brasileira. Relegens Thréskeia: Estudos e Pesquisa em Religião. V. 01, n. 02, p. 3239. 2012 , p. 46.
} 
denominações subsequentes à Cruzada que conseguiram utilizar esses meios com mais eficácia.

Nesta etapa da pesquisa é necessário, para entender o processo de crescimento da Quadrangular no Brasil, acompanhar também o início dos principais líderes como missionários da Cruzada. Destaca-se a conversão de Josué Bengtson, que viria a ser um dos grandes responsáveis pela evangelização em várias cidades. Rosa diz: "isso aconteceu exatamente no dia 28 de janeiro de 1961 ". ${ }^{212}$ A partir desse momento ele se dedicou totalmente à pregação, tornandose um grande missionário na Cruzada. Rosa pontua o início do seu trabalho:

Mais ou menos dois anos depois, portanto em 1963, aquele rapaz saía a campo como evangelista da Cruzada, iniciando sua primeira obra, a 23 de abril daquele ano, na cidade de Paraguassu Paulista. Esse rapaz que iniciava sua primeira obra modestamente, num salão alugado, sem propaganda de rádio, sem propaganda nenhuma, era nada menos do que hoje bastante conhecido missionário Josué Bengtson. [...] Lá permaneceu aproximadamente um ano, percorrendo os estados do Paraná, São Paulo, Minas Gerais, Espírito Santo e Bahia até 1973. Em 1969, iniciava a obra em Feira de Santana, na Bahia. ${ }^{213}$

Depois de percorrer diversas cidades e protagonizar muitas campanhas, o missionário Josué Bengtson levou a Cruzada aos estados mais distantes, como o Pará, onde fez crescer muito a obra com seu trabalho missionário. Santana diz: "ao dar ênfase à cura divina, o pentecostalismo quadrangular tem consciência de que essa cura é responsável em grande parte pelas adesões até de evangélicos que engrossam suas fileiras". ${ }^{214} \mathrm{O}$ fato é decisivo na missão da IEQ.

A Cruzada avançou pelo Nordeste, alcançando Recife. A obra nessa cidade começou muito tumultuada, com perseguição ao missionário já nas primeiras campanhas de cura divina. Rosa lembra:

Era acusado de curandeirismo, simplesmente porque pregava o evangelho e libertava as pessoas pela oração da fé, em nome de Jesus Cristo. A essa altura, ele estava reunindo cerca de dez mil pessoas ao ar livre, em Recife, Estado do Pernambuco. [...] Tratava-se do missionário Antônio Genaro de Oliveira, irmão do missionário Mário de Oliveira. Isso acontecia no ano de $1970 .{ }^{215}$

\footnotetext{
${ }^{212}$ ROSA, J. O., O evangelho quadrangular no Brasil, p. 206.

${ }^{213}$ ROSA, J. O., O evangelho quadrangular no Brasil, p. 206.

${ }^{214}$ SANTANA, Neusa Tolentino. Mover do Espírito Santo na virada do milênio: pentecostais e carismáticos em Goiânia. Dissertação de Mestrado. Universidade Católica de Goiás. Goiânia, 2001. P. 40.

${ }^{215}$ ROSA, J. O., O evangelho quadrangular no Brasil, p. 210.
} 
O caso do missionário Antônio Genaro ganhou repercussão até na tevê, pelos sinais de perseguição religiosa por rejeição de práticas diferentes das então conhecidas na região, como ilustra Rosa: “a própria Rede Globo de TV em Recife entrou em ação, apelando para que as autoridades libertassem o missionário". ${ }^{216}$ Com a sua libertação, a obra em Pernambuco continuou a crescer, consolidando a Cruzada nesse estado. Andrade inclui a IEQ entre as denominações pentecostais clássicas: "hoje se assemelham às Igrejas clássicas, como, por exemplo, a Assembléia de Deus, que constitui uma das três vertentes do Pentecostalismo Clássico brasileiro. As outras duas são constituídas pela Congregação Cristã no Brasil e a Igreja do Evangelho Quadrangular". 217

A chegada de Josué Bengtson e seu sogro Demétrio Maestri foi uma verdadeira aventura. Eles viajaram muito tempo de carro até Belém do Pará. Nesse estado, uma grande obra de evangelização foi conduzida por esses missionários, que não mediaram esforços para anunciar a mensagem pentecostal da Cruzada nos lugares mais distantes. Rosa afirma:

Não era para menos, pois além de haver percorrido os quase mil quilômetros de Vitória da Conquista, na Bahia, até Vitória, no Espírito Santo, Agora o seu dono, corajosamente, se propusera a viajar até Belém, no Pará. Isso acontecia em princípios de 1973. Os passageiros do Volks eram Josué Bengtson e o seu sogro, Demétrio Maestri. ${ }^{218}$

O desbravamento do Pará foi desafiador, mas de grande sucesso, com expressivo crescimento das campanhas do missionário Josué Bengtson, que atraíam multidões. A obra consolidou-se nesse estado e cada vez mais se concretizava o plano de uma Cruzada de nível nacional. A chegada ao Ceará processou-se de maneira bem intensa, tornando-se caso de polícia pela quantidade de participantes das campanhas dos missionários da Cruzada na capital cearense. Rosa diz:

Mas onde se passaram estes fatos? Em Fortaleza, capital do Ceará, a terra natal do missionário Epifânio. A essa altura, perto de umas 20 reportagens já haviam saído em diversos jornais locais, sobre os milagres que aconteciam naquela cidade. Corria o ano de 1974. Entrevistado na televisão, Epifânio teve de responder a cerca

\footnotetext{
${ }^{216}$ ROSA, J. O., O evangelho quadrangular no Brasil, p. 211.

${ }^{217}$ ANDRADE, Paulo Fernando Carneiro de. Sinais dos tempos: Igreja e seitas no Brasil. SDT, p. 232.

${ }^{218}$ ROSA, J. O., O evangelho quadrangular no Brasil, p. 220.
} 
de 15 perguntas, diante de um grupo composto por sacerdotes, psiquiatras, psicólogos, médicos e jornalistas. ${ }^{219}$

O caso no Ceará ganhou destaque, pois os relatos de curas eram muitos e membros da sociedade queriam entender o que se passava e como era de fato o trabalho exercido pelos missionários da Cruzada. Gini diz: “a igreja fundada por Williams trazia como grande novidade para o movimento pentecostal da época o ministério de cura divina". ${ }^{220}$ A obra também chega a Maceió, como assinala Rosa: "o salão foi alugado sem contrato, pois o homem propunha-se a confiar apenas na palavra do homem de Deus. A primeira concentração ali foi no dia 25 de julho de $1975 "{ }^{221} \mathrm{O}$ missionário responsável por essa confiança era Wenceslau Gomes Gonçalves, que enfrentou muitos desafios. Em uma de suas reuniões, um paralítico saiu curado e a notícia espalhou-se pela cidade. Depois desse fato, multidões compareciam às reuniões. Lopes assegura: "a Quadrangular não só foi pioneira, mas também foi a que efetivamente mais trabalhou o dom da cura e de maneira bastante vanguardista". ${ }^{222}$ Percebe-se que a cura faz parte da missão na IEQ.

O plano nacional de evangelização prosperava e a Cruzada se estendia cada vez mais pelo país. Já havia chegado a Minas Gerais, mas a capital, Belo Horizonte, era muito disputada pelos religiosos, encontrando-se ali de tudo no que diz respeito às religiões. Qualquer nova denominação não passaria de mais uma entre tantas outras. A Cruzada tem um plano, exposto por Rosa: "tendo saído de Porto Alegre em março de 1971, Mário de Oliveira não tinha ideia de seu destino ainda. Recebeu, então, proposta do Conselho Nacional para abrir uma obra em Brasília; quando chegou em São Paulo para tratar do assunto, os planos tinham sido mudados, ele deveria seguir para Belo Horizonte". ${ }^{223}$ Era outro grande desafio na vida desse jovem missionário, que já havia recebido outra prova difícil, a evangelização em Porto Alegre, onde a Cruzada só conseguiu se estabelecer pelo seu trabalho missionário. Rosa diz:

\footnotetext{
${ }^{219}$ ROSA, J. O., O evangelho quadrangular no Brasil, p. 223.

${ }^{220}$ GINI, Sérgio. Conflitos no campo protestante: o movimento carismático e o surgimento da Igreja Presbiteriana Renovada (1965-1975). Revista Brasileira de História das Religiões. ANPUH, Ano III, n. 8, p. 121-164. Set. 2010, p. 126.

${ }^{221}$ ROSA, J. O., O evangelho quadrangular no Brasil, p. 229.

${ }^{222}$ LOPES, M., Pentecostalismo no Brasil e a cura divina, p. 105.

${ }^{223}$ ROSA, J. O., O evangelho quadrangular no Brasil, p. 234.
} 
Belo Horizonte ainda hoje continua a ser a "Meca" desses aventureiros. Além disso, Mário observou uma coisa curiosa. Diariamente, era comum encontrar-se no centro da cidade, quase em cada esquina, principalmente na Praça "Sete", a mais central, grupinhos de pregadores, não só pregando, mas orando por revelação, expulsando demônios, vendendo lenços ungidos, levantando ofertas em plena praça pública. Dessa forma, o Evangelho vinha sendo desacreditado, desmoralizado perante o público. Como iniciar um movimento evangelístico com oração pelos enfermos e libertação dos oprimidos diante dessa calamidade? ${ }^{224}$

Ante esse quadro, o missionário decide pôr em prática o plano para alcançar Belo Horizonte. Preferiu não iniciar o trabalho diretamente na capital, escolhendo uma cidade próxima, Juiz de Fora, como forma de melhor se estruturar. Os juizforanos já contavam com uma Cruzada, mas Mário concentrou-se em outro bairro da cidade, sem ligação com o trabalho já estabelecido. O rádio foi de grande ajuda nessa fase, e o missionário Mário de Oliveira utilizava muito bem esse meio de divulgação, conquistando espaço gradualmente até o estabelecimento em Belo Horizonte. Conceição esclarece esse novo marco no protestantismo brasileiro:

Inicia-se nova modalidade de evangelização por utilizar o rádio, portas para o evangelismo de massa e por centrar seu discurso teológico no dom espiritual da cura divina e por utilizar tendas por toda a extensão do Brasil para a realização de cultos dessa natureza, o que daria a ela o título de igreja itinerante em seus momentos iniciais. ${ }^{225}$

A plataforma religiosa que constituía a Cruzada era diversa, sendo seu resultado o esforço de cooperação de várias denominações protestantes. Tureck diz: "Batistas, Metodistas, Luteranos fariam parte desse grande ministério. É claro que muitos foram expulsos por aderirem a essa 'loucura' espiritual, pois criam no poder do Espírito Santo e na cura divina". ${ }^{226}$ A adesão de membros dessas denominações ao movimento gerava tensão no meio protestante, mas havia quem estivesse apenas de passagem, experimentando oportunidades para dar continuidade a trabalhos próprios, como o fundador da Igreja O Brasil para Cristo. Lopes acrescenta: "o fundador da igreja O Brasil para Cristo (BPC) foi o exoperário e diácono da Assembleia de Deus, Manoel de Mello. Mello teve influência não negligenciável no movimento de cura divina, pois, com a chegada das tendas, e impulsionado pela recuperação de uma doença grave, ligou-se à

\footnotetext{
${ }^{224}$ ROSA, J. O., O evangelho quadrangular no Brasil, p. 234.

${ }^{225}$ CONCEIÇÃO. Douglas Rodrigues da. Aspectos religiosos do Brasil contemporâneo. Revista Estudos Amazônicos, Vol. X, nº 1, pp. 86-117. 2014, p. 103.

${ }^{226}$ TURECK, A., Cuidando da comunicação em família, p. 20.
} 
Cruzada Nacional de Evangelização".227 Depois dessa cura, fundou sua denominação com características semelhantes.

A Cruzada continuava se destacando no crescimento entre os pentecostais e atraindo novos adeptos, como afirma Tureck: "a Cruzada cresceria nesses anos, à semelhança de um caudaloso rio, de onde sairiam muitos afluentes, sem que as suas águas jamais diminuíssem". ${ }^{228}$ É preciso ressaltar que o movimento Cruzada Nacional de Evangelização iniciou-se como um projeto interdenominacional com o objetivo de evangelização. Movimento plural dentro do protestantismo, oportunizou novas perspectivas a partir do processo de unificação, e das novas experiências vivenciadas resultaram novas denominações com características semelhantes às suas. Lopes assegura:

Pensamos, assim, que a IEQ influenciou de maneira bastante significativa essa igreja da segunda onda pentecostal brasileira, qual seja, a BPC. Afirmamos isso porque a ênfase da BPC também foi a cura divina e muito embora tenha, em certo sentido, inovado na propagação midiática da fé pentecostal, sua matriz, notoriamente, foi a IEQ. ${ }^{229}$

As denominações O Brasil para Cristo e Deus é Amor surgiram depois da propagação do modelo missionário da Cruzada, seguindo o seu modelo. Lopes destaca: “a IEQ não só influenciou, também inspirou outras igrejas pentecostais de segunda onda. Uma dessas foi a Igreja Pentecostal Deus é Amor (IPDA), fundada em 1962 por David Miranda". ${ }^{230}$ Muitas outras igrejas surgiram com características semelhantes, mas as duas mencionadas exercem papel histórico e recebem reconhecimento no meio pentecostal. Lopes continua: "portanto, a BPC e a IPDA parecem dar conta de evidenciar a influência e inspiração que a IEQ teve enquanto denominação pioneira da segunda onda pentecostal". ${ }^{231}$

As inovações inseridas pela Cruzada na evangelização tornaram-se um legado, proporcionando novas formas de manifestações a que outras denominações somente acrescentaram novos elementos. Lopes diz: "por fim, mas não menos importante, levanta-se a tese de Mendonça de que a IEQ, em certo sentido, lançou as bases do neopentecostalismo". ${ }^{232}$ Mendonça é categórico em

${ }^{227}$ LOPES, M., O legado de uma pioneira, p. 90.

${ }^{228}$ TURECK, A., Cuidando da comunicação em família, p. 21.

${ }^{229}$ LOPES, M., O legado de uma pioneira, p. 90.

${ }^{230}$ LOPES, M., O legado de uma pioneira, p. 90.

${ }^{231}$ LOPES, M., O legado de uma pioneira, p. 91.

${ }^{232}$ LOPES, M., O legado de uma pioneira, p. 92. 
sua afirmação sobre o papel da IEQ no surgimento do modelo de igrejas conhecidas como neopentecostais. Outros pesquisadores não atribuem o surgimento dessas denominações diretamente ao legado da IEQ, mas reconhecem sua contribuição indireta. Lopes informa: "portanto, tanto numa tese quanto noutra, a IEQ, de algum modo, também deu ensejo à formação do neopentecostalismo". ${ }^{233}$ O fato é que antes do movimento Cruzada Nacional de Evangelização não se propagavam no Brasil tais práticas.

A comunidade pentecostal já estava estabelecida no Brasil, quando a Cruzada Nacional de Evangelização tornou pública a experiência da taumaturgia entre os brasileiros. Lopes diz: "não fosse a ênfase taumatúrgica da IEQ na segunda onda pentecostal, talvez fosse improvável que tais igrejas tivessem hoje este usufruto". ${ }^{234}$ Esse tipo de experiências entre o povo democratizou a experiência espiritual, proporcionando a participação do povo leigo, fato que descentralizou o poder das instituições protestantes. Siepierski assegura: “contudo, convém ressaltar que a chegada da IEQ representa um passo em direção ao surgimento de novas formações pentecostais que, com o passar do tempo, se distanciariam do modelo clássico". ${ }^{235}$

Uma série de acontecimentos contribuiu decisivamente para a construção do neopentecostalismo, nome pelo qual ficaram conhecidas algumas denominações que amalgamaram elementos do pentecostalismo com técnicas e grande ênfase na prosperidade. Entretanto o termo neopentecostalismo parece estar em desacordo com a própria etimologia da palavra. Siepierski esclarece: “ora, se o neoclássico é 'neo' por não diferir significativamente do clássico, por que neopentecostalismo, se ele difere sobremaneira do pentecostalismo que o precedeu? Ademais, tradicionalmente o prefixo 'neo' tem sido relacionado com continuidade e não com ruptura". 236

Entre os pesquisadores do pentecostalismo, dois termos são recorrentes na diferenciação dos grupos. Alguns situam a IEQ entre os neoclássicos, pelo seu recorte no tempo e pela indiferenciação teológica dos considerados clássicos, no caso, as primeiras denominações inseridas no Brasil, a Assembleia de Deus e a

\footnotetext{
${ }^{233}$ LOPES, M., O legado de uma pioneira, p. 94.

${ }^{234}$ LOPES, M., O legado de uma pioneira, p. 94.

${ }^{235}$ SIEPIERSKI, Paulo D. Pós-Pentecostalismo e Política no Brasil. Estudos Teológicos, v. 37, n. 1, p. 47-61, 1997, p. 49-50.

${ }^{236}$ SIEPIERSKI, P. D., Pós-pentecostalismo e política no Brasil, p. 51.
} 
Congregação Cristã. Já o termo neopentecostalismo aplica-se a denominações como a Igreja Universal do Reino de Deus. Os dois termos parecem descrever a mesma coisa. Siepierski continua: "é por isso que em outros lugares 'neopentecostalismo' é utilizado para indicar a renovação carismática ocorrida no seio das denominações protestantes, pois ela não diferiu significativamente do pentecostalismo anterior". 237

Pesquisadores do pentecostalismo excluem os chamados neopentecostais do pentecostalismo clássico, por não representarem continuidade teológica e práticas condizentes com o movimento pentecostal, considerando tal grupo como algo dissociável e independente do pentecostalismo. Siepierski informa:

Tamanho distanciamento indica que o fenômeno não é simplesmente uma nova forma de pentecostalismo, um "neopentecostalismo", mas um "póspentecostalismo". Assim, o pós-pentecostalismo é um afastamento do pentecostalismo, tendo como cerne a teologia da prosperidade e o conceito de guerra espiritual. ${ }^{238}$

Esta pesquisa considera as denominações pós-Cruzada como póspentecostalismo, buscando tornar mais claro o entendimento, dada a diferenciação desse grupo do pentecostalismo, com o acréscimo de agentes de maior destaque em sua prática. Assim, Paula considera "a chegada da Quadrangular [...] como o marco inicial de um novo momento na expansão pentecostal pelo Brasil, inaugurando o chamado pentecostalismo neoclássico". ${ }^{239}$ A inauguração do novo momento do pentecostalismo brasileiro iniciado pela Cruzada faz crescer e difundir-se o pentecostalismo, que, antes dessa fase, praticamente se restringia a duas denominações, a Assembleia de Deus e a Congregação Cristã, embora sempre houvesse grupos nas igrejas protestantes históricas que praticassem o pentecostalismo. "O rápido crescimento de ambas foi mantido sem maiores rivalidades até 1945, quando a Igreja do Evangelho Quadrangular iniciou suas atividades preparando o pentecostalismo para uma nova fase". ${ }^{240}$

Nesse momento também é aceitável o conceito de deuteropentecostais, ou seja, instalados depois dos primeiros pentecostais. Diniz assegura:

\footnotetext{
${ }^{237}$ SIEPIERSKI, P. D., Pós-pentecostalismo e política no Brasil, p. 51.

${ }^{238}$ SIEPIERSKI, P. D., Pós-pentecostalismo e política no Brasil, p. 51.

${ }^{239}$ PAULA, V. Religião e política no Vale do Paranapanema, p. 63.

${ }^{240}$ IV Simpósio do GT História das Religiões e Religiosidades, 352.
} 
A segunda onda é constituída pelos deuteropentecostais (deutero significa segundo), que instauram um evangelismo de massa com a cura divina. A diferença da primeira onda para a segunda acontece "pelo corte histórico-institucional, mas não pela existência de diferenças teológica significativa entre ambas. ${ }^{241}$

Não existem grandes variações entre os primeiros e os segundos pentecostais no Brasil, apenas o período de instalação entre eles. O segundo agrega novos elementos, sem rejeitar os primeiros. Diniz prossegue: "mas agregaram o evangelismo massificado". ${ }^{242}$ Ou seja, encontram um caminho para a evangelização entre os brasileiros. Já as igrejas do pós-pentecostalismo diferem bastante, tanto teologicamente como na prática. Diniz informa: "eles agregam e ressignificam as particularidades das outras ondas. Um dos aspectos fundamentais dessa onda é a ênfase na tríade cura-exorcismo-prosperidade". ${ }^{243}$

Houve alterações significativas nesse modelo, criando um modelo autônomo sem associação com o pentecostalismo. É evidente que muitos elementos foram importados do pentecostalismo, principalmente da neoclássica IEQ, a ponto de alguns pesquisadores situarem essa denominação como parte desse grupo, pelos numerosos pontos em comum. Paula comenta: "essa igreja encerra uma grande variedade de práticas que ora se aproximam do pentecostalismo clássico, ora se aproximam da neopentecostalismo. Ademais, no movimento pentecostal brasileiro, as fronteiras doutrinárias e teológicas são facilmente transgredidas". ${ }^{244}$ Por se situar entre os dois extremos, a IEQ parece se associar a ambos os grupos, pela capacidade de inovação.

A IEQ compreende uma grande diversidade na sua missão, muitas vezes inovadora, como já visto. Entretanto, segundo a maioria dos autores, os que a associam ao pós-pentecostalismo o fazem pela forte ênfase na cura divina, também utilizada por tais grupos. Paula destaca:

É justamente por essa ênfase na cura divina e pelos métodos proselitistas diferenciados que os pesquisadores da religião no Brasil consideram a chegada da IEQ, nos 1950, como um marco na história do pentecostalismo brasileiro. Todavia, suas bases teológicas não se distanciaram muito do pentecostalismo clássico. ${ }^{245}$

${ }^{241}$ DINIZ. P. R. J., A Construção do Conceito de Identidade a Partir da Análise Realizada na Igreja do Evangelho Quadrangular, em Juazeiro do Norte, p. 119.

${ }_{242}$ DINIZ. P. R, J., A Construção do Conceito de Identidade a Partir da Análise Realizada na Igreja do Evangelho Quadrangular, em Juazeiro do Norte, p. 119.

${ }^{243}$ DINIZ. P. R. J., A Construção do Conceito de Identidade a Partir da Análise Realizada na Igreja do Evangelho Quadrangular, em Juazeiro do Norte, p. 119.

${ }_{244}$ PAULA, V. A. S., Religião e política no Vale do Paranapanema, p. 43.

${ }^{245}$ PAULA, V., A. S., Religião e política no Vale do Paranapanema, p. 56. 
Mesmo que a IEQ não se distancie do pentecostalismo considerado clássico, algumas de suas doutrinas e práticas missionárias servem de fonte ao póspentecostalismo. Para Zwetsch, a tendência a classificar algumas igrejas como pertencentes ao pentecostalismo clássico serve justamente para dissociá-las do pós-pentecostalismo. Para o autor, "alguns pesquisadores chegam a afirmar que estas são as igrejas do pentecostalismo clássico para diferenciá-las de um novo tipo que vem se firmando como mais adaptado ao mundo da comunicação virtual e às tendências de competição no assim chamado mercado religioso". ${ }^{246} \mathrm{O}$ papel desempenhado pela IEQ no campo religioso brasileiro configura-se, dessa maneira, pela abertura missionária, e independentemente de classificações e nomenclatura, verifica-se forte expansão missionária no protestantismo brasileiro. Oliveira conclui: "nesse sentido, [...] a Igreja Quadrangular, face à sua importância como vanguarda de uma nova fase pentecostal, colaborou na criação de paradigmas que se tornaram pressupostos para praticamente todas as denominações que surgiram a posteriori" ${ }^{247} \mathrm{O}$ cenário religioso brasileiro sofreu grande alteração a partir dos anos 1950, sendo de grande responsabilidade o trabalho missionário exercido pela IEQ, inicialmente com o movimento interdenominacional de evangelização Cruzada Nacional de Evangelização, tendo como elemento central de sua missão a propagação da cura divina de cidade em cidade nas tendas de lona, o que representou uma nova forma de fazer missão.

\section{2.}

A Igreja do Evangelho Quadrangular em sua história e em sua missão

Nesta parte buscaremos evidências da Igreja do Evangelho Quadrangular em sua história e em sua missão por meio da análise dos seus materiais e da autobiografia de McPherson, utilizando-se também o acesso à declaração de fé da Igreja do Evangelho Quadrangular, bem com os estatutos e obras que descrevem a visão da doutrina quadrangular. Dessa forma propõe-se compor um panorama geral desse pentecostalismo para a análise de sua ação missionária.

\footnotetext{
246 ZWETSCH, R. E., Missão como com-paixão, p. 41.

${ }^{247}$ OLIVEIRA, M. A., De pentecostes ao pentecostalismo, p. 136.
} 


\subsection{1.}

\section{Histórico das origens e missão da Igreja do Evangelho Quadrangular}

A Igreja do Evangelho Quadrangular tem origem em Los Angeles, Califórnia, Estados Unidos. O cenário da origem a IEQ é o avivamento pentecostal do século XX, sobre o qual Lima e Bezerra asseguram: "os historiadores dedicados ao estudo do avivamento pentecostal no século XX são unânimes em indicar o endereço situado na Rua Azuza, n. 312, em Los Angeles, Califórnia, Estados Unidos, como o centro irradiador de onde esse movimento começou [...]". ${ }^{248}$ Esse movimento, cujas raízes se apoiam nas doutrinas de John Wesley, ${ }^{249}$ o fundador do Metodismo, ocorreu entre 1906 e 1909, chegando ao Brasil em 1910. Lima descreve algumas características dos seguidores de Wesley: “eram rígidos e regulares em suas expressões religiosas, no exercício de ordem espiritual e no auxílio aos pobres, aos doentes e aos presos. Por causa dessa regularidade, passaram a ser chamados de Metodistas". ${ }^{250} \mathrm{O}$ pentecostalismo do século XX encontra nesse movimento sua raiz histórica. E é nesse ambiente de grande propagação do pentecostalismo nos Estados Unidos que nasce a Igreja do Evangelho Quadrangular.

Aimee Semple McPherson, "fundadora da Igreja do Evangelho Quadrangular, chamava-se Aimee Elizabeth Kennedy, em homenagem à falecida esposa de seu pai, Sra. Elizabeth Kennedy". ${ }^{251}$ McPherson destaca detalhes em

\footnotetext{
${ }^{248}$ LIMA, Josadak; BEZERRA, Cícero Manoel. História e Teologia da Igreja do Evangelho Quadrangular. Curitiba: Intersaberes, 2017, p. 17.

249 John Wesley (1708-1791), filho do pastor anglicano Samuel Wesley e de Suzana Wesley, nasceu em Epworth em 17 de junho de 1703. Viveu e exerceu seu ministério na agitação da Revolução Industrial, quando o mundo ocidental estava voltado para o desenvolvimento de novas tecnologias de produção de bens e de geração de energia. Para apresentar o evangelho de forma relevante para sua época, Wesley fundou, em Oxford, com mais uns poucos jovens, o chamado Clube Santo. Ibid., p. 16-17.

${ }^{250}$ LIMA, J.; BEZERRA, C. M., História e Teologia da Igreja do Evangelho Quadrangular, p. 17.

${ }^{251}$ Em Salford, próximo a Ingersoll, em Ontário, Canadá, viviam o Sr. James Morgan Kennedy e sua esposa, a Sra. Elizabeth Kennedy. A senhora Elizabeth ficou muito doente e James publicou um anúncio para contratar alguém para cuidar dela. A Srta. Mildred Ona Pearce, ou simplesmente "Minnie", que tinha 14 anos de idade, aceitou o emprego. Ela era órfã e filha adotiva de um casal metodista que atuava no "Exército da Salvação", movimento evangelista da Igreja Metodista. Algum tempo depois, a Sra. Elizabeth Kennedy veio a falecer e o Sr. Kennedy, já com 50 anos de idade, tomou a jovem Minnie em casamento. Isso gerou muita confusão no lugar onde moravam, e eles se sentiram forçados a mudar para Michigan, nos Estados Unidos da América, amenizando o escândalo. Em 9 de outubro de 1890, de volta ao Canadá e agora morando em uma fazenda perto de Ingersoll, nasce a filha única do casal James e Minnie, a qual recebeu o nome da falecida esposa de James, Elizabeth Kennedy. Com o passar dos anos, a menina, muito desenvolta, adotou para si mesma o nome de Aimee Elizabeth Kennedy, para diferenciar-se da falecida
} 
sua autobibliografia: "nasceu em 9 de outubro de 1890, cresceu numa fazenda a cinco milhas de Ingersoll, Ontario, Canadá". ${ }^{252}$ Era filha única de James e Minnie Kennedy, fazendeiros e cristãos de matriz metodista. A esse respeito, afirma Lima: "Durante o período de sua adolescência, Aimee frequentou a Igreja Metodista". ${ }^{253}$ Sobre a antecedente vida religiosa dos pais, Myckon de Oliveira diz: "Seu pai era metodista e sua mãe atuava no Exército da Salvação". ${ }^{254}$ A mãe de Aimee teve que abandonar o serviço ativo no "Exército da Salvação". ${ }^{255}$ por problemas de saúde, indo morar na fazenda. McPherson lembra:

Um dia, relendo a história de Ana, em I Samuel, fez um voto ao Senhor. Pediu-lhe uma filha, prometendo dedicá-la ao seu serviço. O Senhor ouviu sua petição e em outubro de 1890, com a filha recém-nascida em seus braços, na fazenda, a mãe de Aimee, comovida e cheia de gratidão, parafraseou o trecho da escritura que tinha se tornado uma parte de sua própria vida: 'Por esta filha eu orei e o Senhor atendeu minha petição, pelo que também eu a entrego ao Senhor por todos os dias de sua vida'. ${ }^{256}$

$\mathrm{Na}$ época do colégio, Aimee assimilou novas concepções do mundo e da vida em sociedade. A esses acontecimentos McPherson ressalta: "na festa do colégio ela dançou pela primeira vez, seu primeiro baile. Seus pais eram contrários a danças, mas, depois desse primeiro baile, Aimee achou que eles estavam errados, pois seu parceiro era um pregador, e ainda havia outros membros da igreja lá". ${ }^{257}$ Sua vida, a partir de então, não se resumia à fazenda dos pais. Seu mundo mudava e novas experiências se sucediam a todo tempo. É Lima quem assegura: "no colégio, fascinou-se pela teoria da evolução de Darwin, passando a duvidar das crenças fundamentais da fé e, até mesmo, de Deus". ${ }^{258}$ Essas experiências causaram muitas incertezas a respeito de sua vida e fé. McPherson continua: "os fundamentos da vida de Aimee desabaram sobre ela. Ela sentiu que

Elizabeth Kennedy. Disponível em: < https://www.nbz.com.br/ieq/aimee.htm>. Acesso em: 11 Ago. 2018.

${ }^{252}$ McPHERSON, Aimee Semple. Aimee Semple McPherson. A história de uma vida. São Paulo: Publicadora Quadrangular, 1991, p. 13.

${ }^{253}$ LIMA, J.; BEZERRA, C. M., História e Teologia da Igreja do Evangelho Quadrangular, p. 19.

${ }^{254}$ OLIVEIRA, Myckon de. Igreja do Evangelho Quadrangular: história, teologia e contribuições ao pentecostalismo. Campinas: Editora Saber Criativo, 2018, p. 25.

255 Um movimento evangelista da Igreja Metodista. Disponível em: < https://www.nbz.com.br/ieq/aimee.htm>. Acesso em: 11 Ago. 2018.

${ }^{256}$ McPHERSON, A. S., Aimee Semple McPherson, p. 13.

${ }^{257}$ McPHERSON, A. S., Aimee Semple McPherson, p. 19

${ }^{258}$ LIMA, J.; BEZERRA, C. M., História e Teologia da Igreja do Evangelho Quadrangular, p. 19. 
estava afundando num lamacento pantanal de dúvidas e incredulidade" ${ }^{259} \mathrm{Um}$ mundo cheio de desafios, contrário a tudo que ela havia experimentado até então em sua vida cristã. McPherson continua: "contudo, a pequena queria ouvir mais. Queria saber mais. Queria ser orientada. Que livros deveria ler para informar-se mais? Darwin? Tom Paine? Voltaire? Ingersoll? Sim, ela os leu todos. Estava arrasada". ${ }^{260}$ Pois, desde sempre ela via o mundo sob a ordem criativa de Deus e tomar conhecimento de tantas outras teorias e possibilidades resultou em grande crise, mesmo que ainda fosse uma adolescente. Ela continua: "seu próximo ataque foi contra o pastor amigo da família, num dia em que ele veio para o chá. 'Se eu tenho que acreditar na Bíblia e na história da criação, o que me diz quanto a seus outros relatos - Deus ainda opera milagres atualmente para provar Sua existência". ${ }^{261}$ Mesmo diante de tantas dúvidas, Aimee queria esgotar todas as suas opções no encontro de respostas. Mas, segundo ela, a resposta do pastor foi frustrante: "menina, o tempo dos milagres terminou. As pessoas hoje devem usar a inteligência e a sabedoria que o Senhor lhes dá através dos recursos médicos e cirúrgicos e eles são realmente maravilhosos, você sabe". ${ }^{262}$ Em resposta, ela cita vários textos bíblicos e continua a busca de algo que lhe restabeleça a convicção e a fé. Certo dia ela afirma: "sem parar de pensar, ela estendeu os braços impulsivamente em direção ao céu e bradou: Ó Deus, se existes, revela-te a mim!" ${ }^{263}$ Realmente ela não queria mais ficar nesse impasse. Lima comenta: "seu gesto mostrava que ela estava determinada a sair daquele marasmo de dúvidas e incertezas no qual se encontrava". ${ }^{264}$ Nessa nova postura, verificam-se mudanças e sua vida entra em novo estágio. Tureck diz: "ela declarava e pedia que Ele se revelasse. Deus não tardou em responder". ${ }^{265}$ As características pentecostais eram assimiladas por ela. McPherson assegura:

Após 48 horas a resposta veio. No dia seguinte, ela descia com seu pai a rua principal da cidadezinha; ele ia a uma cutelaria, no caminho de volta da escola para casa, quando viu um cartaz, sobre a porta de um grande salão, que dizia: 'Cultos Evangélicos de Avivamento'. Aimee, sem conter-se, disse a seu pai: 'papai,

\footnotetext{
${ }^{259}$ McPHERSON, A. S., Aimee Semple McPherson, p. 19.

${ }^{260}$ McPHERSON, A. S., Aimee Semple McPherson, p. 19-20.

${ }^{261}$ McPHERSON, A. S., Aimee Semple McPherson, p. 20.

${ }^{262}$ McPHERSON, A. S., Aimee Semple McPherson, p. 20.

${ }^{263}$ McPHERSON, A., Aimee Semple McPherson, p. 22.

${ }^{264}$ LIMA, J.; BEZERRA, C. M., História e Teologia da Igreja do Evangelho Quadrangular, p. 19.

265 TURECK, A., Cuidando da Comunicação em Família, p. 11.
} 
podemos vir aqui qualquer noite para ouvi-los. Eles gritam 'Aleluia' e 'Amém' e são diferentes. Toda a cidade esta falando do seu entusiasmo. ${ }^{266}$

Como mencionado no texto acima, ela considerou os cultos de avivamento pentecostal a resposta de Deus a ela: "na noite seguinte, ela estava sentada com seu pai num dos bancos da pequena congregação. Ela observava tudo com curiosidade e sem sorrir. Mas quando o evangelista entrou, Aimee sorriu". ${ }^{267}$ Pois o pregador da noite era Robert Semple, com quem viria a se casar. É importante destacar a fala de Semple naquela noite, que se tornaria mais tarde parte da doutrina essencial da Igreja do Evangelho Quadrangular. "Naquela reunião Aimee também foi impactada pelos dons espirituais pentecostais de uma maneira bastante pessoal". ${ }^{268}$ Desde o momento ela busca mais por tais experiências. McPherson diz:

Quando ele terminou de explicar o plano de salvação de Deus e o significado do verdadeiro arrependimento e aceitação de Jesus, começou a expor a doutrina do batismo no Espírito Santo, afirmando que essas duas mensagens deveriam sempre ser pregadas lado a lado. Insistia em que um cristão sem esse batismo não estava vivendo de acordo com a vontade de Deus. Descreveu, de forma impressionante, a cena do dia de Pentecoste e de como os discípulos tinham falado "outras línguas", línguas que não haviam aprendido. Essa era uma evidência bíblica para os dias atuais, tanto quanto fora para os dias do passado. ${ }^{269}$

Aimee presencia algo inédito em sua experiência cristã. Ainda não tinha ouvido nada sobre o dom de Línguas, mas durante sua reflexão sobre o sermão daquela noite, surgiu outro fato importante: "inesperadamente, de olhos fechados e mãos estendidas em sua direção, com voz forte e numa linguagem que ela não entendia, o pregador começou a falar". ${ }^{270}$ Esse momento mexeu bastante com ela, que se sentiu no centro de tais palavras e entendeu que Deus lhe falara diretamente: "você é uma pobre, perdida, miserável pecadora indo para o inferno!". ${ }^{271}$ Com palavras tão duras de exortação, o que, a partir de então, a jovem faria da vida? Durante os dias subsequentes, Aimee inquietou-se profundamente, até ter real convicção de seus pecados, e buscou maior aproximação com Deus. Tureck diz: “a moça, que era de origem Metodista, nunca

\footnotetext{
${ }^{266}$ McPHERSON, A. S., Aimee Semple McPherson, p. 22.

${ }^{267}$ McPHERSON, A. S., Aimee Semple McPherson, p. 22.

${ }^{268}$ LOPES, M., O legado de uma Pioneira, p.81.

${ }^{269}$ McPHERSON, A. S., Aimee Semple McPherson, p. 23.

${ }^{270}$ McPHERSON, A. S., Aimee Semple McPherson, p. 24.

${ }^{271}$ McPHERSON, A. S., Aimee Semple McPherson, p. 24.
} 
ouviu nem entendia uma oração em línguas estranhas". ${ }^{272} \mathrm{O}$ movimento pentecostal iniciava-se e ainda não era muito conhecido.

Lima comenta: "a conversão de Aimee foi completa. Ela decidiu se desfazer de tudo que tinha e que não correspondia mais ao novo caminho que abraçara. Pegou seu discos de jazz, seus romances e seus sapatos de baile e os queimou". ${ }^{273}$ A fundadora da IEQ encarna a doutrina pentecostal e dela faz estilo de vida, chegando ao radicalismo em alguns aspectos. Lima continua: "prometeu, ainda, que leria apenas a Bíblia, pois nenhum outro livro poderia superar a palavra do Senhor em sua vida a partir daquele dia". ${ }^{274}$ É importante acompanhar esse processo de conversão da fundadora, pois sua conduta e seu entendimento dessas primeiras experiências no pentecostalismo serão decisivos na doutrina da IEQ.

A fundadora da IEQ, em sua fase mais radical, demonstrou certo desequilíbrio ao queimar certos discos que possuía, e também ao interromper os estudos. Essa atitude precisa ser contestada, pois, por vezes, o pentecostalismo é visto como intolerante e preconceituoso. $\mathrm{O}$ pentecostalismo mais radical tende a desvalorizar a educação, tanto a secular quanto a teológica, e isso o tem impedido de criar diálogo e gerado retrocesso na vida de muitos seguidores, por falta de capacitação.

Desde então, ela sentia que o Senhor a chamava para o trabalho missionário, mas ainda faltava algo para que estivesse preparada. Pesquisou a bíblia para entender o segredo daqueles que executaram tal serviço. McPherson afirma: "e o que ela pode deduzir dessa sua pesquisa bíblica foi que o segredo era o revestimento de poder, sinônimo do batismo no Espírito Santo". ${ }^{275}$ Munida de suas leituras, ela iniciou a busca pelo batismo no Espírito Santo, o que marcaria os próximos dias de sua vida Lopes diz: "após isso, Aimee iniciou sua busca pela própria experiência pentecostal, de modo que se aplicava constantemente em longas jornadas de oração pelo batismo no Espírito Santo". ${ }^{276}$ No meio pentecostal sempre houve muito incentivo em torno, de uma vida pautada na experiência como em contextualizar o texto bíblico no presente. Lima diz: "foi enquanto estudava a Bíblia, procurando o segredo dos que serviam a Deus, que

\footnotetext{
272 TURECK, A., Cuidando da Comunicação em Família, p. 11.

${ }^{273}$ LIMA, J.; BEZERRA, C. M., História e Teologia da Igreja do Evangelho Quadrangular, p. 20.

${ }^{274}$ LIMA, J.; BEZERRA, C. M., História e Teologia da Igreja do Evangelho Quadrangular, p. 20.

275 McPHERSON, A. S, Aimee Semple McPherson, p. 27.

${ }^{276}$ LOPES, M., O legado de uma Pioneira, p.81.
} 
pôde encontrar, no livro de Atos, a noção de que não bastava crer no Senhor e entregar sua vida a Ele - era preciso ser revestida com poder do Espírito Santo. A partir dessa constatação ela começou a buscar incessantemente esse poder". ${ }^{277}$ Ela alterou seus compromissos cotidianos, separando grande parte do tempo para orações e para estar próxima a pessoas que falavam desse tipo de experiência. Lima explana: "em sua busca, Aimee deixou de ir ao colégio, pois preferia frequentar reuniões na casa de uma irmã que pertencia à Missão Pentecostal na qual ela ouvira a pregação que mudou sua vida. Essa senhora já era batizada com o Espírito Santo, motivo pelo qual Aimee passou a ir constantemente a sua residência". ${ }^{278}$ Sua mãe, então, a partir daquela falta que considerou grave, passou a proibi-la de frequentar quaisquer reuniões pentecostais, "acusando estes de fanáticos". 279

Aimee levou muito a sério o que ela ouviu na pregação de Robert em Ingersoll, como esclarece McPherson: "era este o segredo do seu poder". ${ }^{280}$ As palavras que transformaram sua vida naquele culto ficaram marcadas na vida da fundadora da IEQ. O autor prossegue: "a partir daquele instante, Aimee tornou-se uma incansável suplicante, desejava ardentemente aquele batismo". 281 "Sua primeira experiência extática e mística teria ocorrido em seu batismo espiritual motivado pelos cultos de Robert Semple". ${ }^{282}$ Os acontecimentos subsequentes ao culto pentecostal levou-a a aproveitar todas as oportunidades. Os cultos já não bastavam, ela queria mais, o que encontrou na casa dessa irmã pentecostal de quem ela aprendeu tantas novidades. McPherson diz: "havia, também, reuniões na casa de uma das senhoras da congregação. A casa dela distanciava apenas dois quarteirões do colégio onde Aimee estudava. Forçosamente, Aimee passava por sua porta todos os dias. E aquela casa tornou-se um santuário de bênçãos para ela". ${ }^{283}$ As características da casa frequentada por Aimee no seu pentecostalismo inicial é possivelmente um dos traços de sua igreja no Brasil, pois grande parcela dos pentecostais é compota de pessoas simples. Sobre isso, ela destaca: "era gente pobre, uma família grande com crianças em crescimento. Tinham uma mesa

\footnotetext{
${ }^{277}$ LIMA, J.; BEZERRA, C. M., História e Teologia da Igreja do Evangelho Quadrangular, p. 20.

${ }^{278}$ LIMA, J.; BEZERRA, C. M., História e Teologia da Igreja do Evangelho Quadrangular, p. 21.

${ }^{279}$ TURECK, A., Cuidando da Comunicação em Família, p. 12.

${ }^{280}$ McPHERSON. A. S., Aimee Semple McPherson, p. 27.

${ }^{281}$ McPHERSON, A. S., Aimee Semple McPherson, p. 29.

${ }^{282}$ ALEIXO V. C., "Deus Faz, o Templo dos Anjos Mostra", p. 39.

${ }^{283}$ McPHERSON, A. S., Aimee Semple McPherson, p. 29.
} 
modesta e quando havia mais companhia, eles simplesmente punham mais água na sopa". ${ }^{284}$ Foi esse ambiente familiar acolhedor que proporcionou bons momentos em seu aprendizado prático sobre o Espírito Santo. Tureck diz: “onde se convertera na busca desesperada pelo poder de Deus e que lia a Bíblia todos os dias e não sentia o tempo passar". ${ }^{285}$

Aimee passava horas na casa daquela senhora, que já havia provado do batismo no Espírito Santo, e queria o mesmo para Aimee. McPherson lembra: “o encanto daquelas horas passadas naquela casa residia no fato de que aquela mulher, dona de casa e mãe, fora batizada no Espírito Santo e orava para que Aimee também o fosse". ${ }^{286}$ Ela se dedicou, com todas as forças, a alcançar o batismo, sempre presente nessa casa. Deixando de lado os livros escolares, certo dia, segundo ela, abriu a Bíblia e meditou nas palavras "pedi e dar-se vos-á, de Lucas 11:9-13)". ${ }^{287}$ Persistente e ousadamente decidiu alcançar o poder para concretizar uma grande obra para o Senhor. Essa característica de Aimee foi essencial em todo o seu trabalho missionário. "de sexta para sábado, levantou-se muito cedo, antes do pessoal da casa, ajoelhou-se na sala e, levantando as mãos, começou a clamar pelo Espírito Santo". ${ }^{288}$ E tudo começou a cooperar para o acontecimento tão desejado por ela. McPherson recorda: "uma manhã, às nove horas, o grande momento chegou. Aimee estava presa naquela casa pela neve havia uma semana. Nenhuma carroça nas estradas, os trens não estavam funcionando. As linhas telefônicas estavam interrompidas". ${ }^{289}$ Ao longo dessa semana, ela dedicava-se integralmente às orações, com a consciência de que precisava do poder do Espírito Santo para executar seu trabalho missionário, conforme declara McPherson:

E então, naquela manhã, o grande momento chegou. Aimee foi para a sala de estar da casa. Ninguém ainda havia acordado [...]. Ajoelhada, sozinha na penumbra da sala, Aimee ergueu as mãos e começou a orar, pedindo, buscando, batendo: 'Senhor, enche-me do Teu Espírito! Enche-me para que eu possa servir-Te verdadeiramente e, aprovada por Ti, contar a história do Teu amor. ${ }^{290}$

\footnotetext{
${ }^{284}$ McPHERSON, A. S., Aimee Semple McPherson, p. 29.

${ }^{285}$ TURECK, A., Cuidando da Comunicação em Família, p. 12.

${ }^{286}$ McPHERSON, A. S., Aimee Semple McPherson, p. 29.

${ }^{287}$ McPHERSON, A. S., Aimee Semple McPherson, p. 30.

${ }^{288}$ TURECK, A., Cuidando da Comunicação em Família, p. 12.

${ }^{289}$ McPHERSON, A. S., Aimee Semple McPherson, p. 30.

${ }^{290}$ McPHERSON, A. S., Aimee Semple McPherson, p. 30.
} 
A compreensão do poder segundo Aimee está diretamente relacionada ao serviço da missão como sinônimo de aprovação. Todo poder se converte em missão na anunciação da palavra. Ela recebe a benção do Espírito Santo sobre ela com muita alegria. $\mathrm{O}$ autor relata:

Toda a terra parecia estender-se diante de seus olhos como imenso campo de trigo, branco, pronto para a colheita. De repente, conforme ela via, de olhos fechados, o trigo transformava-se diante dela em rostos humanos e as folhas em mãos humanas estendidas e, acima de tudo, ela parecia ouvir as palavras do Salvador: 'Os campos estão brancos, prontos para a colheita. A seara verdadeiramente é grande e os trabalhadores são poucos. Rogai ao Senhor da seara. ${ }^{291}$

A personificação do poder do Espírito Santo manifestado a Aimee é de caráter missionário. Nesse ínterim, logrou êxito nessa tarefa, mas antes de obter o carisma glossolal, teve uma visão na qual estava subentendido seu chamamento para "o ministério de pregação do Evangelho". ${ }^{292}$

A experiência do Espírito torna-se sua convocação ao trabalho missionário, já que ela entendia esse poder como essencial para essa tarefa. Agora o Senhor concretiza o seu chamado, concedendo-lhe a visão do campo de trigo. Desde o início o poder do Espírito, para a fundadora da IEQ, é mais que a glossolalia. É, sobretudo, o selo que libera o poder do comissionado para as obras. Ela queria executar o trabalho no poder do Espírito e para tanto recebe as palavras do Senhor naquele dia: "dedica-te à tarefa que está à tua frente. Colhe e junta o trigo em preciosos feixes". ${ }^{293}$ O poder alcançado por Aimee é a capacitação para cuidar de vidas, e desde então ela está pronta para iniciar a obra que se tornaria uma das maiores denominações pentecostais do mundo. "Naquele mesmo dia, finalmente, recebeu o que tanto esperava: o batismo com o Espírito Santo, e, falando numa língua estranha". 294

O Senhor alertou Aimee para que não perdesse tempo em conflitos com outros pregadores, pois muitos haviam iniciado bem o trabalho, porém, com o passar do tempo, não mais entendiam suas prioridades e não praticavam a unidade. Sobre isso, ela diz: "muitos ceifadores usam suas foices corretamente por umas poucas horas, depois se voltam para cortar e estraçalhar seus companheiros.

\footnotetext{
${ }^{291}$ McPHERSON, A. S., Aimee Semple McPherson, p. 30.

${ }^{292}$ LOPES, M., O legado de uma Pioneira, p.81.

${ }^{293}$ McPHERSON, A. S., Aimee Semple McPherson, p.31.

${ }^{294}$ TURECK, A., Cuidando da Comunicação em Família, p. 13.
} 
Ninguém pode ferir tão profundamente, porque ninguém tem uma arma tão cortante". ${ }^{295}$ Desde muito cedo, ainda no seu chamado, quando recebeu o poder do Espírito Santo, o Senhor mostra a importância do diálogo e da cooperação. Muitos já não conseguiam manter esses princípios, voltando-se depois de algum tempo aos interesses individuais, o que levava à agressão mútua. McPherson ressalta: "esta foi uma lição que Aimee nunca esqueceu. Enquanto tantos pregadores perdiam tanto tempo com enganos, criticando, denunciando uns aos outros, Aimee procurava sempre lembrar-se daquelas palavras do Senhor e nunca revidou ataques". ${ }^{296}$ Ela levou isso muito a sério em seu trabalho, não perdendo tempo com separações e dissociações, e buscando a unidade entre várias denominações.

McPherson assegura: "o Senhor a revestiu completamente naquele dia e a fez falar numa língua que nunca aprendeu, louvando e glorificando o Seu nome. Ele a revestiu de poder, como revestira os 120 naquele memorável dia de Pentecostes no passado". ${ }^{297}$ Todos "na casa de missão ficaram maravilhados com a experiência de Aimee". 298

"Ela levantou-se com o rosto brilhando". ${ }^{299}$ Concluída toda a experiência, quando todos na casa já haviam acordado, ela lembra: "lá fora a tempestade de neve havia passado. As ruas estavam sendo limpas. Era quase meio-dia. Os membros da família apertaram suas mãos, compartilharam de sua alegria". 300 Toda essa experiência acontece dentro de uma residência, o que é digno de nota, pois reflete na concepção e na prática da missão de Aimee e da IEQ. McPherson testemunha: "no íntimo do coração, Aimee sentia-se vitoriosa pelas duas grandes bênçãos recebidas: primeiro, o Consolador viera para habitar nela e deveria viver e andar em consagração e obediência à vontade de Deus; ela fora chamada para pregar o Evangelho Eterno". ${ }^{301}$ Dessa forma, Aimee ingressa de vez no pentecostalismo. É a partir desse evento que ela adquire a convicção de que viveria toda a vida em missão. Cox diz: "posso ver pelo brilho no seu rosto que

\footnotetext{
${ }^{295}$ McPHERSON, A. S., Aimee Semple McPherson, p. 31.

${ }^{296}$ McPHERSON, A. S., Aimee Semple McPherson, p. 32.

${ }^{297}$ McPHERSON, A. S., Aimee Semple McPherson, p. 31.

${ }^{298}$ TURECK, A., Cuidando da Comunicação em Família, p. 13.

${ }^{299}$ McPHERSON, A. S., Aimee Semple McPherson, p. 31.

${ }^{300}$ McPHERSON, A. S., Aimee Semple McPherson, p. 31.

${ }^{301}$ McPHERSON, A. S., Aimee Semple McPherson, p.31.
} 
você encontrou o que procurava! Que bom! Vai ganhar um número incontável de almas". ${ }^{302}$ A experiência do Espírito para o pentecostal se converge em missão.

Agora ela já se sentia pronta a iniciar uma grande obra: "mas, como posso fazer isso? Perguntei. Onde estava a porta para servir?". ${ }^{303}$ A razão the dizia que ainda era uma criança, que não sabia nada sobre pregação. Que havia muitos pregadores, o país estava cheio deles. "Todos haviam estudado, ou quase todos, durante anos, conheciam teologia. Ela não sabia nada". ${ }^{304}$ Apesar da experiência humana e natural pela qual a jovem passava e da incerteza quanto ao futuro, ela encontrava conforto e refrigério nas palavras consoladoras do Senhor, na Sua contradição em escolher as coisas contrárias, sem sentido segundo a percepção humana. E logo decidiu lançar-se de vez. É McPherson quem assegura:

\begin{abstract}
Então a luta cessou e Aimee rendeu-se totalmente: 'Senhor, por tua graça tomarei a minha cruz e Te seguirei confiante, venha o que vier. Todo o meu ser coloco em Teu altar. Que o Teu caminho seja o meu. Se for para 'ir', se for para 'ficar', que a Tua perfeita vontade se cumpra em minha vida. Sinto minha própria fraqueza e insuficiência, não sei o que o futuro me reserva, não sou senão uma humilde criada, mas eis-me aqui, Senhor, se o Senhor quiser usar tão humilde e inútil vaso. A Questão ficou encerrada no coração de Aimee naquele dia, para sempre, para a eternidade. Uma paz permanente invadiu a sua alma, uma paz que jamais a deixaria. ${ }^{305}$
\end{abstract}

Essa confiança permaneceu, logo após ela ter vencido mais uma batalha sobre a razão. Ainda sem saber, essas palavras fariam parte de toda a sua vida. Ir e ficar, assim foram seus dias desse momento em diante. Suas experiências com os dons espirituais estavam prestes a iniciar-se e sua vida seria o reflexo de uma vida totalmente rendida. Segundo McPherson: "estava convicta de que Deus a chamara para o ministério. Não sabia para onde e não estava mais preocupada em saber de que modo, em Sua vontade, Deus a usaria". ${ }^{306}$ E assim foram o chamado sobrenatural e as primeiras experiências com o Espírito Santo. Esse poder transformou a vida da jovem Aimee e de tantas outras pessoas em todo o mundo. E o movimento pentecostal do início do século XX ganhou uma grande obreira, que ajudaria a desenvolver essa fé, agregando outros elementos ao

\footnotetext{
${ }^{302}$ COX, R. L. Aimee: sua vida sua obra. São Paulo: Editora e Publicadora Quadrangular, 1992. p. 41.

${ }^{303}$ COX, R. L., Aimee, p. 41.

${ }^{304}$ McPHERSON, A. S., Aimee Semple McPherson, p. 32.

305 McPHERSON, A. S., Aimee Semple McPherson, p. 32-33.

${ }^{306}$ McPHERSON, A. S., Aimee Semple McPherson, p. 33.
} 
pentecostalismo clássico. "Descobri que os dons de Deus jamais foram cancelados. A promessa é para quantos o Senhor nosso Deus chamar". 307

Robert Semple foi o pregador para quem o poder do Espírito era essencial na vida do cristão, para a realização das obras. Segundo ele, o crente deveria ser batizado nesse Espírito. Tais palavras mudaram a vida de Aimee. Terminado o trabalho de avivamento em Ingersoll, Ontario, Canadá, Semple dedicou-se a uma campanha de avivamento em Stratford. Entretanto, ele e Aimee mantiveram contato, e McPherson destaca que, apesar da distância, "Robert continuava incentivando e instruindo Aimee por correspondência". ${ }^{308}$ Certa noite, a irmã pentecostal em cuja casa Aimee havia sido batizada no Espírito Santo passava por dificuldades com suas crianças doentes. Aimee gostava muito de todos naquela casa e prontamente foi ajudar a senhora já exausta. De acordo com McPherson, "certa noite, depois de terminar suas tarefas e de acomodar os pequenos em suas camas, Aimee ouviu tocar a campanha da porta. Era Robert Semple. [...] Soube da doença das crianças e viera orar por elas". ${ }^{309}$ Eles oraram pelas crianças e conversaram na sala. "Seus olhos azuis estavam fixo em mim enquanto eu tentava colocar em palavras meu desejo de ser uma ganhadora de almas". 310

Então Robert viu o crescimento espiritual de Aimee, e também lhe contou sobre suas experiências como pregador do Evangelho. Ela ficou maravilhada com os relatos. McPherson lembra: "apanhando sobre a mesa um livro de geografia que pertencia às crianças, Robert apontou um mapa do Oriente, enquanto dizia a Aimee: "Está vendo? Aqui é Hong Kong, na China. Eu vou para lá como missionário". 311 Ela já estava completamente encantada pelas histórias e agora, ao ouvir sobre missões em uma terra distante, ficou ainda mais admirada. McPherson continua: "fascinada, Aimee sentiu que poderia abandonar tudo, sonhos, o conforto do lar, tudo, enfim, para ser uma ganhadora de almas para o mestre". 312 Robert, percebendo que ela compactuava do mesmo chamado missionário, e já não mais suportando guardar seus sentimentos por Aimee, "tomou nas suas as mãos de Aimee e suavemente perguntou-lhe: "Aimee, querida, quer casar-se

\footnotetext{
${ }^{307}$ COX, R. L., Aimee, p. 42.

${ }^{308}$ McPHERSON, A. S., Aimee Semple McPherson, p. 35.

${ }^{309}$ McPHERSON, A. S., Aimee Semple McPherson, p. 35.

${ }^{310}$ COX, R. L., Aimee, p. 43.

311 McPHERSON, A. S., Aimee Semple McPherson, p. 36.

${ }^{312}$ McPHERSON, A. S., Aimee Semple McPherson, p. 36.
} 
comigo e ir comigo para a China? Eu a amo de todo o coração!". ${ }^{313}$ Ela pareceu não acreditar e ficou sem voz para responder, mas antes que ela falasse, ele disse: "vamos orar a respeito". 314

Durante a oração, Aimee teve uma nova experiência com o Espírito Santo, uma visão relacionada ao futuro deles. Relata McPherson: "nela, o aposento pareceu encher-se de anjos que ladeavam um caminho iluminado, imenso, que se estendia à sua frente, na perspectiva de um futuro glorioso de amor e precioso serviço, um caminho que conduzia à cidade do Rei, e nele estavam os dois, ela e Robert, caminhando de mãos dadas!". 315 Em um segundo momento, em nova visão, ela diz, conforme relatado por McPherson: "lá estava o mesmo caminho, mas, desta vez havia apenas uma pessoa caminhando por ele, era Aimee. Ela seguia firme por ele, cercada de luz, como antes, mas estava só!" ${ }^{316}$ A visão não foi compreendida naquele momento, mas tal fato mostra uma das principais características do pentecostalismo: a forte ênfase nas questões espirituais, mesmo diante do pedido de casamento. Entretanto, ela disse sim a Robert. E pouco tempo depois, estavam casados. "A 12 de agosto de 1908, celebrou-se o casamento na velha fazenda". ${ }^{317}$ A cerimônia foi realizada por um ministro do "Exército de Salvação". ${ }^{318}$ E viajando em campanhas de avivamento, como Robert já empreendia antes sozinho. McPherson diz:

Durante essa época de viagens evangelísticas, o Senhor os levou até Chicago, para as reuniões de um pastor de nome Durham. Os estudos e as muitas experiências de que participaram na pequena assembléia da Avenida Norte significaram muito para Aimee nos anos que seguiram. Foi lá que o Senhor concedeu-lhe o dom de interpretação. ${ }^{319}$

O tempo com o pastor Durham foi decisivo para o estabelecimento e o exercício dos dons espirituais de Aimee. A partir desse momento ela também podia interpretar as línguas faladas, compreendendo as manifestações verbais do

\footnotetext{
${ }^{313}$ McPHERSON, A. S., Aimee Semple McPherson, p. 36.

${ }^{314}$ COX, R. L., Aimee, p. 45.

315 McPHERSON, A. S., Aimee Semple McPherson, p. 36.

${ }^{316}$ McPHERSON, A. S., Aimee Semple McPherson, p. 36.

${ }^{317}$ COX, R. L., Aimee, p. 46.

318 ALEIXO, V. C., "Deus Faz, o Templo dos Anjos Mostra, p. 39.

${ }^{319}$ McPHERSON, A. S. Aimee Semple McPherson, p. 37.
} 
Espírito mediante seus servos. "Começaram atrabalhar juntos na evangelização, realizando um trabalho bastante intensivo". ${ }^{320}$ McPherson continua:

Naquele mesmo dia, ao anoitecer, quando ouvia o Reverendo Durham dando uma mensagem em línguas, de novo Aimee sentiu o poder do Espírito jorrando através de sua pessoa em ondas de glória. No momento em que o Espírito cessou de falar através do pregador, Aimee sentiu-se grandemente impulsionada a levantar-se e dar sua interpretação, mas resistiu e permaneceu timidamente sentada. ${ }^{321}$

Sobre o Reverendo Durham, é Myckon quem assegura: "foi pastor da Igreja Batista de Chicago e foi assistente nas reuniões de William Seymour no avivamento de Azusa". ${ }^{322}$ Foi muito especial na vida de Aimee, ensinando-lhe muito sobre os dons do Espírito, tendo participado do grande movimento histórico do pentecostalismo em Azusa. A história inicial da IEQ tem raízes nesse movimento. Aimee deu mais um passo na busca incessante do poder do Espírito, participando de um avivamento em Findlay, Ohio, sendo levada pelo Senhor a confiar na cura. Assim, passou a confiar em Jesus também como médico.

Ela passaria por essa experiência no próprio corpo, após sofrer um acidente quando descia as escadas do prédio da missão onde eram celebrados os cultos. Tendo quebrado o tornozelo, teria que andar de muletas por quatro semanas, sem pôr os pés no chão. É McPherson quem assegura: “Ouviu uma voz que lhe dizia: “se você apanhar o sapato para o seu pé quebrado, voltar à missão e pedir ao reverendo Durham para orar por você, levando o sapato com você, Eu vou curála". ${ }^{323}$ O Senhor a levava a experimentar o poder sobrenatural da cura divina, que viria a ser mais tarde uma das doutrinas cardinais da Igreja do Evangelho Quadrangular. O Reverendo Durham foi o vaso escolhido para lhe proporcionar a primeira experiência em cura divina. Ela sentia muita dor: "porém, aquela voz interior tornou-se tão insistente, que não pôde continuar resistindo". ${ }^{324}$ Com muita dificuldade, ela chegou à missão e contou a todos lá reunidos sobre o acidente e todo o sofrimento. Disse também da voz do Espírito que ouviu, incentivando-a a ir à missão para ser curada pela oração do reverendo Durham. McPherson relata: "o reverendo começou a andar de um lado para o outro, orando silenciosamente.

\footnotetext{
${ }^{320}$ TURECK, A., Cuidando da Comunicação em Família, p. 13.

${ }^{321}$ McPHERSON, A. S., Aimee Semple McPherson, p. 37.

${ }^{322}$ OLIVEIRA. M. A., Igreja do Evangelho Quadrangular, p. 26.

${ }^{323}$ McPHERSON, A. S., Aimee Semple McPherson, p. 38.

${ }^{324}$ McPHERSON, A. S., Aimee Semple McPherson, p. 38.
} 
Então, de repente, ele parou, colocou suas mãos sobre o tornozelo de Aimee e bradou em alta voz: "Em nome de Jesus receba a cura!". ${ }^{325}$ Naquele momento, ela foi imediatamente curada. O temor a envolveu, entretanto, cheia de fé, quebrou o gesso e começou a andar de um lado para outro, exaltando e louvando o Senhor, andando normalmente sem dor alguma. "desde aquele momento teve fé e poder de Deus para orar pelos enfermos também". ${ }^{326}$ A taumaturgia seria elemento principal na IEQ.

Logo a notícia correu e o pastor lhe pediu que testemunhasse sobre a cura. É MacPherson quem assegura: “daquela época em diante, Deus concedeu a Aimee o dom de cura divina, usando-a poderosamente na cura dos enfermos quando ela orava a oração da fé". ${ }^{327}$ Parece que o tempo pedagógico que o Senhor havia planejado para Aimee chegara ao fim. Esse período se iniciara na noite em que ela ouviu a mensagem da salvação, a ser anunciada juntamente com o poder do Espírito Santo, prosseguindo com a grande experiência de receber o batismo no Espírito Santo em um lar simples; em seguida recebeu visões sobre o futuro quando Robert a pediu em casamento; e por ultimo, foi agraciada com o dom da cura divina: "diz que um ano mais tarde teve a experiência da cura divina na Igreja de Durham. A pregação da cura divina veio a ser a característica desta Igreja". ${ }^{328}$ Tudo isso se tornou parte da doutrina da IEQ. A igreja pentecostal busca a experiência do Espírito e sua missão está diretamente relacionada às manifestações do Seu poder. Desse momento em diante, Aimee estava pronta para iniciar seu trabalho missionário. Ela estava instruída para ser Aimee Semple McPherson, a fundadora da Igreja do Evangelho Quadrangular, uma das maiores denominações pentecostais do mundo: "vamos partir para China em seis semanas, anunciou Robert certa noite". 329

Depois da experiência de Aimee, ela experimentou a missão almejada: "a China sempre representou um grande desafio para os missionários cristãos". ${ }^{330} \mathrm{O}$ plano de ir à China se torna real e o casal está pronto para servir ao Senhor com as próprias vidas em missão. “Algum tempo depois, Aimee e Robert seguiram como

\footnotetext{
${ }^{325}$ McPHERSON, A. S., Aimee Semple McPherson, p. 39.

326 TURECK, A., Cuidando da Comunicação em Família, p. 14.

${ }^{327}$ McPHERSON, A. S., Aimee Semple McPherson, p. 39.

${ }^{328}$ WULFHORST, I., O Pentecostalismo no Brasil, p. 10.

${ }^{329}$ COX, R. L., Aimee, p. 51.

${ }^{330}$ ALEIXO, V. C., "Deus Faz, o Templo dos Anjos Mostra, p. 40.
} 
missionários para trabalhar na China". ${ }^{331}$ Sobre esse momento decisivo, McPherson declara: "Pouco tempo após sua volta a Chicago e da maravilhosa e instantânea cura de seu pé quebrado, Aimee ouviu Robert dizer-lhe: 'Querida, sinto que o tempo de irmos para a China é chegado". ${ }^{332}$ Esse momento era aguardado por ela desde o dia, em que na sala da casa daquela senhora pentecostal, sonhou e desejou viver isso. Assim foi a resposta dela: "estou pronta, Robert, para ir a toda parte, ao mundo inteiro com você!". ${ }^{333}$ A pronta resposta dela ao desafio missionário em terra distante fez o esposo ter ainda mais convicção de que ele tinha ao seu lado uma grande companheira disposta e alegre por anunciar a salvação. Lima declara: "depois disso, Robert discerniu que ele e Aimee estavam sendo direcionados por Deus para a China, como missionários". 334 Os próximos passos em direção |à China foram a organização de tudo para a viagem.

Nessas despedidas, Aimee tocava piano e falava da missão. Robert era o pregador, por onde passavam. McPherson informa: "ele era um austero presbiteriano [...]". ${ }^{335}$ Partiram rumo à China: "um apito alto da máquina, o silvo dos breques se soltaram, e lá fomos nós". ${ }^{336}$ Quando chegaram a Hong Kong, "multidões de meninos, como cardumes de peixes, cercavam o navio, alvoraçados, barulhentos, pedindo em altas vozes que os passageiros atirassem moedas para eles na água". ${ }^{337}$ Era tudo muito diferente, as famílias eram bem numerosas, algumas com 14 membros, a alimentação bastante diversa. "Para Aimee a vida na China seria uma sombria realidade". ${ }^{338} \mathrm{Na}$ primeira viagem missionária, eles experimentaram a inculturação da fé no povo chinês: "existe uma amizade estranha e maravilhosa entre os missionários estrangeiros, explicou Robert, depois de acenar com a mão e saudá-los [...] Em nosso país eles ficam fechados em suas conchas presbiterianas, episcopais, metodistas, e outras. Mas aqui são apenas cristãos e unem-se como um só grupo de trabalho". 339

\footnotetext{
${ }^{331}$ TURECK, A., Cuidando da Comunicação em Família, p. 14.

${ }^{332}$ McPHERSON, A. S., Aimee Semple McPherson, p. 39.

${ }^{333}$ McPHERSON, A. S., Aimee Semple McPherson, p. 39.

${ }^{334}$ LIMA, J.; BEZERRA, C. M., História e Teologia da Igreja do Evangelho Quadrangular, p. 22.

${ }^{335}$ McPHERSON, A. S., Aimee Semple McPherson, p.40.

${ }^{336}$ COX, R. L., Aimee, p. 53.

${ }^{337}$ McPHERSON, A. L., Aimee Semple McPherson, p. 43.

${ }^{338}$ McPHERSON, A. L., Aimee Semple McPherson, p. 45.

${ }^{339}$ COX, R. L., Aimee, p. 75.
} 
Durante a missão, Aimee engravidou. Pouco tempo mais tarde, em meio a muito calor às condições sanitárias, entre outros agravantes, a saúde começa a ficar comprometida: "a malária era violenta e ambos a contraíram na sua pior forma, com febre altíssima". ${ }^{340}$ Aqueles que haviam atravessado o mundo para salvar vidas estavam perdendo a suas. "Naquele país, sofreram muito pela causa de Cristo". ${ }^{341}$ Tudo que esses missionários aprenderam e viveram no tocante à cura divina precisaria ser manifestado na vida deles. Mesmo febril, Aimee tentava cuidar de Robert, internados ambos no hospital durante o aniversário do segundo ano de casamento. Robert ficou bem mais debilitado e não era permitido que Aimee o visitasse.

Ele terminava a carreira e o desespero tomou conta de Aimee, quando ele faleceu: "ele se foi, disse o médico em voz baixa". ${ }^{342}$ foi um duro golpe, pois ela perdia seu mentor: "Em missões, ambos pegaram malária na China, e Roberto Semple morreu da doença". ${ }^{343}$ Mais que companheiro, ele lhe mostrou o caminho do poder do Espírito. Ela "sentiu que ia gritar, mas o grito morreu em seus lábios, quando sentiu à sua volta os braços amorosos do Senhor envolvendo-a, e a Palavra veio à sua mente: "o Senhor deu, o Senhor o levou: Bendito seja o nome do Senhor". ${ }^{344}$ Aimee passou pela doença e pela morte do marido durante a gestação, recebendo a ajuda de duas irmãs de Chicago, que lhe enviaram o dinheiro suficiente para o sepultamento de Robert e o preparo para o retorno: "um mês após o falecimento de Robert, nasceu a filhinha deles, naquele mesmo hospital inglês, no alto da montanha em Hong Kong. Aimee deu-lhe o nome de Roberta, em memória do amado esposo". ${ }^{345}$ Ela afirma: "às 9 horas da manhã do dia 17 de setembro de 1910, nossa filha nasceu". ${ }^{346}$ Ela permaneceu ainda seis meses na China até a partida para os Estados Unidos, deixando Robert em terras distantes, porém com a filha nos braços: “Aimee voltou para os Estados Unidos". 347

Novamente ela está diante de todos que a viram partir para a China, que veem seu retorno como grande tragédia e frustração. Foi bastante difícil para ela

\footnotetext{
${ }^{340}$ McPHERSON, A. S., Aimee Semple McPherson, p. 53.

${ }^{341}$ TURECK, A., Cuidando da comunicação em família, p. 14.

${ }^{342}$ COX, R. L., Aimee, p. 95.

${ }^{343}$ BANDINI, C., Ministério Feminino na Igreja do Evangelho Quadrangular, p. 42-43.

${ }^{344}$ McPHERSON, A. S., Aimee Semple McPherson, p. 56.

${ }^{345}$ McPHERSON, A. S., Aimee Semple McPherson, p. 56.

${ }^{346}$ COX, R. L., Aimee, p. 95.

${ }^{347}$ LOPES, M., O legado de uma pioneira, 31.
} 
conviver com essa realidade e cuidar sozinha de sua filha: "essas pessoas não podiam entender por que Deus os tinha enviado à China, deixando Robert morrer lá e, finalmente, permitindo também a sua volta ao lar natal. Esta questão, ventilada ou calada, começava a abalar-lhe os nervos". ${ }^{348}$ Ela já não sabia o que fazer com a solidão e a questões referentes ao trabalho missionário, e afastou-se um pouco da fé: "exatamente na época de sua maior perplexidade, quando ela estava começando a perder sua espiritualidade e a distanciar do Senhor, desejando ter um lar para o nenê, Aimee casou-se novamente [...] a 28 de fevereiro de 1912 ". ${ }^{349}$ Tentando amenizar suas dores "durante os três anos seguintes". ${ }^{350}$ No segundo casamento, ela busca manter seu propósito missionário, tentando reacender as missões e dar um lar seguro à sua filha Roberta. Lima diz sobre o casamento: "dessa vez com Harold Stewart McPherson, com quem teve outro filho, ao qual deu o nome de Rolf Kennedy McPherson". ${ }^{351}$ A vida domestica aos poucos sufocou a perspectiva de missão, agora ela ocupava o cotidiano com os filhos e a casa.

Antes do casamento com Harold, ela o avisara de sua prioridade de ter uma vida de missão, mas ela agora não via tempo para tal: "dia após dia ela tentava libertar-se do tédio e da depressão, procurando manter-se o mais ocupada possível [...] Uma fonte de consolo veio para ela com o nascimento de seu segundo filho, Rolf". ${ }^{352}$ A situação começa agravar-se novamente, como um ciclo sem fim: "Mas eu era um problema constante". ${ }^{353}$ Dessa vez seus nervos já não davam conta, já que recordava os dias passados e vivia uma vida oposta a tudo quanto havia sonhado na juventude. McPherson assegura: "ficou seriamente enferma, foi operada, mas seu estado piorou em vez de melhorar. Complicações internas, problemas cardíacos, de estômago, hemorragias, descontrole do sistema nervoso". ${ }^{354}$ Ela perdeu o chão, não suportando mais a própria vida: “em 1914, a evangelista foi internada e passou por várias operações, sentindo-se próxima da morte, e descreve mais uma experiência extática em que Deus a chama para a

\footnotetext{
${ }^{348}$ McPHERSON, A. S., Aimee Semple McPherson, p. 60.

${ }^{349}$ COX, R. L., Aimee, p. 105.

${ }^{350}$ ALEIXO, V. C., "Deus Faz, o Templo dos Anjos Mostra, p. 41.

${ }^{351}$ LIMA, J.; BEZERRA, C. M., História e Teologia da Igreja do Evangelho Quadrangular, p. 22.

${ }^{352}$ McPHERSON, A. S., Aimee Semple McPherson, p.61.

${ }^{353}$ COX, R. L., Aimee, p. 108.

${ }^{354}$ McPHERSON, A. S., Aimee Semple McPherson, p. 62.
} 
evangelização". ${ }^{355}$ Foi necessária uma segunda operação. Ela destaca: “enquanto tudo estava sendo preparado, do fundo do vale do seu desespero Aimee clamou: 'Ó, Deus, leve-me para o Lar com o Senhor! Não vai ser possível para mim voltar e certamente não posso continuar assim! Sou uma miséria para mim mesma e para todos à minha volta!". ${ }^{356}$ Ao final da operação, uma entre as cinco executadas, ela estava bastante debilitada: "num anoitecer, após o doutor e a enfermeira terem passado ao seu lado em constantes cuidados toda aquela tarde, três jovens internos entraram no aposento e gentilmente a levaram, com colchão e tudo, para um quarto separado, onde as pessoas eram levadas para morrer". ${ }^{357}$ Assim chegou o que parecia ser seu fim, e toda a família foi convocada para o anúncio: "os médicos haviam feito tudo o que estivera ao seu alcance, tudo quanto fora possível para salvá-la, mas agora era o fim". ${ }^{358}$ Como confirma Tureck, o fim aproximava-se para ela e suas dores terminavam, bem como sua missão: "todos aguardavam sua morte a qualquer momento".359

Os fatos subsequentes narram sua grande decisão diante do Senhor: "entretanto, como último soar de campainha, que nunca mais seria esquecido, Aimee tornou a ouvir: 'Agora você que ir? Aimee sabia que ir era o único caminho ou então a morte. Então, no fim de suas forças, ela murmurou inaudivelmente: "Sim, Senhor... eu irei!". ${ }^{360}$ Recuperou-se, então, rapidamente dos processos operatórios, e em duas semanas estava de pé. Por fim, Aimee toma a decisão de praticar o "sim" dito ao Senhor, que a manteve viva, como ela própria informa: "sem perder tempo em cumprir sua promessa, fez suas malas e, com um filho em cada braço, foi para a sua Nínive, onde quer que ela estivesse". ${ }^{361}$ A partir desse momento, ela deixa o marido Harold Stewart McPherson, de quem mantém o nome, sendo conhecida como Aimee Semple McPherson, Semple de Robert e McPherson de Harold. Levou os filhos, porém o esposo não a acompanhou, como atesta Myckon: "divorciou-se de seu segundo marido e começou a realizar campanhas de reavivamento pelos Estados

\footnotetext{
355 ALEIXO, V. C., "Deus Faz, o Templo dos Anjos Mostra, p. 41.

${ }^{356}$ McPHERSON, A. S., Aimee Semple McPherson, p. 62.

${ }^{357}$ McPHERSON, A. S., Aimee Semple McPherson, p. 62-63.

${ }^{358}$ McPHERSON, A. S., Aimee Semple McPherson, p. 63.

${ }^{359}$ TURECK, A. S., Cuidando da Comunicação em Família, p. 14.

${ }^{360}$ McPHERSON, A. S., Aimee Semple McPherson, p. 63.

${ }^{361}$ McPHERSON, A. S., Aimee Semple McPherson, p. 63.
} 
Unidos". ${ }^{362}$ Depois de desfeito o segundo casamento, ela recomeça a missão, levando junto Roberta e Rolf, este último futuro líder da IEQ, substituindo a mãe. Lima comenta: "a partir dali, Aimee não cessou mais de pregar o evangelho poderoso de Cristo". ${ }^{363}$ Os relatos biográficos falam em sofrimentos, abalos emocionais e cura. E dizem que Aimee Semple McPherson retornou ao Evangelho com Igreja do Evangelho Quadrangular: “e assim, Aimee começou seu ministério em 1915, contando então com 25 anos". 364

É preciso esclarecer as circunstâncias e os desdobramentos da vida conjugal da fundadora da Igreja do Evangelho Quadrangular, tema bastante polêmico em sua trajetória e bastante contestado. Logo após deixar o lar, o esposo insistia para que ela voltasse: "em meio à campanha de Mount Forest, recebi vários telegramas de Harold McPherson, pedindo-me para voltar para casa e 'lavar a louça'. Telegrafei de volta, contando que era agora uma evangelista de sucesso crescente na conquista de almas e jamais poderia abandonar minha missão". ${ }^{365}$ No intuito de levar Aimee novamente para casa, o marido foi ao local do seu trabalho missionário e, segundo a própria Aimee, a partir do momento em que a viu pregando o Evangelho concordou que ela continuasse: “o Sr. McPherson veio então a Mount Forest e, depois de me ouvir falar, disse: 'Querida, não tinha ideia de que podia pregar assim. Você não deve parar". ${ }^{366}$ Segundo a própria bibliografia da fundadora, ele a acompanhou durante algum tempo em missão, mas logo depois voltou atrás, dedicando-se ao mundo dos negócios e pedindo o divórcio: "depois de algum tempo no ministério comigo, Harold McPherson voltou ao mundo dos negócios e divorciou-se de mim, casando-se outra vez e deixando-me sozinha para pregar". ${ }^{367}$ Aimee continuou seu trabalho sozinha, mas após o casamento dos filhos ela se sentiu solitária e casou-se novamente. Esse terceiro casamento foi um verdadeiro problema em sua vida: muitas explicações cobradas sobre sua vida matrimonial. Afinal, ela era uma evangelista, por que tantos casamentos? Durante o terceiro casamento, com o Sr. Dave Hutton, a denominação já estava consolidada e Aimee já era bastante conhecida, mais uma razão para muitas explicações: “por que se casou com Dave Hutton?” “Há alguma

\footnotetext{
${ }^{362}$ OLIVEIRA, M. A., Igreja do Evangelho Quadrangular, p. 26.

${ }^{363}$ LIMA, J.; BEZERRA, C. M., História e Teologia da Igreja do Evangelho Quadrangular, p. 22.

${ }^{364}$ BANDINI, C., Ministério Feminino na Igreja do Evangelho Quadrangular, 42-43.

${ }^{365}$ COX, R. L., Aimee, p. 127.

${ }^{366}$ COX, R. L., Aimee, p. 127.

${ }^{367}$ COX, R. L., Aimee, p. 325.
} 
desculpa para um cristão casar de novo enquanto seu ex-marido ou esposa ainda vive?". ${ }^{368}$ Aimee, naquele tempo, entendia que o segundo casamento era permitido aos ministros, mas mudou de opinião, proibindo essa prática no regimento interno da Quadrangular: "alguns anos depois, eu insistiria em que o regime interno quadrangular proibisse o novo casamento de nossos ministros, mas em 1931, minha opinião era diferente". ${ }^{369}$ E continua a explicar:

Mas em resposta à pergunta sobre o meu casamento com David Hutton, eu declarei, em parte: as pessoas às vezes falam comigo como se fosse 'uma evangelista que se casou demais', mas vivi com meus maridos apenas cerca de quatro anos e meio em minha vida. Estava casada havia pouco tempo quando Robert Semple morreu. Tentei acomodar-me à vida doméstica sem fazer o trabalho de Deus, mas não pude. ${ }^{370}$

O segundo casamento, como relatado, impôs uma escolha entre a vida doméstica e a carreira de missionária, e ela optou por pregar o Evangelho: "passados muitos anos, surgiu o Sr. Hutton e pensei que não ficaria mais solitária, que os dias em que meu nome resplendia nas manchetes haviam terminado. Pensei que teria proteção, lar e amor, mas isso não aconteceu e mais uma vez fiquei só". ${ }^{371}$ Para justificar o terceiro casamento, Aimee declarou que o fato de seu ex-marido ter se casado novamente, estando ela ainda viva, configurava o adultério, razão pela qual ele estava morto, e ela livre:

Na ocasião em que me casei com David Hutton, justifiquei minha atitude com base na passagem bíblica que diz que, se o homem deixar a esposa por qualquer razão além do adultério, isso constitui pecado. Mas se um dos cônjuges sair de casa e pecar, quebrando assim os laços conjugais, eles podem separar-se e o infiel pode ser considerado como morto. No Antigo Testamento os adúlteros eram apedrejados até a morte, enquanto no Novo Testamento ficavam como que separados pela morte. $^{372}$

O terceiro casamento de Aimee também terminou em divórcio. Diante da notícia do casamento com David Hutton, uma mulher entrou com processo contra o casal, alegando que ele havia prometido casar-se com ela, além de outros fatos. Aimee adoeceu após esses acontecimentos e combinou com o marido e os

\footnotetext{
${ }^{368}$ COX, R. L., Aimee, p. 325.

${ }^{369}$ COX, R. L., Aimee, p. 325.

${ }^{370}$ COX, R. L., Aimee, p. 325.

${ }^{371}$ COX, R. L., Aimee, p. 325.

${ }^{372}$ COX, R. L., Aimee, p. 326.
} 
familiares passar um tempo na Europa a fim de se recuperar, mas isso, na verdade, decretou o fim do casamento:

Como fiquei embaraçada ao voltar aos Estados Unidos e ver minhas cartas a David publicadas nas primeiras páginas dos jornais! Antes de meu embarque, ele se mudara da casa paroquial e entrara com um processo de divórcio. Começou também a aparecer em palcos de teatro, contando piadas sobre mim e o Templo. ${ }^{373}$

Diante de tantos contratempos, Aimee reconheceu: "eu cometera um erro ao me casar de novo". ${ }^{374} \mathrm{O}$ estatuto da Quadrangular declara: "Artigo 11 - A Igreja do Evangelho Quadrangular reconhece o casamento como instituição divina originada de Deus na ocasião da formação do homem, tendo a mesma o compromisso de abençoar e sancionar os sagrados laços do matrimônio (Hebreus 13:4)". ${ }^{375}$ Sobre pessoas divorciadas, o estatuto diz: " $2^{\circ}$ - É permitida a celebração de casamento de pessoas divorciadas, desde que estejam, na forma da Lei, habilitadas para o novo casamento e não contrariem princípios bíblicos, legais, morais e estatutários que venham comprometer a boa índole da Igreja".376 Entretanto isso não apoia o divórcio como se vê em parte do estatuto dirigida aos membros do Ministério: "artigo 29 - A Igreja do Evangelho Quadrangular, com fundamento nos princípios sagrados da palavra de Deus, não aceita como situação normal para os membros do Ministério o divórcio e a separação de fato ou de direito". ${ }^{377}$ Ou seja, a Igreja do Evangelho Quadrangular não vê como bom exemplo a vida conjugal de sua fundadora, entretanto não cabe a sua canonização aos quadrangulares, reconhecedores que são de que ela necessita de graça, como todas as pessoas. E como visto, a própria fundadora reconhece seu erro. A sua incostancia não se justifica. As separações e os casamentos, no modo como se deram não podem ser tomados como modelos ao contrario, uma vida de missão precisaria conciliasse com a vida de casamento, se existir um casamento. As separações precisam ser fundadas em motivos diferentes.

\footnotetext{
${ }^{373}$ COX, R. L., Aimee, p. 334.

${ }^{374}$ COX, R. L., Aimee, p. 334.

${ }^{375}$ QUADRANGULAR. Estatuto e Regimento Interno da Igreja do Evangelho Quadrangular, p. 134.

${ }^{376}$ QUADRANGULAR. Estatuto e Regimento Interno da Igreja do Evangelho Quadrangular, p. 134.

${ }^{377}$ QUADRANGULAR. Estatuto e Regimento Interno da Igreja do Evangelho Quadrangular, p. 53.
} 


\subsection{2. \\ O conceito e a prática da missão na Igreja do Evangelho Quadrangular}

A IEQ inicia seu modelo missionário por meio de sua fundadora, após sua retomada da pregação do evangelho em campanhas por vários lugares, que sempre fizeram parte da ação missionária da IEQ. Entretanto essa prática já era bem comum na época em que Aimee iniciou sua pregação. Ela apenas manteve o que era já comum no movimento pentecostal do século XX. Assim, decidiu retornar aonde tudo começou, com as primeiras experiências com o Senhor, voltando à fazenda em Ingersoll: "nascera lá, viera de lá e sabia que de lá deveria seguir em frente de novo. Falou aos pais do chamado. Eles facilitaram a sua ida, oferecendose para tomar conta das crianças na sua ausência". ${ }^{378}$ Cox declara, a respeito das intenções de Aimee: "Eu soube que um encontro de pentecostais estava sendo realizado em Kitchener", 379

Assim Aimee retoma o caminho missionário, começando por Kitchener, onde um evangelista dirigia uma campanha de avivamento. Ela e Robert já haviam passado por esta cidade, e Aimee foi muito bem recebida por velhos amigos: "insistiram com ela para que fosse diretamente para a plataforma da grande tenda naquela primeira tarde. Aimee agradeceu, mas recusou-se, dizendolhes que daquela vez preferia ficar no auditório". ${ }^{380}$ Note-se que as tendas já eram utilizadas em campanhas, mas ela ficou maravilhada com tudo o que ouvia na tenda, animando-se ainda mais. A um apelo do evangelista, ela se dirigiu ao altar, sendo a primeira a mostrar a própria indignidade diante do Senhor. Arrependida, quis orar por algum tempo a fim alcançar graça, mas não foi necessário, pois o pregador lhe disse: "muito bem, filha. Não diga mais nada. Você já sofreu o bastante" ${ }^{381}$ Logo em seguida, muito grata, ela deu liberdade ao Espírito para agir na sua vida: "Aimee deu-se conta de que o Espírito estava falando em línguas através dela e dando-lhe interpretação.” Desde então, essa é a forma de atuação da IEQ, ou seja, as experiências pessoais de sua fundadora tornaram-se parte da liturgia quadrangular.

\footnotetext{
${ }^{378}$ McPHERSON, A. S., Aimee Semple McPherson, p. 65.

${ }^{379}$ COX, R. L., Aimee, p. 111.

${ }^{380}$ McPHERSON, A. S., Aimee Semple McPherson, p. 65.

${ }^{381}$ McPHERSON, A. S., Aimee Semple McPherson, p. 66.
} 
Tudo isso aconteceu em uma tenda, e definitivamente a IEQ baseou nessa experiência sua ação missionária inicial, tornando-se conhecida no Brasil como a igreja das tendas. Aimee iniciou seu serviço ali lavando pratos, arrumando mesas e tudo quanto fosse preciso, além de tocar piano. Foi convidada para acompanhar as campanhas em outras cidades, como comenta Cox: "parece que essa é a única coisa por aqui que falta você tentar, não é?". ${ }^{382}$ McPherson diz:

Um dia, após o término da campanha, uma senhora procurou Aimee para convidála a ir até Mont Forest para dirigir cultos num pequeno salão chamado "Missão Vitória". Disse que o Senhor tinha tocado em seu coração para convidá-la. Aimee aceitou o convite e foi para Mont Forest, a algumas milhas de distância, para dirigir seu primeiro culto. E de todos os trabalhos que se seguiram, aquele permaneceu em sua lembrança, como um padrão para aqueles que ainda viriam. ${ }^{383}$

De cooperadora nas tendas, ela dirige seu primeiro culto, tornando-se modelo para missão até a fundação da IEQ, "no que seria o início de um ministério de dimensões mundiais". ${ }^{384}$ Percebe-se seu livre trânsito várias denominações, a exemplo da Missão Vitória. Lima destaca esse início: “o Canadá foi o país em que Aimee realizou sua primeira campanha evangelística, em 1915, na cidade de Mount Forest, num pequeno salão". ${ }^{385}$ Sua terra torna-se o marco inicial de uma longa jornada que se desenharia pelo caminho do Espírito. Nos primeiros dias foram poucos os presentes, não ocupando nem as doze cadeiras do salão. Diante disso Aimee questiona o motivo da pequena adesão do público. Conforme McPherson: “então, Aimee quis saber há quanto tempo ela vinha pregando ali. A resposta foi: 'Há mais de um ano.' Aimee achou que aquela congregação estava acomodada". ${ }^{386}$ McPherson afirma: "pegando uma cadeira, ela disse à sua anfitriã: "Vou sair e trazer uma multidão para cá.' A senhora ficou pensando e quis saber onde ela pretendia ir buscar uma multidão". ${ }^{387}$ Inconformada com a situação, Aimee sabia que algo deveria ser feito para avivar a comunidade, ainda que não lhe ocorresse exatamente o que seria. Ela vai ao

\footnotetext{
${ }^{382}$ COX, R. L., Aimee, p. 115.

${ }^{383}$ McPHERSON, A. S., Aimee Semple McPherson, p. 69.

384 TURECK, A., Cuidando da Comunicação em Família, p. 14.

${ }^{385}$ LIMA, J.; BEZERRA, C. M., História e Teologia da Igreja do Evangelho Quadrangular, p. 23.

${ }^{386}$ McPHERSON, A. S., Aimee Semple McPherson, p. 71.

${ }^{387}$ McPHERSON, A. S., Aimee Semple McPherson, p. 71.
} 
encontro das pessoas, como narra Cox, ao comentar: "a fé sem obras é morta, como sabe". ${ }^{388}$ McPherson continua:

Foi para a principal esquina da cidade, a um quarteirão de distância da missão. Pôs a cadeira no chão e usou-a como púlpito. Subiu na cadeira e ficou por um instante indecisa sobre como agir. "Quando estiver em dúvida, ore." Foi seu pensamento naquele momento. Ela ergueu os braços, fechou os olhos e começou a orar silenciosamente. Quase instantaneamente, pessoas começaram a aproximar-se, rodeando-a. Os comentários eram os mais variados: - O que há com Ela? - Sei lá! - Doida! - Deve ser maluca. - Pode ser catalepsia! - Que tipo de catalepsia? Os comentários aumentavam, as vozes também, e também a multidão. Em seguida, começaram a tocá-la dedos curiosos, para saber se era catalepsia; então ela abriu os olhos rapidamente e pode ver que ali estava a multidão que estava buscando! Saltando da cadeira e segurando-a no alto, exclamou: "Depressa! Depressa! Venham comigo!" E a multidão alvoroçada a seguiu até a missão. Ela rapidamente subiu à plataforma e, em voz alta, falou: "Assim que todos tenham entrado, fechem as portas; não deixem ninguém lá fora!" Assim foi feito. Aimee iniciou sua pregação imediatamente e teve a alegria de constatar que ninguém tentou retirarse. $^{389}$

Esse tipo de atitude, incomum, ainda mais de uma mulher, atraiu muitas pessoas, lotando o recinto. Mas ela ainda estava insatisfeita, como transcreve Cox: "por que não pregar do lado de fora, no gramado? - Alguém sugeriu". ${ }^{390}$ Assim o pequeno salão já não suportava a quantidade de pessoas. Ela passou a utilizar espaços abertos, até que novamente pensou nas tendas, como lembra Tureck: "ao final daquela semana de conferências, com as ofertas doadas pelo povo, comprou uma tenda de lona usada". ${ }^{391}$ O McPherson complementa: "ouviu falar de um homem que tinha uma tenda usada para vender e foi procurá-lo na cidade vizinha, onde ele residia". 392

Comprou a tenda, embora não estivesse em boas condições, como o vendedor anunciara, e tiveram um grande trabalho para erguê-la. Ela não suportou e começou a ceder a uma ventania durante o culto, por pouco não ferindo os presentes, bem no momento em que Aimee entregava a mensagem. $\mathrm{O}$ desespero sobreveio a todos, porém ela orou e presenciou algo sobrenatural: “creiam ou não, a tenda esticou-se e encravou-se aberta sobre uma das estacas salientes e ali deteve-se. Após o término do culto, retiraram a tenda e a abriram no chão". 393

\footnotetext{
${ }^{388}$ COX, R. L., Aimee, p. 115.

${ }^{389}$ McPHERSON, A. S., Aimee Semple McPherson, p. 71-72.

${ }^{390}$ COX, R. L., Aimee, p. 120.

391 TURECK, R., Cuidando da Comunicação em Família, p. 15.

392 McPHERSON, A. S., Aimee Semple McPherson, p. 73.

${ }^{393}$ McPHERSON, A. S., Aimee Semple McPherson, p. 73.
} 
Aleixo atesta que a opção pela tenda não foi somente dela: "como outros tantos missionários da época, compraria uma tenda de lona com o intuito de minimizar os gastos com aluguéis de salões e de ter uma maior mobilidade de sua "capela itinerante". 394

"Uma pregadora era novidade,"395 ressalta Cox. Aimee usou o que tinha à mão, não esperando condições melhores, e com essa ousadia residiu por muito tempo em tendas de lonas. É McPherson quem assegura: "durou dois anos aquela campanha de avivamento em Mont Forest". ${ }^{396}$ Uma campanha de dois anos não é habitual atualmente, mesmo no meio pentecostal. Muitos fiéis da IEQ no Brasil não conhecem os antecedentes da fundadora até a visão do Evangelho Quadrangular. Ela conclui: "as tendas tornaram-se o seu mundo, onde quer que ela vivesse e respirasse. Ela dormia numa cama de lona, de soldado, numa pequena tenda, ao lado da grande tenda, ela e seus filhinhos". 397

O trabalho pesado do caminhar pastoral de Aimee fez com que ela encarnasse verdadeiramente as palavras do Cristo, não valorizando a própria vida e sempre renunciando à segurança para experimentar o avivamento de seu tempo. Depois da primeira experiência liderando uma campanha em tendas, ela empreende a segunda campanha de avivamento, conseguindo comprar uma nova tenda dessa vez, cuja localização recorda em detalhes: "no alto de uma colina, cuja vista dava para a belíssima Baía de Narragansett". ${ }^{398}$ Foi bastante complicado manter a tenda no alto da colina, pois ventava muito, o que mostra a luta da IEQ no seu DNA. Aimee supera os obstáculos e segue adiante, como diz: "a nova tenda, pela qual Aimee havia esperado tanto tempo, foi erguida no Acampamento Holiness, Cape Code, Onsett Bay. E quando estava dirigindo os cultos ali, Aimee sentiu-se chamada por Deus para ir a Corona, Long Island". ${ }^{399}$ Levando a mensagem em tendas, ela buscava ouvir a voz do Senhor, sempre visando a expansão do trabalho, como refere Cox: "o Espírito imediatamente testemunhou

\footnotetext{
${ }^{394}$ ALEIXO, V. C., "Deus Faz, o Templo dos Anjos Mostra, p. 41.

${ }^{395}$ COX, R. L., Aimee, p. 121.

${ }^{396}$ McPHERSON, A. S., Aimee Semple McPherson, p. 75.

${ }^{397}$ McPHERSON, A. S., Aimee Semple McPherson, p. 75.

${ }^{398}$ McPHERSON, A. S., Aimee Semple McPherson, p. 77.

${ }^{399}$ McPHERSON, A. S., Aimee Semple McPherson, p. 79.
} 
ao meu coração". ${ }^{400}$ A missionária completa: "a partir de então, Aimee iniciaria seu movimento reavivalista". 401

O feito dessa corajosa mulher no início do século XX teve muitos outros desdobramentos, com outras possibilidades para o trabalho missionário: "ela vinha pedindo uma máquina de escrever ao Senhor. Precisava de uma porque vinha escrevendo a diversas revistas religiosas. Ela achava que esta era a razão". ${ }^{402}$ Ela dedica-se muito à tarefa de escrever artigos para essas revistas, que também alcançavam muitas pessoas. Em meio às orações ela sempre lembrava o nome Corona, compreendendo, depois de algum tempo, o porquê disso, como declara: "passados alguns dias, recebeu uma carta que dizia: 'Querida irmã McPherson, venha imediatamente a Corona, Long Island. Nuvens de avivamento estão prontas para caírem sobre nós". ${ }^{403}$ Mesmo sem saber muito a respeito de quem a enviara a carta e nem como isso acontecera, Aimee compreendeu que se tratava da vontade do Senhor: a carta confirmava o que já lhe vinha sendo mostrado em meio às suas súplicas.

O pentecostalismo também deixou marcas no povo negro, tanto nos Estados Unidos, no seu início, como no Brasil. Entretanto não se afirma aqui que o pentecostalismo seja herança negra, mas recebeu dos negros grande simpatia e adesão. Isso também pode ser constatado na IEQ, numa experiência de Aimee ao chegar a Corona: "logo a porta foi aberta e, para surpresa de Aimee, o rosto sorridente de uma simpática mãe preta surgiu diante de seus olhos. Aimee achou que havia errado de endereço". ${ }^{404}$ Afinal, mesmo as igrejas praticavam a segregação racial. Aimee revive seu pensamento equivocado: "mas a risonha 'mãe preta' nem a deixou continuar: 'Espere, você não é a irmã McPherson, que esteve pregando em Cape Core? [...] Deus a abençoe, filhinha! Eu estou esperando há uma semana". 405

O avivamento vivenciado no pentecostalismo é unificador e diminui diferenças, o que ocorreu nesse episódio, contradizendo o modo de pensar da missionária. Elas se entenderam bem, e começou o plano da campanha, num local de situação também não muito fácil. Pela idade avançada, Mammy, a senhora

\footnotetext{
${ }^{400}$ COX, R. L., Aimee, p. 129.

401 ALEIXO, V. C., "Deus Faz, o Templo dos Anjos Mostra, p. 41.

${ }^{402}$ McPHERSON, A. S., Aimee Semple McPherson, p. 79.

${ }^{403}$ McPHERSON, A. S., Aimee Semple McPherson, p. 79.

${ }^{404}$ McPHERSON, A. S., Aimee Semple McPherson, p. 81.

${ }^{405}$ McPHERSON, A. S., Aimee Semple McPherson, p. 81.
} 
negra não a pôde acompanhar na busca do local, dizendo: "pode ir que eu fico aqui e peço ao Senhor para guiar você". 406

Aimee não teve sucesso durante sua busca pela cidade, e voltou para casa perguntando-se se Deus realmente queria um reavivamento naquela cidade. Estava descansando quando alguém a chamou na porta, dizendo: "fiquei sabendo que há uma senhora evangelista aqui.' 'É isso mesmo. A irmã McPherson veio para conduzir um reavivamento". 407 Diante da fala da Mammy o homem continuou: "Bem, sou o pastor da Igreja Episcopal Metodista Sueca, aqui nesta rua, e gostaria de saber se ela teria tempo de realizar algumas reuniões para nós". ${ }^{408}$ Quando Aimee ouviu a conversa e foi chamada, quase não pôde acreditar. Sentiu que esse acontecimento era uma resposta do céu, e lembra:

\begin{abstract}
Nessa noite encontrei metade do prédio da igreja cheio de gente, e eles espalhavam a história pela cidade. $\mathrm{Na}$ tarde seguinte a igreja estava repleta, e naquela noite transbordava para a rua, embora os membros de igrejas tivessem sido advertidos por seus ministros para ficarem longe dos pentecostais e não se misturarem com essa gente que falava em línguas. Uma semana depois de iniciadas as reuniões, vieram os resultados. Um professor de escola dominical de uma das grandes igrejas, um homem cuja posição cristã sólida era conhecida de todos há anos, foi o primeiro a receber o batismo. ${ }^{409}$
\end{abstract}

O reavivamento pedido por Mammy agora era real na cidade de Corona, sendo importante, e não era comum ver trabalhos assim liderados por mulheres. McPherson informa: "lembremo-nos que isto foi antes das igrejas ordenarem mulheres para o ministério como atualmente". ${ }^{410}$ Ou seja, a evangelista irmã McPherson começou seu trabalho em um campo dominado por homens, mesmo no pentecostalismo. Ela também vivenciou que em Cristo não existem mais diferenças, como diz: “Aimee pensou consigo mesma que ali estava uma prova positiva de que em Cristo não há nem branco, nem preto, nem escravo, nem livre, nem judeu, nem gentio, porque Cristo derrubou o muro de separação, fazendo de todos um!".411

Nesse cenário a irmã Aimee experimentou uma nova fase no trabalho missionário, pregando o batismo no Espírito Santo, com evidência desses

\footnotetext{
${ }^{406}$ COX, R. L., Aimee, p. 132.

${ }^{407}$ COX, R. L., Aimee, p. 133.

${ }^{408}$ COX, R. L., Aimee, p. 133.

${ }^{409}$ COX, R. L., Aimee, p. 133.

${ }^{410}$ McPHERSON, A. S., Aimee Semple McPherson, p. 83.

${ }^{411}$ McPHERSON, A. S., Aimee Semple McPherson, p. 85.
} 
acontecimentos durante suas reuniões, mas o dom de cura ainda não havia se manifestado. $\mathrm{O}$ primeiro relato de tais sinais em seus trabalhos de reavivamento mostrou-se ainda em Corona, durante uma reunião. É McPherson quem informa:

Certa noite, depois de me ouvir declarar que Jesus Cristo é o mesmo ontem, hoje e para sempre, e que Ele continua vivo para curar, salvar e batizar com seu Espírito Santo, alguns de meus ouvintes aceitaram literalmente a palavra. Fiquei grandemente espantada quando, ao levantar os olhos, vi descendo o corredor central uma figura estranha e patética - uma jovem apoiada em duas muletas. Ela estava curvada e torcida por causa da artrite reumatóide, sendo sustentada à esquerda e à direita, além das muletas, por duas amigas. Ela veio da última fila. Pareceu-me que todos a fitavam. Um murmúrio de piedade percorreu a assembléia. ${ }^{412}$

A evangelista não esperava que sua primeira experiência com o dom de cura fosse um caso tão complexo, e enquanto a jovem dirigia-se à frente toda a assembleia aguardava. Ela continua o relato: "os olhos das pessoas fixaram-se primeiro na jovem e depois em mim. E eu, Deus me ajude, senti minha face ficando cada vez mais vermelha. Mas clamei em meu coração: 'Oh, Senhor, o Senhor pode curá-la, embora eu admita que o caso dela pareça irrecuperável!". ${ }^{413}$ Agora Aimee estava diante de sua primeira experiência em orar durante uma reunião por cura, algo muito desafiador, segundo lembra: "então orou por sua cura, dizendo-lhe que erguesse as mãos e louvasse ao Senhor. Ela poderia facilmente ter replicado que não poderia fazer isto. Contudo, sua obediência foi instantânea: - Glória ao Senhor! Glória ao Senhor!". ${ }^{414}$ A prontidão em obedecer aos comandos de Aimee levou ao acontecimento que marcou não somente a vida dessa jovem chamada: "Louise Messnick". ${ }^{415}$ Mas também a de todos que presenciaram o acontecimento. McPherson assegura:

Louvando a Deus com voz cada vez mais firme, para alegria de todos, as juntas encolhidas começaram a endireitar-se e as suas mãos foram se erguendo mais e mais acima do seu queixo, de seus olhos, até o alto de sua cabeça! Continuando com seu louvor, ela exclamava: 'Louvado seja o nome do Senhor! Esta é a primeira vez que consigo erguer minhas mãos ao alto da minha cabeça, depois de tanto tempo! $!^{416}$

\footnotetext{
${ }^{412}$ COX, R. L., Aimee, p. 135.

${ }^{413}$ COX, R. L., Aimee, p. 135.

${ }^{414}$ McPHERSON, A. S., Aimee Semple McPherson, p. 87.

${ }^{415}$ COX. R. L., Aimee, p. 136.

${ }^{416}$ McPHERSON, A. S., Aimee Semple McPherson, p. 87.
} 
E continua:

As mãos foram subindo, até que ambas as mãos e os braços ficaram praticamente livres. Seu queixo, porém, estivera tanto tempo inclinado sobre o colo que parecia ter nascido ali, com o pescoço praticamente rígido. A cabeça começou a virar-se então, e o queixo começou a levantar-se. Ela olhou para o céu. Num momento estava de pé! Agarrando-se com as mãos na grade, ela começou a andar à medida que seus membros se endireitavam. ${ }^{417}$

Esse acontecimento é muito relevante, o primeiro desse tipo experimentado pela fundadora da Igreja do Evangelho Quadrangular. É também um dos principais traços distintivos da denominação em relação a outras do pentecostalismo, com forte ênfase na glossolalia. A cura da jovem Louise foi considerada por Aimee o maior milagre. Ela própria assegura: "para Aimee este foi o maior milagre que ela jamais havia visto". 418 Aimee vivenciou inúmeros episódios de cura na vida missionária, mas a cura de Louise redefiniu a vida da fundadora dessa denominação, como ela atesta:

\begin{abstract}
Não sei por que eu nunca antes vira uma coisa assim, mas até hoje a cura daquela jovem me parece um dos maiores milagres que já presenciei. Ela foi embora da igreja andando naquela noite. A partir desse dia, Louise tornou-se uma das frequentadoras constantes das reuniões. Dois anos mais tarde, tive a oportunidade de realizar uma campanha na mesma cidade. Tropeçando pelo corredor, apareceu uma senhora baixinha e gorducha que caiu sobre mim como um furacão. "Você lembra de mim?", perguntou. Olhando para os olhos brilhantes, tez delicada e figura atraente, sacudi a cabeça e disse: "Você não é... você é Louise?" "Sou eu mesma, louvado seja o Senhor! Eu agora costuro, faço serviços domésticos, participo dos cultos. Minha família inteira converteu-se. .19 $^{34}$
\end{abstract}

Esse acontecimento, que deu mais evidência ao seu trabalho e lhe rendeu muitos frutos, Aimee deixou Corona e levou a cabo campanhas de reavivamento por outras cidades, como ela comenta: "os campos estavam esperando pelo evangelho e a esplêndida oferta com que a Igreja Batista de Corona recompensou minha campanha tornou possível levá-lo até o sul, até a Flórida, no inverno de 1916-17". ${ }^{420}$ Essa cidade foi determinante na vida da fundadora da Igreja do Evangelho Quadrangular. Como os meios de comunicações não eram de fácil acesso, Aimee compreendeu a necessidade de manter alguma forma de contato

\footnotetext{
${ }^{417}$ COX. R. L., Aimee, p. 137.

${ }^{418}$ McPHERSON, A. S., Aimee Semple McPherson, p. 87.

${ }^{419}$ COX. R. L., Aimee, p. 137-138.

${ }^{420}$ COX. R. L., Aimee, p. 138.
} 
com as cidades das quais ela passava, como afirma Tureck: "Aimee sempre testemunhou que, por maior que fosse sua fadiga, sempre se refazia assim que subisse ao púlpito para conduzir as reuniões". ${ }^{421}$ Cox cita a missionária:

Outro resultado da reunião em Corona foi o Senhor dar-me a máquina de escrever tão longamente desejada! Isto me possibilitou começar depois de alguns meses a edição do Bridal Call (Convite para as Bodas). O primeiro número foi publicado em julho de 1917, impresso em Savana, Geórgia. A princípio não passava de um jornalzinho rural de quatro páginas. Após três meses, porém, fiz um acordo com a União de Obreiros Cristãos e, Montwait, Framingham, Massachusetts, para aumentar o Bridal Call e publicá-lo como uma revista mensal de 16 páginas, de 18 x $25 \mathrm{~cm}$, custando a assinatura US $\$ 0,25$ por ano. Os números incluíam meus sermões, notícias, fotos das campanhas, poemas e outros artigos. Eu agora podia manter-me em contato através de quilômetros de distância com muitas pessoas a quem ministrara em diferentes partes do país. ${ }^{422}$

Assim, de maneira bem autêntica, Aimee Semple McPherson obtém feitos aparentemente impossíveis entre os pentecostais, quando as mulheres ficavam à margem da liderança religiosa. Logo se perceberam seu dinamismo e sua capacidade de administração.

As pregações continuaram, como ela relembra: "durante os dois invernos que preguei na Flórida (1916-17 e 1917-18), a tenda foi erguida não só em Jacksonville e Tampa, mas também em St. Petersburg, Orlando, Palm Beach, Miami, e até Key West, bem ao sul. Foi durante as minhas campanhas na Flórida que minha mãe chegou para ajudar no trabalho". ${ }^{423}$ O trabalho da fundadora da Igreja do Evangelho Quadrangular é bastante itinerante. Seu perfil missionário até então não era voltado a nenhuma denominação, podendo classificar-se como parte do movimento pentecostal muito comum na época. Mas, em tempo de grande propagação do pentecostalismo norte-americano, as dúvidas e críticas eram comuns, como recorda MacPherson:

Lembro-me vivamente de uma reunião especial realizada num grande tabernáculo de madeira em Durant, na Flórida, a $30 \mathrm{~km}$ de Tampa, que produziu um Tomé cheio de dúvidas, o qual foi adequadamente silenciado. Esse homem não aceitava de modo algum a ideia de que a oração da fé ainda salvava os doentes. ${ }^{424}$

\footnotetext{
${ }^{421}$ TURECK, A., Cuidando da Comunicação em Família, p. 15.

${ }^{422}$ COX. R. L., Aimee, p. 138-139.

${ }^{423}$ COX. R. L., Aimee, p. 139.

${ }^{424}$ COX. R. L., Aimee, p. 139.
} 
O pentecostalismo inicial que desbrava e que destaque tinha como principal característica a glossolalia, da qual Aimee também é adepta e difusora, entretanto ela começa a explorar outra característica que se mostraria muito forte em sua missão, a cura divina: "havia sempre separado um lugar para os cegos e paralíticos". 425

Voltemos ao opositor de que se tratou acima. A seu respeito, a missionária diz: "ele então começou uma reunião de oposição do outro lado da cerca que rodeava o terreno, defendendo a teoria de que os milagres eram apenas para os dias bíblicos e que todo o poder sobrenatural cessara ao ser escrito o último capítulo da Bíblia". ${ }^{426} \mathrm{O}$ sobrenatural causa estranheza até nos dias atuais e sempre gerará dúvidas, algo compreensível, dada a grande enganação existente. A autobiografia de Aimee mostra que foi por meio de um acidente no local de culto que se iniciou uma resposta ao questionador:

\begin{abstract}
Vendo que as lâmpadas de querosene e gasolina usadas não iluminavam o suficiente, eu levava comigo um equipamento de iluminação de carbureto de cálcio. Havia evidentemente algum defeito no aparelho, porque, de repente, enquanto eu fazia alguns ajustes, a 'coisa' explodiu. Chamas ardentes envolveramme. Meu primeiro pensamento foi que o grande tabernáculo de madeira seria incendiado. De alguma forma consegui ficar onde estava até que desliguei a torneira e a chama extinguiu-se. ${ }^{427}$
\end{abstract}

A vida da missionária Aimee sempre se fez acompanhar de dores e marcas a ser superadas. Nesse relato ela própria tenta executar um trabalho técnico de estrutura no local da reunião, mesmo enfrentando as consequências, como nesse caso, em que o acidente poderia tê-la matado. Ela continua:

Por um instante, após a explosão, ela sentiu seu rosto insensível, como que congelado, mas em seguida como se estivesse em chamas! Sua aparência tornou-se impressionante. Seu rosto escureceu, suas sobrancelhas e pestanas foram queimadas tanto quanto uma parte de seus cabelos, assim mesmo porque, por sorte, na ocasião ela estava usando um pequeno chapéu. A dor tornou-se tão violenta que ela saiu correndo em direção ao pequeno chalé, onde estava vivendo, e fez a pior coisa que poderia ter feito: pôs o rosto dentro de uma panela de água gelada. Enquanto ela conseguia manter o rosto dentro da água gelada, a dor era aliviada, mas quando, para respirar, o retirava para fora, a dor tornava-se mais forte do que nunca. ${ }^{428}$

\footnotetext{
${ }^{425}$ TURECK, A., Cuidando da Comunicação em Família, p. 16.

${ }^{426}$ COX. R. L., Aimee, p. 139.

${ }^{427}$ COX. R. L., Aimee, p. 140.

${ }^{428}$ McPHERSON. A. S., Aimee Semple McPherson, p. 102.
} 
A situação se complicou pela preocupação com seu opositor. Afinal, uma pregadora da cura aos outros não poderia curar a si mesma? Ela conta em detalhes o doloroso episódio:

\begin{abstract}
Algumas mulheres trouxeram bicarbonato e o aplicaram nas bolhas. Meu medo maior foi concretizado. $\mathrm{O}$ homem em questão levantou-se, ousado como era, e começou a fazer um discurso, afirmando que não haveria reunião naquela noite, pois a senhora que pregava a salvação e a cura divina estava doente, por ter queimado o rosto. ${ }^{429}$
\end{abstract}

Agora o que estava em questão eram o crédito e a continuidade do reavivamento naquele lugar. Aimee, sem opção, ficou muito perturbada com as provocações, pois os dizeres do seu opositor reduziriam sobremaneira seu trabalho, contradizendo-o diante da audiência. Mesmo com queimaduras e muita dor, ela se dirige à reunião, como recorda: “mas, orando a Deus, pedindo forças e dizendo a Ele que avançaria em nome do Senhor, entrei e subi na plataforma". ${ }^{430}$ Para surpresa dos presentes e de seu concorrente, ela consegue chegar ao reavivamento, mas pondera: "Sua figura era impressionante". ${ }^{431}$ Muitas coisas extraordinárias aconteciam nas reuniões, mas sempre com a audiência, nunca com o próprio condutor do culto, mas nesse caso foi assim:

Comecei a cantar o primeiro hino, com os lábios endurecidos pela queimadura, quase impedida de articular as palavras. No final do primeiro verso, levantei uma das mãos e com fé desesperada e manifesta, exclamei: "Louvor ao Senhor porque Ele me cura e tira de mim a dor". Um grande grito se fez ouvir entre a multidão. Meu sofrimento intenso foi imediatamente aliviado e, diante dos olhos da audiência, o vermelho-escuro de meu rosto desapareceu, as bolhas brancas e pequenas que estavam se formando sumiram, e no final do culto a pele tinha voltado à sua aparência natural, isto fez com que a vitória a favor da aceitação do poder de Deus nos dias de hoje fosse conquistada, e o cético fosse envergonhado e silenciado. ${ }^{432}$

Assim o improvável aconteceu, num dos maiores marcos da caminhada de Aimee: "o número de conversões era tal que, em algumas reuniões, metade dos ouvintes se levantava para receber a Cristo". ${ }^{433}$ O caráter itinerante do reavivamento se manteve, como a autora descreve:

\footnotetext{
${ }^{429}$ COX. R. L., Aimee, p. 140.

${ }^{430}$ COX. R. L., Aimee, p. 141

${ }^{431}$ McPHERSON. A. S., Aimee Semple McPherson, p. 103.

${ }^{432}$ COX. R. L., Aimee, p. 141-142.

${ }^{433}$ TURECK, A., Cuidando da Comunicação em Família, p. 16.
} 
A primavera estava chegando, os estados do Norte chamavam, a campanha no Sul terminou triunfante e eu pilotei o carro do evangelho em direção ao norte com minha família. Enquanto meus filhos dormiam no banco de trás, viajei para a Filadélfia e para o cenário de nossa campanha nacional a partir de julho de 1917. 'Guerra!' 'Gripe!' 'Dezenas de Milhares Morrem!' 'Falta de Caixões Atrasa Sepultamentos!' Essas eram as manchetes dos jornais diários; a epidemia se abatera sobre o Leste com toda a sua fúria. E eu tinha um longo itinerário de reuniões marcadas através dos estados de Massachussetts, Connecticut e Nova York! As escolas públicas, os teatros e as igrejas em toda parte foram colocados de quarentena. Nossas bandeiras flutuavam apáticas sobre milhares de sofredores. As flâmulas anunciando o reavivamento balançavam molemente no ar úmido de outono. Todavia, milagrosamente, quando eu chegava a cada cidade, as proibições eram suspensas, sendo novamente impostas só depois da campanha. ${ }^{434}$

Não se pretende dizer aqui que a vida da fundadora só se compôs de façanhas e feitos inéditos, mas omitir essa vivência à frente do seu tempo não contribui para a história do pentecostalismo. O cenário de quarentena das epidemias em tempos de guerra tornava a vida da missionária ainda mais pesada, como ela relata: "fui recebida no alto com a notícia de que minha filhinha pegara gripe e pneumonia dupla. 'Oh, Jesus', solucei, 'nós podemos aguentar até certo ponto. O Senhor levou Robert, n-não leve agora R-Roberta!". 435

A dor da perda do primeiro esposo na China se fez presente novamente na vida de Aimee, com o medo de perder a filha para uma doença tão grave. Entretanto, dessa vez a resposta do Senhor foi diferente: "não temas, sua pequenina viverá e não morrerá. Além disso, vou dar-lhe uma casa na Califórnia, onde seus filhos irão à escola". ${ }^{436}$ A vida que a sua família levava era pesada demais para as crianças, cuidadas apenas por Aimee e sua mãe. Então, o Senhor promete um lar para eles, o que se cumpriu pouco tempo depois. McPherson informa: "a primeira Guerra Mundial acabara. A epidemia se fora. Deus estava no seu céu, tudo ia bem na terra, e nós nos encaminhamos novamente para a ensolarada Califórnia". ${ }^{437}$ Um novo tempo aguardava a missionária, um novo ciclo estava prestes a iniciar-se em sua missão. "A mensagem da salvação e do batismo com o Espírito Santo era o seu ponto forte, mas eram sempre seguidas de sinais e de prodígios". 438

\footnotetext{
${ }^{434}$ COX. R. L., Aimee, p. 142.

${ }^{435}$ COX. R. L., Aimee, p. 148.

${ }^{436}$ COX. R. L., Aimee, p. 148.

${ }^{437}$ COX. R. L., Aimee, p. 153.

438 TURECK, A., Cuidando da Comunicação em Família, p. 17.
} 
A continuidade da missão passa agora por um lugar histórico para o pentecostalismo: "na 'Cidade dos Anjos', onde o poder pentecostal se derramara tão maravilhosamente quinze anos antes na rua Azusa, ficamos sabendo que várias diferenças doutrinárias haviam desviado os olhos de muitos do Senhor e que havia carência na terra". ${ }^{439}$ Entretanto, Aimee via cada vez mais claramente a necessidade de um reavivamento nesse local, sem saber, no entanto, de que forma isso seria possível, dada a grande quantidade de igrejas pentecostais de peso na região, e sentindo-se incapaz. Em Denver, ela afirma:

Depois do primeiro culto de cura divina na noite de quarta-feira, quando os coxos andaram e correram, atirando fora suas bengalas e muletas, os jornais anunciaram os milagres: 'Os Surdos Ouvem! Os Cegos Vêem! Os Coxos Andam!' Depois disso a polícia teve de ser chamada para cuidar das multidões, já que um número cada vez maior dos que não conseguiam entrar no prédio reunia-se nas ruas fora da igreja. ${ }^{40}$

A manifestação de cura divina nesse reavivamento foi tão grande que locais especiais tinham que ser preparados para atender a demanda de pessoas com algum tipo de limitação física, como ela lembra: "locais especiais para doentes e inválidos que não podiam andar e sentar foram arranjados". ${ }^{441}$ Nesse momento chegava ao fim uma importante etapa da missão de Aimee: "a campanha de 1921 durou três semanas". ${ }^{442}$ Ela partiu então para aquele que seria considerado seu último reavivamento itinerante. É McPherson quem diz:

\begin{abstract}
Meu último reavivamento na América do Norte antes da dedicação do Templo Angelus foi uma grande reunião numa tenda na cidade de Oakland, na Califórnia. Nesse reavivamento foi que o conceito do evangelho como sendo "quadrangular" brotou em meu coração. Eu não estava satisfeita com as designações pentecostal ou Evangelho Pleno. Como já disse, foi durante o reavivamento em Oakland, em julho de 1922. A grande audiência ouvia arrebatada minha mensagem sobre "A Visão de Ezequiel". ${ }^{433}$

O trabalho missionário desenvolvido até então por Aimee ainda não tinha assumido estrutura institucional. Porém a indefinição denominacional fazia-o parecer-se ou confundir-se com outros, até a sua satisfação com o conceito de
\end{abstract}

\footnotetext{
${ }^{439}$ COX. R. L., Aimee, p. 154.

${ }^{440}$ COX. R. L., Aimee, p. 157.

${ }^{441}$ COX. R. L., Aimee, p. 159.

${ }^{442}$ COX. R. L., Aimee, p. 161.

${ }^{443}$ COX. R. L., Aimee, p. 163.
} 
quadrangular, segundo ela, "revelado quando pregava num tabernáculo para mais de cinco mil pessoas". ${ }^{444}$ Continua:

$\mathrm{Na}$ face do leão, contemplamos Aquele que batiza poderosamente com o Espírito Santo e com fogo. A face do boi tipifica Aquele que carrega os fardos, que levou sobre si nossas fraquezas e enfermidades, que em seu amor infindo e em sua provisão divina supre cada uma de nossas necessidades. Na face da águia, vemos refletidas as visões arrebatadoras do Rei vindouro, cujas asas logo abrirão caminho nos céus brilhantes, cuja voz ressoará através do universo nas cadências vibrantes do poder da ressurreição, quando vier buscar sua noiva que o aguarda. E na face do homem contemplamos o Salvador, o homem de dores, que sabe o que é padecer, morrendo na cruz pelos nossos pecados. Este é um evangelho perfeito, completo, para o corpo, a alma, o espírito e para a eternidade, um evangelho que olha diretamente e ao mesmo tempo em quatro direções. ${ }^{445}$

As representações do Evangelho Quadrangular foram ganhando mais identidade e tornando-se cada vez mais definidas, agregando-se também cores simbólicas, como ela acrescenta:

\begin{abstract}
Quatro cores foram reveladas através do estudo das Escrituras, que Aimee aplicou às quatro faces do ministério de Cristo: Vermelho, simbolizando seu precioso sangue que Ele derramou na cruz, morrendo por toda a humanidade, para a primeira Salvação. Amarelo Ouro, simbolizando o fogo que caiu do céu no dia do Pentecostes, para a segunda fase - Batismo no Espírito Santo. Azul, a cor do céu, de onde vem a terceira fase - Cura Divina. Púrpura, a cor da realeza, para a quarta fase - A Segunda Vinda de Cristo, como Rei. ${ }^{446}$
\end{abstract}

Expostas as revelações que alicerçam a doutrina quadrangular, o movimento ganha estrutura institucional, preparando-se para o processo de organização dos interessados em compor a organização, como ela informa:

Durante a última semana da Campanha foi realizada uma reunião ministerial com o propósito de reunir leigos e pastores na América que aceitavam e praticavam a mensagem do Evangelho Quadrangular. A nova organização, nascida do espírito de unidade e oração, seria conhecida como: Igreja do Evangelho Quadrangular. Durante 14 anos ela havia percorrido o mundo, pregando o Evangelho de nosso Senhor Jesus Cristo. ${ }^{447}$

Esse momento contava com a participação de diversas pessoas, inclusive leigos, que se tornam instrumento essencial para o desenvolvimento e o crescimento da missão da Igreja do Evangelho Quadrangular.

\footnotetext{
${ }^{444}$ TURECK, A., Cuidando da Comunicação em Família, p. 17.

${ }^{445}$ COX. R. L., Aimee, p. 165.

${ }^{446}$ McPHERSON. A. S., Aimee Semple McPherson, p. 138.

${ }^{447}$ McPHERSON. A. S., Aimee Semple McPherson, p. 138.
} 
Um novo desafio é proposto a Aimee, a cidade de Los Angeles, como ela lembra: "então o Senhor, muito amavelmente, mas inquestionavelmente, começou a revelar a Aimee a sua vontade, que havia um método no plano que Ele estava guiando e que na 'Cidade dos Anjos', Los Angeles, Califórnia, eles construiriam uma casa para o Senhor". ${ }^{448}$ Relembre-se que essa cidade é marco do pentecostalismo e qualquer empreitada ali envolvia muita responsabilidade. A estratégia ali seria a construção de um grande templo, pelo peso que representava a cidade no campo religioso pentecostal, embora a missionária relutasse quanto à tarefa. McPherson afirma:

Quando este fardo veio do céu pela primeira vez, tentei pô-lo de lado, supondo que a ideia pudesse ser minha. Mas o chamado persistiu. Recuei então diante de tarefa tão ambiciosa. Quem jamais ouvira falar de uma mulher, sem apoio terreno ou qualquer organização para patrociná-la, empreendendo a coleta de fundos e a edificação de um prédio desse tipo? ${ }^{449}$

Diante da persistência de alguns, que reiteravam a necessidade de um reavivamento na cidade e a ardente vontade do seu chamado, Aimee assegura: "certo dia, no verão de 1920, o chamado soou tão urgente em meu coração que subi no automóvel com minha mãe e fiz uma pesquisa do terreno". ${ }^{450}$ A busca não levou muito tempo, culminando com a chegada a uma parte bela da cidade arborizada, com parque e estrutura: "Em poucos minutos chegamos ao Echo Park". 451

Ela pensou na longa caminhada missionária, nas chuvas, no frio, em lugares locados disputados com artistas, nas licenças e nas muitas tendas armadas e desarmadas. Pensou como seria bom ter um lugar fixo capaz de acomodar todos em segurança, como lembra: "logo depois do parque vimos um terreno de forma circular. 'Que lugar ótimo para o tabernáculo!', exclamei. Como um raio vindo do céu, visualizei o plano geral da estrutura e a segurança nasceu em meu coração: 'Este é o lugar!". 452

Ela buscou informações sobre o terreno, mas algo parecia estar errado: um terreno naquela proporção e localização se manter vago, como recorda: "perto

\footnotetext{
${ }^{448}$ McPHERSON. A. S., Aimee Semple McPherson, p. 143.

${ }^{449}$ COX. R. L., Aimee, p. 175.

${ }^{450}$ COX. R. L., Aimee, p. 176.

${ }^{451}$ COX. R. L., Aimee, p. 177.

${ }^{452}$ COX. R. L., Aimee, p. 177.
} 
havia uma imobiliária. Quando mencionamos o terreno que tínhamos em mente, o corretor declarou: 'Mas, senhoras, essa propriedade não está à venda. Talvez seja a única vazia neste distrito que não esteja no mercado". ${ }^{453}$

Ela manteve a fé, acreditando que o terreno estava reservado para a construção do templo. Quando novamente pesquisaram o terreno, ele já estava à venda, o que parecia impossível, visto que a proprietária tinha muitas posses e não precisava vender nenhum de seus terrenos, e justamente o desejado por Aimee foi anunciado. É McPherson quem assegura: "uns dois dias mais tarde sentimo-nos levadas a inspecionar novamente o terreno. Encontramos um aviso anunciando a venda da propriedade e insistindo: ‘Agarre esta oportunidade!". ${ }^{454}$

Ela não tinha o dinheiro para a compra, apesar do ótimo preço. Foi então cumprir uma de suas campanhas agendadas, na expectativa de que, na volta, pudesse adquirir a propriedade. Conseguiu concretizar o negócio, como afirma Tureck: "Aimee comprou um terreno na cidade de Los Angeles e iniciou pela fé a construção do Templo Sede Internacional”. ${ }^{455}$

Seguiram-se dias de muito trabalho para construção do grande templo e Aimee participou de cada etapa, liderando a construção e levantando recursos. Ela também cuidou dos detalhes, e até mesmo do texto fixado sobre o altar: "Jesus Cristo é o mesmo ontem, hoje e eternamente". ${ }^{456}$ Pois aquele lugar, segundo sua fé, seria um local de constantes reavivamento na cidade.

Chegou o dia da inauguração, como lembra McPherson: "desde o dia em que as portas se abriram, a $1^{\circ}$ de janeiro de 1923, um poderoso reavivamento espiritual invadiu o Templo Angelus com poder e fervor sempre crescentes". ${ }^{457}$ Assim findou-se o período das grandes tendas na missão de Aimee Semple McPherson, dando lugar a outros desafios. Com local próprio e certa segurança e estabilidade, a Igreja do Evangelho Quadrangular começou a desenvolver outras estruturas. Aimee conseguiu uma concessão de rádio para propagar a mensagem e manteve sua revista. E pensando na preparação de seus missionários, também organizou um instituto bíblico, do qual saíram vários missionários, que levaram a mensagem quadrangular por várias partes do mundo, inclusive o Brasil.

\footnotetext{
${ }^{453}$ COX. R. L., Aimee, p. 177.

${ }^{454}$ COX. R. L., Aimee, p. 178.

455 TURECK, A., Cuidando da Comunicação em Família, p. 17.

${ }^{456}$ McPHERSON, A. S., Aimee Semple McPherson, p. 146.

${ }^{457}$ COX. R. L., Aimee, p. 187.
} 


\subsection{3. \\ Os estatutos e a visão geral da fé, do culto e da prática da Igreja do Evangelho Quadrangular}

Esta parte do trabalho analisa a estrutura institucional da Igreja do Evangelho Quadrangular, traçando um panorama geral que abrange desde os estatutos e a declaração de fé até sua visão geral. A parte inicial do estatuto diz: "parte Primeira da Corporação Eclesiástica. Título I. Das Disposições Preliminares. Capítulo I - das Origens. Artigo $1^{\circ}$ - A Igreja do evangelho Quadrangular é o prosseguimento do movimento cristão pentecostal iniciado nos tempos apostólicos que atravessou os séculos e chegou até nossos dias". ${ }^{458}$ Verifica-se que os quadrangulares asseguram sua raiz pentecostal no estatuto, ligando seu pentecostalismo à história do cristianismo. A respeito do primeiro artigo do capítulo um desse estatuto, Duffield e Cleave asseguram: "o movimento pentecostal não se baseia unicamente em uma experiência, mas se firma em toda a Bíblia como Palavra de Deus". ${ }^{459}$ A IEQ visa assim estruturar seu pentecostalismo como prática e missão, daí a importância do detalhamento e do assentamento na história do cristianismo. Eis o segundo capítulo desse estatuto:

Capítulo II - do Histórico. Artigo $2^{\circ}$ - O movimento pentecostal, reavivado no início do século XX na Europa e nos Estados nos Estados Unidos, foi um marco de um novo tempo de avivamento espiritual no mundo e como consequência, nasceu a mensagem Quadrangular sob inspiração Divina em julho de 1922, na cidade de Oakland - Califórnia, por revelação específica de Deus, segundo Ezequiel 1: 4 10, à fundadora da "International Church of the Foursquare Gospel", missionária Aimée Semple McPherson, que elaborou a Declaração de Fé, base doutrinária da Igreja do Evangelho Quadrangular. ${ }^{460}$

Novamente se situa a IEQ no cristianismo pentecostal, acrescentado sua origem e base inspiradora, como também destacando que a declaração de fé que rege a denominação foi elaborada pela própria fundadora, a partir de sua visão do Evangelho Quadrangular. Já no capítulo subsequente o estatuto traz a data de fundação e sua localização no Brasil, destacando-se:

\footnotetext{
${ }^{458}$ QUADRANGULAR. Estatuto e regimento interno da Igreja do Evangelho Quadrangular: São Paulo: Quadrangular, 2011. p. 19.

${ }^{459}$ DUFFIELD, P. G.; CLEAVE, N. M. V., Fundamentos da teologia pentecostal. Vol. I, p. 4.

${ }^{460}$ QUADRANGULAR. Estatuto e regimento interno da Igreja do Evangelho Quadrangular, p. 19.
} 
Capítulo III - da Denominação. Artigo $3^{\circ}$ - Em 15 de novembro de 1951 no Brasil, na cidade de São João da Boa Vista, SP, os Missionários Harold Edwin Willians e Jesus Emílio Vasques Ramos fundaram a Igreja Evangélica do Brasil, que após a Convenção Nacional de 11 de janeiro de 1958, passou a denominar-se Igreja do Evangelho Quadrangular. ${ }^{461}$

Como já dito, inicialmente a IEQ não pôde ser nomeada como é hoje, por se tratar de ramo autônomo no Brasil receber sua atual ser denominada por essa nomenclatura, pois era um ramo automono no Brasil. Afinal, Harold Williams foi enviado como missionário da IEQ dos Estados Unidos à Bolívia, e não ao Brasil. Ao conhecer o peruano Emílio Vasques, funda com este a Igreja Evangélica do Brasil, que se iniciou "em uma casa na cidade de Poços de Caldas, Minas Gerais". ${ }^{62}$ Mais tarde, Harold Williams se acerta com os superiores e a denominação passa a ser Igreja do Evangelho Quadrangular.

O capítulo quatro trata da delimitação de sua natureza jurídica, fins e endereço da sede no Brasil. "Capítulo IV - Da Duração e Da Sede. Artigo 4 - A Igreja do Evangelho Quadrangular, no Brasil, entidade sem fins lucrativos e com duração por prazo indeterminado, tem a sua sede administrativa nacional na Rua Conselheiro Nébias, 1122, na cidade de São Paulo, SP" ${ }^{463}$ A igreja tem por direção seu conselho nacional, cujo presidente é "eleito pela Convenção Nacional" e a lidera". ${ }^{464}$ O quinto capítulo traça o objetivo da instituição:

Capítulo V - Dos Objetivos. Artigo $5^{\circ}$ - A Igreja do Evangelho Quadrangular tem como objetivos: I - proclamar ao mundo as mensagens de fé e de poder do Evangelho de Nosso Senhor Jesus Cristo, salientando a doutrina Quadrangular "SALVAÇÃO, BATISMO COM O ESPÍRITO SANTO, CURA DIVIVA E SEGUNDA VINDA DE CRISTO”, pugnando pela pregação, defesa e prática dos ensinamentos da Bíblia Sagrada e adotando para sua orientação a Declaração de Fé constante do Título seguinte; II - manter uma Cruzada Nacional de Evangelização para a promoção de movimentos evangelísticos de avivamento espiritual e cura divina em território brasileiro e estrangeiro, usando para tanto, tendas, salões, terrenos baldios, programas de rádio e televisão, difusão de publicações, "internet" e outros meios de comunicações disponíveis; III - promover, administrar e manter trabalhos missionários nacionais e internacionais. ${ }^{465}$

\footnotetext{
${ }^{461}$ QUADRANGULAR. Estatuto e regimento interno da Igreja do Evangelho Quadrangular, p. 20.

${ }^{462}$ BARROS, Onésimo de. Catecismo Quadrangular. São Paulo: Quadrangular, 2005. p. 75.

${ }^{463}$ QUADRANGULAR. Estatuto e regimento interno da Igreja do Evangelho Quadrangular, p. 20.

${ }^{464}$ PAULA, V. A. S, Religião e Política no Vale do Paranapanema, p. 51.

${ }^{465}$ QUADRANGULAR. Estatuto e regimento interno da Igreja do Evangelho Quadrangular, p. 20.
} 
Por princípios doutrinais a IEQ mantém a característica missional, e em seu objetivo primário sua composição passa diretamente por questões da evangelização. Assim é formada sua identidade de igreja pentecostal de cunho missionário, que se projeta visando a expansão e a difusão de sua doutrina e de princípios de fé. O título dois, capítulo único, da doutrina, assegura:

Título II - Dos Princípios Basilares. Capítulo Único - Da Doutrina. Artigo $6^{\circ}$ - A Igreja do Evangelho Quadrangular, uma Corporação interdenominacional em espírito, evangélica na mensagem, internacional no projeto, composta pela união de fiéis que se congregam para a promoção da causa do evangelismo no mundo e para a pregação do Evangelho Quadrangular do Reino de Jesus Salvador, Batizador, Médico e Rei que voltará, tem os seus fundamentos doutrinários na Bíblia Sagrada, de onde se extraiu a seguinte Declaração de Fé: ${ }^{466}$

Os quadrangulares compreendem que sua salvação está diretamente ligada à missão, e sendo salvos devem ampliar e possibilitar a salvação a outros, "por meio do testemunho pessoal". ${ }^{467}$ Assim, apresentam o assim chamado Evangelho Quadrangular, voltado para quatro direções, a partir da visão de Ezequiel que inspirou Aimee Semple McPherson. A Igreja do Evangelho Quadrangular é dirigida por sua declaração de fé, composta por 25 artigos, assim organizados:

I. As Sagradas Escrituras, II. A Divindade Eterna, III. A Queda do Homem, IV. O Plano de Redenção, V. Salvação pela Graça, VI. Arrependimento e Aceitação, VII. O Novo Nascimento, VIII. Vida Cristã Diária, IX. Batismo, X. Santa Ceia, XI. Consagração de Crianças, XII. Batismo no Espírito Santo, XIII. Vida Cheia do Espírito Santo, XIV. Os Dons do Espírito, XV. O Fruto do Espírito, XVI. Moderação, XVII. Cura Divina, VXIII. Segunda Vinda de Cristo, XIX. Relações Para com a Igreja, XX. Governo, XXI. O Juízo Final, XXII. O Céu, XXIII. O Inferno, XXIV. Evangelismo, XXV. Dízimos e Ofertas. ${ }^{468}$

Os artigos XII, XIII, XIV e XV estão diretamente associados a questões pneumatológicas. A forte presença e o cuidado com o tema do Espírito mostram claramente o teor e a prioridade conferida pelos quadrangulares à doutrina do Espírito, cuja experiência do Espírito baseia-se em sua hermenêutica dos textos bíblicos. Por isso sua declaração de fé situa no primeiro artigo sua principal declaração e exposição de sua fé - a Bíblia Sagrada:

\footnotetext{
${ }^{466}$ QUADRANGULAR. Estatuto e regimento interno da Igreja do Evangelho Quadrangular, p. 21. ${ }^{467}$ BARROS, O., Catecismo Quadrangular, p. 75.

${ }^{468}$ QUADRANGULAR. Declaração de fé da Igreja do Evangelho Quadrangular: edição especial comentada. São Paulo: Quadrangular, 2018. p. 6.
} 
I. As Sagradas Escrituras. Cremos que a Bíblia Sagrada é a Palavra do Deus Vivo; Verdadeira imutável, firme, inabalável, como o Senhor Javé; que foi escrita por santos homens do passado, conforme eram movidos pelo Espírito Santo e por Ele inspirados; que ela é uma lâmpada acesa para guiar um mundo perdido, desde as profundezas do pecado e tristeza até as elevações da honradez da glória; um espelho claro que revela a face de um Salvador crucificado; um prumo a tornar reta a vida de cada indivíduo ou comunidade; uma afiada espada de dois gumes para convencer do pecado e maldade, um forte elo de amor e ternura para levar os arrependidos a Cristo Jesus; um bálsamo, sob o sopro do Espírito Santo, que pode curar e vivificar todo o coração desfalecente; único sustentáculo verdadeiro da comunhão e unidade cristã. Apelo de amor de um Deus infinitamente amantíssimo; advertência solene, trovejar distante da tempestade e da ira e retribuição que cairá sobre os desatentos; uma seta apontada para o céu; um sinal de perigo que adverte quanto ao inferno; o divino, supremo e eterno tribunal por cujos padrões todos os homens, nações, credos e argumentos serão julgados. ${ }^{469}$

Esta pesquisa está circunscrita à missão da IEQ, compreendendo-a como diretamente associada à sua pneumatologia. Na teologia quadrangular, "o Espírito Santo batiza e enche os crentes, dando-lhes poder para servir". ${ }^{470}$ Assim se faz necessária uma investigação nos artigos de sua declaração de fé que tratam da temática do Espírito, título de quatro dos 25 artigos da denominação. $\mathrm{O}$ artigo 12, intitulado "O Batismo no Espírito Santo", assim diz:

\begin{abstract}
XII. O Batismo no Espírito Santo. Cremos que o batismo no Espírito Santo é o recebimento do prometido Consolador, em poderosa e gloriosa plenitude, a fim de revestir o crente com o poder do alto; para glorificar e exaltar o Senhor Jesus; para dar uma palavra inspirada em testemunho d'Ele; para promover o espírito de oração, santificação e sobriedade para capacitar o indivíduo e a igreja a ganhar almas de maneira eficiente, prática, alegre, cheio do Espírito; e que, sendo esta ainda a dispensação da graça, tem o crente todo o direito de esperar o seu recebimento da mesma maneira pela qual o receberam judeus e gentios igualmente, nos dias bíblicos, conforme se encontra registrado na palavra, de modo que possa ser dito de nós o que foi com respeito à casa de Cornélio; o Espírito Santo caiu sobre eles, no princípio, assim como em nós agora. ${ }^{471}$
\end{abstract}

O batismo no Espírito Santo para a IEQ é muito relevante, pois faz parte da sua liturgia cotidiana e dos cultos e da fé dos quadrangulares. No artigo em tela percebe-se que esse batismo remete ao tempo bíblico e se estende ao presente. Seu artigo 13 busca, intitulado "A Vida Cheia do Espírito Santo", mostra a importância do requerimento e de sua importância na vida do cristão:

\footnotetext{
${ }^{469}$ QUADRANGULAR. Declaração de fé da Igreja do Evangelho Quadrangular, p. 14.

${ }^{470}$ DUFFIELD, P. Guy; CLEAVE, Nathaniel. M. Van. Fundamentos da teologia pentecostal. Vol II. São Paulo: Quadrangular, 1991. p. 21.

${ }^{471}$ QUADRANGULAR. Declaração de fé da Igreja do Evangelho Quadrangular, p. 58.
} 
XIII. A Vida Cheia do Espírito Santo. Cremos que o Espírito Santo é o próprio Deus, se manifesta de maneiras diversas como um vento poderoso e veemente, como línguas de chamas vivas que podem sacudir e convulsionar comunidades inteiras para Deus. Ele é também como uma delicada pomba, facilmente ofendido e magoado pela impiedade, frieza, vãs conversações, jactância e espírito de crítica ou julgamento, bem como pensamentos e ações que desonrem o Senhor Jesus e que é, portanto, vontade de Deus que vivamos e andemos no Espírito, momento a momento, sob o precioso sangue do Cordeiro, a pisar respeitosa e suavemente na presença do Rei, sendo pacientes, amorosos, verdadeiros, sinceros de coração, não murmuradores, estando a tempo e fora de tempo servindo ao Senhor. ${ }^{472}$

A vida cheia do Espírito Santo se caracteriza pela sua manifestação na vida do crente. Assim, como destacado, a glossolalia faz parte da vida cheia do Espírito, segundo os quadrangulares: "acreditamos que a evidência inicial do batismo no Espírito Santo seja falar em outras línguas, conforme o Espírito concede". ${ }^{473}$ Segundo o mesmo artigo o Espírito Santo é o próprio Deus, que se manifesta de diversas maneiras, como vento e pomba, e o cristão deve dar devida importância à vida no Espírito: “é uma nova experiência espiritual, mediante a qual Jesus enche os cristãos com Seu poder para que Lhe sirvam e deem testemunhos". ${ }^{474}$ Executando a missão e buscando cada vez mais os dons do Espírito.

O capítulo 14 da declaração de fé dá sequência a essa seção:

XIV. Os Dons do Espírito. Cremos que o Espírito Santo tem diversos dons a conceder à igreja crente e fiel ao Senhor Jesus Cristo, e há também diversidade no Ministério e na operação dos mesmos dons como o propósito de um fim proveitoso e útil. Deus nos aconselha a que busquemos zelosamente ser portadores destes dons e que procuremos ser abundantes neles, visando a edificação da igreja. ${ }^{475}$

A formação da estrutura da declaração de fé da IEQ caminha para a construção da identidade de sua doutrina pentecostal, enfatizando fortemente o Espírito Santo. O artigo em análise exorta o crente a buscar de forma diligente os dons espirituais para o progresso da igreja e de sua própria fé. Destaca-se aqui também, tendo em vista o recorte desta pesquisa, o artigo 17 , dedicado à missão da IEQ, decorrente de sua forte ênfase nas questões do Espírito. O artigo tem por título "Cura Divina", uma das doutrinas cardeais da IEQ e um de seus pilares de prática missionária:

\footnotetext{
${ }^{472}$ QUADRANGULAR. Delcaração de fé da Igreja do Evangelho Quadrangular, p. 62.

${ }^{473}$ DUFFIELD, P. G.; CLEAVE, N. M. V. Fundamentos da teologia pentecostal. Vol II, p. 80.

${ }^{474}$ BARROS, O., Catecismo Quadrangular, p. 28.

${ }^{475}$ QUADRANGULAR. Declaração de fé da Igreja do Evangelho Quadrangular, p. 66.
} 
XVII. Cura Divina. Cremos que a cura divina é uma manifestação do poder do Senhor Jesus Cristo para curar os enfermos e os aflitos, em resposta à oração sincera que Ele, sendo o mesmo ontem, hoje e para sempre, jamais mudou, mas é, ainda, um auxílio plenamente suficiente na hora da dor, capaz de saciar as necessidades, vivificar o corpo, a alma e o espírito a uma novidade de vida em resposta à fé daqueles que oram com submissão à Sua vontade divina e soberana. ${ }^{476}$

Perceber-se na atuação missionária da IEQ a cura divina como parte indissociável de sua concepção e ação do Espírito. Assim, cinco artigos da declaração de fé da IEQ debruçam-se sobre questões pneumatológicas, sendo a cura divina o principal diferencial que a IEQ traz ao movimento pentecostal brasileiro.

A Igreja do Evangelho Quadrangular brasileira é independente da Quadrangular dos Estados Unidos, mas até a década de 1980 a presidência da IEQ no Brasil era indicada e nomeada pela Igreja Internacional do Evangelho Quadrangular. Somente a partir do final dos anos 1980 é que a IEQ no Brasil passar a ter na liderança presidentes brasileiros: “em 1988 a Convenção elegeu o presidente de acordo com a nova regra estatutária, o Pr. Eduardo Zdrojewsky". ${ }^{477}$ Conserva-se, porém, a doutrina perante a Igreja Internacional do Evangelho Quadrangular, como se destaca no estatuto:

Título III - Das Relações com a Igreja Internacional. Capítulo I. Do Relacionamento Diplomático. Artigo $7^{\circ}$ - A Igreja do Evangelho Quadrangular, no Brasil, mantém relações diplomáticas de natureza amistosa com a Igreja Internacional do Evangelho Quadrangular - "International Church of Foursquare Gospel" -, com o objetivo de conservar a originalidade e a unidade internacional da doutrina. ${ }^{478}$

Nos últimos anos a IEQ brasileira passou a ser presidida por brasileiros, sem interferência da sede mundial de Los Angeles, mantendo, no entanto, a visão do Evangelho Quadrangular e suas doutrinas cardeais, além da declaração de fé. Ainda na época em que a Quadrangular no Brasil era presidida pelos estadunidenses, diversos materiais de conteúdo ligado à doutrina quadrangular foram traduzidos do inglês, no esforço de assegurar a fidelidade aos mesmos princípios: "ela é indivisível, e temos de preservar isto, ela é uma só em todo o

\footnotetext{
${ }^{476}$ QUADRANUGLAR. Declaração de fé da Igreja do Evangelho Quadrangular, p. 78.

477 IGREJA DO EVANGELHO QUADRANGULAR. Uma Igreja em 60 Anos: igreja do Evangelho Quadrangular em fotos. São Paulo, 2011. p. 88.

${ }^{478}$ QUADRANGULAR. Estatuto e regimento interno da Igreja do Evangelho Quadrangular, p. 44.
} 
mundo. Cada país tem sua autonomia". ${ }^{479} \mathrm{O}$ que muda nessa relação é a liderança e os vínculos com Los Angeles, sede mundial. No título 6 a IEQ brasileira destaca seu compromisso para com seus deveres no Brasil:

Título IV Das Responsabilidades Político-Sociais. Capítulo I - Da Igreja Diante do Homem. Artigo 10 - A Igreja do Evangelho Quadrangular reconhece como sua tarefa docente capacitar os membros de suas congregações para o exercício da cidadania. Parágrafo Único - O propósito primordial dessa missão é servir ao Brasil, através da participação ativa do povo Quadrangular, na formação de uma sociedade consciente de suas responsabilidades. ${ }^{480}$

Já na continuidade da sua estruturação como instituição, o artigo 15 do capítulo único do Título 5 - dos Elementos Fundamentais - formaliza os princípios regimentais que conduzem a Igreja do Evangelho Quadrangular no Brasil:

Título V Dos Elementos Fundamentais. Capítulo Único - Dos Vínculos. Artigo 15 - A Igreja do Evangelho Quadrangular, na forma deste diploma estatutário, reconhece e aprova como elementos básicos e fundamentais à sua unidade e caracterização os seguintes vínculos: I - a doutrina original do Evangelho Quadrangular, nos moldes da "Internacional Church of the Foursquare Gospel"; II - a declaração de Fé, na forma do artigo $6^{\circ}$ deste Estatuto; III - a forma de governo episcopal e o sistema representativo. ${ }^{481}$

Dos três pilares que sustentam essa organização, o primeiro é a manutenção da doutrina original, de acordo com a Igreja Internacional; o segundo é a sua declaração de fé; e por último, sua forma de governo representada no sistema episcopal. Mas a consulta ao estatuto da IEQ revela também os pré-requisitos para ingresso dos seus membros:

Título VI Dos Membros da Corporação. Capítulo I - Da Admissão. Artigo 16 - A Igreja do Evangelho Quadrangular pode aceitar como membro aquele que: I aceitar o Senhor Jesus Cristo como seu Salvador pessoal; II - confessar arrependimento de seus pecados, mostrando evidências de possuir genuína experiência de novo nascimento; III - ser batizado nas águas, por imersão, em nome do Pai, do Filho e do Espírito Santo; IV - aceitar e viver as doutrinas, regulamentos e tradições da Igreja; e V - solicitar o seu registro no livro da igreja. ${ }^{482}$

\footnotetext{
479 JESUS. Marli de. Onésimo de Barros: série memórias quadrangular. São Paulo: Editora Quadrangular. 2003. p. 116.

${ }^{480}$ QUADRANGULAR. Estatuto e regimento interno da Igreja do Evangelho Quadrangular, p. 45. ${ }^{481}$ QUADRANGULAR. Estatuto e regimento interno da Igreja do Evangelho Quadrangular, p. 47. ${ }^{482}$ QUADRANGULAR. Estatuto e regimento interno da Igreja do Evangelho Quadrangular, p. 48.
} 
Nesse aspecto a IEQ não difere muito de outras denominações protestantes, com regras mínimas a ser aceitas e praticadas pelos adeptos, como as ordenanças: "O batismo com água e a Ceia do Senhor". 483

O capítulo 1 do título 7 - Do Ministério - subdivide o campo ministerial ou sacerdotal em três categorias eclesiásticas:

Título VII Do Ministério. Capítulo I - Da Composição. Artigo 23 - O Ministério da Igreja do Evangelho Quadrangular, no Brasil, é composto por três categorias eclesiásticas: Ministros, Aspirantes e Obreiros Credenciados, estes últimos quando nomeados pelo Conselho Nacional de Diretores como Pastores titulares. ${ }^{484}$

Como se observa, há uma hierarquia, que na ordem crescente se estabelece da seguinte forma: obreiros credenciados, aspirantes e ministros. Este último é o grau maior na hierarquia eclesiástica na IEQ. O caminho inicial no sacerdócio quadrangular é o obreiro credenciado, que basicamente passa pelo ITQ (Instituto Teológico Quadrangular) em um curso fundamental de teologia e por uma convenção, e é apresentado diante da comunidade eclesiástica e ministerial. Depois de alguns anos, no exercício e direção de uma igreja ou congregação local, o obreiro pode passar a aspirante, e depois de anos na direção de uma igreja local, pode se tornar ministro. Essas promoções, bem como as eleições dos conselhos estaduais de diretores e do conselho nacional de diretores, órgão máximo na organização da IEQ, acontecem também nas chamadas convenções. A convenção nacional, que trata da direção e dos projetos de nível nacional, é anual: “título VIII Das Convenções. Capítulo I - Das Realizações das Convenções. Artigo 45 - A Igreja do Evangelho Quadrangular realiza, periodicamente, convenções Nacionais e Estaduais, em caráter ordinário e extraordinário". ${ }^{485}$ Nessas convenções unificase a visão quadrangular e se reafirma sua estrutura institucional.

A Igreja do Evangelho Quadrangular, como instituição eclesiástica, foi descrita até aqui, existindo, no entanto, muita dúvida sobre o termo que origina a denominação. McPherson mesmo questiona: “o que é o Evangelho Quadrangular? Apesar do crescimento notável, porém, a pergunta continua: o que é o Evangelho Quadrangular? Algumas vezes, as pessoas indagam: ‘o que vocês querem dizer

\footnotetext{
${ }^{483}$ BARROS, O., Catecismo Quadrangular, p. 35.

${ }^{484}$ QUADRANGULAR. Estatuto e regimento interno da Igreja do Evangelho Quadrangular, p. 50.

${ }^{485}$ QUADRANGULAR. Estatuto e regimento interno da Igreja do Evangelho Quadrangular, p. 62.
} 
com Quadrangular'?”. ${ }^{486}$ Esse termo não é de simples assimilação, mas é assim explicado por Barros: “originou-se pela inspiração de Deus para a irmã Aimée Semple MacPherson em 1922", ${ }^{487}$ Ou seja, o termo surge a partir da interpretação de Aimee Semple McPherson, fundadora da IEQ, da visão do profeta Ezequiel, no primeiro capítulo do seu livro. Porém McPherson informa:

Origem da expressão 'Evangelho Quadrangular'. A Expressão 'Evangelho Quadrangular' teve origem no reconhecimento de Jesus Cristo como resposta a toda necessidade humana. A irmã McPherson havia proclamado esta mensagem durante cerca de quatorze anos, quando, repentinamente, descobriu o termo "quadrangular" para descrever este evangelho! ${ }^{488}$

A interpretação da fundadora da IEQ não fica retida na sua visão inicial a partir de Ezequiel, mas vai além, associando-a ao ministério terreno de Jesus Cristo e compreendendo que essa seria a forma de apresentar um evangelho completo: “a inspiração veio em Oakland, Califórnia, em fins de julho de 1922, durante sua última campanha de re-avivamento nos Estados Unidos, antes da inauguração do Templo Angelus em Los Angeles, no Dia de Ano Novo (os meses intermediários foram gastos na evangelização na Austrália.)". ${ }^{489}$ Ela já difundia esse tipo de evangelho, que chama de evangelho completo, já que olha em todas as direções, mas esse dia específico marcou o inicio do termo Quadrangular. Em uma de suas campanhas de reavivamento e perante pessoas de denominações diversas é que ela recebeu o entendimento desse termo, como relata: "uma congregação transbordante enchera a grande tenda. Na plataforma, estavam sentados os pastores principais, representando as Igrejas Episcopal, Presbiteriana, Batista, Congregacional, Metodista, Nazarena, Exército da Salvação, Aliança Missionária Cristã e Pentecostal" ${ }^{490}$ Chama atenção a representação denominacional diversa presente no momento da verbalização do termo Quadrangular, entrevendo-se a possibilidade de alguma unidade e diálogo. Cox refere: "a evangelista, talvez, jamais tivesse falado a uma audiência mais atenta. $\mathrm{O}$ assunto-tema foi 'A Visão de Ezequiel”. ${ }^{491}$

\footnotetext{
${ }^{486}$ COX, R. L. O evangelho quadrangular: a visão de Aimee Semple McPherson. São Paulo: Quadrangular, 1991.p. 12.

${ }^{487}$ BARROS, O., Catecismo Quadrangular, p. 76.

${ }^{488}$ COX, R. L., O evangelho quadrangular, p. 12, p. 13.

${ }^{489}$ COX, R. L., O evangelho quadrangular, p. 13.

${ }^{490}$ COX, R. L., O evangelho quadrangular, p. 13.

${ }^{491}$ COX, R. L., O evangelho quadrangular, p. 13.
} 
A revelação do texto exposta naquela noite leva Aimee a mergulhar em uma dimensão espiritual durante seu envolvimento com o descrito no texto do livro do profeta Ezequiel, em seu primeiro capítulo. McPherson assegura: "nas nuvens do céu - que se enrolavam e desenrolavam em flamejante glória - Ezequiel contemplara o Ser, cuja glória nenhum mortal pode descrever. Enquanto olhava fixamente para aquela revelação maravilhosa do Onipotente, percebeu quatro rostos. Os rostos de homem, de leão, de boi e de águia". ${ }^{492}$ Diretamente ela faz uma associação a partir de sua hermenêutica, contextualizando a visão do profeta Ezequiel no ministério de Jesus Cristo e dividindo-o em quatro facetas, como sintetiza Paula: "esse simbolismo é complementado com a associação das qualidades principais de Cristo às mensagens centrais contidas nos Evangelhos". ${ }^{493}$ Assim, Aimee estrutura sua visão daquilo que viria a ser o Evangelho Quadrangular, de acordo com Cox: "estes quatro rostos foram comparados, por nós, às quatro fases do evangelho de Jesus Cristo". ${ }^{994} \mathrm{~A}$ fundadora acrescenta então sua interpretação da visão do profeta, com essência missionária voltada às questões pnematológicas e a elementos do pentecostalismo:

No rosto do Homem, contemplamos o Homem de Dores que sabe o que é padecer, morrendo na cruz. No rosto do Leão, contemplamos Aquele que batiza com o Espírito Santo e com fogo. O rosto do Boi tipifica o grande Carregador de Fardos, que levou sobre si as nossas enfermidades e as nossas dores, que, em seu amor ilimitado e provisão divina, suprirá cada uma de nossas necessidades. No rosto da Águia, vimos refletidas as visões arrebatadoras do Rei que virá, cujas asas em breve abririam caminho nos céus brilhantes, cuja voz límpida faria ecoar a Via Láctea, quando viesse arrebatar a sua noiva. ${ }^{495}$

A partir desse momento a visão recebe uma tipificação do ministério do Cristo, e nasce a base das quatro doutrinas norteadoras do Evangelho Quadrangular, "nos quatro evangelhos", ${ }^{496}$ mostrando a salvação ofertada por Cristo na cruz, o batismo no Espírito Santo, a cura oferecida por Ele e sua segunda vinda. McPherson assegura: "um evangelho perfeito. Um evangelho completo para o corpo, a alma, o espírito e a eternidade. Um evangelho que olha diretamente em todas as direções". ${ }^{497}$ É importante lembrar que tudo isso acontece

\footnotetext{
${ }^{492}$ COX, R. L., O evangelho quadrangular, p. 13-14.

${ }^{493}$ PAULA, V. A. S., Religião e Política no Vale do Paranapanema, p. 58.

${ }^{494}$ COX, R. L., O evangelho quadrangular, p. 14.

${ }^{495}$ COX, R. L., O evangelho quadrangular, p. 14.

${ }^{496}$ BARROS, O., Catecismo Quadrangular, p. 76.

${ }^{497}$ COX, R. L., O evangelho quadrangular, p. 14.
} 
durante uma campanha de reavivamento em um tenda lotada, num momento descrito por McPherson:

A tenda inteira foi envolvida, estremecendo! Era como se cada alma entrasse em harmonia com a música celestial. Fiquei ali, quieta e atenta, agarrando o púlpito, tremendo de espanto e alegria, depois exclamei: 'Olhe, olhe, é o E-v-a-n-g-e-l-h-o Q-u-a-d-r-a-n-g-u-l-a-r!' As palavras explodiram do meu coração incandescente. ${ }^{498}$

A base da doutrina quadrangular, como a maioria das denominações cristãs, alicerça-se na Bíblia, como reforça Barros: "é a mensagem de Deus aos homens". ${ }^{499}$ McPherson lembra: "O Evangelho Quadrangular nas Sagradas Escrituras. A Bíblia é, sem sombra de dúvida, o ponto de partida e de apoio de todo ensinamento doutrinário da Igreja do Evangelho Quadrangular". 500 Compreendendo a importância desse fundamento, a IEQ afirma a autoridade do texto bíblico sem variação, totalmente inspirado e revelado por Deus: “a Bíblia é a palavra de Deus e a IEQ em todo o mundo se mantém inflexível quanto a isso e quanto à sua absoluta e inegável autoridade". ${ }^{501}$ Assumindo essa verdade, a IEQ esforça-se em examinar o termo Quadrangular na Bíblia com o propósito de melhor estabelecer a visão, sobre a palavra "quadrangular". Como explica Scotti, "Quadrangular" (ou "quadrado") é uma palavra associada "a elementos que representam a aproximação, a aceitação e a adoração do Deus Todo-Poderoso por parte do homem pecador! Além disso, ela é pronunciada pela própria voz de Javé!". ${ }^{502} \mathrm{Na}$ sua pesquisa inicial, os quadrangulares concluíram que, geralmente, onde essa palavra é mencionada, ela está relacionada de alguma maneira à adoração ou ao próximo. Basicamente o seu emprego teve relação com o serviço e com a formalização das construções voltadas à adoração a Deus ou ao seu serviço, o que se percebe em passagens do Antigo Testamento. McPherson destaca:

As três ocasiões seguintes, onde aparece esse vocábulo, referem-se à maneira como os obreiros obedeceram às instruções divinas e fizeram os dois altares e o peitoral quadrados. As referências são dadas a seguir: Êxodo 27.1 cita as instruções de Deus relativas ao altar do sacrifício, que ficaria na entrada do pátio do tabernáculo: "Farás também o altar de madeira de acácia: de cinco côvados será o seu comprimento, e de cinco a largura, será quadrado o altar, e de três côvados a

\footnotetext{
${ }^{498}$ COX, R. L., O evangelho quadrangular, p. 14.

${ }^{499}$ BARROS, O., Catecismo Quadrangular, p. 7.

500 SCOTTI, Ignez Terezinha. Evangelho quadrangular: teologia confessional. Curitiba: SGEC, 2010. p. 17.

${ }^{501}$ SCOTTI, I. T., O evangelho quadrangular, p. 17.

502 SCOTTI, I. T., O evangelho quadrangular, p. 18.
} 
altura". Êxodo 28.16 transmitiu a Moisés as instruções divinas, referentes ao peitoral do sumo sacerdote: "Quadrado e duplo, será de um palmo o seu comprimento, e de um palmo a sua largura". Êxodo 30.1-2 dá as ordens de Deus sobre o altar de incenso de ouro, que ficaria diante do véu, o qual se achava dentro do lugar santo do tabernáculo, para separar o Santo dos santos: "Farás também um altar para queimares nele o incenso; de madeira de acácia o farás. Terá um côvado de comprimento, e um de largura, será quadrado, e dois de alto; os chifres formarão uma só peça com ele. ${ }^{503}$

Essas passagens bíblicas determinam as normas para a edificação de um cenário de adoração, podendo-se construir uma teologia que parte desses princípios. Segundo a concepção quadrangular, traduzida por Duffield e Cleave, a palavra sagrada "é uma narrativa dos esforços de Deus para revelar-se ao homem". ${ }^{504}$ Diante disso a IEQ busca fundamentar sua tese, associando o significado das palavras "quadrangular" ou "quadrado" na Bíblia à sua teologia. E faz uma explanação desse vocábulo, que consolida as bases do Evangelho Quadrangular, identificando o termo à escritura sagrada e contextualizando-o na mensagem quadrangular, como observa Cox:

\begin{abstract}
O Senhor, a seguir, indicou e ungiu um homem, chamado Bezalel, para cuidar da construção do tabernáculo e seus acessórios. Com quanta fidelidade Bezalel e seus ajudantes executaram as ordens de Deus, com respeito à forma dos altares e peitoral, está documentado nas passagens seguintes. Êxodo 38.1 descreve o altar do sacrifício: "Fez também o altar do holocausto de madeira de acácia; de cinco côvados era o comprimento, e de cinco a largura, era quadrado o altar, e de três côvados a altura". Exodo 28.1 descreve o peitoral: "Era quadrado; duplo fizeram o peitoral: de um palmo o seu comprimento, e de um palmo dobrado a sua largura". Êxodo 37.25 registra como Bezalel "fez de madeira de acácia o altar de incenso; tinha um côvado de comprimento, e um de largura, era quadrado, e dois de altura; os chifres formavam uma só peça com ele. ${ }^{505}$
\end{abstract}

Mais uma vez é notável que o surgimento da palavra passe diretamente por detalhes concernentes ao serviço e à adoração, e é exatamente nesses detalhes que se configura a força do emprego do termo. Mesmo se tratando de uma palavra que aparece poucas vezes nos textos bíblicos, os quadrangulares não dispensam sua importância, mostrando que muitas vezes o termo vinha diretamente da orientação do Senhor, como, por exemplo, nos pormenores das confecções e construções que tinham por delimitação a forma quadrada. Essas orientações vinham diretamente de Deus, o que leva a uma reflexão importante sobre essa palavra para os quadrangulares. McPherson continua:

\footnotetext{
${ }^{503}$ COX, R. L., O evangelho quadrangular, p. 15-16.

${ }^{504}$ DUFFIELD, P. G.; CLEAVE, N. M. V. Fundamentos da teologia pentecostal. Vol I, p. 2.

${ }^{505}$ COX, R. L., O evangelho quadrangular, p. 16.
} 
O altar do holocausto simbolizava, no Antigo Testamento, aquele altar final, a cruz de Cristo, onde Jesus ofereceu um único sacrifício pelo pecado, para sempre. O altar de ouro do incenso e o peitoral do sumo sacerdote estão ligados à intercessão pela qual o homem se aproxima de Deus. E agora, desde que o véu do templo se rasgou de alto a baixo como resultado do Calvário, todo crente - e não apenas um sacerdócio hereditário - está convidado: “Achemo-nos, portanto, confiadamente, junto ao trono da graça, a fim de recebermos misericórdia e acharmos graça para socorro em ocasião oportuna" $(\mathrm{Hb} 4.16) .{ }^{506}$

O termo quadrangular não se restringe ao Antigo Testamento, o que, segundo Barros, conduz a uma interpretação da adoração e do sacrifício, de acordo com a teologia quadrangular: "porque Ele veio redimir a humanidade". 507 Cristo, na cruz, assume toda a forma representativa do Antigo Testamento, logo, todos os componentes da estrutura da adoração do Antigo Testamento apontavam para o Cristo. Cox continua a enumeração:

Essa palavra aparece mais quatro vezes na Bíblia. I Reis 7.31 descreve detalhes do templo de Salomão como "quadrados, não redondos". Este templo substituiu, naturalmente, o tabernáculo como centro de adoração de Israel. De qualquer maneira, as Escrituras declaram, especificamente, que o átrio deste santuário terá esta forma: "Ele mediu o átrio: comprimento cem côvados, largura cem côvados, um quadrado; o altar estava diante do templo" (Ez. 40.47). Além do mais, a oferta santa a ser oferecida neste templo é dita como sendo do mesmo tipo: "Toda a oferta será de vinte e cinco mil canas com mais de vinte e cinco mil; em quadrado oferecereis a santa oferta, com a possessão da cidade" (Ez. 48.20, IBB). A última ocorrência dessa palavra é encontrada na penúltima página de quase todas as Bíblias. Com respeito à Nova Jerusalém, João declara: "A cidade é quadrangular, de comprimento e largura iguais. E mediu a cidade com a vara até doze mil estádios. O seu comprimento, largura e altura são iguais" (Ap. 21.16). Temos aqui o antítipo do Santo dos santos, do tabernáculo e dos templos que haviam sido também quadrados, com o comprimento, a largura e a altura iguais. ${ }^{508}$

Por último, a palavra "quadrangular" aparece na descrição da nova Jerusalém, que trata da esperança e da redenção do homem. Por isso a formação da doutrina quadrangular presume o aprofundamento dos estudos do termo. McPherson conclui: "em cada uma das dez referências bíblicas contendo a palavra quadrado, este termo é aplicado a elementos que representam a redenção do homem pela adoração a Deus e a aceitação da parte dele". ${ }^{509}$ Por se tratar de

\footnotetext{
${ }^{506}$ COX, R. L., O evangelho quadrangular, p. 16.

${ }^{507}$ BARROS, O., Catecismo Quadrangular, p. 21.

${ }^{508}$ COX, R. L., O evangelho quadrangular, p. 17.

${ }^{509}$ COX, R. L., O evangelho quadrangular, p. 17.
} 
denominação de cunho pentecostal e missionária, a aplicação dos detalhes bíblicos é muito relevante para o conceito de Evangelho Quadrangular.

Primeira doutrina cardeal: Jesus Cristo, o Salvador.

Os quatro pilares da IEQ são Jesus Cristo, O Salvador; Jesus Cristo, Aquele que Batiza; Jesus Cristo, Aquele que Cura; e Jesus Cristo, O Rei que Virá.

O primeiro desses pilares, a soteriologia quadrangular, apresenta Cristo como aquele que salva, tendo vindo com essa missão, tornando-se o mediador, ou seja, nas palavras de Duffield e Cleave, "o ponto nevrálgico do plano da salvação". ${ }^{510}$ Essa é a primeira e essencial fase do ministério de Jesus Cristo, que possibilita a vida a todos. É McPherson quem afirma:

\begin{abstract}
A primeira e principal fase do Evangelho Quadrangular é, portanto, Jesus Cristo, o Salvador, o único Salvador oferecendo qualquer esperança legítima para a humanidade perdida. "E não há salvação em nenhum outro", proclamou o apóstolo Pedro, "porque abaixo do céu não existe nenhum outro nome, dado entre os homens, pelo qual importa que sejamos salvos" (At 4.12). Cristo anunciou uma reivindicação idêntica e exclusiva ao afirmar: "Eu sou o caminho, e a verdade, e a vida; ninguém vem ao Pai senão por mim" (Jo 14.6). Alguns dias antes, Ele dissera: "Eu sou a porta das ovelhas" (Jo 10.7). Eu sou a porta. Se alguém entrar por mim, será salvo" (Jo 10.9). "O que não entra pela porta no aprisco das ovelhas, mas sobe por outra parte, esse é ladrão e salteador" (Jo 10.1). Jesus Cristo é o único Salvador e a salvação representa o maior projeto iniciado por Deus. ${ }^{511}$
\end{abstract}

Jesus tipificado no rosto de homem

Nessa primeira doutrina cardeal da Igreja do Evangelho Quadrangular, Jesus Cristo é representado, na visão do profeta Ezequiel, num rosto de homem, tipificando aquele que se assemelha ao homem, vivendo de forma humana e assumindo essa postura. Scotti diz:

Na descrição dos seres vistos por Ezequiel e descritos no primeiro capítulo de seu livro encontramos, em primeiro lugar, o rosto de homem, o qual simboliza Jesus como Salvador. Isso porque Cristo teve de deixar Sua glória e se manifestar em carne, como homem, para poder cumprir o plano de Deus. ${ }^{512}$

A aceitação da vida de homem por parte de Jesus revela um Deus humano que ama e sofre com os seus, participando de sua vida. Scotti continua:

\footnotetext{
${ }^{510}$ DUFFIELD, P. G.; CLEAVE, N. M. V. Fundamentos da teologia pentecostal, vol. I, p. 240.

${ }^{511}$ COX, R. L., O evangelho quadrangular, p. 72-73.

${ }^{512}$ SCOTTI, I. T., Evangelho quadrangular, p. 58.
} 
A salvação só foi possível por meio do milagre da concepção virginal pelo Espírito Santo. Ao nascer, Jesus assumiu a forma humana e passou a viver de acordo com essa segunda face de sua dupla natureza, com o propósito de viver debaixo das mesmas fraquezas que o homem e sendo tentado em tudo, porém, sem pecar. O Jesus divino possuía o poder de vencer as tentações, mas não era capaz de salvar a humanidade. Apenas o Jesus humano podia fazê-lo, pois era preciso que Ele sofresse as tentações e as vencesse para tornar-se o Cordeiro imaculado do sacrifício. ${ }^{513}$

Pelo sacrifício e pela vida terrena de Cristo, a salvação tornou-se possível à humanidade perdida em pecado, pois somente o sangue poderia pagar o preço da libertação do perdão. Um diferencial, segundo Duffield e Cleave: "o cristianismo difere de todas as outras religiões no que diz respeito à morte de seu fundador". ${ }^{514}$ Por isso, a IEQ entende que o rosto de homem na visão de Ezequiel apresenta Jesus como salvador, pois ele viveu e padeceu como homem para salvar o homem. Scotti frisa: "no brasão da Igreja do Evangelho Quadrangular, o Rosto de Homem aparece na parte superior e com os voltados para cima, em direção ao céu" ${ }^{515}$ mostrando que a salvação só pode vir do céu, da parte de Deus. A teologia da Quadrangular entende que cada um dos quatro evangelhos encaixa-se no Evangelho Quadrangular. Nessa primeira doutrina cardeal o evangelho que representa a salvação vinda do Cristo é o de Lucas. Scotti assegura:

Cada um dos quatro evangelhos apresenta Jesus sob um determinado aspecto. Lucas fala do Filho do Homem, cujo ministério era voltado para a salvação. Essa expressão aparece 19 vezes nesse livro, o qual apresenta a história de Jesus sob um ponto de vista, em certos momentos, diferente dos demais evangelhos. ${ }^{516}$

Segundo a teologia quadrangular, o Evangelho de Lucas apresenta um Jesus humano e está voltado para a salvação, fazendo uso desse termo diversas vezes. Revela também o seu destinatário, pois o povo grego buscava o homem perfeito. Assim, Lucas apresenta Jesus como o único capaz de salvar a humanidade. Scotti continua:

O ideal grego era poder alcançar o "homem perfeito" em seu intelecto e em seu físico. Para eles, a educação era a coisa mais importante, por meio da qual procuravam atingir a perfeição. Lucas entendeu essa faceta do povo grego e aproveitava para mostrar-lhe sua visão a respeito de Jesus, apresentando-o como o

\footnotetext{
${ }^{513}$ SCOTTI, I. T., Evangelho quadrangular, p. 58.

${ }^{514}$ DUFFIELD, P. G.; CLEAVE, N. M. V. Fundamentos da teologia pentecostal, vol. I, p. 242.

${ }^{515}$ SCOTTI, I. T., Evangelho quadrangular, p. 58.

${ }^{516}$ SCOTTI, I. T., Evangelho quadrangular, p. 58.
} 


\begin{abstract}
"Homem Divino", o único ser humano perfeito e capaz de salvar a humanidade. "E crescia Jesus em sabedoria em sabedoria, e em estatura, e em graça para com Deus e os homens" (Lc 2.52). O fato de Jesus ser filho de Deus não o impediu de crescer como qualquer ser humano. Registra a visita de Jesus a Jerusalém (Lc 2.49) Sua intenção era mostrar o conhecimento de Cristo a respeito de Sua missão desde a infância. Com doze anos, Jesus já sabia o porquê de estar na terra e mostrava sua responsabilidade em aplicar-se no estudo das Escrituras e na obediência ao Pai. A Bíblia descreve a natureza humana de Jesus de forma clara, principalmente, nos evangelhos. Jesus viveu na terra como homem para poder sentir as mesmas coisas sentidas pelo ser humano a fim de, não apenas servir como sacrifício vivo em nosso favor, mas compreender nossas fraquezas e poder ser nosso intercessor junto ao Pai. Ele não padeceu somente na cruz, mas em muitos outros momentos que viveu em carne. Cristo foi humilhado, rejeitado, maltratado das piores formas, mas suportou tudo por amor à humanidade..$^{517}$
\end{abstract}

Uma característica do evangelho de Lucas é que ele mostra Jesus crescendo de forma natural entre os homens, evidenciando sua forma humana. A salvação parte de um homem, quando Cristo cumpre sua missão vivendo na sua humanidade. O evangelho quadrangular também se compõe de elementos simbólicos representativos de cada fase do ministério de Jesus Cristo. Na primeira doutrina a simbologia é representada pela cruz. McPherson diz: "a cruz representa o emblema mais eloquente possível para proclamar que Jesus Cristo é o único Salvador". 518

A primeira doutrina quadrangular tem por cor representativa o vermelho, figurando simbolicamente na bandeira da denominação. Cox explica: "o vermelho tipifica o sangue de Jesus, derramado para salvar os pecadores". ${ }^{519}$ Em síntese, essa primeira doutrina cardeal compõe-se do seguinte conjunto: Jesus Cristo, o Salvador, representado na visão do profeta Ezequiel no rosto de homem, tendo por base o Evangelho de Lucas, e o símbolo da cruz é apresentado na bandeira quadrangular na cor vermelha.

A segunda doutrina cardeal: Jesus Cristo, aquele que batiza

A segunda doutrina quadrangular está em consonância com a visão mostrada em Ezequiel 1:10 - o segundo rosto visto por ele foi o de leão. A teologia quadrangular associa o rosto de leão ao ministério de Jesus Cristo, aquele que batiza com o Espírito Santo. Segundo os quadrangulares, o rosto de leão representa o batismo no Espírito Santo, como informa Scotti: "o segundo rosto visto por Ezequiel foi o de um leão, o qual tipifica Jesus Cristo como Aquele que

\footnotetext{
${ }^{517}$ SCOTTI, I. T., Evangelho quadrangular, p. 59-60.

${ }^{518}$ COX, R. L., O evangelho quadrangular, p. 229.

${ }^{519}$ COX, R. L., O evangelho quadrangular p. 231.
} 
batiza com o Espírito Santo". 520 O desenvolvimento da segunda doutrina quadrangular trata de sua pneumatologia, também diretamente tipificada no ministério de Jesus Cristo. É Cox quem esclarece:

Ao aproximar-se o momento de sua ascensão, Jesus reiterou a iminência da entrada no seu ministério de batismo, como João proclamara. Além disto, Ele ordenou aos discípulos que não só esperassem, mas também procurassem esta experiência: "Eis que envio sobre vós a promessa de meu Pai; permanecei, pois na cidade, até que do alto sejais revestidos de poder" (Lc 24.49). Marcos cita Cristo, dando ordem a seus seguidores: "Estes sinais hão de acompanhar aqueles que creem: em meu nome... falarão novas línguas" (Mc 16.17), enquanto Atos 1.4-9 nos leva até o momento exato da ascensão e registra, como as últimas palavras de Jesus, uma referência a este batismo: "E, comendo com eles, (Jesus) determinou-lhes que não se ausentassem de Jerusalém, mas esperassem a promessa do Pai, a qual, disse ele, de mim ouviste. Porque João, na verdade, batizou com água, mas vós sereis batizados com o Espírito Santo, não muito depois destes dias. Então os que estavam reunidos lhe perguntavam: Senhor, será este o tempo em que restaures o reino a Israel? Respondeu-lhes: Não vos compete conhecer tempos ou épocas que o Pai reservou para sua exclusiva autoridade; mas recebereis poder, ao descer sobre vós o Espírito Santo, e sereis minhas testemunhas tanto em Jerusalém, como em toda a Judéia e Samaria, e até aos confins da terra. Ditas estas palavras, foi Jesus elevado às alturas, à vista deles, e uma nuvem o encobriu dos seus olhos. ${ }^{521}$

A manifestação do Espírito é promessa indissociável do evangelho de Cristo. Ele é quem prepara o caminho e afirma essa promessa, como explana Duffield e Cleave: "a igreja não depende da presença física do Senhor para ser guiada por Ele. Tal orientação é feita pelo Espírito Santo". ${ }^{522}$ Como denominação pentecostal, a Igreja do Evangelho Quadrangular estrutura sua doutrina sobre essa plataforma e desenvolve profundamente essa prática. Cox lembra: "as últimas palavras de Jesus, portanto, combinaram a promessa de poder com o propósito do poder". ${ }^{523}$ Ao afirmar a importância dessa delimitação do evento da ascensão do Cristo, Cox prioriza o ministério de Jesus em reafirmar a promessa do Espírito Santo, o que a Quadrangular destaca como um dos quatro pilares de sua doutrina. O Evangelho de João representa Jesus Cristo como Filho de Deus, como afirma Scotti: "o Evangelho de João apresenta Jesus Cristo como Filho de Deus (João $1.34 ; 3.18 ; 5.25 ; 9.35 ; 20.31$; etc.). Em vários outros versículos, você encontrará essa apresentação de Jesus, pois o apóstolo João testificou inúmeras vezes que ele

\footnotetext{
${ }^{520}$ SCOTTI, I. T., Evangelho quadrangular, p. 71.

${ }^{521}$ COX, R. L., O evangelho quadrangular, p. 94-95.

${ }_{522}$ DUFFIELD, P. G.; CLEAVE, N. M. V. Fundamentos da teologia pentecostal. Vol II, p. 13.

${ }^{523}$ COX, R. L., O evangelho quadrangular, p. 95.
} 
é, verdadeiramente, o filho de Deus". ${ }^{524}$ Logo, na teologia quadrangular, esse evangelho apresenta a ligação e a intimidade profunda de Jesus com o Pai. Assim, o Evangelho segundo João compõe a doutrina pneumatológica da Igreja do Evangelho Quadrangular. Scotti expõe:

\begin{abstract}
Vejamos alguns aspectos importantes a respeito do Deus Filho apresentado em João. Ele era o "verbo" (Jo 1.1) - O que você pode aprender com essa afirmação é a de que Jesus não apenas fala ou expressa o que Deus quer que seja dito, mas Ele é a própria expressão da Palavra de Deus. O verbo é o elemento da frase que indica a ação do sujeito e, portanto, Jesus é a ação do Pai em todas as coisas, pois "estava com Deus" desde o início de toda a criação. Identidade (Jo 14.7-11; 19-20) - Jesus identifica-se com o Pai nesses versículos. Ele diz que está no Pai e o Pai está n'Ele, como está em nós. Cristo é um com Deus (Jo 10.30; 17.22). Eles são uma só pessoa, apesar de serem três (juntamente com o Espírito Santo). Esse é o maravilhoso milagre da trindade. O evangelho de João difere dos Evangelhos de Mateus, Marcos e Lucas, os quais são considerados missionários e tratam do ministério de Cristo sob a ótica de Sua história, ensinamentos, milagres, entre outras coisas. João aborda esse mesmo ministério de um ponto de vista mais intimista, mais intenso. ${ }^{525}$
\end{abstract}

A segunda doutrina cardeal da Igreja do Evangelho Quadrangular também dispõe de um símbolo, a pomba, que, segundo a teologia quadrangular, está representada nos textos bíblicos na relação com o Espírito Santo. Scotti informa:

\begin{abstract}
A pomba possui características que a tornam símbolo de brandura, doçura, amabilidade, inocência, suavidade, paz, pureza e paciência. Esse simbolismo está ligado, de certa forma, aos frutos do Espírito, citados em Gálatas 5.22, e que são: amor, gozo, paz, longanimidade, benignidade, bondade, fé, mansidão, temperança. Para os quadrangulares, a relação entre a pomba e o Espírito Santo não está firmada apenas no simbolismo colocado acima, mas no fato dela ter sido citada diretamente nos evangelhos como forma tomada pelo Espírito Santo ao descer sobre Jesus, logo após seu batismo nas águas com João Batista (Mt. 3.16; Mc 1.10; Lc 3.22; Jo 1.32). ${ }^{526}$
\end{abstract}

A representação maior da pomba como símbolo do Espírito Santo se mostra na passagem que narra o pós-batismo de Cristo, fundamentando essa doutrina cardeal quadrangular, antes representada pela tocha, como revela Cox: "os quadrangulares mostram a tocha para simbolizar o ministério de Jesus, Aquele que batiza com o Espírito Santo". ${ }^{527}$ A pomba, no entanto, mostrou melhor associação, prevalecendo sobre a tocha como símbolo do batismo com o Espírito

\footnotetext{
${ }^{524}$ SCOTTI, I. T., Evangelho quadrangular, p. 72.

${ }^{525}$ SCOTTI, I. T., Evangelho quadrangular, p. 72.

${ }^{526}$ SCOTTI, I. T., Evangelho quadrangular, p. 73-74.

${ }^{527}$ COX, R. L., O evangelho quadrangular, p. 229.
} 
Santo para os quadrangulares. A cor ouro representa essa segunda doutrina na bandeira quadrangular, como diz Scotti: "o ouro representa o fogo do Espírito Santo". ${ }^{528}$ Resumindo, portanto, a segunda doutrina cardeal quadrangular se compõe do conjunto: Jesus Cristo, Aquele que Batiza, representado na visão de Ezequiel 1:10 no rosto do leão; a pomba, apresentada no Evangelho de João, figurando na bandeira quadrangular na cor ouro.

A terceira doutrina cardeal: Jesus Cristo, aquele que cura

A terceira doutrina quadrangular também segue a ordem de Ezequiel 1:10. A teologia quadrangular associa o rosto de boi ao ministério de Jesus Cristo, como aquele que cura, pois a força do boi no transporte de carga encontra representatividade em Cristo, que levou as dores dos homens e seus fardos. É Scotti quem assegura: "na Doutrina Quadrangular, em relação à cura divina, quanto às quatro faces da visão bíblica quadrangular, Jesus é tipificado no rosto de Boi. O terceiro rosto da visão de Ezequiel era o Rosto de Boi, o qual simbolizava Jesus Cristo como o Médico Divino ou Aquele que Cura". ${ }^{529}$ A terceira doutrina cardeal quadrangular está baseada na experiência, assemelhando-se nesse ponto á segunda doutrina, o batismo com o Espírito Santo. A doutrina da cura invoca uma experiência, componente do cotidiano da liturgia quadrangular. É Cox quem explica:

Acontece com a cura o mesmo que no batismo com Espírito Santo. O homem que tem uma experiência jamais fica à mercê daquele que tem apenas um argumento. Centenas de milhares, talvez milhões de cristãos, experimentam a cura divina e dão testemunho do restabelecimento, através da fé em Jesus Cristo como seu grande médico. Jesus não salva apenas a alma do pecador e capacita seu espírito com o batismo do Espírito Santo. Ele também cura o corpo doente. ${ }^{530}$

A teologia quadrangular mostra que suas bases estão fundadas no pentecostalismo, uma vez que sua terceira doutrina cardeal também reside na experiência. A cura divina nessa terceira fase do evangelho é possível, pois Cristo a praticou em vários momentos. Os quadrangulares, que têm por lema de fé $\mathrm{Hb}$ 13.8, dizem que Ele é o mesmo ontem e hoje. A partir dessa hermenêutica, os quadrangulares buscam contextualizar a doutrina da cura. Continua:

\footnotetext{
${ }^{528}$ COX, R. L., O evangelho quadrangular, p. 229.

${ }_{529}$ SCOTTI, I. T., Evangelho quadrangular, p. 83.

${ }^{530}$ COX, R. L., O evangelho quadrangular, p. 149.
} 
Essa verdade é um dos fundamentos da fé quadrangular, pois, a terceira fase deste evangelho exalta Jesus Cristo como aquele que cura! A fé nele, hoje, produzirá o mesmo resultado que a fé assegurou nos dias bíblicos. Jesus ainda diz aos crentes: "A tua fé te salvou" (Mt 9.22). Ele também diz: "Seja feito conforme a tua fé" (Mt 8.13), porque Ele "ontem e hoje é o mesmo, o será para sempre" (Hb 13.8). A parte do homem é buscar com fé o ministério daquele que cura. Jesus fará então a sua parte divina e irá devolver-lhe a saúde! ${ }^{531}$

O pentecostalismo quadrangular evidencia, em pelo menos duas das suas quatro doutrinas, a prioridade da experiência. Se a segunda doutrina dirige-se ao batismo no Espírito Santo, a terceira volta-se para a cura física do corpo, apresentando Jesus Cristo como médico que restaura o homem em sua dimensão física. A construção da teologia dessa doutrina entende que Cristo continua disponibilizando à igreja esse dom. O Evangelho de Marcos representa a terceira doutrina quadrangular. A teologia desenvolvida pelos quadrangulares a partir de Marcos mostra um Jesus servo. Scotti diz:

Marcos, em seu evangelho, apresenta Jesus como Servo de Deus, "porque o Filho do homem também não veio para ser servido, mas para servir e dar a sua vida em resgate de muitos" (Mc 10.45) Jesus mostra claramente sua submissão ao declararse como "servo" nesse versículo. Ninguém foi ou será tão obediente à vontade de Deus como Ele foi. E o mais interessante é que Cristo dedicava sua servidão a nós, como exemplo para os que $\mathrm{O}$ seguiriam. Ele mesmo disse que "qualquer que dentre vós quiser ser o primeiro, será servo de todos" (Mc 10.44). Sua intenção, como deve ser a nossa, era de servir a Deus e aos homens no intuito de levar a Palavra de Deus, a salvação e a cura a todos. Seu amor estava e está acima de qualquer coisa. ${ }^{532}$

A terceira doutrina quadrangular é o que a diferencia no movimento pentecostal, o conjunto de sua pneumatologia com a doutrina da cura divina estrutura a teologia quadrangular como pentecostal experiencial: "penso que devemos sempre apresentar ao lado da salvação a mensagem da cura divina". 533 Essas duas doutrinas caminham juntas na prática da liturgia quadrangular e não é possível dissociá-las, como afirma Scotti:

Atos 5.12-16 - Após o batismo com o Espírito Santo, ninguém mais pôde deter a evolução do cristianismo e os milagres que seguiam aos fiéis. Até à "sombra de Pedro" eram colocados enfermos para serem curados. Atos 9.33-34 - Enéias era paralítico e estava em uma cama há doze anos quando Pedro o encontrou e o curou,

\footnotetext{
${ }^{531}$ COX, R. L., O evangelho quadrangular, p. 149.

${ }^{532}$ SCOTTI, I. T., Evangelho quadrangular, p. 84.

533 JESUS. Marli de. George Faulkner: série memórias quadrangular. São Paulo: Editora Quadrangular. 1999.p. 135.
} 
declarando: "Enéias, Jesus Cristo te dá saúde; levanta-te e faze a tua cama" (grifo da autora). Atos 19.11-12 - A fé entre os cristãos crescia a cada dia e Paulo operava maravilhas no meio deles. Até seus lenços e aventais eram levados aos enfermos e estes eram curados. ${ }^{534}$

Os elementos da liturgia quadrangular partem exatamente desses exemplos bíblicos, com a unção com óleo e a oração pelos enfermos. Os quadrangulares acreditam na cura divina e a praticam, além da glossolalia. A terceira doutrina está representada pelo cálice, como diz Cox: "o emblema do ministério de Cristo de Cura para o corpo é o cálice. Usamos o cálice como um símbolo da cura divina, por causa da ordem, em Tiago 5.14-15, para que os presbíteros sejam chamados, a fim de ungir com óleo e fazer a oração de fé pelos doentes". ${ }^{535}$ O cálice representa, na doutrina quadrangular, a cura divina, e figura na cor azul na sua bandeira, como explica Cox: "o Azul simboliza a saúde celestial ministrada aos corpos doentes por Jesus, o Médico divino". ${ }^{536}$ A terceira doutrina cardeal quadrangular se traduz no seguinte conjunto: Jesus Cristo, Aquele que Cura, representado na visão de Ezequiel 1:10; o rosto do boi, representado pelo Evangelho de Marcos; e a cor azul na bandeira quadrangular.

A quarta doutrina cardeal: Jesus Cristo, o rei que virá

A quarta e última doutrina quadrangular também obedece a Ezequiel 1:10 e descreve o rosto de águia como o último dos quatro revelados na visão, representando o Jesus Cristo como rei que voltará nas nuvens em sua segunda vinda, como refere Scotti: “o quarto rosto visto por Ezequiel foi o Rosto de Águia, o qual representa Jesus Cristo como o Rei que há de vir". ${ }^{537}$ Essa fase da doutrina quadrangular está associada à sua escatologia. Em contraste com as três primeiras apresentadas, que se concentram na experiência pessoal e presente da pessoa e da igreja, a última aponta para a futuridade. Dessa forma, os quadrangulares mantêm, em um dos pilares que alicerçam suas doutrinas, o advento escatológico da segunda vinda de Jesus Cristo de maneira perceptível aos olhos humanos, como esclarece Cox:

Três das quatro ênfases principais do Evangelho Quadrangular, relativas ao ministério do Senhor Jesus Cristo, pertencem a experiências atuais. Jesus salva os

\footnotetext{
${ }^{534}$ SCOTTI, I. T., Evangelho quadrangular, p. 86.

${ }^{535}$ COX, R. L., O evangelho quadrangular, p. 230.

${ }^{536}$ COX, R. L., O evangelho quadrangular, p. 231.

${ }^{537}$ SCOTTI, I. T., Evangelho quadrangular, p. 98.
} 
crentes agora, nos dias de hoje, nesta dispensação da Igreja... Do mesmo modo, Jesus está batizando inúmeros crentes no Espírito Santo todos os dias. O mesmo pode ser dito sobre o ministério de cura de Cristo. O Senhor ministra constantemente hoje, como Salvador, como Aquele que batiza e Aquele que cura. Todavia, Ele não começou ainda sua carreira como o Rei que virá. Mas, fará isto e a Palavra de Deus encoraja os crentes a esperarem sua vinda próxima! ${ }^{538}$

A manutenção da esperança escatológica, que faz parte da teologia pentecostal quadrangular, enfatiza fortemente a volta de Jesus Cristo. "a segunda vinda de Cristo é uma vinda ou retorno literal". ${ }^{539} \mathrm{Na}$ prática pentecostal esse elemento está sempre presente seja nos sermões, hinos e percepção da fé, como diz Cox: "não há dúvida de que Jesus Cristo voltará. Os anjos anunciaram que tal fato ocorreria. Os profetas predisseram esta volta. O próprio Cristo a prometeu. Deus a informa. Ele enviará seu Filho uma segunda vez do céu. A maior notícia de toda a história será anunciada em tempo oportuno". ${ }^{540}$ A propagação da volta de Jesus Cristo também se faz presente na liturgia quadrangular, e a teologia da denominação entende o Evangelho de Mateus como o mais representativo de Jesus como rei, como afirma Scotti:

\begin{abstract}
Mateus apresenta Jesus Cristo como o futuro Rei. Ao ser questionado por Pilatos sobre se Ele era o "Rei dos Judeus", Jesus respondeu: "Tu o dizes" (Mt 27.11). Nessa resposta, Ele estava falando sobre Seu reinado eterno e não um reinado terreno, pois sabia que estava indo para a morte. Sem saber o que estavam fazendo, pois intentavam apenas fazer chacota de Jesus, os homens que $\mathrm{O}$ crucificaram colocaram escrita sobre Sua cabeça na cruz Sua acusação: "este é Jesus, o rei dos judeus" (Mt 27.37). Só que, na realidade, eles estavam afirmando a majestade de Cristo, pois Ele morreu como homem, mas voltará como Rei. ${ }^{541}$
\end{abstract}

Os quadrangulares encontram elementos no Evangelho segundo Mateus que destacam Jesus como rei. Assim, esse evangelho representa a quarta doutrina cardeal quadrangular, cuja simbologia se serve da coroa, símbolo de majestade de Cristo. Cox destaca:

A coroa simboliza o Rei vindouro, Três emblemas apontam para o passado e o presente - a salvação, o batismo com o Espírito Santo e a cura divina ministram às necessidades presentes dos homens - e repousam sobre a obra do Cristo encarnado consumada na terra. Um emblema olha para o futuro. A coroa faz-nos vibrar com firme esperança no futuro. Jesus Cristo voltará primeiro para buscar a sua Igreja e,

\footnotetext{
${ }^{538}$ COX, R. L., O evangelho quadrangular, p. 157.

${ }^{539}$ DUFFIELD, P. G.; CLEAVE, N. M. V. Fundamentos da teologia pentecostal. Vol. II, p. 263.

${ }^{540}$ COX, R. L., O evangelho quadrangular, p. 157.

${ }^{541}$ SCOTTI, I. T., Evangelho quadrangular, p. 99.
} 
depois, com a sua Igreja. Jesus reinará como Rei dos Reis e Senhor dos Senhores. ${ }^{542}$

A cor simbólica representada na bandeira dessa quarta doutrina é o púrpura, que, segundo Cox, "indica a realeza do Rei vindouro".543 A quarta doutrina cardeal quadrangular, portanto, é composta pelo seguinte conjunto: Jesus Cristo, o Rei que Virá, representado na visão de Ezequiel pelo rosto de águia; o mesmo Rei representado pelo Evangelho de Mateus; sua representação na bandeira quadrangular na cor púrpura.

A bandeira quadrangular

A fundadora da Igreja Quadrangular foi bastante detalhista e confeccionou uma bandeira representativa do evangelho quadrangular. Entre outros símbolos, a bandeira quadrangular se destaca, com as cores quadrangulares tipificando cada fase desse evangelho. A própria Aimee foi responsável pela elaboração e confecção da primeira bandeira quadrangular, como registra Cox:

Inúmeros outros símbolos projetam dramaticamente a mensagem quadrangular. Talvez, o mais familiar seja a nossa bandeira. Em 1930, Aimee Semple McPherson sentiu necessidade de um estandarte, que representasse a plenitude do evangelho mais adequadamente do que a respeitada bandeira cristã. Durante os primeiros seis meses do ano seguinte, ela costurou a primeira bandeira quadrangular. A primeira fotografia desta bandeira apareceu no Bridal Call Foursquare de julho de $1931 .{ }^{544}$

A bandeira quadrangular faz parte da história e da propagação da doutrina da denominação, assim como o brasão, que une elementos dessa doutrina, contendo as cores da bandeira, os quatro rostos da visão de Ezequiel, um quadrado branco com uma bíblia aberta e o número 4. Scotti diz:

O brasão da Igreja do Evangelho Quadrangular possui quase o mesmo significado, pois ele pode representar a nação quadrangular, o soberano Cristo, a família de Deus, as cores da nossa bandeira, a cidade eterna - a Nova Jerusalém etc. Ele é, portanto, usado para simbolizar a nossa fé. Esse brasão, no Brasil, é formado por um quadrado branco, tendo sobre ele uma Bíblia aberta, sustentando, no centro da Bíblia, o número 4 na cor amarelo-ouro. O quadrado tem, em seus lados, os quatro rostos da visão de Ezequiel, assim posicionados: 1 - O rosto de homem, para cima e na cor vermelha-carmesim; 2 - O rosto de leão, à direita e na cor amarelo-ouro; 3 - $\mathrm{O}$ rosto de boi, à esquerda e na cor azul-celeste; 4 - $\mathrm{O}$ rosto de águia, para baixo e na cor púrpura. ${ }^{545}$

\footnotetext{
${ }^{542}$ COX, R. L., O evangelho quadrangular, p. 230.

${ }^{543}$ COX, R. L., O evangelho quadrangular, p. 231.

${ }_{544}$ COX, R. L., O evangelho quadrangular, p. 230.

${ }^{545}$ SCOTTI, I. T., Evangelho quadrangular, p. 23.
} 
A fé dos quadrangulares está associada a vários elementos que expressam sua visão, como já apresentado. Por se tratar de denominação de viés pentecostal, a maioria desses símbolos converge para essa experiência. O evangelho quadrangular também utiliza um lema bíblico que exprime sua fé, como afirma Scotti:

Além dos emblemas, da bandeira e dos hinos de batalha, o movimento possui um lema bíblico que resume a nossa fé. Hebreus 13.8, segundo o Regime Interno Quadrangular, deve aparecer no auditório de cada Igreja do movimento: "Jesus Cristo ontem e hoje é o mesmo, e o será para sempre". Este versículo enfatiza nossa insistência de que a Igreja de hoje tem, à sua disposição, cada bênção e cada ministério existente na Igreja apostólica nos dias bíblicos. ${ }^{546}$

Ao concluir esta tentativa de expor a fé quadrangular, apresentamos seu lema bíblico que reivindica a fé em Jesus Cristo no tempo presente. Os quadrangulares acreditam que a pessoa dotada da experiência nunca será refém de quem tem somente argumentos. Isso faz parte do seu pentecostalismo e a maior parte de sua doutrina está centrada na experiência. Daí a esperança, pois Jesus Cristo é o mesmo hoje. Por último, a Igreja do Evangelho Quadrangular tem um hino oficial, intitulado "Eia Salvos Avançai", de autoria de McPherson, mostrando o perfil missionário da Quadrangular por meio de uma letra que convoca todos a ser missionários e pregar o evangelho quadrangular de Jesus Cristo. Segundo o seu estatuto:

\section{O Hino Oficial da Igreja do Evangelho Quadrangular}

"Eia Salvos Avançai” da autoria da Missionária Aimee Semple McPherson:

$$
\begin{gathered}
\text { Eia salvos avançai } \\
\text { Nada de temer } \\
\text { Vamos firmes batalhar } \\
\text { Prontos pra vencer } \\
\text { Vai conosco o General, nosso bom Jesus } \\
\text { Ele nos dará vitória pela cruz } \\
\text { Coro } \\
\text { Avante, pois, e sem parar } \\
\text { O evangelho anunciar } \\
\text { O evangelho Quadrangular } \\
\text { De Deus o nosso eterno Pai } \\
\text { Pois Cristo salva o pecador } \\
\text { Para que seja um bom cristão }
\end{gathered}
$$

${ }^{546}$ SCOTTI, I. T., Evangelho quadrangular, p. 232. 
Cura também a sua dor

Qualquer doença e aflição

Com seu poder, quer batizar

Do céu virá pra nos levar

E com Ele nós havemos sempre de reinar

Vamos templos levantar por todo o Brasil

A pregar sem descansar

Nosso Rei gentil

Vamos missionários ser, todos, todos nós

Transmitindo com prazer de Deus a voz! ${ }^{547}$

${ }^{547}$ QUADRANGULAR. Estatuto e regimento interno da Igreja do Evangelho Quadrangular, p. 129. 


\section{3 \\ A missão na perspectiva de José Comblin}

Este capítulo propõe-se estudar a missão a partir da perspectiva de Comblin, para isto recorreremos a texto do autor e também de seus comentadores desta maneira poderemos descrever um panorama geral de sua teologia, mostrando o perfil de Comblin como teólogo e missionário. A partir dessa perspectiva tentarse-á encontrar os precedentes da formação de Comblin e a dimensão dessas influências em sua teologia e no seu estilo missionário. Ainda neste capítulo, estudos gerais sobre Comblin priorizarão contribuições recebidas por sua prática missionária, demonstrando suas tentativas e inspiração. O capítulo também se concentra na teologia da missão em Comblin, recorrendo aos textos pneumatológicos do autor cujo tema seja o Espírito, e também na missão e nas contribuições de seus comentadores. Buscaremos ver o conceito de sua missão e pilares de sua prática missionária, rastreando indícios da relação entre a pneumatologia e a missão em Comblin, analisando-se ainda a percepção do autor da missão leiga e dos cristãos em geral, e a relação de sua teologia com o tema. Os aspectos escolhidos que envolvem discussões sobre Comblin são os que tratam de seu empreendimento missionário.

\section{1.}

\section{Linhas gerais da teologia de José Comblin}

Nesta primeira parte do capítulo proporemos uma visão das linhas gerais da teologia de Comblin, buscando, a partir de seus textos e dos de seus comentadores, compreender nesse autor, de forma abrangente, o teólogo e missionário. Pretende-se entender desde o primeiro Comblin europeu e sua constante transformação até o Comblin missionário entre o povo nordestino, assim como a série de eventos que forjaram sua teologia e o inspiraram na missão. 


\subsection{1. \\ Perfil do teólogo Comblin}

A missão da Igreja do Evangelho Quadrangular no Brasil requer a reflexão à luz de um teólogo contemporâneo que vivenciou o cenário de transformação e os novos desafios propostos ao cristianismo em geral, entre ao quais elegemos aqui José Comblin, presente em São Paulo no final dos anos 1950, período de expansão da Cruzada Nacional de Evangelização, movimento que originou a Igreja Quadrangular no Brasil. Canova afirma:

Em 1958 começou a "aventura" missionária e teológica de Comblin no nosso continente. Tornou-se, dentro de poucos anos, um grande protagonista na construção dos fundamentos e passos educativos de um novo modelo de Igreja e na elaboração de uma teologia latino-americana chamada depois "da Libertação. ${ }^{548}$

O primeiro trabalho desenvolvido por Comblin no Brasil é justamente no berço expansionista da Igreja do Evangelho Quadrangular em São Paulo. Ele trabalha como educador em Campinas, e, como afirma Thomé, "Comblin, ao chegar ao país, primeiramente foi professor do ensino secundário de física e química, bem como capelão do mesmo colégio católico na cidade de Campinas/SP" ${ }^{549}$ Mesmo fazendo parte de outra matriz religiosa, como missionário católico, ele acompanhou o desenvolvimento do pentecostalismo brasileiro dos anos 1950 em diante. Sobre ele, Charles diz: "Padre J. Comblin foi um teólogo contemporâneo do século XX, radicado no 'continente da esperança'. Nosso autor nasceu em Bruxelas, no dia 22 de março de 1923 " ${ }^{550}$ Os pais, simples, mas trabalhadores e persistentes, conheceram-se na Igreja, como esclarece Muggler: "os pais, Alice e Firmino, não eram tão jovens quando se casaram. A mãe já tinha 33 anos e o pai 47 anos. O pai era filho de humildes agricultores da região das Ardenas, nasceu em Hargimont, conseguiu estudar,

\footnotetext{
${ }^{548}$ CANOVA, Hermínio. José Comblin e a Igreja dos pobres. Paralellus, Recife, v. 4, n. 7, p. 21 32, jan./jun. 2013, p. 23.

${ }^{549}$ THOMÉ, Adriana. A Arte de Educação Popular e o Processo de Libertação no Pensamento de Comblin. Dissertação de Mestrado. UMESP. São Bernardo do Campo, 2012, p. 28.

${ }^{550}$ CHARLES. Carlos Roberto de Oliveira. Comunidade segundo o Espírito: fraternidade e libertação. Uma aproximação pneumatológica entre Francisco de Assis e José Comblin. Tese de Doutorado. PUC-RIO, 2015, p. 19.
} 
migrou para a cidade e tornou-se funcionário público". 551 Pouco tempo após o casamento, nasceram os filhos, no pós-guerra. Muggler afirma: "José Comblin nasceu cinco anos após o final da Primeira Guerra Mundial, a guerra de 19141918. Tempos trágicos que deixaram marcas profundas na população da Europa". ${ }^{552}$ Entre incertezas e muita dureza, o menino Comblin passa a infância aprendendo as mazelas sociais. Muggler acrescenta: "também os pais de José Comblin carregavam consigo a angústia da pobreza, o medo de não ter o que comer. Assim, o menino José teve uma infância marcada por uma vida austera". ${ }^{553}$ Mesmo em meio à dificuldade, Comblin buscava o conhecimento, obtendo boa formação. Durante o período de guerra, muitas doenças espalhavamse e a população alimentava-se precariamente. Comblin ficou doente, como relata Muggler:

Depois de três anos em Lovaina, José Comblin ingressou no Seminário São José em Malinas. Em 1943 cursou o $1^{\circ}$ ano de teologia. Em 1944, entrou no Seminário Maior e cursou o $2^{\circ}$ e o $3^{\circ}$ ano de teologia. Por causa da guerra, a austeridade foi grande: comida limitada, frio intenso, pois a eletricidade e o carvão para o aquecimento eram racionados. José acabou adoecendo: pegou uma tuberculose, doença grave naquele tempo e muitas vezes fatal. O seminário o mandou para casa, pois certamente os cuidados maternos poderiam ajudá-lo mais. Na cidade, tudo era difícil, inclusive a comida. Mas como seus tios eram agricultores e moravam no campo, sempre a família recebia deles uma farta feira de produtos do campo: leite de vaca, queijo artesanal, carnes. Graças a isso, José teve uma alimentação substancial que ajudou decisivamente a vencer a tuberculose. Curado, voltou imediatamente ao seminário. ${ }^{554}$

Recuperado, Comblin mantém a persistente, destacando-se entre os estudantes. Aluno promissor, ingressou na faculdade, ambiente que muito contribuiu para toda a sua vida intelectual, proporcionando-lhe liberdade e propiciando-lhe construir conhecimento. Muggler esclarece esse ambiente:

A Faculdade de Teologia correspondia ao Seminário Universitário, para onde eram enviados os mais capazes. O período dos estudos em Lovaina foi marcado sobretudo por um ambiente de liberdade: todos eram estudantes de diferentes cursos universitários, com horários distintos. Aí não havia controle nem vigilância, cada qual fazia seu programa, organizava a sua vida e saía livremente para as suas atividades. Os alunos tinham liberdade e estavam bem conscientes de que aquele

\footnotetext{
${ }^{551}$ MUGGLER, Monica Maria. Padre José Comblin: uma vida guiada pelo Espírito. São Bernardo do Campo: Nhanduti Editora, 2012, p. 23.

552 MUGGLER, M. M., Padre José Comblin, 2012. p. 24.

${ }^{553}$ MUGGLER, M. M., Padre José Comblin, 2012, p. 24.

${ }^{554}$ MUGGLER, M. M., Padre José Comblin, 2012, p. 36.
} 
era um ambiente bem diferente daquilo que se vivia normalmente em qualquer seminário maior. ${ }^{555}$

A preparação missionária e o início de sua formação sacerdotal foram na Europa. A fase que antecede sua chegada ao Brasil é marcada por estruturação e capacitação, muito úteis na caminhada missionária. Charles continua: "foi ordenado sacerdote em 9 de fevereiro de 1947. Atendendo à solicitação do bispo de Campinas, foi enviado para o Brasil no ano de 1958, onde foi professor de seminário e da Universidade Católica. De 1962 a 1965 também lecionou na Universidade Católica de Santiago, no Chile". ${ }^{556}$ Sua prática missionária na América Latina inicia-se na docência: pela formação adquirida, Comblin estava apto a contribuir com o povo de Deus. Adriana Thomé lembra: “é nessa conjuntura social que Joseph Jules Comblin recebeu a sua ordenação sacerdotal, em 9 de fevereiro de 1947, na cidade de Malines - Bélgica. Ali permaneceu no sacerdócio até 1958, exercendo a função de vigário colaborador na Paróquia Sagrado Coração de Jesus, localizada em Bruxelas". ${ }^{557}$ Comblin sempre buscou equilíbrio entre teoria e prática, compreendendo a necessidade de sintonia entre ambas, desde a Europa, segundo Thomé: "paralelamente ao seu trabalho sacerdotal, durante o ano de 1951, também exerceu o magistério no Centro de Formação para Seminaristas em serviço militar da Bélgica e auxiliou a Juventude Operária Católica". ${ }^{558}$ Durante o trabalho na Europa, descortinava oportunidades de um futuro promissor, mas o engajamento na causa missionária na América Latina mostrou-se contraditório, na opinião de alguns professores, dada a sua carreira na Europa, como ainda relata Muggler:

Na Bélgica, a sua decisão surpreendeu a muitos. Sobretudo um de seus professores no curso de teologia em Lovaina, o padre Coppens, de Antigo Testamento, comentou certa vez com um de seus alunos, Gustavo Gutiérrez, que ficara penalizado com a decisão do jovem padre José Comblin: "Ele, um rapaz tão inteligente, foi para a América Latina...”. Ir para a América Latina era ir para o fim do mundo, lugar sem perspectivas nem desenvolvimento. Lugar atrasado para quem prometia ser um brilhante intelectual. Também em Campinas, muitos não entendiam como pessoas tão inteligentes deixavam a Europa para vir para o Brasil. Afinal, o Primeiro Mundo era o sonho impossível de toda a classe intelectual e

\footnotetext{
${ }^{555}$ MUGGLER, M. M. Padre José Comblin, 2012, p. 37.

${ }^{556}$ CHARLES. C. R. d., O. Comunidade segundo o Espírito, p. 19.

${ }^{557}$ THOMÉ, A., A Arte de Educação Popular e o Processo de Libertação no Pensamento de Comblin, p.25.

558 THOMÉ, A., A Arte de Educação Popular e o Processo de Libertação no Pensamento de Comblin, p.25.
} 
mesmo clerical. Certa vez, um cônego do clero de Campinas perguntou bem confidencialmente ao padre José Comblin: "Qual foi o pecado que o senhor cometeu no seu país para ter que vir para o Brasil?" Comblin respondeu que veio voluntariamente, atraído pela missão, mas, visivelmente, o cônego não acreditou e respeitou o silêncio do jovem padre José Comblin [...]. ${ }^{559}$

Era incompreendida a opção de Comblin de dedicação à América Latina, mesmo no Brasil, como mencionado acima. Logo após a chegada ao Brasil, sua primeira obra foi publicada na Europa, início de tantas outras. Thomé lembra:

Quando já estava aqui no Brasil, em 1959, Comblin teve a sua primeira obra publicada na cidade de Paris, sob o título de La Résurrection de Jesus-Christ, escrita enquanto ainda trabalhava como sacerdote na Bélgica. Foi traduzida para vários idiomas, tais como: italiano, espanhol, alemão e inglês. Em português recebeu o título de "Ressurreição". Em 1960, sua segunda obra foi publicada com o título Théologie de la Paix: Principes, em francês, italiano e alemão. E ainda teve a terceira obra publicada, com o título Échec de l'eAction Catholique?, nos seguintes idiomas: alemão, francês e espanhol. Ressalta-se que essas duas obras não foram publicadas na língua portuguesa. ${ }^{560}$

Logo após as primeiras publicações, iniciava-se o Concílio Vaticano II, evento que muito influenciou a reflexão e o desenvolvimento do trabalho missionário de Comblin, como destaca Thomé: “em 1962, iniciou-se o Concílio Vaticano II, considerado um dos acontecimentos eclesiásticos mais importantes da história da Igreja Católica". ${ }^{561}$ Comblin vivenciou muitos momentos decisivos no cristianismo latino-americano, que lhe exigiram muito dinamismo, como resume Charles:

No início dos anos 70 passou a orientar um grupo de seminaristas que buscavam um estudo comprometido com a realidade rural. Criou, então, um modo de estudo que ficou conhecido como "Teologia da Enxada". A convite do CELAM, de 1968 a 1972 foi professor de teologia em Quito, Equador. Considerado subversivo e ameaçador ao sistema, Comblin foi expulso do Brasil em 24 de março de 1972, quando retornou ao Chile, estabelecendo-se em Talca até 1980. Neste mesmo ano ocorreu a sua expulsão do Chile, quando retornou ao Brasil com visto de turista, obrigando-o a sair do país a cada três meses durante seis anos para a renovação do mesmo. Em 1986 foi anistiado e recebeu novamente o visto permanente. Com o grupo da "Teologia da Enxada" e o apoio de Dom José Maria Pires, de João Pessoa, fundou em 1981, em Pernambuco, o Seminário Rural. ${ }^{562}$

\footnotetext{
${ }^{559}$ MUGGLER, M. M., Padre José Comblin, 2012, p. 49.

${ }^{560}$ THOMÉ, A., A Arte de Educação Popular e o Processo de Libertação no Pensamento de Comblin, p. 30-31.

${ }^{561}$ THOMÉ, A., A Arte de Educação Popular e o Processo de Libertação no Pensamento de Comblin, p. 30.

${ }^{562}$ CHARLES. C. R. d., O. Comunidade segundo o Espírito, p. 19-20.
} 
A preocupação com o contexto e o comprometimento com a vida levou Comblin a uma transformação em sua concepção missionária, o que se deu também por influência do avanço do Concílio Vaticano II. Magalhães esclarece: “José Comblin é um teólogo da geração do Concílio Vaticano II. A questão pertinente é a relação da fé cristã com o mundo moderno, que o leva a construir seu pensamento, motivado por uma Igreja comprometida com os contextos sócioeconômico, político, cultural e religioso, especialmente na defesa e opção pelos mais pobres". 563 Essa nova agenda, que guiaria toda a sua ação missionária, formaria sua identidade teológica e o situaria em caminhos não tradicionais, como detalha Magalhães:

Sua eclesiologia está estritamente ligada aos princípios inspiradores do Vaticano II. É o movimento pós-conciliar que não acontece por acaso, mas que vem sendo construído, gradativamente, a partir de uma percepção da carência de se explicar a missão da Igreja nas realidades do mundo contemporâneo. ${ }^{564}$

Os desafios permanentes no curso da evangelização fizeram com que Comblin, aos poucos, reinterpretasse sua ação missionária, algo possibilitado em parte pelo cenário no qual emerge, como pontua Sousa: "na esteira do Concílio Vaticano II, Comblin consolida na prática o que defendia e compreendia como sua teologia: um serviço a ser prestado em especial aos pobres de forma que possa contribuir para seu desenvolvimento pessoal a partir do aprofundamento da compreensão de suas vidas com Deus". ${ }^{565}$ Tais esclarecimentos são importantes para a compreensão dos alicerces teológicos da missão de Comblin. Magalhães explica o contexto geral dos teólogos da geração de Comblin:

Antes do Concílio Vaticano II o ambiente católico vivia num clima de confronto e de condenações: com os protestantes em Trento e com o mundo moderno no Concílio Vaticano I. O Concílio Vaticano II (1962-1965) abre a Igreja para o diálogo com todas as realidades da humanidade. A Igreja sai do isolamento e depara-se, corajosamente, com as múltiplas realidades complexas nos níveis: social, político, religioso e cultural. Ela é chamada a responder à sua missão de evangelizar em todos esses ambientes. ${ }^{566}$

\footnotetext{
${ }^{563}$ MAGALHÃES, Cicero Edvam. Religiosidade e Teologia Popular à Luz da Eclesiologia de José Comblin. Dissertação de Mestrado. FAJE - Belo Horizonte, 2012, p. 38.

${ }^{564}$ MAGAlHÃES, C. E. Religiosidade e Teologia Popular à Luz da Eclesiologia de José Comblin, p. 38.

${ }^{565}$ SOUSA, Alzirinha Rocha de. A prática de Comblin: a Igreja do chão da realidade. Horizonte, Belo Horizonte, v. 15, n. 45, p. 239-255, jan./mar. 2017 - ISSN 2175-5841, p. 240.

${ }^{566}$ MAGALHÃES, C. E., Religiosidade e Teologia Popular à Luz da Eclesiologia de José Comblin, p. 39.
} 
A história da Igreja foi marcada por tentativas de diálogo e abertura, na busca de contextualização da ação missionária da Igreja, como relata Thomé: “o Concílio Ecumênico Vaticano II teve o seu início solene no dia onze de outubro de 1962, sob o papado de João XXIII, na Basílica de São Pedro". ${ }^{567}$ Novas perspectivas se abriam aos missionários, com uma agenda centrada no diálogo ecumênico, na abertura ao mundo e numa igreja dos pobres, que animava teólogos e missionários, principalmente os que estavam na América Latina. Não cabe aqui analisar a agenda do Concílio Vaticano II, apenas situar o ambiente teológico que engendrou o autor em questão, como destaca Canova:

Durante o Concílio Vaticano II (1962- 1965, em Roma, Itália), 40 bispos conciliares (a maioria latino-americanos), em sintonia com o sonho do Papa de então, João XXIII, de uma "Igreja pobre a serviço dos pobres", desceram nas catacumbas dos primeiros cristãos e lá assumiram o compromisso de voltarem para seus países e suas igrejas para viverem pobres "no meio do povo. ${ }^{568}$

A sociedade passava por mudanças. No Brasil era comum que as pessoas deixassem as zonas rurais para viver em grandes cidades, o que alterou as relações sociais. No campo religioso, a explosão pentecostal atraiu muitos e gerou grande pluralidade de denominações. Algo deveria ser feito e a igreja católica precisava de nova postura, como explica Thomé:

Desta forma, o Concílio Vaticano II deu início à abertura de uma nova etapa histórica, em que se objetivava discutir e entender a Igreja Católica a partir de outros pontos de vista. Essa mudança se fazia indispensável diante do ritmo frenético das transformações sociais e das necessidades de se construir uma coesão entre os cristãos. Foi diante desse quadro que surgiu a necessidade de se convocar um grande concílio ecumênico, evento ocorrido diante do papado de João XXIII. ${ }^{569}$

Mesmo não tendo comparecido ao Concílio, Comblin atualizou-se com as reflexões e desafios propostos no evento. Ele contribuiu ativamente na propagação, mobilizando e escrevendo sobre o assunto, assim como ajudando no entendimento das novidades propostas. Canova afirma: "José Comblin não participou do Concílio de Roma, mas acompanhou tudo e escreveu muito para

\footnotetext{
${ }^{567}$ THOMÉ, A., A Arte de Educação Popular e o Processo de Libertação no Pensamento de Comblin, p. 31.

${ }^{568}$ CANOVA, H., José Comblin e a Igreja dos pobres, p. 23.

${ }^{569}$ THOMÉ, A., A Arte de Educação Popular e o Processo de Libertação no Pensamento de Comblin, p. 31 .
} 
ajudar a entender as mudanças trazidas por aquele evento". ${ }^{570}$ Ele via com esperança o caminho apontado no Concílio, muito trabalhando para estabelecer a agenda, como aponta Canova: "Comblin percebeu as novidades e mudanças possíveis na Igreja e começou uma grande atividade de viagens, contatos, escritos, articulações a fim de refletir, formar pessoas e consolidar o modelo de Igreja Povo de Deus nos países e dioceses por ele frequentados". ${ }^{571}$ O Concílio teve longa duração, segundo Thomé: “o Vaticano II teve o seu encerramento, quatro anos depois, no dia 8 de dezembro de 1965, sob o pontificado de Paulo VI". ${ }^{572}$ As mudanças que se seguiram visavam encontrar um caminhar comum da Igreja, que não podia mais se manter separada da sociedade, como indica Thomé: “o Concílio provocou fortes mudanças estruturais na Igreja Católica, favorecendo uma abertura para a Igreja ir ao encontro do mundo, ao invés de caminhar separada ou à margem dele, como procedia há séculos". ${ }^{573}$ Para os comentadores de Comblin, o evento foi decisivo para a missão, ao se abrir para ela, com novas alternativas de diálogos e causas missionárias, conforme Thomé: "esse evento fez com que a Igreja entrasse na história do século $\mathrm{XX}$ sacudindo a poeira imperial e estabelecesse um diálogo profundo com a cultura moderna". 574

Comblin passa a se expor a riscos para ele inauditos, compreendendo que a ação missionária necessita de atualidade, o que envolve toda a estrutura social e humana de uma missão integral, como destaca Charles: "no 'continente da esperança', Comblin teve o privilégio de participar do primeiro grupo dos futuros teólogos da 'Teologia da Libertação' (TdL), ainda em gestação, nas reuniões de Cuernavaca, Petrópolis, Montevidéu, Santiago, em 1964 e nos anos seguintes". 575 Desde a chegada à América Latina, Comblin sempre esteve engajado em causas populares, o que enriqueceu sua abrangência no círculo teológico, como destaca Sousa:

\footnotetext{
${ }^{570}$ CANOVA, H., José Comblin e a Igreja dos pobres, p. 23.

${ }^{571}$ CANOVA, H., José Comblin e a Igreja dos pobres, p. 23.

572 THOMÉ, A., A Arte de Educação Popular e o Processo de Libertação no Pensamento de Comblin, p. 32.

${ }^{573}$ THOMÉ, A., A Arte de Educação Popular e o Processo de Libertação no Pensamento de Comblin, p. 31.

${ }^{574}$ THOMÉ, A., A Arte de Educação Popular e o Processo de Libertação no Pensamento de Comblin, p. 31.

${ }^{575}$ CHARLES. C. R. d., O. Comunidade segundo o Espírito, p. 20.
} 
Após sua primeira experiência em Campinas e na cidade de São Paulo por três anos, parte para o Chile, onde mescla o universo acadêmico (Universidade Católica de Santiago) com o pastoral. Começa a ganhar espaço em seu pensamento a relação direta entre teoria e prática e suas obras revelam a preocupação pela missão e evangelização nesse novo contexto. ${ }^{576}$

A região de maior relevância para seu trabalho foi Recife, como destaca Sousa: “contudo, é no Nordeste brasileiro, após 1965 (quando se instala no Recife para assessorar D. Helder Câmara), que Comblin ritmiza seu processo de mudança teológica". ${ }^{577}$ A experiência nordestina possibilitou ao trabalho missionário a esperança de uma missão mais humana e próxima do cotidiano do povo. Comblin esforça-se em dar voz aos marginalizados, como afirma Magalhães: "o conteúdo eclesiológico do teólogo parte do norte constitucional do Concílio como evento de atualização de toda a comunidade eclesial às exigências aos novos tempos". ${ }^{578}$ Comblin não é compreendido por muitos, por levantar elementos emergentes da realidade atual de seu tempo, buscando encontrar maneiras de manter a igreja dinâmica, em comunicação com a humanidade. Magalhães explica: "é essa consciência de sintonia com a realidade do mundo que perpassa o pensamento de José Comblin. A Igreja deste tempo em sua missão de evangelização, em seus diversos planos pastorais, toma uma postura profética e os vários ministérios despertam para a libertação dos oprimidos". ${ }^{579}$ Ao experimentar vários fatores da fé popular, Comblin percebe um caminho para o cristianismo, entendendo a maior probabilidade de êxito em um cristianismo popular proveniente das camadas populares, estrato da atual cultura, como diz Canova:

\begin{abstract}
Algumas linhas de teologia tomam por base que o sentido do fazer teológico teórico é possível restringindo-se somente à articulação de conceitos. Outras não se compreendem sem a confirmação de sua teoria na prática. Outras, ainda, iniciam seu fazer teológico a partir da prática, das experiências concretas que pessoas fazem em seu cotidiano, considerando aí o espaço privilegiado de suas experiências com Deus. Notadamente, a última perspectiva é a de Comblin, reforçando a evidente contextualidade de sua teologia. ${ }^{580}$
\end{abstract}

Comblin reúne em si qualidades de poucos, o que lhe confere maior possibilidade de encontrar caminhos concretos para a missão contemporânea, como relata Canova: "homem de profunda espiritualidade e de vasta cultura,

\footnotetext{
${ }^{576}$ SOUSA, A. R. D., A prática de Comblin, p. 242-243.

${ }^{577}$ SOUSA, A. R. D., A prática de Comblin, p. 243.

${ }^{578}$ MAGALHÃES, C. E., Religiosidade e Teologia Popular à Luz da Eclesiologia de José, p. 38.

${ }^{579}$ MAGALHÃES, C. E., Religiosidade e Teologia Popular à Luz da Eclesiologia de José, p. 39.

${ }^{580}$ SOUSA, A. R. D., A prática de Comblin, p. 241.
} 
Comblin analisava criticamente os processos políticos e sociais e percebia as tendências para o futuro". ${ }^{51}$ Sua diversidade intelectual, somada à sua proximidade ao povo, proporcionou uma perspectiva diferenciada na teologia latino-americana. O cristianismo brasileiro se beneficiou do trabalho desse missionário, que, com suas experiências de campo, teorizou de forma simples e popular as questões da evangelização. Canova acrescenta:

Foi protagonista de um novo modo de fazer teologia e dedicou muito tempo à fundação e acompanhamento de várias Escolas de Formação para leigos e leigas vocacionados/as à Missão, no Nordeste do Brasil, no Chile e no Equador. Membro da Igreja Católica, Comblin foi amigo-irmão de Teólogos e Pastores desta sua Igreja e de outras Igrejas Cristãs. ${ }^{582}$

Suas obras abriram espaço ao diálogo, pois ele circulou entre cristãos de diversas denominações, compartilhando desafios comuns. Os elementos de sua missiologia provêm parcialmente de experiências pessoais, profissionais ou ministeriais, como esclarece Sousa: "essa contextualidade vem de dois conjuntos de elementos que se encontram: o pessoal e o profissional". ${ }^{53}$ Das experiências pessoais destacam-se seu exemplo familiar, propiciado pela missão do irmão, como destaca Sousa: "soma-se a isso a experiência missionária de seu irmão André Comblin que, pertencente à Congregação dos Padres Brancos, viveu em Ruanda até o evento do genocídio naquele país, quando, por razões de saúde, retornou à Bélgica". ${ }^{584}$ Tais acontecimentos influenciaram diretamente sua forma de fazer missão, enfatizando a sua compaixão. Na perspectiva profissional ele busca a simplicidade, em caminhos não convencionais, como afirma Sousa:

Do lado profissional, destacamos o interesse de Comblin em partilhar sua teologia de uma outra maneira que não a "tradicional". Concluindo seu Doutorado em Bíblia na cidade de Leuven e tendo realizado algumas experiências no ensino das Sagradas Escrituras em Aalst, aos seminaristas que estavam em serviço militar, empenhando-se também no ensino acadêmico na América Latina trinta anos antes de sua morte, finalmente decidiu dedicar-se aos leigos e às formações "não acadêmicas". ${ }^{855}$

A percepção do trabalho de Comblin depende da ótica do observador, pois ele pode ser considerado, de acordo com o ponto de vista, sacerdote, missionário,

\footnotetext{
${ }^{581}$ CANOVA, H., José Comblin e a Igreja dos pobres, p. 23.

${ }^{582}$ CANOVA, H., José Comblin e a Igreja dos pobres, p. 23.

${ }^{583}$ SOUSA, A. R. D., A prática de Comblin, p. 241.

${ }^{584}$ SOUSA, A. R. D., A prática de Comblin, p. 241.

${ }^{585}$ SOUSA, A. R. D., A prática de Comblin, p. 241-242.
} 
professor, teólogo e irmão de fé, como afirma Canova: “quero lembrar José Comblin como padre diocesano, missionário, pedagogo da fé cristã, teólogo da libertação, cientista político, mas, sobretudo e, acima de tudo, como teólogo do Povo de Deus e educador dos leigos e das leigas comprometidos/as com a caminhada e as lutas das comunidades do campo e das periferias". ${ }^{586}$ Contudo, Comblin optou por dedicar boa parte da vida à formação de leigos, o que o conduziu à reflexão sobre o a atuação do Espírito na missão e ao desenvolvimento de boa parte dos seus escritos pneumatológicos, como afirma Charles: "nos últimos 30 anos, J. Comblin dedicou a maior parte do seu tempo à formação de leigos, produzindo um vasto material, contendo temas importantes para a retomada do Espírito Santo na reflexão teológica". ${ }^{587}$ A escolha de Comblin pela América Latina estava associada à sua concepção de ser Igreja. Thomé destaca: "desde o princípio Comblin teve consciência de que a sua vinda à América Latina não era para evangelizar, mas para contribuir com o desenvolvimento de uma identidade própria da Igreja desse continente". ${ }^{588}$ Quando ele se propôs o desafio latino-americano, sabia que era possível participar com o povo de Deus de muitas maneiras. A concepção combliniana de Igreja passava pelo compromisso com a vida e por tudo que a compõe, como relata Canova: "procurou a América Latina, tendo a informação de que aqui o Cristianismo era mais dinâmico e criativo e que a Igreja Católica entrava por novos caminhos e novas práticas libertadoras, buscando novas formas de organização comunitária e de militância cristã". ${ }^{589}$

A combinação entre seu trabalho missionário com leigos e sua reflexão pneumatológica é essencial ao interesse desta pesquisa, daí a opção por esse autor. Sousa lembra: "a prática pastoral de Comblin é reflexo de sua compreensão teológica, a exemplo dos projetos desenvolvidos no Nordeste brasileiro". $590 \mathrm{Seu}$ engajamento em uma missão voltada a leigos e por eles executada destaca esse autor na referida temática, fazendo do seu nome referência. Sousa pontua: "a experiência da missão, associada à formação de leigos e leigas, é especialmente a mais querida de Comblin". 591

\footnotetext{
${ }^{586}$ CANOVA, H., José Comblin e a Igreja dos pobres, p. 22.

${ }^{587}$ CHARLES, C. R. d. O., Comunidade segundo o Espírito, p. 20.

${ }^{588}$ THOMÉ, A. A arte de educação popular e o processo de libertação no pensamento de Comblin, p. 28.

${ }_{589}$ CANOVA, H. José Comblin e a Igreja dos pobres, p. 22.

${ }^{590}$ SOUSA, A. R. D., A prática de Comblin, p. 245.

${ }^{591}$ SOUSA, A. R. D., A prática de Comblin, p. 250.
} 
A perspectiva missionária combliniana passa diretamente pelos leigos, agentes de missão, segundo esse conceito, que pela ação do Espírito, que rege toda missão, torna-se instrumento ao se transformar em missão. Charles comenta: “a partir de então, passou a dedicar-se prioritariamente à formação de lideranças populares". ${ }^{592}$ Mais um desafio se lhe impõe, o de tentar sistematizar uma teologia para o leigo. O desafio consistia em traduzir de forma simplificada o saber teológico ao leigo. Mikuska acrescenta que ele "percebe a necessidade de se elaborar uma teologia para o leigo, superando a teologia do leigo, que foi bem exposta por Congar na sua obra 'Os leigos na Igreja'. Nessa perspectiva, na década de 1980, Comblin publica vários títulos que contém uma teologia mais acessível a todos". 593

A temática dos leigos já era refletida por Congar, entretanto Comblin lhe traz avanços significativos, pois sua prática missionária com leigos o leva ao estado secundário, o da reflexão, como afirma Magalhães: "para Comblin, a palavra povo tem uma conotação de revelação que implica uma pertença diretamente a Deus. É um conceito bíblico dentro da tradição judaico-cristã" ${ }^{594}$ Consciente da missão do povo de Deus, ele pauta sua vida pelo serviço a esse povo. Sua compreensão de povo de Deus ultrapassa os limites da Igreja Católica, como destaca Thomé:

Observa-se um traço de sua personalidade, marcante em todo o desenvolvimento de seu trabalho, a persistência no seu objetivo, que não era de evangelizar católicos, mas de contribuir para o desenvolvimento de uma Igreja com características singulares próprias ao seu continente e realidade. ${ }^{595}$

Nesse contexto Comblin busca estruturar o modo de ser missionário, fazendo da missão seu estilo de vida, como explica Sousa: "é a partir da identificação da necessidade de missionários no processo de evangelização do Nordeste que Comblin dá início, em 1989, às Escolas de Formação Missionária". ${ }^{596}$ Sua opção pela missão leiga fez perceber que esta talvez fosse

\footnotetext{
${ }^{592}$ CHARLES. C. R. O., Comunidade segundo o Espírito, p. 20.

${ }^{593}$ MIKUSZKA, Gelson Luiz. O discípulo missionário na perspectiva de José Comblin: implicações para uma paróquia missionária. Tese de Doutorado. FAJE, Belo Horizonte, 2016, p. 20.

${ }^{594}$ MAGALHÃES, C. E., Religiosidade e teologia popular à luz da eclesiologia de José Comblin. p. 40.

595 THOMÉ, A., A arte de educação popular e o processo de libertação no pensamento de Comblin, p. 29.

${ }^{596}$ SOUSA, A. R. D., A prática de Comblin, p. 251.
} 
uma resposta aos seus diversos desafios, pois ele acreditava que a ação evangelizadora dos leigos poderia dinamizar a missão. Sousa continua: "visionário que era, Comblin via na proximidade e na compreensão da realidade a formação de leigos e leigas maduros na fé e, na consciência eclesial, a saída preventiva contra a secularização que invadia a Igreja europeia na qual viveu". 597

Parece que em Comblin a temática leiga e pneumatológica está completamente sintonizada, pois na sua visão a missão do Espírito também se cumpre por meio dos leigos. Mikuszka lembra: "em 1975, escreveu seu primeiro artigo sobre o Espírito Santo, 'A missão do Espírito', observando que a teologia ocidental cristã padece da ausência do Espírito Santo". ${ }^{598}$ Mesmo no campo missionário, em plena execução de seu estilo de vida em missão, Comblin continua suas reflexões teológicas. Nessa fase, percebendo que pouca atenção era dada à pneumatologia. Mikuszka explica, a respeito do autor: “[...] já observava a carência da reflexão sobre a pneumatologia. Quando retornou ao Brasil, em 1980, além dos congressos, conferências e palestras ministradas, predominaram seu trabalho com os leigos e a elaboração do seu ensaio sobre a pneumatologia". 599 A busca do equilíbrio entre a missão e a teoria proporcionou a Comblin uma teologia composta pela integração desses elementos, caracterizando o alcance de uma missão refletida e real.

A participação do leigo na missão na noção combliniana é marcada pela popularização dos carismas. A chegada do movimento pentecostal, no início do século XX, ao protestantismo e depois ao catolicismo, intensificou a participação do povo na missão da igreja, como explica Mikuszka: "ele via a participação do leigo na Igreja com grande esperança, mas sabia que isso dependia de uma maior consciência sobre a ação do Espírito e da valorização dos carismas e ministérios eclesiais". ${ }^{600}$ Comblin estava atento às mudanças da sociedade e sua missão, voltada à atualidade, dialogava com o presente. Por isso fez adaptações e mudanças na sua concepção enquanto notava as transformações, como esclarece Sousa:

\footnotetext{
${ }^{597}$ SOUSA, A. R. D., A prática de Comblin, p. 253.

${ }^{598}$ MIKUSZKA, G. L., O discípulo missionário na perspectiva de José Comblin, p. 18.

${ }^{599}$ MIKUSZKA, G. L., O discípulo missionário na perspectiva de José Comblin, p. 19

${ }^{600}$ MIKUSZKA, G. L., O discípulo missionário na perspectiva de José Comblin, p. 19.
} 
O que queremos destacar, contudo, é que as mudanças pelas quais passou agregaram e o ajudaram positivamente a construir o direcionamento de sua teologia: como poucos, consegue colocar em consonância seu arcabouço intelectual e prático, solidificando em sua prática a compreensão teórica de que Teologia não pode ser outra coisa senão serviço. ${ }^{601}$

O dinamismo e o crescimento do pentecostalismo brasileiro, contemporâneos a Comblin, e parte do seu sucesso pode ser atribuída ao trabalho dos leigos. Na concepção dos interlocutores de Comblin, o leigo ocupa lugar de destaque, como afirma Sousa: "os missionários leigos são os que, impulsionados pelo Espírito de Jesus, assumem espontaneamente um modo de viver itinerante, evangelizando em povoados e lugares isolados e reunindo pessoas nas praças e nas ruas, com permissão da Igreja, iniciativa e disponibilidade pessoal". ${ }^{602}$ Essa participação envolve todos na missão, proporcionando integração à igreja e a anunciação do Reino. Sousa continua: "trata-se de uma expressão de Igreja itinerante que circula pelos caminhos do mundo". ${ }^{603} \mathrm{Na}$ liberdade do Espírito, todos são chamados a viver em missão, e na força do Espírito o povo de Deus se desloca na ação evangelizadora. Mikuszka afirma:

Tudo isso demonstra o esforço de Comblin em formar cristãos para agirem através da Igreja na ação evangelizadora. Essas observações nos auxiliaram a compreender que, na perspectiva de Comblin, o discípulo missionário de Jesus é toda pessoa que age pelo bem comum através dos ministérios eclesiais, orientada pelo Evangelho, na força do Espírito Santo. ${ }^{604}$

Embora tenha sido sempre importante à prática missionária no cristianismo, nunca foi tão necessário repensá-la, no seu nodo de atuar, como no nossos tempo, e o movimento pentecostal parece conseguir fazer isso em sua ação missionária, a cujo respeito declara Sousa: "ora, a prática missionária não é uma novidade para a Igreja, só que foi sendo anulada por diversas razões ao longo do tempo. Jesus foi o primeiro missionário itinerante, exemplo que foi seguido por seus discípulos". ${ }^{605}$ Sempre em sintonia com seu tempo, Comblin assume em sua missão a totalidade da força do Espírito. A partir dessa postura, a Teologia, sobretudo a pneumatologia, ganha um grande teólogo no desenvolvimento de sua reflexão, como destaca Mikuszka:

\footnotetext{
${ }^{601}$ SOUSA, A. R. D., A prática de Comblin, p. 243.

${ }^{602}$ SOUSA, A. R. D., A prática de Comblin, p. 250-251.

${ }^{603}$ SOUSA, A. R. D., A prática de Comblin, p. 250-251.

${ }^{604}$ MIKUSZKA, G. L., O discípulo missionário na perspectiva de José Comblin, p. 19.

${ }^{605}$ SOUSA, A. R. D., A prática de Comblin, p. 251.
} 
A vivência da totalidade dos ministérios a partir dos discípulos faz com que a comunidade assuma o Evangelho e viva na força do Espírito. Isso nos faz refletir que a estrutura comunitária é importante e que terá aversão às estruturas, ou tentar destituir toda institucionalidade eclesial que não auxilia a obra da evangelização. ${ }^{606}$

A contribuição de Comblin, em uma ação missionária direcionada pelo Espírito, simplifica em parte o processo estrutural, proporcionando maior mobilidade e flexibilidade na evangelização, como adverte Mikuszka: "contudo, é preciso ter consciência de que as estruturas precisam ser flexíveis e sempre abertas ao novo para servirem à ação evangelizadora". ${ }^{607}$ Ao abrir-se ao novo, o missionário, na concepção combliniana, deixa-se sempre dirigir pelo Espírito, como também pensam os interlocutores de Comblin, a exemplo de Muggler:

A vida de José Comblin, sacerdote e teólogo, é um testemunho contundente da ação do Espírito Santo. Ao narrar a trajetória de sua vida verificamos a verdade de uma das afirmações que sempre fez nas jornadas de formação missionária: A Missão não se pode planejar: temos que deixar o Espírito Santo conduzir. Podemos, sim, decidir aonde iremos; mas ao chegar, se tivermos abertura e sensibilidade ao que encontrarmos, não mais podemos planejar: cada situação exige uma resposta, uma ação, uma continuação... será o Espírito que dirá o que fazer, como prosseguir! $!^{608}$

O missionário no caminho do Espírito reinventa perspectivas de vida, encontrando o diálogo com o outro, bem como novas faces, pois o Espírito age de forma plural. Mikuszka acrescenta: "nessa perspectiva, o cristão é impulsionado pela força do Espírito Santo a agir, assumindo um novo modo de viver" ${ }^{609} \mathrm{O}$ alinhamento pneumatológico combliniano age por meio do cristão na força do Espírito. É o povo de Deus, em missão de participação, que pratica a ação evangelizadora. Mikuszka assegura: "isso nos possibilita dizer que, na perspectiva de Comblin, o discípulo missionário de Jesus é aquele que age orientado pelo Evangelho na força do Espírito e, portanto, age e vive com liberdade" ${ }^{610}$ Em sua caminhada e tentativa de propagar a missão no poder do Espírito, Comblin buscava viver na dimensão proposta pelo Espírito, aguardando seu itinerário. Muggler lembra uma de suas falas:

\footnotetext{
${ }^{606}$ MIKUSZKA, G. L., O Discípulo Missionário na Perspectiva de José Comblin, p. 21. ${ }^{607}$ MIKUSZKA, G. L., O Discípulo Missionário na Perspectiva de José Comblin, p. 21. ${ }^{608}$ MUGGLER, M. M., Padre José Comblin, 2012, p. 19.

${ }^{609}$ MIKUSZKA, G. L., O Discípulo Missionário na Perspectiva de José Comblin, p. 25.

${ }^{610}$ MIKUSZKA, G. L., O Discípulo Missionário na Perspectiva de José Comblin, p. 27.
} 
A Missão não se pode planejar. É a única coisa que não se pode planejar. Numa paróquia tudo se planeja: a catequese, a liturgia, as pastorais... mas a ação missionária não se pode planejar. É o Espírito que conduz, passo a passo. Assim falava o padre José Comblin, aos 85 anos de idade, em um retiro para jovens que se preparavam para a vida missionária, em Esperantina, Piauí. Sabedoria adquirida ao longo de seus 50 anos de vida missionária pelos caminhos da América. Atento ao Espírito, ele mesmo buscou e forjou caminhos. ${ }^{611}$

Em sua pneumatologia, Comblin retorna às bases bíblicas que destacam a temática, aproximando-se da Teologia de Paulo, o que também se verifica entre teólogos pentecostais, pois as comunidades paulinas experimentaram a missão do Espírito. Mikuszka diz: "ao refletir sobre o discípulo a partir da ação, focando diretamente a pneumatologia, Comblin afina sua reflexão com a teologia paulina". ${ }^{612}$ Além dessa sintonia com Paulo, Comblin também se aproxima de teólogos pentecostais, abrindo a possibilidade de diálogo e da cooperação com a missão, de acordo com Canova: "membro da Igreja Católica, Comblin foi amigoirmão de Teólogos e Pastores desta sua Igreja e de outras Igrejas Cristãs". ${ }^{613}$ Alguns elementos aproximam pentecostais e comblinianos, como sua pneumatologia e missão. Os vários pontos de divergência entre os escritos pentecostais e os de Comblim não inviabilizam a sua soma com a prática pentecostal, sobretudo com o pentecostalismo da Igreja do Evangelho Quadrangular.

As proporções alcançadas pela Teologia e pela vida missionária de Comblin ganham destaque em novas reflexões, de que servem como exemplo as suas várias publicações. Como afirma Cabral: "no campo dos estudos das religiões, há expoentes que são como tufões. Na Teologia, em específico, um tufão eurotropical tem nome: José Comblin! Europeu, fez-se latino-americano; nascido na Bélgica, optou por viver grande parte de sua vida no Brasil, onde Joseph ficou o nosso "bom José" [...]". ${ }^{614}$ A fase que antecede sua chegada ao Brasil passa pelo seu trabalho paroquial em Bruxelas, quando ele se encontra com a realidade e percebe que outro caminho precisava ser trilhado. Ottaviani afirma:

Em 1950, ao terminar seu doutoramento, Comblin quis colocar em prática todo o conhecimento adquirido na Universidade e pede ao Cardeal van Roey a

\footnotetext{
${ }^{611}$ MUGGLER, M. M., Padre José Comblin, 2012, p. 49.

${ }^{612}$ MIKUSZKA, G. L., O Discípulo Missionário na Perspectiva de José Comblin, p. 28.

${ }^{613}$ CANOVA, H., José Comblin e a Igreja dos pobres, p. 23.

${ }^{614}$ CABRAL, Newton Darwin de Andrade; MARQUES, Luiz Carlos Luz. Um tufão chamado José Comblin. Paralellus, Recife, v. 9, n. 22, set./dez. 2018, p. 593-596, p. 594.
} 
possibilidade de trabalhar numa paróquia. Foi nomeado vigário da Igreja Sagrado Coração, em Bruxelas. Nesse trabalho paroquial, o jovem padre percebeu a grande distância entre a religião tradicional e a sociedade. ${ }^{615}$

Comblin não vê muita perspectiva para seu trabalho na Bélgica e busca se tornar missionário. Poderia ser enviado ao continente africano, mas manifestou a intenção de servir na América Latina. Ottaviani continua: "Comblin logo se deu conta de que não haveria futuro na Igreja da Bélgica e quis se colocar em estado de missão. Não optou pelo continente africano - onde atuava seu irmão mais novo, André, da Congregação dos Missionários da África, mais conhecidos por Pères Blancs - e se colocou à disposição para partir à América Latina”. ${ }^{616}$ Nesse período no Brasil, Dom Paulo de Tarso Campos solicitou três sacerdotes doutores para a Diocese de Campinas, por ter ele próprio estudado em Lovaina. Silva diz: "nesse contexto, surge um convite da parte de Dom Paulo de Tarso Campos (que havia estudado em Lovaina), solicitando a ida de três sacerdotes que fossem doutores para a Diocese de Campinas". ${ }^{617}$ Comblin estava entre o três que viriam a Campinas, e quando soube que viria para o Brasil, deu início à sua preparação, buscando antecipar-se, pois precisava aprender a língua. Silva continua: "ao saber que viria para o Brasil, Comblin buscou de pronto ter uma intimidade com a língua. Seu entusiasmo foi tão grande que decidiu partir da Bélgica seis meses antes dos outros dois companheiros". ${ }^{618}$ Durante o trabalho missionário no Brasil, Comblin exerceu muitas funções, mas dedicou a maior parte do tempo ao Nordeste, onde a vida pedia esperança e justiça. Dias afirma: "o padre belga José Comblin trabalhou desde 1958 no Brasil como autor e ativista político-social, e viveu boa parte do tempo no Nordeste; ainda assim teve também passagem pelo Sudeste, lecionando em diversos lugares". ${ }^{619}$ Comblin poderia viver em outros lugares, levando vida mais confortável, ou ainda ter exercido a profissão de professor universitário ou outra na estrutura da Igreja, mas sentia-se vocacionado a agir. Aguiar declara: "é possível afirmar que em Comblin nada se resolve em

\footnotetext{
${ }^{615}$ OTTAVIANI, Edelcio Serafim; FREZZATO, Anderson. Teologia a Marteladas. Paralellus, Recife, v. 9, n. 22, set./dez. 2018, p. 597-619, p. 606.

${ }^{616}$ OTTAVIANI, E. S.; FREZZATO, A., Teologia a marteladas, p. 606.

${ }^{617}$ SILVA, Mariane de Almeida. Dom Paulo de Tarso Campos e a Vinda do Padre José Comblin ao Brasil. Paralellus, Recife, v. 9, n. 22, set./dez. 2018, p. 621-633, p. 624.

${ }^{618}$ SILVA, M. d. A., Dom Paulo de Tarso Campos e a Vinda do Padre José Comblin ao Brasil, p. 624.

${ }^{619}$ DIAS, Júlio César Tavares. Comblin, mais uma vez Comblin. Paralellus, Recife, v. 6, n. 11, Especial José Comblin, p. 5-8, 2015, p. 5-6.
} 
abstrações, mas em vinculação a um ativo agir". ${ }^{620}$ Ele constrói sua reflexão a partir do trabalho missionário. Ottaviani descreve uma lista de diversas áreas de conhecimento que contribuíram para a formação combliniana, e relata:

Outro aspecto que chama a atenção sobre suas "Notas" são os instrumentos que ele utiliza para ver melhor o que o circunda, ou seja, a realidade antropológica, eclesial e pastoral do Brasil no final da década de 50. Uma passada de olho pela bibliografia nos dá a ideia de que ele se cercou de sociólogos de renome, tais como Maria Isaura Pereira de Queiroz (1918), especialista em sociologia da religião e expert no conhecimento dos movimentos messiânicos, para entender a sensibilidade religiosa do brasileiro; Gilberto Freyre (1900-1987), para conhecer as raízes da cultura brasileira e os traços da formação do homem brasileiro; o filósofo e cientista político Hélio Jaguaribe (1923-2018), para o entendimento dos problemas nacionais, além de Sérgio Buarque de Holanda (1902-1982), para o conhecimento da História Geral da Civilização brasileira. No que concerne ao pensamento teológico elaborado no Brasil, Comblin cita a Revista Eclesiástica Brasileira (REB). Foram quase 50 livros lidos em pouco mais de dois anos! $!^{621}$

Seu caminhar na América Latina percorre o itinerário do Espírito, por isso conheceu várias faces da realidade do povo, tornando-se profundo conhecedor da cultura e da fé. A partir desse conhecimento, ele apontava as novas perspectivas e desafios. Suess diz: "caminhada e movimento, palavras-chave de sua biografia, o levaram para Campinas, São Paulo, Santiago do Chile, Recife, Camaragibe (PE), Quito, Riobamba, Lovaina, Talca, Serra Redonda (PB), Bayeux (1995), na periferia de João Pessoa (PB), e, finalmente, para Barra (BA)". ${ }^{622}$ Sua cooperação na formação de uma Teologia contextualizada na América Latina passa pela Teologia da Libertação, da qual foi um dos fundadores, além de desenvolver outras teologias que buscavam inserir-se na realidade. Dias afirma: "foi um dos fundadores da Teologia da Libertação. De seu contato com grupos rurais nasceu sua metodologia de estudos que veio a se chamar 'Teologia da enxada'. Viveu no Chile de 1962 até 1965, quando voltou para o Brasil para trabalhar com Dom Helder Câmara, em Recife". ${ }^{623}$ Comblin, como mestre, desenvolveu seu trabalho a partir do círculo de ação em que levava o discípulo a pensar sua realidade e transformá-la. Foi um grande pedagogo que acreditava que o essencial da igreja é estar em missão. Soares esclarece: "grande pedagogo, deixa discípulos e

\footnotetext{
${ }^{620}$ AGUIAR, J. R. d. A., José Comblin: um intelectual orgânico em tempo de neoliberalismo, p. 25.

${ }^{621}$ OTTAVIANI, E. S.; FREZZATO, A., Teologia a marteladas, p. 609.

${ }^{622}$ SUESS, Paulo. Missionário migrante - teólogo militante José Comblin: O retorno do enviado do Pai. Paralellus, Recife, v. 6, n. 11, Especial José Comblin, p. 75-80, 2015, p. 78.

${ }^{623}$ DIAS, J. C. T., Comblin, mais uma vez Comblin, p. 5-6.
} 
discípulas em diversos campos, desde o pensar teológico até o exercício da tarefa de evangelização e da ação pastoral. Para ele, essencial na Igreja é sentir-se enviada, missionária". ${ }^{624}$ Comblin escreve a partir da realidade, principalmente após sua chegada ao Nordeste, e sobre os desafios que lhe se apresentavam, e seus escritos permanecem muito atuais. Como afirma Hoornaert: "os escritos de José Comblin estão quase todos relacionados a questões da atualidade". ${ }^{625}$ A definição de Comblin é mais um desafio para seus comentadores, pois é grande a diversidade de seus escritos, tendo ele transitado por várias áreas. E em sua atuação ainda pode ser definido amplamente, como explica Soares:

Neste sentido, foi radicalmente político, porque profeta, político e amplamente ecumênico. Daí, sua fina atenção à profecia e ao Espírito Santo em confronto com os sistemas de poder. Não por acaso escreveu muito sobre o Espírito. Entre outros textos, "A Força da Palavra", "O Tempo da Ação", "O Espírito Santo e a Libertação", "O Espírito Santo e a Tradição de Jesus", e "Vocação para a Liberdade"...626

O pensamento combliniano reproduz a centralidade do contexto teológico que o gerou a partir da relação da igreja com os pobres. Soma-se isso o impacto sofrido em campo de missão, quando em contato com a realidade nordestina e o legado dos missionários que o antecederam nessa terra, a exemplo do Padre Ibiapina. Aguiar esclarece: "a organicidade do pensamento de Comblin está relacionada principalmente à sua profunda vinculação com a cultura, a história e a política da classe subalterna". ${ }^{627}$ Sua metodologia de ensino era muito questionadora, provocando os ouvintes e os levando à reflexão para que chegassem a certas conclusões. Dias afirma: "não se interessava apenas por 'ensinar', sua maneira de produzir Teologia era 'provocar' para que as pessoas não só 'aprendessem' mas, sobretudo, 'apreendessem' (agarrassem o objeto) e fizessem o processo de reflexão por elas mesmas, mesmo que as conclusões não fossem necessariamente as suas". ${ }^{628}$ Durante o período em que esteve em missão sofreu repressão, pois sempre participou das lutas, não se omitindo, e por isso

\footnotetext{
${ }^{624}$ SOARES, Sebastião Armando Gameleira. José Comblin, homem do Espírito. Paralellus, Recife, v. 6, n. 11, Especial José Comblin, p. 51-58, 2015, p. 56-57.

${ }^{625}$ HOORNAERT, Eduardo. O tema da transformação no pensamento de José Comblin. Paralellus, Recife, v. 6, n. 11, Especial José Comblin, p. 29-42, 2015, p. 30.

${ }^{626}$ SOARES, S. A. G., José Comblin, homem do Espírito, p. 53.

${ }^{627}$ AGUIAR, J. R. d. A., José Comblin: um intelectual orgânico em tempo de neoliberalismo, p. 26.

${ }^{628}$ SOARES, S. A. G., José Comblin, homem do Espírito, p. 54.
} 
sofreu com o povo. Produziu muitos artigos e livros, e participou de muitos eventos, como lembra Dias:

Por sua pastoral atuante e por sua visão crítica sofreu a repressão política no Brasil, de onde foi expulso pelo governo militar em 1972 e no Chile, de onde foi expulso em 1980. Faleceu no mês de março 2011, aos 88 anos. Escritor profícuo, por ocasião dos seus oitenta anos fez-se um levantamento de sua produção que na época já contabilizava 309 títulos de sua produção de artigos e conferências. ${ }^{629}$

Comblin passou a vida entre o povo nordestino, como afirma Suess: "dia 27 de março, no $3^{\circ}$ Domingo da Quaresma, pelas 8h30, José Comblin partiu para a sua Grande Viagem, como costumava dizer, e retornou à casa do Pai. Faleceu no pequeno sítio 'Recanto da Transfiguração', município de Simões Filho (BA), na periferia da metrópole de Salvador (BA)". ${ }^{630}$ Sua partida foi marcada pela simplicidade e discrição que nutria, e de forma tranquila encerrou sua missão ao preparar-se para mais um dia. Mas antes de sair ao encontro do seu povo, voltou novamente até a cama. Naquele dia o peregrino nos deixou. Suess relata os detalhes:

Hospedado num apartamento, na sacristia da capela do "Recanto da Transfiguração", no dia de sua "Grande Viagem", o peregrino fez a barba, como sempre, tomou seu remédio, colocou o relógio e abriu as duas portas de passagem para a capela e o jardim. Logo retornou. Monica, que o viu do outro lado do jardim, logo veio com um guarda-chuva, pois garoava. Chamou: "José!" - silêncio. Adentrou até o quarto e lá estava José sentado na cama, inerte. Mais tarde, o cardiologista constatou uma embolia cerebral. Morte instantânea. Na hora do crepúsculo, dom Cáppio convidou a celebrar a Eucaristia de corpo presente. Com um sorriso velado nos lábios, José irradiava paz. Terça-feira, dia 28 , foi sepultado no município de Solânea (PB), ao lado do padre-mestre Ibiapina, como era seu desejo. $^{631}$

Depois de tantas peregrinações Comblin guarda a fé, mas sua obra e seu legado permanecem para a Teologia e para missão. Brito diz: "Padre Comblin ou Padre Zé, como o chamava o povo pobre de sua convivência, partiu em peregrinação definitiva no dia 27 de março de 2011 " ${ }^{632}$ Sua vida a serviço do povo nordestino fez de Comblin grande conhecedor dessa cultura de forma

\footnotetext{
${ }^{629}$ DIAS, J. C. T., Comblin, mais uma vez Comblin, p. 5-8, 2015. p. 6.

${ }^{630}$ SUESS, P., Missionário migrante - teólogo militante José Comblin: O retorno do enviado do Pai, p. 78.

${ }^{631}$ SUESS, P., Missionário migrante - teólogo militante José Comblin: O retorno do enviado do Pai, p. 79.

${ }^{632}$ BRITO, José Artur Tavares de. "O que escutei do Padre Comblin...". Paralellus - Recife, v. 4, n. 7, p. 33-41, jan./jun. 2013, p. 38.
} 
diferenciada e ele soube utilizar deste conhecimento em sua atuação. Cabral afirma: "do meio século vivido na América Latina, em grande parte dele residiu e atuou no Nordeste do Brasil, onde hauriu de sua cultura como poucos nativos da região souberam (ou sabem) fazer". ${ }^{63}$ Desse jeito o missionário José Comblin passou a vida em missão na força do Espírito.

\subsection{2.}

\section{Alguns precedentes da teologia de Comblin}

Para compreender as bases comblinianas, é importante conhecer um pouco de seus antecedentes na temática pneumatológica e do laicato. Acredita-se que um dos influenciadores de Comblin seja o dominicano francês Yves Congar. Ele antecedeu Comblin e foi um dos maiores teólogos do século XX. Yves Congar influenciou muitos teólogos, principalmente nos temas em pauta nesta pesquisa, o laicato e a pneumatologia. Fagundes afirma: "um dos maiores desafios à aproximação do pensamento de Yves Congar é justamente sua abundância e criatividade sem a correspondente organicidade". ${ }^{634}$ Durante sua vida Congar vivenciou várias mudanças que o fizeram progredir em sua Teologia, percebendo sérios desafios no cristianismo, e dedicou-se a refletir. Tornou-se importante teólogo e contribuiu com o Concílio Vaticano II, destacando-se na reflexão pneumatológica. Fagundes explica:

Yves Congar (1905-1995) foi testemunha privilegiada das grandes transformações que construíram o século XX. Desde cedo abraça o desafio de refletir também teologicamente a realidade que o cerca. Após muitas incompreensões e dissabores acaba sendo reconhecido em muitas intuições (refaz muitas outras) e presta decisiva contribuição ao Concílio Vaticano II como perito e redator. Teólogo múltiplo, abordou a problemática da vocação laical, desenvolveu o conceito de Eclesiologia de comunhão e, instado por desafios como o da Renovação Carismática Católica (mas não só), lançou-se à reflexão pneumatológica. ${ }^{635}$

O alcance teológico das reflexões congarianas foi de bastante relevância, pois ele trabalhou temas pertinentes à Igreja. Tais assuntos careciam de

${ }^{633}$ CABRAL, N. D.; D. A., MARQUES, L. C. L., Um tufão chamado José Comblin, p. 594.

${ }^{634}$ FAGUNDES, Claudiberto . A "Pneumatologia Cristológica" de Yves Congar e a Cristologia do "Pro-Seguimento com Espírito" de Jon Sobrino uma Proposta para um Mundo Desigual e Plural. Dissertação de Mestrado. PUC-RS. Porto Alegre, 2006, p. 52.

${ }^{635}$ FAGUNDES, C., A "Pneumatologia Cristológica" de Yves Congar e a Cristologia do "ProSeguimento com Espírito" de Jon Sobrino uma Proposta para um Mundo Desigual e Plural, p. 10. 
atualização para a proposição de um diálogo com as novas realidades. Como relata Baylão: "as características da teologia de Congar perpassam sua experiência e sua história de vida pessoal que o encaminharam a teologizar sobre temas de grande importância para a Igreja, tais como: a pneumatologia; o ecumenismo; a eclesiologia; a cristologia". ${ }^{636}$ Quando Congar iniciou seus ensaios e primeiras publicações, Comblin estava em formação teológica, era estudante. A escolha de Congar de mapeamento dos antecedentes da teologia combliniana pressupõe que Comblin sofra sua influência, principalmente na temática pneumatológica e do laicato. Amaral informa:

Em 1941 o dominicano francês escreveu os seus Ensaios sobre o mistério da Igreja, com quatro capítulos e dois apêndices sobre a eclesiologia de Möhler. Em 1952 introduziu nesse mesmo livro um quinto capítulo (ou ensaio) e retirou os apêndices dedicados ao teólogo de Tubinga. O novo ensaio realizava uma análise do Espírito Santo e do corpo apostólico enquanto realizadores da obra de Cristo. Congar tinha a intenção de explicar que Cristo tinha fundado a Igreja enviando os Apóstolos e o Espírito. $^{637}$

O teólogo dominicano escreveu sobre diversos temas, buscando aproximação entre a Teologia e a prática cristã, visando às experiências das primeiras comunidades cristãs. Segundo Couto: "os primeiros escritos de Yves Congar inserem-se dentro do vasto movimento da eclesiologia católica para restaurar a consideração do elemento interno da Igreja, numa teologia à luz do Corpo místico". ${ }^{638}$ Os escritos congarianos tornam-se atuais ao dialogarem com os estudos contemporâneos a partir da compreensão do termo ruah, que evoca movimento e ação. Baylão diz:

É possível então afirmar que a reflexão de Congar está em concordância com os estudos exegéticos atuais que demonstram que a compreensão sobre o Espírito Santo está mais ligada à experiência que ao próprio significado das palavras. Na acepção etimológica da palavra, ruah pode significar simplesmente um movimento de ar surpreendente e forte. ${ }^{639}$

\footnotetext{
${ }^{636}$ BAYLÃO, Alexandre. A Pneumatologia no Pensamento de Yves Congar. Dissertação de Mestrado: PUC-SP. São Paulo, 2016, p. 12.

${ }^{637}$ AMARAL, Miguel de Salis. O Espírito Santo e a Igreja: respostas de Congar e do Concílio Vaticano II à questão "carisma e instituição". Teocomunicação, Porto Alegre, v. 41, n. 2, p. 200220, jul./dez. 2011, p. 204.

${ }^{638}$ COUTO, A. Sílvio. A Igreja peregrina à luz da Trindade na eclesiologia de Yves Congar. Didaskalia. Lisboa. ISSN 0253-1674. 34:2 (2004) 145-194, p. 147.

${ }^{639}$ BAYLÃO, A., A Pneumatologia no Pensamento de Yves Congar, p. 23.
} 
Na percepção congariana, que vê a missão do Cristo e do Espírito na mesma proporção de igualdade, mesmo com características distintas, ambas se completam. Para Congar, o Espírito é constituinte da Igreja. Achille afirma: "se a Igreja é obra de Cristo e missão do Espírito Santo, então o Cristo é aquele que instituiu a Igreja. Segundo os próprios termos de Yves Congar, é o Espírito o coinstituinte da Igreja". ${ }^{640}$ Seguindo esse pensamento, o Espírito não se resume a um papel auxiliar, mas desenvolve sua missão no mundo em curso, e este tempo da história é a missão do Espírito. Baylão explica:

O Espírito Santo possui sua missão no mundo e a realiza na Igreja e através dela, sendo ela fruto desta missão. Na Igreja, e por ela, o Espírito Santo age como continuidade do ato auto-comunicador de Deus à sua criação, onde Ele se deixa perscrutar. Em sua teologia, Congar apresenta considerações sobre como o Espírito Santo é fonte e fundamento da Igreja, dando a ela seus princípios existenciais e também a munindo de dons e carismas para que possa alcançar seu objetivo e realizar sua tarefa de ser sinal sacramental de Deus, manifestando seu amor e promovendo o Evangelho de Cristo. ${ }^{641}$

A preocupação do teólogo Yves Congar em contribuir na reflexão sobre o papel do Espírito na Igreja o levou a continuar a escrever sobre o tema. Os resultados de suas pesquisas possibilitaram uma reflexão da Igreja sobre sua própria atuação. Amaral diz: "o dominicano francês aprofundou as suas ideias sobre a relação Espírito-Igreja nos anos seguintes, especialmente depois do Concílio Vaticano II. De fato, nos anos 1979-1980, Congar publicou três livros sobre o Espírito Santo". ${ }^{642}$ Todo o esforço de Congar visava a preservar o lugar do Espírito, corrigindo uma teologia desequilibrada que valorizou mais a cristologia, deixando a pneumatologia de lado. Fagundes esclarece:

Congar propõe uma Cristologia pneumatológica e histórica. Tais realidades estão intimamente unidas - não há Cristologia sem Pneumatologia e vice-versa - e operam conjuntamente em vista da santificação e da redenção de todo o universo. Dessa forma, Cristologia e Pneumatologia desembocam na antropologia e conjugam, sem radicalizações ou contraposição, carisma e instituição em favor da pessoa humana. ${ }^{643}$

\footnotetext{
${ }^{640}$ ACHILLE, Atta Amichia. A ação do Espírito Santo e a Missão da Igreja frente ao desafio do Pentecostalismo da Igreja Universal do Reino de Deus. Tese de Doutorado. PUC-SP. São Paulo 2012, p. 75.

${ }^{641}$ BAYLÃO, A., A Pneumatologia no Pensamento de Yves Congar, p. 56.

${ }^{642}$ AMARAL, M. D. S., O Espírito Santo e a Igreja: respostas de Congar e do Concílio Vaticano II à questão "carisma e instituição", p. 206.

${ }^{643}$ FAGUNDES, C., A "Pneumatologia Cristológica" de Yves Congar e a Cristologia do "ProSeguimento com Espírito" de Jon Sobrino uma Proposta para um Mundo Desigual e Plural, p. 53.
} 
Percebem-se traços das reflexões de Congar na pneumatologia combliniana, que segue a ideia de Espírito como força que participa dessa dinâmica, bastante utilizada por Comblin. Fagundes acrescenta: "Congar, portanto, conclui sua breve reflexão sobre o significado e ou etimologia do termo ruah dizendo que o espíritosopro é aquele que age e faz agir e, quando se trata do Sopro de Deus, anima e faz agir, mas, especificamente para realizar o desígnio de Deus, e realizar seu plano". ${ }^{644}$ A problemática em torno do significado da palavra ruah leva o autor à revisão, pois seu sentido torna-se incoerente com a proposta original. A questão, relacionada à prática cristã, é importante, não se restringindo ao campo teórico. A recuperação do termo toca diretamente a ação missionária. Baylão continua:

[...] inicia sua abordagem pela definição e importância do termo ruah na experiência do Povo de Israel e que é traduzido posteriormente para o grego como pneuma significando sopro, respiração, ar, vento ou alma, e até mesmo pode-se encontrar este termo traduzido no sentido específico de "sopro" no Novo Testamento, que, segundo Congar dá ao texto bíblico um realismo que o termo cristão "espírito" pode não oferecer. ${ }^{645}$

$\mathrm{Na}$ tentativa de ressignificar o papel do Espírito, como diz Baylão, "Congar reconhece que apenas o sentido léxico do termo não é capaz de satisfazer a necessidade de se encontrar o sentido real" ${ }^{646}$ Fugindo à limitação e à abstração, Congar prefere o sentido de sopro de Deus, concepção que proporciona acontecimentos. Baylão segue: “é possível, como indica o próprio autor, encontrar vários sentidos e qualificações para o termo ruah-pneuma, mas para ele o qualificativo que mais interessa é o de Espírito ou sopro de Deus, que expressa toda a força e o poder do sujeito pelo qual as coisas acontecem [...]". ${ }^{647} \mathrm{Em}$ Congar não é possível ter Igreja sem Espírito, assim sua pneumatologia aponta para uma missão do Espírito na Igreja, como afirma Achille:

Sem o Espírito Santo não há Igreja. Entre 1975-1985, Yves Congar manifesta sua sensibilidade em relação à dimensão pneumatológica da Igreja. Entre 1979-1981, ele publica "Eu creio no Espírito", em três volumes sobre a crença do teólogo

\footnotetext{
${ }^{644}$ BAYLÃO, A., A Pneumatologia no Pensamento de Yves Congar, p. 22-23.

${ }^{645}$ BAYLÃO, A., A Pneumatologia no Pensamento de Yves Congar, p. 22.

${ }^{646}$ BAYLÃO, A., A Pneumatologia no Pensamento de Yves Congar, p. 23.

${ }^{647}$ BAYLÃO, A., A Pneumatologia no Pensamento de Yves Congar, p. 23.
} 
francês na divindade e no poder do Espírito Santo. Yves Congar reinterpreta quatro modos da ação do Espírito a partir de quatro notas de Igreja. ${ }^{648}$

Congar abre caminho para a reflexão da relação entre a Igreja e o Espírito, visando a construir um pneumatologia sintonizada com a missão da Igreja, como refere Couto: “desta forma Yves Congar abre-nos à consideração da acção eclesial do Espírito Santo ou, dito por outras palavras, a Igreja na sua relação com o Espírito Santo". ${ }^{649}$ O teólogo nutria grande sensibilidade aos desafios apresentados, e suas reflexões buscam contribuir para o caminhar da Igreja. Por isso dedicou-se ao aprofundamento de uma eclesiologia pnematológica, entendendo ser essa a direção a tomar diante das novas realidades, como esclarece Couto:

É o Espírito Santo quem põe a Igreja em movimento. Isso mesmo procurou Yves Congar aprofundar na sua eclesiologia pneumatológica, desenvolvida nos anos anteriores ao Concílio Vaticano II, vivida ao tempo do Concílio e, a partir de 1967, mais profundamente esclarecida, de forma particular, em Je crois en Esprit-Saint (1979-1980) e La Parole et le Souffle (1984). ${ }^{650}$

A influência congariana chega ao Vaticano II, como lembra Amaral: “quando Congar considerava a pneumatologia do Concílio Vaticano II - no seu livro Eu creio no Espírito Santo (publicado em 1979-1980) -, recordava-nos que o Concílio tinha retomado a comparação entre os aspectos visível e espiritual, humano e divino, da Igreja, e a união das duas naturezas em Cristo". ${ }^{651}$ Pode-se considerar Congar um teólogo inovador ao refletir sobre uma pneumatologia participante em que o Espírito funda a Igreja e a conduz em missão, como lembra Amaral: "este pressuposto tão rico podia ser desenvolvido de muitos modos. De fato, no livro Eu creio no Espírito Santo, Congar afirmava que o Espírito funda a Igreja, e aprofundava os modos e as condições através das quais isso se realizava". ${ }^{652}$ Congar esteve à altura dos desafios do seu tempo, foi ousado e por vezes incompreendido, mas suas reflexões teológicas foram essenciais, como comenta Fagundes:

\footnotetext{
${ }^{648}$ ACHILLE, A., A. A Ação do Espírito Santo e a Missão da Igreja Frente ao Desafio do Pentecostalismo da Igreja Universal do Reino de Deus, p. 76.

${ }^{649}$ COUTO, A. S., A Igreja peregrina à luz da Trindade na eclesiologia de Yves Congar, p. 158.

${ }^{650}$ COUTO, A. S., A Igreja peregrina à luz da Trindade na eclesiologia de Yves Congar, p. 165.

${ }^{651}$ AMARAL, M. D. S., O Espírito Santo e a Igreja: respostas de Congar e do Concílio Vaticano II à questão "carisma e instituição", p. 216.

${ }^{652}$ AMARAL, M. D. S., O Espírito Santo e a Igreja: respostas de Congar e do Concílio Vaticano II à questão "carisma e instituição", p. 216.
} 
Congar acabou por tornar-se um retrato da própria situação da Igreja do século XX com suas contínuas evoluções, retrocessos, correções. É o preço que se paga por "ser um homem afinado com sua época". Tematizando o Espírito Santo, é levado à explicitação das relações indissociáveis entre e a Pneumatologia e a Cristologia, e evolui: se não é possível encontrar o tema em seus primeiros escritos cristológicos, acabará por tratar exaustivamente o assunto em obras posteriores. O Espírito Santo o levou à Cristologia; é ela o paradigma: viver no Espírito Santo é fazer o que Jesus fez. A grande obra do Espírito é a Encarnação: não há vida segundo o Espírito sem os pés fincados na realidade, sem assumi-la, sem transformá-la como Jesus fez. ${ }^{653}$

A teologia congariana embarca no novo, que corresponde à ação do Espírito e à sua missão, mesmo consciente de que o novo enfrenta desconfiança. Sua dedicação à justificação do agir do Espírito, buscando dialogar com outras faces da teologia, é destacada por Baylão: "a teologia de Congar reconhece e justifica, assim como a Teologia Clássica, a ação do Espírito Santo na história e que este agir do Espírito Santo visa o cumprimento de sua missão. O Espírito Santo 'suscita o novo, embora esse novo seja para nós algo desconcertante". ${ }^{654} \mathrm{Na}$ teologia congariana, Pneumatologia e Cristologia caminham juntas, completandose, mas ele aponta a necessidade de renovação, algo proporcionado a partir da animação do Espírito, que atualiza a ação missionária, como afirma Fagundes:

A Cristologia é a garantia de que a Pneumatologia não se transforme em sedativo, ópio alienante. A Pneumatologia é a garantia de que a Cristologia não se paralise em esquemas ultrapassados ou cristalizados apenas como uma institucionalização burocrática. A dinâmica do Espírito busca respostas sempre mais atuais, renova estruturas, modifica e anima para que o Evangelho não pare, para que não emudeça sua força transformadora, para que não envelheça a eterna novidade do Reino de Deus. Mas não é a mudança pela mudança, não se trata de fazer concessões para agradar: não há, enfim, Espírito sem Verbo. O caminho de Congar, partindo do primeiro, encontra, necessariamente, o segundo. É isso que garante a atualidade de sua contribuição. ${ }^{655}$

As reflexões de Congar inspiraram uma geração de teólogos com temas diversificados, porém atuais, que precisavam de atenção. Seus trabalhos abrangeram assuntos como ecumenismo, laicato e a missão na perspectiva pneumatológica, entre outros, como lembra Couto: “Congar despertou, reflectiu e propôs alguns dos temas que fizeram a eclesiologia do pós-Concílio Vaticano II:

${ }^{653}$ FAGUNDES, C., A "Pneumatologia Cristológica" de Yves Congar e a Cristologia do "ProSeguimento com Espírito" de Jon Sobrino uma Proposta para um Mundo Desigual e Plural, p. 100. ${ }^{654}$ BAYLÃO, A., A Pneumatologia no Pensamento de Yves Congar, p. 47.

${ }^{655}$ FAGUNDES, C., A "Pneumatologia Cristológica" de Yves Congar e a Cristologia do "ProSeguimento com Espírito" de Jon Sobrino uma Proposta para um Mundo Desigual e Plural, p. 100. 
ecumenismo, teologia do laicato e do sacerdócio, a reflexão sobre a Igreja, o sentido da missão num aprofundamento pneumatológico". ${ }^{656}$ A missão da Igreja está diretamente associada à missão do Espírito, e os desafios examinados à luz da reflexão teológica caminharam para uma eclesiologia mais pneumatológica, como afirma Amaral: "trata-se de um dos valores indicados pelo Concílio Vaticano II e justamente acolhido nas principais pesquisas eclesiológicas que procuram valorizar a dimensão pneumatológica da Igreja, como a de Congar". ${ }^{657}$

Essa direção alcança o segundo estágio e ganha destaque na teologia de Congar, que aponta para a participação do leigo na missão. A partir de suas ricas reflexões, Congar percebeu que a missão do Espírito passa pelo leigo, como destaca Couto: "é o Espírito Santo quem suscita na Igreja a atividade profética Congar aprofunda-o em Vraie et fausse réforme dans l'Eglise -, coloca os leigos a assumir a sua vocação e missão - veja-se Jalons pour ume théologie du laicat -, coloca a Igreja numa tensão escatológica e em abertura ao mundo". ${ }^{658}$ A participação do leigo é vinculada, na teologia congariana, a partir do termo Povo de Deus, compreendendo estes como inseridos na missão do Espírito. Couto continua: "Yves Congar empenhou-se, em Jalons pour une théologie du laicat (1953), em definir o leigo duma forma intra-eclesial a partir da sua pertença batismal ao Povo de Deus". ${ }^{659}$ Ele fundamenta sua teologia do laicato a partir de apontamentos do interesse pelo mundo, pois a responsabilidade diante de toda a criação envolve o leigo e todos. Couto destaca: "outro aspecto apresentado por Congar, na definição de leigo, foi o interesse pelo mundo, numa descoberta positiva de um conjunto de responsabilidades, de tarefas e de compromissos que são a sorte do homem desde a Criação até à Cidade eterna", 660

O desenvolvimento da teologia de Congar considera a crítica oriental da desvalorização da pneumatologia no Ocidente, contribuindo para uma eclesiologia em harmonia com a pneumatologia e assegurando o envolvimento do leigo na ação missionária na força do Espírito. Fagundes explica:

\footnotetext{
${ }^{656}$ COUTO, A. S., A Igreja peregrina à luz da Trindade na eclesiologia de Yves Congar, p. 145.

${ }^{657}$ AMARAL, M. D. S., O Espírito Santo e a Igreja: respostas de Congar e do Concílio Vaticano II à questão "carisma e instituição", p 220.

${ }^{658}$ COUTO, A. S., A Igreja peregrina à luz da Trindade na eclesiologia de Yves Congar, p. 165.

${ }^{659}$ COUTO, A. S., A Igreja peregrina à luz da Trindade na eclesiologia de Yves Congar, p. 184.

${ }^{660}$ COUTO, A. S., A Igreja peregrina à luz da Trindade na eclesiologia de Yves Congar, p. 184.
} 
Na medida em que avança sua reflexão, vai mostrando-se uma vez mais o Congar pensador da Eclesiologia. Uma Eclesiologia que pretende ser pneumatológica, aberta à crítica oriental nesse ponto e capaz de avaliar erros e percalços, avanços e conquistas. Tematiza o Vaticano II e a sua importância para uma nova elaboração pneumatológica da Igreja que ultrapasse as estruturas inserindo-a no serviço ao mundo. Nesse serviço o leigo tem um papel importantíssimo [...]. ${ }^{661}$

O resultado da teologia do laicato de Congar está estruturado sobre dois princípios fundamentais, o apostolado e a missão da Igreja, como afirma Couto: "poderemos apresentar a perspectiva de Yves Congar sobre a teologia do laicado sob duas coordenadas principais: apostolado dos leigos e vocação da Igreja no mundo". ${ }^{662} \mathrm{O}$ autor foi responsável por iniciativas que abriram o caminho para outros teólogos, dedicando-se à busca de respostas que correspondessem ao mundo e a suas profundas transformações. Ele pautou temas importantes e complicados, entretanto buscou proporcionar o diálogo e encontrar caminhos. Fagundes explica:

\begin{abstract}
O primeiro, dominicano europeu cuja vida abarcou a quase totalidade do século passado, viu desenvolverem-se os primeiros impulsos de renovação que, cultivados, levariam ao Concílio. Engajou-se na procura de respostas e de novas maneiras de propor as verdades da fé a fim de descobrir como a mensagem cristã pode ser vivida num contexto plural onde a Igreja é apenas mais "uma voz entre outras". O movimento de renovação o levou ao estudo do laicato e deste à Eclesiologia. Dentro dela debateu-se com a Renovação Carismática e partiu para o estudo da Pneumatologia. Tantos desafios geraram uma obra que, embora carecendo de maior organicidade, não pode ser apontada como desligada das principais questões que o mundo moderno propôs à discussão. ${ }^{663}$
\end{abstract}

As reflexões congarianas também chegaram ao Concílio Vaticano II, num trabalho de atualização que desafiava a Igreja. Baylão destaca: "assim sendo, Congar colaborou muitíssimo para que no Concílio Vaticano II algumas mudanças importantes acontecessem em relação à Teologia do Laicato". ${ }^{664} \mathrm{O}$ engajamento em constantes e novos desafios em defesa da Igreja a uma eclesiologia contextualizada levou o autor ao ecumenismo em suas reflexões, como afirma Fagundes: “tal 'Eclesiologia total' fez de Congar um tematizador

\footnotetext{
${ }^{661}$ FAGUNDES, C., A "Pneumatologia Cristológica" de Yves Congar e a Cristologia do "ProSeguimento com Espírito" de Jon Sobrino uma Proposta para um Mundo Desigual e Plural, p. 54. ${ }^{662}$ COUTO, A. S., A Igreja peregrina à luz da Trindade na eclesiologia de Yves Congar, p. 185.

${ }^{663}$ FAGUNDES, C., A "Pneumatologia Cristológica" de Yves Congar e a Cristologia do "ProSeguimento com Espírito" de Jon Sobrino: uma proposta para um mundo desigual e plural, p. 99100.

${ }^{664}$ BAYLÃO, A., A pneumatologia no pensamento de Yves Congar, p.15.
} 
constante do ecumenismo derivado, em última instância, do próprio Espírito Santo". 665

$\mathrm{Na}$ investigação de elementos contributivos de sua pneumatologia, Congar percebe que João reunia importante fundamento bíblico para a defesa de uma cristologia pneumatológica, não podendo dissociar as duas, pois haveria desequilíbrio, como já apontado antes. Baylão esclarece: "Congar encontra em João também fundamentação bíblica para sua afirmação de que a única cristologia que podemos defender é pneumatológica, e a cristologia que sofre da ausência do Espírito Santo pode vir a tornar-se cristomonismo". ${ }^{666}$ Congar entende o ecumenismo como decisivo para a compreensão de que o serviço missionário passa pelo diálogo. Baylão continua: "do ponto de vista de Congar, a abertura ao diálogo ecumênico não é somente importante, mas necessária e indispensável para que a Igreja possa viver plena e puramente sua vida e missão no mundo". ${ }^{667}$ A descrição de alguns aspectos do trabalho de Congar, ao tratar aqui de José Comblin, justifica-se por ser ele precursor em muitas frentes que mais tarde Comblin assumiria em sua Teologia. Antes do Vaticano II, Congar já buscava o diálogo com outros cristãos, situando-se muito à frente do seu tempo, como afirma Couto:

\begin{abstract}
A atitude de Yves Congar no diálogo com os "outros" cristãos antes do Concílio Vaticano II será vista por alguns como tolerada, por outros como provocadora, mas para os cristãos não-católicos, como uma abertura da própria Igreja Católica. A vocação ecumênica, bebeu-a Yves Congar no contexto sócio-religioso onde nasceu, tendo sido cultivada pelo ambiente da escola teológica dominicana Le Saulchoir. Com efeito, esta, através da refontalização bíblico-patrística e do estudo intenso, preparou, de forma tenaz, teólogos de têmpera lutadora e humilde. ${ }^{668}$
\end{abstract}

No conjunto de sua Teologia, o teólogo dominicano foi protagonista em seu tempo ao afirmar que o Espírito não veio somente animar, mas agir, intervir e transformar. Amaral afirma: "Congar esclarecia o seu significado, considerando que o Espírito não tinha vindo só para animar [...]". ${ }^{669}$ Ao analisar as reflexões teológicas de Congar é possível perceber a sensibilidade do autor quanto a

${ }^{665}$ FAGUNDES, C., A "Pneumatologia Cristológica" de Yves Congar e a cristologia do "PróSeguimento com Espírito" de Jon Sobrino uma proposta para um mundo desigual e plural, p. 54. ${ }^{666}$ BAYLÃO, A., A pneumatologia no pensamento de Yves Congar, p. 33.

${ }^{667}$ BAYLÃO, A., A pneumatologia no pensamento de Yves Congar, p. 16.

${ }^{668}$ COUTO, A. S., A Igreja peregrina à luz da Trindade na eclesiologia de Yves Congar, p. 187.

${ }^{669}$ AMARAL, M. D. S., O Espírito Santo e a Igreja: respostas de Congar e do Concílio Vaticano II à questão "carisma e instituição", p. 217. 
temáticas de muita importância para missão da Igreja e seu caminhar no mundo. Couto diz: "a abordagem do pensamento de Yves Congar permite-nos compreender o seu grande amor à Igreja como reflexo da Santíssima Trindade, enquanto peregrina e condutora de peregrinos". ${ }^{670}$ Sua compreensão ultrapassa os limites de sua igreja e alcança o diálogo com os demais cristãos, razão pela qual Couto afirma:

Yves Congar é conhecido e será recordado antes de mais como ecumenista, pioneiro do ecumenismo doutrinal dentro da Igreja Católica desde os anos 30, sobretudo com a sua obra Chrétiens désunis. Principes d'un "oecuménisme" catholique (1937), em que contribuiu, como poucos, para a preparação, remota e próxima, do Concílio Ecuménico Vaticano II. ${ }^{671}$

A vocação para o ecumenismo de Congar inicia-se antes de ele se tornar o influente teólogo do século $\mathrm{XX}$, tendo contato com o protestantismo, o que o ajudou a compreender o outro. Assim, ele trouxe sua experiência pessoal à sua Teologia, como esclarece Couto:

\begin{abstract}
A preparação para a vocação ecuménica de Yves Congar remonta à sua origem: Sedan é um dos grandes centros do protestantismo dos séculos XVI e XVII, onde o pequeno Yves tem discussões "teológicas" sobre a missa com o filho do pastor, partilhando com os calvinistas a capela que o ministro destes pusera à disposição do 'cura' católico após a destruição da Igreja pelos ulanos. Foi sobretudo no Saulchoir que esta inquietação floresceu, convertendo-se num desejo progressivo de trabalhar (intelectual e pastoralmente) pela unidade dos cristãos. ${ }^{672}$
\end{abstract}

A vida e a teologia de Congar parece ter repercutido em muitos teólogos, inclusive Comblin, que compartilha aspectos de seu pensamento com a Teologia congariana. Mas enquanto José Comblin é um teólogo que vem da esteira do Vaticano II, Congar antecedeu o Concílio em alguns de seus temas e parece influenciar alguns de seus temas. Assim, Congar parece ter proporcionado novas perspectivas teológicas, que continuaram avançando mesmo depois do Concílio.

Um corte histórico na vida de Comblin separa o intelectual do missionário, o que se percebe a partir de sua chegada a Recife. Antes professor universitário, seguindo o curso comum tradicional, passa por uma virada na forma de atuar, como esclarece Hoornaert: "a diferença entre Comblin professor na Universidade Católica de Santiago do Chile (antes de 1965) e Comblin professor no Instituto

\footnotetext{
${ }^{670}$ COUTO, A. S., A Igreja peregrina à luz da Trindade na eclesiologia de Yves Congar, p. 145.

${ }^{671}$ COUTO, A. S., A Igreja peregrina à luz da Trindade na eclesiologia de Yves Congar, p. 174.

${ }^{672}$ COUTO, A. S., A Igreja peregrina à luz da Trindade na eclesiologia de Yves Congar, p. 175.
} 
Teológico de Recife (ITER) (a partir de 1965) é marcante". ${ }^{673}$ A participação no seminário nordestino mudou definitivamente sua forma de fazer Teologia e o tornou o Comblin doutor dos pobres. Seu encontro com a cultura e a fé nordestinas revelou-lhe a espiritualidade e a devoção do povo pelo Padre Ibiapina. Acredita-se que Ibiapina foi a grande inspiração de Comblin para continuar em missão entre o povo nordestino, como afirma Oliveira: "no semiárido nordestino, Comblin descobriu a experiência missionária do Padre José Antonio Maria Ibiapina, lembrado pelo povo como o Padre Mestre, ou mais recentemente, o Apóstolo da Caridade no Nordeste". ${ }^{674} \mathrm{O}$ impacto causado por Ibiapina envolveu Comblin e o transformou radicalmente, da vivência à teologia. As mudanças iniciam-se pelas características de suas produções. Ele já não escreve exaustivamente, mas agora vive e escreve de modo muito mais simples, encarnando a espiritualidade do povo de Ibiapina e de Padre Cícero. Torna-se aos poucos o Padre Zé. Hoornaert, ao encontrar-se com a irmã de Comblin, é interpelado por esta, a quem causa estranhamento a nova atitude do irmão. O próprio Hoornaert relata:

Mas é em Recife que se revela, com os anos, um Comblin que não escreve mais livros volumosos, muda de estilo, não só na maneira de escrever, mas também na maneira de se apresentar, falar, se relacionar, viver. Ele entra num processo de transformação que, com os anos, culmina na imagem do "Padre Zé", orientador de escolas missionárias, devoto de Ibiapina e do Padre Cícero, tal qual o conhecemos atualmente. Em 1980, a própria irmã de José Comblin, perplexa, me perguntou (foi em Bruxelas): “o que vocês, lá no Brasil, fizeram com José? Ele não é mais o mesmo". De longe, ela percebera que seu irmão se transformou. Em consequência disso, ele passou a olhar tudo sob o prisma da transformação. ${ }^{675}$

Entre os comentadores de Comblin é forte a percepção da influência da fé local, como afirma Pereira: "outro cearense que faz parte de sua vida, além do D. Hélder, é o Pe. Ibiapina, cuja ação missionária é por ele resgatada nos seus escritos. E além de comemorar datas importantes de sua vida lá em Santa Fé, onde repousa Ibiapina, disse querer ficar por lá, quando chegasse seu dia". ${ }^{676} \mathrm{O}$ trabalho

\footnotetext{
${ }^{673}$ HOORNAERT, E., O tema da transformação no pensamento de José Comblin, p. 30.

${ }^{674}$ OLIVEIRA, Anastácio Ferreira de. Igreja dos Pobres e Imagens de Deus em José Comblin: convites à práxis cristã emergentes da Missão Ibiapina no semiárido nordestino. Dissertação de Mestrado em Teologia FAJE - Faculdade Jesuíta de Filosofia e Teologia Belo Horizonte 2013, p. 92.

${ }^{675}$ HOORNAERT, E., O tema da transformação no pensamento de José Comblin, p. 30-31.

${ }^{676}$ PEREIRA, Paulo César. Transitando entre diferentes esferas da vida: uma abordagem sobre a multifacetada caminhada de José Comblin II. Paralellus, Recife, v. 4, n. 7, p. 59-78, jan./jun. 2013, p. 62 .
} 
missionário de Ibiapina foi tão admirado por Comblin que este manifestou o desejo de ser sepultado próximo ao seu túmulo, como destaca Silva Filho:

Um grupo de 13 professores, mestrandos e egressos do Programa de PósGraduação em Ciências da Religião da Unicap realizou, nos dias 25 e 26 de agosto de 2012, uma excursão ao Santuário de Santa Fé, em Solânea, na Paraíba, em busca da memória de José Comblin. Em Santa Fé, há o Santuário do Pe. Ibiapina, no qual estão o túmulo e o Memorial do Padre José Comblin. Ibiapina (1806-1883) inspirou Comblin na sua missão evangelizadora pelo fato de ser o grande peregrino e construtor de Casas de Caridade. ${ }^{677}$

Por inspiração de Ibiapina, Comblin dedicou-se à causa das pessoas simples, envolvendo-se profundamente na realidade do povo nordestino, participando de suas lutas e desfrutando da sua comunhão. Souza acrescenta: "Comblin se mostrou um apaixonado da causa libertária dos pobres, na perspectiva do seguimento de Jesus. Por eles e com eles viveu e morreu, sempre educando para uma esperança militante". ${ }^{678}$ Comblin dedicou-se também à defesa da memória do Padre Ibiapina, segundo ele o maior missionário do Nordeste brasileiro, sem o devido reconhecimento. Oliveira afirma: "Comblin considerou o Padre Ibiapina o maior missionário do Nordeste e denunciou que houve 'injusto silêncio, quase uma reprovação' da pessoa dele". ${ }^{679}$ Comblin teve a sensibilidade que surge nos grandes missionários e por isso identificou-se com os missionários que o antecederam. A missão comblianina, a mesma de Ibiapina e de Cícero, era centrada no povo simples, sedento de uma espiritualidade transformadora, como relata Oliveira:

O protagonismo dos pobres, dos leigos na Igreja e na sociedade, através da educação para o trabalho, da oração comprometida com a caridade, é um dos grandes legados do Padre Ibiapina e do Padre Cícero. Comblin, ao mergulhar na realidade nordestina e colocar o pé na estrada ao encontro dos pobres, redescobriu a riqueza espiritual e pastoral, guardada na memória dos pobres. ${ }^{680}$

Bastante contextualizado, Comblin levou sua experiência ao campo da reflexão, encarnando a realidade nordestina desde que chegou e deu sequência à

\footnotetext{
${ }^{677}$ FILHO, Mariano Vicente da Silva. Dossiê: José Comblin. Paralellus - Recife, v. 4, n. 7, p. 3-6, jan./jun. 2013, p. 3.

${ }_{678}$ SOUZA, Alzirinha; ARAGÃO, Gilbraz. Fazer a Igreja Católica se mover: a pertinência do Evangelho no Mundo Contemporâneo. Paralellus, Recife, v. 9, n. 22, set./dez. 2018, p. 670.

${ }^{679}$ OLIVEIRA, A. F., Igreja dos pobres e imagens de Deus em José Comblin: convites à práxis cristã emergentes da Missão Ibiapina no semiárido nordestino, p. 92.

${ }^{680}$ OLIVEIRA, A. F., Igreja dos Pobres e Imagens de Deus em José Comblin: convites à práxis cristã emergentes da Missão Ibiapina no semiárido nordestino, p. 143.
} 
sua teologia, a partir desse novo elemento que o transformou. Souza diz: "por sua vez, Joseph Comblin, teólogo belgo-brasileiro (1923-2011), realizou a sua reflexão acerca dos temas eclesiais a partir do continente latino-americano, que escolheu para viver desde 1957, quando aqui chegou através da Fidei Donum". ${ }^{6}$ Grande influenciador de Comblin no Nordeste brasileiro, o Padre Ibiapina também se destacou no campo missionário na luta pelos pobres, como lembra Oliveira: "Ibiapina foi estudante no seminário de Olinda, em 1823, por pouco tempo, e foi morar com os padres Oratorianos". ${ }^{682}$ Acontecimentos em sua vida o fizeram renunciar a uma vida estável para viver a causa dos pobres. O Padre Ibiapina teve boa formação em outras áreas, como diz Oliveira: "segundo Comblin, 'Padre Ibiapina ordenou-se aos 47 anos depois de uma carreira de advogado, juiz de direito, deputado nacional no Rio de Janeiro [...]". ${ }^{683}$ Ibiapina torna-se uma luz para Comblin, com sua luta pelo povo nordestino, mas também Dom Hélder destaca-se como grande incentivador para a missão combliniana, ao buscar praticar as novidades propostas pelo Concílio. Hoornaert explica: "em Recife, ele entrou no turbilhão de uma Igreja que optava por executar as linhas diretrizes do Concílio Vaticano II, tomava posição diante do golpe militar de 1964 e fazia uma opção pelas populações pobres. Ficou, como muitos, fascinado pela figura de Dom Hélder Câmara". ${ }^{64}$ Para Comblin, está claro o caminho a percorrer: seu trabalho missionário, diretamente ligado ao leigo nordestino, levaria à reflexão teológica, numa nova forma de viver, como afirma Soares: "para ele, o caminho a seguir era claro: investir na formação do laicato e, particularmente, do laicato pobre, para que a Igreja se transformasse, por isso erigiu como ícone da Igreja no Nordeste a figura do Padre Ibiapina [...]" ${ }^{685}$ A inspiração de Comblin a partir de Ibiapina passa por sua maneira de exercer a missão. Enquanto muitos missionários anunciavam o fim do mundo, Ibiapina defende uma vida mais digna, assumindo a causa dos pobres, como interpreta Oliveira:

\footnotetext{
${ }^{681}$ SOUZA, A; ARAGÃO, G., Fazer a Igreja Católica se Mover: a pertinência do Evangelho no Mundo Contemporâneo, p. 669-670.

${ }^{682}$ OLIVEIRA, A. F. Igreja dos pobres e imagens de Deus em José Comblin: convites à práxis cristã emergentes da Missão Ibiapina no semiárido nordestino, p. 93.

${ }^{683}$ OLIVEIRA, A. F. igreja dos pobres e imagens de Deus em José Comblin: convites à práxis cristã emergentes da Missão Ibiapina no semiárido nordestino, p. 93.

${ }_{684}^{68}$ HOORNAERT, E. O tema da transformação no pensamento de José Comblin, p. 30.

${ }^{685}$ SOARES, S. A. G. José Comblin, homem do Espírito, p. 55.
} 
Compreende-se a admiração que Comblin nutriu pelo Padre Ibiapina, devido à sua intensa atividade missionária em favor dos pobres e à sua vida dedicada à oração. O profícuo apostolado do Padre Mestre estava fortalecido na mística do trabalho a serviço do próximo, em vista da vida eterna. O Padre Mestre recuperou a dimensão escatológica do povo de Deus numa perspectiva diferente dos demais missionários, que passaram pelo sertão anunciando o fim do mundo. Ibiapina une a esperança da vida eterna à esperança de dias melhores, no exercício efetivo da caridade e do perdão. ${ }^{686}$

Nessas bases inspiradoras se instala a fase inicial que contribui para o conceito de Comblin de missão e teologia, o qual chamaria a atenção de muitos, como afirma Souza: "ele continua sendo uma figura simbólica para muitos cristãos e cidadãos espalhados pelo mundo e, sobretudo, na América Latina e no Nordeste brasileiro. Nele, reconhecemos um dos teólogos da aurora da Teologia da Libertação". ${ }^{687}$ A partir dessa perspectiva de missão, Comblin constrói seu perfil missionário, sistematizando a missão nordestina e envolvendo o leigo na evangelização. Para isso elaborou alguns programas missionários, e ao escrever sobre eles, contribuiu para a formação do leigo e para uma missão mais dinâmica, como lembra Souza: "de modo especial da Teologia da Enxada - com uma produção privilegiada, seja quanto à qualidade, seja quanto ao seu incansável ritmo de produção, destacando-se a publicação, até o final de sua vida, de centenas de artigos e mais de setenta livros". ${ }^{688}$ Entretanto, se ele tivesse seguido carreira no Chile, poderia ter se destacado como intelectual, pois reunia qualidades comparáveis às dos grandes teólogos contemporâneos. Hoornaert diz:

No Chile, seu destino teria sido o de um professor brilhante, original, capaz, erudito, estudioso e ao mesmo tempo controvertido e desafiador. Bom escritor, conferencista apreciado, intelectual de peso e arguto observador da realidade eclesial e política em geral. Essas qualidades ainda aparecem de forma eminente nos dois volumosos livros que ele escreveu, entre 1970 e 1974, sobre a teologia da revolução: "Théologie de la Révolution" (COMBLIN, 1970) e "Théologie de la Pratique révolutionnaire" (COMBLIN, 1974), ambos editados pelas Éditions Universitaires de Paris. ${ }^{689}$

\footnotetext{
${ }^{686}$ OLIVEIRA, A. F., Igreja dos Pobres e Imagens de Deus em José Comblin: convites à práxis cristã emergentes da Missão Ibiapina no semiárido nordestino, p. 95-96.

${ }^{687}$ SOUZA, A; ARAGÃO, G., Fazer a Igreja Católica se Mover: a pertinência do Evangelho no Mundo Contemporâneo, p. 670.

${ }^{688}$ SOUZA, A.; ARAGÃO, G., Fazer a Igreja Católica se mover: a pertinência do Evangelho no mundo contemporâneo, p. 670.

${ }^{689}$ HOORNAERT, E., O tema da transformação no pensamento de José Comblin, p. 30.
} 
Contudo, o legado missionário do Padre Ibiapina e toda a sua história de luta pela transformação das vidas nordestinas o cativaram. Sobre Ibiapina Oliveira diz: "Comblin entende que o testemunho do pai e do irmão mais velho martirizados na luta por liberdade, a dura orfandade e as privações financeiras, fortaleceram no juiz e deputado, e mais tarde no missionário José Antonio Ibiapina, a consciência de justiça social e solidariedade com os pobres". ${ }^{690}$ Inseminada pela obra de Ibiapina, a missão combliniana vai ganhando forma, somando a formação europeia à prática missionária nordestina, o que resulta numa missão equilibrada. Soares afirma: "viveu dedicado a ensinar. Em certo momento decidiu não mais colaborar na formação do clero, em seminários e faculdades, e dedicar-se à tarefa de promover a formação teológica e pastoral do laicato, sobretudo de gente do interior, mulheres e homens, e, em particular, do sertão do Nordeste". ${ }^{61}$ A vida de Comblin no Nordeste do Brasil é exemplo de missão, e a dedicação e a simplicidade ao aplicar suas reflexões a uma ação missionária não convencional, que sempre buscava envolver o povo leigo como agente de missão, o levou a tornar-se símbolo desse povo. Pereira o compara ao mandacaru, símbolo de resistência nordestina, reunindo em si sobrevivência e continuidade, e apontando para a esperança:

Por todo o seu trabalho, por sua teologia que surge de um conhecimento da prática e conduz necessariamente à prática; por seu testemunho de vida, por seus recomeços depois de repetidos cortes, há dois símbolos do Nordeste que retratam perfeitamente o Pe. Comblin. O primeiro é o Mandacaru, planta que resiste à seca e ainda salva vidas com suas gotas d'água. É por isso que cantamos: "só Mandacaru, só Mandacaru resistiu tanta dor". "Como Mandacaru, você é duro José". ${ }^{692}$

Comblin, símbolo de missão entre o povo nordestino, é o sucessor do anúncio de Ibiapina, que praticara uma ação missionária voltada à transformação da realidade. Oliveira diz: "[Comblin] reconhece que o grande missionário foi ao encontro dos desprezados de sua época, movido pela compaixão solidária, e criou experiência original de Igreja com rosto sertanejo, no jeito de rezar e de

\footnotetext{
${ }^{690}$ OLIVEIRA, A. F., Igreja dos Pobres e Imagens de Deus em José Comblin: convites à práxis cristã emergentes da Missão Ibiapina no semiárido nordestino, p. 99.

${ }^{691}$ SOARES, S. A. G., José Comblin, homem do Espírito, p. 56.

${ }^{692}$ PEREIRA, P. C., Transitando entre diferentes esferas da vida: uma abordagem sobre a multifacetada caminhada de José Comblin II, p. 62.
} 
trabalhar". ${ }^{693}$ O trabalho missionário do Padre Ibiapina não ficou restrito a palavras; ele concretizou sua missão com construções que envolviam a todos. Oliveira continua: "mobilizou, através da palavra, multidões para o trabalho em mutirões e, a exemplo de Jesus e dos profetas, sua práxis foi também desqualificada pelo poder". ${ }^{64}$ Segundo Pereira, Comblin ainda pode ser comparado a outro símbolo nordestino, o fogo do monturo, que queima de dentro para fora. Pereira esclarece:

Outro símbolo nordestino da ação do Pe. Comblin é o fogo do monturo. Para quem não sabe é costume no Nordeste juntar folhas, pedaços de madeira, graças a Deus na época não existia plástico. Juntava-se o lixo no quintal e formava o monturo. Aí se tocava fogo. Este vai queimando por dentro sem aparecer na superfície. E queima tudo e por fim cai o aparente. A ação de Comblin é como o fogo de monturo porque vai formando de dentro para fora na mudança de valores, de conceitos, de referências e de atitudes e na compreensão da realidade. ${ }^{695}$

A opção pelos pobres levou Comblin a assumir-se em favor deles, assumindo seu estilo na totalidade. Comblin não foi somente um teórico da liberação, ele viveu essa Teologia, como afirma Pereira: “o Comblin realmente fez opção pelos pobres, não só pelo que ele escreve, mas porque foi viver pobre. Um homem da cultura dele, com os recursos dele, vem morar aqui no sertão da Paraíba, levar vida mais simples". ${ }^{696}$ Ele marcou uma geração de teólogos por defender uma prática bastante rebatida, mas aprofundou-se tanto na causa que as perseguições não tiveram poder direto sobre ele. Souza destaca: "tornou-se conhecido como missionário e profeta, famoso por incomodar e desinstalar, por denunciar o culto religioso e pregar a memória de Jesus Cristo, apontando as mazelas e armadilhas dos poderosos e das instituições". ${ }^{697}$ A perseguição ao tema da libertação no campo teológico era uma realidade, e em uma de suas publicações Comblin expõe os pensadores que de certa forma assumiram esse modo fazer Teologia, citando-os:

\footnotetext{
${ }^{693}$ OLIVEIRA, A. F., Igreja dos pobres e imagens de Deus em José Comblin: convites à práxis cristã emergentes da Missão Ibiapina no semiárido nordestino, p. 92.

${ }^{694}$ OLIVEIRA, A. F., Igreja dos pobres e imagens de Deus em José Comblin: convites à práxis cristã emergentes da Missão Ibiapina no semiárido nordestino, p. 92.

${ }^{695}$ PEREIRA, P. C., Transitando entre diferentes esferas da vida: uma abordagem sobre a multifacetada caminhada de José Comblin II, p. 62.

${ }^{696}$ PEREIRA, P. C., Transitando entre diferentes esferas da vida: uma abordagem sobre a multifacetada caminhada de José Comblin II, p. 75.

${ }^{697}$ SOUZA, A; ARAGÃO, G., Fazer a Igreja Católica se Mover: a pertinência do Evangelho no Mundo Contemporâneo, p. 670.
} 
Quero dar testemunho de que os teólogos da seguinte lista, que conheci ou conheço pessoalmente, crêem no lugar central de Cristo, no cristianismo, e não defendem a pobrelogia. Quero defender publicamente Gustavo Guitierrez, Juan Luis Segundo, Ronaldo Muñoz, João Batista Libanio, Luiz Carlos Susin, Cleto Caliman, Leonardo Boff, Carlos Palácio, Francisco Taborda, Agenor Brighenti, Jon Sobrino, Ignacio Ellacuría, Pedro Trigo, Luis del Valle, Carlos Bravo, Miguel Concha, Virgilio Elizondo, Hugo Echegaray, Víctor Codina, Alberto Parra, Roberto Oliveros, José Luis Caravias, Pablo Richard, Paulo Suess, Diego Irrarázaval, Marcelo Barros, Juan Hernándes Pico. Estes teólogos acreditam no lugar central de Cristo e não substituem Cristo pelos pobres. Todos querem destacar o lugar que ocupam os pobres na revelação cristã, mas ninguém os coloca no lugar de Cristo. ${ }^{698}$

Comblin esteve em sintonia com as propostas de seu tempo, e os apontamentos eram assumidos pelos órgãos eclesiásticos, como afirma Pereira: “o Concílio era para ele como um breviário. No Concílio se falou de uma Igreja que faz opção preferencial pelos pobres. A CNBB, logo após o Concílio, adotou isso quase que como norma sua". ${ }^{699}$ A forma como Comblin exercia a missão levou-o a elaborar várias estratégias para o diálogo com a realidade, continuando seu ensino de modo calmo, quase tímido, mas ele foi capaz de planejar e executar vários projetos, como destaca Soares:

\begin{abstract}
Seu jeito de lecionar era tido como "monótono", sempre no mesmo tom de voz, e, no entanto, era intensamente procurado para ser "ouvido". Tímido, mas ousado estrategista e por isso fundador ou inspirador de múltiplas iniciativas, e planejador ou formulador de novos projetos: "Teologia da Enxada"; Seminário Rural que se tornou Centro de Formação Missionária, em Serra Redonda e em Mogeiro (Paraíba); Associação de Missionários e Missionárias do Campo; "Curso da Árvore"; seminário para a formação de gente do interior do sertão para várias dioceses da Bahia e outras (Piauí, Paraíba...); Fraternidade do Discípulo Amado e diálogo periódico com um grupo de pastores protestantes. E outras. ${ }^{700}$
\end{abstract}

Comblin sempre levou vida simples, em sua residência, sem dissociar a vida privada da missionária, como lembra Pereira: "o lugar em que morava, a sacristia ao lado da igreja, só tinha uma pequena divisão para o banheiro e a cama dele. $\mathrm{O}$ resto, aquele salão enorme com os livros. Trabalhava ali". ${ }^{701}$ Por ter renunciado a tanto, Comblin estava sempre se reinventando, livre de estruturas e amarras e

\footnotetext{
${ }^{698}$ COMBLIN, José. As estranhas acusações de Clodovis Boff. Revista Eclesiástica Brasileira. v. 69, n. 273 (2009) p. 196.

${ }^{699}$ PEREIRA, P. C., Transitando entre diferentes esferas da vida: uma abordagem sobre a multifacetada caminhada de José Comblin II, p. 75.

${ }^{700}$ SOARES, S. A. G., José Comblin, homem do Espírito, p. 56.

${ }^{701}$ PEREIRA, P. C., Transitando entre diferentes esferas da vida: uma abordagem sobre a multifacetada caminhada de José Comblin II, p. 75.
} 
pronto a contribuir. Suess inicia uma de suas publicações homenageando Comblin:

Peregrino, profeta, professor, sempre três em um, memória ambulante, missionário, mediador; com passo lento e voz mansa ordena tempos, tece redes, cata ventos; posseiro militante do tempo que ara, traz de cavernas remotas notícias de vida e sobreviventes. Romeiro entre Santiago e Recife, Padre-mestre de Talca, Barra e o mundo, testemunha sem ruído, beato, como Cáppio e Ibiapina, peregrino na selva da história, e veleiro que do alto mar traz a tempestade como se fosse a brisa suave da tarde. Lutaste por terra para viver, Porque a vida só se dá para quem se deu, para quem amou, para quem lutou, para quem sofreu. Sonhaste vinho e pão, divina energia repartida, porque todos os seres têm direito à vida. Neste tempo em que o sol está baixo e anões fazem sombras de gigantes não coube em nada e nada lhe coube; indignação contida, discordância drenada na represa da mansidão do povo. José, não do Egito, mas sonhador como este, na cisterna e na via láctea, entre desespero e esperança. ${ }^{702}$

Indiferente à comodidade possível no seu país de origem, Comblin optou por passar a vida lutando ao lado de uma igreja de pobres, buscando encontrar sua teologia e prática. E como diz Dom José Maria, em entrevista a Pereira: “[...] Apesar de ser um homem letrado e de vir de um país do Primeiro Mundo, chamava a atenção o seu compromisso com os pobres, com a Igreja pobre". ${ }^{703}$

Esta parte do trabalho buscou mapear os antecedentes de Comblin que influenciaram sua ação missionária e teologia, de Congar a Ibiapina, o primeiro no campo da reflexão, o segundo na prática missionária; parece que em Comblin encontram-se os dois.

\subsection{3.}

\section{Estudos gerais sobre Comblin}

A nova porta aberta pelo Vaticano II redobrou o ânimo de muitos missionários que presenciavam um tempo de progresso e inovação. Gonçalves afirma: "a eclesiologia do Concílio Vaticano II foi um avanço em termos de abertura da igreja romana, principalmente quando propôs o tema do povo de Deus para identificar a eclesiologia" ${ }^{704}$ As conclusões missionárias do Vaticano II

\footnotetext{
${ }^{702}$ SUESS, P., Missionário migrante - teólogo militante José Comblin: o retorno do enviado do Pai, p. 76.

${ }^{703}$ PEREIRA, P. C., Transitando entre diferentes esferas da vida: uma abordagem sobre a multifacetada caminhada de José Comblin II, p. 75.

${ }^{704}$ GOÇALVES, Alonso S. Desafios pastorais para uma eclesiologia aberta. Ciberteologia Revista de Teologia \& Cultura ISSN 1809-2888 - Ano XI, n. 50. 2015, p. 59.
} 
intentam a salvação a todos os povos, porém para Comblin essa postura não se reflete na prática:

O Concílio Vaticano II proclamou que a Igreja está a serviço do mundo e não é um fim em si mesma. Sua finalidade é a salvação de todos os povos, da humanidade inteira. Ele reconhece a autonomia do mundo e reconhece que já não é a Igreja que dirige o mundo, como nos tempos da cristandade. Na Gaudium et Spes se renuncia ao projeto de cristandade. No entanto, as palavras dizem uma coisa e a realidade é diferente. $^{705}$

As propostas refletidas no Concílio inauguraram o diálogo com as novas realidades, é de ser considerar que vários dos temas trabalhados no Vaticano II já eram refletidos por teólogos que antecederam o evento. E como diz Comblin: "o Concílio Vaticano II abriu as portas para uma reflexão já inaugurada por teólogos do século passado e deste século XXI". ${ }^{706}$ O que parece é que o Concílio foi uma voz profética, apontando para uma nova perspectiva lançando o povo de Deus em missão. Gonçalves explica:

\begin{abstract}
Embora o Concílio Vaticano II rompeu com essa concepção eclesiológica, reforçando o modelo de comunhão, não foi possível a ele subsistir e ganhar dimensões eclesiais por conta de uma forte resistência por parte de alguns setores da igreja romana. Quem demonstra isso com clareza é José Comblin quando da disputa entre a hierarquia e a noção de povo de Deus. O que o Concílio Vaticano II pretendia, era eliminar a concepção eclesiológica de supremacia da hierarquia e em seu lugar ver o surgimento da dimensão do símbolo bíblico povo de Deus. ${ }^{707}$
\end{abstract}

As inovações propostas no Concílio Vaticano II não alcançaram todas as áreas de atuação. Comblin chega mesmo a relatar certo empenho em enfraquecer a eclesiologia proposta, como afirma Gonçalves: “em seu livro, Comblin demonstra uma espécie de orquestração para enfraquecer a eclesiologia do Vaticano II, principalmente com o Sínodo de 1985 [...]" ${ }^{708}$ Comblin mostra o desinteresse no estudo da história da Igreja em séculos mais remotos, detectando o início dos estudos de caráter científico a partir do século XIX: "a história da Igreja começou a ser estudada seriamente no século XVII, mas de modo mais científico e com mais documentos a partir do século XIX, e em muitas partes da Igreja somente depois de Vaticano II. Antes disso, a história é uma realidade muito fragmentária

\footnotetext{
${ }^{705}$ COMBLIN, José. As grandes incertezas na igreja atual. REB-Revista Eclesiástica Brasileira v. 67, n. 2652007 , p. 51.

${ }^{706}$ COMBLIN, José. A virada da teologia cristã. Mandrágora, v.20. n. 20, 2014, p. 85-100, p. 97.

${ }^{707}$ GONÇALVES, A, S., Desafios pastorais para uma eclesiologia aberta, p. 59.

${ }^{708}$ GONÇALVES, A, S., Desafios pastorais para uma eclesiologia aberta, p. 59.
} 
e a crítica dos documentos, muito fraca". ${ }^{709}$ Com o cenário criado a partir do Vaticano II, muitos passaram a incentivar novas concepções missionárias, e é a partir dessas aberturas que Comblin desenvolve seu trabalho, como explica Tracco:

A partir dessas primeiras experiências de evangelização, o clero brasileiro se sentiu ainda mais estimulado após o clima de abertura que se seguiu ao Concílio Vaticano II. Dentro da nova eclesiologia nascida nas sessões conciliares, as comunidades de base passam a ser mencionadas e estimuladas em vários importantes documentos eclesiásticos que se seguem ao concílio: o Primeiro Plano Pastoral de Conjunto (PPC) emitido pela CNBB em $1965 .{ }^{710}$

Por falta de empenho nos projetos pós-Concílio, os envolvidos com as CEBs optaram por vias não oficiais, alimentando um pulsar missionário e inovador que aproximava a proposta do Concílio de uma nova eclesiologia mundial, como afirma Comblin: "no entanto, na América Latina, houve uma experiência básica que podia ter dado uma resposta. Foi a experiência das CEBs.

A experiência continua, mas não foi adotada oficialmente pela Igreja". ${ }^{711} \mathrm{O}$ movimento espalhou-se no Brasil, como ação missionária contextualizada que encontrou acolhida na sociedade brasileira. $\mathrm{O}$ primeiro encontro intereclesial foi Vitória, no Espírito Santo, durante o movimento de expansão das CEBs, a partir dos anos 1970, como comenta Tracco: "as CEBs, como experiência evangelizadora, cresceram vigorosamente no Brasil nas décadas de 70 e 80 . Em 1975 deu-se o primeiro encontro intereclesial de CEBs, ocorrido em Vitória (ES)". 712

O crescimento das CEBs levou a organização a promover encontros periódicos a cada três anos. Mas após a década de 1980, as CEBs já não contavam mais com incentivos da hierarquia a suas ações. Tracco continua: "desde então, novos encontros vêm ocorrendo no intervalo entre três a quatro anos. O último, o $13^{\circ}$, foi em janeiro de 2014, em Juazeiro do Norte (CE). Porém, a partir da década de 80 houve uma falta de estímulo por parte da hierarquia para com as CEBs". ${ }^{713}$ O cenário da Igreja no Brasil mostrou-se como via de mão dupla que foi, ao

\footnotetext{
${ }^{709}$ COMBLIN, J., A Virada da Teologia Cristã, p. 97.

${ }^{710}$ TRACCO, Celso Luiz. As CEBs em Aparecida. A retomada de um modelo de evangelização? Revista de Cultura Teológica, Ano XXII No 84 Jul/Dez 2014, p. 36.

${ }^{711}$ COMBLIN, J., As Grandes Incertezas na Igreja Atual, p. 47.

${ }^{712}$ TRACCO, C, L., As CEBs em Aparecida. A retomada de um modelo de evangelização? p. 37.

${ }^{713}$ TRACCO, C, L., As CEBs em Aparecida. A retomada de um modelo de evangelização? p. 37.
} 
avançar com o ânimo recebido do Vaticano II, desenvolvendo o trabalho missionário do povo de Deus passando pelas CEBs, e voltou, quando se recolheu, como afirma Tracco: "fundamentalmente a Igreja instituição passa a desestimular uma prática eclesiástica que saiu do Vaticano II, a de uma Igreja ministerial, participativa do Povo de Deus. Volta-se para uma Igreja sacerdotal e sacramental, onde o centro não é mais o povo, a assembleia de fieis, mas o clero". ${ }^{714}$ As CEBs se enfraqueceram primeiramente por falta de respaldo oficial, e suas ações passaram a ser marginais, como esclarece Comblin: "não se the deu nenhum estatuto oficial, e as CEBs permanecem como algo estranho e frágil, porque qualquer pároco ou qualquer bispo pode desfazer um trabalho fecundo de dezenas de anos". ${ }^{715}$ As CEBs concentravam sua ação missionária principalmente entre os mais carentes, servindo de luz aos participantes, muitos deles desassistidos em quase tudo, como relata Tracco:

\begin{abstract}
A experiência evangelizadora das CEBs, principalmente nas décadas de 60 e 70 do século passado, foi uma verdadeira luz para aqueles que participaram. Primeiro, para os que conduziram a ação evangelizadora, reconhecendo toda a precariedade da vida da população. Uma população desassistida, sem qualquer participação nas decisões sobre política, economia ou religião que influenciavam sua vida. Atuaram em áreas onde a população não tinha formação religiosa, educacional e eram economicamente excluídos, mas tinham uma grande piedade e religiosidade popular. $^{716}$
\end{abstract}

Esse novo horizonte que surgia diante dos missionários representava um conjunto de acontecimentos que ganharam corpo a partir do Concílio Vaticano II na perspectiva católica. Souza esclarece: "nesse sentido, podemos afirmar que as modificações que o Concílio Vaticano II aportou à Igreja refletem, e de certa maneira, tentam responder e se aproximar das mudanças e das revoluções que aconteciam pelo mundo". ${ }^{717}$ Comblin vivenciou muitas mudanças sociais durante o serviço missionário, e muita tentativa de avanço também por parte da Igreja. Dedicando muito de sua vida à América Latina, passou por momentos delicados, como quando foi expulso do Brasil. Oliveira comenta: "o teólogo belga José Comblin, viveu 53 anos na América Latina, entre o serviço ao povo de Deus, a

\footnotetext{
${ }^{714}$ TRACCO, C, L., As CEBs em Aparecida. A retomada de um modelo de evangelização? p. 37.

${ }^{715}$ COMBLIN, J., As grandes incertezas na igreja atual, p. 47.

716 TRACCO, C. L., As CEBs em Aparecida. A retomada de um modelo de evangelização? p. 41.

${ }^{717}$ SOUZA, Alzirinha Rocha de. O Vaticano II no cotidiano do Nordeste brasileiro: a contribuição de D. Hélder Câmara e José Comblin à renovação da Igreja de Recife (1965-1972). Paralellus, Recife, v. 4, n. 8, p. 275-289, jul./dez. 2013. p. 276.
} 
profecia e o exílio. Ligado à tradição latino-americana de Medellin e Puebla, expressou a vivência e compreensão da fé na Teologia da Libertação". 718

Comblin esteve ao lado do povo simples, desafiando a falta de esperança e dispondo-se a servir aos mais frágeis. Ele descobriu uma espiritualidade que emanava do povo, como relata Oliveira: "atravessou o Concílio Vaticano II, vivenciou e apoiou profeticamente a emergência do povo de Deus nas CEBs e movimentos sociais, nas décadas de 1960 e 1970". ${ }^{719}$ Ele jamais desertou da causa teológica da reflexão sobre uma eclesiologia mais atuante e participante no mundo, retomando sua saga pneumatológica, buscando abarcar com a missão todo o povo de Deus. Libânio afirma: "José Comblin mostrou-se fortemente preocupado em atribuir ao Espírito Santo papel relevante na teologia que, no Ocidente, o esquecera". ${ }^{720}$

Comblin compromete-se com a coerência, buscando o equilíbrio entre teologia e prática, atualizando suas experiências e refletindo sempre a partir da perspectiva do povo de Deus, sob a ótica de Congar. Oliveira comenta: "Comblin salienta a atualidade do artigo de Yves Congar sobre a Igreja como povo de Deus e diz que 'ainda pode ser um programa de restauração da teologia do povo de Deus [...]". ${ }^{721}$ A Teologia de Comblin germinava no terreno onde estava plantada, e suas reflexões buscavam primeiramente resistir, para depois denunciar o pecado da injustiça em prol da liberdade do oprimido, participando da vida do povo de acordo com a missão anunciada, como explica Barros:

Penso que, sob o ponto de vista sócio-político, a reflexão teológica de Comblin teve três etapas principais. a) Na década de 70 [1970] e começo dos anos 80 [1980], a reflexão do Comblin era uma reação e propunha uma resistência revolucionária às ditaduras latino-americanas. b) A partir dos meados da década de 80, o Comblin mais maduro aprofunda uma Teologia nova e que, em si mesma, seja libertadora e geradora de uma humanidade nova. c) Finalmente, a partir do final dos anos 90 e começo desse século, o Comblin se dedicará mais à formação das lideranças de base, a uma crítica mais profunda à instituição eclesiástica e a uma inserção na realidade dos pobres e da vida cotidiana. ${ }^{722}$

${ }^{718}$ OLIVEIRA, A. F., Igreja dos Pobres e Imagens de Deus em José Comblin: convites à práxis cristã emergentes da Missão Ibiapina no semiárido nordestino, p. 17.

${ }^{719}$ OLIVEIRA, A. F., Igreja dos Pobres e Imagens de Deus em José Comblin: convites à práxis cristã emergentes da Missão Ibiapina no semiárido nordestino, p. 17.

${ }^{720}$ LIBÂNIO, João Batista. O Espírito Santo e a tradição de Jesus. Paralellus, Recife, v. 4, n. 7, p. 121-125, jan./jun. 2013, p. 121.

${ }^{721}$ OLIVEIRA, A. F., Igreja dos pobres e imagens de Deus em José Comblin: convites à práxis cristã emergentes da Missão Ibiapina no semiárido nordestino, p. 58.

${ }_{722}$ BARROS, Marcelo. O Padre Comblin e a sua Teologia política. Paralellus, Recife, v. 6, n. 11, Especial José Comblin, p. 67-74, 2015, p. 70. 
Comblin encontrou na América Latina sua vocação missionária dentro num contexto de prática de uma teologia encarnada, como comenta Oliveira: "para Comblin, na América Latina, os teólogos, bispos e padres, que participavam dos movimentos sociais, sonhavam e lutaram por uma Igreja dos pobres, onde pudessem unir fé e vida, sem precisar afastar-se da Igreja ou da luta do povo". ${ }^{723}$ O percurso do teólogo belga na América Latina foi marcado por um vasto itinerário de anúncio profético da esperança, em que sua pneumatologia discursava sobre a força do Espírito, como comenta Oliveira: "em sua longa peregrinação histórica, desde a saída da Bélgica em 1958 para o Brasil, a passagem pelo Chile e a ida para o Nordeste brasileiro, vivenciou uma fé itinerante, cheia de esperança profética sob os ventos do Espírito". ${ }^{724} \mathrm{O}$ contexto de atuação de Comblin como teólogo comprometido com as causas emergentes é de significativas transformações, sendo o Vaticano II um exemplo dessas mudanças, como esclarece Souza: "observando-se o movimento dos acontecimentos civis, eclesiásticos e teológicos dos anos 50 e 60, resta-nos claro que o Concílio Vaticano II foi realizado em uma época de transição histórica". ${ }^{725}$ A atuação de Comblin em meio a esse cenário sempre foi muito diversificada: como professor ou assessor, esteve sempre em movimento. Oliveira afirma:

Comblin deu aulas em alguns países latino-americanos e na Europa desde 1958. Partilhou da caminhada eclesial e assessoria direta a Dom Hélder Câmara no Recife, a Dom Manuel Larraín em Talpa - Chile, a Dom Leônidas Proaño em Riobamba - Equador, e a alguns outros bispos que chamava de Santos Padres da América Latina. ${ }^{726}$

O teólogo belga passou por diversas fases em sua vasta produção teológica, mas suas reflexões partiam daquilo que via, como afirma Barros: "na segunda metade dos anos 60 [1960], Comblin viveu e aprofundou sua crítica ao Imperialismo que ele já mostrava presente em seu livro O Cristo no Apocalipse

\footnotetext{
${ }^{723}$ OLIVEIRA, A. F., Igreja dos pobres e imagens de Deus em José Comblin: convites à práxis cristã emergentes da Missão Ibiapina no semiárido nordestino, p. 77.

${ }^{724}$ OLIVEIRA, A. F., Igreja dos pobres e imagens de Deus em José Comblin: convites à práxis cristã emergentes da Missão Ibiapina no semiárido nordestino, p. 150.

${ }^{725}$ SOUZA. A. R., O Vaticano II no cotidiano do Nordeste brasileiro: a contribuição de D. Hélder Câmara e José Comblin à renovação da Igreja de Recife (1965-1972), p. 276.

${ }^{726}$ OLIVEIRA, A. F., Igreja dos pobres e imagens de Deus em José Comblin: convites à práxis cristã emergentes da Missão Ibiapina no semiárido nordestino, p. 17.
} 
(1965)". ${ }^{727}$ Quando Comblin vai ao Nordeste brasileiro ela primeira vez, encontra um ambiente propício ao desenvolvimento e à prática de suas reflexões sobre a Teologia da missão, segundo Oliveira:

Em janeiro de 1964, o Padre José Comblin e alguns companheiros belgas vão ao Nordeste do Brasil pela primeira vez, numa das férias do Seminário de Santiago do Chile, onde dava aulas. Comblin e seus companheiros conheceram em Fortaleza o padre Hélio Campos na experiência dos grupos de base do Pirambu. Em Recife, estiveram com o padre Marcelo Cavalheira e a equipe do Seminário de Camaragibe. $^{728}$

Ainda em 1964 Comblin foi convidado a participar dos trabalhos no Nordeste. Nessa época ele conheceu Dom Hélder Câmara, e ficou surpreso com sua simplicidade, como lembra Oliveira: "Comblin é convidado para integrar a equipe. Em julho do mesmo ano, retorna ao Nordeste, conhece Dom Hélder Câmara, fica impressionado com a humildade daquele pequenino homem". ${ }^{729}$ Motivado com o novo desafio, Comblin lança-se na missão nordestina, na qual seria conhecido para sempre como doutor dos pobres. Era o início de um longo caminho, o que é explicado por Oliveira: "Comblin mergulha na realidade nordestina, através da missão na Igreja de Olinda e Recife, ao lado de Dom Hélder Câmara e seus colaboradores, dando aulas no Instituto de Teologia e Pastoral do Recife (ITER)". ${ }^{730}$ Durante seu trabalho no instituto, Comblin esteve ao lado de teólogos que, como ele, aceitaram os desafios do Nordeste. Souza esclarece essa fase: "os estudos de Teologia e Filosofia passaram a ser realizados no recémfundado (1967) ITER - Instituto de Teologia do Recife, que contava com a responsabilidade do pastoralista francês René Guerre e do teólogo José Comblin, decisivos na ruptura da formação com os antigos cânones". ${ }^{731}$ Sempre atualizado quanto aos desafios teológicos, Comblin continuava a escrever. Para ele, prática e reflexão eram a mesma coisa, e foi assim que escreveu uma grande obra nessa etapa de sua vida, como afirma Barros:

\footnotetext{
${ }^{727}$ BARROS, M., O Padre Comblin e a sua Teologia política, p.70.

${ }^{728}$ OLIVEIRA, A. F., Igreja dos pobres e imagens de Deus em José Comblin: convites à práxis cristã emergentes da Missão Ibiapina no semiárido nordestino, p. 90-91.

${ }^{729}$ OLIVEIRA, A. F., Igreja dos pobres e imagens de Deus em José Comblin: convites à práxis cristã emergentes da Missão Ibiapina no semiárido nordestino, p. 90-91.

${ }^{730}$ OLIVEIRA, A. F., Igreja dos pobres e imagens de Deus em José Comblin: convites à práxis cristã emergentes da Missão Ibiapina no semiárido nordestino, p. 91.

${ }^{731}$ SOUZA, A. R., O Vaticano II no cotidiano do Nordeste brasileiro: a contribuição de D. Hélder Câmara e José Comblin à renovação da Igreja de Recife (1965-1972), p. 286.
} 
Ainda no final dos anos 60, escreveu Théologie de La Révolution (1970), uma obra imensa em dois volumes. No primeiro volume, ele abordava as teorias das revoluções, e quem até hoje ler esse livro, fica impressionado com a quantidade e a qualidade de informações de que Comblin dispunha, o conhecimento que ele tinha sobre isso. Já no segundo volume, igualmente enorme, ele trata as práticas das revoluções históricas até então no mundo. ${ }^{732}$

Os comentadores da vida e obra de Comblin tiveram em conta a sua relação com o cenário da época e as dificuldades que o teólogo experimentou. Eles mostraram traços da evolução de sua teologia. Esses dados aparecem nos relatos conforme explanados a seguir.

O cenário, então, se iluminava com as novas perspectivas do caminhar da Igreja sob a direção do Vaticano II e o clima tomava a Igreja nordestina. Oliveira lembra: "Dom Hélder, cheio do entusiasmo do Pentecostes, que foi o Concílio Vaticano II, procurava implantar as orientações conciliares em sua arquidiocese. Era tempo de muita criatividade pastoral no novo jeito de exercer o ministério episcopal". ${ }^{733}$ Dom Hélder conduzia os trabalhos de modo a envolver todos ao redor, com atividades desafiadoras, buscando o diálogo com outras igrejas e chegando às periferias. Oliveira destaca: “o 'Dom' acolhia a todos, mas de maneira especial aos pobres, que sentiam nele o amor preferencial de Deus. Visitava constantemente as periferias e favelas, buscou diálogo com outras igrejas e culturas e investiu na renovação litúrgica e catequética". ${ }^{734}$ Comblin o ajuda em tudo quanto lhe é possível e torna-se coordenador de estudos, como destaca Souza: "No ano acadêmico de 1967, Comblin se torna o coordenador de estudos e René Guerre, coordenador da ação Pastoral". ${ }^{735}$ A missão frutificava no Nordeste, mas a ditadura no Brasil limitava as atividades e impunha represálias, como o exílio de Comblin no Chile. Mesmo então ele produzia reflexões, como destaca Oliveira: "quando assessor de Dom Hélder Câmara e professor de teologia no seminário de Olinda-PE, sofreu represálias por parte da ditadura instalada no Brasil em 1964, inclusive o exílio no Chile. Suas obras são densas de informações

\footnotetext{
${ }^{732}$ BARROS, M., O Padre Comblin e a sua Teologia política, p.71.

733 OLIVEIRA, A. F., Igreja dos pobres e imagens de Deus em José Comblin: convites à práxis cristã emergentes da Missão Ibiapina no semiárido nordestino, p. 91.

${ }^{734}$ OLIVEIRA, A. F., Igreja dos pobres e imagens de Deus em José Comblin: convites à práxis cristã emergentes da Missão Ibiapina no semiárido nordestino, p. 91.

${ }^{735}$ SOUZA, A. R., O Vaticano II no cotidiano do Nordeste brasileiro: a contribuição de D. Hélder Câmara e José Comblin à renovação da Igreja de Recife (1965-1972), p. 286.
} 
e reflexões, fundamentadas na história, na Bíblia e na Tradição da Igreja". ${ }^{736}$ Mesmo com limitações, a formação no campo nordestino gerava esperança apontando para um novo momento na missão, que passava pelo leigo. Souza afirma: "nessa mesma linha de formação, no período de 69 a 71, José Comblin e René Guerre desenvolvem a experiência de formação rural de seminaristas [...]" ${ }^{737}$ Não é possível ler as obras de Comblin sem associá-las ao seu exemplo de engajamento na causa missionária. Por isso, de tais experiências nascem importantes caminhos missionários, como a Teologia da Enxada. Oliveira explica:

Nascerá desta experiência a Teologia da Enxada, iniciada com grupos de seminaristas do ITER, que consideravam a teologia muito acadêmica, embora de cunho progressista. Desejavam novo método de estudo que os pusesse em contato direto com os pobres do meio rural, onde aprendessem no meio do povo o serviço pastoral. Iniciaram em 1969 duas comunidades inseridas no meio rural, uma na Paraíba e a outra em Pernambuco. ${ }^{738}$

Nesse envolvimento com o povo simples é que Comblin encontra sua vocação de experimentar novas maneiras de fazer missão. Oliveira continua: "da experiência de três anos, de 1969 a 1971, surgem a mística e a metodologia teológica e pastoral que ficou conhecida como Teologia da Enxada". ${ }^{739}$ Comblin refletiu em sua prática a opção pelos pobres nordestinos, formando missionários para assumir a causa dos necessitados. Oliveira destaca:

A preocupação de Comblin com a formação de padres comprometidos com os pobres, mergulhados na vida do povo, era coerente com a perspectiva eclesial na qual ele investiu toda a sua vida, a Igreja povo de Deus, em que os pobres, preferidos de Deus, exercem o protagonismo de seu ministério sacerdotal, profético e pastoral. ${ }^{740}$

$\mathrm{Na}$ época, os colaboradores de Dom Hélder estavam em dificuldades. Oliveira relata que "Comblin foi impedido de continuar em terras brasileiras. ${ }^{741}$

\footnotetext{
${ }^{736}$ OLIVEIRA, A. F., Igreja dos pobres e imagens de Deus em José Comblin: convites à práxis cristã emergentes da Missão Ibiapina no semiárido nordestino, p. 17.

${ }^{737}$ SOUZA, A. R., O Vaticano II no cotidiano do Nordeste brasileiro: a contribuição de D. Hélder Câmara e José Comblin à renovação da Igreja de Recife (1965-1972), p. 286.

${ }^{738}$ OLIVEIRA, A. F., Igreja dos pobres e imagens de Deus em José Comblin: convites à práxis cristã emergentes da Missão Ibiapina no semiárido nordestino, p. 91.

${ }^{739}$ OLIVEIRA, A. F., Igreja dos pobres e imagens de Deus em José Comblin: convites à práxis cristã emergentes da Missão Ibiapina no semiárido nordestino, p. 138.

${ }^{740}$ OLIVEIRA, A. F., Igreja dos pobres e imagens de Deus em José Comblin: convites à práxis cristã emergentes da Missão Ibiapina no semiárido nordestino, p. 138.

${ }^{741}$ OLIVEIRA, A. F., Igreja dos pobres e imagens de Deus em José Comblin: convites à práxis cristã emergentes da Missão Ibiapina no semiárido nordestino, p. 91-92.
} 
Os escritos de Comblin daquele tempo parecem ter sido determinantes para seu exílio, mas faziam parte de sua natureza ousada e crítica. Conseguindo permanecer na América Latina, ele "acabou acolhido no Chile". ${ }^{742}$ Durante esse período, relatou sua experiência nas formações no Nordeste do Brasil, como afirma Oliveira: "no exílio, Comblin sistematizou a experiência do seminário rural e da Teologia da Enxada". ${ }^{743}$ Esse tempo serviu para que Comblin pudesse refletir sobre os acontecimentos atuais, e assim ele escreveu mais uma obra, como descreve Barros: "nessa fase, Comblin escreveu ainda (1977) 'O poder militar na América Latina (a ideologia da segurança nacional)". ${ }^{744}$ Depois de quase uma década de exílio, ele também foi expulso do Chile, como diz Oliveira: "o exílio durou oito anos até ser expulso do Chile pela ditadura de Pinochet”. ${ }^{745}$ O período passado no Chile até a expulsão foi o suficiente para sua nova entrada no Brasil. Pereira afirma: "bom, por esse tempo Comblin já podia voltar para o Brasil. Quando chegou, fomos ao aeroporto, todos com medo, levamos até advogado... Fomos, Dom Hélder, Dom Paulo Evaristo, eu. Vimos Comblin descendo do avião. Passou tranquilamente pela área de desembarque. Alívio! Pronto! Está vivo!....” ${ }^{746}$ As diversas obras de Comblin marcaram períodos de sua vivência pessoal, mas não se limitaram a isso. Elas mostram sua capacidade de percorrer diversas áreas do saber, como reflete Libânio: "os livros de Comblin reconhecem-se por características bem marcantes. Revelam ampla visão histórica" ${ }^{747}$ Sua sensibilidade lhe permitia a leitura precisa da história dos fatos pelos quais passava. Mesmo antes do surgimento da Teologia da Libertação, ele já trabalhava sob essa ótica. Barros esclarece: “em 1968, antes que se falasse em Teologia da Libertação, antes de Gustavo [Gutierrez] e de Leonardo [Boff], o padre Comblin escreveu, a pedido de Dom Helder, um texto que deveria servir como subsídio para as discussões dos bispos brasileiros em preparação à Conferência Episcopal

\footnotetext{
742 OLIVEIRA, A. F., Igreja dos pobres e imagens de Deus em José Comblin: convites à práxis cristã emergentes da Missão Ibiapina no semiárido nordestino, p. 91-92.

743 OLIVEIRA, A. F., Igreja dos pobres e imagens de Deus em José Comblin: convites à práxis cristã emergentes da Missão Ibiapina no semiárido nordestino, p. 91-92.

${ }^{744}$ BARROS, M., O Padre Comblin e a sua Teologia política, p.71.

745 OLIVEIRA, A. F., Igreja dos pobres e imagens de Deus em José Comblin: convites à práxis cristã emergentes da Missão Ibiapina no semiárido nordestino, p. 92.

746 PEREIRA, P. C., Transitando entre diferentes esferas da vida: uma abordagem sobre a multifacetada caminhada de José Comblin II, p. 73.

${ }^{747}$ LIBÂNIO, J. B., O Espírito Santo e a tradição de Jesus, p. 121.
} 
de Medellin". ${ }^{748}$ O primeiro livro tendo por título a Teologia da Libertação é atribuído a Gustavo Gutiérrez, mas Comblin já havia escrito sobre essa perspectiva, como diz Lara:

Aliás, como se sabe, já em 1968, antes mesmo do ano da $1^{\text {a }}$ edição do livro de Gustavo Gutiérrez (1971), Teologia da Libertação (1986), Comblin escreveu um documento, a pedido de Dom Helder, para servir de contribuição à Conferência de Medellín e nele propôs um jeito novo da Igreja testemunhar autenticidade evangélica: fazer oposição à ditadura militar, aproximar-se das classes populares e priorizar a formação dos leigos. ${ }^{749}$

Destinado originalmente a poucos leitores, o texto não tardou a chegar à imprensa, atraindo a repressão, como afirma Barros: "apesar de que o texto tinha sido escrito para ser um subsídio interno e até reservado a poucas mãos, ele foi descoberto pela imprensa e caiu nas mãos da repressão". ${ }^{750} \mathrm{O}$ texto orientava a denúncia política do regime militar, incentivando oposição por parte da Igreja. Barros informa: "Esse texto era politicamente muito forte, denunciava claramente a ditadura militar brasileira e propunha resistência e oposição da Igreja". ${ }^{751} \mathrm{O}$ conceito teológico do autor traz as marcas da libertação, remetendo ao cativeiro do povo de Israel, escravizado no Egito, e às promessas e alianças pela conquista da liberdade, para a qual caminha o povo de Deus, como explica Oliveira:

Em sua teologia Comblin aprofunda e apresenta de maneira clara que o conceito de povo nasceu na experiência primordialmente religiosa, na história de Israel, na relação com Deus no contexto de escravidão no Egito. Foi no processo de libertação e na Aliança entre Deus e seu povo que Israel se constituiu como povo da promessa, na busca da terra livre. A compreensão de povo é, portanto, relação, construção, meta, esperança de vida digna e liberdade. ${ }^{752}$

É verdade que não se pode limitar Comblin aos textos, pois sua prática reproduz suas reflexões, como afirma Barros: "no entanto, eu gostaria de frisar que a teologia do Comblin não se expressava somente nos seus escritos, mas, principalmente, nas realizações concretas que ele inspirava e animava" ${ }^{753} \mathrm{O}$ doutor dos pobres decidiu-se por um estilo de vida que refletisse sua forma de

\footnotetext{
${ }^{748}$ BARROS, M., O Padre Comblin e a sua Teologia política, p.71.

${ }^{749}$ LARA, Valter Luiz. Hermenêutica Bíblica para Compreender Paulo em Comblin. Paralellus, Recife, v. 9, n. 22, set./dez. 2018, p. 653-66, p. 662.

${ }^{750}$ BARROS, M., O Padre Comblin e a sua Teologia política, p.71.

${ }^{751}$ BARROS, M., O Padre Comblin e a sua Teologia política, p.71.

${ }^{752}$ OLIVEIRA, A. F., Igreja dos pobres e imagens de Deus em José Comblin: convites à práxis cristã emergentes da Missão Ibiapina no semiárido nordestino, p. 86.

${ }^{753}$ BARROS, M., O Padre Comblin e a sua Teologia política, p.71.
} 
fazer Teologia, aquela que sai do povo, que encontra ouvintes. Ele se faz entender porque se expressa na linguagem popular e vive de maneira simples, como o próprio nordestino, embora sua boa formação na Europa o nivelasse aos grandes teólogos. Barros explica:

Era uma teologia vivida na pastoral e na inserção. Um homem formado nas universidades da Europa, com mestrado e doutorado, um teólogo que pode ser comparado com os grandes teólogos europeus da época (Congar, Chenu, Rahner etc.), aqui no Nordeste inspirou a Teologia da Enxada, uma forma de formar lavradores e pessoas simples a ligar teologia e vida, uma espécie de "universidade popular" que queria formar missionários/as lavradores. Dessa experiência, surgiu a intuição das missões populares que se espalharam por todo o Nordeste, resgatando as antigas missões populares [...]. ${ }^{754}$

O caminho da liberdade construído na teologia combliniana passa pela sua hermenêutica dos textos bíblicos, encontrando bases para a construção da libertação. Oliveira diz: "segundo Comblin, vê-se no Novo Testamento que constituir aliança com Deus na liberdade traz para o povo a exigência de se deixar guiar pelos princípios éticos, inaugurados pela práxis amorosa e servidora de Jesus. A liberdade de Jesus está em servir o seu povo e comunicar a liberdade e a vida em plenitude". ${ }^{755}$ Mantendo seu compromisso com o povo de Deus e dando sequência aos escritos após o término da ditadura no Brasil, ele descreve três modelos de teologia, numa de suas obras. Barros afirma: “em 1985, um ano depois da queda da ditadura no Brasil, ele escreveu um livro comparando três modelos de teologia: a da libertação, a neoconservadora, então muito forte, e a liberal. [...]". ${ }^{756}$ Comblin esperava que, a partir de Medellin, a Igreja embarcaria em uma nova fase, como relata Oliveira: "Comblin situa a Conferência LatinoAmericana de Medellin, em 1968, no contexto histórico em que o discurso da Igreja Imperial da Cristandade entrava na fase terminal". ${ }^{757}$ Ele acreditava que se apresentava um momento inédito, em que a Igreja levaria ao diálogo, a abraçar, em vez de apartar. Oliveira continua: "o caminho foi aberto por João XXIII ao lançar o olhar de otimismo para o mundo e ao propor à Igreja a prática da

\footnotetext{
${ }^{754}$ BARROS, M., O Padre Comblin e a sua Teologia política, p.71.

755 OLIVEIRA, A. F., Igreja dos pobres e imagens de Deus em José Comblin: convites à práxis cristã emergentes da Missão Ibiapina no semiárido nordestino, p. 87.

${ }^{756}$ BARROS, M., O Padre Comblin e a sua Teologia política, p.72.

${ }^{757}$ OLIVEIRA, A. F., Igreja dos pobres e imagens de Deus em José Comblin: convites à práxis cristã emergentes da Missão Ibiapina no semiárido nordestino, p. 71.
} 
misericórdia em vez das condenações". ${ }^{758}$ Barros apresenta um panorama de três intensas etapas da Teologia comblianiana:

Eu teria a tendência de comparar com os três grandes momentos da Bíblia judaica: em um primeiro tempo, o Êxodo; em um segundo tempo, a atuação dos profetas; e finalmente, em terceiro tempo, a Sabedoria, no sentido da experiência cotidiana. Vamos tentar lembrar esses três momentos fortes da teologia do Comblin. ${ }^{759}$

O teólogo belga diz que Medellin avançou ao expor a temática da justiça, mas compreende que essa palavra não é tolerada pela sociedade, o que gera muitos embates. Oliveira esclarece: "Comblin nos diz que Medellin toca na palavra proibida: Justiça. A sociedade até aceita falar na pobreza, desde que não a associe à Justiça". ${ }^{760}$ Comblin participou dos eventos que marcaram a realidade de muitos teólogos na América Latina, como diz Cabral: “em sintonia com os sinais dos tempos, participou - direta ou indiretamente - das duas mais decisivas, entre as até agora realizadas, Assembleias Gerais do Episcopado da América Latina: a segunda, em Medellín (Colômbia, 1968), e a terceira, em Puebla (México, 1979)" ${ }^{761}$ A postura profética, assumida em Medellin, da denúncia de pecados e injustiças sociais expõe seus seguidores a perseguições - e muitos se tornaram mártires - mas cria outra face na Igreja da América latina. Oliveira destaca:

Medellin adquire o tom profético ao denunciar o pecado social na injustiça planejada. Comblin cita, como exemplo dessa Igreja convertida aos pobres que descobriu o povo de Deus, o arcebispo de El Salvador, Dom Oscar Romero, martirizado em 24 de março de 1980 porque assumiu a liberdade profética da Palavra em favor do povo. Através de Romero e outros bispos, a Igreja da América Latina ganhou um novo rosto. ${ }^{762}$

Nessa época as perseguições aos teólogos da libertação aumentaram, e por isso eles planejaram publicar escritos da visão libertadora. Barros afirma: "naquele tempo, já sob muita pressão e censura, os teólogos da libertação resolveram fazer a coleção 'Teologia e Libertação', uma tentativa de fazer uma

\footnotetext{
${ }^{758}$ OLIVEIRA, A. F., Igreja dos pobres e imagens de Deus em José Comblin: convites à práxis cristã emergentes da Missão Ibiapina no semiárido nordestino, p. 71.

${ }^{759}$ BARROS, Marcelo. O Padre Comblin e a sua Teologia política. Paralellus, Recife, v. 6, n. 11, Especial José Comblin, p. 67-74, 2015, p. 70.

${ }^{760}$ OLIVEIRA, A. F., Igreja dos pobres e imagens de Deus em José Comblin: convites à práxis cristã emergentes da Missão Ibiapina no semiárido nordestino, p. 72.

${ }^{761}$ CABRAL, N. D. A.; MARQUES, L. C. L., Um tufão chamado José Comblin, p. 594.

762 OLIVEIRA, A. F., Igreja dos pobres e imagens de Deus em José Comblin: convites à práxis cristã emergentes da Missão Ibiapina no semiárido nordestino, p. 72.
} 
enciclopédia de vários assuntos, todos abordados a partir da visão libertadora". ${ }^{763}$ Medellin e Puebla destacam-se por dar voz a quem não a tinha, mediante o tom profético anunciado por teólogos comprometidos com a vida e com tudo quanto lhe diz respeito. Oliveira esclarece: "Comblin faz parte da tradição de Medellin e Puebla, que recolheu os grandes gritos e anseios dos pobres de Deus do continente latino-americano e seus movimentos de libertação. Com vários outros teólogos latino-americanos, articulou fé cristã e engajamento social, e reencontrou os pobres de Jesus". ${ }^{764}$ As publicações de Comblin continuaram, e ele também iniciou uma coleção, infelizmente inconclusa, mas relevante e conhecida por títulos como "O Espírito Santo é a Libertação". Barros esclarece:

\begin{abstract}
Nessa coleção que ficou inacabada, Comblin escreveu três livros: "A Antropologia Cristã" (1985), "O Espírito Santo e a Libertação" (1987) e já quando a coleção estava parada, ele publicou ainda nessa coleção: "O neoliberalismo, ideologia dominante na virada do século" (2000). Era a época da perseguição aberta a teólogos da libertação. Comblin sofreu censuras, proibições de bispos locais a que ele pudesse falar aqui e ali, mas não sofreu diretamente perseguição na Cúria Romana. ${ }^{765}$
\end{abstract}

A construção dos textos de Comblin acompanha sua percepção e ação no mundo, optando por um caminho crítico frente aos desafios, e seus textos se fazem acompanhar de criatividade e muitas provocações. Libânio comenta: "ele trabalha os temas na perspectiva do processo de desenvolvimento ao longo do tempo. Implica leituras e pesquisas que lhe oferecem o material básico. Além do mais, carrega o texto de intuições profundas, criativas e provocantes". ${ }^{766}$ Os estudos das reflexões comblinianas ganharam espaço em algumas universidades, como comenta Lara:

A vida, o pensamento e a obra do Padre José Comblin têm sido objeto de estudos de especialistas em teologia e ciências da religião. Grupos de estudos e de pesquisa estão em plena atividade animando encontros, seminários e releituras da obra do mestre. Os grupos da UNICAP de Recife e da PUC de São Paulo, entre outros, representam esse esforço de recuperação e atualização do pensamento de Comblin. ${ }^{767}$

\footnotetext{
${ }^{763}$ BARROS, M., O Padre Comblin e a sua Teologia política, p. 72.

${ }^{764}$ OLIVEIRA, A. F., Igreja dos pobres e imagens de Deus em José Comblin: convites à práxis cristã emergentes da Missão Ibiapina no semiárido nordestino, p. 13.

${ }^{765}$ BARROS, M., O Padre Comblin e a sua Teologia política, p. 72.

${ }^{766}$ LIBÂNIO, J. B., O Espírito Santo e a tradição de Jesus, p. 121.

${ }^{767}$ LARA, V. L., Hermenêutica bíblica para compreender Paulo em Comblin, p. 653-666, p. 654.
} 
Uma das universidades que reserva espaço aos estudos comblinianos é a UNICAP, na qual ele deixou sua biblioteca, como refere Dias: "ele deixou na UNICAP não apenas a sua grande biblioteca, mas também muitos amigos, com a tarefa de continuar semeando uma espiritualidade libertária e compromissada". ${ }^{768}$

Mas o interesse pelo pensamento combliniano estende-se a outras universidades brasileiras. Dias continua: "há grupos de estudo sobre o pensamento do padre José Comblin espalhados em várias Universidades e Comunidades. No Nordeste brasileiro esses grupos possuem uma dinâmica própria de reuniões e encontros". ${ }^{769}$ O traço mais forte dos escritos de Comblin é a sua capacidade de comunicação com gente simples, malgrado sua elevada formação acadêmica em universidades europeias, como comenta Oliveira: "teólogo de pensamento profundo e incisivo nas questões eclesiais e sociais, dada a sua preparação acadêmica e profícua experiência pastoral, desenvolveu vasta obra teológica". 770 O trabalho de Comblin não se resume a informar o leitor pobre, mas o convoca à reflexão e à ação por meio de práticas transformadoras. Seus textos surgiam a partir das experiências com o povo, do contato, da observação, e tudo na sua vivência levava-o à reflexão. Libânio esclarece: "estas nasciam de enorme capacidade crítica, de contacto com as pessoas, de observação da vida que o cercava, sobretudo da inserção no meio pobre. Não deixa o leitor simplesmente informado. Incita-o à reflexão e à mudança de óticas e de práticas". ${ }^{771}$ Leite menciona alguns dos livros de Comblin e destaca os que mais o impressionaram:

Entre seus livros, escolhi: "O provisório e o definitivo" (1968), que considero sempre atual. "O povo de Deus" (2002), "O caminho: ensaio sobre o seguimento de Jesus Cristo" (2004) e "A vida: em busca da liberdade" (2007). E o fiz desejando que retomemos as questões levantadas em todos eles, para fundamentar nossa fé e sua prática. ${ }^{772}$

Em seus escritos o teólogo relata um distanciamento entre o cristianismo e o Cristo, tendo aquele inserido outros elementos. Profeticamente ele chama o cristianismo de volta ao Cristo. Segundo Oliveira: "Comblin analisa a maneira

\footnotetext{
${ }^{768}$ DIAS, J. C. T., Comblin, mais uma vez Comblin, p. 5-8, 2015, p. 6.

${ }^{769}$ DIAS, J. C. T., Comblin, mais uma vez Comblin, p. 5-8, 2015, p. 6.

${ }^{770}$ OLIVEIRA, A. F., Igreja dos pobres e imagens de Deus em José Comblin: convites à práxis cristã emergentes da Missão Ibiapina no semiárido nordestino, p. 17.

${ }^{771}$ LIBÂNIO, J. B., O Espírito Santo e a tradição de Jesus, p. 121.

772 LEITE, Maria Celina Correia. Comblin e a espiritualidade do provisório. Paralellus, Recife, v. 6, n. 11, Especial José Comblin, p. 43-50, 2015, p. 45.
} 
como o Cristianismo distanciou-se da práxis de Jesus, à medida que assimilou vários elementos do judaísmo em seu interior, mais ainda, da cultura grecoromana a partir dos séculos III e IV", 773

Para Comblin a Igreja não acompanhou as transformações do mundo, não consegue responder aos desafios atuais, e por isso encontra dificuldade em prosseguir. Ele almeja uma reforma que objetive um cristianismo mais coerente e integrado à vida atual. Libânio afirma: "o alvo principal das críticas reside na forma religiosa que a Igreja assumiu na Cristandade e que conserva até hoje em muitos aspectos. Esta Igreja não responde, segundo Comblin, aos apelos e interpelações dos tempos atuais, configurados pela modernidade". ${ }^{774}$ A estrutura dos escritos de Comblin é bastante profunda, ainda que emerja da realidade, porém ele alerta que o rigor técnico não deve impedir o acesso do povo simples. Lara afirma:

A obra de análise e intepretação bíblica de Comblin é imensa. Sua hermenêutica, tal como ele apresenta, embora seja simples, não é tão fácil assim do ponto de vista prático e existencial, nem mesmo do ponto de vista técnico e acadêmico. Mas, como ele mesmo orientou, o caráter técnico não deve sufocar ou impedir que a Palavra de Deus chegue aos mais simples [...]. ${ }^{775}$

O potencial teórico de Comblin fez dele um teólogo reconhecido e comparável aos grandes teólogos de sua época, mas sua vida e sua dedicação na América Latina fizeran-o teólogo do povo. Oliveira afirma: "teólogo de grande envergadura intelectual e de larga experiência pastoral em vários países latinoamericanos, e radicou-se na América Latina por 53 anos". ${ }^{776}$ Suess comenta um dos últimos livros de Comblin, no qual ele previa o final do seu combate:

Um dos seus últimos livros sobre "A profecia na Igreja", José Comblin terminou assim: "Eu estou no final da vida. Tive o privilégio de conhecer de perto e de participar da vida de grandes profetas e também de muitos pequenos profetas, homens e mulheres, que não entraram oficialmente na história. Desejo que muitos jovens possam fazer a mesma experiência. ${ }^{777}$

\footnotetext{
773 OLIVEIRA, A. F., Igreja dos pobres e imagens de Deus em José Comblin: convites à práxis cristã emergentes da Missão Ibiapina no semiárido nordestino, p. 18.

${ }^{774}$ LIBÂNIO, J. B., O Espírito Santo e a tradição de Jesus, p. 121.

${ }^{775}$ LARA, V. L., Hermenêutica bíblica para compreender Paulo em Comblin, p. 657.

${ }^{776}$ OLIVEIRA, A. F., Igreja dos pobres e imagens de Deus em José Comblin: convites à práxis cristã emergentes da Missão Ibiapina no semiárido nordestino, p. 68.

${ }^{777}$ SUESS, P., Missionário migrante - teólogo militante José Comblin: O retorno do enviado do Pai, p. 79.
} 
O modo de vida de Comblin transformou muitas vidas, dado o seu compromisso com o povo ao assumir a missão na força do Espírito. Oliveira diz: "percorreu o Brasil inteiro no serviço à Igreja dos pobres e, identificou-se profundamente com o povo do semiárido nordestino nas experiências eclesiais, nas lutas sociais de convivência com o bioma caatinga". ${ }^{778}$ Hoornaert, no entanto, faz um importante alerta sobre a criação dos textos de Comblin. Para ele, o único que não foi elaborado no calor do momento foi sobre a Teologia do Espírito Santo:

Ele mesmo dizia que o único trabalho não 'ocasional' dele era a teologia do Espírito Santo, que não resultou numa obra unificada, mas em cinco livros, publicados ao longo de 25 anos. A isso temos de acrescentar seu último livro "O Espírito Santo e a Tradição de Jesus" (COMBLIN, 2012), que de certa forma expressa uma síntese do pensamento de Mestre Comblin. ${ }^{779}$

Na última fase de sua vida, Comblin dedicou-se a escrever mais para o povo e a viver no meio dos simples. Refletia constantemente sobre os traços da ruralidade ainda existentes na Igreja, problematizando o contraste entre essa Igreja e um Brasil cada vez mais urbano. Barros comenta: "nos últimos anos de vida, o padre Comblin quis escrever mais para as bases e, principalmente, quis ele mesmo viver mais a experiência de base. Estava preocupado por achar que a Igreja ainda vivia muito a missão voltada para a cultura rural quando o Brasil tinha se tornado de repente um país urbano". ${ }^{780}$ Seus últimos escritos percorriam os desafios da missão nas cidades. Comblin estava sempre atento às transformações em curso na sociedade e sempre pronto a refletir a seu respeito, como afirma Barros:

Escreveu dois livros sobre esse desafio: a missão da Igreja nas cidades (1998 e 2002). Certa ocasião, numa Páscoa que foi passar comigo no mosteiro de Goiás, disse-me que se sentia muito feliz porque o povo de Bayeux, onde ele morava na Paraíba, lhe via como "padre José", um simples padre do interior. No último ano de sua vida, foi viver com os pobres na Barra, BA, e fazer parte da equipe pastoral de Dom Luis Cappio. ${ }^{781}$

Suas últimas produções eram voltadas ao povo e seu caminhar profético preparava o povo de Deus para novas realidades, como afirma Barros: "seus

\footnotetext{
778 OLIVEIRA, A. F., Igreja dos pobres e imagens de Deus em José Comblin: convites à práxis cristã emergentes da Missão Ibiapina no semiárido nordestino, p. 68.

${ }^{779}$ HOORNAERT, E., O tema da transformação no pensamento de José Comblin, p. 30.

${ }^{780}$ BARROS, M., O Padre Comblin e a sua Teologia política, p.72.

${ }^{781}$ BARROS, M., O Padre Comblin e a sua Teologia política, p.72.
} 
últimos livros 'Vocação para a Liberdade' (1998), 'O povo de Deus' (2002) e ‘A profecia na Igreja' (2008) são, de todos os seus livros, alguns dos mais acessíveis a qualquer leitor(a)". ${ }^{782}$ Hoornaert lembra que uma obra inconclusa de Comblin trata justamente do Espírito Santo:

Vejamos por uns instantes seu último trabalho, publicado depois de sua morte: "O Espírito Santo e a Tradição de Jesus" (COMBLIN, 2012). Redigido em cinco Versões (todas incompletas), esse trabalho é uma filosofia da história, baseada na ideia da transformação. Quem compara as diversas Versões entre si não demora em detectar que Comblin trata basicamente das transformações operadas pelo Espírito Santo, como se pode ver na quinta e última Versão (igualmente incompleta). ${ }^{783}$

Em seus livros ele propunha novas percepções para a caminhada do povo de Deus na missão sob a força do Espírito, agindo na transformação do mundo. Barros conclui: "em todos eles, transparece a proposta de uma Igreja nova e inserida no meio do povo e em função do Reino de Deus que vem transformar todas as estruturas desse mundo". ${ }^{784}$ Por sua leitura de mundo a partir da vivência na América Latina, e mais ainda no Nordeste do Brasil, com o olhar profético para o caminhar missionário, é que seus textos servem de reflexão para a continuidade na busca de vias possíveis à missão.

\section{2. \\ A teologia da missão em Comblin}

$\mathrm{Na}$ segunda parte do capítulo nos concentraremos no aprofundamento da teologia da missão em Comblin e em sua perspectiva de missão, que envolve o Espírito em concretudes de ações do leigo e do cristão em geral, bem como no seu esforço de mobilização de estruturas para a preparação do leigo para o engajamento.

\footnotetext{
${ }^{782}$ BARROS, M., O Padre Comblin e a sua Teologia política, p.72.

${ }^{783}$ HOORNAERT, E., O tema da transformação no pensamento de José Comblin, p. 40.

${ }^{784}$ BARROS, M., O Padre Comblin e a sua Teologia política, p.72.
} 


\subsection{1.}

\section{Conceito e prática da missão em Comblin}

Passamos agora à reflexão combliniana sobre o tema da missão. A missiologia de Comblin tem por base o agir do Espírito, assim como sua opção de vida. Silva diz: "dessa maneira, o sonho de ser um padre missionário teve uma maneira pneumatológica de se realizar". ${ }^{785}$ A teoria proposta por Comblin também parte de Atos 2, acrescentando diversos momentos como o de Pentecostes, mas este é diferente, como assinala Comblin: "o livro dos Atos dos Apóstolos refere vários fenômenos de vinda do Espírito. Contudo, o primeiro deles tem um significado especial e único. O que aconteceu no dia de Pentecostes foi único" ${ }^{786}$ Esse acontecimento foi primordial para a história do cristianismo e Comblin resgata a comparação lucana sobre a sua importância do dia de Pentecostes, ao afirmar: "São Lucas destaca o significado do acontecimento comparando o dia de Pentecostes com o dia da aliança no Sinai". ${ }^{787}$

Durante sua vida missionária, o autor escreveu sobre o Espírito Santo, sendo forte na sua teologia a questão pneumatológica, à qual ele se dedicou, como lembra Cabral: “ocuparam suas atenções, enquanto teólogo, as mais variadas abordagens, inclusive escreveu sobre o Espírito Santo (seis obras)" ${ }^{788}$ Em algumas de suas obras o autor toma a discussão pneumatológica a partir de comparações com as igrejas orientais. Para Comblin existe certa acusação contra a Teologia e, consequentemente, contra a prática da Igreja no Ocidente. Isso se aplica a católicos e protestantes. Comblin diz:

Os orientais acusam constantemente os ocidentais, católicos e protestantes, de não reconhecerem o papel do Espírito Santo na Igreja. De fato, na prática como na teologia do Ocidente, o Espírito parece acrescentado a uma realidade definida sem ele. No protestantismo a Igreja é constituída pela palavra de Deus. A palavra existe primeiro. O Espírito ajuda, mas não constitui. Para os católicos, de acordo com a teologia de Belarmino que prevaleceu na teoria e na prática até o Vaticano II e ainda prevalece na prática desde então, a Igreja é uma organização fundada por Jesus, dirigida pela hierarquia que garante a fiel execução das funções definidas

\footnotetext{
${ }^{785}$ SILVA, Mariane de Almeida. Dom Paulo de Tarso Campos e a vinda do Padre José Comblin ao Brasil. Paralellus, Recife, v. 9, n. 22, set./dez. 2018, p. 621-633. p. 623-624.

${ }^{786}$ COMBLIN, José. O Espírito Santo no Mundo. São Paulo: Paulus, 2009, p. 18.

${ }^{787}$ COMBLIN, J., O Espírito Santo no mundo, p. 19.

${ }^{788}$ CABRAL, N. D. A.; MARQUES, L. C. L., Um tufão chamado José Comblin, p. 595.
} 
por Jesus graças aos poderes recebidos dele. O Espírito Santo vem autentificar, santificar, sacralizar, dar força e autoridade ao que faz a Igreja. ${ }^{789}$

Comblin é bastante crítico quanto ao afastamento entre Teologia e prática, afirmando: "a consequência da metodologia adotada é que os teólogos, como os filósofos gregos, tendem a formar um mundo fechado. Somente outros teólogos podem entender o que um teólogo ensina. Os discursos dos teólogos dirigem-se a outros teólogos". 790 A situação levantada por Comblin sobre o estado da pneumatologia ocidental, seguindo as críticas orientais, leva à reflexão sobre o assunto que muito importa ao pentecostalismo. O enunciado de Comblin aponta para uma prática que, segundo ele, delimita o Espírito como auxílio. Nessa prática o Espírito está sempre presente, mas de forma a contribuir, a ajudar. Entretanto, para ele o Espírito gera vida, sendo o responsável pela missão. A problemática acontece, segundo ele, por desequilíbrio entre cristologia e pneumatologia. Comblin explica:

\begin{abstract}
Na origem do cristianismo houve dois fatos de igual importância. De acordo com a doutrina cristã os dois fatos estão intimamente relacionados e não se pode dar a um mais valor do que ao outro. O primeiro fato é Jesus desde o seu nascimento até sua morte e a sua ressurreição. O segundo fato é a experiência do Espírito Santo nas comunidades primitivas. ${ }^{791}$
\end{abstract}

Comblin afirma que o evento Cristo sozinho não cumpre a tarefa de explicar a Igreja e o cristianismo. Ele está convicto ao dizer que, sem o Espírito, a obra se tornaria incompleta. Por outro lado, a experiência do Espírito sem Jesus não poderia ter gerado o cristianismo, sendo impossível a separação entre os dois fatos. Por isso ele caminha para a ressignificação da experiência do Espírito na missão da Igreja, e diz:

O fato "Jesus" não basta para explicar a Igreja e o cristianismo. A vida, a morte e a ressurreição de Jesus não produziram nada na história deste mundo por si só. Sem o fato da experiência do Espírito Santo, Jesus não teria deixado nada. Sem dúvida, a experiência do Espírito por si só não teria gerado o cristianismo. Não pode separar-se do fato Jesus. ${ }^{792}$

A construção dessa lógica combliniana pode estar em sintonia com a prática pentecostal que, de certa forma, destaca a ação do Espírito, ressignificando sua

\footnotetext{
${ }^{789}$ COMBLIN, José. O Espírito Santo e a libertação. Petrópolis: Vozes, 1987, p. 105.

${ }^{790}$ COMBLIN, J., A virada da teologia cristã, p. 87.

${ }^{791}$ COMBLIN, J., O Espírito Santo e a libertação, p. 16.

${ }^{792}$ COMBLIN, J., O Espírito Santo e a libertação, p. 16.
} 
vivência cristã. Comblin chama a atenção para a questão, que, para ele, vai além das divergências teológicas entre cristãos orientais e ocidentais. A questão está ligada ao desafio que o cristianismo tem por diante das novas sociedades, que somente conhecem a Cristo pela ação do Espírito. Comblin continua:

A teologia ocidental, porém, deu pouco valor ao fato "Pentecostes" e pretendeu derivar tudo do fato "Páscoa". Uma teologia assim mutilada não pode ser eficaz no plano da ação. Sem a experiência do Espírito Santo, Jesus não teria movido os homens do seu tempo, nem sequer os seus ouvintes e os seus discípulos. Se foi assim naquele tempo podemos pensar que assim será em todos os tempos. ${ }^{793}$

Tratando-se da investigação a prática missionária pentecostal, que tem em Pentecostes o marco fundamental, necessita-se apurar melhor as questões pneumatológicas apontadas por Comblin. Afinal, ele esforçou-se em estruturar a missão leiga no Brasil num período de fortes mudanças, como esclarece Lara:

O tempo pós-conciliar com as mudanças que geraram as Conferências Episcopais latino-americanas de Medellín (1968), Puebla (1979), Santo Domingo (1992) e Aparecida (2007) deixaram suas marcas no pensamento de Comblin, até porque ele mesmo participou dessa história como um de seus protagonistas. ${ }^{794}$

Teólogo de destaque em temas populares, Comblin trabalhou por uma prática cristã simplificada. Em seus apontamentos ele também questiona, por exemplo, o que a reforma reformou, acreditando que o que mais requeria mudança não foi alterado: "ao lado da crise atual da Igreja ocidental, a Reforma foi brincadeira: os reformadores do século XVI deixaram o essencial da tradição ocidental no seu lugar. Mudaram a superfície, não tocaram no fundo da questão". ${ }^{795}$ Coexistem em Comblin a inconformidade com a atualização, o lugar e ação do Espírito, sua base argumentativa em comparação à Teologia ocidental, que, segundo ele, situa o Espírito no mesmo nível que o Cristo, sendo tais as duas faces que completam a mesma realidade, sem a qual não haveria cristianismo. Comblin descreve a realidade da Teologia oriental, mostrando que esta atribui ao Espírito também a inauguração de um novo mundo. Pentecostes estabelece um novo tempo, o Espírito criador transforma a realidade e a vida, e tudo quanto existe é por ele formado. Comblin explica:

\footnotetext{
${ }^{793}$ COMBLIN, J,. O Espírito Santo e a libertação, p. 17.

${ }^{794}$ LARA, V. L., Hermenêutica bíblica para compreender Paulo em Comblin, p. 662.

${ }^{795}$ COMBLIN, J., O Espírito Santo e a libertação, p. 63.
} 
A teologia ocidental insistiu muito menos sobre o Espírito na criação do que a teologia oriental. Esta parte da liturgia. A celebração de Pentecostes na Igreja oriental refere-se também à transformação da criação inteira pelo Espírito. Pentecostes foi uma nova criação: o paraíso entrou neste mundo. No ritual da Epifania celebra-se "a grande bênção da água". A ação do Espírito nas águas restaura também o universo. ${ }^{796}$

A Teologia sempre atribuiu ao Espírito participação em todas as obras de Deus, mas segundo Comblin, isso tem se verificado de modo desequilibrado, prejudicial ao cristianismo, e esse desequilíbrio tem sido cobrado pelos desafios a ele impostos. Ele acredita que o reconhecimento do devido lugar do Espírito na Teologia pode vir a ser um caminho para o cristianismo, algo já encontrado em muitos movimentos, nos quais o Espírito tem atuado. Assim se declara a fé pentecostal, e por isso Comblin busca resignificar o lugar do Espírito na Teologia:

Do princípio ao fim, a vida do mundo e a do homem procedem do Espírito de Deus e são dirigidas por ele. O Espírito de Deus está na origem de tudo. Enviado pelo Pai, segundo a inspiração da Palavra que é o Filho de Deus, o Espírito conduz tudo à plena realização do Reino de Deus. ${ }^{797}$

Isso não é novo no cristianismo: o Espírito sempre esteve presente na Teologia, e o que Comblin critica é a falta de destaque, num momento em que a Teologia deveria acompanhar a prática propagada em várias partes do mundo. Sobre o Cristo, Comblin argumenta: "toda a sua vida, morte e missão culminaram na chegada do Espírito Santo". ${ }^{798}$ Ele chama a atenção para o grande evento Cristo, por vezes resumo do cristianismo, compreendendo a centralidade do Cristo na Teologia e na cristandade, mas esse mesmo Cristo conclui sua missão no mundo ao inaugurar a missão do Espírito. E isso se torna central ao cristianismo da Igreja de Atos, como explica Comblin: "o cristomonismo resulta primeiro do desequilíbrio entre as missões do Filho e do Espírito Santo no Ocidente: sempre houve uma cristologia, mas sempre faltou uma pneumatologia paralela, em toda a tradição escolástica até os últimos tempos". ${ }^{799}$ A situação requer atenção, o pentecostalismo católico e protestante é realidade presente e sem volta. Cabe à Teologia sistematizar uma pneumatologia coerente com a realidade, contribuinte dessa ação. Para Comblin, outros assuntos, como o advento do reino, poderiam ser

\footnotetext{
${ }^{796}$ COMBLIN, J., O Espírito Santo e a libertação, p. 68.

${ }^{797}$ COMBLIN, José. Breve curso de teologia: o Espírito Santo e sua missão. São Paulo: Ed. Paulinas, 1983, p. 9.

${ }^{798}$ COMBLIN, J., O Espírito Santo no mundo, p. 6.

${ }^{799}$ COMBLIN, J., O Espírito Santo e a libertação, p. 30.
} 
discutidos no futuro: "o advento do reino de Deus na sua glória fica para uma data ulterior, indeterminada, visivelmente muito remota, e que não deve preocupar". 800

$\mathrm{O}$ atual momento requer uma pneumatologia que responda e auxilie a prática pentecostal da Igreja, ocupando a centralidade: “o que deve preocupar e chamar a atenção é essa vinda iminente do Espírito". ${ }^{801}$ Perdeu-se muito tempo na Teologia, pois, para a tradição, os fenômenos espirituais da fase inicial da Igreja já não existiam porque não havia necessidade, devendo a Igreja agir de outras maneiras. Com isso deixou-se de refletir sobre o tema, e a Teologia pneumatológica passou a receber menor atenção. Comblin diz: "a teologia tradicional dizia que os fenômenos espirituais dos primeiros tempos tinham desaparecido porque já não eram mais necessários". ${ }^{802}$ Segundo o autor, a Teologia ocidental precisar de uma pneumatologia útil na práxis pentecostal e em geral:

Em lugar de uma teologia, podemos ter uma visão da tradição que seja significativa, que seja realmente uma palavra para os contemporâneos, que seja a vida de Jesus em uma época determinada. O objeto dessa "teologia", em se querendo manter a palavra, é a vida de Jesus manifestada na imensa variedade de suas realizações, na vida vivida na tradição. Trata-se da Escritura sagrada lida pela tradição. ${ }^{803}$

Segundo Comblin, o problema começa na definição do vocábulo. O significado da palavra espírito remete a algo abstrato: "primeiramente, precisamos fazer um esclarecimento de vocabulário: trata-se da palavra 'espírito'. Em português, como em todos os idiomas europeus, a palavra espírito sugere imediatamente o contrário de matéria". ${ }^{804}$ A problemática é histórica, sempre relacionada a algo imaterial. Entretanto, na atualidade a sociedade tem rejeitado tudo o que não é material e concreto. Essa forma de viver tem se tornado um desafio à pneumatologia cristã, como adverte Comblin:

Um dos grandes obstáculos à fé no Espírito Santo é a própria palavra Espírito, com suas conotações conscientes ou inconscientes em todas as línguas do Ocidente. Trata-se de uma herança que vem dos gregos. Desde os gregos, as palavras "espírito", "espiritual" estão relacionadas com "pensamento", "intelectual", com

\footnotetext{
${ }^{800}$ COMBLIN, J., O Espírito Santo no mundo, p. 6.

${ }^{801}$ COMBLIN, J., O Espírito Santo no mundo, p. 6.

${ }^{802}$ COMBLIN, J., O Espírito Santo e a libertação, p. 12.

${ }^{803}$ COMBLIN, J., A virada da teologia cristã, p. 92.

${ }^{804}$ COMBLIN, J., O Espírito Santo no mundo, p. 9.
} 
atividades não-materiais. Na tradição grega, espiritual se opõe a material, como se houvesse uma separação entre a matéria e o espírito. Ora, no mundo e na cultura moderna valoriza-se negativamente tudo o que não é material. Falar em nãomaterial equivale a falar em não-real. Espiritual corresponde a aéreo, sem densidade e sem conteúdo real. ${ }^{805}$

A percepção combliniana de espírito está associada a algo concreto, uma ação real, embora a palavra conduza ao sentido oposto: "espontaneamente, o 'espírito' evoca a ideia de não matéria, imaterial". 806 Para Comblin, as manifestações do Espírito na Bíblia acontecem de forma concreta, transformando, e suas ações são visíveis:

Ora, na Bíblia dá-se o contrário. Espírito quer dizer vida, movimento, realidade. O Espírito não se opõe à matéria, mas à morte, à letra morta, à carne frágil e mortal. O Espírito quer dizer força. Mas este sentido de espírito não corresponde ao modo de entender de nossos contemporâneos. ${ }^{807}$

Qual seria o caminho? Como se poderia resolver isso? Para Comblin, o caso talvez não tenha solução na língua portuguesa, pela origem do vocábulo original de que deriva: "pode ser que o árabe seja mais adequado, porque pertence à mesma família da língua de Jesus". ${ }^{808}$ Mesmo reconhecendo as limitações de interpretações impostas pela contradição de expressão do termo, Comblin insiste em levantar a questão, pois o sentido da palavra remete justamente ao contrário do que aponta o idioma português: "tudo isso serve para dizer que o nome não deve enganar: quando damos à terceira pessoa da Santíssima Trindade o nome de 'Espírito', queremos dizer exatamente o contrário daquilo que o nome evoca". ${ }^{809}$ Toda reflexão proposta serve para estabelecer o diálogo entre a práxis cristã que se destacou a partir do século XX e a Teologia, buscando referências sólidas em torno da temática. Comblin destaca: "o Espírito Santo como pessoa. No Antigo Testamento, o Espírito aparece mais como força divina. Sua personalidade não se evidencia claramente. Ele é a força que move os heróis do passado, os juízes, os profetas, o futuro Messias". 810

Se a ação do Espírito manifestava-se pela força evidente, mudando estruturas, é possível que assim também ocorra nestes dias, ou que essa operação

\footnotetext{
${ }^{805}$ COMBLIN, J., Breve curso de teologia, p. 330.

${ }^{806}$ COMBLIN, J., O Espírito Santo no mundo, p. 9.

${ }^{807}$ COMBLIN, J., Breve curso de teologia, p. 330.

${ }^{808}$ COMBLIN, J., O Espírito Santo no mundo, p. 10.

${ }^{809}$ COMBLIN, J., O Espírito Santo no mundo, p. 10.

${ }^{810}$ COMBLIN, J., Breve curso de teologia, p. 334.
} 
já esteja em curso. Comblin destaca: "conforme as palavras semíticas, a nossa palavra 'espírito' significa a força de Deus, uma força de tempestade, como a força do vento, a força do temporal, aquela que se manifestou no dia de Pentecostes". ${ }^{811}$ A ação do Espírito como descrita na Bíblia é intensa, a mesma de Deus que formou o mundo, como assegura Comblin: "quando a Bíblia diz que o Espírito estava ou desceu na pessoa de Davi, ou de Elias, ou dos profetas, isso significa que a força de Deus estava neles, que havia neles uma força inaudita, uma força de Deus, a força pela qual Deus tinha feito o mundo". ${ }^{812}$ No Novo Testamento ela ainda aparece como a força de Deus, mas ainda no Novo Testamento surge uma nova percepção do Espírito como pessoa. Os textos que assim apresentam o Espírito conferem a perspectiva de que a pessoa do Espírito assume o lugar de Cristo, dando sequência à missão:

No Novo Testamento, o Espírito ainda é a força de Deus. No entanto, seu caráter pessoal já aparece mais claramente. Nos textos não joaninos ainda poderíamos vacilar e interpretá-los todos como se se tratasse de uma força impessoal. Entretanto, os textos de João falam nitidamente do Espírito como uma pessoa semelhante ao Filho e capaz de substituir a presença do Filho de Deus. Devemos ler à luz dos textos de são João todos os demais. O Espírito Santo é um sujeito, igual ao Pai e ao Filho. É o autor de ações. Não é uma simples força movida pelo Pai ou pelo Filho. ${ }^{813}$

A conclusão da missão do Cristo inaugura a do Espírito. A força que tudo criou está novamente presente, e agora tudo pode ser feito novamente. Quem prometeu foi Cristo, na ação do Espírito, que o mundo será conduzido até o final. Comblin diz: "ao prometer e anunciar a vinda do Espírito, Jesus abre o caminho para a entrada da força de Deus: a força que criou o mundo e volta a este mundo para refazê-lo, para completá-lo e levá-lo ao seu destino final", ${ }^{814}$

O que está em curso no momento é a missão do Espírito. Daí a necessidade de clarear o assunto desde a problemática do sentido da palavra espírito em português até o desequilíbrio na Teologia. Sobre o problema do significado, Comblin afirma: “o que existe é um mero problema de palavra. O pior é que não há outra palavra disponível em português. Vemo-nos obrigados a usar a palavra de sempre, mas com o compromisso de explicar o seu significado cada vez que a

\footnotetext{
${ }^{811}$ COMBLIN, J., O Espírito Santo no mundo, p. 10.

${ }^{812}$ COMBLIN, J., O Espírito Santo no mundo, p. 10.

${ }^{813}$ COMBLIN, J., Breve curso de teologia, p. 334.

${ }^{814}$ COMBLIN, J., O Espírito Santo no mundo, p. 10-11.
} 
usamos". ${ }^{815}$ Então, a concepção combliniana de Espírito se vê compromissada com a contextualização do real sentido da palavra: "na língua hebraica, o Espírito se diz por uma palavra feminina (ruah). Na língua grega, o Espírito diz-se por uma palavra de gênero neutro: pneuma. Em latim e nas línguas latinas, traduz-se por spiritus, palavra masculina". 816

A atualização de uma Teologia do Espírito é urgente, devendo nascer da prática, pois, para muitos teóricos, a perda da fé pode estar associada à falta de uma Teologia do Espírito. Comblin afirma: "hoje em dia vários autores mostram que há uma conexão entre o triunfo do ateísmo no mundo moderno e a teologia do Espírito Santo, ou seja, melhor dito, a ausência de uma teologia e de uma prática do Espírito Santo". ${ }^{817}$ Além da falta da construção de uma pneumatologia, o autor também chama a atenção para uma cristologia com pouco Espírito: "além disto, fez-se uma cristologia praticamente sem o Espírito Santo". ${ }^{818}$

Comblin entende que a cristologia poderia contemplar mais o Espírito, o que teria ajudado mais o cristianismo, pois o Espírito foi a grande promessa missionária para a Igreja feita por Cristo. Na verdade pode-se interpretar esse entrelaçamento como duas missões diferentes, que, entretanto, se completam: "há uma diferença radical entre a missão do Filho e a missão do Espírito Santo. Porque o Filho se encarnou num indivíduo humano, fazendo-se uma Pessoa divina encarnada num ser humano". 819

A limitação geográfica do Cristo já não é mais a do Espírito que pode estar em todos, não se limitando pela encarnação, como afirma Comblin: "o Espírito Santo não se encarna em nenhum indivíduo humano, porque se torna presente em todos". ${ }^{820} \mathrm{O}$ Filho concluiu sua missão pela encarnação, em um momento e em um lugar da história. O Espírito age em todo o tempo na história, não se limitando a um único lugar:

O Filho age pela encanação. Pela encarnação o Filho está presente num indivíduo humano só, um escolhido entre bilhões: num lugar determinado e num momento determinado da história da humanidade. O Verbo pronuncia palavras determinadas, pronunciadas num idioma particular, escritas numa língua única. O evangelho é

\footnotetext{
${ }^{815}$ COMBLIN, J., Breve curso de teologia, p. 330.

${ }^{816}$ COMBLIN, J., O Espírito Santo e a libertação, p. 59.

${ }^{817}$ COMBLIN, J., O Espírito Santo e a libertação, p. 60.

${ }^{818}$ COMBLIN, J., O Espírito Santo e a libertação, p. 31.

${ }^{819}$ COMBLIN, J., Breve curso de teologia, p. 328.

${ }^{820}$ COMBLIN, J., Breve curso de teologia, p. 328.
} 
destinado a todos os homens, mas parte de um lugar determinado e único da história e da superfície da terra. ${ }^{821}$

Não se trata de inferiorizar a missão do Filho frente à do Espírito, mas de pontuar as diferenças. Comblin destaca: "o Filho foi enviado a um único homem e se uniu hipostaticamente a uma só natureza humana individual". ${ }^{822}$ A promessa do Espírito feita por Cristo ultrapassa os limites humanos, sendo ilimitada, podendo agir em todos, portanto são missões bem diferentes. Ele continua: "na realidade, a missão do Espírito é muito diferente da missão de Jesus, no sentido de que esta foi muito limitada no tempo, foi uma missão brevíssima, ao passo que a missão do Espírito Santo se estende ao longo da História". ${ }^{823}$

As manifestações do Espírito é que possibilitaram os acontecimentos no dia de Pentecostes, e é dessa maneira que ele parece agir atualmente no pentecostalismo, tanto no protestantismo quanto no catolicismo. Comblin afirma: “o Espírito é enviado a uma multidão incontável e age no interior de uma imensa diversidade de pessoas". ${ }^{824}$ Comblin destaca a importância da diferenciação entre as duas missões, para mostrar que a missão do Cristo proporcionava a salvação, mas estava refém do tempo e da história. Assim, o que se tem no tempo presente é a missão do Espírito:

Ora, tão importante como a missão do Filho é a missão do Espírito Santo. O Espírito Santo não se encarna num indivíduo. Não está ligado a um indivíduo, nem a um ponto determinado do tempo e do Espaço. O Espírito Santo é enviado a todos os países em todos os tempos. Está presente em toda a humanidade, age em todos os homens de todas as culturas e religiões. O Espírito Santo habita na multiplicidade. Assume a diversidade, cria um movimento de comunhão e convergência a partir da imensa diversidade humana. ${ }^{825}$

Precisa-se entender exatamente a completude proporcionada por uma missão a outra. As duas executam a missão de Deus no mundo, como ressalta Comblin: "a missão do Filho e do Espírito não se opõem, mas se completam. O Espírito é quem torna Jesus presente na vida de todos os homens em todas as gerações". 826

\footnotetext{
${ }^{821}$ COMBLIN, J., O Espírito Santo e a libertação, p. 178.

${ }^{822}$ COMBLIN, J., Tempo da ação, p. 28.

${ }^{823}$ COMBLIN, J., O Espírito Santo no mundo, p. 11.

${ }^{824}$ COMBLIN, J., Tempo da ação, p. 29.

${ }^{825}$ COMBLIN, J., O Espírito Santo e a libertação, p. 179.

${ }^{826}$ COMBLIN, J., Breve curso de teologia, p. 337.
} 
Veremos, no capítulo quarto como isso se relaciona com a interpretação quadrangular desse fato. Comblin frisa que essa realidade não diminui o Cristo, pelo contrário, liga todos a Ele: "exaltar o Espírito, convém insistir, não é depreciar o Cristo, nem reduzi-lo a um segundo plano. A missão do Espírito é de integrar todos os homens no Cristo". ${ }^{827}$ Compreendesem as duas missões como a forma missionária de Deus agir no mundo. Comblin acrescenta:

A expressão é de S. Irineu: O Pai age pelas suas duas mãos, o verbo e o Espírito Santo. As duas mãos são iguais em força e valor. As duas agem em conjunto. Não são idênticas. Cada uma produz uma operação diferente, mas ambas se complementam, e delas procede um resultado final. ${ }^{828}$

A situação na qual o cristianismo se encontra obriga a repensar propostas de ações de interação com a nova realidade. Comblin afirma:

A missão do Espírito não suprime a do Cristo. Não a reduz em nada. Pelo contrário, exalta-a, visto que faz surgir seu verdadeiro sentido. Mas é diferente e complementar. Não desaparece diante da missão do Cristo. Ela lhe é necessária por causa, justamente, de sua diferença. ${ }^{829}$

Muito mais agora, quando o cristianismo é amplamente desafiado por uma grande pluralidade religiosa, é fundamental essa assimilação das missões do Cristo e do Espírito como parceiras na missão de Deus, como diz Comblin: "as duas missões se complementam e se interpenetram, mas ambas são necessárias para realizar a única ação do Pai" ${ }^{830}$ Assim, estamos diante da missão do Espírito, como afirma Comblin: "a experiência de Pentecostes foi renovada várias vezes". ${ }^{831}$ Isso se verifica no livro de Atos e nas igrejas paulinas, surgindo novamente no pentecostalismo do século $\mathrm{XX}$, que reivindica as práticas bíblicas no tempo atual, inclusive os carismas, como destaca Comblin: "de repente, no século vinte aparece o movimento pentecostal, que afirma que nele se renovam os carismas das origens, inclusive o dom de línguas e o batismo no Espírito". 832

A fase inicial desse pentecostalismo foi vista com desconfiança por teólogos e igrejas, pois a Teologia cristã atribui tais acontecimentos à época da Igreja primitiva. Para Comblin, a reaparição dos carismas foi desordenada e as igrejas

\footnotetext{
${ }^{827}$ COMBLIN, J., Tempo da ação, p. 31.

${ }^{828}$ COMBLIN, J., O Espírito Santo e a libertação, p. 178.

${ }^{829}$ COMBLIN, J., Tempo da ação, p. 28.

${ }^{830}$ COMBLIN, J., Tempo da ação, p. 28.

${ }^{831}$ COMBLIN, J., O Espírito Santo e a libertação, p. 20.

${ }^{832}$ COMBLIN, J., O Espírito Santo no mundo, p. 106.
} 
não conseguiam conduzir os acontecimentos: "a questão dos carismas foi reatualizada de modo totalmente imprevisto no século passado. A teologia cristã considerava-os como uma realidade típica do primeiro século que desaparecera totalmente durante os séculos ulteriores". 833

Mas embora os fatos no cristianismo tenham ultrapassado uma realidade não prevista, o pentecostalismo pode ser considerado resposta de atualização da missão. Entendendo que o papel da Igreja sucede a anunciação das memórias de Jesus, Comblin diz: "a Igreja não foi simplesmente uma criação nascida da memória de Jesus. Esta não foi suficiente. Uma segunda vinda do Espírito foi necessária". ${ }^{834}$ Essa vinda do Espírito, já ocorrida em outros momentos, da história, agora se repete: "na história da Igreja houve muitas vezes fenômenos semelhantes, horas de fervor e de intensidade em que a presença do Espírito se tornou sensível". ${ }^{835}$ Para Comblin, tal experiência lança os homens em uma nova vivência, tornando possível uma missão na força do Espírito: "longe de ser um fechamento da consciência sobre si mesma, a experiência do Espírito lança os homens para o mundo como se estivesse infundindo neles energias supra-humanas para realizar uma obra supra-humana". ${ }^{836}$ Essa ação conduz a uma nova direção, uma realidade a partir da experiência do Espírito.

A marca da comunidade de Cristo é o Espírito em ação, bem como sua evidência manifestada na prática, como assegura Comblin: “o Espírito é o objeto evidente para a comunidade, a prova de que Jesus permanece com ela". ${ }^{837}$ Essa marca, surgida no pentecostalismo, destaca a frequência das manifestações do Espírito em ambientes comunitários, e não quando se está sozinho, como reflete Comblin: “o pentecostalismo aparece numa época em que reaparece a comunidade: os fenômenos pentecostais sempre aparecem em comunidade e nunca quando a pessoa está só. Da mesma maneira, os fenômenos dos Atos são sempre realizados em comunidade" ${ }^{838}$ A experiência em comunidade não acontece por acaso, e juntos seus membros sentem-se vocacionados à missão. A comunidade então experimentara um momento espiritual que faz dela igreja.

\footnotetext{
${ }^{833}$ COMBLIN, J., O Espírito Santo no mundo, p. 106.

${ }^{834}$ COMBLIN, J., O Espírito Santo e a libertação, p. 20.

${ }^{835}$ COMBLIN, J., O Espírito Santo e a libertação, p. 20.

${ }^{836}$ COMBLIN, J., O Espírito Santo e a libertação, p. 20.

${ }^{837}$ COMBLIN, J., O Espírito Santo e a libertação, p. 21.

${ }^{838}$ COMBLIN, J., O Espírito Santo no mundo, p. 112.
} 
Comblin argumenta que a igreja não deriva somente de Cristo e os discípulos tornam-se ativos a partir da experiência do Espírito em comunidade:

Os membros das comunidades experimentam por si mesmos uma realidade nova. A pura palavra não gera a comunidade cristã. Nem a simples adesão à organização eclesiástica. Não se trata de fazer recrutamento de membros novos por meios humanos, atribuindo depois o efeito ao Espírito Santo invisível. Não existe comunidade simplesmente pela adesão passiva a uma Igreja preexistente. A comunidade nasce de pessoas que fizeram a experiência espiritual juntas. Esta experiência é uma assimilação ativa da palavra e a entrada como membro ativo na organização da Igreja. O Novo Testamento sabe bem que a Igreja não deriva de Cristo diretamente. Não deriva certamente da sua atividade durante a sua vida mortal: os evangelhos mostram os discípulos passivos. Ora, a Igreja nasce quando os passivos se tornam ativos. Isto acontece somente depois da vinda do Espírito Santo. Nem sequer foi Jesus aparecido aos discípulos quem deu origem à Igreja. Foi o Espírito Santo como realidade experimentada e vivida pelos discípulos. ${ }^{839}$

A presença dos carismas era real e manifesta-se nas comunidades paulinas.

A partir daí Paulo orienta a que os dons estejam a serviço das comunidades. Comblin diz:

Ele enxerga os dons espirituais a partir do ponto de vista do papel na comunidade: são serviços. O dom não é considerado pela satisfação que dá ao sujeito: o que se estima no dom é o serviço que presta. Os dons correspondem a diversos papéis sociais, diversos papéis que concorrem para a construção da comunidade. ${ }^{840}$

Comblin constrói sua pneumatologia direcionando-a questões sociais, sua ocupação durante parte da vida. Ele tinha em mente uma ação do Espírito que age integralmente: "a Igreja é em primeiro lugar chamada a agir: chamada a realizar a missão do Espírito Santo". ${ }^{841}$ Quando se trata da glossolalia, Comblin busca basear-se na questão paulina, que remete o fenômeno a segundo plano. Entretanto, ao analisar o evento Pentecostes em At 2, ele chega à conclusão de que tais manifestações não seriam necessárias para fundamentar a missão e a nova aliança, reconhecendo, no entanto, os fatos apresentados:

Houve, no dia de Pentecostes, esse fenômeno de explosão de alegria, e explosão de expressão que os vizinhos interpretaram como embriaguez. Essa explosão barulhenta, explosão de linguagem, não era necessária nem para a missão, nem para a inauguração da nova aliança: há algo gratuito que parece ter sido dado aos participantes como dom místico, como experiência sem outro significado a não ser dar relevo, importância subjetiva ao momento: "fez-se ouvir do céu um ruído,

\footnotetext{
${ }^{839}$ COMBLIN, J., O Espírito Santo e a libertação, p. 107.

${ }^{840}$ COMBLIN, J., O Espírito Santo no mundo, p. 107.

${ }^{841}$ COMBLIN, J., O Espírito Santo e a libertação, p. 120.
} 
como se soprasse impetuoso vendaval, enchendo toda a casa onde estavam reunidos. Então viram como que umas línguas de fogo, as quais, repartindo-se, pousaram sobre cada um. Todos ficaram cheios do Espírito Santo e começaram a falar línguas estranhas, conforme o Espírito lhes concedia falar" (At 2,2-4). ${ }^{842}$

A Igreja em Atos deveria ser o exemplo para as demais, pois seu dinamismo sob a ação do Espírito levou ao crescimento natural. Não se trata de estratégia ou plano de evangelização, mas da presença do Espírito conduzindo sua expansão, como lembra Comblin:

O livro dos Atos dos Apóstolos oferece uma bela imagem de dinamismo. Mostra como a Igreja não cresce a partir de si mesma por uma espécie de crescimento orgânico. Não cresce pela assimilação de elementos novos. Nem, tampouco, cresce por uma expansão do centro para a periferia. ${ }^{843}$

A interpretação combliniana de uma missão exercida pelo poder do Espírito é promissora, pois nessa missão é o Espírito que abre as portas e alcança outras pessoas. É a presença do Espírito que as atrai, e a comunidade torna-se o instrumento pela qual o Espírito exerce sua missão:

Ora, a presença do Espírito na comunidade manifesta-se pelos movimentos para fora: não para conquistar outros membros ou outros povos, mas para compartilhar com eles os dons do Espírito. O Espírito é quem abre as portas e janelas, e lança os cristãos para o mundo. Pois o Espírito quer agir no mundo. A comunidade existe para estar a serviço dele na missão do mundo. ${ }^{84}$

As experiências sucessivas em Atos de vários momentos de pentecostes mostram que esse é o sinal de uma nova aliança entre Deus e seu povo. Segundo Comblin, as várias manifestações do Espírito registradas em Atos são, na verdade, o estabelecimento da missão, e nem todas contaram com a marca do falar em línguas, mas um elemento estava presente em todos os momentos da ação do Espírito. Sempre que a ação do Espírito se fazia sentir, a missão era o acontecimento subsequente, levando pessoas a agregar-se nas comunidades:

Há nos Atos dos Apóstolos uma série de "pentecostes" sucessivos. O primeiro acontecimento tem aspectos peculiares, que não se reproduzem depois. Aparece como um sinal da fundação do povo de Deus, como uma nova aliança não mais na lei, mas no Espírito. Aparece também como um sinal da missão. Por sinal, entre a

\footnotetext{
${ }^{842}$ COMBLIN, J., O Espírito Santo no mundo, p. 109-110.

${ }^{843}$ COMBLIN, J., Tempo da ação, p. 52.

${ }^{844}$ COMBLIN, J., O Espírito Santo e a libertação, p. 120.
} 
missão e o novo povo de Deus, a conexão é imediata, já que não se trata de um povo étnico, e sim de um povo missionário. ${ }^{845}$

As primeiras comunidades cristãs praticavam a missão de acordo com a ação do Espírito. Já não havia expectativas de promessa para o futuro. Viviam na plenitude do Espírito no presente, como explica Comblin:

Desde as primeiras comunidades, não há dúvida de que os cristãos consideraram o dom do Espírito como a presença atual das promessas de Deus. O centro da sua atenção já não era mais o futuro, e sim o presente. Viviam com a certeza de que o Espírito estava entre eles e dava resposta às suas aspirações. ${ }^{846}$

A prática das primeiras comunidades não consistia apenas em anunciar a Cristo, mas também o Espírito que concretizava a missão:

A mensagem cristã não é apenas o anúncio de Cristo, mas também o anúncio do Espírito Santo. Ora, o Espírito está agindo nos povos pagãos e em todas as religiões desde o início da humanidade. O Espírito conduz os povos e as religiões num movimento que não podemos saber previamente. Podemos apenas observar os sinais da ação do Espírito e acompanhá-la. ${ }^{847}$

$\mathrm{Na}$ perspectiva combliniana a missão é forçada pelo Espírito, levando a comunidade a propagar o evangelho. Ao lançar a comunidade em missão, o Espírito atrai as pessoas. Comblin explica que na teologia lucana tudo acontece por intermédio da ação do Espírito, que envolve os apóstolos na missão:

Na teologia de Lucas, primeiro vem o Espírito. O Espírito suscita os apóstolos. Por meio deles, o Espírito suscita as comunidades: em cada comunidade está a Igreja. O mesmo povo de Deus está em cada comunidade e no movimento missionário que as reúne numa unidade dinâmica. ${ }^{848}$

O desafio missionário combliniano e da geração que tentou uma teologia a partir da realidade da América Latina com a temática dos pobres foi muitas vezes contestada, mas Comblin afirma: "os pobres não tomam o lugar de Cristo, mas eles têm um lugar especial, fundamental, central, em Cristo. Que a teologia da libertação morra ou não, não importa. Mas, depois de Medellín, a teologia não poderá continuar sendo o que era". 849

\footnotetext{
${ }^{845}$ COMBLIN, J., O Espírito Santo no mundo, p. 109.

${ }^{846}$ COMBLIN, J., O Espírito Santo e a libertação, p. 66-67.

${ }^{847}$ COMBLIN, J., O Espírito Santo e a libertação, p. 201.

${ }^{848}$ COMBLIN, J., O Espírito Santo e a libertação, p. 107.

${ }^{849}$ COMBLIN, J., As estranhas acusações de Clodovis Boff, p. 202.
} 
A grande tarefa missionária em exercício no mundo é a do Espírito, agindo nas comunidades e estabelecendo o reino de Deus. Toda a espiritualidade da Igreja está associada à missão. Comblin diz: "o Espírito foi enviado para suscitar o reino de Deus no mundo. A Igreja está a serviço desta tarefa". ${ }^{850}$ Ser espiritual é ser missionário, e essa é, sem dúvida, a maior evidência da ação do Espírito em determinada comunidade. Comblin afirma: "isto quer dizer que o espiritual na Igreja é o movimento que a leva para fora, além dos seus limites". 851

Seria impossível alguém conhecer a Cristo sem a ação do Espírito. É exatamente o Espírito que impulsiona ao anúncio do Evangelho, como destaca Mikuszka: “em si, é o Espírito que faz os discípulos viverem o Evangelho em todas as condições. Na mesma ótica, Comblin afirma que só podemos viver e anunciar o Evangelho quando somos impulsionados pelo Espírito". ${ }^{852}$ E o Espírito manifesta sua presença no ser humano habitando-o, mas este não perde a identidade:

O modo da presença do Espírito nos homens recebe o nome de habitação: o Espírito habita nos homens que o aceitam. Habitar é um sinal de que é hóspede, não é o próprio sujeito. Está no sujeito humano sem ser o sujeito humano. Pois não se diz que o Filho de Deus habita em Jesus, mas que é Jesus. Não se diz que o Espírito Santo é Pedro ou Paulo, mas que habita em Pedro ou em Paulo. ${ }^{853}$

O agir no homem por habitação leva a buscar a missão, pois o Espírito Santo é Deus e quer levar todos à salvação. Comblin destaca: "mas o Espírito Santo é realmente Deus e mostra que Deus é aquele que anima as forças internas dos homens que buscam, a partir de seu íntimo, a libertação. Querer mudar as coisas não constitui algo contra Deus, mas algo que vem de Deus". ${ }^{854}$ Assim, o conceito e a prática da missão em Comblin estão associados à missão do Espírito Santo, e a evangelização oriunda da sua ação leva a comunidade à anunciação de Cristo. É o próprio Espírito que impulsiona à participação da comunidade, e a comunidade à missão. Buscando uma missão mais dinâmica, Comblin menciona $\mathrm{o}$ Documento de Aparecida:

\footnotetext{
${ }^{850}$ COMBLIN, J., O Espírito Santo e a libertação, p. 120.

${ }^{851}$ COMBLIN, J., O Espírito Santo e a libertação, p. 120.

${ }^{852}$ MIKUSZKA, G. L., O discípulo missionário na perspectiva de José Comblin, p. 28.

${ }^{853}$ COMBLIN, J., Breve curso de teologia, p. 338.

${ }^{854}$ COMBLIN, J., Breve curso de teologia, p. 328.
} 
O Documento de Aparecida está construído em torno de dois eixos, um secundário e outro principal. O eixo secundário é a afirmação da continuidade de Medellín e Puebla. Daí o compromisso com as comunidades eclesiais de base e a opção pelos pobres. O outro eixo é o projeto de transformar a Igreja de uma Igreja centrada nos templos para uma Igreja metida no mundo para evangelizar. O projeto é grandioso. ${ }^{855}$

O compromisso de uma Igreja em diálogo, inserida no mundo, mostra-se bastante ousado. Para Combin, a marca que a Conferência de Aparecida deixa para a missão é justamente a retomada de Medellín: “a meu ver, a Conferência de Aparecida ficará na história por dois motivos. Primeiro, porque reatou a continuidade com a tradição de Medellín e Puebla, renovando com muita insistência as opções daquele tempo". ${ }^{856}$ Ele entende que a partir de Aparecida abriu-se uma ação pastoral mais atualizada, e considera a Conferência um avanço da ação pastoral rumo à evangelização no mundo: "em segundo lugar, porque a Conferência abriu o caminho para uma mudança total na pastoral. Trata-se de abandonar uma pastoral de conservação, encarnada hoje em dia em quase todas as instituições, para uma pastoral de evangelização no meio do mundo". 857 O conceito e a prática de missão em Comblin passam pelo esforço prático e teórico de realizar. Prático, pela inserção ao lado do povo, e teórico, pelas várias tentativas de apelar para a abertura e a contextualização na ação missionária, dadas as mudanças significativas no mundo, o que pede uma nova forma de fazer missão.

\subsection{2.}

\section{A missão leiga ou dos cristãos em geral}

Na sessão anterior a prática da missão em Comblin foi retratada como possível graças à força do Espírito e a missão combliniana, vista como missão do Espírito. Essa missão pode ser a missão do leigo. Cabral afirma, a respeito de Comblin: "para tanto, abordou desde temáticas como o lugar da formação em Filosofia ministrada em institutos e seminários, até chegar à proposição de

\footnotetext{
${ }^{855}$ COMBLIN, José. O papel histórico de Aparecida. Revista Eclesiástica Brasileira. v. 67, n. 268 (2007), p. 865.

${ }^{856}$ COMBLIN, J., O papel histórico de Aparecida, p. 883.

${ }^{857}$ COMBLIN, J., O papel histórico de Aparecida, p. 883-884.
} 
alternativas, como as experiências do Centro de Formação Missionária e da Teologia da Enxada, para ficar com apenas duas". 858

Nesta seção o trabalho se concentrará na missão dos leigos ou dos cristãos em geral. Pois, se a missão é ação do Espírito, logo se estende a todos na comunidade, como argumenta Comblin: "o livro dos Atos dos Apóstolos mostra, no início do povo de Deus, essa efusão do Espírito sobre todos. E acrescenta o discurso de Pedro, que revela o alcance do acontecimento: nasceu um povo de profetas! Todos vão poder pronunciar as palavras do Espírito". ${ }^{859}$

A partir do derramamento do Espírito, todos são comissionados a anunciar o Evangelho, missão do Espírito, ao povo que se torna profeta pelo poder do Espírito. Comblin continua: "todos vão poder ser colaboradores do Espírito: "sobre meus servidores e servidoras derramarei meu espírito e eles profetizarão" (At 2,18)". ${ }^{860}$ As comunidades paulinas foram exemplos de missão leiga a partir do agir do Espírito. A igreja de Corinto exemplifica a missão dos leigos no Espírito, que experimentaram os dons espirituais que fizeram deles profetas:

As epístolas paulinas mostram a realização concreta de Pentecostes. Entre todas as igrejas paulinas, a mais representativa é a de Corinto. Na Igreja de Corinto, houve essa explosão de dons: todos recebem um dom; todos são portadores da força do Espírito; todos têm alguma palavra para pronunciar, alguns em discursos, outros em sinais, mas todos são realmente profetas. ${ }^{861}$

A missão leiga ou dos cristãos em Comblin está associada à sua hermenêutica, que entende a leitura bíblica a partir da escuta espiritual que vem em primeiro lugar, como explica Lara:

A hermenêutica de Comblin insiste na leitura espiritual da Bíblia, não evidentemente em contraposição à materialidade da vida, mas como escuta e dom do Espírito Santo. Novamente ele afirma o caráter secundário da exegese em relação à leitura iluminada pelo Espírito. ${ }^{862}$

Novamente várias manifestações de experiências do Espírito estão presentes no cristianismo, exatamente as que representam o objeto de reflexão desta pesquisa. Comblin afirma: "estamos assistindo ao surgimento de muitas formas

\footnotetext{
${ }^{858}$ CABRAL, N. D, d, A., MARQUES, L. C. L., Um tufão chamado José Comblin, p. 595.

${ }^{859}$ COMBLIN, J., O Espírito Santo no mundo, p. 58.

${ }^{860}$ COMBLIN, J., O Espírito Santo no mundo, p. 58.

${ }^{861}$ COMBLIN, J., O Espírito Santo no mundo, p. 58.

${ }^{862}$ LARA, V. L., Hermenêutica bíblica para compreender Paulo em Comblin, p. 659.
} 
diversas de experiências do Espírito Santo". ${ }^{863}$ A importância primária do poder do Espírito derramado é fazer de todos profetas, e por isso Paulo preconiza aos Coríntios, que sobrevalorizavam o dom de línguas, a prioridade da profecia, como explica Comblin:

Parece que os Coríntios davam grande valor ao dom de línguas, que para eles devia
parecer mais extraordinário. Esse dom ressuscitou em nossos dias, no movimento
pentecostal, depois de dezenove séculos de ausência. O que nos interessa é que
Paulo, embora tenha sido favorecido também ele com esse dom, não o colocava em
primeiro lugar, mas em último lugar. Aos Coríntios mostra, pelo contrário, a
superioridade do dom de profecia. E o mais interessante de tudo é o motivo que ele
dá. ${ }^{864}$ Não se trata de preferência por determinado dom, mas de coerência quanto ao objetivo, pois a manifestação do Espírito e de seus dons se dá por finalidade missionária, conforme esclarece Comblin: "a profecia situa-se, portanto, na continuidade do dom de evangelização: o evangelho cria e funda a comunidade; a profecia constrói sobre os fundamentos. É a mesma palavra, mas adaptada a novas circunstâncias". ${ }^{865}$ Em Comblin as mudanças são bem-vindas, e ele recebe as novidades como oportunidade de missão. Hoornaert afirma: "é por isso que Comblin nunca é dogmático. Enquanto o pensamento dogmático é rígido e defende a imutabilidade, o pensamento da transformação é fluido, e acompanha os ritmos da vida e demonstra sensibilidade pelas leis da natureza". ${ }^{866}$ Toda manifestação do Espírito está relacionada à missão, e assim os carismas precisam estar de acordo com o plano. Comblin lembra: “o Espírito está em missão. É enviado ao mundo". 867

A animação do Espírito envolve o ser humano e o orienta na prática missionária, como afirma Comblin: "ora, Deus envia ao mundo seu Espírito. Envia sua ação, e essa ação é a origem e a força que anima, orienta e explica a ação humana autêntica". ${ }^{868}$ Comblin sempre tenta construir pontes entre a história e os acontecimentos da atualidade. Segundo Hoornaert: "suas exposições teológicas são sempre de teor histórico, acompanham os ritmos de vida. Nunca

\footnotetext{
${ }^{863}$ COMBLIN, J., O Espírito Santo e a libertação, p. 22.

${ }^{864}$ COMBLIN, J., O Espírito Santo no mundo, p. 59.

${ }^{865}$ COMBLIN, J., O Espírito Santo no mundo, p. 59.

${ }^{866}$ HOORNAERT, E., O tema da transformação no pensamento de José Comblin, p. 40.

${ }^{867}$ COMBLIN, José. Tempo da Ação. Petrópolis: Vozes, 1982, p. 39.

${ }^{868}$ COMBLIN, J., Tempo da ação, p. 51.
} 
são definitórias, não pretendem definir ou prender os ritmos da vida em conceitos imutáveis". ${ }^{869}$

É possível tentar aproximar essa percepção missionária das comunidades pentecostais contemporâneas, importando lembrar que não existe unanimidade quanto à aceitação dos movimentos atuais. Comblin acrescenta: "entre as objeções feitas aos movimentos atuais estão as acusações de fuga para longe das tarefas temporais, de atração pelos fenômenos emocionais fortes, como o dom de línguas, a falta de atenção aos problemas sociais". ${ }^{870}$ Essa lacuna surgiu, na maioria das vezes, porque grande parte do movimento está justamente entre os menos favorecidos na sociedade; em outras palavras, o pentecostalismo faz mais sucesso entre os mais pobres.

A missão combliniana passa pela dinâmica construída entre o Espírito, a palavra e o povo, sendo a palavra elemento essencial na capacitação do povo: "a missão fundamental da palavra também é a edificação do povo de Deus. O Espírito usa a palavra para construir esse povo. Estamos sempre na série: Espírito - palavra - povo". 871

Sobre a anunciação da palavra, Comblin reflete que nos últimos tempos a Igreja tem se dedicado mais à tarefa da anunciação da palavra no poder do Espírito, e isso a tem feito crescer novamente: "nos últimos anos, a Igreja voltou a tomar consciência mais clara de que sua missão essencial é obedecer ao Espírito, que a leva a anunciar a palavra de Deus de tal modo que o povo de Deus possa surgir e crescer" 872

A atuação do Espírito não depende da consciência da Igreja, mas do empenho desta em compreender a missão do Espírito que age na comunidade, tornando-a missionária e revelando sua verdadeira razão em ser Igreja, que é anunciar o Evangelho. Comblin é enfático:

O Espírito Criador é o Espírito missionário, porque a criação alcança seu ponto final na missão, e o ato da evangelização é o ato culminante da criação, o ato mediante o qual o homem, centro da criação, chega a ser criador de si mesmo, espiritual e dirigido pelo Espírito. ${ }^{873}$

\footnotetext{
${ }^{869}$ HOORNAERT, E., O tema da transformação no pensamento de José Comblin, p. 40.

${ }^{870}$ COMBLIN, J., O Espírito Santo e a libertação, p. 23.

${ }^{871}$ COMBLIN, J., O Espírito Santo no mundo, p. 60.

${ }^{872}$ COMBLIN, J., O Espírito Santo no mundo, p. 60.

${ }^{873}$ COMBLIN, José. Breve curso de teologia: o Espírito Santo e sua missão. São Paulo: Ed. Paulinas, 1983, p. 11.
} 
Comblin desenvolve sua pneumatologia de acordo com sua missiologia, ambas complementando-se mutuamente. A missão combliniana se concretiza mediante o Espírito em missão que age no crente, e isso abarca o leigo, pois o Espírito chama todos à missão. Lara destaca: "para Comblin, a leitura no Espírito garante que a Bíblia tenha significado atual para cada um dentro de sua situação histórica específica, no respeito à diversidade das culturas e das necessidades de cada pessoa". 874

A simplificação do acesso do povo de Deus a todas as áreas do cristianismo tem facilitado a missão em vários lugares, e o povo tem incorporado a prática missionária no cotidiano, que passa pela leitura da Bíblia, cuja interpretação o povo já alcança. Comblin diz: "na atualidade, em muitos lugares do mundo, especialmente na América Latina, o povo cristão lê a Bíblia de novo segundo uma exegese espiritual" ${ }^{875}$ Essa proximidade com a palavra leva o povo de Deus a querer vivenciar um cristianismo parecido com o experimentado pelas primeiras comunidades. Lara afirma:

Comblin quer nos lembrar que o desafio hermenêutico é não perder de vista a centralidade dos Evangelhos como critério para a leitura do Antigo e dos demais textos do Novo Testamento; e, além disso, voltar sempre a distinguir a relatividade de certas imagens que foram sendo construídas de Cristo, pois, ao invés de ser expressão do Cristo vivo, são mais espelhos e projeções de subjetividades incompatíveis com a do Jesus bíblico. ${ }^{876}$

Segundo Comblin, a Teologia, nos últimos tempos, tem começado a se dedicar ao fenômeno do pentecostalismo: "a teologia começou a perceber o fenômeno e procura interpretá-lo". ${ }^{877}$ É uma Teologia do povo que segue sua prática, na qual o leigo é envolvido e torna-se missionário. Quando se trata de comunidade, todos que a compõem estão incluídos. Comblin esforça-se bastante em destacar que o Evangelho paulino ultrapassava o discurso e estava construído sobre feitos do poder do Espírito: "as comunidades paulinas não estão construídas sobre discursos, palavras, ensinamentos teóricos. Partiram de fatos concretos, evidentes, irrefutáveis". ${ }^{878} \mathrm{O}$ poder manifestado chega a todos os integrantes da

\footnotetext{
${ }^{874}$ LARA, V. L., Hermenêutica bíblica para compreender Paulo em Comblin, p. 659.

${ }^{875}$ COMBLIN, J., O Espírito Santo e a libertação, p. 28.

${ }^{876}$ LARA, V. L., Hermenêutica bíblica para compreender Paulo em Comblin, p. 659.

${ }^{877}$ COMBLIN, J., O Espírito Santo e a libertação, p. 36.

${ }^{878}$ COMBLIN, J., O Espírito Santo e a libertação, p. 17.
} 
comunidade, e um novo tempo se inaugura, quando todos são chamados a participar da missão de Deus. Comblin diz: "agora, no povo, todos e todas são profetas. Todos e todas são conduzidos pelo Espírito, que é a força de Deus". ${ }^{879}$

A missão agora é tarefa de todos, pois o Espírito proporciona o fazer. A experiência do Espírito é algo maravilhoso na comunidade, e consequentemente, na vida do cristão, pois além da salvação, oportuniza a participação na missão. Comblin diz: "foi pelas obras da Lei que recebestes o Espírito? Paulo não apela para um Espírito invisível, apela para uma experiência bem concreta que tiveram e ainda têm". ${ }^{880} \mathrm{O}$ autor ressalta a importância de não reduzir a experiência do Espírito a fenômenos de caráter pessoal, mesmo que estes também tenham sua importância. Deve prevalecer o melhor proveito comunitário dos dons. Ele diz:

Não devemos, como certos corintos, confundir esta experiência do Espírito com certos fenômenos extáticos como o dom de línguas. Ela é menos ainda uma pura emoção ou um sentimento religioso. Muito pelo contrário, Paulo insiste no caráter secundário, marginal, acessório dos fenômenos emocionais ou sentimentais assim como dos fatos maravilhosos como o dom de línguas. A experiência à qual se referem as epístolas paulinas está ligada a um agir histórico. ${ }^{881}$

A nova fase da missão está sob a responsabilidade dos leigos, o que se constata nas comunidades pentecostais. Lara diz:

A recepção da palavra de Deus é sempre condicionada pela situação histórica e sociocultural. Comblin lembra que a leitura da Bíblia feita pelos pobres é diferente e mais adequada para compreender o conteúdo genuíno da palavra que mostra a ação de Deus na história. ${ }^{882}$

No caso do segmento religioso que mais tem crescido em números nos últimos tempos, Comblin diz: "trata-se de uma experiência vivida na ação pela qual o cristão e toda a comunidade constroem a Igreja, e, pela Igreja, um mundo novo". ${ }^{883}$ A experiência não se restringe à vida privada do indivíduo que experimentou essa integração. As mudanças estendem-se à sua vida pública, mostrando um novo rumo para a sociedade. Comblin afirma: "os membros que

\footnotetext{
${ }^{879}$ COMBLIN, J., O Espírito Santo no mundo, p. 19-20.

${ }^{880}$ COMBLIN, J., O Espírito Santo e a libertação, p. 17.

${ }^{881}$ COMBLIN, J., O Espírito Santo e a libertação, p. 18.

${ }^{882}$ LARA, V. L., Hermenêutica bíblica para compreender Paulo em Comblin, p. 660.

${ }^{883}$ COMBLIN, J., O Espírito Santo e a libertação, p. 18-19.
} 
constituíram uma comunidade estão conscientes da mudança radical no seu modo de viver". 884

As comunidades assim alimentadas envolvem seus participantes, integrando-os e dialogando com todas as áreas da vida pessoal. É dessa maneira que a vida particular deixou de ser a prioridade e um novo plano está em curso, não podendo haver dualidade. A vida a está a serviço da fé e da comunidade. Comblin afirma: "a comunidade torna-se o centro da vida: melhor dito, ela cria uma vida social em que todos participam. É a fonte de uma existência superior. Quem entrou numa comunidade passou a um limiar superior da vida". 885

Para Comblin o sentido de espiritualidade se revela em comunidade e isso se aplica também à leitura bíblica, como afirma Lara: "a palavra-chave em Comblin para a leitura da Bíblia é comunidade". ${ }^{886}$ A presença dessas comunidades é crescente e tem ganhado destaque em muitos lugares, como reflete Comblin: "tais comunidades existem entre os católicos e os protestantes", 887

Essas comunidades poderiam ser a resposta a um tempo de individualismo que as sociedades têm vivido, desafiando-o, mas para Mikuszka a vivência não basta, devendo a anunciação do Evangelho ocupar a centralidade, o que poderá levar a comunidade a experimentar essa vivência, que produz mudança em sua vida:

Por meio da comunhão que ele promove, todos partem do mesmo Espírito e podem viver a unidade na diversidade. Neste sentido, o significado do Batismo para a vida do discípulo está relacionado à participação na mesma comunidade eclesial. Isso desencadeia uma vida nova, pois aprofunda o caráter de se reunir como povo de Deus em comunidade. Porém, a nosso ver, essa vivência só acontecerá se o Evangelho for anunciado. ${ }^{888}$

As experiências das comunidades são decisivas para a missão na atualidade, a forma atual e contextualizada de se fazer missão, à qual muitos leigos e leigas têm se dedicado, como comenta Comblin: "são heróis que conseguem tempo e energia e se dedicam à missão com muita generosidade e gratuidade". ${ }^{889} \mathrm{O}$ evangelismo de integração abarca a pessoa na experiência comunitária em que a

\footnotetext{
${ }^{884}$ COMBLIN, J., O Espírito Santo e a libertação, p. 47.

${ }^{885}$ COMBLIN, J., O Espírito Santo e a libertação, p. 47.

${ }^{886}$ LARA, V. L., Hermenêutica bíblica para compreender Paulo em Comblin, p. 661.

${ }^{887}$ COMBLIN, J., O Espírito Santo e a libertação, p. 48.

${ }^{888}$ MIKUSZKA, G. L., O discípulo missionário na perspectiva de José Comblin, p. 33.

${ }^{889}$ COMBLIN, J., As grandes incertezas na igreja atual, p. 48.
} 
ação do Espírito se manifesta, como lembra Comblin: "os livros joaninos referemse a uma comunidade que vive essencialmente uma experiência espiritual" ${ }^{890} \mathrm{O}$ que Comblin reforça é que as experiências do Espírito não podem mais ser compreendidas no âmbito do imaterial. Ele afirma: “A experiência do Espírito está no concreto." 891

Todo esse destaque à pneumatologia é necessário, pois tanto para Comblin quanto para os pentecostais só existe missão no poder do Espírito. A missão é a primeira característica do espiritual. Ele esclarece: "o espiritual da experiência fica em primeiro lugar na percepção de uma missão". ${ }^{892}$ Se a Teologia conceber uma missão exercida no poder do Espírito, também terá que se dedicar com mais atenção aos carismas, manifestos no cotidiano da missão. Ou seja, a presença do Espírito é confirmada pelos carismas para servir. Mikuszka diz:

Por entender que o ministério é o carisma concedido a cada pessoa transformado em serviço à comunidade, vale dizer que o fundamento dos ministérios está no Espírito e no serviço. Nesse sentido, Jesus garante que veio para servir e mostra que sua missão é servir (cf. Mc 10, 45). ${ }^{893}$

Missão e experiência espiritual relacionam-se: a missão deriva da experiência que lança todos em missão: "não se separa a experiência do agir da experiência do Espírito que age, a experiência do Espírito da experiência do 'eu' e do "nós". ${ }^{894}$ A construção de uma comunidade a partir da experiência espiritual não é nova no cristianismo. Na verdade, essa foi a base das primeiras comunidades. Comblin explica:

Construir um povo na base de uma experiência do Espírito foi um admirável paradoxo. Parece uma pura contradição. Como foi possível construir uma Igreja que se pretende animada por um Espírito invisível? Contudo, os autores do Novo Testamento, os apóstolos e os que escreveram sob a sua autoridade proclamaram a primazia do Espírito, a primazia da experiência sobre qualquer outro tipo de orientação. Para S. Pedro a autoridade do Espírito é soberana. Ele mesmo se inclina diante dela (At. 10,47). S. Paulo exige: "Não extingais o Espírito" (1 Ts 5,19). ${ }^{895}$

\footnotetext{
${ }^{890}$ COMBLIN, J., O Espírito Santo e a libertação, p. 21.

${ }^{891}$ COMBLIN, J., O Espírito Santo e a libertação, p. 40.

${ }^{892}$ COMBLIN, J., O Espírito Santo e a libertação, p. 40.

${ }^{893}$ MIKUSZKA, G. L., O discípulo missionário na perspectiva de José Comblin, p. 36.

${ }^{894}$ COMBLIN, J., O Espírito Santo e a libertação, p. 50.

${ }^{895}$ COMBLIN, J., O Espírito Santo e a libertação, p. 52-53.
} 
O entendimento paulino do Evangelho está baseado na versão de Lucas que compreende o Espírito como o objeto do Evangelho. A pregação é o Espírito em seu agir. E para Comblin na teologia paulina a ação do Espírito corresponderia à proclamação do reino. Comblin afirma:

A teologia paulina está na base da mensagem de Lucas. Segundo S. Paulo o objeto próprio do evangelho é o Espírito Santo. Na teologia paulina o reino de Deus ficou reduzido a algumas alusões. O Espírito ocupa o lugar do reino na proclamação da Boa-Nova. Assim, na Epístola aos Romanos, que é uma ampla explicitação do evangelho, o capítulo 8 representa o anúncio do evangelho e está dedicado ao Espírito. ${ }^{896}$

Quando se propõe uma missão leiga, trata-se de uma missão do Espírito, pois é Ele quem concretiza a missão. Deus marcou seu povo com o seu Espírito, por isso já não é possível mais pensar em uma missão que não seja de todo o povo de Deus. Comblin lembra: "Deus 'nos marcou com selo e colocou em nossos corações o penhor do Espírito (2 Cor 1,22).' 'Nós aguardamos no Espírito a esperança da justiça (Gl 5,5).' 'Fostes selados pelo Espírito da promessa, o Espírito Santo, que é o penhor da nossa herança (Ef. 1,13-14)", ${ }^{897}$

A abrangência de todo o povo de Deus levou muitos cristãos em geral a abraçar a missão, como lembra Comblin: "há muitos leigos e leigas que trabalham efetivamente como missionários e missionárias, geralmente sem mandato, sem reconhecimento oficial, sem poder, e gratuitamente". ${ }^{898}$ Os relatos bíblicos que respaldam uma missão de todos estão relacionados ao Espírito que faz de todo o povo de Deus um povo de profetas que recebem e anunciam a palavra de Deus. Comblin afirma: “o Espírito já não é reservado aos profetas, que aparecem de vez em quando. Agora, todos são profetas e recebem a palavra de Deus nos seus corações". ${ }^{899}$ Assim, a missão leiga é a missão do Espírito. Comblin alerta para a necessidade de atualização na formação dos cristãos em geral e diz: "uma pastoral urbana supõe uma reforma total da formação dos sacerdotes, dos religiosos e dos leigos". 900

Para Comblin, o evangelho segundo João tem a finalidade de apresentar a promessa do Espírito Santo: "quanto ao evangelho segundo João, o reino de Deus

\footnotetext{
${ }^{896}$ COMBLIN, J., O Espírito Santo e a libertação, p. 66.

${ }^{897}$ COMBLIN, J., O Espírito Santo e a libertação, p. 66.

${ }^{898}$ COMBLIN, J., As grandes incertezas na igreja atual, p. 48.

${ }^{899}$ COMBLIN, J., O Espírito Santo no mundo, p. 19.

${ }^{900}$ COMBLIN, J., A virada da teologia cristã, p. 99.
} 
ficou mais apagado ainda e a promessa é o Espírito Santo. S. João não exclui um juízo final nem uma realização final da promessa, mas o centro da sua mensagem é o Espírito Santo: O que Jesus dá é o Espírito". 901

Exemplificando e fundamentando a missão leiga a partir do poder do Espírito, que faz tudo novo e leva a Igreja a vivenciar um caminho de novidade mediante os carismas, Comblin destaca: "Pentecostes representa esta vocação de todas as nações. Estas não perdem a sua identidade. Todas falam na sua língua. A nova humanidade não perde a sua diversidade por estar unificada em Cristo."902 Tanto Paulo quanto João tratam de uma nova realidade após a ação do Espírito na vida pessoal. Mikuszka diz:

O apóstolo Paulo diz que a força do Espírito leva a pessoa a uma realidade nova e o evangelista João chama isso de novo nascimento (cf. 2Cor 5, 17; Jo 3, 3). Pelo que vimos, essa força renovadora do Espírito, despertada pelo Evangelho na sensibilidade humana, leva a pessoa a querer agir de modo dinâmico. ${ }^{903}$

Na pnematologia combliniana o Espírito não é enviado à Igreja, mas constitui a Igreja, que existe porque o Espírito a enviou:

O Espírito Santo não é enviado a uma Igreja já constituída antes da sua missão. A missão do Espírito Santo é constitutiva da Igreja. Pois a Igreja existe porque o Espírito Santo lhe foi enviado. Surge a partir deste dom. Por isso a Igreja não é nem anterior, nem exterior à missão do Espírito. Primeiro há uma missão do Espírito a toda a criação para que esta criação exista. Dentro desta missão geral surge e existe a Igreja. ${ }^{904}$

Essa dinâmica é determinante para uma missiologia do Espírito e democratiza o acesso à palavra e a propagação do Evangelho, já que toda ação parte do Espírito, que envolve também os leigos, como afirma Souza: "a esperança atual, segundo Comblin, está com os leigos. A mudança virá de uma Igreja laical, que reage com consciência cristã no (e desde o) meio que ocupam na sociedade". ${ }^{905}$ A partir desse caminho pode-se tratar de uma Teologia do laicato. Comblin continua:

\footnotetext{
${ }^{901}$ COMBLIN, J., O Espírito Santo e a libertação, p. 66.

${ }^{902}$ COMBLIN, J., O Espírito Santo e a libertação, p. 69.

${ }^{903}$ MIKUSZKA, G. L., O discípulo missionário na perspectiva de José Comblin, p. 31.

${ }^{904}$ COMBLIN, J., O Espírito Santo e a libertação, p. 104.

${ }^{905}$ SOUZA, A.; ARAGÃO, G., Fazer a igreja católica se mover: a pertinência do evangelho no mundo contemporâneo, p. 667-697, p. 692.
} 
Esta observação é importante. Ela mostra que a ação do Espírito não é determinada pela ação da Igreja. Não é a Igreja que mostra os rumos do Espírito. Ao invés, a Igreja deve seguir e somente existe na medida em que segue os rumos do Espírito. O Espírito faz da Igreja o seu instrumento e a sua mediação para agir no mundo, um dos seus instrumentos e uma das suas mediações, ainda que privilegiada. ${ }^{906}$

Os comentadores de Comblin também entendem a missão como ação do Espírito, mas Mikuszka acrescenta que evangelizar também é libertar. Ele diz: "assim, tanto para Paulo quanto para Comblin, a libertação depende do Espírito e do Evangelho". 907 O avanço da libertação, segundo Mikuszka, acontece enquanto o cristão evangeliza e vai se libertando na força do Espírito. Mikuszka esclarece: "assim, o cristão se liberta quando age, anunciando o Evangelho ao mundo, pois sua ação se dá na força do Espírito". ${ }^{908}$ É assim que o Espírito mostra a obra concreta.

Comblin insiste em mudar a forma como a tradição cristã interpreta o agir do Espírito: “neste caso, o Espírito não está verdadeiramente na Igreja. Está sobre a Igreja como um selo que autentifica, mas não é o autor donde procedem a Igreja e o seu agir". ${ }^{909}$ Essa volta ao Espírito oferecida por Comblin muito soma à pentecostalidade atual, mesmo que em alguns pontos haja diferenciação. A contribuição, no entanto, supera as diferenças e proporciona aproximação, principalmente porque, segundo ele, "por um lado a teologia esqueceu-se do Espírito Santo". 910

Comblin compreende que a Teologia do povo de Deus abriu a participação do leigo na missão. Oliveira diz: "para Comblin, a teologia do povo de Deus também fundamentou a promoção dos leigos e revelou a intenção do Concílio de superação do clericalismo". ${ }^{911}$ Porem, a prática seguiu seu caminho sem a Teologia, cabendo a esta acompanhar a Igreja no caminhar do Espírito. Comblin prossegue: "por um lado temos experiências espirituais sem referências teológicas, e por outro lado uma teologia da graça sem referências experimentais". 912

\footnotetext{
${ }^{906}$ COMBLIN, J., O Espírito Santo e a libertação, p. 104.

${ }^{907}$ MIKUSZKA, G. L., O discípulo missionário na perspectiva de José Comblin, p. 52.

${ }^{908}$ MIKUSZKA, G. L., O discípulo missionário na perspectiva de José Comblin, p. 52.

${ }^{909}$ COMBLIN, J., O Espírito Santo e a libertação, p. 105.

${ }^{910}$ COMBLIN, J., O Espírito Santo e a libertação, p. 156.

${ }^{911}$ OLIVEIRA, A. F., Igreja dos pobres e imagens de Deus em José Comblin: convites à práxis cristã emergentes da missão ibiapina no semiárido nordestino, p. 65.

${ }^{912}$ COMBLIN, J., O Espírito Santo e a libertação, p. 156.
} 
Para Comblin a aproximação é necessária, pois as duas partes se complementam. Ele faz um alerta ao catolicismo, que também pode se estender ao protestantismo em geral: "se a teologia do Espírito e as experiências espirituais permanecem separadas, a teologia carecerá da renovação necessária e as experiências não se integrarão na comunidade da grande católica". ${ }^{913} \mathrm{O}$ alerta de Comblin não deriva simplesmente de um referencial teórico, mas de desafios concretos postos diante do cristianismo na atualidade. Ele explica:

Claro que esta virada leva a rever desde um novo ponto de vista as obras de Hegel ou Schleiermacher que, de certo modo, no início da grande explosão do mundo moderno depois da revolução Francesa, já procuraram dar uma nova fundamentação à fé cristã no meio do mundo. [...] Sabiam que a teologia cristã tradicional do Ocidente levava inevitavelmente ao ateísmo. Procuraram no Espírito o ponto de partida de uma releitura do cristianismo. ${ }^{914}$

Isso é real e tem crescido o abandono das igrejas históricas. Por isso Comblin vê com urgência a necessidade de uma missão pneumatológica. Hoornaert diz: "prova disso é a articulação de sua teologia em torno da figura do Espírito Santo e da ação do Espírito Santo na história". ${ }^{915}$ As pessoas precisam de uma prática religiosa que as envolva. Comblin alerta: "agora, diante da queda estrondosa da prática religiosa nas igrejas históricas, ninguém pode negar o avanço do ateísmo". ${ }^{916}$ Isso pode ser resultado da falta de diálogos com a nova realidade, a falta de comunicação renovação e comunicação. Enquanto isso, os movimentos mais carismáticos e flexíveis têm conseguido algum sucesso. Comblin afirma: "hoje em dia a defensiva equivale a um suicídio". 917 Não existe outro caminho, primeiro porque é esse o caminho percorrido pelas primeiras comunidades cristãs; segundo, a realidade do mundo atual só pode ser alcançada dessa forma. Comblin esclarece: "o Espírito é quem revela Cristo às nações". 918 Comblin concorda com o pentecostalismo, pois as bases da missão paulina tinham como centralidade a anunciação do seu Evangelho pelo poder do Espírito. Mikuszka afirma:

\footnotetext{
${ }^{913}$ COMBLIN, J., O Espírito Santo e a libertação, p. 156.

${ }^{914}$ COMBLIN, J., O Espírito Santo e a libertação, p. 34-35.

915 HOORNAERT, E., O tema da transformação no pensamento de José Comblin, p. 40.

${ }^{916}$ COMBLIN, J., O Espírito Santo e a libertação, p. 35.

${ }^{917}$ COMBLIN, J., O Espírito Santo e a libertação, p. 35.

${ }^{918}$ COMBLIN, J., O Espírito Santo e a libertação, p. 202.
} 
A ação ministerial, vinda do carisma, é afirmada também pelo apóstolo Paulo, quando profere: "Minha palavra e minha pregação nada tinham de persuasiva linguagem da sabedoria, mas eram uma demonstração de Espírito e poder, a fim de que a nossa fé se baseie [...] no poder de Deus" (1Cor 2, 4-5). Logo, Comblin tem razão ao dizer que a ação ministerial é a ação na força do Espírito que, pelo Evangelho, foi despertada na pessoa e a fez agir no mundo. ${ }^{919}$

A principal missão do Pentecostes e dos sucessivos pentecostes de Atos foi a evangelização. O poder do Espírito teve por objetivo a expansão do Evangelho. Pode-se compreender esses acontecimentos em, pelo menos, duas fases. Comblin acrescenta: "de certo modo, o livro dos Atos dos Apóstolos é uma apresentação dessas duas fases do grande passo pelo qual o povo de Deus vai adquirindo a sua verdadeira dimensão". ${ }^{920}$ A fase inicial tem como destaque Pedro, que participa da primeira expansão para além das fronteiras. Comblin afirma:

Primeiro teve que agir Pedro. O Espírito obrigou-o a abrir as portas aos pagãos, no caso do centurião Cornélio (At 10-11). Vendo que o Espírito descia sobre a família de Cornélio, que era pagã, exatamente como descera sobre os discípulos em Jerusalém, Pedro compreendeu que as barreiras estavam destruídas. ${ }^{921}$

É inconcebível, para Comblin, uma missão que distingue os povos, pois ela parte do princípio missionário das primeiras comunidades. E como Oliveira diz: "segundo Comblin, no Novo Testamento, o povo de Deus não está separado dos outros povos. Vive no meio deles, participando da sua vida". ${ }^{922}$ Nessa primeira fase a liderança de Pedro na ação do Espírito leva a comunidade de Jerusalém a se abrir para algo até então inaceitável. Comblin continua: "Pedro convenceu a comunidade de Jerusalém e todos a aceitaram o que para eles outrora teria ida uma blasfêmia. 'Eis que Deus concedeu também às demais nações a conversão que leva para a vida! (At. 11, 18)"'. ${ }^{923}$ A segunda etapa tem como personagem Paulo, que leva o Evangelho aos pagãos, expandindo a missão numa nova fase do cristianismo primitivo. Comblin continua: "a segunda fase foi presidida por Paulo. O Espírito tomou posse dele, em vista dessa missão (At. 9,17). Paulo foi o instrumento do Espírito para suscitar comunidades inteiras no meio dos pagãos.

\footnotetext{
${ }^{919}$ MIKUSZKA, G. L., O discípulo missionário na perspectiva de José Comblin, p. 36.

${ }^{920}$ COMBLIN, J., O Espírito Santo no mundo, p. 20.

${ }^{921}$ COMBLIN, J., O Espírito Santo no mundo, p. 20-21.

922 OLIVEIRA, A. F., Igreja dos pobres e imagens de Deus em José Comblin: convites à práxis cristã emergentes da missão ibiapina no semiárido nordestino, p. 60.

${ }^{923}$ COMBLIN, J., O Espírito Santo no mundo, p. 21.
} 
[...]". ${ }^{924}$ Sobre o crescimento do cristianismo a partir da ação do Espírito na vida de Paulo, Lucas explica que o direcionamento seguido por Paulo estava de acordo com o propósito do Espírito Santo, e Comblin acrescenta:

São Lucas destaca o momento decisivo na carreira de Paulo. Foi o encontro de Jerusalém, em que os representantes das primeiras comunidades feitas de judeus reconheceram que a missão de Paulo era acertada e que Jesus e o Espírito queriam mesmo suprimir todas as barreiras (At. 15, 28). Por sinal, São Lucas mostra como o Espírito conduziu Paulo a cada momento. Os passos dados em virtude da autoridade do Espírito, que forçou o seu apóstolo a seguir o itinerário marcado por ele. ${ }^{925}$

No livro de Atos verificam-se acontecimentos decisivos para o cristianismo, mas, na perspectiva comblianiana, é na centralidade de Atos que se estabelece o povo de Deus: "o objeto do livro dos Atos dos Apóstolos é o lançamento ou fundação do povo de Deus". ${ }^{926}$ Comblin dedicou-se também a escrever sobre o tema. Ele vê a força do Espírito como geradora do povo de Deus. Soares explica:

Para ele, aliás, "povo" não é, antes de tudo, categoria sociológica, mas teológica, uma vez que o princípio formador não é o poder mundano, mas o Espírito, é o Espírito a força capaz de formar o povo e infundir-lhe o senso de "aliança". Escreveu "O Povo de Deus", tema radicalmente bíblico, sua atenção se centra no chamado "laicato" (o "laós" de Deus) e, particularmente, nos pobres. ${ }^{927}$

O destaque feito, em seguida, por Comblin continua sob o trabalho missionário de Paulo, em experiências nas comunidades de forte manifestação da força do Espírito:

A segunda experiência de Paulo lhe foi inspirada pela comunidade de Corinto. Aí Paulo viu como uma comunidade nasce de baixo para cima pela força de Espírito. Ela nasce mais forte quando o Apóstolo que a funda se contenta com anunciar o evangelho, sem pretender organizar, impor normas, introduzir todo um regulamento. ${ }^{928}$

A exemplo da comunidade de Corinto, marcada pelos carismas, Comblin crê que o caminho da missão passa cada vez mais pelos dons do Espírito: "no futuro, os ministros serão reconhecidos e identificados pelas comunidades, graças

\footnotetext{
${ }^{924}$ COMBLIN, J., O Espírito Santo no mundo, p. 21.

${ }^{925}$ COMBLIN, J., O Espírito Santo no mundo, p. 21.

${ }^{926}$ COMBLIN, J., O Espírito Santo no mundo, p. 22.

${ }^{927}$ SOARES, S. A. G., José Comblin, homem do Espírito, p. 52.

${ }^{928}$ COMBLIN, J., O Espírito Santo no mundo, p. 24.
} 
às suas qualidades de profeta e a seus dons espirituais". ${ }^{929}$ Trata-se de uma comunidade que cresce a partir das experiências espirituais, tão numerosas que requereram a orientação do fundador, pois a liberdade nessa comunidade causou divergências, como lembra Comblin:

A Igreja de Corinto organizou-se a si própria pela abundância dos carismas, ou seja, de dons que o Espírito suscitou nela (1Cor 12-14). Essa liberdade trouxe brigas e problemas, mas Paulo achou melhor aguentar tudo isso do que impor um sistema de regras que excluem. ${ }^{930}$

Para a percepção combliniana, Paulo aceita passar por tais situações, compreendendo a impossibilidade de evangelização sem a ação do Espírito. O melhor é uma comunidade na força do Espírito, e Comblin apresenta em poucas palavras o papel do profeta:

Ora, a palavra dos profetas tinha dois objetivos: denunciar o mal do povo, lembrando-lhe as origens e a vocação no futuro. No caso de Jesus, a missão profética recebe um novo objetivo, que ficará mais claro ainda no tempo dos apóstolos. Por isso Jesus escolhe, para se apresentar, o texto de Is 61, 1-2: "O Espírito do Senhor está sobre mim... para levar a Boa-nova aos pobres. ${ }^{931}$

É claro que a missão do leigo em Comblin não pode ser concebida sem a ação do Espírito. Assim foi o exemplo do Cristo: diante da oportunidade de expor sua missão, ele reconhece o Espírito como situado sobre ele para anunciação da boa nova. O sentido continua sendo o mesmo para todos os cristãos, tornados profetas:

O Espírito fez os profetas e deu-lhes as palavras de Deus. No caso de Jesus, o Espírito põe em sua boca as palavras que não somente denunciam, ou anunciam de longe; são palavras que mostram a presença, anunciam a realização das promessas; são palavras de boa-nova, de evangelho. O Espírito faz o evangelizador. ${ }^{932}$

Se Cristo necessitou do poder do Espírito para anunciar a boa nova, também os crentes precisam dessa força para a tarefa missionária que estão comissionadaos a cumprir. Suess destaca um livro de Comblin que trata da concepção humanizada de Jesus:

\footnotetext{
${ }^{929}$ COMBLIN, J., As grandes incertezas na igreja atual, p. 48.

${ }^{930}$ COMBLIN, J., O Espírito Santo no mundo, p. 24.

${ }^{931}$ COMBLIN, J., O Espírito Santo no mundo, p. 46.

${ }^{932}$ COMBLIN, J., O Espírito Santo no mundo, p. 46.
} 
Um dos livros mais belos de José Comblin é "O Enviado do Pai", sobre a centralidade da missão no Evangelho de S. João. Comblin fez de sua vida e de sua teologia um desdobramento dessa centralidade da missão. O livrinho é um vademécum missionário que nos mostra em Jesus "um novo modo de ser humano, ou, melhor dito, o modo de ser autenticamente humano". ${ }^{933}$

Comblin qualifica o Evangelho de João como responsável por estruturar o Espírito evangelizador agindo em Jesus: “o Evangelho de João é o que desenvolve o tema do Espírito evangelizador que reveste Jesus e faz dele o evangelizador total e definitivo, o evangelizador permanente. O quarto evangelho mostra a presença da palavra que envolve a pessoa de Jesus". ${ }^{934}$ A ação do Espírito em Jesus Cristo, durante seu ministério terreno, é diferente, como explica Comblin: "antes da ressurreição, Jesus era portador das palavras de Deus e era conduzido pelo Espírito. Diferente dos profetas, seus antecessores, Jesus tinha consigo o Espírito de tal modo que seus atos já mostravam o poder do Espírito". 935

Entretanto, faz-se sentir uma mudança significativa na relação entre Cristo e Espírito, dado que, após a ressurreição, Cristo é quem envia o Espírito. Comblin explana:

Contudo, após a ressurreição, houve uma transformação: Jesus tomou a iniciativa. Realizou-se então o que anunciara no dia dos tabernáculos: ele próprio enviou o Espírito. Pois ele se identificou então na sua totalidade com a plenitude da palavra do Pai. Jesus assumiu o Espírito em plenitude. ${ }^{936}$

Acrescentando ainda a percepção quadrangular, Ele agora também batiza com Espírito Santo. A liberdade que parte do Espírito gerar o ambiente missionário, como esclarece Comblin:

O próprio Jesus salientou a total liberdade do Espírito que sopra onde quer. Nada limita o seu poder. Pode estar presente e agir em qualquer lugar e não depende de ninguém. Tal liberdade, porém, não impede que o Espírito use instrumentos humanos. Na realidade, Jesus reuniu os apóstolos e o Espírito revestiu-os de uma missão. ${ }^{937}$

Os cristãos estão na expectativa da proximidade de Cristo. A obra dos discípulos e suas ações são continuação da missão de Cristo. A Teologia

\footnotetext{
${ }^{933}$ SUESS, P., Missionário migrante - teólogo militante José Comblin: o retorno do enviado do Pai, p. 76.

${ }^{934}$ COMBLIN, J., O Espírito Santo no mundo, p. 46.

${ }^{935}$ COMBLIN, J., O Espírito Santo no mundo, p. 49.

${ }^{936}$ COMBLIN, J., O Espírito Santo no mundo, p. 49.

${ }^{937}$ COMBLIN, J., O Espírito Santo no mundo, p. 50.
} 
combliniana assim entende: “a missão dos Apóstolos é a continuação da missão de Jesus no sentido de que ela também pertence à ordem do profetismo. O serviço ou ministério dos Apóstolos é também ministério da palavra". ${ }^{938} \mathrm{O}$ reconhecimento da missão leiga a partir do Concílio Vaticano II levou à publicação de documentos que apontam para o assunto, como afirma Comblin: "no linguajar do Vaticano II os leigos foram promovidos. Desde então foram publicados muitos documentos excelentes sobre os leigos na Igreja". 939

A anunciação da boa nova só pode ser concluída pelo engajamento de todo o povo de Deus. É Cristo quem chama o leigo e o envia. Comblin afirma: “porém, na prática, nada mudou. Os leigos não têm mais poder, mais autonomia do que antes. Tudo ficou nas palavras, porque nada mudou na instituição". ${ }^{940}$ A missão é o anúncio do evangelho de Cristo, serviço confiado a todo o povo de Deus. Na força do Espírito, todos são chamados a ser profetas e discípulos de Cristo. Comblin afirma:

A missão do apóstolo é evangelizar, pronunciar o evangelho, a Boa-nova: "a missão que Deus me confiou junto de vós: dar pleno cumprimento à palavra de Deus" $(\mathrm{Cl} 1,25)$. O serviço da palavra, eis a sua vocação! O anúncio do evangelho, "a propagação do evangelho" (F1 1,5), "a consolidação do evangelho" (F1 1,7), essas são as tarefas dos apóstolos. ${ }^{941}$

A transformação provocada pelo Espírito agindo no cristão vem diretamente de Deus. Os arranjos comblinianos tentam escapar da rigidez, buscando uma dinâmica animada pela liberdade do Espírito, reconhecendo, no entanto, que somente a ação do Espírito corresponderá a transformações eficazes. Pommrening explica:

A regra, segundo Comblin, para se manter livre, é necessário submeter-se ao discernimento do Espírito para escolher o que edifica e verificar as possibilidades mais convenientes dentro da responsabilidade da livre escolha, lembrando que este discernimento vai na contramão das convenções dogmáticas constituídas, pois vão além de simples obrigações, deveres e moralismos, levando em conta a promoção da vida em todas as suas nuances. ${ }^{942}$

\footnotetext{
${ }^{938}$ COMBLIN, J., O Espírito Santo no mundo, p. 50.

${ }^{939}$ COMBLIN, J., As grandes incertezas na igreja atual, p. 39.

${ }^{940}$ COMBLIN, J., As grandes incertezas na igreja atual, p. 39.

${ }_{941}^{9}$ COMBLIN, J., O Espírito Santo no mundo, p. 50.

942 POMMRENING, Claiton Ivan. Fragmentos de uma Teologia do Espírito para o Pentecostalismo Clássico. Congresso Internacional da Faculdades EST, 2., 2014, São Leopoldo. p. 463.
} 
A ação do Espírito é concreta, material, bem real, e suas ações necessitam estar presentes, como sempre. Comblin assegura:

O Espírito escreve nos corações. Os pecadores tornam-se santos, generosos, dedicados, sacrificados. Os covardes tornam-se valentes. Os desesperados e resignados da vida nascem para a esperança. Os desanimados começam a trabalhar. O evangelho é aquela palavra que desperta a vida, estimulando a confiança e a audácia. ${ }^{943}$

A força do Espírito é poderosa e estabelece novas comunidades, levando o pecador ao convencimento, e eu agir transforma o perdido em nova criatura. Por isso Paulo não se desespera diante de suas lutas. Sua confiança é clara: a missão é obra do Espírito que envolve a comunidade e a faz missionária na anunciação do Evangelho que prega Cristo, mas também o Espírito Santo. Comblin explica:

A partir de tal experiência é que se pode compreender qual é a força do Espírito: é aquela força que se revela no evangelho para suscitar comunidades. Por isso mesmo é que Paulo se nega a "combater com armas da carne" $(2$ Cor 3,4$)$. Não quer invocar nem argumentos de autoridade, nem usar o prestígio, a capacidade de pressão que tem para influir nas igrejas. Pretende apoiar-se unicamente naquela força do Espírito que tem a palavra do evangelho, lembrar insistentemente o evangelho e citá-lo sempre como motor permanente da vida nova. ${ }^{944}$

Paulo insiste em justificar seu evangelho no poder do Espírito. Ao mencionar tais acontecimentos da vida missionária, Paulo é exato, porque neste trabalho o conceito de missão só faz sentido a partir do Espírito. Comblin afirma:

Tão convencido estava Paulo da força do evangelho! Tinha visto em todos os cantos esse poder do evangelho pela força do Espírito (Rm 15,13-19). 'Minha palavra e pregação não consistiram em discursos persuasivos de sabedoria, mas em demonstração do Espírito e do poder de Deus (1Cor 2,4-5) ${ }^{945}$

Não basta ser igreja, para Comblin ela precisa se envolver com tudo o que diz respeito ao mundo. Pauly afirma: "para Comblin 'o desafio principal' da modernidade é 'a presença da igreja no mundo". ${ }^{946}$ A anunciação da palavra estava reservada àqueles que apresentavam o Espírito em suas vidas. Comblin continua: "entre todos os portadores da palavra do Espírito, os apóstolos ocupam

\footnotetext{
${ }^{943}$ COMBLIN, J., O Espírito Santo no Mundo, p. 55.

${ }^{944}$ COMBLIN, J., O Espírito Santo no Mundo, p. 55.

${ }_{945}^{9}$ COMBLIN, J., O Espírito Santo no Mundo, p. 55.

946 PAULY, Evaldo L. Modernidade e pastoral urbana: um depoimento teórico e pessoal. Estudos Teológicos ISSN 2237-6461, v. 34, n. 1 (1994), p. 34.
} 
um lugar eminente. Bem depressa, uma categoria destacar-se-á na Igreja primitiva: alguns têm um dom extraordinário para evangelizadores". 947

Um dom parece ser dado aos grandes evangelizadores, como os que fundaram grandes comunidades e anunciaram a palavra a muitos, entretanto para Paulo essa tarefa é de todo o povo de Deus. Comblin esclarece: “esse é o dom supremo, de acordo com Paulo, o primeiro carisma. Todos os discípulos, todos os cristãos são evangelizadores, mas alguns têm um dom tão extraordinário que devem reservar toda a sua vida para esse ministério do Espírito". ${ }^{948}$ Todos os dons visam ao crescimento espiritual da comunidade para o serviço, cujo objetivo geral é a evangelização. As comunidades cujos dons são visíveis são prova de que tal comunidade está em missão. Comblin explica:

\begin{abstract}
Vários são os dons espirituais, mas é o mesmo Espírito; vários são os mistérios, mas é o mesmo Senhor; várias são as obras, mas é o mesmo Deus que operará em todos. A cada um é dada a manifestação do Espírito, em vista da utilidade. A um, é dada pelo Espírito uma palavra de sabedoria; a outro, a fé no mesmo Espírito; a outro, o dom de curar, neste único Espírito; a outro, a diversidade de línguas; a outro, o discernimento do espírito; a outro, o dom de interpretá-las. Mas tudo isso é o único e o mesmo Espírito que opera, que distribui em particular a cada um como quer (1 Cor 12,4-11)". O mais notável é que todos receberam um dom. Infelizmente, nem sempre em todas as comunidades houve tantas manifestações. Nós temos, antes impressão de que tais comunidades são excepcionais. ${ }^{949}$
\end{abstract}

A comunidade animada pelo Espírito, a exemplo da Igreja de Corinto, é composta de uma dinâmica da intensidade. Comblin diz: "contudo, potencialmente todas são chamadas. Os obstáculos procedem do temor, da prudência que faz com que prefiramos comunidades mais sossegadas, em que não acontece nada". ${ }^{950}$ A unidade do Espírito se manifesta mesmo diante da diversidade. Em ambiente cada vez mais plural, as sociedades precisam ser evangelizadas na mesma dinâmica. Assim, o caminho mais diversificado do povo de Deus é o leigo, parte integrante das novas sociedades. Comblin esclarece: "o dom do Espírito, que é o penhor a vida eterna, manifesta-se em formas diversas. É um dom multiforme. Há uma grande variedade de atos, que o tornam atual". ${ }^{951}$ Em diálogo com essa atualidade, Comblin reflete, e sua pneumatologia aponta

\footnotetext{
${ }^{947}$ COMBLIN, J., O Espírito Santo no mundo, p. 57.

${ }^{948}$ COMBLIN, J., O Espírito Santo no mundo, p. 57.

${ }^{949}$ COMBLIN, J., O Espírito Santo no mundo, p. 58-59.

${ }^{950}$ COMBLIN, J., O Espírito Santo no mundo, p. 59.

${ }^{951}$ COMBLIN, J., O Espírito Santo no mundo, p. 103.
} 
para inovações e caminha junto da missão. Em Comblin a missão está no ambiente pneumatológico. Hoornaert explica:

Comblin trabalha igualmente com metáforas. Sua teologia não define, mas descreve e das descrições tira conclusões práticas, ou seja, que se aplicam à ação. Nos cinco livros que ele dedica ao Espírito Santo, Comblin fala em ação, palavra, povo de Deus, liberdade, desobediência. Ao longo de sua atuação como teólogo, a Pneumatologia sustentará suas ousadas afirmações. ${ }^{952}$

A missão no Espírito sempre fez parte da Igreja, ou seja, o Espírito em missão sempre suscitou comunidades, como lembra Comblin: "durante o segundo século a Igreja ainda é carismática: ainda apela em primeiro lugar para a experiência do Espírito". ${ }^{953}$ Um breve levantamento mostra que a missão de todo o povo de Deus na ação do Espírito era a forma de anunciar o Evangelho. Não havia grandes planos de missões, e as experiências espirituais em comunidade é que punham o povo em missão. Comblin continua: "tudo indica que tais fenômenos eram mais ou menos frequentes nas comunidades recentemente fundadas. Grupos de novos discípulos recebiam uma efusão visível do Espírito".954

O que se questiona nessa questão é a possibilidade de comparação dos fenômenos pentecostais contemporâneos com os relatados nas primeiras comunidades cristãs. Comblin explica:

Poderíamos pensar que os fenômenos místicos, os fenômenos pentecostais espirituais do primeiro século e talvez os fenômenos pentecostais dos nossos dias sejam várias expressões de uma realidade mais genérica. A diversidade seria relativa à cultura duma época. E todos seriam formas de dons do Espírito Santo como sinais visíveis ou sensíveis do penhor do Espírito, sinais do Reino de Deus antecipado no momento presente. ${ }^{955}$

Os fenômenos atuais levantaram a face inicial da Igreja do primeiro século.

Esse estudo comparativo entre os dois fenômenos é bastante desafiador. Por isso Comblin diz: "deixemos para outros o problema da comparação com o pentecostalismo contemporâneo". ${ }^{956}$ Independentemente de aproximações ou diferenciações com o pentecostalismo atual, importa no momento um caminho ao

${ }^{952}$ HOORNAERT, Eduardo. O Apocalipse como fonte inspiradora da Cristologia de José Comblin. Paralellus, Recife, v. 6, n. 11, Especial José Comblin, p. 59-66, 2015, p. 64-65.

${ }^{953}$ COMBLIN, J., O Espírito Santo e a libertação, p. 54.

${ }^{954}$ COMBLIN, J., O Espírito Santo no mundo, p. 111.

${ }^{955}$ COMBLIN, J., O Espírito Santo no mundo, p. 111.

${ }^{956}$ COMBLIN, J., O Espírito Santo no mundo, p. 111. 
cristianismo contemporâneo. Mikuszka diz que é preciso "reconhecer que um ministério é dado para servir às necessidades de uma comunidade e os carismas dados aos discípulos significam assimilar que Deus, em seu Espírito, conhece as necessidades de cada contexto". 957

Sempre atento à atualidade, Comblin insiste: "hoje há a prioridade da evangelização e de uma Igreja missionária". 958 Os fenômenos atuais têm se dado em uma época contraditória, desafiando as previsões em um momento da história da humanidade em que o individualismo se destaca. Comblin afirma: "é uma coincidência que os fenômenos místicos tenham ocorrido justamente na época do individualismo e na época da descoberta da interioridade". ${ }^{959}$ Voltando aos acontecimentos bíblicos, é notável que a missão acontecia pelo poder do Espírito, e por isso se constituía no modelo a seguir. Comblin esclarece:

\begin{abstract}
A epístola aos Tessalonicenses confirma que a pregação dos apóstolos era apoiada por sinais sensíveis do Espírito: provoca comoções ou emoções tão fortes que eram verdadeiros sinais para novas comunidades. "O nosso evangelho não foi apresentado a vós unicamente por meio de palavras, mas também com obras poderosas, com a ação do Espírito Santo... De vossa parte, vos fizestes imitadores nossos e do Senhor, acolhendo a palavra em meio a grande tribulações, com a alegria do Espírito Santo" (1 Ts 1,5-6). Longe de subestimar esses fenômenos espirituais, Paulo diz no fim da epístola: "Não apagueis o Espírito" (1 Ts 5,19). ${ }^{960}$
\end{abstract}

$\mathrm{Na}$ atualidade a missão precisa residir no Espírito, e isso o pentecostalismo tem anunciado na prática. Mas, como é o agir do Espírito na prática combliniana? Para Mikuszka: “Comblin define o Espírito Santo como 'força de Deus', que faz a pessoa agir no mundo". ${ }^{961}$ O Espírito age na vida do crente, levando-o à anunciação do Evangelho que apresenta Cristo e o Espírito. A ação do Espírito é concreta, real.

\title{
3.2.3.
}

\section{Discussões sobre a missão em Comblin}

A decisão do teólogo José Comblin de participar da vida dos leigos mudou para sempre sua forma de viver e de interpretar a fé. Mikuszka acrescenta: "o

\footnotetext{
${ }^{957}$ MIKUSZKA, G. L., O discípulo missionário na perspectiva de José Comblin, p. 40.

${ }^{958}$ COMBLIN, J., A virada da teologia cristã, p. 99.

${ }^{959}$ COMBLIN, J., O Espírito Santo no mundo, p. 112.

${ }^{960}$ COMBLIN, J., O Espírito Santo no mundo, p. 113.

${ }^{961}$ MIKUSZKA, G. L., O discípulo missionário na perspectiva de José Comblin, p. 30.
} 
teólogo belga não desmerece o saber teológico sistematizado, porém faz opção por uma formação teológica simples". ${ }^{962}$ Ele não foi apenas um teórico, mas foi coerente a sua teologia ao fazer dela seu cotidiano em meio ao povo, e assim Comblin se tornou conhecido por seu envolvimento em questões populares, sempre junto ao povo. Cabral lembra: "os que estudam o pensamento do teólogo e sociólogo - Comblin, constatam o quanto se preocupou com o entendimento e a valorização do catolicismo popular". ${ }^{963}$

Ele não foi o primeiro teólogo a dedicar-se ao tema, mas a forma como o faz no contexto brasileiro é marcante, principalmente em um país onde o pentecostalismo tem crescido bastante e o seu crescimento parece estar relacionado à sua atuação missionária popular e simples, pelo comissionamento do leigo. Para alguns comentadores de Comblin, o fundamento teológico que sustenta esse modo de fazer missão é a proximidade entre a fé e as demais áreas da vida praticante. Mikuszka afirma:

\begin{abstract}
A base teológica desse tipo de formação é a coerência entre a vida e a fé dos envolvidos com o Evangelho e, quanto mais próxima da realidade e das ações do povo, mais essa teologia consegue historicizar a Revelação. Essa parece ser a proposta de Comblin ao elaborar a teologia "para" o leigo, buscando uma formação integrada com a realidade pelo diálogo, respeito e crítica às contingências históricas, delimitando etapas e avaliando atitudes. Sem viver tal processo, corre-se o risco de que as ações sejam vazias, mecanizadas e teóricas. ${ }^{964}$
\end{abstract}

A proposta do teólogo é evangelizar, inserindo o leigo como agente de missão. Na análise de Mikuszka, a evangelização, para Comblin, pode ser descrita em três atos. Mikuszka lembra: "já dissemos acima que para Comblin evangelizar é um ato que acontece em três graus: 'Evangelizar é anunciar os evangelhos; os evangelhos anunciam Jesus Cristo; Jesus Cristo anuncia o advento do Reino do Pai"". 965 De acordo com o desenvolvimento desta pesquisa, acrescenta-se um quarto grau, o anúncio do Espírito, posto que também já se viu que em Comblin a evangelização acontece no poder do Espírito. Mikuszka continua: "sua preocupação fundamental não é a salvação de almas isoladas, e sim o povo de Deus, o verdadeiro povo de Israel". ${ }^{966}$ Em Comblin, a salvação integral implica

\footnotetext{
${ }^{962}$ MIKUSZKA, G. L., O discípulo missionário na perspectiva de José Comblin, p. 78.

${ }^{963}$ CABRAL, N. D. A.; MARQUES, L. C. L., Um tufão chamado José Comblin, p. 596.

${ }^{964}$ MIKUSZKA, G. L., O discípulo missionário na perspectiva de José Comblin, p. 78.

${ }^{965}$ MIKUSZKA, G. L., O discípulo missionário na perspectiva de José Comblin, p. 84.

${ }^{966}$ COMBLIN, J., O Espírito Santo no mundo, p. 14.
} 
uma preocupação com o todo que envolve a vida. Em um plano maior, o povo de Deus.

A Igreja existe a partir do derramamento do Espírito em Pentecostes. Cristo, ao derramar o Espírito, inaugura sua Igreja missionária, que, a partir de então, inicia a evangelização. Comblin afirma: "a razão de ser da Igreja é evangelizar. Evangelizar é propriamente a missão da Igreja; ela existe para evangelizar". ${ }^{967}$ Pela evangelização a Igreja existe na essência e está em missão no mundo. O Espírito lança a Igreja na evangelização. Comblin pergunta: “o que é evangelizar? Evangelizar diz respeito aos 'evangelhos': evangelizar é anunciar e publicar a mensagem dos evangelhos, e consiste nisto: o anúncio de Jesus Cristo". ${ }^{968}$ O autor chama a atenção para as questões carentes de análise, pois o futuro da evangelização passa pela consciência da história dos povos em que ela acontece. Soares diz:

Desde cedo no Brasil, particularmente pela Revista REB, insistia em mostrar como a nova evangelização e a ação pastoral só serão possíveis na medida em que tomemos consciência da história de nossos países e de nossa trágica história como Igreja no Continente e façamos análise crítica da ação praticada junto a nossos povos - aborígenes, africanos, as massas pobres. ${ }^{969}$

No evangelho segundo Marcos o ato de evangelizar transforma a realidade e gera nova identidade. Comblin continua: "para Marcos o essencial da evangelização é que ela constitui por si própria o novo modo de ser". ${ }^{970}$ Não se pode limitar a missão da evangelização a um discurso; a evangelização é a presença concreta da manifestação de Cristo pela ação do Espírito, em missão no mundo. Comblin destaca: "o Cristo da missão não será um discurso humano sobre Cristo, mas uma presença viva e real de Jesus feito homem pobre e sem poder, de uma maneira capaz de tocar no coração dos pobres das nações". ${ }^{971}$

A missão direcionada pelo Espírito é exatamente a aceitação de ações concretas. Segundo Comblin, “dizer que o Espírito é enviado aos homens é dizer que a ação nos precede". ${ }^{972}$ Já foi visto nesta pesquisa que toda missão deriva do

\footnotetext{
${ }^{967}$ COMBLIN, José. Evangelizar. Petrópolis: Vozes, 1980, p. 7.

${ }^{968}$ COMBLIN, J., Evangelizar, p. 7.

${ }^{969}$ SOARES, S. A., G. José Comblin, homem do Espírito, p. 54-55.

${ }^{970}$ COMBLIN, J., Evangelizar, p. 35.

${ }^{971}$ COMBLIN, J., O Espírito Santo e a libertação, p. 202.

${ }^{972}$ COMBLIN, J., Tempo da ação, p. 51.
} 
agir do Espírito, que lança o povo de Deus na missão de evangelizar, e evangelizar é anunciar Cristo e o poder do Espírito. Comblin explica:

O Espírito é enviado e quer agir. Penetrar e produzir ações. Nossas ações procedem, assim, de uma ação anterior. Não agimos a partir de nós mesmos, mas, sim, a partir da ação que o Espírito, que concede a ação antes de nós, pondo-a em movimento antes de nós. ${ }^{973}$

A ação do Espírito é sólida e pode ser testemunhada. É Ele quem convence e atrai os novos convertidos. Comblin define assim essa ação: "o Espírito força as portas para empurrar para dentro novos membros". $974 \mathrm{O}$ uso da expressão "força" para designar uma ação atribuída ao Espírito contrapõe-se justamente à ideia de invisibilidade imaterial que se tornou sinônimo de espírito para muitos cristãos. Comblin é enfático: "o Espírito força o crescimento abrindo o corpo de seu povo". 975

Todo o plano de salvação está em curso na missão e a eficácia dessa obra depende da unidade. Comblin afirma: "desse modo, Cristo e o Espírito estão unidos também na missão e somente a sua unidade torna possível a missão nesta hora do mundo". ${ }^{976}$ É o Espírito o catalizador que transforma a simples ação humana em grandes feitos, as palavras dos servos em salvação, as profecias do povo simples em fatos, gerando esperança onde não há. Comblin assegura: "ao contrário de tudo isso, o povo de Deus cresce porque o Espírito faz surgir novos fragmentos na periferia e, depois, força a entrada desses fragmentos na Igreja". 977 Comblin é categórico ao afirmar a indisposição para a evangelização eficaz, nutrindo, entretanto, a esperança do retorno à palavra de Deus e, a partir disso, uma missão na força do Espírito que flui de uma hermenêutica do povo. Ele diz:

Fala-se de missão e evangelização, mas falta a coragem para fazer as transformações necessárias, por exemplo, na teologia e na formação cristã em geral. Não podemos perder a esperança. Um dia chegará quando teremos a coragem de voltar às origens para reunirmo-nos de novo com a tradição de vida que é a palavra de Deus. ${ }^{978}$

\footnotetext{
${ }^{973}$ COMBLIN, J., Tempo da ação, p. 52.

${ }^{974}$ COMBLIN, J., Tempo da ação, p. 52.

${ }^{975}$ COMBLIN, J., Tempo da ação, p. 52.

${ }^{976}$ COMBLIN, J., O Espírito Santo e a libertação, p. 203.

${ }_{977}$ COMBLIN, J., Tempo da ação, p. 52.

${ }^{978}$ COMBLIN, J., A virada da teologia cristã, p. 100.
} 
A Igreja está encontrando uma nova velha forma de agir no mundo, em que o novo tem envolvido a igreja. Comblin diz: "não é o antigo que absorve o novo". ${ }^{979}$ A missão nunca será um projeto humano, com metas e objetivos a ser compridos. O que deve acontecer é uma rendição ao Espírito e ao seu agir. Comblin esclarece: "por isso não precisamos partir para a missão já com um projeto de Igreja, nem com um projeto de evangelho elaborado". 980 Não se pode fixar o evangelho em ação humanas. Toda missão combliniana rende ao Espírito a chave da missão: "cristo é Espírito e o Espírito é Cristo. Cristo não é conhecido por meio de discursos fixos como numa Torá. Cristo é conhecido por meio da práxis conduzida pelo Espírito. E o Espírito não inspira qualquer coisa fantasiada pela imaginação dos cristãos". ${ }^{981}$ A concepção de engajamento missionário em Comblin sofre a influência dos acontecimentos de seu tampo, destacando-se aqui a Conferência de Medellín:

Por isso, houve a Conferência de Medellín, que foi como o descobrimento de Jesus Cristo em sua realidade, em sua presença. Era preciso descobrir os pobres para descobrir Jesus Cristo. A Conferência de Medellín foi preparada pelo Pacto das Catacumbas. No dia 16 de novembro de 1965, poucos dias antes do encerramento do Concílio, 40 bispos do mundo reuniram-se na catacumba de santa Domitila, em Roma, e assinaram o Pacto das Catacumbas. Cada um se comprometia a viver pobre, a rejeitar todos os símbolos ou os privilégios do poder e a colocar os pobres no centro de seu ministério pastoral. Não era comédia, porque já estavam agindo assim. Nesses quarenta havia um número expressivo de brasileiros e latinoamericanos, e, mais tarde, outros subscreveram também. ${ }^{982}$

Os discípulos de Cristo renderam-se ao Espírito, completando a missão em unidade. Mikuszka afirma: "isso nos faz crer que o Pentecostes foi o momento em que os discípulos conceberam que a força do Espírito agisse neles". ${ }^{983}$ A renovação do povo de Deus é dirigida pelo agir de Deus no mundo, agir que considera o novo, recria tudo, vai além das ações humanas é a concretude da força que tudo criou. Comblin afirma: "o Espírito reinventa, cria". ${ }^{984}$ Esse mesmo Espírito também leva o povo ao movimento, ao agir, e intervir é parte da missão do povo de Deus, dado que o Espírito o lança a acreditar mesmo no que não se vê. Comblin destaca esse aspecto: “o Espírito nos é enviado para nos fazer agir. Suas

\footnotetext{
979 COMBLIN, J., Tempo da ação, p. 52.

${ }^{980}$ COMBLIN, J., O Espírito Santo e a libertação, p. 202

${ }^{981}$ COMBLIN, J., O Espírito Santo e a libertação, p. 203.

${ }^{982}$ COMBLIN, J., As estranhas acusações de Clodovis Boff, p. 200.

${ }^{983}$ MIKUSZKA, G. L., O discípulo missionário na perspectiva de José Comblin, p. 30.

${ }^{984}$ COMBLIN, J., Tempo da ação, p. 53.
} 
ações são nossas ações. O Espírito não tem ações próprias. Tem apenas as nossas. Deste modo, nossas ações se tornam ações do Espírito de Deus, tornam-se missão do Espírito". 985

O agir espontâneo do Espírito leva a missão a novos paradigmas, e assim a evangelização não se torna refém de determinada cultura. Mikuszka diz: “Comblin cita o 'impulso não programado do Espírito' para mostrar que o Espírito concede ao discípulo a possibilidade de agir na realidade de modo diverso, plural e livre. Em si, ele não age por si mesmo, mas sim na força do Espírito". ${ }^{986}$ Para Mikuszka, todos que agem na força do Espírito na anunciação do evangelho podem ser considerados discípulos de Cristo. Nessa condição é o Espírito que o qualifica e testifica: "podemos considerar que o discípulo de Jesus é todo aquele que age na força do Espírito desde o Evangelho". ${ }^{987}$ Comblin busca uma forma de manter o diálogo com a atualidade, sem o qual, segundo ele, a evangelização não será significativa:

\begin{abstract}
Outra sugestão se refere ao diálogo. A evangelização não deve ser um convite direto a uma conversão, mas primeiro um intercâmbio, um diálogo teórico e prático com outras religiões do mundo dentro de encontros culturais. Em tais diálogos os missionários devem estar dispostos a aprender. Pois não há diálogo sem reciprocidade. Se um dos interlocutores acha que já tem toda a verdade, não está disposto a receber, mas apenas tolera que o outro faça um discurso antes de repetir o seu próprio. ${ }^{988}$
\end{abstract}

Não se pode entender a missão do Espírito apenas na perspectiva humana. A missão de Deus abrange o mundo e todos. Ele é o criador de toda a diversidade. Os missionários não devem trabalhar pela uniformidade, como afirma Comblin: "por outro lado, em virtude da missão do Espírito, os homens são assumidos por Deus em sua multiplicidade e diversidade". ${ }^{989}$ Ele afirma, ainda: "a multiplicidade e a diversidade são necessárias para o reino de Deus: fazem parte do modo de unidade desejado por Deus". 990

A exemplo da grande diversidade do cenário brasileiro, que tem proporcionado o surgimento de novas formas de religiosidade, Canova diz: "o berço onde nasceram as práticas e formulações deste novo modelo de Igreja foi

\footnotetext{
${ }^{985}$ COMBLIN, J., Tempo da ação, p. 53.

${ }^{986}$ MIKUSZKA, G. L., O discípulo missionário na perspectiva de José Comblin, p. 35.

${ }^{987}$ MIKUSZKA, G. L., O discípulo missionário na perspectiva de José Comblin, p. 36.

${ }^{988}$ COMBLIN, J., O Espírito Santo e a libertação, p. 201.

${ }^{989}$ COMBLIN, J., Tempo da ação, p. 29.

${ }^{990}$ COMBLIN, J., Tempo da ação, p. 29.
} 
sem dúvidas a Religiosidade Popular dos povos latino-americanos". ${ }^{991}$ É a partir dessa dinâmica que a prática combliniana desenvolve sua missão. Comblin percebia que onde estava o povo estava a Igreja, vivendo no meio do povo em serviço, como afirma Cabral:

Sem dúvidas sua vida e atuação, junto a outros conceituados pastoralistas, teólogos, cientistas da religião etc., foram prenúncio de algo ainda não concretizado: uma tempestade, com intensidade semelhante à de um terremoto cujo epicentro seja o Evangelho, que venha a exigir novos alicerces e estruturas a partir dos quais formulemos uma inversão na perspectiva eclesiológica de modo a podermos, em substituição à sedimentada sentença anterior, proclamar que Onde está o povo, aí está a Igreja! Comblin acreditava nisso. E decorre sobremaneira daí o fato de a sua teologia guardar inquietante e propulsora perenidade. ${ }^{992}$

Como já dito, o Comblin teólogo e intelectual preferiu dedicar-se aos simples. Viveu boa parte da vida entre o povo nordestino. Ottaviani diz: "será ali, no Nordeste brasileiro, que Comblin se sentirá livre para apresentar o Concílio Vaticano II aos membros das futuras Comunidades Eclesiais de Base [...]". ${ }^{993}$ Muggler destaca: "investiu na pessoa humana, de modo particular acreditou na mulher e no homem nordestino! Como raras pessoas, compreendeu a psicologia muito própria e se apaixonou pelo jeito do povo nordestino". 994

Ao cumprir a missão, concretizava sua forma de compreensão de Igreja. Lara afirma: "o modelo das Comunidades Eclesiais de Base (CEBs) e a teologia da libertação influenciaram a hermenêutica dos textos de Comblin, bem como toda a sua visão de Igreja". ${ }^{995} \mathrm{O}$ trabalho de Comblin no Nordeste do Brasil foi decisivo para a sua Teologia, podendo ele somar sua teoria à nova realidade em que se inseria. Sousa resume essa fase da missão de Comblin:

Contudo, é no Nordeste brasileiro que José Comblin decide instalar-se desde 1965, quando, a convite de D. Hélder Câmara, chega à cidade do Recife para iniciar uma nova etapa de sua vida na América Latina que viria a ser, apesar do intervalo forçado pela ditadura entre 1972-1980, sua residência definitiva. Inicialmente, dedica-se à formação acadêmica, na qual vai compor a equipe de formadores do recém-formado ITER (Instituto de Teologia do Recife), juntamente com D. Marcelo Carvalheira e René Guerre, entre outros. Nessa instituição, dedica-se à estruturação dos cursos de Filosofia e Teologia. Este último não só atenderia os

\footnotetext{
${ }^{991}$ CANOVA, H., José Comblin e a Igreja dos pobres, p. 23.

992 CABRAL, N. D. A.; MARQUES, L. C. L., Um tufão chamado José Comblin, p. 596.

${ }^{993}$ OTTAVIANI, E. S.; FREZZATO, A. Teologia a marteladas, p. 606-607.

${ }^{994}$ MUGGLER, M. M., Padre José Comblin, p. 20-21.

${ }^{995}$ LARA, V. L., Hermenêutica bíblica para compreender Paulo em Comblin, p. 662.
} 
estudantes seminaristas do Nordeste, mas também os leigos(as), sendo o primeiro curso de Teologia a abrir-lhes espaço. ${ }^{996}$

A tentativa do missionário de praticar os novos desafios após o Concílio Vaticano II objetiva inicialmente envolver os leigos na missão da evangelização. Sousa afirma: "desde os primeiros anos, buscando estar em linha com as novas perspectivas do Concílio Vaticano II, que se findara em 1965, a equipe do ITER buscava abertura e inovações para seus alunos". 997

A concretização de sua Teologia ganha forma a partir da formação de leigos no Nordeste brasileiro, quando ele propõe a contextualização de sua prática missionária. Sousa destaca:

Comblin entra nessa dinâmica para colaborar na construção de uma Igreja renovada e contextualizada. Denominamos as iniciativas por ele realizadas para esse processo 'a prática de Comblin'. Estas podem ser subdivididas principalmente em três: CEBs, Teologia da Enxada e Escolas de Formação Missionária. ${ }^{998}$

Quando Comblin deixou a Europa para ser missionário na América Latina, tal fato já parecia loucura aos olhos de seus conhecidos, quanto mais a missão no Nordeste do Brasil, como diz Ottaviani:

Ao contrário, ali onde o trabalho apostólico será realmente organizado, ele dará frutos numerosos. Nessas passagens, podemos contemplar a visão profética do jovem teólogo a respeito do que viria a ocorrer no pensamento teológico e na ação pastoral do Brasil durante as décadas de 70 e $80 .{ }^{999}$

São tentativas de fazer uma teologia que participa da vida do povo e fazer o povo suscitar novas teologias. É nessa dinâmica que Comblin desbrava novos caminhos em missão. Sousa assegura: "é igualmente importante ressaltar como a prática de Comblin reflete a sua teoria". ${ }^{1000}$ Dos três exemplos apresentados por Sousa, os centros de formação missionária têm por características a evangelização por intermédio do leigo, tratando de formar o povo leigo, incentivando-o à pratica da evangelização e estimulando a vocação. Sousa acrescenta: "os Centros de Formação Missionária (CFM) possibilitaram o avanço no processo de

\footnotetext{
996 SOUSA, Alzirinha Rocha de. Formação de "missionários profetas": a centralidade das narrativas no método de formação das EFM do Nordeste do Brasil. Teoliterária V. 8 - N. 15 2018 , p. 67.

${ }^{997}$ SOUSA, A. R., Formação de "missionários profetas", p. 67.

${ }^{998}$ SOUSA, A. R., Formação de "missionários profetas", p. 67-68.

${ }^{999}$ OTTAVIANI, E. S.; FREZZATO, A. Teologia a marteladas, p. 616.

${ }^{1000}$ SOUSA, A. R., Formação de "missionários profetas", p. 68.
} 
evangelização, tornando-se espaços de referência de formação para a vocação laical missionária". ${ }^{1001}$ Comblin contribui com os Centros de Formação Missionária em, pelo menos, dois países, além do Brasil: o Chile e o Equador. Ottaviani descreve:

E ao lado de tantos leigos e leigas com os quais trabalhou nos Centros de Formação Missionária (femininos e masculinos), que ajudou a fundar não só no interior do Brasil quanto em outros países da América Latina (Chile e Equador, em particular). Suas "Notas" revelam um olhar crítico e ao mesmo tempo visionário do teólogo, missionário e educador belga radicado no Brasil. ${ }^{1002}$

A diferença entre os exemplos apontados mostra Comblin como um grande visionário, pois os centros de formação missionária têm por objetivo a continuidade da missão, enquanto nas CEBs o leigo anima os participantes da comunidade; já o leigo participante dos CMF evangeliza aqueles que não compõem a comunidade. Existiam também as escolas de formação missionaria.

Sousa comenta:

Em sentido oposto ao das CEBs, onde os leigos assumem a responsabilidade da animação das comunidades em movimento intracomunitário, as EFM encarnam o novo ministério nascido na América Latina: o missionário leigo. Trata-se de pessoas enviadas por suas comunidades para evangelizar os que não pertencem a ela, configurando uma Igreja itinerante até o descobrimento do desconhecido, em movimento no espaço e em saída para o encontro de pessoas novas. ${ }^{1003}$

As iniciativas para alcançar outras pessoas levam o leigo a evangelizar localidades remotas do Nordeste do Brasil. A dimensão do país proporciona diversas ações missionárias. Silva explica:

O Brasil foi, e continua sendo, celeiro de ações missionárias e palco para as pessoas que buscam se doar por meio da ação evangelizadora, o que torna fácil a tarefa de destacar nomes importantes neste processo. Entre estas pessoas, percebemos a figura de um jovem padre belga que chegou em nossa terra há exatamente 60 anos. ${ }^{1004}$

Isso faz Comblim pensar na preparação desses missionários, como esclarece Sousa: “ora, no Nordeste Brasileiro, os leigos também começaram a tomar a iniciativa de visitar as comunidades isoladas. É a partir dessa

\footnotetext{
${ }^{1001}$ SOUSA, A. R., Formação de "missionários profetas", p. 69-70.

${ }^{1002}$ OTTAVIANI, E. S.; FREZZATO, A. Teologia a marteladas, p. 617.

${ }^{1003}$ SOUSA, A. R., Formação de "missionários profetas", p. 70.

${ }^{1004}$ SILVA, M. d. A., Dom Paulo de Tarso Campos e a vinda do padre José Comblin ao Brasil, p. 623.
} 
identificação que Comblin dá início, em 1989, às EFM que até esta data se encontram em atividade". ${ }^{1005}$ No início das atividades das EFM, nome pela qual se tornou conhecido este trabalho, houve interferência. Pereira afirma: "mas veio uma carta de Roma estranhando muito que eu tivesse organizado na diocese um curso que não atendia as exigências mínimas para a formação sacerdotal". ${ }^{1006}$ Nesse momento receou-se que os trabalhos fossem interrompidos, mas Comblin pensou em uma solução. Pereira continua:

Então temos de parar?... Comblin disse: - Vamos mudar o nome. Em vez de Seminário, vamos chamar de Centro de Formação Missionária. Não mais para formar padres, mas para formar missionários. Formados os missionários, o bispo avalia o desempenho deles e se quiser ordená-los padres, pode ordenar. Sem precisar licença nem de Roma nem de ninguém. ${ }^{1007}$

Sousa descreve a estrutura que fundamenta a necessidade desse tipo de trabalho no Nordeste Brasileiro. A primeira das justificativas é o baixo número de sacerdotes; a segunda é criar espaço para a formação contextualizada do leigo simples, possibilitando a integração pedagógica e geográfica adequada; e a terceira, segundo Sousa, é formar leigos capazes de competir com o novo pentecostalismo:

Da análise da realidade sugiram as questões de fundo que motivariam a estruturação do projeto. A primeira questão, que é a mesma que se coloca atualmente, é o baixo número de sacerdotes para fazer frente a todas as paróquias e comunidades que se situam em regiões isoladas. Para avançar na evangelização, era necessário pensar uma formação estruturada para os leigos de forma que eles pudessem sustentar as comunidades na ausência dos padres. A segunda questão, e a principal, foi criar um espaço de formação adequado aos leigos nordestinos, isto é, gente simples da região, seja na questão pedagógica, seja na questão geográfica. A terceira questão ou motivação, descrita por Comblin em 1991, trata de formar leigos capazes de fazer frente ao avanço dos novos movimentos religiosos pentecostais [...]. ${ }^{1008}$

O trabalho missionário de Comblin contava com a simpatia de muitos. Pereira destaca o testemunho de Dom José Maria Pires: "Dom José Maria Pires Pe. José Comblin foi um sacerdote belga que deu uma contribuição muito positiva a todo o Nordeste, num período da maior dificuldade, o da ditadura militar no

\footnotetext{
${ }^{1005}$ SOUSA, A. R., Formação de "missionários profetas", p. 71.

${ }^{1006}$ PEREIRA, P. C., Transitando entre diferentes esferas da vida: uma abordagem sobre a multifacetada caminhada de José Comblin II, p. 72.

${ }^{1007}$ PEREIRA, P. C., Transitando entre diferentes esferas da vida: uma abordagem sobre a multifacetada caminhada de José Comblin II, p. 72.

${ }^{1008}$ SOUSA, A. R., Formação de "missionários profetas", p. 71.
} 
Brasil". ${ }^{1009} \mathrm{O}$ funcionamento das EFM tornou-se realidade no Nordeste brasileiro. Sousa continua: "a partir de então, foram estruturadas seis EFM que reagrupavam em seus cursos leigos vindos de todas as regiões. Atualmente, elas são compostas por seus centros de formação, localizados em diversos estados da região Nordeste". ${ }^{1010}$ Comblin foi recebido em Recife por Dom Hélder, que o convida a ministrar cursos. Pereira diz: "veio para Recife, a pedido de Dom Hélder, e ali começou o trabalho de formação. Dava cursos, atendia aos jovens". ${ }^{1011}$ Sousa divide o objetivo da formação em sete pontos:

O objetivo da formação pode ser apresentado em sete pontos essenciais: 1) oferecer formação a cristãos de classe popular, de forma a prepará-los para atuar no mundo à maneira de Jesus; 2) priorizar a formação humana que desenvolve a personalidade, trabalhando o ser, o ver e o atuar das pessoas; 3) formar para a liberdade e com liberdade no Espírito de Jesus; 4) desenvolver o espírito missionário e a mística da missão entre os pobres além das fronteiras eclesiais; 5) realizar a formação através do testemunho de educadores, com uma metodologia simples e orientada para a cultura popular e o mundo dos pobres; 6) manter a perspectiva de um novo caminho para a Igreja, que sustenta a participação e a comunhão, modelo estudado e vivido na convivência de um mês intensivo de formação, e 7) finalmente manter uma formação constante que seja, sobretudo estímulo, espaço de troca de experiências e desafios que levem ao mútuo estímulo entre os participantes. ${ }^{1012}$

Buscando a compreensão da estrutura e do funcionamento das EFM, criadas por Comblin com finalidade de preparar eficazmente o povo leigo para a evangelização, servimo-nos da explicação de Sousa: "para tanto, foi estruturada uma pedagogia de longo prazo. A formação é constituída em quatro anos, organizada em duas etapas: a primeira, realizada a distância, com acompanhamento de monitores locais [...]". ${ }^{1013}$ Essa experiência demostra claramente o empenho de Comblin em defender uma missão que envolvesse o leigo, não se limitando ao discurso. Sousa esclarece a segunda parte da formação dos alunos:

A segunda etapa consiste em um período intensivo de experiência comunitária e de imersão de 30 dias, em que são desenvolvidos os seguintes temas: espiritualidade,

1009 PEREIRA, P. C., Transitando entre diferentes esferas da vida: uma abordagem sobre a multifacetada caminhada de José Comblin II, p. 71.

${ }^{1010}$ SOUSA, A. R., Formação de "missionários profetas", p. 72.

1011 PEREIRA, P. C., Transitando entre diferentes esferas da vida: uma abordagem sobre a multifacetada caminhada de José Comblin II, p. 71.

1012 SOUSA, A. R., Formação de "missionários profetas", p. 73.

${ }^{1013}$ SOUSA, A. R., Formação de "missionários profetas", p. 74. 
conselho pastoral, celebrações populares, liturgia e análise da situação social e política do Nordeste brasileiro. ${ }^{1014}$

A fase inicial dos Centros de Formação Missionária acontece na maneira combliniana bem simples. No fundo do salão estava o seu quarto, e após as aulas fazia visitas, por vezes, a pé. Pereira afirma:

Comblin começa o trabalho. O Centro de Formação Missionária: lá no fundo o quarto dele, mais à frente o salão enorme, com os livros dele. Ali dava as aulas para os alunos. Depois saía com aquele chapéu de palha, naquele sol, para visitar a comunidade tal, às vezes a pé. $\mathrm{O}$ homem se dedicou inteiramente a isso... Formamse os primeiros missionários, começam a trabalhar, o trabalho é excelente. Alguns foram ordenados. ${ }^{1015}$

Nessa perspectiva missionária o convertido precisa também assumir uma postura semelhante à do missionário ou missionária que lhe serviu, como Cappelletti explica:

O convertido assume como desafios para sua própria vida lutar pela justiça com base no Reino de Deus. A pessoa se transforma em promotor do Reino e da justiça por encontrar com o Cristo e, assim, modifica a maneira de viver segundo as atitudes e ensinamentos de Jesus. ${ }^{1016}$

Toda a estrutura do projeto combliniamo é a execução de sua Teologia, e ele estava à disposição para vivenciar o agir do Espírito. Sousa afirma: "é importante destacar que a estrutura das EFM reflete a compreensão de Comblin acerca da missão". ${ }^{1017}$ A dimensão desse experimento de Comblin serviu sob medida ao seu exemplo de missão geral do cristianismo. O evangelho que transforma e envolve toda a vida é o que ele ousa. Sousa enfatiza:

Em convergência com esta ideia, Comblin compreende também a vocação leiga missionária na Igreja: o lugar dos leigos é estar no mundo. Por isso a formação deve ajudá-los a atuar no meio das coisas temporais. Trata-se de mudar o mundo pela força do testemunho de vida. ${ }^{1018}$

O mundo está em constante mudança, e a desigualdade e a pobreza continuam a causar desequilíbrio social. Igualmente no período bíblico o pobre continua a fazer parte do desafio, como comenta Sousa: "a finalidade da formação

\footnotetext{
${ }^{1014}$ SOUSA, A. R., Formação de "missionários profetas", p. 75.

${ }^{1015}$ PEREIRA, P. C., Transitando entre diferentes esferas da vida: uma abordagem sobre a multifacetada caminhada de José Comblin II, p. 73.

${ }^{1016}$ CAPPELLETTI, Paulo. Conceito de conversão no pensamento de José Comblin. Paralellus, Recife, v. 9, n. 22, set./dez. 2018, p. 635-651, p. 637.

${ }^{1017}$ SOUSA, A. R., Formação de "missionários profetas", p. 75.

${ }^{1018}$ SOUSA, A. R., Formação de "missionários profetas", p. 76.
} 
dos leigos é atuar no mundo popular (pobre), pois já estão em movimentos ou atividades humanas em geral, naquilo que constitui o mundo". ${ }^{1019}$ Mikuszka destaca: "exercer o ministério pelo poder-serviço é agir na força do Espírito, explicitando ao mundo um novo modo de viver, que consiste em agir valorizando as relações fraternas e solidárias desde o Evangelho". ${ }^{1020}$

Os alunos de Comblin, por vezes, estranhavam a forma como ele conduzia suas aulas. Sua natureza provocadora levava muitos deles a pensar; já outros achavam que ele acabava com tudo, não deixando nada. Sousa lembra:

Agora me vem à lembrança um pequeno artigo que alunos do Instituto de Teologia de Recife (ITER) redigiram nos idos de 1972 acerca da estranheza, causada pelo modo de ser do professor José Comblin. Publicado na Revista Eclesiástica Brasileira (REB) em setembro de 1972 (p. 635-637), intitulado "O Padre José Comblin e a Vida Religiosa". Esse artigo relata as dificuldades que os estudantes demonstram em compreender o jeito do professor. Alguns o acham "negativo e irônico, que ridiculariza tudo, acaba com tudo", mas, por outro lado, todos reconhecem sua simplicidade, sua disponibilidade em orientar as pessoas e sua capacidade em "obrigar a pensar". ${ }^{1021}$

Mas nenhum empreendimento de Comblin tem intenção de causar separação ou propor afastamento da Igreja institucional. O que ele apresenta é uma forma contextualizada de fazer missão. Sousa assegura: "em nenhum momento, essa estrutura supõe o enfrentamento ou separação da Igreja institucional [...]". ${ }^{1022} \mathrm{O}$ conceito e a prática missionária em Comblin ultrapassam o sistema convencional. Ele pensa em uma missão mais participativa concentrada nas mãos do povo e ativa nas relações sociais, pois é nesse ambiente que a vida acontece. Toda a área torna-se causa missionária, como define Sousa:

O autor afirma que o verdadeiro ministério missionário consiste em estar presente onde a Igreja está ausente: nas fábricas, nas prisões, nos sindicatos, entre os políticos, nos meios ou grupos em risco. Há muitos espaços aonde a mensagem do Evangelho não chega, por isso é necessário sair da Igreja, entrar no mundo e tornar posições cristãs nos diversos meios. ${ }^{1023}$

A teologia combliniana inspira-se no conceito paulino de missão, cuja marca, no poder do Espírito, ganhou destaque, assim como as comunidades por

\footnotetext{
1019 SOUSA, A. R., Formação de "missionários profetas", p. 76.

${ }^{1020}$ MIKUSZKA, G. L., O discípulo missionário na perspectiva de José Comblin, p. 39.

${ }^{1021}$ HOORNAERT, E., O tema da transformação no pensamento de José Comblin, p. 31.

1022 SOUSA, A. R., Formação de "missionários profetas", p. 76.

${ }^{1023}$ SOUSA, A. R., Formação de "missionários profetas", p. 77.
} 
ele fundadas. Sousa esclarece: "em suma, Comblin sustenta, em sua prática, a coerência com sua teoria eminentemente paulina de compreensão da missão como testemunho". 1024

Comblin se destaca entre os pensadores por sua forma de interpretar a conversão, pois o convertido é levado a cooperar. Cappelletti afirma:

Diante disso, deve-se afirmar que o pensamento de Comblin sobre a conversão é diferenciado de alguns pensadores, tanto católicos como protestantes. Para ele, a conversão leva ao movimento de cooperação com o necessitado e esse movimento pode ser denominado Reino de Deus. ${ }^{1025}$

O caminho missionário proposto por Comblin entende a anunciação do evangelho como o próprio Cristo. O poder do Espírito em curso é a mesma força que agiu no ato da criação. Esse poder tudo pode recriar e o que foi feito pode ser refeito. Sousa diz: "o testemunho, no pensamento combliniano, é palavra dirigida (com ação impulsionada pelo Espírito) aos homens que estão organizados no mundo compreendido e por isso é transformador à medida que é dado pelas pessoas que se libertaram igualmente das estruturas". ${ }^{1026}$ Comblin está convencido da vivência do proposto em seu tempo, influenciado por inúmeros eventos e mudanças nesse momento contextualizadas. Aguiar afirma:

Ao analisarmos a linguagem de José Comblin enquanto discurso, não podemos deixar de considerar que sua linguagem não é apenas um sistema de signos utilizado para sua comunicação, ela é resultado de sua interação, um modo de produção social, um lugar para manifestação de sua ideologia, não podendo ser avaliada fora do seu contexto, nem de suas condições de produção. ${ }^{1027}$

A atitude prática de sua missão está de acordo com sua concepção teológica, que compreende a importância do ato profético na missão, dado que essa percepção abre possibilidade ao novo, como descreve Aguiar, "tendo definido um sentido para compreensão do profeta, como gerador de inovações no campo religioso [...]". ${ }^{1028}$ Comblin vivenciou muitas mudanças no cenário social e religioso, em duas faces, como teólogo e intelectual, e na simplicidade do povo leigo, acreditando ser esse o caminho da missão no tempo atual e atribuindo a isso

\footnotetext{
${ }^{1024}$ SOUSA, A. R., Formação de "missionários profetas", p. 77.

${ }^{1025}$ CAPPELLETTI, P., Conceito de conversão no pensamento de José Comblin, p. 636.

${ }^{1026}$ SOUSA, A. R., Formação de "missionários profetas", p. 78.

${ }^{1027}$ AGUIAR, Jorge Roberto A. A. José Comblin e os sinais de Deus na profecia. Paralellus, Recife, v. 4, n. 7, p. 7-19, jan./jun. 2013, p. 12

${ }^{1028}$ AGUIAR, J. R. A. A., José Comblin e os sinais de Deus na profecia, p. 12.
} 
uma missão dirigida pelo Espírito. Sousa ressalta: "trata-se, agora, de uma realidade nova à qual não há alusão nos documentos da Igreja do Brasil”. ${ }^{1029}$

A empreitada assumida por Comblin não é nova no cristianismo brasileiro. Os pentecostais já exerciam missão semelhante em boa parte do Brasil. Como já mencionado, o seu intento de idealizar os centros de formação missionária tinham em mente o avanço do pentecostalismo. Entretanto, a prática combliniana, mesmo que incomparável em números com a pentecostal, insere o labor teológico e apurado do doutor dos pobres. Sousa afirma:

Os missionários impulsionados pelo Espírito de Jesus assumem espontaneamente um modo de viver itinerante e começam a evangelizar os pequenos povoados e lugares isolados, reunindo pessoas nas praças e nas ruas. Certamente com permissão eclesial, mas com iniciativa e disponibilidade pessoal, trata-se enfim de uma nova expressão de Igreja itinerante que circula pelos caminhos do mundo. ${ }^{1030}$

A atuação missionária experimentada por Comblin destaca-se por ele ter conseguido manter-se no ambiente da reflexão teológica, mesmo vivendo em pleno campo missionário, ao contrário do que geralmente acontece, quando as reflexões teológicas são dominadas por aqueles que se ocupam do universo acadêmico, como descreve Suess: "sempre aluno e professor, guiado pelo Espírito e a Palavra de Deus, trouxe de cada uma de suas estações biográficas experiências de Deus, enraizadas na vida do povo. Soube transformá-las em experiência teológico-pastoral marcante - a mais notória delas, a "Teologia da Enxada". ${ }^{1031}$

Não se pretende aqui afirmar a prática cobliniana como solução para a missão. Este trabalho entende que, por tratar-se de um teólogo contemporâneo ao crescimento pentecostal no Brasil, Comblin conseguiu extrair significativamente indícios promissores que podem contribuir para uma missão mais contextualizada. Poder-se-ia talvez ariscar que, em certa medida, Comblin também foi influenciado pelo movimento pentecostal. Sousa diz: “de fato, a prática missionária não é nova na Igreja. Pelo contrário, ela encontra a fundamentação de sua vocação na pessoa mesma de Jesus, que é o primeiro missionário itinerante, exemplo seguido por seus discípulos". ${ }^{1032}$

\footnotetext{
${ }^{1029}$ SOUSA, A. R., Formação de "missionários profetas", p. 70.

${ }^{1030}$ SOUSA, A. R., Formação de "missionários profetas", p. 70.

${ }^{1031}$ SUESS, P., Missionário migrante - teólogo militante José Comblin: o retorno do enviado do Pai, p. 78.

${ }^{1032}$ SOUSA, A. R., Formação de "missionários profetas", p. 70.
} 
Como já mencionado, Comblin reúne em si muitas realidades, daí o interesse pentecostal em sua Teologia, embora, para Canova, "possivelmente ele se inspirou na afirmação que sempre fazia dom Helder Câmara de que precisava mudar sempre para ser sempre o mesmo; precisava mudar, renovar, inovar sempre para ser sempre fiel ao compromisso evangélico". ${ }^{1033}$ A boa aceitação de Comblin em relação às novidades estava associada às suas diversas experiências no curso de sua missão, e isso o foi transformando a cada dia. Por isso ele assumiu sua preferência pelo povo pobre, compreendendo essa necessidade na realidade concreta. Não foi uma escolha limitada à investigação teológica, como ele mesmo afirma:

Compreendi melhor a centralidade dos pobres, no cristianismo, num episódio de minha vida. Foi no Equador também. Foi em 1976, quando 17 bispos foram presos, em Riobamba. Havia também umas 40 pessoas: padres, religiosas, leigos e leigas. Entre estes, estava Adolfo Pérez Esquivel, prêmio Nobel da Paz. Eu estava no meio deles. Fomos todos levados por soldados armados de metralhetas até um quartel de Quito e deixados numa sala, sem explicação. No meio da noite, alguns bispos acharam que seria muito bom celebrar a Eucaristia. Mas, como achar pão e vinho? Uma senhora equatoriana foi falar com os soldados e conseguiu convencê-los a trazer um pouco de pão e de vinho. ${ }^{1034}$

Comblin afirma que é impossível aprender em humildade com os pobres, assim como Jesus o fez: "quem não é pobre pode aprender dos pobres, com a condição de ser muito humilde. Jesus viveu a impotência, a fragilidade dos pobres. Para entendê-lo é preciso entrar na mesma condição". ${ }^{1035}$ Nesse testemunho, Comblin mostra que somente a partir da própria vivência do Evangelho pode-se experimentar o que é chorar com os que choram. Ele menciona um bispo que, ao celebrar a Eucaristia, experimentou pela primeira vez o seu sentido real, preso, limitado, impotente. Comblin lembra:

Celebramos a Eucaristia. Ora, nesse mesmo dia, um dos bispos presentes, dom Parra León, bispo de Cumaná, na Venezuela, celebrava seus 50 anos de sacerdócio. Estava tão emocionado que chorava. E disse: "Faz 50 anos que celebro a Eucaristia todos os dias, sem perder nenhum dia. Mas, só agora estou entendendo! Pode-se celebrar a Eucaristia pensando em tudo o que ensinam os teólogos e os liturgistas. Pode-se celebrar com muita piedade e devoção, com muitos sentimentos de amor, mas sem entender. Não se entende a Eucaristia, e de modo geral não se entende Jesus Cristo, a partir da piedade, dos sentimentos religiosos, ou a partir dos

\footnotetext{
${ }^{1033}$ CANOVA, H., José Comblin e a igreja dos pobres, p. 25.

${ }^{1034}$ COMBLIN, J., As estranhas acusações de Clodovis Boff, p. 199.

${ }^{1035}$ COMBLIN, J., As estranhas acusações de Clodovis Boff, p. 200.
} 
conhecimentos teológicos. Tudo isso é secundário e não permite penetrar na realidade. Quando o bispo estava preso (uma prisão ainda bem suave), estava numa situação de impotência, era pobre. Então entendeu. ${ }^{1036}$

A fé que leva a uma vida na força do Espírito é nova, experimentando várias faces da mesma verdade. Mikuszka diz: "refletir assim possibilita uma fé concreta, pois a ação evangelizadora entra em relação direta com o humano, assumindo que Deus age pelas mediações humanas e possibilita afirmar que o Reino de Deus pode ser vivido no mundo desde agora". ${ }^{1037}$ A apresentação do evangelho nessa perspectiva proporciona caminhos alternativos para a missão, mas todos levarão a Cristo no poder do Espírito. Mikuszka afirma: "essa dinâmica aumenta a autoridade da Igreja, pois traduz ao mundo uma diversidade de serviços diferentes e em harmonia". ${ }^{1038}$

A percepção da missão em Combin aponta para a esperança, e ele não é apenas um crítico, mas buscou um futuro melhor para o povo de Deus. Lara afirma: "Comblin é fruto de seu tempo, como cristão católico e, profeta da Igreja, é um homem devotado a alimentar em todos não só a crítica do presente, mas a esperança de um futuro melhor". ${ }^{1039}$ A missão na atualidade tem mais um caminho, que é a prática missionária do povo missionário no poder do Espírito.

\footnotetext{
${ }^{1036}$ COMBLIN, J., As estranhas acusações de Clodovis Boff, p. 199.

${ }^{1037}$ MIKUSZKA, G. L., O discípulo missionário na perspectiva de José Comblin, p. 51.

${ }^{1038}$ MIKUSZKA, G. L., O discípulo missionário na perspectiva de José Comblin, p. 46.

${ }^{1039}$ LARA, V. L., Hermenêutica bíblica para compreender Paulo em Comblin, p. 661.
} 


\section{4 \\ Relações entre os estudos e sugestões pastorais}

Aqui se investigarão as relações entre as partes envolvidas na pesquisa, buscando aproximar os conceitos de missão mediante os textos quadrangulares e comblinianos, edificando um diálogo entre as vertentes, examinando suas diferenças e notando a prática da missão quadrangular à luz da teologia. Essa parte da pesquisa mostrará um esforço de aproximação entre duas vertentes, dados alguns pontos comuns de atuação, como a atuação do Espírito e a participação do leigo. Veremos ainda a centralidade da ação missionária dos quadrangulares aparentemente associada à taumaturgia e à percepção de Comblin. O capítulo retomará a estrutura de ação evangelizadora da Igreja Quadrangular, somando-se a isso os novos conceitos a partir dos estudos dos próprios quadrangulares e de Comblin. Seguem-se sugestões para a ampliação da prática missionária dos quadrangulares por meio dos novos conceitos de missão e de um possível diálogo ecumênico. Por último, serão examinadas as contribuições da tese para a pastoral missionária de todos os cristãos, principalmente os leigos, unindo-se percepções de propostas de reflexão na construção da inserção do leigo e também na recuperação da prática da Cruzada Nacional de Evangelização, de resultados positivos para a missão dos quadrangulares.

\section{1.} Aproximações sobre o conceito de missão

Buscar-se-á aproximar os conceitos de missão dos quadrangulares e de Comblin, empreendendo um possível diálogo, tendo como chaves de aproximação a compreensão, nos textos comblinianos, do termo "missão", visto em relação com o pentecostalismo, e estendendo-se especialmente aos quadrangulares. 


\subsection{1. Pontos em comum no conceito e nos métodos para a missão}

O pentecostalismo estudado nesta pesquisa é conhecido como pentecostalismo clássico, ou até neoclássico, segundo alguns pesquisadores. Embora se reconheça aqui a multiplicidade das ramificações surgidas, estas não cabem no escopo deste trabalho, focado nas denominações nascidas a partir do início do século $\mathrm{XX}$, entre as quais está inserida a Igreja do Evangelho Quadrangular, objeto de estudo deste trabalho. Passos e Rocha ressaltam a dificuldade de mapear o pentecostalismo no Brasil: "inicialmente, é bom que se ressaltem as imensas dificuldades das tentativas de criar uma tipologia do pentecostalismo brasileiro". ${ }^{1040}$ Tal esclarecimento justifica-se pela menção de Comblin às denominações, que protagonizaram a fase inicial e a expansão missionária pentecostal no Brasil até o início dos anos 1950.

Dentro desse recorte encontra-se a Igreja do Evangelho Quadrangular. Comblin destaca: "o movimento pentecostal protestante foi e ainda é muito desprezado e caluniado. Sem dúvida, tal reação se deve ao caráter popular destas comunidades". ${ }^{1041}$ Pouco mais de meio século depois do início do pentecostalismo protestante, o movimento aparece também entre os católicos. Comblin observa: “até 1967, o movimento pentecostal não interessava diretamente aos católicos. Mas justamente em 1967, em distintos lugares dos Estados Unidos, nasceu um pentecostalismo católico. Esse movimento espalhou-se rapidamente em quase todos os países católicos". ${ }^{1042}$ Tal expansão alcançou o Brasil, motivando reflexões por parte de Comblin, como lembra Canova: "Comblin soube articular a grande cultura que ele possuía com a fé e a experiência de vida do Povo Pobre da América Latina. “'Doutor', na Igreja, é aquele que dá visibilidade e sistematiza as experiências de fé do povo cristão". ${ }^{1043}$ De certa forma Comblin tenta sistematizar

\footnotetext{
1040 PASSOS, Mauro; ROCHA, Daniel. Em tempos de pós-pentecostalismo: repensando a contribuição de Paulo Siepierski para o estudo do pentecostalismo brasileiro. Angelus Novus, (3), 261-290, p. 276.

${ }^{1041}$ COMBLIN, José. O Espírito Santo e a libertação. Petrópolis: Vozes, 1987, p. 24.

1042 COMBLIN, José. O Espírito Santo no Mundo. São Paulo: Paulus, 2009, p. 106.

${ }^{1043}$ CANOVA, H., José Comblin e a Igreja dos pobres, p. 22.
} 
a experiência popular. E diz: “em primeiro lugar podemos fazer alguma experiência da liberdade espiritual que é a grande novidade do cristianismo". ${ }^{1044}$

O movimento pentecostal, notável pelo expansionismo, está diretamente associado à experiência pessoal do cristão, inclusive o leigo, que se torna participante da missão do Espírito. Para Amado, “a experiência cristã é, de algum modo, a contínua busca por uma nova linguagem. O anúncio do Ressuscitado impele à comunhão."1045 Assim, pode-se acrescentar atenção à missão pentecostal. Seria ela uma nova linguagem? Comblin questiona: "qual é o significado e o alcance das novas experiências do Espírito Santo na atualidade? De certo modo elas constituem um retorno à Igreja primitiva passando por cima de muitos séculos."1046 As experiências evidentes no pentecostalismo retomam de algum modo as memórias neotestamentárias, destacando o leigo. Segundo Oliveira, “a fé pentecostal reabilitou os leigos por meio da atualidade dos dons espirituais, transformando cada cristão em uma pessoa naturalmente engajada na causa do evangelho". ${ }^{1047}$ Esse apontamento é bastante relevante, por identificar a estrutura que sustenta a missão pentecostal. Comblin destaca a reivindicação do pentecostalismo aos carismas e à sua chave hermenêutica, que estabelecem "continuação ou sequência" ao período neotestamentário. O autor compreende que esses apontamentos transformaram a interpretação da ação missionária nos últimos tempos:

Desde as origens do cristianismo nunca sucedeu uma transformação tão radical no mundo como aquela que está sucedendo agora. Para a Igreja esta transformação haverá de ser mais importante do que a passagem do cristianismo de Israel para as nações, mais importante do que o advento do Constantinismo, mais importante do que as Reformas do século XVI: a transformação atual obriga a ir mais a fundo e contesta muito mais do que tudo o que foi contestado até agora. ${ }^{1048}$

Não há unanimidade quanto a essa declaração, mas experiências cristãs do último século mostram mudanças no cristianismo católico e no protestante, baseadas nestes três fatores: 1) grande adesão popular; 2) necessidade de flexibilização das igrejas históricas; e 3) abertura da possibilidade de diálogo com

\footnotetext{
${ }^{1044}$ COMBLIN, José. A maior esperança. Petrópolis: Vozes, 1974. p. 36.

1045 AMADO, Joel Portella. Leigos na linha de frente? Uma reflexão a respeito do laicato no atual momento evangelizador. ATeo, Rio de Janeiro, v. 20, n. 53, p. 387-416, mai./ago.2016, p. 412. ${ }^{1046}$ COMBLIN, J. O Espírito Santo e a libertação, p. 25.

${ }^{1047}$ OLIVEIRA, David Mesquiati de. Pentecostalidade da Missão Latino-Americana: uma nova reforma na igreja? Revista Reflexus v. 5, n. 6 p. 89-98, (2011), p. 92.

${ }^{1048}$ COMBLIN, J. O Espírito Santo e a libertação, p. 26.
} 
a crescente pluralidade. Comblin acrescenta: "somente o Espírito fará surgir as novas expressões da fé cristã". ${ }^{1049}$ Para Comblim, tal ação do Espírito faz parte do papel do leigo na missão, decisivo no nosso tempo, segundo ele. Mikuszka explica: "introduzir o leigo na ação missionária da Igreja mostra o interesse do nosso autor em valorizar todos os ministérios, para que a prática e o serviço ao povo sejam plurais e diversos." ${ }^{1050} \mathrm{O}$ desafio missionário, na concepção combliniana, portanto, acompanha a marcha do mundo, traçando uma ação missionária correspondente. A diversidade é pautada na ação missionária, mas o desafio da missão na atualidade conclama a colaboração de todos os cristãos. Cardoso defenderia que não se deveria criar novos muros, mas alargar o ecumenismo: "ao contrário, como se poderá notar, de um campo somos convidados a alargar o desejo e a tarefa de ecumenismo". ${ }^{1051}$ Em meio à pluralidade de reflexões sobre o tema, Comblin defende a volta às origens da Igreja, percebendo a experiência do Espírito como a melhor forma de atrair as pessoas a Cristo:

Diante desta situação, vários autores acham que a Igreja precisa voltar às suas origens, ao tempo da experiência do Espírito. Aliás, somente uma experiência vivencial e atual, com fatos concretos, poderá atrair para Cristo os nossos contemporâneos, e mais ainda os seus descendentes. Nem o Deus Criador, nem o Cristo histórico poderão convencê-los. Mais do que nunca podemos, somo S. Paulo, mostrar o Cristo segundo o Espírito, pois o Cristo Segundo a carne não convence, nem chama a atenção. ${ }^{1052}$

Comblin concebe a autonomia do leigo e sua inserção como meios de tornálo parte do sacerdócio: "quanto às Igrejas pentecostais populares, um dos aspectos que lhes dão mais alegria, mais sentimento de liberdade e autonomia, é o fato de terem rejeitado o jugo dos sacerdotes". ${ }^{1053}$ A dinâmica leigo-missão parece propor possibilidades de missão a católicos e pentecostais, numa situação que pode ser ilustrada pelo trânsito do leigo em meio à tensão do mundo igreja, como destaca Amado: "são os (as) leigos(as) que permitem, com o seu vai-e-vem entre o mundo e a Igreja, que a ação missionária não se torne acomodada, monologal, girando em torno de si mesma, afastada da vida de pessoas e povos, numa espécie de idioma

\footnotetext{
${ }^{1049}$ COMBLIN, J. O Espírito Santo e a libertação, p. 26.

${ }^{1050}$ MIKUSZKA, G. L., O Discípulo Missionário na Perspectiva de José Comblin, p. 77.

${ }^{1051}$ CARDOSO, M. T. F. Paulo e o Ecumenismo. Atualidade Teológica Ano XIII, ${ }^{\circ} 32$, maio a agosto / 2009, p. 244.

${ }_{1052}$ COMBLIN, J., O Espírito Santo e a libertação, p. 26.

${ }^{1053}$ COMBLIN, J., O Espírito Santo e a libertação, p. 44.
} 
técnico desconhecido dos interlocutores."1054 Essa autonomia remete à responsabilidade do leigo de responder pela missão, envolvendo todos e provocando maior animação: "agora os leigos podem começar a pensar por si próprios". ${ }^{1055}$ Comblin comprometeu-se com essa nova realidade da Igreja, muito trabalhando para simplificar a formação e a preparação do leigo missionário. Adaptou diversos temas teológicos, tornando-os acessíveis, com uma linguagem menos formal, e estabelecendo assim comunicação com o povo missionário, como explica Canova:

Na realidade, os escritos de Comblin são de fácil acesso para os leigos e as leigas comprometidos/as, missionários/as, animadores de comunidades, padres e religiosas, militantes cristãos e sociais. Comblin traduziu vários temas teológicos em cartilhas, com exemplos da vida e textos bíblicos, para contribuir na formação nas Escolas Missionárias. ${ }^{1056}$

No entendimento combliniano, a palavra tem o poder de envolver quem dela se aproxima, numa via de mão dupla. Enquanto o transmissor missionário anuncia a palavra, também é por ela transformado: "quem descobriu a palavra sente-se empurrado a publicá-la. Vocações missionárias surgem nas comunidades". ${ }^{1057}$ A interpretação combliniana possibilita o diálogo ao pentecostalismo da Igreja do Evangelho Quadrangular, pois sua visão de missão ultrapassa os muros denominacionais. Ele continua: “a Igreja é feita da complementação mútua dos carismas. A comunidade não é uniformidade, mas diversidade organizada, de tal modo que cada um possa exercer o seu carisma, e assim atingir a plenitude da liberdade possível nesta vida." 1058

O encontro com a palavra reside na prática missionária na comunidade, acrescentando a experiência do Espírito, e todos são chamados a anunciar a palavra e vocacionados pelo Espírito a testemunhar: "a experiência da palavra atinge o seu ponto culminante quando o seu receptor se torna um transmissor. A experiência do Espírito é completa no testemunho público". ${ }^{1059}$ A posição do leigo de vivenciar as realidades da Igreja e do mundo faz dele chave para a missão, tornando-o voz missionária que encontra espaço. Amado afirma: "na vivência do

\footnotetext{
${ }^{1054}$ AMADO, J, P., Leigos na linha de frente? , p. 413.

${ }^{1055}$ COMBLIN, J., O Espírito Santo e a libertação, p. 46.

${ }^{1056}$ CANOVA, H. José Comblin e a Igreja dos pobres, p. 30.

${ }^{1057}$ COMBLIN, J., O Espírito Santo e a libertação, p. 46.

1058 COMBLIN, José. Vocação para liberdade. São Paulo: Paulus, 1998, p. 298.

${ }^{1059}$ COMBLIN, J., O Espírito Santo e a libertação, p. 46.
} 
duplo espaço Igreja e mundo, os (as) leigos(as) têm diante de si uma grande riqueza pneumatológica, pois permitem à Igreja falar, se assim se pode dizer, uma língua diferente das cotidianas, porque é a língua da comunhão de vida, a qual, por isso mesmo, é compreensível por todos(as)". ${ }^{1060}$ Agrega-se a isso o fator pneumatológico que caminha junto à missão leiga. Comblin compreende a importância dos fenômenos atuais, mesmo não associados ao tempo bíblico, dada a sua identificação:

Notemos que essa identidade não é necessária ao movimento. Os fenômenos atuais têm que ser julgados pelo que são em si mesmos. Podem valer, ainda que não tenham nada em comum com os fenômenos referidos pelo Novo Testamento. Os líderes, porém, afirmam que há identidade e justificam os fenômenos antes de tudo pela identidade. Deixaremos a questão aberta. ${ }^{1061}$

No entanto, as atuais práticas do pentecostalismo focam as ações nos exemplos do Novo Testamento, destacando os aspectos de maior manifestação do Espírito e dos carismas. Comblin acrescenta: "as comunidades estão redescobrindo a oração. Restituindo a palavra aos leigos e aos pobres, abrem-se para a inspiração de todos os membros". ${ }^{1062}$ A legalização combliniana em favor dessa atuação leiga retoma em parte a história da Igreja, destacando as missões protestantes: "os missionários geralmente foram mais homens práticos do que intelectuais e passaram mais tempo trabalhando materialmente do que ensinando teoricamente". ${ }^{1063}$ Por tratar esta pesquisa da análise da prática missionaria de viés pentecostal protestante, esse conceito de missão que emerge da prática torna-se fundamental.

Buscou-se até aqui aproximar a missão pentecostal da Igreja do Evangelho Quadrangular à percepção combliniana. A partir deste ponto será utilizada, para composição do diálogo com Comblin, a obra de Duffield e Cleave, autores de Fundamentos da teologia pentecostal, que descreve os fundamentos do pentecostalismo e da Igreja do Evangelho Quadrangular, idealizadora da obra referida. Os autores asseguram a importância da experiência do movimento pentecostal, associado a outros movimentos da história da Igreja. Duffield e Cleave dizem:

\footnotetext{
${ }^{1060}$ AMADO, J, P., Leigos na linha de frente? , p. 413.

${ }^{1061}$ COMBLIN, J., O Espírito Santo no Mundo, p. 106.

1062 COMBLIN, J., O Espírito Santo e a libertação, p. 173.

${ }^{1063}$ COMBLIN, J., O Espírito Santo e a libertação, p. 201.
} 
Chegamos agora ao estudo dessa experiência poderosa que foi responsável pelo crescimento milagroso da igreja cristã nos anos apostólicos e pós-apostólicos, tendo sido a causa principal do reavivamento dinâmico que varreu o mundo desde a entrada do século $\mathrm{XX}$ - o maior reavivamento, em termos numéricos, que o mundo já experimentou. ${ }^{1064}$

O pentecostalismo apresentou o cristianismo às massas, pois, celebrando, segundo a tradição pentecostal, um ato contínuo da Igreja do tempo bíblico. Na teologia pentecostal a grande promessa ao mundo é a salvação por meio do Cristo, compreendendo-se, entretanto, que a maior promessa feita à Igreja é o poder do Espírito Santo, como explica Duffield e Cleave: "a maior promessa feita ao mundo inteiro é, naturalmente, esta: '[...] para que todo o que nele crê não pereça, mas tenha a vida eterna' (Jo 3:16); a maior promessa para a igreja é, porém, esta: ‘...mas recebereis poder, ao descer sobre vós o Espírito Santo [...] (At 1:8).". 1065 A teologia pentecostal caminha em paralelo com sua prática, assegurando a atualidade do poder do Espírito em ação, que se propaga pelos multiformes carismas. Para Comblin, "o dom do Espírito Santo e a sua ação em meio aos homens constituem a etapa atual do reino de Deus, o começo da libertação total". 1066

No pentecostalismo quadrangular o batismo com o Espírito Santo, concedido por Jesus Cristo, é que assegura a missão, constituindo uma das quatro doutrinas cardeais da Igreja do Evangelho Quadrangular. Duffield e Cleave destacam:

O batismo com o Espírito Santo é a segunda das quatro verdades fundamentais em que se baseia o Evangelho Quadrangular - Jesus Cristo é quem batiza com o Espírito Santo. Isso tem uma enorme importância com relação à vida espiritual e ao serviço de cada crente. O batismo com o Espírito Santo é o segredo do poder da Igreja. ${ }^{1067}$

É exatamente a experiência do batismo com o Espírito Santo que garante o caminhar e a expansão da Igreja. A interpretação quadrangular proporciona

\footnotetext{
${ }^{1064}$ DUFFIELD, P. G.; CLEAVE, N. M. V., Fundamentos da teologia pentecostal, vol. II, p. 55.

${ }^{1065}$ DUFFIELD, P. G.; CLEAVE, N. M. V., Fundamentos da teologia pentecostal, vol. II, p. 56.

${ }^{1066}$ COMBLIN, José. Breve curso de teologia: o Espírito Santo e sua missão, Tomo II, p. 340.

${ }^{1067}$ DUFFIELD, P. G.; CLEAVE, N. M. V., Fundamentos da teologia pentecostal, vol. II, p. 56.
} 
diálogo com a pneumatologia combliniana nessa fase inicial de aproximação, como esclarece Duffield e Cleave: "a maior necessidade em cada esfera da atividade cristã é que a mensagem da salvação possa ser proclamada com a unção divina, que é a única a assegurar o seu sucesso". ${ }^{1068}$ O pentecostalismo pode ser notado por sua característica litúrgica, com fortes manifestações emotivas durante o culto, mas para Oliveira:

O elemento que distingue o pentecostalismo não é tanto o seu culto emotivo e expressivo, mas sua pneumatologia: o pentecostalismo insiste no batismo com o Espírito Santo como evento posterior à conversão e na atualidade dos dons espirituais (charismata). Por isso em suas reuniões terão um espaço reservado para orar por curas e por avivamento, com amplas manifestações de dons espirituais. ${ }^{1069}$

O pentecostalismo define o batismo com o Espírito Santo como elemento essencial, sem o qual não haveria missão. Esse poder é decisivo na missão pentecostal e a fundamenta, como afirma Duffield e Cleave:

O principal propósito do batismo com o Espírito Santo é que o crente tenha poder para o serviço cristão. É possível que a maior promessa dada ao cristão seja aquela que Jesus fez aos seus discípulos pouco antes de sua ascensão: “[...] mas recebereis poder, ao descer sobre vós o Espírito Santo, e sereis minhas testemunhas tanto em Jerusalém como em toda a Judéia e Samaria, e até aos confins da terra" (At 1:8). Este poder para serviço especial é o resultado específico de ter sido cheio com o Espírito. ${ }^{1070}$

A missão torna-se manifestação de Deus, proporcionada pela revelação de Cristo mediante o Espírito Santo entre o povo de Deus. Duffield e Cleave esclarecem: "Deus agora se manifesta através da revelação de Cristo, feita pelo Espírito Santo, através de canais humanos". ${ }^{1071}$ A completude do batismo com o Espírito Santo diferencia a percepção missionária pentecostal, como afirma Oliveira: "é preciso desejar esse batismo e viver uma vida piedosa. A finalidade é capacitá-lo sobrenaturalmente (Lc 24,49), transformá-lo em testemunha poderosa do evangelho (At 1,8) e unir o corpo de Cristo, derrubando barreiras e preconceitos $(\mathrm{Ef} 4,4)$ "' ${ }^{1072}$ Na percepção pentecostal é impossível um cristianismo sem o poder do Espírito Santo, que capacita o povo de Deus à missão, sendo seu

\footnotetext{
${ }^{1068}$ DUFFIELD, P. G.; CLEAVE, N. M. V., Fundamentos da teologia pentecostal, vol. II, p. 56.

1069 OLIVEIRA, D, M, d. Pentecostalidade da Missão Latino-Americana, p. 93-94.

1070 DUFFIELD, P. G.; CLEAVE, N. M. V., Fundamentos da teologia pentecostal, vol. II, p. 62.

${ }^{1071}$ DUFFIELD, P. G.; CLEAVE, N. M. V., Fundamentos da teologia pentecostal, vol. II, p. 35.

1072 OLIVEIRA, D, M, d., Pentecostalidade da Missão Latino-Americana, p. 94.
} 
autor. Para Barro, "agora é tempo para o Espírito Santo, através dos discípulos e da comunidade, avançar". ${ }^{1073}$

Por isso o movimento pentecostal só pode aceitar um cristianismo que execute as ações do Espírito, como reforça Duffield e Cleave: "qualquer conceito de cristianismo que não possua como padrão de caráter o fruto do Espírito é um conceito falso". ${ }^{1074} \mathrm{O}$ princípio parte do exemplo missionário de Cristo, ungido com o Espírito Santo antes de iniciar o ministério, como lembra Duffield e Cleave: "Jesus foi ungido com o Espírito Santo antes de começar o seu ministério público e Ele realizou suas obras poderosas pelo poder do Espírito. Ele pregou e curou sob a unção do Espírito Santo". ${ }^{1075}$

Os pentecostais percebem que a missão do Cristo é exemplo e a igreja deve dar sequência, almejando uma obra semelhante, no que diz respeito à proclamação do evangelho. Barro afirma: "através do poder e da unção do Espírito Santo, somos chamados para proclamar salvação, libertação, perdão, cura e restauração marcas visíveis do Reino de Deus". ${ }^{1076}$

Os pesquisadores do pentecostalismo conhecem bem esse fato e o reconhecem como tão válido para o período bíblico como para o presente, compondo o caminhar da Igreja onde ela estiver. Por atualizar os carismas bíblicos, a Igreja se associa com Pentecostes, porque, como afirma Duffield e Cleave, "ele não é apenas para os que viveram nos dias dos apóstolos". ${ }^{1077} \mathrm{~A}$ teologia pentecostal compreende a importância da prática missionária como tarefa do povo de Deus, que envolve a todos e não se restringe aos ministros e vocacionados ao serviço missionário, como insiste Duffield e Cleave:

Ele não é simplesmente para os ministros, missionários e aqueles em serviço especial para o Senhor. Se uma verdade é enfatizada no Novo Testamento é a da unidade do Corpo de Cristo e a importância e cada membro para esse Corpo. O apóstolo Paulo, clara e enfaticamente, ensina que nenhum membro é mais importante que outro. ${ }^{1078}$

O destaque do teólogo pentecostal dialoga com a noção combliniana da ação do Espírito: “o Espírito é enviado a uma multidão incontável e age no interior de

\footnotetext{
${ }^{1073}$ BARRO, Jorge Henrique. De cidade em cidade. Londrina: Descoberta, 2006, p. 95.

${ }^{1074}$ DUFFIELD, P. G.; CLEAVE, N. M. V., Fundamentos da teologia pentecostal, vol. II, p. 38.

${ }^{1075}$ DUFFIELD, P. G.; CLEAVE, N. M. V., Fundamentos da teologia pentecostal, vol. II, p. 62.

${ }^{1076}$ BARRO, J, H., De cidade em cidade, p. 54.

${ }^{1077}$ DUFFIELD, P. G.; CLEAVE, N. M. V., Fundamentos da teologia pentecostal, vol. II, p. 66.

${ }^{1078}$ DUFFIELD, P. G.; CLEAVE, N. M. V., Fundamentos da teologia pentecostal, vol. II, p. 67.
} 
uma imensa diversidade de pessoas". ${ }^{1079}$ Comblin considera a importância do fenômeno registrado em Atos, mas acrescenta: "mas ao lado desses aspectos predominantes no primeiro fenômeno de Atos 2, há outros aspectos que se reproduzem nas outras vezes". ${ }^{1080}$ Ele assinala o equilíbrio entre o fenômeno e o compromisso com tudo que envolve a missão da Igreja: "entre os dois polos do presente e do futuro, há lugar para uma grande diversidade de espiritualidades cristãs". ${ }^{1081}$ Pela sua pluralidade, impõe-se o desafio de contextualizar a importância dos carismas. A compreensão da ação dos carismas sobre todo o povo de Deus facilita o entendimento de que todos são vocacionados e participantes da missão, conforme enfatiza Mikuszka:

\begin{abstract}
Assim, assumir que os ministérios provêm dos carismas do Espírito é reconhecer a igualdade e a sacralidade de todos, superando a teoria dos dois gêneros, que tende a separá-los. A condição de igualdade e totalidade dos ministérios condiz com a noção de Igreja como povo de Deus e tende a dignificar todos os cristãos. ${ }^{1082}$
\end{abstract}

A relevância dessa percepção comunga com o caminhar rumo a passos concretos da missão leiga, associada à forte pneumatologia. E tratando-se de missão, é preciso também recorrer a Bosch, autor de Missão transformadora, obra essencial à reflexão que apresenta: "na dispensação do Novo Testamento, o Espírito (à semelhança do sacerdócio) foi dado a todo o povo de Deus, não a indivíduos selecionados". ${ }^{1083}$ Os temas apontados por Bosch condizem com o diálogo católico-pentecostal proposto na pesquisa.

José Comblin refletiu e escreveu acerca de diversos temas, mas delimitamse nesta pesquisa apenas suas obras pneumatológicas e sua teologia da missão, buscando comparar a missão da Igreja do Evangelho Quadrangular com a teologia da missão e do Espírito. A viabilidade da pesquisa pela intimidade entre missão pentecostal e missão do Espírito, como assegura Comblin: “a Igreja é, em primeiro lugar, chamada a agir: chamada a realizar a missão do Espírito Santo". ${ }^{1084}$ A missão do Espírito Santo pode ser comparada à prática missionária exercida pela Igreja do Evangelho Quadrangular. A forma como ela desenvolve

\footnotetext{
${ }^{1079}$ COMBLIN, J. Tempo da ação, p. 29.

${ }^{1080}$ COMBLIN, J. O Espírito Santo no Mundo, p. 109.

${ }^{1081}$ COMBLIN, J. O Espírito Santo no Mundo, p. 99.

${ }^{1082}$ MIKUSZKA, G. L. O Discípulo Missionário na Perspectiva de José Comblin, p. 50.

${ }^{1083}$ BOSCH, David J. Missão transformadora: mudanças de paradigmas na teologia da missão. São Leopoldo, RS: EST, Sinodal, 2002, p. 563.

${ }^{1084}$ COMBLIN, J. O Espírito Santo e a libertação, p. 120.
} 
sua missão está associada a manifestações atribuídas ao Espírito. As doutrinas cardiais da Igreja do Evangelho Quadrangular (Jesus Salva, Batiza no Espírito Santo, Cura e a Segunda vinda de Cristo) podem ser comparadas à teologia do Espírito e da missão de José Comblin.

Esta seção da pesquisa busca comparar a prática teologica da Igreja do Evangelho Quadrangular à teologia de José Comblin quanto à missão e ao Espírito. Por meio das obras pneumatológicas de Comblin, em especial $O$ Espírito Santo no mundo, de 2009, O Espírito e a libertação, de 1987, e Teologia da missão. Essa comparação tem possibilitado dialogar com os escritos da Igreja do Evangelho Quadrangular sobre a missão e peculiaridades da teologia pentecostal.

O termo pentecostal abarca também a Igreja do Evangelho Quadrangular, por esta fazer parte do movimento e da história do pentecostalismo. Por meio desse entendimento cria-se um diálogo com Comblin, que usa o termo pentecostal em seus textos. Souza ressalta: “a preocupação pelo trabalho pastoral é uma das marcas da prática de Comblin, que compreende a teologia a partir de sua destinação". ${ }^{1085}$

A propósito, Comblin destaca: "mas nestes últimos tempos a vitalidade e a expansão missionária das comunidades pentecostais impõem a atenção de todos. Implícita ou explicitamente o dinamismo do movimento pentecostal estimula e provoca todas as Igrejas do Ocidente". ${ }^{1086}$ A previsão de Comblin pode ser confirmada no crescimento do pentecostalismo, como assegura Canova:

\begin{abstract}
Mas, talvez, a maior contribuição que ele deu à nossa caminhada seja o próprio "Método de análise e de trabalho teológico" que ele usava. Este método tinha dois pressupostos essenciais. Em primeiro lugar, Comblin refletia e escrevia sobre o que ele fazia e sobre o que ele via, não sobre o que ele imaginava. ${ }^{1087}$
\end{abstract}

A gênese da teologia combliniana proporciona sua autoridade quanto ao assunto. Entretanto, ainda reside certa lacuna na pesquisa pentecostal, inclusive sobre a Igreja do Evangelho Quadrangular, que não recebeu o mesmo destaque de outras denominações pentecostais. Comblin diz: "por outro lado, até há poucos anos atrás o pentecostalismo evangélico permaneceu socialmente marginalizado [...]. Somente nos últimos anos é que vem sendo estudado com mais simpatia por

\footnotetext{
1085 SOUZA. A. R. A teologia da cidade segundo José Comblin, p. 588.

${ }^{1086}$ COMBLIN, J., O Espírito Santo e a libertação, p.11.

${ }^{1087}$ CANOVA, H., José Comblin e a Igreja dos pobres, p. 26.
} 
alguns católicos ou protestantes das denominações mais "nobres". ${ }^{1088}$ Assim nesta seção já se verifica uma colaboração desta pesquisa para a denominação pentecostal ao, comparando sua missão com a teologia da missão e do Espírito de Comblin, que presenciou o crescimento do pentecostalismo brasileiro no qual se insere a Igreja do Evangelho Quadrangular. Canova explica as credenciais que capacitam Comblin ao diálogo com o pentecostalismo:

Deixou a Academia e optou por uma vida simples e mais perto do povo, para ter condições de repensar a teologia e a tradição de Jesus a partir das comunidades, grupos e militantes das causas sociais. Deixou a cátedra e pegou nas mãos a enxada. No Brasil, Comblin, com o doutorado em teologia na Université Catolique de Louvain, entrou em sintonia com a cultura do povo nordestino e soube articular o saber acadêmico que possuía amplamente com a fé do povo pobre. Ele fez teologia com os pés na realidade, que é sempre cheia de conflitos e desigualdades, de humilhações e injustiças. ${ }^{1089}$

Comblin refletiu sobre a importância do leigo no serviço missionário, "ligada a uma mudança profunda na leitura da Bíblia pelo povo cristão, na oração dos leigos, na vitalidade da comunidade cristã". ${ }^{1090}$ Essa concepção de mudança notada por Comblin, se comparada às calorosas comunidades pentecostais, em que os grupos marginalizados se sentiram acolhidos e irmanados, não revela um primeiro diálogo da teologia e da prática pentecostais com essa noção combliniana de igreja?

A teoria de Comblin parece estar em harmonia com a práxis pentecostal missionária, que vem ganhando destaque, o que faz da temática objeto de um promissor estudo, para o desenvolvimento da pastoral contemporânea, além de ajudar a inserir no contexto a pesquisa sobre a teologia pentecostal da Igreja do Evangelho Quadrangular. Em diálogo com alguns estudos de Comblin, Muggler lembra: "no seu incansável trabalho de formação humana e cristã, padre José Comblin promoveu, cultivou, estimulou centenas de pessoas a se tornarem cidadãos com a marca do evangelho de Jesus Cristo". ${ }^{1091}$ Souza destaca o esforço e o comprometimento com a missão e afirma: “a preocupação pela evangelização

\footnotetext{
${ }^{1088}$ COMBLIN, J., O Espírito Santo e a libertação, p.11.

${ }^{1089}$ CANOVA, H., José Comblin e a Igreja dos pobres, p. 25.

${ }^{1090}$ COMBLIN, J., O Espírito Santo e a libertação, p.23.

${ }^{1091}$ MUGGLER, M. M., Padre José Comblin, 2012, p. 20-21.
} 
das massas foi um dos primeiros temas tratados por Comblin desde sua chegada ao Brasil". 1092

$\mathrm{O}$ crescimento das igrejas pentecostais poderia se mostrar um paradoxo à vida contemporânea, de crescente materialismo, mas o ritmo acelerado do cotidiano teve como efeito a opção pela experiência do sagrado, com o segmento pentecostal figurando como opção, tendo em vista sua flexibilidade e capacidade de adaptação. Afirma Comblin: "as igrejas protestantes históricas sentem-se desorientadas pelo êxito das igrejas de tipo pentecostal". ${ }^{1093}$ O que se vivencia em muitas cidades e ilustra o caminho desenhado na comunicação da missão. Ainda de acordo com Comblin, "sem dúvida alguma, as mensagens pentecostais caem num ambiente bem disposto. É uma mensagem bem inculturada. Além disso, o meio de comunicação usado é aquele mesmo que a estrutura da cidade oferece". ${ }^{1094}$ Os citadinos têm buscado certa aproximação com o elemento místico das igrejas pentecostais.

Para Escobar, "o poder expansionista desse protestantismo popular vem de sua habilidade em mobilizar o povo leigo e adotar formas realmente contextualizadas de culto, vida congregacional e práticas pastorais". ${ }^{1095}$ Além dos desafios que se impõem tanto a católicos quanto a pentecostais no tocante à missão, outra relação se insinua entre as vertentes. Para Costa, "é inegável a influência pentecostal nos grupos carismáticos". ${ }^{1096}$ A subsequência dos movimentos carismáticos atuais ao movimento pentecostal do início do século XX expõem evidentes elementos em comum.

Tanta simplicidade na prática dos seguidores desses modelos tem gerado uma comunicação eficaz. Para Comblin, "muitos se convertem a um movimento carismático porque ali acham algo interessante". ${ }^{1097}$ A maioria dos grupos que provam o crescimento compartilha uma espiritualidade intensa, oposta à vida social em geral, e busca uma grande transcendência da vida presente. Comblin afirma:

\footnotetext{
${ }^{1092}$ SOUZA. A. R. A teologia da cidade segundo José Comblin, p. 570.

${ }^{1093}$ COMBLIN, José. Viver na cidade: pistas para a pastoral urbana. 2. ed. São Paulo: Paulus, 1996, p. 39.

${ }^{1094}$ COMBLIN, J. Viver na cidade, p. 40.

${ }^{1095}$ ESCOBAR, Samuel. Desafios da igreja América Latina: história, estratégia e teologia de missões. Viçosa: Ultimato, 1997, p. 28.

${ }^{1096}$ COSTA, Rovílio. O pentecostalismo e o culto do divino na atualidade. Teocomunicação,

Porto Alegre, v. 37, n. 158, p. 586-600, dez. 2007, p. 597.

${ }^{1097}$ COMBLIN, J. Viver na cidade, p. 41.
} 
O reino de Deus é uma disposição harmoniosa de corpos em movimento ou em repouso. Por isso a Bíblia apresenta-o em forma de cidade. Os últimos profetas anunciaram o advento do Reino numa Jerusalém transfigurada. $\mathrm{O}$ Novo Testamento mostra a plena realização do Reino numa nova Jerusalém, oferecida por Deus como última etapa de todas as tentativas humanas. ${ }^{1098}$

A forte espiritualidade manifestada pelas comunidades pentecostais parece ser característica central de sua missão. A crescente expansão das igrejas pentecostais é alcançada principalmente pela ação e pelo trabalho missionário do povo leigo, que, segundo a tradição pentecostal da missão do Espírito, participa da missão da igreja. Porém essa missão do leigo é limitada, o que se comprova pelo grande número de ramificações do pentecostalismo, que pode levar à perda da identidade das doutrinas que fizeram do movimento pentecostal um dos maiores acontecimentos do cristianismo dos últimos tempos.

Lembre-se que a missão pentecostal da Igreja do Evangelho Quadrangular buscou outras denominações, ao menos em sua fase de instalação no Brasil. E como Mendonça diz, "a cruzada atingiu as igrejas tradicionais, bem como as pentecostais clássicas. Muitos pastores e leigos dessas igrejas, influenciados pela nova prática religiosa, vieram a fundar várias igrejas no mesmo estilo. $\mathrm{Na}$ verdade, a Cruzada Nacional de Evangelização foi a origem dos neopentecostais". 1099

Com a teologia da missão e do Espírito de Comblin, pode-se comparar a missão no pentecostalismo da Igreja do Evangelho Quadrangular à reflexão de missão e de Espírito. Canova destaca: "outro aspecto deste método foi a precisão e a pesquisa sistemática que Comblin usava no seu labor científico e teológico; usava dados precisos, frutos de pesquisas e de informações diretas e de constatações pessoais". ${ }^{1100}$

A missão pentecostal da Igreja do Evangelho Quadrangular, como contribuinte da história e do legado pentecostal, sustenta a pauta dos diálogos entre católicos e pentecostais e ecumênico. Comblin percebeu o crescimento pentecostal no Brasil e na América Latina, assim como o desafio do pentecostalismo ao cristianismo e à teologia, e principalmente à sua missão:

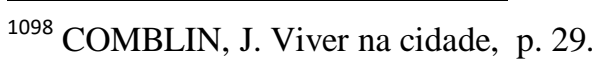

1099 MENDONÇA, Antonio Gouvêa. O protestantismo no Brasil e suas encruzilhadas. Revista USP, São Paulo, n. 67, p. 48-67, set/nov, 2005, p. 61.

${ }^{1100}$ CANOVA, H., José Comblin e a Igreja dos pobres, p. 26.
} 
As Igrejas evangélicas estão passando também por uma renovação da consciência do Espírito Santo. O movimento pentecostal nasceu no protestantismo, já no início deste século. Durante muito tempo não conseguiu influenciar as grandes denominações fixadas na sua tradição própria. Todas se sentem chamadas a retornar às suas próprias tradições sobre o Espírito Santo para revivificá-las. ${ }^{1101}$

O movimento pentecostal chegou ao Brasil discretamente, mas a partir de 1950, quando se destacou grandemente, abrangeu a chegada da Igreja do Evangelho Quadrangular. Pesquisadores atribuem a visibilidade do pentecostalismo brasileiro ao trabalho missionário da IEQ, que iniciou as atividades no Brasil em tendas, com a "Cruzada Nacional de Evangelização", como pontua César: O novo método de evangelização em tendas era uma herança de Aimee McPherson". 1102

Esse fato histórico do pentecostalismo brasileiro tanto alterou a vida cristã protestante das denominações históricas quanto influenciou a inovação e o surgimento de novas igrejas, que perceberam a aceitação do modelo missionário da IEQ. O início da Igreja do Evangelho Quadrangular no Brasil é ecumênico, pelo menos entre os protestantes, como ressalta César: "em pouco tempo, mais de 300 brasileiros foram ordenados para o ministério da Igreja Quadrangular e alguns deles receberam uma tenda de lona e um sistema de alto-falantes para realizar um ministério itinerante". ${ }^{1103}$

Comblin levanta também essa possibilidade em sua obra sobre o Espírito Santo, na qual ressalta: "por sinal, a renovação da fé no Espírito Santo poderia ser o lugar preferencial do ecumenismo". ${ }^{1104}$ A pergunta do autor é importante, pois se pode notar que a Quadrangular busca essa ação em sua gênese no Brasil. César aponta: "Pastores da Igreja Presbiteriana Independente e da Igreja Metodista deram apoio". ${ }^{1105}$ O cenário desenhado por Comblin quanto ao fenômeno pentecostal se parece muito com a história da Igreja do Evangelho Quadrangular no Brasil, mesmo no que se refere à atuação e ao sucesso entre o povo mais simples. Comblin alerta: "católicos e protestantes podem também aprender muito das comunidades pentecostais populares, muito mais pobres, simples e

\footnotetext{
${ }^{1101}$ COMBLIN, J., O Espírito Santo e a libertação, p.11.

${ }^{1102}$ CÉSAR, Elben M. Lenz. História da evangelização do Brasil; dos jesuítas aos neopentecostais. Viçosa: Ultimato, 2000. p.131.

${ }^{1103}$ CÉSAR, E, M. L., História da evangelização do Brasil, p.131.

${ }^{1104}$ COMBLIN, J., O Espírito Santo e a libertação, p.11.

${ }^{1105}$ CÉSAR, E, M. L. História da evangelização do Brasil, p. 131.
} 
espontâneas do que as grandes denominações históricas". ${ }^{1106}$ Seria então essa tese uma contribuição à missão contemporânea? Em meio ao desafio que a pastoral encontra no cotidiano, esta pesquisa aproxima uma experiência pentecostal à teoria de Comblin, saudado por Muggler: "durante 53 anos viveu na América: Chile e Brasil foram suas pátrias, de modo particular, o Nordeste". 1107

A aproximação da noção combliniana de missão e do Espírito com a vivência pentecostal pode ajudar no desenvolvimento de práticas pastorais mais compreensíveis, pois a parte da Igreja que experimenta os desafios missionários da práxis cristã carece de auxílio, como o próprio Comblin destaca: "na América Latina dá-se a experiência do Espírito, muitas vezes sem nome. Ora, um dos papéis da teologia consiste em dar nomes às realidades". ${ }^{1108} \mathrm{O}$ caminho da atual missão cristã passa pela prática pentecostal, que supera de longe as previsões de insucesso das religiões frente ao progresso na sociedade. Cabe, de maneira ecumênica, à Igreja cristã na América Latina, buscar respostas e dialogar com os pentecostais. Canova comenta: "quero acrescentar esta minha convicção; Comblin com sua obra teológica rompeu a barreira do 'acadêmico' separado do 'leigo'; Comblin também não apostou na ruptura polêmica entre intelectuais e pastores na Igreja". 1109

Os dons espirituais não ficam restritos aos pastores, mas todos que fazem parte do corpo podem recebê-los. Macedo diz: "os pentecostais acreditam que podem receber o dom divino da cura através do Espírito Santo. Essa prática não se restringe aos pastores, mas é também manifestada por assistentes, muitos sendo mulheres". ${ }^{110}$ A força da missão pentecostal está diretamente relacionada ao Espírito Santo, base de toda a doutrina pentecostal. Esse ponto é essencial, pois a missão pentecostal é do Espírito, o que inclui seus carismas e um forte desenvolvimento dos dons do Espírito Santo. Comblin alerta: “o mesmo Espírito leva a rejeitar este mundo atual e a trabalhar com todas as energias para modificálo, porque é intolerável". ${ }^{1111}$ Parece haver certa distância entre a prática pentecostal e a vida no mundo, o que cria grande dualismo entre Espírito e

\footnotetext{
${ }^{1106}$ COMBLIN, J. O Espírito Santo e a libertação, p. 12.

${ }^{1107}$ MUGGLER, M. M. Padre José Comblin, 2012, p. 20.

${ }^{1108}$ COMBLIN, J. O Espírito Santo e a libertação, p. 12.

${ }^{1109}$ CANOVA, H. José Comblin e a Igreja dos pobres, p. 30.

${ }_{1110}$ MACEDO, Emiliano Unzer. Pentecostalismo e religiosidade brasileira. Tese de Doutorado, USP. São Paulo, SP, 2007, p. 94.

${ }^{1111}$ COMBLIN, J. O Espírito Santo no mundo, p. 100.
} 
mundo. É preciso ser coerente com os resultados que podem transformar a realidade. Talvez essa seja a contribuição combliniana na investigação, ao ajudar a sistematizar a missão pentecostal da Igreja do Evangelho Quadrangular e da igreja cristã como um todo.

Ao se analisarem os textos de Comblin, em que figuram os termos 'pentecostal' e 'pentecostalismo', compreende-se que tais referências podem abarcar a Igreja do Evangelho Quadrangular, autoidentificada como pentecostal em sua declaração de fé e em seus estatutos: "artigo $1^{\circ}$ - A Igreja do Evangelho Quadrangular é o prosseguimento do movimento cristão pentecostal iniciado nos tempos apostólicos que atravessou os séculos e chegou até nossos dias". ${ }^{112}$ A identificação da Igreja do Evangelho Quadrangular com o movimento pentecostal iniciado no século $\mathrm{XX}$ pode ser notada na prática quadrangular, cujas características são assim descritas por Campos:

Nesses meios enfatizavam-se a necessidade de conversão/novo nascimento; santificação; cura divina; volta de Jesus à Terra para inaugurar o milênio; retorno do Espírito Santo na forma de um "batismo de fogo"; coisas que provocariam sinais físicos, particularmente, o falar em línguas desconhecidas. ${ }^{1113}$

E segue:

Artigo $2^{\circ}$ - O movimento pentecostal, reavivado no início do século XX na Europa e nos Estados Unidos, foi o marco de um novo tempo de avivamento espiritual no mundo e como consequência, nasceu a mensagem Quadrangular sob inspiração Divina em julho de 1922, na cidade de Oakland - Califórnia. ${ }^{114}$

Comblin comenta: "o movimento pentecostal defende a tese de que os fenômenos que ocorrem dentro das suas comunidades (católicas ou protestantes) são idênticos aos fenômenos que Paulo e Lucas mencionam nas primeiras comunidades cristãs". ${ }^{1115}$

Durante a escolha de textos que contribuíssem com esta pesquisa, encontraram-se indícios de que a IEQ buscou dialogar com Comblin, tendo sido

\footnotetext{
${ }^{1112}$ QUADRANGULAR. Estatuto e regimento interno da Igreja do Evangelho Quadrangular, p. 19.

${ }^{1113}$ CAMPOS, Leonildo Silveira. As origens norte-americanas do pentecostalismo brasileiro: observações sobre uma relação ainda pouco avaliada. Revista USP, São Paulo, n. 67, p. 100-115, setembro/novembro 2005, p. 109.

${ }^{1114}$ QUADRANGULAR. Estatuto e regimento interno da Igreja do Evangelho Quadrangular, p. 19.

${ }^{1115}$ COMBLIN, J. O Espírito Santo no mundo, p. 106.
} 
encontradas várias obras desse autor passíveis de embasamento das apostilas do curso preparatório de seus pastores pelo ITQ - Instituto Teológico Quadrangular. Comblin é encontrado em títulos do curso da Igreja do Evangelho Quadrangular, como Introdução à missiologia e Missão integral da igreja. Tais obras estão relacionadas à missão, ou seja, verifica-se um amplo diálogo entre as partes. Canova destaca: "a obra escrita de Comblin é reconhecida pelo Povo Cristão da América Latina como uma referência, um inteligente e precioso aprofundamento e compreensão da fé cristã e do seguimento de Jesus Cristo". 1116

É mesmo possível constatar no material de estudos elaborado pela Igreja do Evangelho Quadrangular algumas poucas referências bibliográficas a Comblin, mencionado quando o assunto em pauta é a missão, como citado em Missão integral da igreja:

Conforme o Censo de 1991, a taxa de urbanização média do Brasil é de $75 \%$. Para o ano de 2000, estaria ao redor de $80 \%$. A população urbana no Brasil em 1960 era 32 milhões. Pelo Censo de 1991 temos cerca de 110 milhões de cidadãos brasileiros habitando nossas cidades. (ZABATIERO, Julio. Um paradigma para a educação teológica. (S.I: S.N), 2000. COMBLIN, José. Viver Nas Cidades. Curso de verão ano VIII, p. 130. $)^{1117}$

Constata-se o recurso a Comblin no material de preparação dos futuros pastores da Igreja do Evangelho Quadrangular quando se trata de discutir a missão. Seu trabalho pode ser encontrado nesse material pela amplitude de sua teologia, como ele próprio afirma: "a missão propriamente dita é obra de reconciliação: saída ao encontro dos povos do mundo para uma reunião universal". ${ }^{1118}$ A obra combliniana no tocante aos demais temas, ela é citada, mesmo que poucas vezes, nas obras que tratam da missão, sobretudo em seus desafios atuais. Ele não é citado com o intuito de verificação teológica da missão, mas do encontro de um caminho missionário capaz de responder ao cenário atual, como em Missão integral da igreja:

Já para Comblin, a cidade é a comunidade de pessoas, ideias, religiões, culturas, modos de viver, profissões, atividades e projetos, partidos e grupos. Cada grupo precisa de atendimento específico. Os desafios a serem vencidos começam a partir das famílias. Os valores precisam ser reforçados, para vencer uma estrutura que

\footnotetext{
${ }^{1116}$ CANOVA, H. José Comblin e a igreja dos pobres, p. 30.

${ }^{1117}$ BEZERRA, C. M. Missão Integral da Igreja, p. 57.

${ }^{1118}$ COMBLIN, José. Teologia da missão. Petrópolis: Vozes, 1983, p. 89.
} 
envolva os jovens, através da mídia e outros veículos de comunicação. Principalmente a educação teológica. ${ }^{1119}$

Os elaboradores das apostilas de formação quadrangular acreditam na contribuição de Comblin nas questões relacionadas ao desafio missionário. A partir dessas informações da obra que acabamos de citar é possível a abertura de um diálogo entre Igreja do Evangelho Quadrangular e o Comblin, o que pode ser feito pelo desafio missionário lançado a todos, daí a necessidade de criação do diálogo a fim de analisar práticas e apontar novos rumos para a missão. Encontrase ainda uma referência a partir da obra Teologia da cidade, de Comblin, muito importante na temática da missão urbana:

No Rio de Janeiro, a quarta parte da população vive em favelas, barracas feitas de madeira e material de segunda mão, em condições precárias e insalubres. E nada mais parecido a um campo de concentração que os imensos arredores de Santiago do Chile, onde se concentra, longe do contato com as zonas burguesas, cerca de um terço dos habitantes da cidade, que conta com mais de dois milhões. Hoje as fábricas são confortáveis e alegres, mas os homens continuam vivendo em casinhas improvisadas. (COMBLIN, José. Teologia da Cidade. São Paulo: Paulinas, 1991, p. $134-135) .{ }^{120}$

Partimos do pressuposto de que o crescimento da Igreja do Evangelho Quadrangular tem a ver com sua missiologia, que atua por meio dos leigos (capilaridade), criando ambientes comunitários e fraternos. Bosch afirma: "as missões católicas sempre tiveram um significativo envolvimento de leigos". ${ }^{1121}$ Na teologia combliniana é decisiva a participação do leigo na missão e ele dedicase a isso, clamando por um avanço teológico que envolva a temática. Ele explica:

São leigos os que pedem uma evolução da teologia. Por eles se busca uma mensagem mais direta, mais clara, melhor explicada; por eles se procura introduzir a luz de Cristo no mundo do pensamento contemporâneo, nas realidades deste mundo, nos seus sonhos e nas suas ambições. ${ }^{1122}$

Se combinarmos isso com a teologia da missão e do Espírito de Comblin, essa reflexão poderá contribuir para uma igreja mais capaz de chegar às pessoas na atualidade. Isso é o que temos procurado apontar neste capítulo. Ao mesmo tempo, é uma contribuição para a missão, atendendo uma preocupação de

\footnotetext{
${ }^{1119}$ BEZERRA, C. M., Missão Integral da Igreja, p. 58.

${ }^{1120}$ BEZERRA, Cícero Manoel. Missão Integral da Igreja. Curitiba: SGEC; Igreja do Evangelho Quadrangular, 2010, p. 32.

${ }_{1121}$ BOSCH, D, J. Missão transformadora, p. 561.

${ }^{1122}$ COMBLIN, José. Teologia da ação. São Paulo: Editora Herder, p. 124.
} 
Comblin, que buscava reformar a teologia dando mais atenção à vivência da fé e à experiência do Espírito:

Uma das grandes mudanças da teologia mundial dos últimos 20 anos foi a reformulação dos seus objetivos e da sua metodologia a partir desta experiência do Espírito pela Igreja. Ao mesmo tempo, a teologia tornou-se mais atenta à vivência da fé das comunidades e menos dedicada aos trabalhos puramente acadêmicos. ${ }^{1123}$

A prática pentecostal missionária da Igreja do Evangelho Quadrangular pode ser comparada à teologia da missão e do Espírito Santo, de Comblin, tendo em vista sua reflexão sobre o agir do Espírito mediante os leigos e a popularidade que essa prática missionária proporcionou ao pentecostalismo. A hipótese desta pesquisa é que, ao citar o movimento pentecostal, Comblin abre espaço ao diálogo entre católicos e pentecostais protestantes. Tal hipótese poderá, ao final da pesquisa, contribuir para uma missão mais animada pelo Espírito.

Que características definem uma Igreja pentecostal? A Igreja do Evangelho Quadrangular faz parte do movimento pentecostal? Que principais características do pentecostalismo clássico aparecem na Igreja do Evangelho Quadrangular? A missão nessa denominação é uma missão do Espírito? O conceito e a prática da missão em Comblin podem ser aplicados aos pentecostais? Como a teologia do Espírito Santo de Comblin pode contribuir para a missão da Igreja do Evangelho Quadrangular e para a pastoral em geral? A vinculação de Comblin à realidade pentecostal torna-se possível a partir de suas obras sobre o Espírito e a missão, como ele alerta: “o que poderá levar os nossos contemporâneos a Cristo, a não ser uma nova experiência forte e convicente? Não serão palavras sobre Cristo, mas apenas realidades vividas e experimentadas, o que nós chamamos uma experiência do Espírito". 1124

A questão central deste texto está em fazer dialogar ecumenicamente parte da teologia pentecostal e a prática missionária da Igreja do Evangelho Quadrangular com parte da teologia sistemático-pastoral católica, de maneira aberta e direta. Cardoso descreve um possível caminho: "assim, cristãos que dialogam são exercitados numa arte de diálogo que os prepara para um diálogo mais amplo, são mesmo impelidos para fazerem crescer seu círculo de relação

${ }_{1124}^{1123}$ COMBLIN, J. O Espírito Santo e a libertação, p. 16.

${ }^{1124}$ COMBLIN, J. O Espírito Santo e a libertação, p. 17. 
fraterna". ${ }^{1125}$ A reflexão teológica, dessa forma, contribui com a missão e o trabalho relevante que a Igreja do Evangelho Quadrangular vem executando no Brasil com sua forma de fazer missão, por meio do leigo. Canova afirma: "ele optou pela Igreja do Povo de Deus e dos Pobres, onde o labor teológico e a inteligência da fé são colocados a serviço da vivência cristã, da formação missionária e das práticas libertadoras dos leigos e das leigas comprometidos com o Reino de Deus". ${ }^{1126}$ A recuperação que o missionário leigo propõe à missão pode ser compreendida na percepção da sensibilidade do tema, como afirma Amado: "por estar no mundo, o(a) leigo(a) conhece as alegrias, as esperanças, as dores e as concretizações deste mesmo mundo. Conhece as estruturas de pensamento e as condições interpretativas". ${ }^{1127}$

Observamos aqui a missão da Igreja do Evangelho Quadrangular pentecostal da Segunda Onda. Não se discutirá a questão dos neopentecostais, grupo muito peculiar e com poucos traços em comum com o grupo em pesquisa. Os chamados "neopentecostais" ou "pós-pentecostalismo", na percepção de Siepierski, distanciaram-se dos pentecostais clássicos ou neoclássicos, como aponta Passos e Rocha: "talvez o pós-pentecostalismo, que, segundo Siepierski, rompeu com sua herança protestante e com o pentecostalismo clássico". ${ }^{1128}$

A análise da questão mostra muito do que foi produzido e pesquisado em torno da temática proposta, mas, como foi dito no capítulo introdutório a contribuição desta pesquisa está em comparar a prática pentecostal da Igreja do Evangelho Quadrangular com parte da teologia sistemática pastoral católica de Comblin, especialmente em relação com a missão. Porém, uma hipótese muito promissora aponta que o crescimento da Igreja do Evangelho Quadrangular está relacionado à atuação direta de seus membros leigos e à sua concepção de missão, de forte espiritualidade, embasada na força do Espírito. Caso essa hipótese inicial se confirme ao final da pesquisa, o resultado contribuirá diretamente com a ação missionária da IEQ, com o pentecostalismo e com os cristãos leigos em geral. Comblin adverte: “a nova época da Igreja estará sob o signo do Espírito Santo e

\footnotetext{
${ }^{1125}$ CARDOSO, M. T. F., Paulo e o Ecumenismo, p. 243.

${ }^{1126}$ CANOVA, H., José Comblin e a Igreja dos pobres, p. 30.

${ }^{1127}$ AMADO, J, P., Leigos na linha de frente? , p. 413.

${ }^{1128}$ PASSOS, M; ROCHA, D. Em tempos de pós-pentecostalismo, p. 277.
} 
terá um aspecto de experiência muito mais acentuado do que tudo o que existiu desde o século II". ${ }^{1129}$

\subsection{2.}

Diferenças principais no conceito e nos métodos para a missão

Em suas previsões Comblin indicava que uma possível crise poderia se instalar no cenário religioso da América Latina, como lembra Souza: "consultado pela primeira vez em 2005 sobre a crise da religião na América Latina, Comblin estava convicto de que esta ainda demoraria 30 a 50 anos para chegar ao continente." ${ }^{1130} \mathrm{O}$ cenário atual tornou-se desafiador e o mundo hoje dispõe de muita informação, o que, longe de gerar solidez, desfez fundamentos antes tidos como inabaláveis, como ressalta Amado: “o que antes servia como explicação já não serve mais. Valores, critérios e fundamentos entram em crise, no sentido mais autêntico da palavra, isto é, necessitam de recompreensão e rearrumação na escala de prioridades."

$\mathrm{O}$ apontamento do autor trata dos desafios às religiões para continuarem se expandindo, mas, quanto aos movimentos pentecostais, Souza destaca: "os movimentos pentecostais e neopentecostais de todas as ondas indicavam que a religião não só não estava em crise, como se encontrava em pleno 'estado de explosão', com o surgimento de novos movimentos religiosos e novas religiões." ${ }^{1132}$ Nessa perspectiva, o movimento pentecostal não fica imune à crise, mas esta se abateria sobre ele em um segundo momento. O que cabe ser levantado aqui é a situação missionária, que a todos abarca. As cidades e as novas configurações de sociedades, bem como a forma como se vive, tornou-se um desafio constante à ação missionária. A Quadrangular concorda com o pensamento comblianiano quanto aos novos desafios, como define Bezerra: "na cidade há variedades de religiões. A cidade vive de novidades. As ações da cidade são formadas por associações com fins limitados. Estes fins são econômicos,

\footnotetext{
${ }^{1129}$ COMBLIN, J. O Espírito Santo e a libertação, p. 36-37.

${ }^{1130}$ SOUZA, A.; ARAGÃO, G. Fazer a Igreja Católica se Mover, p. 686.

1131 AMADO, Joel Portella. Mudança de época e conversão pastoral: uma leitura das conclusões de Aparecida. Atualidade Teológica ano XII n 30, setembro/dezembro 2008, p. 390.

${ }^{1132}$ SOUZA, A.; ARAGÃO, G. Fazer a Igreja Católica se Mover, p. 686.
} 
políticos, sociais, culturais, ecológicos e referem-se à saúde, à segurança, às festas etc." 1133 O diálogo pentecostal com o escritos comblinianos é possível, pois ele, em sua hipótese de estudo, considerava o movimento pentecostal - e seus interlocutores atestam isso -, como comenta Souza:

Segundo Comblin, o século XX foi o do pentecostalismo e do grande movimento de conversão de milhares de cristãos. Esse não foi um movimento unicamente social, mas teológico. O pentecostalismo, na visão de Comblin, tem sua origem em dois elementos: a explosão demográfica que em um século registrou um crescimento de seis milhões de pessoas e, decorrente desta, o movimento migratório campo-cidade." 1134

Percebe-se que a noção combliniana do pentecostalismo considera este como um movimento teológico, que provoca o questionamento do próprio Comblin: "dentro deste contexto, a pergunta que se impõe é a seguinte: Por que os pentecostais fazem tanto sucesso e por que as comunidades católicas não crescem, envelhecem e têm tanta dificuldade para se renovar? Qual é o segredo?". ${ }^{1135}$ Não parece haver um grande plano ou vultoso preparo teológico que justifique o crescimento pentecostal, mas os pesquisadores do pentecostalismo retomam pelo menos uma hipótese, que envolve este trabalho. Segundo Oliveira, são três os princípios que ordenam a missão pentecostal: "percebo a missiologia assentada em três pilares: 1) ministério dos leigos, 2) apocalíptica e, 3) experiências com o Espírito Santo". 1136

Comblin considera, a respeito do sucesso expansionista do pentecostalismo, que a missão necessita de atenção. O que se propôs nesta pesquisa é que a prática missionária pentecostal parece conter elementos capazes de contribuir na elaboração de um caminho para a missão em geral. Comblin continua: "tenho a impressão de que por esta entrada vamos poder entender melhor o que acontece na Igreja católica como conjunto". ${ }^{1137}$ Para isso, é preciso compreender a ação missionária pentecostal e como se projetam suas ações. No pentecostalismo da Quadrangular, quadro desta pesquisa, o trabalho missionário começa a se reestruturar ainda durante a preparação dos pastores. Em seu material sobre

\footnotetext{
${ }^{1133}$ BEZERRA, C. M. Missão Integral da Igreja, p. 58.

${ }^{1134}$ SOUZA, A.; ARAGÃO, G. Fazer a Igreja Católica se Mover, p. 692.

${ }^{1135}$ COMBLIN, J. Olhando para o horizonte, p. 832.

${ }^{1136}$ OLIVEIRA, D, M, d. Pentecostalidade da Missão Latino-Americana, p. 95.

${ }^{1137}$ COMBLIN, J. Olhando para o horizonte, p. 832.
} 
missão integral, a Quadrangular propõe um plano missionário mais contextualizado:

Os convertidos irão fazer diferença em seu convívio social, no trabalho, na escola, em todos os segmentos da sociedade onde tiverem oportunidade. A salvação não se restringe a uma experiência particular. Salvação na verdade é algo tão forte e tão sobrenatural que ao passar pela vida do indivíduo, acaba alcançando todos que fazem parte do seu contexto existencial. ${ }^{1138}$

Nesse momento a missão Quadrangular assume um viés missionário pouco comum no pentecostalismo, a preocupação com o todo que envolve a vida do salvo. A transformação experimentada pelo indivíduo altera tudo que o envolve. Já para interlocutores de Comblin, como Souza, a questão do pentecostalismo passa pela sua atuação missionária, que de certa forma dialoga com os pobres:

Mantido o nível de cultura trazido do campo, os pentecostais oferecem aos pobres o que era próprio de suas referências: uma cosmologia religiosa tradicional (Deus, Satanás, céu, terra e inferno, pecado e castigos divinos, e o problema da salvação como o problema básico da religião). Centram-se na pessoa de Jesus, eliminam os Santos e se emancipam do clero. ${ }^{1139}$

O missionário Comblin buscou estar atento a possíveis rumos da missão, criticando por vezes a ação missionária de sua confissão de fé e acreditando em uma missão em sintonia com a realidade. Green diz: "todos sabem que o principal assunto de Atos é a obra do Espírito Santo, e que ele é o agente supremo na missão cristã. Porém, é exatamente este fator o mais esquecido nos estudos sobre a conversão na igreja primitiva". ${ }^{1140}$ Assim, falta disposição para assumir os riscos. Em um de seus artigos, Comblin compara sua Igreja e os pentecostais, mostrando a necessidade de mudança: "o mundo muda. A Igreja não muda. O eclesiocentrismo afeta todos os níveis da instituição católica, inclusive as comunidades eclesiais de base. Por isso, falta a mística de Jesus e os pentecostais e outras religiões oferecem uma mensagem que atrai mais". ${ }^{1141}$ Os acontecimentos das últimas décadas pedem atenção, importando ressaltar as mudanças na compreensão da missão, como explica Bosch: "durante o último meio século,

\footnotetext{
${ }^{1138}$ BEZERRA, C. M. Missão Integral da Igreja, p.13.

${ }^{1139}$ SOUZA, A.; ARAGÃO, G. Fazer a Igreja Católica se mover, p. 692.

${ }^{1140}$ GREEN, Michael. Evangelização na igreja primitiva. São Paulo: Vida Nova, 2000, p. 184.

${ }^{1141}$ COMBLIN, José. Olhando para o horizonte. Revista Eclesiástica Brasileira, v. 65, n. 260

(2005), p. 831.
} 
aproximadamente, houve uma sutil, porém decisiva mudança no sentido de se entender a missão como missão de Deus". ${ }^{1142}$

Comblin, como teólogo, sempre esteve atento às mudanças, elaborando, a partir de tais observações, suas previsões. Nota-se, em alguns de seus textos, a percepção de que o pentecostalismo respondia à missão: "na Igreja católica não existe o fervor missionário que há nas denominações pentecostais. Tudo isso questiona a pastoral popular". ${ }^{1143}$ A conexão entre o pentecostalismo e Comblin viabiliza-se porque ele presenciou a expansão do movimento e via nele algo que atraía as massas, residindo nessa empatia algo a ser aprendido com as comunidades pentecostais:

Harvey Cox escreveu um dia que o pentecostalismo era o maior fenômeno religioso ocorrido desde a Reforma do século XVI. De fato, ele estimava que pelo menos uns 300 milhões de cristãos aderiram a uma denominação pentecostal e, desde então, o número continuou crescendo. Claro está que o fenômeno é importante e não pode ser descartado como um episódio sem consequiências. Acho que ele veio para ficar. ${ }^{1144}$

$\mathrm{Na}$ visão comblianiana a missão pentecostal avança ao buscar novas maneiras de exercer a prática missionária: "o pentecostalismo questiona toda a estrutura de cristandade, inclusive tudo o que subsistiu da cristandade medieval nas Igrejas ditas históricas, que também são herdeiras desta cristandade". ${ }^{1145} \mathrm{Em}$ comparação com a Igreja católica e as protestantes históricas, o pentecostalismo tem obtido melhor resultado missionário, pois não depende de uma grande estrutura. A dinâmica da missão pentecostal ganha espaço por sua melhor enculturação, como explica Bosch: "a inculturação também possui uma dimensão crítica. A fé e sua expressão cultural - mesmo que não seja possível nem prudente apartar uma da outra - jamais são totalmente coincidentes". ${ }^{1146}$

O tema da inculturação vem se popularizando cada vez mais no que tange à missão, embora toda abertura necessite de limites, como pondera Brasil: "a inculturação requer muito cuidado e limites, do contrário o cristianismo urbano corre o risco de ficar irreconhecível ou sincrético a ponto de não conseguirmos

\footnotetext{
${ }^{1142}$ BOSCH, D, J. Missão transformadora, p. 466.

${ }^{1143}$ COMBLIN, J. Sinais dos Novos Tempo - 40 Anos do Vaticano II, p. 585.

${ }^{1144}$ COMBLIN, J. Sinais dos Novos Tempos, p. 583.

1145 COMBLIN, J. Sinais dos Novos Tempos, p. 583.

${ }^{1146}$ BOSCH, D, J. Missão transformadora, p. 543.
} 
distingui-lo de tantas outras propostas urbanas". ${ }^{1147}$ Não se pretende aqui defender barreiras ou fechar-se, não é essa questão, apenas se frisa que a missão requer diálogo e flexibilidade, contudo sem perda de centralidade e de vocação, conforme Oliveira: "contudo, a inculturação também tem seus limites". ${ }^{1148}$ Isso é vital para o avanço da missão diante de novos desafios. Abrir-se sem perder-se.

Comblin prestigia o agir missionário pentecostal, mas ao mesmo tempo encara o pentecostalismo como desafio: "não tenho a resposta ao desafio pentecostal, mas posso trazer alguns elementos de reflexão". ${ }^{1149}$ Ele reconheceu não ter concluído seu pensamento sobre o pentecostalismo, mas levantou questões em torno da missão pentecostal.

Já foi comentado nesta pesquisa que a opção pelo diálogo entre Comblin e a Quadrangular se dá justamente pela sua atenção ao curso da missão e a suas novas perspectivas, e sua mensagem permanece adequada ao contexto presente, como afirma Tracco: "as palavras do Pe. José Comblin, proferidas há mais de 40 anos, permanecem atuais [...]". ${ }^{1150}$ As mudanças pelas quais passou na vida missionária parecem ter deixado alguma frustação, como comenta Tracco: "a utopia se desvaneceu, os pobres voltam para os seus lugares, fora das prioridades espirituais e temporais da sociedade e da Igreja e os leigos, clericalizados, são subservientes ao clero". ${ }^{1151}$ Por outro lado existe também as atuações leigas inclusive das missões que não são clericalizadas. Elas são importantes no contesto da missão.

Por isso Comblin interessou-se pelo percurso da missão pentecostal, utilizando, para tanto, a estrutura de aproximação para tentar expor o que a diferenciava tanto e o que a fazia crescer: "alguns fatos podem explicar em parte o fenômeno. Primeiro, os pentecostais estão presentes nas massas, enquanto a Igreja católica tem uma presença muito fraca nelas". ${ }^{1152}$ Lançar-se na missão talvez seja a expressão que melhor represente o desprendimento assumido por aquele que encarna tal estilo de vida. Ele continua: "os missionários procedem de uma comunidade mais ou menos fechada, ultrapassam as fronteiras para enfrentarem o

\footnotetext{
${ }^{1147}$ BRASIL, Jefferson Grijo. Missão e Urbanização no Século 21: o desafio missionário na cidade. São Paulo: Fonte Editorial, 2016, p. 35.

${ }^{1148}$ OLIVEIRA, David Mesquiati de. A Dimensão Comunicativa da Ação Missionária e as

Culturas. Revista Reflexus v. 3, n. 3 (2009), p. 85.

${ }^{1149}$ COMBLIN, J. Sinais dos Novos Tempos, p. 583.

${ }^{1150}$ TRACCO, Celso Luiz. As CEBs em Aparecida. A retomada de um modelo de evangelização? Revista de Cultura Teológica, Ano XXII n. 84 Jul/Dez 2014, p. 48.

${ }^{1151}$ TRACCO, C, L. As CEBs em Aparecida, p. 38.

${ }^{1152}$ COMBLIN, J. Sinais dos Novos Tempo, p. 585.
} 
risco de um encontro ainda desconhecido". ${ }^{1153}$ A individualidade não pode resultar em missão eficaz, a comunidade é a essência de qualquer missão, como lembra Bosch: "pois é a comunidade que é o portador primordial da missão". ${ }^{1154}$ Comunidade e missão, portanto, caminham em parceria.

Comblin atribui à forte presença o sucesso do pentecostalismo e de sua maneira de agir. Segundo ele, a dinâmica pentecostal sempre acompanha os novos rumos da sociedade e da cultura, ou seja, de certa forma o pentecostalismo, por ser fragmentado, é fortemente plural:

Os pentecostais reagem imediatamente, quando se abre um conjunto habitacional novo, uma vila nova. A Igreja católica reage muito mais tarde, com um ritmo de burocracia. No distrito Marcos Moura, vizinho meu, há uns 5.000 habitantes, todos pobres e muito pobres, gente que teve de sair do campo, recentemente. Ali há 84 capelas pentecostais e 3 comunidades católicas. Notemos que esta é uma boa paróquia: é excepcional que haja 3 comunidades católicas num distrito como este. Assim mesmo, chegaram 84 pastores em poucos meses. ${ }^{1155}$

O exemplo apontado pelo autor destaca sua própria percepção da prática pentecostal e sua dinâmica missionária. Por isso Aguiar afirma: "é notório, na produção de José Comblin, que ele se colocou no lugar das vítimas, optou pela ótica dos rejeitados e excluídos, e se revestiu de suas energias para fazer parte do movimento real que superasse o estado das coisas existente". ${ }^{1156}$ Nota-se que o estilo de vida do missionário Comblin vai ao encontro das novas perspectivas missionárias da Igreja Quadrangular, que prestigia a missão integral. Aguiar continua: "ele estava convencido de que o povo possuía inteligência, um ponto de vista proveniente das suas necessidades elementares". ${ }^{1157}$ Para comentadores de Comblin, a exemplo de Souza, a ação missionária é fruto da força libertadora, que proporciona vida em dignidade e justiça. Assim, os missionários precisam ser voz profética, como esclarece Souza:

Segundo nosso autor, o que o Cristianismo oferece é a libertação da humanidade e não uma concepção de vida, uma doutrina fechada em si mesma. Ele oferece a possibilidade de que homens e mulheres, reunidos em comunidade e motivados pelo Evangelho, estabeleçam ações de fraternidade capazes de transformar o mundo, em si mesmos, de forma a construir o respeito e a dignidade humanos. A

\footnotetext{
${ }^{1153}$ COMBLIN, J. Teologia da missão, p. 89.

${ }^{1154}$ BOSCH, D, J. Missão transformadora, p. 563.

${ }^{1155}$ COMBLIN, J. Sinais dos Novos Tempo, p. 585.

${ }^{1156}$ AGUIAR, J. R. d. A. José Comblin, p. 20.

${ }^{1157}$ AGUIAR, J. R. d. A. José Comblin, p. 20.
} 
ação libertadora das comunidades cristãs em meio ao mundo é a contribuição dos cristãos e a maneira como Jesus permanece presente e se multiplica em todo o mundo. ${ }^{1158}$

A Quadrangular compartilha da visão crítica ao estilo de Comblin. Se, por um lado, o teólogo católico convida a repensar a missão, a Quadrangular, por sua vez, vê a necessidade urgente de atualizar a ação missionária no pentecostalismo, como considera Bezerra: "a comunidade evangélica, com raríssimas exceções, está alienada, com as portas trancadas. Quando analisamos a proposta evangélica para a atualidade, nos assustamos". ${ }^{1159}$ Talvez esse seja um dos grandes desafios a ser superado pelo pentecostalismo, o dos exageros na atuação de suas vertentes mais fechadas. Oliveira alerta: "o evangelho é transmitido através da cultura e as muitas situações culturais na vida da Igreja Primitiva não deveriam ser tomadas como modelos fechados para a igreja". ${ }^{1160}$ Comblin e a Quadrangular posicionamse criticamente frente à questão missionária da matriz em que se inserem. Esse ponto pode unir ambas as vertentes do cristianismo em um desafio comum, que recai sobre a cristandade em geral: o desafio da missão. Parte da experiência de Comblin se deu nas comunidades eclesiais de base como ele próprio relata:

Faz 43 anos que estou participando das chamadas comunidades eclesiais de base. Fui primeiro no Chile, nos anos 1962-1965 e nas poblaciones callampas da zona Sul de Santiago, sobretudo na población La Légua, que era famosa porque tinha a reputação de ser a cova em que se refugiavam os delinquentes da cidade. La Légua foi também famosa porque ali foram párocos alguns dos melhores sacerdotes do Chile: Rafael Maroto, Fernando Ariztia (mais tarde bispo e presidente da conferência episcopal), Mariano Puga e outros. Estes nomes gozam do maior prestígio em Santiago, embora todos tenham um pouco o rótulo de esquerdistas. Mesmo assim, são sumamente respeitados por todos. ${ }^{1161}$

A Quadrangular continua sua crítica ao modelo missionário praticado na maioria do seguimento pentecostal, numa postura importante, pois a missão precisa descobrir novos caminhos e o passo mais importante passa pelo próprio reconhecimento. A partir disso se podem criar alternativas que ultrapassem os limites do templo. Como define Bezerra:

Os projetos são "cultualistas" (tudo gira em torno do culto; se a igreja está cheia aos domingos, os pastores se dão por satisfeitos); "ritualistas" (nos conformamos

\footnotetext{
${ }^{1158}$ SOUZA. A. R. A teologia da cidade segundo José Comblin, p. 569.

${ }^{1159}$ BEZERRA, C. M. Missão Integral da Igreja, p. 59.

${ }^{1160}$ OLIVEIRA, D, M, d. A Dimensão Comunicativa da Ação Missionária e as Culturas, p. 82.

${ }^{1161}$ COMBLIN, J. Olhando para o horizonte, p. 832.
} 
com o 'ritual', e não enfatizamos a reflexão nem a prática da Palavra de Deus). Construímos um muro altíssimo, às vezes intransponível, entre a igreja e aqueles que precisam de Jesus. ${ }^{1162}$

A pesquisa reúne aqui a prática missionária de Comblin com as propostas da Igreja Quadrangular, daí a importância de colher, na experiência do autor, momentos de prática da dimensão do desafio que a missão tem por diante. Em um desses momentos ele diz:

Depois disso, conheci as comunidades do Encontro de Irmãos, no Recife, sobretudo em Ponte dos Carvalhos, onde Geraldo Leite era vigário, um artista, poeta, de grande dinamismo, que deixou várias canções nos cancioneiros litúrgicos do Brasil inteiro. Morreu prematuramente de câncer aos 50 anos. Ao mesmo tempo eu acompanhava as comunidades rurais da "teologia da enxada", no interior de Pernambuco e da Paraíba. Depois da expulsão do Brasil em 1972, voltei para o Chile, desta vez no interior, em Talca. Era tempo de regime militar e as comunidades eram constantemente vigiadas. Já não se atreviam a sair das atividades propriamente religiosas. No entanto, aí começou uma formação de dirigentes de comunidades que não tem correspondente na América do Sul, graças ao carisma do padre Enrique Correa, falecido também prematuramente de câncer aos 60 anos. $^{1163}$

Ao reunir as propostas missionárias dessas duas vertentes aqui analisadas, espera-se um somatório da missão em geral. A questão aplica-se à pastoral em geral, pois os desafios sempre se apresentaram, como afirma Barro: "a fé manifesta-se verdadeira na prática da misericórdia. Sempre haverá desafios suficientes para exercitá-la a partir da realidade de onde vivemos". ${ }^{1164}$ Não se pretende fazer de toda situação missionária um protótipo bíblico, pois a manifestação ou configuração da fé representa um desafio à missão, como esclarece Oliveira: "não se trata de fazer aplicações diretas e literais sobre o pretexto de fidelidade bíblica. A própria natureza ocidental da fé cristã é um desafio na teologia da missão". 1165

A Quadrangular percebe a necessidade de uma pastoral que envolva a renúncia, assim como foi a prática missionária do autor, que, mesmo sendo teórico, manteve os pés no chão da missão. A Quadrangular concorda com Comblin quanto a uma pastoral de renúncia, como afirma Bezerra: "também

\footnotetext{
${ }^{1162}$ BEZERRA, C. M. Missão Integral da Igreja, p. 59-60.

${ }^{1163}$ COMBLIN, J. Olhando para o horizonte, p. 832.

${ }^{1164}$ BARRO, J, H., De cidade em cidade, p. 26.

${ }^{1165}$ OLIVEIRA, D, M, d. A dimensão comunicativa da ação missionária e as culturas, p. 82.
} 
precisamos de uma pastoral de renúncia”. ${ }^{1166}$ Comblin, durante seu trajeto, passou muitos anos no Nordeste, dedicando-se à proposição de alternativas missionárias. Retornou ao Brasil, pôs-se a preparar leigos para contribuírem com a prática missionária, como ele próprio lembra:

De volta no Brasil em 1980, com um grupo de ex-alunos, fundamos algumas instituições de formação missionária, todas orientadas para as comunidades populares, com extensão em quase todos os Estados do Nordeste. Foram 25 anos dedicados sobretudo à formação de animadores em diversos níveis e ao acompanhamento das comunidades, através de diversos métodos. ${ }^{1167}$

A pauta para a missão quadrangular passa pela reestruturação do conceito de missão, valendo destacar que a atual prática missionária da Igreja Quadrangular não é a mesma do seu início no Brasil. As campanhas continuam, mas no interior de templos, e não mais em tendas itinerantes. Essa mudança é alvo de críticas, o que se constata no próprio material de preparação dos pastores, como argumenta Bezerra:

Precisamos desenvolver uma pastoral comunitária, pois os pastores e os líderes cristãos se tornaram gerentes e executivos de igrejas, se esquecendo de sua função principal. Nos gabinetes, eles tentam resolver os problemas numa perspectiva clínica e gerencial. Não seguem o estilo de vida praticado e ensinado pelo apóstolo Paulo, onde se exalta a pessoa de Cristo, anulando a si mesmo. ${ }^{168}$

Foram-lhe incorporados novos elementos e isso tem levado a uma compreensão mais ampla e responsável do mundo e da vida, como propõe Sanches: "a Igreja não é uma entidade isolada do mundo, mas ela o integra e participa direta ou indiretamente da sua transformação". ${ }^{1169}$ Nessa perspectiva, busca-se adotar o sentido das primeiras comunidades cristãs, resgatando princípios que acompanham o kerygma, como aponta René: “o que aconteceu nestes últimos anos foi na verdade uma recuperação da perspectiva bíblica segundo a qual não basta falar do amor de Deus em Cristo Jesus: é preciso vivê-lo e demonstrá-lo em termos de serviço. O kerygma é inseparável tanto da diakonia como da koinonia". 1170

\footnotetext{
${ }^{1166}$ BEZERRA, C. M. Missão integral da igreja, p. 60.

${ }^{1167}$ COMBLIN, J. Olhando para o horizonte, p. 832-833.

${ }^{1168}$ BEZERRA, C. M. Missão integral da igreja, p. 60.

${ }^{1169}$ FERNANDES SANCHES, Regina. Teologia da missão integral. São Paulo: Reflexão, 2009, p. 145.

${ }^{1170}$ C. RENÉ, Padilla. O que é missão integral? Viçosa, MG: Ultimato, 2009, p. 53.
} 
Reconhecer que a nova forma de vida tornou-se um grande desafio à missão é o primeiro passo rumo à sua atualização e suscita sugestões à prática missionária. Como já dito, a Igreja do Evangelho Quadrangular começa uma nova postura ao reconhecer sua limitação no campo da missão. O mesmo faz Comblin ao expor sua experiência, sendo importante aqui ressaltar que tal crítica não se dirige à Igreja Católica, como é bem comum em seus textos, mas às experiências missionárias das comunidades eclesiais de base, projeto no qual ele muito acreditava como caminho necessário à missão. Por isso essa crítica combliniana é tão relevante, dada a sua referência à missão em que ele acreditava e ao reconhecimento das limitações dessa missão:

Muitas comunidades tinham um grande dinamismo. No entanto, havia algo um pouco estranho, que para mim era um problema. Na grande maioria, os animadores eram e ainda são pessoas que vêm do catolicismo tradicional, do velho fundo religioso rural, com todas as virtudes vividas no meio da cultura rural durante muitas gerações. As comunidades recolheram os melhores elementos do catolicismo tradicional. Mas elas não fazem muitas conversões, nem conseguem atingir muito as pessoas que já se tinham distanciado da religião tradicional ou tinham apenas com elas contatos superficiais. Por que será? ${ }^{171}$

Seus apontamentos mostram as falhas desse modelo, e um deles é o baixo número de conversões. Comblin está, dessa forma, em busca de novos caminhos para a missão. Já no caso do pentecostalismo, um problema diagnosticado pela Quadrangular é a necessidade de pessoas carismáticas que conduzam grandes eventos. Para a Quadrangular, a dificuldade disso tem como consequência a impossibilidade de reprodução dessa ação por todo o povo na prática, como esclarece Bezerra:

A verdade perturbadora sobre os modelos pastorais contemporâneos é que, em grande parte, eles não podem ser reproduzidos. Os homens apresentados nas conferências como aqueles aos quais vale a pena ouvir são pessoas carismáticas, servos altamente dotados (eu lhes desejo bem!). Contudo seus talentos são naturais e singulares. Seus dons e sua personalidade não podem ser empacotados, colocados numa caixa, embrulhados para presente e entregues. ${ }^{1172}$

Pode-se ver que a tensão em torno da missão envolve tanto católicos como pentecostais, e ambos buscam de alguma forma dar respostas úteis à missão. Brasil aponta: "são muitos os desafios impostos a esta geração de acesso a tantas

\footnotetext{
${ }^{1171}$ COMBLIN, J. Olhando para o horizonte, p. 833.
}

1172 BEZERRA, C. M. Missão integral da igreja, p. 61. 
informações simultâneas. Como ela será atraída a uma proposta da fé cristã? Tal é o diagnóstico que temos nas mãos". ${ }^{1173} \mathrm{O}$ desafio ao cristianismo em geral é inédito, e a questão vai além da diversidade religiosa, passando pelo questionamento quanto ao significado de religião ou de fé. Ou como viver a experiência cristã. $\mathrm{O}$ sentido de estar em missão tem atravessado rápidas transformações e fluidez, como alerta Amado:

Vivemos num tempo de pluralismo, em que circulam inúmeras formas de compreender a realidade, tanto em nível sociocultural quanto em nível pessoal. Vários são os caminhos. Neste contexto, o ser humano se torna fragmentado nos critérios de enfrentamento da realidade. ${ }^{1174}$

Comblin continua a apontar as limitações do modelo missionário das comunidades eclesiais de base às quais ele se dedicou. Em sua avaliação ele notava que esse modelo ainda não estava completo, algo faltava:

\begin{abstract}
Além disso, neste percurso todo, sempre fiquei com uma certa impressão de malestar. Mal-estar é uma palavra forte demais. Uma impressão de que alguma coisa faltava. Havia muitas pessoas vivendo em verdadeira santidade, pessoas dedicadas, sacrificadas, capazes de amor e de serviço ao próximo, pessoas que, com certeza, existiam "virtualmente" antes de existirem as comunidades, que se encontravam "virtualmente" nelas, mas que encontraram nelas uma oportunidade para produzir muitos frutos. 1175
\end{abstract}

A percepção de Comblin mostra que a missão precisa seguir uma agenda do Espírito, ou seja, uma concepção missionária que priorize a experiência pneumatológica. Para ele, a teologia não deu a devida atenção à questão pneumatológica, e somente nos últimos tempos verificou-se esse despertar. A Quadrangular parecer fazer o caminho inverso, por já contar, na prática, com a experiência do Espírito como base de sua missão, e tentando agora trazer sua missão para ações concretas, e tal é o alerta de Bezerra: “a pastoral precisa ser genuína. Ela é construída a partir do serviço e da comunhão com Deus. No lugar comum da existência humana, o cotidiano passa a ser 'educativo' (aprender com as atividades do dia a dia)". ${ }^{1176}$

O mapeamento de Comblin parece aproximar-se da missão de cunho pentecostal. Caso isso se confirme, caberia perguntar se a missão de tradição

\footnotetext{
${ }^{1173}$ BRASIL, J, G. Missão e urbanização no século 21, p. 54.

${ }^{1174}$ AMADO, J, P. Mudança de época e conversão pastoral, p. 306.

${ }^{1175}$ COMBLIN, J. Olhando para o horizonte, p. 833.

${ }^{1176}$ BEZERRA, C. M., Missão integral da igreja, p. 61.
} 
católica aqui representada por Comblin demostra que a prática missionária carece de foco em uma missão do Espírito. Por sua vez, a missão quadrangular levanta questões que apontam falta de ações concretas. Ações nas quais Comblin sempre esteve engajado, como sua missão libertadora, que conclama à transformação da realidade. A pergunta que se impõe é: por que não juntar ambas? A proposta resultante reuniria o conceito buscado por ambas as vertentes, eliminando a atual lacuna. Macedo diz: "a integração social oferecida por denominações pentecostais nas periferias urbanas certamente explica consideravelmente o crescimento pentecostal no Brasil". ${ }^{1177}$

É verdade que no interior do próprio pentecostalismo convivem evolução e retrocesso, caracterizados pela diversidade estrutural. Passos e Rocha dizem: "trata-se de um fenômeno extremamente dinâmico e em constante mutação. Novas doutrinas e ênfases teológicas surgem a cada momento, dificultando uma análise que leve em conta apenas aspectos teológicos para se categorizar as diferentes igrejas pentecostais". ${ }^{1178}$

A chave hermenêutica que conduz à pratica do pentecostalismo intriga Comblin, que vê o processo como simples experiência de vida em comunhão: "por outro lado, há o seguinte fato tantas vezes observado: Se se pergunta a um crente por que virou crente, ele ou ela responde: 'Porque agora descobri Jesus, conheço Jesus e leio a Bíblia". ${ }^{1179}$ Esse envolvimento que faz do crente participante talvez seja parte do progresso da missão pentecostal, que o posiciona como missionário ativo. A Quadrangular, por sua vez, insiste em que a pastoral também faça a diferença na comunidade onde cumpre sua missão, como sintetiza Bezerra: "precisamos de uma pastoral que faça diferença na comunidade em que estiver inserida". ${ }^{1180}$ Missão e comunidade constituem a mesma realidade, uma completando a outra, ecoando o que diz René: "nesta era de individualismo, é preciso recuperar esta perspectiva comunitária e missiológica". ${ }^{1181}$ Nota-se que a popularidade do pentecostalismo se dá mediante sua missiologia atual, por meio do leigo, e nesse entendimento todo cristão é vocacionado à missão. Oliveira

\footnotetext{
${ }^{1177}$ MACEDO, E, U. Pentecostalismo e religiosidade brasileira, p. 98.

${ }^{1178}$ PASSOS, M; ROCHA, D. Em tempos de pós-pentecostalismo, p. 276.

${ }^{1179}$ COMBLIN, J. Olhando para o horizonte, p. 834.

${ }^{1180}$ BEZERRA, C. M. Missão integral da igreja, p. 61.

${ }^{1181}$ C. RENÉ, P. O que é missão integral?, p. 57.
} 
destaca: "o crescimento vertiginoso no século passado aponta para essa flexibilidade, nova linguagem e resposta atualizada da fé cristã". ${ }^{182}$

Repensar a missão tem se tornado um desafio constante ao cristianismo em geral. Cada segmento tem buscado alternativas que deem voz à missão na atualidade, e são muitos os esforços em prol dessa agenda. Comblin aponta que uma das lacunas desse modelo talvez seja a ausência de uma postura mais mística, como esclarece:

Isto que sucede a nível de comunidades de base - a ausência de uma verdadeira mística de Jesus - não estaria caracterizando a Igreja católica em todos os seus níveis? Não posso negar que, em todos os níveis, há místicos que, evidentemente, não vivem dessa maneira. ${ }^{1183}$

No âmbito quadrangular a questão também passa pela formação, já que as igrejas de linha histórica proporcionam formação teológica mais completa, algo ainda incomum no pentecostalismo em geral, o que alça o leigo a uma posição de destaque, como afirma Bezerra: "algumas destas Igrejas exigem uma formação teológica muito completa de seus líderes, particularmente denominações de cunho histórico. Mas em outras, que no geral são igrejas novas, as quais têm sido aninhadas por pessoas leigas, a formação teológica é limitada". ${ }^{1184}$

Diferenciam-se o conceito e a prática de missão entre a Igreja Quadrangular e Comblin, mas percebem-se pontos em comum. Um desses pontos é a identificação do êxito e do fracasso em ambos os lados. Para Comblin, "a suspeita é a seguinte: Os católicos têm por objeto religioso central a Igreja. O seu interesse é a Igreja. Todas as atividades tendem a reforçar essa presença da Igreja. O proselitismo católico procura expandir a Igreja, aumentar o número de fiéis da Igreja, dar mais vida à Igreja". ${ }^{1185}$ No conceito de missão pentecostal, o processo de mudança de vida pelo qual passa o converso o prepara para uma vida posterior, entretanto essa vida começa aqui, e eis aí certa aproximação com o ponto de vista de Comblin, expresso há pouco. Afinal, o converso também é alvo da igreja e representa sua expansão, tanto no catolicismo quanto no pentecostalismo.

A autoanálise da Igreja Quadrangular mostrou que sua ação missionária não atinge o mesmo êxito em todas as camadas da sociedade, como assegura Bezerra:

\footnotetext{
1182 OLIVEIRA, D, M, d. Pentecostalidade da missão latino-americana, p. 91.

${ }^{1183}$ COMBLIN, J. Olhando para o horizonte, p. 834.

${ }^{1184}$ BEZERRA, C. M. Missão integral da igreja, p. 65.

${ }^{1185}$ COMBLIN, J. Olhando para o horizonte, p. 835.
} 
"a maioria das igrejas urbanas evangélicas é de classe média baixa ou popular". ${ }^{1186}$ Não somente os membros da Quadrangular, mas também das demais denominações pentecostais clássicas, em grande parte, compõem essa parcela da população, como afirma Oliveira: "o pentecostalismo mostrou-se um corpo includente e foi favorecido pela crescente urbanização". ${ }^{1187}$ Esse cenário que sustenta o pentecostalismo brasileiro suscita novas teologias a partir realidade, de modo que já não é mais o pentecostalismo que absorve as novas realidades, mas é ele próprio absorvido pela conjuntura. González diz: "a teologia surge do cotidiano de milhões de cristãos que vivem sua fé em relação à pobreza, a outras tradições religiosas, à violência, à guerra, à incerteza, à falta de serviços de saúde e a outros males relacionados com o processo de globalização econômica". ${ }^{1188}$ Esse modelo de igreja, assim, exerce papel significativo na sociedade, como afirma Kirk: "as novas igrejas agem como famílias substitutas, dando um sentimento de pertença e um forte sentido de dignidade para a pessoa que, ao contrário, tem tido uma vida degradante". ${ }^{1189}$

Essa afirmação é relevante, se considerar que a missão precisa alcançar a todos. Qual seria a causa disso? Seguindo as pistas passíveis de responder a essa indagação, a Quadrangular compreende tal comportamento pode estar relacionado ao tipo de formação teológica e à dupla jornada da maioria da liderança pentecostal; ou seja, o líder carismático conduz seu trabalho de evangelização pari passu com as atividades profissionais. A missão torna-se parte dessa rotina, como Bezerra esclarece: "seus líderes tendem a ser autodidatas, bivocacionados, líderes natos que utilizam um modelo, algo caudilhista, em suas lideranças. Têm demonstrado dons ou 'carisma', mas têm pouca formação teológica". ${ }^{1190}$

Essa situação foi predominante na fase inicial do pentecostalismo, entretanto o movimento tem passado por mudanças em decorrência de sua pluralidade interna, que o fragmentam consideravelmente, uma análise de sua totalidade já não é possível. Mas o recorte trabalhado nesta pesquisa centra-se no pentecostalismo da Igreja do Evangelho Quadrangular, de certa forma partícipe dessas mudanças, e hoje bem diferente do perfil assumido em sua fase inicial no

\footnotetext{
${ }^{1186}$ BEZERRA, C. M. Missão integral da igreja, p. 65 .

${ }^{1187}$ OLIVEIRA, D. M. d. Pentecostalidade da missão latino-americana, p. 92.

${ }^{1188}$ L. GONZÁLEZ, Justo; ORLAND, Carlos Cardoza. História do movimento missionário. São Paulo: Hagnos, 2008, p. 530.

${ }^{1189}$ KIRK, J. Andrew. O que é missão? Londrina: Descoberta, 2006, p. 288.

${ }^{1190}$ BEZERRA, C. M. Missão integral da igreja, p. 65.
} 
Brasil. Ainda assim a maior parte de sua liderança se enquadra nessa descrição de bivocacionados, carismáticos, mas de pouca formação teológica. Invertendo um pouco a análise, tentando compreender as raízes que intrigam Comblin na busca de uma missão relevante na atualidade, é preciso recorrer mais uma vez à sua própria experiência:

Comecei minha vida sacerdotal numa paróquia de cidade, exatamente em Bruxelas. Naquele tempo havia muitos sacerdotes. A paróquia tinha 15.000 habitantes. Uns 4.000 assistiam à missa cada domingo porque havia 6 missas. Éramos 4 sacerdotes e eu era o mais jovem, o último na graduação. Havia naturalmente muitas atividades na paróquia. Creio que a paróquia não era nem melhor, nem pior do que as outras, e nós, os padres, nem melhores, nem piores do que os outros. Todos éramos muito bem disciplinados e representávamos exatamente o modelo que nos tinha sido inculcado no seminário. Nada de especial, nem de original, simplesmente o modelo romano perfeitamente aplicado. ${ }^{1191}$

Pouco tempo depois dessa primeira experiência, o autor já se inseria na realidade religiosa da América Latina, bem diversa, com abertura para novas atitudes missionárias. E como se destaca no material sobre a missão integral da Igreja do Evangelho Quadrangular, “a América Latina apresenta uma grande variedade de opções religiosas. Têm se desenvolvido muitas denominações evangélicas, que apresentam característica dos novos movimentos religiosos conhecidos em outras latitudes". 1192

Parte da missão pentecostal chega a lugares que o Estado não alcança. Kirk explica: "as favelas das grandes cidades das nações do Terceiro Mundo são lugares onde o crescimento é mais notável. São comunidades compostas por milhares de pessoas, geralmente de experiências étnicas diferentes, que vêm de áreas rurais remotas em busca de trabalho". ${ }^{1193}$ Se a missão tem penetrado em tais lugares, é preciso proclamar a libertação, anunciando a Boa Nova, como assegura Neto: "a pastoral cristã reconhecerá sempre que a fonte de testemunho de todo cristão na defesa dos direitos dos pobres é o evangelho, e não uma ideologia". ${ }^{1194}$

Certamente a missão é destinada a todos, mas há que se comprometer com a situação de pobreza e injustiça em que se encontra grande parte da população. Bosch afirma: "também hoje Cristo está onde se encontram as pessoas famintas e

\footnotetext{
${ }^{1191}$ COMBLIN, J., Olhando para o horizonte, p. 837.

1192 BEZERRA, C. M., Missão Integral da Igreja, p. 69.

${ }^{1193}$ KIRK, J. A., O que é missão?, p. 288.

${ }^{1194}$ LONGUINI NETO, Luiz. O novo rosto da missão: os movimentos ecumênico e evangelical no protestantismo latino-americano. Viçosa: Ultimato, 2002p. 240.
} 
as enfermas, as exploradas e as marginalizadas". ${ }^{1195}$ Já imerso na realidade da América Latina, Comblin relembra seu início e as preocupações que tomavam a agenda. Para ele, a Igreja ocupava a centralidade, não cedendo espaço a atividades que não a tivessem como eixo:

Nas reuniões do clero, o assunto era sempre a paróquia, a organização das atividades, os melhoramentos necessários. Era: como tornar a paróquia mais atraente e mais eficiente? Como aplicar as pequenas reformas que eram permitidas? O assunto era sempre a Igreja e, afinal de contas, o poder da Igreja mediante a nossa paróquia. Estávamos representando localmente a Igreja, esta imensa fortaleza que Deus tinha colocado no mundo para distribuir a salvação e governar a sociedade, ainda que houvesse muitos incrédulos que já não aceitavam essa submissão. Ainda havia um número suficiente de fiéis, para acalmar as apreensões ou os temores. Ainda éramos uma força social impressionante. ${ }^{1196}$

Aqui retomamos a análise combliniana da prática de missão e da Igreja do Evangelho Quadrangular, conceitos divergentes. O primeiro Comblin vai mudando sua teologia e sua prática missionária, mas seu conceito difere da prática quadrangular que aponta para a evangelização, envolvendo a dinâmica pessoal e individual do agente que promove a missão e daqueles a quem ela se dirige. Mais uma vez aqui se recorre ao material da Igreja do Evangelho Quadrangular concernente à missão:

Através da evangelização pessoal e da visitação muitas pessoas ouviram o testemunho cristão. Através da prática do amor, muitos foram convencidos da veracidade da mensagem evangelística que ouviram. A missão era, nos estágios iniciais, mais do que uma mera função; ela era uma expressão fundamental da vida da igreja. ${ }^{1197}$

Fica clara a distinção entre o conceito e a prática de missão quadrangular e o panorama descrito por Comblin, em sua fase europeia. Esse panorama descrito por Comblin mostrou alguns dados da missão na Igreja Católica. Comblin também refletiu como deve ser a missão de modo mais adequado, com mais participação dos cristãos. Para a Igreja Quadrangular a missão passa diretamente pelo agente missionário, que, em larga escala, envolve o leigo encarregado das visitas, da comunicação da palavra e do testemunho do amor. O redator da apostila quadrangular faz esse esforço ao retomar a missão cristã das primeiras comunidades, o que suscita a crítica de Comblin:

\footnotetext{
${ }^{1195}$ BOSCH, D, J. Missão transformadora, p. 509.

${ }^{1196}$ COMBLIN, J. Olhando para o horizonte, p. 837.

${ }^{1197}$ FLUCK, M. R. Introdução à missiologia, p. 14.
} 
Não me lembro de que alguma vez tenhamos falado de Jesus Cristo entre nós, a não ser como objeto que usávamos para organizar o culto, a pregação e assim por diante. Em princípio estávamos ali para servir a Jesus e na prática era Jesus quem nos servia, porque nos dava a justificação do nosso trabalho. Jesus existia para que a paróquia fosse próspera e não a paróquia para que Jesus fosse anunciado, apesar de sempre se dizer o contrário. ${ }^{1198}$

A crítica de Comblin é importante para a compreensão da sua proposta de missão. Tanto ele quanto os quadrangulares percebem que a missão necessita ser repensada. Amado diz: "não estamos numa etapa em que as transformações são grandes apenas na quantidade, não atingindo, entretanto, os critérios de compreensão do real". ${ }^{1199} \mathrm{O}$ desafio vai além de outras formas de crer, passando pelo sentido da própria percepção da vida e tudo mais que a integra. A perspectiva quadrangular diz: "no geral, está ocorrendo uma diversificação nas igrejas. Ainda dentro das denominações vê-se uma grande variedade teológica, e o número de igrejas novas independentes apresenta outra gama de opções teológicas". ${ }^{1200}$ A pluralidade é um desafio preocupante, segundo a percepção quadrangular, pois a independência e a autonomia das ramificações desafiam constantemente a prática missionária. Até certo ponto, a força da propagação pentecostal banalizou a prática de missão, o que tornou o desafio ainda maior e impôs a busca de um caminho que rompa a barreira do descrédito.

Comblin pensa que sua vertente religiosa não tem um projeto de missão, uma agenda que reconheça esse processo de continuidade e descontinuidade, recuperando uma missão que obtenha voz e se comunique numa linguagem atual. Em processo semelhante, o pentecostalismo da Igreja do Evangelho Quadrangular também busca reatar um elo com sua fase inicial, mediante a ligação direta com as primeiras comunidades cristã citadas no período testamentário. $\mathrm{Na}$ apostila de introdução à missiologia, Fluck lembra "a difusão do evangelho se deu muitas vezes através dos lares cristãos. A atmosfera informal e descontraída, onde se exercia a hospitalidade cristã, contribuiu para o sucesso da evangelização. Muitas das casas dos cristãos foram utilizadas como centros missionários, como a casa de Lídia ou do carcereiro (em Atos 16)". ${ }^{1201}$

\footnotetext{
${ }^{1198}$ COMBLIN, J. Olhando para o horizonte, p. 837.

${ }_{1199}$ AMADO, J, P. Leigos na linha de frente, p. 390.

${ }^{1200}$ BEZERRA, C. M. Missão integral da igreja, p. 70.

${ }^{1201}$ FLUCK, M. R. Introdução à missiologia, p. 14.
} 
É assim que o pentecostalismo quadrangular tenta retomar o modelo pessoal de missão de casa em casa. A cristandade precisa, de alguma maneira, manter a chama da missão, mesmo frente a questões desafiadoras, o que requer muita criatividade dos envolvidos e comprometidos com a causa. E exatamente como Comblin diz, "trata-se de aterrissar, de entrar no mundo de hoje tal com o é, de perguntar-se: o que fazemos aqui? O que significa evangelizar neste mundo em que estamos? As novas gerações sentem a ausência de um projeto”. ${ }^{1202}$ Pela seriedade do assunto, a Teologia tem pela frente questões inéditas que carecem de respostas atuais. A partir do modo de vida atual, cabe a questão levantada por Comblin: o que significa evangelizar na atualidade, ou ainda mais, o que é missão no mundo de hoje? Como fazer missão? Tais desafios não cabem em um programa ou plano de evangelização. A questão ultrapassa tal organicidade. Bosch diz: "mesmo que se tenha que levar a sério essas advertências, continua sendo extraordinariamente difícil determinar o que é missão. Todo este estudo parte da premissa de que a definição de missão é um processo contínuo de peneirar, testar, reformular e descartar". ${ }^{1203}$

A missão passa por esse processo, mas sempre encontra um caminho de renovação e criatividade. Ela sempre continua, como afirma Comblin: "e a missão de Jesus Cristo permanece e se renova a cada passo no caso de cada pessoa humana em cada geração". ${ }^{1204}$ Mesmo que o conceito e a terminologia mudem de acordo com a época, a missão ultrapassa todos os desafios. A propósito, Bosch destaca: “o conceito 'evangelizar' e seus derivados já existem, de fato, há muito mais tempo que a palavra 'missão' e, é óbvio, ocorrem com relativa frequência no Novo Testamento (eungelizein [ou euangelizesthai] e euangelion)" ${ }^{1205}$ Em certos círculos os termos parecem sinônimos, e assim, evangelizar e fazer missão seriam uma única face da mesma realidade. Souza afirma: "acabamos de afirmar que a possiblidade de o cristianismo despertar na cidade está no processo de evangelização não realizado pela imposição, mas pela missão, que significa presença de pessoas preparadas para o anúncio do Evangelho". ${ }^{1206}$ Evangelizar, assim, faria parte da missão, mas ambos os termos se destacam quando se trata da

\footnotetext{
${ }^{1202}$ COMBLIN, J. Olhando para o horizonte, p. 846.

${ }^{1203}$ BOSCH, D, J. Missão transformadora, p. 609.

${ }^{1204}$ COMBLIN, J. Teologia da missão, p. 24.

${ }^{1205}$ BOSCH, D, J. Missão transformadora, p. 489.

${ }^{1206}$ SOUZA. A. R. A teologia da cidade segundo José Comblin, p. 594.
} 
frente cristã. Bosch comenta: “desde o início do século 19, o verbo 'evangelizar' e seus derivados 'evangelismo' e 'evangelização' foram, porém, reabilitados em círculos da igreja e da missão". ${ }^{1207}$

Pensando a marcha da igreja, toda ação evangelizadora deve apontar para o cuidado e o compromisso com a vida, o que proclama a justiça e a esperança do reino de Deus, conforme afirma Sanches: "a missão da igreja no mundo deve contemplar esta realidade e integrá-la em sua ação. O modo de se realizar isto é vivendo e anunciando na realidade histórica a justiça, a harmonia e a paz do reino de Deus, que é uma categoria escatológica". ${ }^{1208}$

Mesmo que evangelismo e missão se mostrem diferentes nos detalhes, apontam na mesma direção no âmbito da anunciação da esperança do reino de Deus. O evangelismo é um elemento que integra a missão acontece. O evangelismo é o núncio. $\mathrm{O}$ evangelismo parece ser dar no contato direto com a realidade, enquanto a missão abrange todo o projeto de ação da igreja. Bosch afirma: "falando em termos genéricos, a controvérsia prevalece em duas áreas: as diferenças (se existem) entre "evangelismo" e "missão", e o escopo ou abrangência do evangelismo. Além disso, essas questões apresentam uma estreita vinculação". ${ }^{1209}$ Assim, enquanto se pratica a ação evangelizadora, a missão está em curso, e quando a missão está em curso, evangeliza-se. Dessa maneira a igreja é vocacionada a cooperar. Sanches diz: "é nessa realidade humana integral e complexa que a Igreja é chamada a missionar, portanto, não há outra forma de realizar a missão no mundo, senão na perspectiva da integralidade". ${ }^{1210}$ Essa exposição se faz necessária para que se compreenda a questão missionária como em constante transformação. E enquanto a missão transforma a realidade e as vidas, ela também é transformada. Bosch esclarece: "sinuosidades, no significado como as que identificamos acima, são sintomáticas de um estado em que prevalece a fluidez constante no pensamento missionário e do período de transição em que vivemos". 1211

As variações em torno da questão missionária são tão pertinentes quanto o desafio que o presente tempo apresenta à realidade missionária, como conclui

\footnotetext{
${ }^{1207}$ BOSCH, D, J. Missão transformadora, p. 489.

${ }^{1208}$ FERNANDES SANCHES, R., Teologia da missão integral, 2009, p. 150.

${ }^{1209}$ BOSCH, D, J. Missão transformadora, p. 490.

${ }^{1210}$ FERNANDES SANCHES, R. Teologia da missão integral, 2009, p. 147.

${ }^{1211}$ BOSCH, D, J. Missão transformadora, p. 492.
} 
Bosch: "básica para minhas considerações é a convicção de que missão e evangelismo não constituem sinônimos, mas, a despeito disso, estão indissoluvelmente vinculados e inextricavelmente entretecidos na teologia e na práxis". ${ }^{1212}$ Assim mesmo, não são a mesma coisa, mas se integram mutuamente. Já em outras percepções podemos encontrar definições diferentes ou com apontamentos relevantes, a exemplo de Wright: "falamos mais facilmente da missão como 'pregar o evangelho'. Embora isto seja absolutamente vital (porque as boas novas têm que ser comunicadas com palavras), não é o quadro bíblico completo de como o evangelho deve ser comunicado". ${ }^{1213}$ Tal declaração mostra o sentido mais comum de evangelização e missão como verbalização do evangelho, o que, para estudiosos da missão, já está superado. Não que a pregação ou a verbalização do evangelho sejam dispensáveis, mas outros componentes integram essa ação. Bosch afirma: "o evangelismo é parte integrante da missão."1214 Outra faceta da questão a ser analisada é o significado de evangelizar, aqui entendido como conversar com alguém, como explica Souza: "a questão é: onde, quem e como se evangeliza? Evangelizar significa conversar com alguém concreto, situado num contexto concreto, em determinado momento concreto da história". ${ }^{1215}$ Encerramos a questão neste âmbito mencionando a fase inicial da ordenança recebida pelos discípulos do Cristo de serem testemunhas, como lembra Bosch: "o evangelismo implica testemunhar o que Deus fez, está fazendo e fará" ${ }^{1216}$ Dessa forma, em testemunho, é que abarcamos a essência da vida em missão.

\subsection{3.}

Sucessos e limites da prática missionária da Igreja Quadrangular à luz da Teologia

Iniciamos esta seção com a afirmação de Comblin: "de fato o Espírito veio. Tanto os discípulos, como os judeus puderam saber que Deus cumpre suas

\footnotetext{
1212 BOSCH, D, J. Missão transformadora, p. 492.

${ }^{1213}$ WRIGHT, Chistopher J. H. A missão do povo de Deus: uma teologia bíblica da missão da igreja. São Paulo: Vida Nova: Instituto Betel Brasileiro, 2012, p. 330.

${ }_{1214}$ BOSCH, D, J. Missão transformadora, p. 493.

1215 SOUZA. A. R. A teologia da cidade segundo José Comblin, p. 593.

${ }^{1216}$ BOSCH, D, J. Missão transformadora, p. 493.
} 
promessas". ${ }^{1217}$ Munidos desse norteamento é que se analisam aqui os princípios que fundamentam a missão do pentecostalismo na Igreja do Evangelho Quadrangular. Isso é essencial para que não se corra o risco de concepções equivocadas. A teologia quadrangular concebe a missão do Espírito como já manifesta antes mesmo de Pentecostes, em Atos. Duffield e Cleave afirmam: "vamos dispensar completamente a ideia de que o Espírito Santo não veio ao mundo até o dia de Pentecostes, descrito em Atos 2, pois será notado que o Espírito tem estado ativo em cada dispensação e tem estado presente sempre que Deus se revela". ${ }^{1218}$

A reflexão combliniana também caminha nessa direção: “com certeza, o Espírito tinha sido prometido no Antigo Testamento. Apareceu em Jesus respondendo assim ao apelo das promessas. Mas essa primeira vinda anunciava apenas uma efusão universal prometida de novo por Cristo". ${ }^{1219}$ A pneumatologia do autor é bem sólida e situa-se próxima ao pentecostalismo quadrangular, e malgrado consideráveis divergências, principalmente quanto à finalidade dos dons, guarda fortes aproximações na concepção da missão que envolve o Espírito Santo. Segundo ele, "Jesus fez promessas durante sua convivência com o povo de Israel. Despertou ou reanimou a esperança. O primeiro objeto de suas promessas é o Espírito". ${ }^{1220}$

O que acontece em Atos 2, segundo a base teológica do movimento pentecostal, parte do pressuposto de que a propagação do evangelho se dá a partir da manifestação do Espírito que impulsiona a missão. Duffield e Cleave destacam: "a seguir, no dia de Pentecostes, o Espírito Santo prometido foi derramado sobre a igreja com sinais visíveis e audíveis, e eles começaram a falar nas línguas preditas na Grande Comissão". ${ }^{1221}$ Toda a esperança cristã aponta para questões peneumatológicas, como comenta Comblin: "assim a esperança cristã dirige-se, em primeiro lugar, para o dom do Espírito". ${ }^{1222}$ Esse ponto é decisivo na diferenciação desse modelo de missão, que busca ultrapassar os conceitos normativos da vivência em comunidade. A missão dirigida à centralidade do Espírito é uma missão do próprio Espírito. Duffield e Cleave dizem: “a missão da

\footnotetext{
${ }^{1217}$ COMBLIN, J. A maior esperança, p. 35.

${ }^{1218}$ DUFFIELD, P. G.; CLEAVE, N. M. V. Fundamentos da teologia pentecostal, vol. II, p. 1.

${ }^{1219}$ COMBLIN, J. A maior esperança, p. 33.

${ }^{1220}$ COMBLIN, J. A maior esperança, p. 33.

${ }^{1221}$ DUFFIELD, P. G.; CLEAVE, N. M. V. Fundamentos da teologia pentecostal, vol. II, p. 91.

${ }^{1222}$ COMBLIN, J. A maior esperança, p. 33.
} 
igreja consiste em muito mais que apenas propagar uma nova filosofia ou chamar para uma nova moral". ${ }^{1223} \mathrm{O}$ testemunho como missão inicia-se com o Espírito. Ele é quem dá testemunho do Cristo, e para os cristãos, evangelização e missão implicam testemunho, como cita Comblin:

Se alguém me ama, guardará minha palavra, e meu Pai o amará, e viremos a ele, e estabeleceremos nele a nossa morada (Jo 14,23). Todavia o Consolador, o Espírito Santo, que o Pai há de vos enviar em meu nome, ele vos ensinará todas as coisas e vos trará a memória tudo o que vos disse (Jo 14,26). Quando vier o Consolador, que eu enviarei da parte do Pai, o Espírito de verdade, que procede do Pai, Ele dará testemunho de mim (Jo 15,26). ${ }^{1224}$

A sistematização de uma teologia do Espírito tem sido um esforço constante, tanto de pentecostais protestantes quanto de católicos. No caso da Igreja do Evangelho Quadrangular, o termo 'espirituais' está associado aos dons, como explica Duffield e Cleave:

Espirituais, "pneumática": "A respeito dos dons espirituais, não quero, irmãos, que sejais ignorantes" (v.1). Note que a palavra "dons" está em itálico, significando que ela não se encontra no original grego. A primeira referência aos fenômenos espirituais, chamados de dons espirituais, os classifica simplesmente como "espirituais" ou "coisas do Espírito. ${ }^{1225}$

Os quadrangulares entendem que os dons espirituais se apresentam de diversas maneiras, entretanto sua finalidade é a mesma, a capacitação pela graça. Duffield e Cleave afirmam: "dons espirituais, 'charismata': 'Ora, os dons são diversos [...]' (v.4). O termo grego charisma, que é interpretado como 'dom espiritual', procede da palavra básica charis, que significa 'graça'. Um charisma é, portanto, uma capacitação, uma concessão ou bênção dada espontaneamente por Deus". ${ }^{1226}$ A questão também remete à completude, que tem por finalidade a marcha missionária que envolve o corpo de Cristo, como esclarece Kirk: “a parceria no corpo de Cristo é enfatizada naquelas passagens que falam acerca dos dons (charismatoi) dados pelo Espírito Santo a cada membro do corpo". ${ }^{1227}$

Essa capacitação atribuída ao Espírito tem se tornado decisiva na ação pentecostal. Para Comblin, essa capacitação estimulada pelo Espírito leva a ação

\footnotetext{
${ }^{1223}$ DUFFIELD, P. G.; CLEAVE, N. M. V. Fundamentos da teologia pentecostal, vol. II, p. 91. ${ }^{1224}$ COMBLIN, J. A maior esperança, p. 34.

${ }^{1225}$ DUFFIELD, P. G.; CLEAVE, N. M. V. Fundamentos da teologia pentecostal, vol. II, p. 92.

${ }^{1226}$ DUFFIELD, P. G.; CLEAVE, N. M. V. Fundamentos da teologia pentecostal, vol. II, p. 92.

${ }^{1227}$ KIRK, J. A., O que é missão?, p. 248.
} 
humana ao testemunho. Para além de simples ação, ela é responsável pela mudança que gera vida, apontando para a esperança, e é comentada pelos estudiosos de Comblin, como Souza: "nesse sentido a ação humana estimulada pelo Espírito não é mais uma simples ação, mas se transforma em um testemunho. É uma ação que dá vida aos homens e que os motiva à realização de novas ações de esperança". ${ }^{1228}$

Já se tratou no capítulo anterior do desequilíbrio na teologia ocidental, que envolve cristologia e pneumatologia. Oliveira afirma: "mas é preciso avançar para uma cristologia pneumatológica também, pois a história da salvação é inseparavelmente cristológica e pneumatológica". ${ }^{1229}$ Comblin propõe que a teologia recupere a questão pneumatológica, sem diminuir a missão do Cristo frente à missão do Espírito, antes mostrando ambas como necessárias à Missio Dei. Oliveira continua: “o problema é que nessa relação, o Espírito acaba sendo 'ofuscado' pela obra de Cristo e pela cristocentricidade das abordagens teológicas". ${ }^{1230}$ É necessário o conhecimento de ambas as missões, como afirma Comblin: "é igualmente necessário que conheçamos as duas missões [...]". ${ }^{1231}$ Para os quadrangulares, é Cristo quem conduz a missão. Isso difere da interpretação combliniana, segundo a qual é o Espírito que torna Cristo presente aos homens. Na fé quadrangular, foi Cristo quem comissionou os primeiros discípulos, tornando-os missionários, e hoje também tem guiado sua missão por meio do povo de Deus. Duffield e Cleave explicam: "em outras palavras, o mesmo Salvador que deu ordens àqueles primeiros discípulos, através do Espírito Santo, está guiando e dirigindo os empreendimentos de seus servos hoje por intermédio do mesmo Espírito Santo bendito". ${ }^{1232}$

O aprofundamento da questão torna semelhantes a teologia quadrangular e a combliniana, no que diz respeito à direção da missão. A teologia quadrangular também compreende a desnecessidade da presença física do Senhor para conduzir a missão, já que tal tarefa é do Espírito. Duffield e Cleave afirmam: “a Igreja não depende da presença física do Senhor para ser guiada por Ele. Tal orientação é

\footnotetext{
${ }^{1228}$ SOUZA, A., Análise da ação humana a partir do pensamento de José Comblin, p. 14.

1229 OLIVEIRA, David Mesquiati de. A pneumatologia de Lutero: uma aproximação. Reflexus, Ano XI, n. 17, 2017/1, p. 174.

${ }^{1230}$ OLIVEIRA, D, M, d. A pneumatologia de Lutero, p. 174.

1231 COMBLIN, J. Tempo da ação, p. 28.

${ }^{1232}$ DUFFIELD, P. G.; CLEAVE, N. M. V. Fundamentos da teologia pentecostal, vol. II, p. 13.
} 
feita pelo Espírito Santo". ${ }^{1233}$ São visíveis pontos de contato com a pneumatologia de Comblin, cujos comentadores, como Mikuszka, afirmam: "interessante que o evangelista João chama o Espírito Santo de Defensor (cf. Jo 14,16.17.26; 15,26; 16,7). João se diferencia da perspectiva sinótica porque explana a pessoa de Jesus como Filho que procede do Pai e que dá o Espírito (cf. Jo 7,39; 15,16; 18,30; 20, 22)". ${ }^{1234}$ Os quadrangulares concordam com Comblin quanto à propriedade de Cristo de concede o Espírito, a exemplo de Duffield e Cleave: "Cristo é quem concede o Espírito Santo". ${ }^{1235}$

No pentecostalismo, o crente precisa buscar o batismo com o Espírito Santo, em meio a orações intensas, na maioria das vezes em comunidade, mas também individualmente. Costa explica: “o Espírito Santo é concedido ao crente, na medida em que o pedir. Deus cumpre a promessa do batismo do Espírito Santo, se o candidato tomar consciência da necessidade do poder do Espírito Santo e o buscar com perseverança e ardor". ${ }^{1236} \mathrm{O}$ pentecostal compreende que esse batismo o credencia em missão e o imerge na força do Espírito. Barro diz: "esta mesma salvação deve ser proclamada através da instrumentalidade dos discípulos e da igreja, no mesmo poder do Espírito Santo". ${ }^{1237}$

A percepção inicial quadrangular do Espírito primeiramente reflete sobre o termo parakletos, consolador. A teologia quadrangular pensa que a tradução desse termo como "consolador" não seja adequada, e nesse ponto se aproxima mais de Comblin: "o Espírito faz com que a pessoa supere, de certo modo, os limites da sua condição histórica, para atingir uma perfeição que é imagem da perfeição do Pai”. ${ }^{1238} \mathrm{O}$ recurso de Comblin à pneumatologia parece objetivar o encontro de um ação que proporcione a transformação da realidade em que a missão é conduzida. Para ele o Espírito modifica toda a estrutura com sua ação. Nesse aspecto, os quadrangulares também compreendem que o conceito de Espírito como força é mais coerente com o termo bíblico, mesmo que traduções o mostrem como consolador. Duffield e Cleave explicam:

\footnotetext{
${ }^{1233}$ DUFFIELD, P. G.; CLEAVE, N. M. V. Fundamentos da teologia pentecostal, vol. II, p. 13.

${ }^{1234}$ MIKUSZKA, G. L. O Discípulo Missionário na Perspectiva de José Comblin, p. 28.

${ }^{1235}$ DUFFIELD, P. G.; CLEAVE, N. M. V. Fundamentos da teologia pentecostal, vol. II, p. 13.

${ }^{1236}$ COSTA, R. O pentecostalismo e o culto do divino na atualidade, p. 592.

${ }^{1237}$ BARRO, J, H. De cidade em cidade, p. 95.

${ }^{1238}$ COMBLIN, J. O Espírito Santo no mundo, p. 93.
} 
A palavra traduzida "consolador" na KJV é o termo grego parakletos. A ideia moderna de "consolador" não é mais adequada para descrever o ministério do Espírito Santo. Pensamos em consolador como alguém que conforta nos momentos de tristeza. O Espírito não só nos consola em nossa dor, mas também dá força e vitória sobre as nossas tristezas. É verdade que os discípulos se entristeceram com a partida anunciada pelo Senhor, mas o outro Paracleto iria remover esse sentimento, tomando o lugar de Jesus. ${ }^{1239}$

A teologia quadrangular destaca o Espírito, o que Comblin conclama a todos a fazer. Na definição do conceito que melhor representa o Espírito, quadrangulares e Comblin acenam com pontos de contato, embora Comblin continue a insistir em que a razão dessa força são as atividades: "os dons de Deus não permanecem inertes: são fontes de atividade". ${ }^{1240}$ Para ele, essa fonte é primordial à missão. Na visão quadrangular, toda a sua missão passa pela concepção de batismo com o Espírito Santo. Duffield e Cleave afirmam: "a coisa mais importante que Jesus fez por seus seguidores, depois de ter comprado a redenção através de sua morte e ressurreição, talvez tenha sido batizá-los com o Espírito Santo". ${ }^{1241}$ A missão, como empreendimento de Deus, envolve toda a criação, desde o universo até a vida individual de cada ser, atuando na história na missão do Espírito, como explica René:

A missão cristã é primordialmente missio Dei (missão de Deus). Nasce no coração de Deus, atua na história pelo poder do Espírito Santo, e visa a exaltação de Jesus Cristo como Senhor do universo e de cada área da vida humana, para a glória de Deus. Em síntese, a missão cristã começa e termina em Deus. ${ }^{1242}$

A Igreja Quadrangular também se preocupou em refletir sobre a relação entre o Espírito e Cristo, como conclui Duffield e Cleave: "vimos brevemente a revelação do Pai através do Filho e depois a nova revelação do Filho através do Espírito Santo". ${ }^{1243}$ Nessa concepção o Espírito é quem revela Cristo, daí a importância da reflexão pneumatológica. Quadrangulares e Comblin discordam radicalmente quanto à forma de atuação do Espírito na pessoa humana. Enquanto, para os pentecostais, o Espírito age com evidências físicas, a exemplo do falar em línguas, para Comblin a atuação do Espírito volta-se mais ao impulso à execução

\footnotetext{
${ }^{1239}$ DUFFIELD, P. G.; CLEAVE, N. M. V. Fundamentos da teologia pentecostal, vol. II, p. 27.

${ }^{1240}$ COMBLIN, J. O Espírito Santo no mundo, p. 91.

${ }^{1241}$ DUFFIELD, P. G.; CLEAVE, N. M. V. Fundamentos da teologia pentecostal, vol. II, p. 13.

${ }^{1242}$ C. RENÉ, P. O que é missão integral?, p. 63.

${ }^{1243}$ DUFFIELD, P. G.; CLEAVE, N. M. V. Fundamentos da teologia pentecostal, vol. II, p. 13.
} 
de atividades que tornariam o humano mais humano, e não divino. Comblin esclarece:

O Espírito, por sua vez, é enviado para preservar a pessoa humana de todos. Não se encarna em ninguém. Não faz com que nenhum homem seja o Espírito Santo. Sua presença, porém, faz com que a pessoa humana seja mais pessoa e mais humana, mais ela mesma, distinta de qualquer outra pessoa humana. ${ }^{1244}$

A ideia de que a ação do Espírito tem por finalidade atividades humanizadoras parece ser superficial, já que Comblin não aprofunda muito a questão desse agir pessoal, como afirma Mikuszka: "no entanto, em todo o seu enunciado de pneumatologia, ele não explica como o Espírito começa a agir na pessoa". ${ }^{1245}$ No pentecostalismo, tenta-se descrever o agir do Espírito na pessoa, que se inicia a partir do batismo com o Espírito Santo, o que leva a crer que a presente era é do Espírito em missão, como Bosch explica:

Pentecostes: Os movimentos pentecostais e carismático tendem a ver Pentecostes como a obra de Deus par excellence. Algumas pessoas, inclusive, chegam a dizer que, depois de uma era da história eclesiástica em que se enfatizava Deus pai, seguida pela era do Filho, ingressamos agora - sobretudo desde o princípio do século 20 - na era do Espírito. Nessa nova dispensação, emprenhamo-nos pela riqueza toda do céu e pelo êxtase incessante agora. Assim, encontramos, nesse círculo, reivindicações quanto à ocorrência de acontecimentos miraculosos e o regozijo por uma cadeia ininterrupta de experiências apicais. ${ }^{1246}$

Todos esses acontecimentos e apontamentos em torno da temática da pneumatologia têm início ainda no final do século XIX e compõem o pentecostalismo propagado a partir de Azusa, como lembra Campos: "muitas das crenças que iriam se unir na identidade pentecostal no final do século XIX circulavam separadamente, em diversas camadas do protestantismo norteamericano, todas, porém, ligadas aos movimentos de santidade ou de reavivamento espiritual". ${ }^{1247}$

A teologia quadrangular também entende que toda missão parte do Espírito, na linguagem bastante recorrente no pentecostalismo quadrangular, que sempre menciona o Espírito Santo. Segundo os quadrangulares, o batismo com o Espírito Santo é subsequente à salvação, e a função desse batismo é o poder de servir.

\footnotetext{
${ }^{1244}$ COMBLIN, J. O Espírito Santo e sua missão, p. 337.

${ }^{1245}$ MIKUSZKA, G. L. O discípulo missionário na perspectiva de José Comblin, p. 30.

${ }^{1246}$ BOSCH, D, J. Missão transformadora, p. 615.

${ }^{1247}$ CAMPOS, L. S. As origens norte-americanas do pentecostalismo brasileiro, p.109.
} 
Duffield e Cleave ressaltam: "[...] o batismo com o Espírito Santo, que é um derramamento do Espírito subsequente à salvação, não constituindo uma transmissão de vida espiritual, mas sim poder para serviço espiritual". ${ }^{1248} \mathrm{Na}$ fé quadrangular existe diferença no agir do Espírito, que pode ser trabalhado da seguinte forma: 1) O Espírito Santo batiza os crentes no Corpo de Cristo, e isso é para todos que estão em Cristo; 2) Uma operação do Espírito Santo pode ocorrer a todos; 3) O batismo com o Espírito Santo é obra de Jesus, e Ele é quem batiza. Duffield e Cleave explicam: "existe uma diferença vital entre o Espírito Santo batizar crentes no Corpo de Cristo, uma operação do Espírito Santo, e ser batizado com o Espírito Santo, que é uma obra de Jesus. João Batista disse: 'Eu vos tenho batizado com água; ele, porém vos batizará com o Espírito Santo’ (Mc 1,8)". ${ }^{1249}$ A tradição quadrangular menciona o batismo de Cristo em sua essencialidade ao serviço, como exemplifica Duffield e Cleave: "o batismo mencionado em 1 Coríntios 12,13 é conduzido por Jesus Cristo e está ligado com o poder para servir". ${ }^{1250}$ É primordial ao pentecostalismo a manifestação da glossolalia, evidência do batismo, como aponta Costa:

O batismo dos crentes no Espírito Santo é testemunhado pelo sinal físico inicial do falar em línguas, na medida em que é Deus quem dá essa fala: "Ficaram todos cheios do Espírito Santo, e começaram falar em outras línguas, conforme o Espírito Santo lhes concedia falar" (At 2,4). O falar em línguas é igual ao dom das línguas: "Há diversidade de dons, mas um só Espírito."."251

Para os quadrangulares, portanto, a obra do Espírito se faz em dois momentos. O primeiro se dá quando a pessoa entra no Corpo de Cristo por meio da obra do Espírito; no segundo momento Cristo batiza a pessoa com o Espírito e a lança em missão. Duffield e Cleave afirmam: "no primeiro desses dois batismos - a entrada no Corpo de Cristo - o Espírito Santo é o agente, enquanto o Corpo de Cristo, a igreja, é o meio. No segundo, Cristo é o agente, e o Espírito Santo é o meio". ${ }^{1252}$ Tudo passa pelo Espírito, a obra do Cristo conclui-se e inaugura a missão do Espírito em todos. O Espírito é quem gera a vida, ao ressuscitar o

\footnotetext{
${ }^{1248}$ DUFFIELD, P. G.; CLEAVE, N. M. V., Fundamentos da teologia pentecostal, vol. II, p. 15.

${ }^{1249}$ DUFFIELD, P. G.; CLEAVE, N. M. V., Fundamentos da teologia pentecostal, vol. II, p. 16.

${ }^{1250}$ DUFFIELD, P. G.; CLEAVE, N. M. V. Fundamentos da teologia pentecostal, vol. II, p. 16.

${ }^{1251}$ COSTA, R. O pentecostalismo e o culto do divino na atualidade, p. 591.

${ }^{1252}$ DUFFIELD, P. G.; CLEAVE, N. M. V. Fundamentos da teologia pentecostal, vol. II, p. 16.
} 
Cristo, garantindo ao cristão a vida, mas para isso ele precisa habitar na pessoa, conforme Comblin:

Ora, o Espírito que deu a vida e a vida eterna, a vida de Filho de Deus a Jesus Cristo, dará também a vida eterna a todos os membros do corpo de Cristo. "Se habita em vós o Espírito daquele que dentre os mortos ressuscitou a Jesus, ele, então, que ressuscitou a Cristo Jesus dos mortos, dará também a vida a vossos corpos mortais em virtude de seu Espírito que habita em vós" $(\mathrm{Rm} 8,11) .{ }^{1253}$

A marca do crente é o Espírito e a comunidade pentecostal é centralizada nas ações do Espírito, desde sua espiritualidade até a promessa da parúsia, como define Duffield e Cleave: "o selo de propriedade de Deus sobre o seus santos é a presença do Espírito Santo habitando no coração deles. Este é o penhor ou sinal de que lhe pertencem, até o dia em que voltará para recebê-los". ${ }^{1254} \mathrm{Na}$ pneumatologia combliniana também se compreendem os dons como penhor: "porém os dons recebidos até agora são apenas o penhor dos dons que nos são prometidos. As promessas do Espírito ainda são atuais. Jesus Cristo ainda hoje promete o envio do Espírito". ${ }^{1255}$ Quanto ação do Espírito, as partes pesquisadas neste trabalho têm diferentes posições: em contraponto à forte ênfase pentecostal às manifestações do Espírito sobre o corpo físico, para tentar responder as questões que se desdobram a partir do batismo com o Espírito Santo, Comblin aponta para a concretude do agora, acreditando que os carismas são destinados a atividades transformadoras da realidade, entendendo também que a vida eterna já é para ser vivida neste mundo: "a vida eterna já é dada desde agora, para ser vivida neste mundo". ${ }^{1256}$ Pode-se dizer que a pneumatologia comblianiana aponta para um Espírito dirigido à realidade da vida, não à espiritual, mas à humana e a sua estrutura.

A teologia quadrangular compreende que a ação do Espírito no crente é o poder que o leva à missão. Aguardar na cidade até que do alto os missionários fossem revestidos de poder, eis a credencial que leva os discípulos à missão na força do Espírito, como afirma Duffield e Cleave:

\footnotetext{
${ }^{1253}$ COMBLIN, J. O Espírito Santo no mundo, p. 89.

${ }^{1254}$ DUFFIELD, P. G.; CLEAVE, N. M. V. Fundamentos da teologia pentecostal, vol. II, p. 17.

${ }^{1255}$ COMBLIN, J. A maior esperança, p. 37.

${ }^{1256}$ COMBLIN, J. O Espírito Santo no Mundo, p. 90.
} 
O Espírito Santo batiza e enche os crentes, dando-lhes poder para servir. As palavras familiares da Grande Comissão, como expressas em Marcos 16:15; "Ide por todo o mundo e pregai o Evangelho a toda a criatura", são seguidas pela nova ordem do Senhor, como lemos em Lucas 24:49: "[...] permanecei, pois, na cidade até que do alto sejais revestido de poder". Este batismo com o Espírito Santo e com fogo (Lc 3:16) e a unção peculiar de poder que viria como resultado deveria ser uma nova fase na obra do Espírito Santo. ${ }^{1257}$

Segundo os quadrangulares, o batismo com o Espírito Santo é posterior à regeneração, exatamente o que capacita e fortalece os homens para dirigir a missão que lhes foi comissionada, como declara Duffield e Cleave: "o batismo com o Espírito Santo é diferente e subsequente à sua obra regeneradora no coração dos perdidos. Este batismo é especialmente para que os homens possam ter força espiritual necessária para conduzir o ministério que lhes foi entregue". ${ }^{1258} \mathrm{Na}$ prática pentecostal, o Espírito Santo é sempre o assunto centralizador, pois toda a ação pentecostal deriva da sua ação, como afirma Duffield e Cleave: "orar sob a unção do Espírito Santo torna-se uma das experiências mais preciosas do cristão". ${ }^{1259}$

A dinâmica dessa unção mostra o imprevisível, o que não se pode definir, que foge à compreensão humana, mas aponta pistas a partir das quais se formam definições, como pontua Bosch: "está mediando a presença de Deus Espírito, que sopra onde quer, sem que saibamos de onde vem e para onde vai (Jo 3.8)". ${ }^{1260}$ A finalidade da ação do Espírito na vida do cristão, para os quadrangulares, é a anunciação da palavra. Testemunhar, e não somente proferir um evangelho de palavras. Firmar-se no poder do Espírito Santo, como afirma Duffiel:

O Espírito Santo concede poder para pregar a Palavra de Deus. Paulo testemunhou: "A minha palavra e a minha pregação não consistiram em linguagem persuasiva de sabedoria, mas em demonstração do Espírito e de poder..." (1 Co 2:4). Ele repete: "Porque o nosso evangelho não chegou até vós tão-somente em palavras, mas sobretudo em poder, no Espírito Santo..." (1Ts 1:5). Pedro reconheceu a presença do Espírito Santo em sua pregação, ao testemunhar diante do Sinédrio judeu em Jerusalém. Ele declarou: "Ora, nós somos testemunhas destes fatos, e bem assim o Espírito Santo...” (At 5:32). ${ }^{1261}$

\footnotetext{
${ }^{1257}$ DUFFIELD, P. G.; CLEAVE, N. M. V., Fundamentos da teologia pentecostal, vol. II, p. 21.

${ }^{1258}$ DUFFIELD, P. G.; CLEAVE, N. M. V., Fundamentos da teologia pentecostal, vol. II, p. 21-

22.

${ }^{1259}$ DUFFIELD, P. G.; CLEAVE, N. M. V., Fundamentos da teologia pentecostal, vol. II, p. 23.

${ }^{1260}$ BOSCH, D, J., Missão transformadora, p. 589.

${ }^{1261}$ DUFFIELD, P. G.; CLEAVE, N. M. V. Fundamentos da teologia pentecostal, vol. II, p. 23.
} 
O modelo missionário dos quadrangulares parte da inspiração bíblica, ou seja, sua teologia tipifica o conceito de que a mesma ação do período bíblico pode ser viável na atualidade: "Jesus era de fato Deus, mas quando veio a este mundo parece que Ele sujeitou-se ao Pai, de modo que seu ministério realizou-se através da orientação e do poder do Espírito Santo". ${ }^{1262}$ A submissão de Jesus propõe um caminho missionário em fraqueza, a ser refletido. Comblin esclarece:

$\mathrm{Na}$ verdade Jesus estava completamente desarmado no meio dos homens, e quis estar assim. Estava desarmado para poder alcançar o homem na fonte da sua humanidade, no nível da maior universalidade: concretamente para poder ser recebido pelo mais humilde dos homens, para se encontrar com a humanidade em todos os homens. ${ }^{1263}$

Os quadrangulares recorrem frequentemente a tais exemplos, algo bem comum no pentecostalismo, ao ligarem diretamente o período bíblico à missão atual. Verifica-se na posição de Comblin, exemplificada acima, um trabalho hermenêutico fiel ao conceito do Cristo como cumpridor de uma missão orientada pelo Espírito, como esclarece Duffield e Cleave: “o Espírito Santo ungiu Jesus com poder para o ministério. 'Batizado Jesus, saiu logo da água, e eis que se lhe abriram os céus, e viu o Espírito de Deus descendo como pomba, vindo sobre ele. E eis uma voz dos céus, que dizia: Este é meu Filho amado, em quem me comprazo' (Mt 3:16,17)". ${ }^{1264}$ O pentecostalismo quadrangular percorre a teologia que identifica a missão do Cristo guiada pelo Espírito, pois os quadrangulares compreendem que foi a concessão do Espírito que lançou o Cristo na missão, segundo Duffield e Cleave: "a concessão do Espírito Santo qualificou-o oficialmente para o seu ministério público". ${ }^{1265}$

O ministério público do Cristo é visto pela denominação como a chave que tipifica a fase inicial da missão para o crente. A partir daí, todo crente precisa da promoção do Espírito, o que abre o caminho para a missão inspirada na força do Espírito, com todas as suas atribuições, a exemplo da pregação, pois a prática da pregação se concretizou quando o Cristo anunciou que o Espírito estava sobre Ele, como reforça Duffield e Cleave: "ministério de pregação - Não foi senão depois disto que lemos sobre Jesus ensinar e pregar (Lc 5:14,15; Mt 4:17). 'O Espírito do

\footnotetext{
${ }^{1262}$ DUFFIELD, P. G.; CLEAVE, N. M. V. Fundamentos da teologia pentecostal, vol. II, p. 10.

${ }^{1263}$ COMBLIN, J. Teologia da missão, p. 56.

${ }^{1264}$ DUFFIELD, P. G.; CLEAVE, N. M. V. Fundamentos da teologia pentecostal, vol. II, p. 10.

${ }^{1265}$ DUFFIELD, P. G.; CLEAVE, N. M. V. Fundamentos da teologia pentecostal, vol. II, p. 10.
} 
Senhor está sobre mim, pelo que me ungiu para evangelizar aos pobres [...]' (Lc 4:18). É costume pensar que as palavras graciosas que saíram de sua boca resultaram de sua própria grandeza inerente, mas Jesus as atribui à unção do Espírito". ${ }^{266}$ A hermenêutica praticada pelo pentecostalismo da Quadrangular exalta a atuação do Espírito sobre o Cristo. Para Comblin, Jesus dedicou-se à exposição da necessidade do cumprimento do recebimento do Espírito:

Jesus prometeu-o à samaritana: Todo aquele que bebe desta água terá sede de novo; mas aquele que beber da água que eu lhe der não voltará a ter sede: a água que eu lhe der transformar-se-á nele em fonte que brota até a vida eterna (Jo 4,1314). Na festa dos Tabernáculos, Jesus repete aos judeus: Se alguém tiver sede que venha a mim e beba. Se crer em mim, assim diz a Escritura: 'Do seu seio correrão rios de água viva'. Disse isto referindo-se ao Espírito que haviam de receber os que acreditassem nele (7,37-39). Outra vez disse: Eu sou a luz do mundo; o que me segue não caminhará nas trevas, mas terá a luz que conduz à vida $(8,12) .{ }^{1267}$

A pregação é atribuída à ação do Espírito e tudo o que envolve a missão é obra por Ele coordenada, da pregação às demais manifestações estimadas pelo pentecostalismo, inclusive a taumaturgia, elemento diferenciador do pentecostalismo da Quadrangular, quando ela se iniciou no Brasil, enquanto o pentecostalismo da época acentuava mais glossolalia. Duffield e Cleave esclarecem: "ministério de cura - 'Como Deus ungiu a Jesus de Nazaré como o Espírito Santo e poder, o qual andou por toda a parte, fazendo o bem e curando a todos os oprimidos do diabo, porque Deus era com ele' (At 10,38). De fato, foi como resultado do poder que o Espírito Santo lhe concedeu que Ele pôde operar milagres". 1268

A recuperação desse dom de cura foi essencial na missão quadrangular e faz parte da luta pela vida, pois os doentes são oprimidos, como assinala Comblin: "com a doença, o corpo todo fica enfraquecido, e não somente o corpo, mas o espírito e todas as energias". ${ }^{1269} \mathrm{Na}$ percepção combliniana, a doença é também pauta da manifestação missionária, pois degrada a vida: "a doença é um enfraquecimento da vida. Por isso, é uma situação em que a pessoa precisa de

\footnotetext{
${ }^{1266}$ DUFFIELD, P. G.; CLEAVE, N. M. V. Fundamentos da teologia pentecostal, vol. II, p. 10. 1267 COMBLIN, J. A maior esperança, p. 33-34.

1268 DUFFIELD, P. G.; CLEAVE, N. M. V. Fundamentos da teologia pentecostal, vol. II, p. 10. ${ }^{1269}$ COMBLIN, José. Breve curso de teologia: a sabedoria cristã. Tomo IV. São Paulo: Paulinas, 1983, p. 200.
} 
ajuda, mais do que nunca, ajuda material, e espiritual, ajuda de si mesma, dos próximos, de Deus e todas as forças da natureza". ${ }^{1270}$

A Quadrangular acredita que a taumaturgia segue a prática missionária, e para tanto utiliza o escopo da atuação missionária do Cristo, ou seja, o campo de atuação da missão quadrangular perpassa o Cristo taumatúrgico. Duffield e Cleave afirmam:

Jesus curou todos os que se aproximaram dele em certas ocasiões, mas foi limitado em outras pela falta de fé por parte do povo (Mt 13,58). Do que temos certeza é que Deus fez provisão para que a cura física fosse um ministério da sua igreja e que os dons de cura iriam operar juntamente com a fé. ${ }^{1271}$

$\mathrm{Na}$ história e na teologia quadrangular, a taumaturgia alcança grande destaque, sendo mencionada, por vezes, em seus documentos, como declaração de fé, constituindo uma das quatro doutrinas cardinais da Igreja do Evangelho Quadrangular. Desde a fundação da denominação, a taumaturgia é indissociável de sua missão. Comblin tenta esclarecer as suas possíveis causas ou raízes:

No judaísmo dos tempos de Jesus, essas forças de morte eram atribuídas aos demônios. Desse modo, a doença era provocada pelos demônios. Jesus e os evangelistas falavam do mesmo modo. A Igreja nunca deu definições claras sobre a interpretação desses demônios. Se as forças de morte, que constituem as doenças, têm que ser atribuídas habitualmente aos demônios ou não, fica ainda como dúvida. O que são os demônios, é uma outra dúvida. ${ }^{1272}$

O enunciado de Comblin está de acordo com alguns pressupostos pentecostais, por vezes componentes do culto, como o exorcismo e a evocação da cura divina. Macedo acrescenta: "entendemos agora que o batismo na água por imersão, a glossolalia, a 'cura divina' e as possessões espirituais constituem importantes práticas do Pentecostalismo brasileiro. Cada dom é enfatizado diferencialmente de acordo com a doutrina da denominação pentecostal". ${ }^{1273}$ Comblin continua buscando as causas das doenças e retoma o período bíblico: "antigamente, tanto na Bíblia como na mentalidade dos povos, dizia-se que a doença era castigo de Deus. Procurava-se saber qual era o pecado que provocava esse castigo. Os doentes eram considerados pecadores. Pensava-se que era preciso

\footnotetext{
${ }^{1270}$ COMBLIN, J. A sabedoria cristã, p. 200.

${ }^{1271}$ DUFFIELD, P. G.; CLEAVE, N. M. V. Fundamentos da teologia pentecostal, vol. II, p. 100.

${ }^{1272}$ COMBLIN, J. A sabedoria crista, p. 200.

${ }^{1273}$ MACEDO, E.U. Pentecostalismo e religiosidade brasileira, p. 95.
} 
conseguir primeiro o perdão de Deus para recuperar a saúde". ${ }^{1274}$ Essa interpretação é bastante opressora, sobrepondo-se a culpa, merecida ou não, à dor e ao desprezo com o qual o doente teria que conviver. Ele continua:

Ora, Jesus não aceita essa interpretação. A doença não é castigo do doente como se o próprio doente tivesse pecado mais que outros. Embora seja verdade que Deus permite a doença, e nada acontece sem que Deus o permita, não podemos daí concluir que Deus permite a doença como castigo. ${ }^{1275}$

A questão é que a doença também faz parte da pauta missionária, pois é contrária à vida. A taumaturgia é mencionada por Comblin, que compreende que Jesus atraía pessoas carentes de curas, compreendendo-as como as mais fracas da sociedade: "Jesus foi interpelado e quase assaltado por todos os doentes, aleijados, endemoninhados, lunáticos e paralíticos, como diz Mt 4.24. Essas pessoas são as massas populares, os pobres, os mais pobres". ${ }^{1276}$

A suspeita de Comblin de que a taumaturgia que envolvia o Cristo estava relacionada aos mais pobres da sociedade parece vincular-se com a prática do pentecostalismo quadrangular. Por mais que a denominação atinja outras classes sociais, seu maior campo de concentração é a parcela mais simples da sociedade, como ressalta Comblin: "as massas vêm a Jesus procurando um milagre. Descobrem em Jesus um taumaturgo. Querem a saúde, a libertação do seu corpo, prisioneiro da doença". ${ }^{1277}$

A temática da cura divina é um dos eixos que norteiam o Evangelho Quadrangular, embora o assunto seja bastante questionado, por diversos motivos, que vão de conceitos teológicos até a conotação pejorativa, que tem se tornado cada vez mais abrangente, e que está ligada aos abusos do termo "cura" junto com a ingenuidade e a fragilidade de muitos. Por isso, é preciso procurar ver um pouco mais as bases da doutrina quadrangular e sua aplicação. É preciso igualmente estar atento a uma reflexão crítica que modere o uso da temática da cura divina.

Para a IEQ, de acordo com a obra Fundamentos da Teologia Pentecostal, a origem da doença estaria no pecado adâmico, razão pela qual a promessa de redenção se aplicaria também ao corpo físico. Os quadrangulares percebem no Cristo a disposição de curar, em paralelo com a anunciação das Boas Novas:

\footnotetext{
${ }^{1274}$ COMBLIN, J. A sabedoria cristã, p. 201.

${ }^{1275}$ COMBLIN, J. A sabedoria cristã, p. 201.

${ }^{1276}$ COMBLIN, J. Sinais dos novos tempos, p. 584

${ }^{1277}$ COMBLIN, J. Sinais dos novos tempos, p. 584
} 
Quando Adão pecou, ambas as partes de sua natureza foram afetadas pela queda, Isto se aplica a todos os homens desde então, pois eles herdaram a sua natureza decaída. A alma do homem é corrompida pelo pecado; seu corpo fica exposto à doença. O plano completo da redenção de Cristo inclui ambas as naturezas do homem e providencia a restauração da sua vida espiritual, provendo também quanto aos resultados do pecado em seu corpo físico. Uma redenção completa deve anular o efeito completo do pecado e satisfazer a necessidade total da humanidade. Esta verdade é ilustrada no ministério de Jesus, que curou todos os doentes que se chegaram a Ele, assim como derramou seu precioso sangue para oferecer o perdão dos pecados. Isto é também indicado na dupla comissão dada aos discípulos: "Ide por todo o mundo e pregai o Evangelho toda criatura. Quem crer e for batizado será salvo... se impuserem as mãos sobre enfermos, eles ficarão curados" (Mc 16,1518). ${ }^{1278}$

De acordo com a teologia quadrangular, a morte é a penalidade máxima do pecado, e a doença está relacionada com a morte:

A morte é a maturação da doença. A morte é o resultado do pecado. Assim sendo, a doença deve ser também resultado do pecado, desde que o maior (a morte) contém o menor (a doença). Isto significa que, se não houvesse pecado no mundo, não haveria doença. ${ }^{1279}$

Desse modo, os quadrangulares supõem que a doença é originada no pecado e na condenação anunciada. Entretanto, o sacrifício do Cristo reconciliou o homem com Deus, rompendo a condenação. Os quadrangulares também levam em conta que Cristo evidenciou a vontade de curar durante o ministério terreno:

A teologia do leproso, quando se aproximou inicialmente de Jesus, é quase universal hoje. "Se quiser, você pode." No momento em dizemos "Se for da tua vontade" na oração para a cura do doente, estamos lançando toda responsabilidade sobre Deus. Estamos tornando Deus responsável pela doença, estamos dizendo que o Senhor poderia curar, se quisesse. Isto não é bíblico; o Senhor coloca a responsabilidade sobre quem busca seu toque de cura. ${ }^{1280}$

Nessa perspectiva, estariam caminhando junto a vontade divina de cura e a busca da cura. Os quadrangulares consideram que a cura resultaria ainda da vontade divina e que os escritos sagrados continuam válidos nos dias atuais, no tocante à cura divina:

Nada mudou desde os dias apostólicos no que se refere às provisões de Deus para as necessidades do ser humano. Cristo morreu e ressuscitou, o Espírito Santo foi

${ }^{1278}$ DUFFIELD, P. G.; CLEAVE, N. M. V. Fundamentos da teologia pentecostal, vol. II, p. 142.

${ }^{1279}$ DUFFIELD, P. G.; CLEAVE, N. M. V. Fundamentos da teologia pentecostal, vol. II, p. 143.

${ }^{1280}$ DUFFIELD, P. G.; CLEAVE, N. M. V. Fundamentos da teologia pentecostal, vol. II, p. 153. 
derramado e a Grande Comissão continua vigorando. As devastações do pecado e suas terríveis consequências ainda se manifestam no mundo de hoje. ${ }^{1281}$

Parece incoerência para os quadrangulares, crer em tudo quanto o Evangelho diz, menos na inoperância da cura: "os médicos, com todo o seu conhecimento e dedicação, continuam perplexos diante das aflições e doenças. Ninguém pode provar que Deus, que é sempre o mesmo, tenha jamais alterado a sua vontade sobre a cura da doença". ${ }^{1282}$ A questão é muito delicada, com vários conceitos, como afirma Duffield e Cleave: "muitos falsos conceitos estão sendo divulgados com respeito ao ministério de cura de Jesus enquanto Ele estava na terra". 1283

Os quadrangulares não dissociam a cura divina de outras ações bem aceitas nos dias atuais: "se a era dos milagres passou, então os mesmos opositores teriam de concluir que a possibilidade de conversão não existe, porque a conversão é tão milagrosa e sobrenatural quanto a cura divina". ${ }^{1284}$ A doutrina dos quadrangulares considera possíveis os milagres do período neotestamentario pela fé e pela oração, entretanto alerta sobre o milagre da ressurreição: "os quadrangulares creem em todos os milagres mencionados, exceto a ressureição de mortos, e não consideram inconcebível que Deus ressuscite os mortos, caso as circunstâncias exijam isso". ${ }^{1285}$ A doutrina da IEQ alerta para o cuidado e a prevenção com o corpo, como sinaliza Duffield e Cleave: "não é afirmado que os crentes jamais adoecerão, quaisquer que sejam as circunstâncias. Quando os crentes sobrecarregam o corpo ou desobedecem às leis da natureza, eles têm probabilidade de adoecer", 1286

A temática da cura, entretanto, necessitaria de outras observações, seja sobre a Bíblia, seja sobre a situação real das enfermidades e das tentativas de cura no campo da medicina e também em relação com a fé. Por exemplo, no contexto do evangelho, a enfermidade de uma pessoa não deve ser vista como ligada a pecado, conforme Jesus mostrou a respeito do cego de nascença (cf. Jo 9, 3). Também seria importante não ligar exclusivamente a morte como maturação da enfermidade, pois nem sempre estão diretamente ligadas. O que parece dever

\footnotetext{
${ }^{1281}$ DUFFIELD, P. G.; CLEAVE, N. M. V. Fundamentos da teologia pentecostal, vol. II, p. 169.

${ }^{1282}$ DUFFIELD, P. G.; CLEAVE, N. M. V. Fundamentos da teologia pentecostal, vol. II, p. 169.

${ }^{1283}$ DUFFIELD, P. G.; CLEAVE, N. M. V. Fundamentos da teologia pentecostal, vol. II, p. 181.

${ }^{1284}$ DUFFIELD, P. G.; CLEAVE, N. M. V. Fundamentos da teologia pentecostal, vol. II, p. 203.

${ }^{1285}$ DUFFIELD, P. G.; CLEAVE, N. M. V. Fundamentos da teologia pentecostal, vol. II, p. 206.

${ }^{1286}$ DUFFIELD, P. G.; CLEAVE, N. M. V. Fundamentos da teologia pentecostal, vol. II, p. 209.
} 
prevalecer é que se o mal da doença ou o da morte aparecem antes como consequências de pecado original, e a redenção seja em perspectiva completa do ser humano de modo integral, o fato é que a fé deve se reportar a uma esperança de redenção total e à vontade divina de curar o ser humano de modo total. A cura em primeiro momento é sanar problemas do ser humano na sua saúde física ou espiritual. Seria como uma superação ou libertação de males.

A IEQ se reportaria a milagres de cura no evangelho ou em outros livros do Novo Terstamento. Pode-se pensar, no entanto, que nem sempre a cura seja propriamente um milagre, no sentido de algo inexplicável humanamente. Por outro lado, nem sempre se pode oferecer a cura para os males. Sobre isso existem controvérsias. A mensagem do evangelho sobre libertação e curas deve ser aprofundada, para que não se façam interpretações simplistas ou inadequadas.

A questão taumatúrgica tornou-se avessa entre muitos, principalmente no campo das pesquisas sobre ciências e religiões, pois são muitos os exageros e a manipulação, que causam verdadeiros escândalos, a ponto de muitos já não acreditarem, nem mesmo dentro da IEQ, na própria proposição do tema: “diversos falsos cultos ensinam realmente um tipo de cura, mas suas doutrinas de cura estão longe de serem semelhantes à doutrina ortodoxa, bíblica, da cura divina”. ${ }^{1287}$ As denominações que creem sinceramente e buscam práticas de fé em relação à cura devem se posicionar contra as falsidades em torno do assunto: "além do mais, a cura ensinada pela maioria dos falsos cultos não é divina, mas uma vitória da mente sobre a matéria, uma cura psíquica". ${ }^{1288}$ Uma cura de ordem psíquica não seria em si uma coisa má, porém não cabe julgar como milagres os passos de ordem natural que são compreensíveis no conjunto das ciências.

Na perspectiva quadrangular, o ápice da experiência da fé cristã não é a cura divina, e sim a salvação. No entanto, essa perspectiva compreende que a cura também faz parte do Evangelho da salvação: “omitir a mensagem da cura é pregar um Evangelho parcial. As boas novas da Salvação também se referem ao corpo mortal que foi remido por um preço (1Co 6:19-20)". ${ }^{1289}$ Está claro, portanto, que a cura não é em nada dissociada dos demais atributos do Evangelho, como afirma Duffield e Cleave: "finalmente, é necessário advertir que a cura jamais deve ser

\footnotetext{
${ }^{1287}$ DUFFIELD, P. G.; CLEAVE, N. M. V. Fundamentos da teologia pentecostal, vol. II, p. 210.

${ }^{1288}$ DUFFIELD, P. G.; CLEAVE, N. M. V. Fundamentos da teologia pentecostal, vol. II, p. 211.

${ }^{1289}$ DUFFIELD, P. G.; CLEAVE, N. M. V. Fundamentos da teologia pentecostal, vol. II, p. 212.
} 
pregada separadamente da redenção da alma e de outras verdades fundamentais do evangelho. A cura não é um evangelho em si mesma, ela é um aspecto do evangelho de Cristo". ${ }^{1290}$

Nesse caso, se Deus é justo, por que nem todos alcançam a graça da cura? Duffield e Cleave questionam:

Se o Senhor é Javé, nosso Médico, e nunca muda; se a cura é provida na expiação de Jesus Cristo; se a doença é obra do diabo e Jesus foi manifestado para destruir as obras de Satanás; se Deus é Todo-poderoso; se o Senhor é cheio de compaixão, por que então nem todos por quem são feitas orações recebem cura instantâneas de suas doenças?. ${ }^{1291}$

Isso não parece justo da parte de Deus, mas os quadrangulares não atribuem essa responsabilidade a Deus, como esclarece Duffield e Cleave:

Devemos concluir que a falha não é de Deus. Ela deve ser do homem; seja da pessoa pela qual se faz oração, seja daqueles que oram. Devemos compreender, no entanto, que a cura do corpo, por mais maravilhosa que seja, não é a coisa mais importante que pode acontecer a uma pessoa. A salvação e o crescimento espiritual são mais importantes que a saúde física. Haverá, sem dúvida, ocasiões em que a bênção espiritual deve ter precedência sobre a física. Cremos sinceramente que Deus quer que seus filhos gozem ambos os benefícios em sua plenitude, mas algumas vezes surgem impedimentos. ${ }^{1292}$

A cura é parte da mensagem quadrangular, e o objeto desta pesquisa reside justamente em considerar o seu discurso, mas não se vai verificar a confirmação das curas em si. O crescimento e a expansão dessa denominação pentecostal estão sendo orientadas pela sua atuação missionária, que anuncia a cura divina, mas não somente a cura. Ou seja, nuncia a salvação e considera que ela pode trazer curas ou outras formas de libertação.

Quando os quadrangulares apresentam o exemplo do Cristo e dos primeiros cristãos, destacando sua prontidão para a cura, evidencia-se um aspecto de cuidado e de compaixão diante do sofrimento humano. Parece que esse aspecto é o mais importante a se desenvolver hoje: ou seja, não somente a busca de curas, que podem ser muitas vezes pelas ciências médicas, mas trata-se de valorizar todas as formas de cuidado e de compaixão, como foi dito acima.

${ }^{1290}$ DUFFIELD, P. G.; CLEAVE, N. M. V. Fundamentos da teologia pentecostal, vol. II, p. 212.
${ }^{1291}$ DUFFIELD, P. G.; CLEAVE, N. M. V. Fundamentos da teologia pentecostal, vol. II, p. 191.
${ }^{1292}$ DUFFIELD, P. G.; CLEAVE, N. M. V. Fundamentos da teologia pentecostal, vol. II, p. 191. 
$\mathrm{Na}$ atualidade, são muitos os sofrimentos humanos carentes de gestos de atenção ao outro. Assim, sugere-se a expansão da dimensão da cura para a do cuidado. A cura das pessoas poderia ser vista não somente como cura de enfermidades, mas em relação com cuidados sobre todos os tipos de sofrimento. Haveria também uma cura da sociedade e até do planeta, que estaria no âmbito da responsabilidade com a vida, ou seja, no cuidado com o comum, que diz respeito à vida de todos. Não seriam milagres, mas ações de cuidado e trabalho em favor da vida e do bem comum.

Os quadrangulares encarnam a taumaturgia como essencial, não somente à missão, mas como à igreja inteira, a ponto de rejeitarem completamente qualquer ação que não reivindique esse princípio, como afirma Duffield e Cleave: “a cura é tão comum no ministério de Jesus e no dos apóstolos que uma igreja sem o dom de 'curas' pareceria bastante afastada do padrão bíblico". ${ }^{1293}$ Comblin se pronunciou pelas libertações dos males e sofrimentos, e assim também das curas que Jesus realizou. Ele se mantém cauteloso pela transmissão oral dos relatos sobre a ação de Jesus. Para ele, os fatos podem ter sido superestimados, embora concorde com a ausência de contradições na prática taumatúrgica de Jesus: "podese imaginar que na descrição dos milagres a tradição oral tenha amplificado os fatos e que os primeiros escritos recolheram visões populares do acontecido. Mas não se pode duvidar que Jesus tenha sido taumaturgo". ${ }^{1294}$ Embora esta pesquisa não tenha visto uma frase explícita de Comblin sobre esse ponto em relação com a IEQ, pode-se supor que a teologia dele concorda com a percepção da Igreja Quadrangular de que Jesus foi taumaturgo, também para curas, e eis aqui um ponto de contato entre a hermenêutica quadrangular e Comblin, assim como o conceito que torna a missão da Igreja Quadrangular tão popular entre as massas. Bosch afirma: "missão significa servir, curar e reconciliar uma humanidade dividida e machucada". ${ }^{1295}$ O tema da cura, portanto, se relaciona com a ação de Jesus e pode ser visto com essa ação de Jesus libertadora em vários aspectos obra de caridade e compaixão. Comblin acentua a ação libertadora.

Os quadrangulares vêm propagando e incentivando a taumaturgia, em sua liturgia, suas canções e suas estratégias de missão, como afirma Duffield e

\footnotetext{
${ }^{1293}$ DUFFIELD, P. G.; CLEAVE, N. M. V. Fundamentos da teologia pentecostal, vol. II, p. 100.

${ }^{1294}$ COMBLIN, J. Sinais dos novos tempos, p. 584.

${ }^{1295}$ BOSCH, D, J. Missão transformadora, p. 589.
} 
Cleave: “a cláusula 'aqueles que crêem' sugere que os sinais ou 'dons' não deveriam ser exercidos pelos apóstolos apenas, mas por todos os que tivessem fé". ${ }^{1296}$ Aqui a teologia quadrangular possibilita a taumaturgia a todos, não somente à liderança, mas também aos leigos. É exatamente essa amplitude que fez da Igreja do Evangelho Quadrangular uma das maiores denominações do pentecostalismo clássico. O exercício da taumaturgia, respaldado pela fé, é reconhecido por Comblin em Jesus, mas ele alerta que Jesus não buscou essa atividade, aceitando essa condição ao ser visto como taumatúrgico, tentando mesmo fugir, mas sendo ao fim movido pela dor do outro:

Ele aceitou ser visto como taumaturgo. O povo vinha a ele esperando milagres e Jesus se prestou a essa relação. Aceitou o papel de taumaturgo, ainda que não o tenha procurado voluntariamente. Alguns textos insinuam que ele trata de fugir, mas globalmente fez os milagres. Foi movido pela compaixão e não anuncia outra coisa aos que cura. ${ }^{1297}$

$\mathrm{Na}$ teologia quadrangular fica evidente o esforço de construção do exercício missionário baseado na taumaturgia. Esse viés leva o pentecostal a encarnar uma ação missionária que transforma vidas, como afirma Duffield e Cleave: "no mandamento e promessa de Jesus, a 'imposição de mãos' deveria ser a expressão externa da fé e amor por parte dos que orassem e mostraria que Deus usa os crentes fiéis como canal do seu poder". ${ }^{1298}$ Tocar os doentes é gesto de compaixão pelo próximo que revela o amor de Deus. Exercitar a cura divina, na perspectiva quadrangular, é anunciar o Evangelho do Reino e cumprir as promessas do Cristo quanto aos sinais que seguiriam aos que creem.

Esta pesquisa propõe que a ideia da teologia da IEQ de fazer referências às curas, aos gestos e aos sinais que Jesus realizou no evangelho poderia também ser complementada ou aperfeiçoada com esses outros aspectos de ação libertadora: de curas, mas não necessariamente milagres (que não podem ser garantidos), mas ações também curativas ou de caridade e compaixão, ou ainda, todas as ações pelo bem das pessoas e até do conjunto do planeta como casa de todos, como se verá na próxima seção deste capítulo.

Outra discussão aparece nos questionamentos de Comblin, que também se contrapõem: "afinal de contas, temos que dizer, como Jó, no fim das suas

${ }^{1296}$ DUFFIELD, P. G.; CLEAVE, N. M. V. Fundamentos da teologia pentecostal, vol. II, p. 100.

${ }^{1297}$ COMBLIN, J. Sinais dos novos tempos, p. 584.

${ }^{1298}$ DUFFIELD, P. G.; CLEAVE, N. M. V. Fundamentos da teologia pentecostal, vol. II, p. 100. 
provocações, que há na doença, sobretudo na doença das crianças, dos seres humanos incompletamente formados etc., sofrimentos que não podemos nem justificar, nem explicar". ${ }^{1299}$ Algo parece fugir do entendimento humano, esvaziando as tentativas de explicar. Daí sua discordância: “cura os doentes e estes saem felizes, mas não receberam uma mensagem mais explícita, não receberam a mensagem recolhida pelos discípulos. Taumaturgos havia em todos os países." 1300 Para ele, trata-se de uma mensagem incompleta, embora não negasse o alívio daqueles que recebiam a cura. Os quadrangulares não são tão pessimistas quanto Comblin, em sua generalização. A teologia e a estrutura organizacional da Igreja do Evangelho Quadrangular, como foi tratado mais acima, têm em grande estima a taumaturgia, como explica Duffield e Cleave:

\begin{abstract}
A seção quatorze da Declaração de fé da Igreja Internacional do Evangelho Quadrangular afirma: "Cremos que a cura divina é o poder do Senhor Jesus Cristo para curar os enfermos e aflitos, em resposta à oração sincera; que Ele, sendo o mesmo ontem, hoje e para sempre, jamais mudou, mas é, ainda, um auxílio plenamente suficiente na hora da dor, capaz de saciar as necessidades, vivificar o corpo, a alma e o espírito a uma novidade de vida, em resposta à fé daqueles que oram com submissão à Sua vontade. Esta preciosa doutrina engloba uma quarta parte do Evangelho Quadrangular e não deve ser negligenciada por aqueles que ministram a Palavra de Deus. ${ }^{1301}$
\end{abstract}

Tal relato mostra a importância da taumaturgia no pentecostalismo quadrangular e se mostra relevante a ponto de integrar a base do Evangelho Quadrangular, estruturado nas quatro doutrinas cardinais do construto teológico e missionário quadrangular. Comblin vê a situação como parte de toda religião popular: "o milagre é parte de todas as religiões e as massas populares buscam o milagre. Jesus entra na dinâmica do milagre, na religião do milagre". ${ }^{1302}$ Concluise, então, que esse elemento torna popular a missão quadrangular, cujos seguidores encontram no Cristo inspiração para a propagação da ação missionária, já que a cura divina, na visão quadrangular, liga-se diretamente à atuação do Espírito sobre o crente, como assinala Duffield e Cleave:

Enquanto se achava na sinagoga em Nazaré, Jesus abriu o rolo do profeta Isaías no capítulo 61 e começou a ler a mensagem profética que descrevia o seu ministério

\footnotetext{
${ }^{1299}$ COMBLIN, J. A sabedoria cristã, p. 201.

${ }^{1300}$ COMBLIN, J. Sinais dos novos tempos, p. 584.

${ }^{1301}$ DUFFIELD, P. G.; CLEAVE, N. M. V., Fundamentos da teologia pentecostal, vol. II, p. 137.

${ }^{1302}$ COMBLIN, J. Sinais dos novos tempos, p. 584.
} 
terreno. "O Espírito do Senhor está sobre mim, pelo que me ungiu para evangelizar aos pobres [...] para proclamar libertação aos cativos e restauração da vista aos cegos, para pôr em liberdade os oprimidos [...]" (Lc 4:18). ${ }^{1303}$

A Igreja do Evangelho Quadrangular interpreta o texto de Lc 4,18 em uma perspectiva na qual enfatiza a cura, enquanto Comblin prioriza a libertação, como deixa claro: "os milagres são sinais do Reino de Deus, mas não aparecem necessariamente assim para os doentes que ficam curados. Para eles o reino de Deus é a saúde recuperada, e não vão mais longe". ${ }^{1304}$ Para Comblin, a missão estabelecida sob o conceito da taumaturgia não alcança o propósito, não leva o doente à plenitude do Reino de Deus, pois a cura torna-se o Reino para quem a recebeu. Isso, para ele, é de certa forma empecilho ao curado, fazendo da cura um fim em si mesmo:

O sinal do reino de Deus será a ausência de doentes. Entre os sinais messiânicos está a superação de todas as doenças. A saúde é parte fundamental da vida: saúde é qualidade de vida superior. Ela é a aspiração fundamental. Com razão as pessoas apreciam-na como o maior de todos os bens nesta terra. ${ }^{1305}$

Por isso ele afirma que os milagres são sinais. Esse é o único ponto de aproximação com a percepção quadrangular: "na Grande Comissão registrada por Marcos (Mc 16:15-18), Jesus prometeu que sinais seguiriam os ministérios que dessem testemunho do evangelho da salvação". ${ }^{1306}$

Para Comblin, as igrejas pentecostais oferecem os milagres, e ao dizer isso ele afirma que o pentecostalismo apresenta sinais do Reino de Deus entre os aflitos: "as igrejas pentecostais oferecem os milagres. Oferecem uma resposta às massas humanas angustiadas por problemas urgentes, dolorosos. Se não houvesse os milagres de Deus, as massas não teriam esperança nenhuma". ${ }^{1307}$ A missão pentecostal volta-se às massas, palco de grandes tensões sociais, indicando a esperança a quem sofre. Os quadrangulares veem o quadro geral da seguinte maneira: "o propósito dos dons espirituais é a edificação da igreja. Se a prática dos dons não edificar o corpo, ele não tem valor". ${ }^{1308}$ Não é possível analisar a missão quadrangular dissociando-a da taumaturgia, pois desde a fundação a

\footnotetext{
${ }^{1303}$ DUFFIELD, P. G.; CLEAVE, N. M. V., Fundamentos da teologia pentecostal, vol. II, p. 144.

${ }^{1304}$ COMBLIN, J. Sinais dos novos tempos, p. 584.

${ }^{1305}$ COMBLIN, J. A sabedoria crista, p. 202.

${ }^{1306}$ DUFFIELD, P. G.; CLEAVE, N. M. V. Fundamentos da teologia pentecostal, vol. II, p. 100.

${ }^{1307}$ COMBLIN, J. Sinais dos novos tempos, p. 585.

${ }^{1308}$ DUFFIELD, P. G.; CLEAVE, N. M. V. Fundamentos da teologia pentecostal, vol. II, p. 94.
} 
denominação tem construído sua pauta missionária a partir dessa prática, como lembra Kirk: "muito do crescimento é acompanhado por um ministério maciço de cura através da imposição de mãos e oração. Existe uma expectativa de que Deus agirá diretamente". ${ }^{1309}$ Na perspectiva combliniana, quem recebe a cura em uma igreja pentecostal atribui o fato a Jesus: "nas Igrejas pentecostais as massas recebem milhares e milhares de milagres, qualquer que seja a explicação científica que se possa dar ao fato. Em todo caso, para as pessoas favorecidas, não há dúvida: foi Jesus quem me curou". ${ }^{1310} \mathrm{O}$ pentecostalismo quadrangular tenta recuperar em sua missão a taumaturgia por vezes contestada na própria tradição cristã, mas a temática tornou-se atrativa em sua atuação missionária e encontrou recepção na sociedade. Esse fato, atribuído à ação do Espírito, produz uma dinâmica comunicativa às massas.

Os quadrangulares insistem em que as raízes para esses acontecimentos estão na atuação do Espírito, como foi em Jesus. Duffield e Cleave lembram: "Jesus declarou ter sido especialmente ungido para o seu ministério de pregação (Lc 4:18,19). Se isto foi necessário para Ele, certamente o será para todos os servos menores da Cruz". ${ }^{1311}$ Comblin, por seu turno, indaga da adesão das massas as igrejas pentecostais. Não se trata dos milagres, dada a sua recorrência em outras tradições. No entanto, segundo Comblin, a busca das massas pelo segmento tradicional vem perdendo força: "por que as massas procuram os milagres nas Igrejas pentecostais e não os procuram mais nas tradições católicas, com os santos católicos tradicionais? Em primeiro lugar, ainda há uma maioria que recorre aos milagres católicos. No entanto, essa maioria vai diminuindo de forma acelerada". 1312

Comblin alerta para um assunto bem recorrente na missão do presente tempo, o desafio lançado às igrejas históricas pelo pentecostalismo, que vem tomando proporções e apontando um caminho sem volta ao cristianismo contemporâneo. Afora a questão da taumaturgia, Duffield e Cleave retoma a origem do sentido da missão pentecostal, cuja centralidade é a concessão do Espírito para a propagação do Evangelho no poder do Espírito:

\footnotetext{
${ }^{1309}$ KIRK, J. A. O que é missão?, p. 288.

${ }^{1310}$ COMBLIN, J. Sinais dos novos tempos, p. 585.

${ }^{1311}$ DUFFIELD, P. G.; CLEAVE, N. M. V. Fundamentos da teologia pentecostal, vol. II, p. 24.

${ }^{1312}$ COMBLIN, J. Sinais dos novos tempos, p. 585.
} 
Esta é a mensagem do pregador, e Deus deu o Espírito Santo para conceder poder à pregação. É o Evangelho de Jesus Cristo, e não o milagre que o acompanha, que é o poder de Deus para a salvação (Rm 1:16,17). Nós, que vibramos com a mensagem do Pentecostes, jamais deveríamos deixar de ter em mente este pensamento!". ${ }^{1313}$

A Igreja Quadrangular, assim, não se centra no milagre como, mas o considera que pode sinal que acompanha a anunciação do Evangelho no poder do Espírito Santo: “esse foi o padrão da experiência pentecostal". ${ }^{1314}$ Por isso, na perspectiva missionária da Igreja Quadrangular, os milagres acontecem como ação subsequente à pregação do Evangelho, outra missão do Espírito, como conclui Comblin: "hoje em dia há de existir o dom de curar os doentes, se existiu nas origens da Igreja. De fato, notamos que muitas pessoas têm o dom de curar por meios extraordinários, que não são simplesmente os da medicina". ${ }^{1315}$

Se a missão atual é uma missão do Espírito, a cura divina é parte dessa missão, não se podendo aceitar um Espírito meramente direcionado a questões sociais. Essa vertente importa muito, é parte da agenda missionária, mas a reivindicação dos milagres aponta para a missão que age na força do Espírito.

Porém, seja para uma atuação missionária que pretenda seguir uma compreensão de curas ou de taumaturgia, como na IEQ, seja na perspectiva de Comblin de atuar com libertação pela ação do Espírito, não se pode reivindicar ou agir na pretensão de se fazer milagres ou prometer milagres, só por se estar anunciando um evangelho de libertação e de ação do Espírito. Existe a fé no Espírito, mas não se pode interpretar a ação do Espírito na forma de que nossa missão seja capaz de fazer ou garantir milagres, de cura ou de outras situações.

A missão, na perspectiva de Comblin, é libertação. A missão comblianiana abarca tudo quanto diz respeito a justiça e vida, como atos de liberdade. Assim, para o autor, missão é prática que emancipa a vida, e nesse sentido, as Boas Novas transformam a realidade.

A missão, na perspectiva da Igreja do Evangelho Quadrangular, é uma ação pneumatológica. As Boas Novas iniciam-se com forte ênfase taumatúrgica que passa a integrar a mensagem quadrangular, e isso tem sido o eixo de sua missão, desde a mensagem evangelizadora até os fundamentos de suas doutrinas. Por isso também se pode atribuir à missão da IEQ um ato libertador, pois ao assumir o

\footnotetext{
${ }^{1313}$ DUFFIELD, P. G.; CLEAVE, N. M. V. Fundamentos da teologia pentecostal, vol. II, p. 24.

${ }^{1314}$ DUFFIELD, P. G.; CLEAVE, N. M. V., Fundamentos da teologia pentecostal, vol. II, p. 80.

${ }^{1315}$ COMBLIN, J., A sabedoria crista, p. 205.
} 
engajamento por transformação em torno da taumaturgia, ela proclama ações de libertação.

Em Comblin, a missão é libertação, conduzida na força do Espírito; já para os quadrangulares, a missão é o Espírito executando práticas libertadoras. Ambos os conceitos apontam para a transformação, mas diferem na ordem sequencial que estrutura as respectivas missões. Para a IEQ, a missão se concretiza como atos sequenciais de ações do Espírito, até mesmo os atos de evangelização. Para Comblin, a liberdade é um ato concreto que corrponde á atuação do Espírito.

Constatam-se elementos comuns, entretanto o fim, ou resultado final dessas missões, também difere: enquanto em Comblin as ações do Espírito rompem com atos de injustiça, estabelecendo ações concretas que alteram a realidade, mas priorizando uma pauta de cunho mais social e político, a mensagem evangelizadora quadrangular concentra-se na ação do Espírito que liberta prioritariamente o indivíduo, pois a taumaturgia, a glossolalia e o exorcismo são práticas libertadoras pessoais. Conclui-se que a missão comblianiana é mais ampla e a missão quadrangular, e uma aplicação mais estrita. Podemos pensar que existe um contato no aspecto libertador e poderia existir uma complementação das várias dimensões de libertação, sociais e individuais.

Na noção de evangelização da Evangelii Nuntiandi, Paulo VI que toda ação corresponde ao evangelho. O evangelho tem dimensão libertadora. Também o Papa Francisco, na exortação Evangelii Gaudium, fala em evangelização e missão, com ação e anúncio. A Igreja Quadrangular e Comblin propõem, em aspectos diversos, o anúncio e a ação de libertação e cura. Anúncio e ação são importantes no contexto atual, de necessidade de cuidado do indivíduo, da sociedade e de toda a criação.

Evangelizar é proclamar Cristo. O conceito de evangelização, na percepção católica, passa pela Evangelii Nuntiandi, como Paulo define VI: "pode-se assim definir a evangelização em termos de anúncio de Cristo àqueles que o desconhecem, de pregação, de catequese, de batismo e de outros sacramentos que hão de ser conferidos". ${ }^{1316} \mathrm{O}$ anúncio de Cristo é ato evangelizador que proporciona novidade de vida, transformando a realidade do indivíduo

\footnotetext{
${ }^{1316}$ PAULO VI, PP. Exortação Apostólica Evangelli Nuntiandi do Papa Paulo VI ao Episcopado, ao Clero aos Fiéis de Toda a Igreja Sobre a Evangelização no Mundo Contemporâneo. p. 7.
} 
evangelizado ao alterar sua vivência no mundo. Consequentemente, esses atos também transformam a realidade de onde o evangelho é proclamado. É verdade que o anúncio de Cristo abarca outras questões que se somam à ação evangelizadora, ainda em Paulo VI:

18. Evangelizar, para a Igreja, é levar a Boa Nova a todas as parcelas da humanidade, em qualquer meio e latitude, e pelo seu influxo transformá-las a partir de dentro e tornar nova a própria humanidade: "Eis que faço de novo todas as coisas". (46) No entanto não haverá humanidade nova, se não houver em primeiro lugar homens novos, pela novidade do batismo (47) e da vida segundo o Evangelho. (48) A finalidade da evangelização, portanto, é precisamente esta mudança interior; e se fosse necessário traduzir isso em breves termos, o mais exato seria dizer que a Igreja evangeliza quando, unicamente firmada na potência divina da mensagem que proclama, (49) ela procura converter ao mesmo tempo a consciência pessoal e coletiva dos homens, a atividade em que eles se aplicam, e a vida e o meio concreto que lhes são próprios. ${ }^{1317}$

É importante perceber o significado da evangelização para além de Comblin no ambiente católico, e a partir desse exame a pesquisa poderá contextualizar seu diálogo entre pentecostalismo e catolicismo. O Papa Francisco, na exortação Evangelii Gaudium, contribui com o tema: "111. A evangelização é dever da Igreja. Este sujeito da evangelização, porém, é mais do que uma instituição orgânica e hierárquica; é, antes de tudo, um povo que peregrina para Deus". ${ }^{1318}$ A evangelização como tarefa de toda a igreja cumpre o mandato de Cristo. Assim, evangelizar, para Francisco, também é a pregação do Evangelho:

19. A evangelização obedece ao mandato missionário de Jesus: «Ide, pois, fazei discípulos de todos os povos, baptizando-os em nome do Pai, do Filho e do Espírito Santo, ensinando-os a cumprir tudo quanto vos tenho mandado» (Mt 28, 19-20). Nestes versículos, aparece o momento em que o Ressuscitado envia os seus a pregar o Evangelho em todos os tempos e lugares, para que a fé n'Ele se estenda a todos os cantos da terra. ${ }^{1319}$

Tais afirmações prestam-se a contextualizar a hipótese desta pesquisa sobre a participação dos leigos na ação evangelizadora que também encontra reflexão em Paulo VI: "70. Os leigos, a quem a sua vocação específica coloca no meio do mundo e à frente de tarefas as mais variadas na ordem temporal, devem também

\footnotetext{
${ }^{1317}$ PAULO VI, PP. Exortação Apostólica Evangelli Nuntiandi, p. 7.

${ }^{1318}$ PAULO VI, PP. Exortação Apostólica Evangelli Nuntiandi, p. 89.

${ }^{1319}$ FRANCISCO, PP. Exortação apostólica Evangelii Gaudium, sobre o anúncio do Evangelho no mundo atual. p. 19.
} 
eles, através disso mesmo, atuar uma singular forma de evangelização". ${ }^{1320}$ A ação evangelizadora em investigação também é pneumatológica, pois Paulo VI afirma que não é possível evangelizar sem a ação do Espírito Santo, já que foi na força do Espírito que a missão aconteceu em Cristo: “75. Nunca será possível haver evangelização sem a ação do Espírito Santo. Sobre Jesus de Nazaré, esse Espírito desceu no momento do batismo, ao mesmo tempo que a voz do Pai, 'Este é o meu Filho amado, em quem me comprazo', (107) manifestava de maneira sensível a eleição e a missão do mesmo Jesus". ${ }^{1321}$ No mesmo seguimento de Paulo VI, Francisco enfatiza a atribuição do Espírito na ação evangelizadora e acentua a questão da transformação e da libertação na anunciação da Boa Nova que acontece na força do Espírito:

259. Evangelizadores com espírito quer dizer evangelizadores que se abrem sem medo à acção do Espírito Santo. No Pentecostes, o Espírito faz os Apóstolos saírem de si mesmos e transforma-os em anunciadores das maravilhas de Deus, que cada um começa a entender na própria língua. Além disso, o Espírito Santo infunde a força para anunciar a novidade do Evangelho com ousadia (parresia), em voz alta e em todo o tempo e lugar, mesmo contra-corrente. Invoquemo-Lo hoje, bem apoiados na oração, sem a qual toda a acção corre o risco de ficar vã e o anúncio, no fim de contas, carece de alma. Jesus quer evangelizadores que anunciem a Boa Nova, não só com palavras mas sobretudo com uma vida transfigurada pela presença de Deus. ${ }^{1322}$

O tema da missão e da evangelização tem sido examinado neste trabalho a fim de unir em diálogo e ação todos que testemunham do evangelho anunciado pelo Cristo para que, por meio de gestos e atitudes de colaboração entre cristãos, se possa chegar à mensagem do Cristo encarnado. Para Paulo VI: “o testamento espiritual do Senhor diz-nos que a unidade entre os fiéis que o seguem, não somente é a prova de que nós somos seus, mas também a prova de que ele foi enviado pelo Pai, critério de credibilidade dos mesmos cristãos e do próprio Cristo". ${ }^{1323}$ Na Carta Encíclica Laudato Si Francisco convoca a reflexão da unidade, em testemunho de evangelização, mas, sobretudo, em ação, chamando à responsabilidade para com o planeta, reconhecendo a urgente necessidade da ação missionária para com a vida:

\footnotetext{
${ }^{1320}$ PAULO VI, PP. Exortação Apostólica Evangelli Nuntiandi, p. 30.

${ }^{1321}$ PAULO VI, PP. Exortação Apostólica Evangelli Nuntiandi, p. 32.

${ }^{1322}$ FRANCISCO, PP. Exortação apostólica Evangelii Gaudium, p. 195.

${ }^{1323}$ PAULO VI, PP. Exortação Apostólica Evangelli Nuntiandi, p. 35.
} 
13. O urgente desafio de proteger a nossa casa comum inclui a preocupação de unir toda a família humana na busca de um desenvolvimento sustentável e integral, pois sabemos que as coisas podem mudar. O Criador não nos abandona, nunca recua no seu projecto de amor, nem Se arrepende de nos ter criado. A humanidade possui ainda a capacidade de colaborar na construção da nossa casa comum. ${ }^{1324}$

A missão de evangelizar incorpora a responsabilidade para com a casa comum, envolvendo todos. São vários os desafios que se apresentam à evangelização nos dias atuais, por isso se torna impossível presumir que as soluções surgiram de um único caminho, cabendo aos cristãos, em sua amplitude, ultrapassar os limites denominacionais para alcançar o direito à vida. Na Carta Encíclica Laudato Si, Francisco afirma: "157. O bem comum pressupõe o respeito pela pessoa humana enquanto tal, com direitos fundamentais e inalienáveis orientados para o seu desenvolvimento integral". ${ }^{1325}$ É importante destacar que a percepção de missão defendida pela IEQ está diretamente associada à sua pneumatologia, entretanto, na atualidade, cobram-se muitos métodos e caminhos para a evangelização eficaz, ignorando-se que para Paulo VI, todas as empreitadas de evangelização só surtem efeito sob ação do Espírito Santo. Eis aqui outro profundo diálogo católico com os pentecostais da IEQ, que percebem similarmente a ação evangelizadora. A abertura ao diálogo encontra-se na Evangelli Nuntiandi:

As técnicas da evangelização são boas, obviamente; mas, ainda as mais
aperfeiçoadas não poderiam substituir a ação discreta do Espírito Santo. A
preparação mais apurada do evangelizador nada faz sem ele. De igual modo, a
dialética mais convincente, sem ele, permanece impotente em relação ao espírito
dos homens. E, ainda, os mais bem elaborados esquemas com base sociológica e
psicológica, sem ele, em breve se demonstram desprovidos de valor. ${ }^{1326}$

Nesta parte do trabalho busca-se compreender de maneira mais abrangente o conceito de evangelização na percepção católica, o que requereu esclarecimento para além da percepção comblianiana. A Exortação Apostólica Evangelli Nuntiandi esclarece: "nenhuma definição parcial e fragmentária, porém, chegará a dar a razão da realidade rica, complexa e dinâmica que é a evangelização, a não

\footnotetext{
${ }^{1324}$ FRANCISCO, PP. Carta encíclica Laudato Si', sobre o cuidado da casa comum, p. 12.

${ }^{1325}$ FRANCISCO, PP. Carta encíclica Laudato Si', p. 121.

${ }^{1326}$ PAULO VI, PP. Exortação Apostólica Evangelli Nuntiandi, p. 33.
} 
ser com o risco de a empobrecer e até mesmo de a mutilar". ${ }^{1327}$ Mesmo que evangelização seja dinâmica, ela parte da percepção das Boas Novas.

\section{2. \\ Sugestões para aprofundamentos}

A última parte do capítulo tem por objetivo apontar sugestões de aprofundamentos na questão missionária, explicitando as possíveis contribuições do estudo para a pastoral missionária dinâmica, abrangendo também o leigo e superando o desafio do extremismo na missão ao aproximar duas práticas de missão pneumatológicas e comprometidas com a realidade.

\subsection{1. \\ Contribuições da Igreja do Evangelho Quadrangular para o enriquecimento da reflexão e prática da missão segundo a perspectiva apontada por Comblin}

O modelo de missão da Cruzada Nacional de Evangelização, movimento coordenado por missionários de doutrina quadrangular no Brasil, foi um dos maiores empreendimentos do pentecostalismo brasileiro, acompanhando o processo do êxodo rural rumo às grandes cidades, o que demonstra a boa adaptação da Cruzada Nacional de Evangelização ao novo cenário nacional. Foi exatamente nesse período que Williams fez sua primeira tentativa de estabelecerse em missão, organizando uma denominação. César lembra:

Naquele mesmo ano (1951), fundou a Igreja Evangélica do Brasil, de doutrina quadrangular, que era a mentora da Cruzada Nacional de Evangelização. Em 1958, sete anos depois, a igreja mudou de nome, passando a chamar-se Igreja do Evangelho Quadrangular, como nos Estados Unidos. ${ }^{1328}$

Durante a primeira década, esse modelo de missão uniu protestantes de diferentes denominações por meio das campanhas de cura divina nas tendas itinerantes. Vários elementos contribuíram para expansão do movimento, entre os

\footnotetext{
${ }^{1327}$ PAULO VI, PP. Exortação Apostólica Evangelli Nuntiandi, p. 7.

${ }^{1328}$ CÉSAR, Elben M. Lenz. História da evangelização do Brasil; dos jesuítas aos neopentecostais. Viçosa: Ultimato, 2000, p. 131.
} 
quais se destacam a novidade dos instrumentos musicais inseridos na liturgia, que envolviam o público durante o culto, a participação de diversas denominações, mostrando unidade e diálogo, e mesmo as tendas dos cultos, novidade no Brasil, assim como a participação do leigo nas atividades. Mas sem dúvida o principal elemento de expansão da Cruzada Nacional de Evangelização em terras brasileiras foi a cura divina, primeiramente associada à vida. A vida é dom e valor sagrado, como explica Cardoso:

A Igreja proclama o valor sagrado da vida. A vida é um dom primeiro e fundamental. Para a fé cristã, a vida humana é realidade preciosa e sagrada, seja por seu caráter de dom primeiro e fundamental, insubstituível, seja pela sua destinação de eternidade. ${ }^{1329}$

A cura divina na missão toca diretamente na vida das pessoas e determinou a comunicação com as massas necessitadas de bem-estar físico. "Somente pelo exercício de todos os dons, como algo necessário para a saúde e bem-estar de todo o corpo, pode haver crescimento até a idade madura". ${ }^{1330}$ Lembre-se que o avanço da missão da Cruzada Nacional de Evangelização pelo país se dá partir do estado de São Paulo, enfatizando-se a taumaturgia na explosão do crescimento da Cruzada Nacional de Evangelização, por intermédio de um missionário pregador de cura divina. César esclarece:

Desta vez o trabalho deslanchou, especialmente nos Estados de São Paulo e Paraná. Willians trouxe, algumas vezes, ao Brasil o evangelista e pregador de cura divina Raymond Boatright, seu amigo desde os tempos de seminário (o Life Bible College, fundado por Aumee McPherson, onde todos os primeiros líderes da denominação estudaram). ${ }^{1331}$

A prática desse tipo de missão tornou-se uma pauta, pois as denominações de grande popularidade têm destacado a propagação da taumaturgia, e nesse aspecto a CNE foi precursora, dado o alívio que proporcionou àqueles que sofriam. A prática da cura e do alívio do que sofre pode ser considerada uma prática do amor que um discípulo de Cristo deve abraçar. Como afirma Cardoso: "no seguimento de Cristo, o discípulo está no caminho do Mestre e este caminho é

${ }^{1329}$ CARDOSO, M. T. F. No sentido da vida. Em diálogo sobre a prevenção do suicídio. Atualidade Teológica Ano XV n ${ }^{\circ} 38$, maio a agosto/2011, p. 320.

${ }^{1330}$ KIRK, J. A. O que é missão?, p. 248.

${ }^{1331}$ CÉSAR, E, M. L. História da evangelização do Brasil, p.131. 
o do amor. O cristão encontra em Cristo uma motivação para amar a todos e para socorrer e aliviar a quem sofre". ${ }^{1332}$

A temática proporciona ao missionário a anunciação das Boas Novas de Cristo e quem recebe o alívio alcança salvação. A cura divina em missão parece personificar, nesse sentido, o próprio evangelho, e como Wright afirma, "o evangelho é a boa-nova que precisa ser ouvida e vista. Ela precisa de palavras e ações, mensagem e prova". ${ }^{1333}$ As campanhas de cura divina contavam com a atuação da dupla norte-americana Willians e Raymond Boatright. César continua: “o ex-caubói pregava e o ex-galã de cinema interpretava, primeiro em São João da Boa Vista, depois em São Paulo". ${ }^{1334}$ Essa mensagem encontrou recepção entre os brasileiros, num cenário urbano desenhado com as transformações sociais da época, que deixaram marcas em várias áreas, e para muitos a religiosidade tornouse um estilo de vida, sobre o que Amado esclarece: “[...] deparamo-nos com formas contemporâneas de prestação de serviços. Por certo, nossas dores muitas vezes só encontram acolhida no campo religioso, na relação com Deus". ${ }^{1335}$ Parece que naquela época a missão da Cruzada Nacional de Evangelização já tinha essa percepção e a mensagem da cura divina nas tendas foi assumindo proporções cada vez maiores. Os missionários trouxeram uma grande tenda dos Estados Unidos para o prosseguimento das campanhas, como lembra César:

Pouco depois, a dupla foi para Araçatuba, Presidente Prudente e Americana, no interior de São Paulo. A procura era tão grande e os lugares de reunião, tão pequenos, que Willians foi aos Estados Unidos para trazer uma tenda e um órgão Hammond. A tenda de 1.200 lugares foi usada pela primeira vez no bairro do Cambuci, em São Paulo, em fevereiro de $1954 .{ }^{1336}$

Percebe-se nessa ação missionária seu compromisso com a vida. Para atualizar a missão, é preciso dialogar com o contexto em vigor. Cardoso diz: "é natural querer viver, querer viver mais, querer viver melhor. O ser humano está voltado para uma plenitude de vida. É vocacionado para a vida eterna. Para participar da vida divina. Para ser feliz na comunhão do Amor". ${ }^{1337}$ A essência do

\footnotetext{
${ }^{1332}$ CARDOSO, M. T. F. No sentido da vida. Em diálogo sobre a prevenção do suicídio, p. 321.

${ }^{1333}$ WRIGHT, C, J. H. A missão do povo de Deus, p. 329.

${ }^{1334}$ CÉSAR, E. M. L. História da evangelização do Brasil, p.131.

${ }^{1335}$ AMADO, Joel Portella. O Documento de Aparecida e sua proposta para toda a Igreja. ATeo, Rio de Janeiro, v. 22, n. 58, p. 65-90, jan./abr.2018, p. 86.

${ }^{1336}$ CÉSAR, E. M. L. História da evangelização do Brasil, p. 131.

${ }^{1337}$ CARDOSO, M. T. F. No sentido da vida. Em diálogo sobre a prevenção do suicídio, p. 320.
} 
cuidado com a vida está na raiz da missão desenvolvida mediante a cura divina. Essa missão está comprometida com a restauração e mostra o poder e o amor do Espírito Santo. Mikuszka destaca: "a ação evangelizadora que explana a imagem do Deus misericordioso, cheio de amor, é coerente com o Evangelho. Jesus pede que os discípulos creiam que 'Deus é amor' (1Jo 4,8)". ${ }^{1338}$

Faz parte também da ação evangelizadora a preocupação dos primeiros missionários da Cruzada Nacional de Evangelização com o preparo teológico dos obreiros, tão relevante que muitos pesquisadores afirmam que a Igreja do Evangelho Quadrangular no Brasil organizou-se antes mesmo das tradicionais Assembleias de Deus já instaladas no Brasil pelo menos quarenta anos antes. César explica:

Diferente dos demais grupos pentecostais e bem antes das Assembléias de Deus, os quadrangulares encorajaram o preparo bíblico e teológico de seus obreiros. Em 1957, seis anos depois da organização da Igreja do Evangelho Quadrangular no Brasil, chegou a missionária Dorothy Marguerite Hawley para cuidar desta área. Ela fundou em São Paulo o Instituto Foursquare, atualmente chamado Instituto Teológico Quadrangular. ${ }^{1339}$

Também houve avanços significativos no ambiente da missão, como comenta Bosch: "a missão constitui um ministério multifacetado em termos de testemunho, serviço, justiça, cura, reconciliação, libertação, paz, evangelização, comunhão, implantação de igrejas, contextualização, etc". ${ }^{1340}$ A missão, assim, se abre ao diálogo e à recuperação da vida em todos os sentidos. Parece que a missão cujo fulcro é a cura divina pode se enquadrar nesse novo paradigma, pois intervém na dor e proporciona esperança. Lara acrescenta: "Comblin vai mais longe e chega a afirmar que a Palavra de Deus é mensagem revelada, que embora precise usar palavras como produto da cultura, ultrapassa os limites das palavras humanas". ${ }^{1341} \mathrm{O}$ apontamento para experiências taumatúrgicas e pneumatológicas faz parte da estrutura pentecostal, na qual tais princípios sempre estiveram associados aos seus empreendimentos missionários. Como explica Oliveira:

\footnotetext{
${ }^{1338}$ MIKUSZKA, Gelson Luiz. A Reforma Protestante e a ação evangelizadora da Igreja Católica. REB, Petrópolis, volume 77, número 305, p. 55-73, Jan./Mar. 2017, p. 67.

${ }^{1339}$ CÉSAR, E. M. L. História da evangelização do Brasil, p. 131.

${ }^{1340}$ BOSCH, D, J., Missão transformadora, p. 610.

${ }^{1341}$ LARA, V. L., Hermenêutica Bíblica para Compreender Paulo em Comblin, p. 656.
} 
As experiências espirituais apontam para uma missão marcada por sinais miraculosos: a maioria dos grandes projetos missionários pentecostais começa a partir de reuniões de oração, onde buscam orientações através de sonhos, visões e revelações específicas. ${ }^{1342}$

Essa marca sempre esteve presente na missão pentecostal em campanhas evangelísticas e na hermenêutica. Entretanto, o pentecostalismo em geral e especificamente a Igreja do Evangelho Quadrangular tem buscado novas frentes de atuação missionária. A denominação abandonou o movimento da Cruzada Nacional de Evangelização e seguiu o caminho convencional dos templos, onde, já a partir da segunda década no Brasil, verificava-se sua dinâmica, o que contribuiu para sua solidificação como organização religiosa. Porém, depois de meio século, a IEQ parece necessitar de nova dinâmica, pois os templos não têm conseguido dar voz à missão. Damazio, em Cruzando rios tomando cidades, uma publicação quadrangular utilizada para inspirar novas práticas de missão, apresenta novas sugestões: "Deus está chamando a Igreja para seguir os modelos bíblicos no templo e de casa em casa; tanto a corporação como a casa são padrões de Deus". ${ }^{1343}$ Para os comentadores de Comblin a questão vai além da leitura da Bíblia. E como Lara diz, "para Comblin, a leitura bíblica não é simples leitura de obra literária, é mais do que isso". ${ }^{1344}$ As preocupações com o desafio que se tornou realidade para a missão leva muitos pensadores a propor formas alternativas de comunidade. Para Comblin a vida cristã já não passa pela atividade do templo: "no cristianismo, os templos já não têm lugar". ${ }^{1345} \mathrm{O}$ autor compreende que os templo em geral é pouco utilizado pelo grande custo financeiro e propõe novas estruturas de comunidades, que serão retomadas adiante.

Entretanto, essa afirmação parece um contrassenso, pois o que se percebeu nas últimas décadas foi a explosão no surgimento de novos templos. Brasil alerta: "mesmo assim é necessário um lugar para a comunhão na cidade". ${ }^{1346} \mathrm{Na}$ história da missão a Igreja do Evangelho Quadrangular experimentou diversas faces da missão, mas apenas duas serão classificadas aqui. A primeira foi efetivada nas tendas de cura divina da Cruzada Nacional de Evangelização e a segunda, nos

\footnotetext{
${ }^{1342}$ OLIVEIRA, D. M. d. Pentecostalidade da Missão Latino-Americana, p. 96.

${ }^{1343}$ DAMAZIO, Frank. Cruzando rios, tomando cidades. São Paulo: Editora Quadrangular. 2001, p. 194.

${ }_{1344}$ LARA, V. L. Hermenêutica bíblica para compreender Paulo em Comblin, p. 658.

${ }^{1345}$ COMBLIN, José. Teologia da cidade. São Paulo: Paulinas, 1991, p. 256.

${ }^{1346}$ BRASIL, J, G. Missão e urbanização no século 21, p. 54.
} 
templos. Mas hoje a Quadrangular esboça uma atuação missionária que passa pelos grupos em casas ou células. A nomenclatura pode variar, mas a denominação tem buscado um equilíbrio, percebendo tanto a impossibilidade de retorno ao período das barracas itinerantes quanto a insuficiência da ação nos templos. O conceito inicia-se com a proposta de espalhar tipos de casa em missão, como esclarece Damazio:

Para construir casa gloriosas que se tornarão centros de ministério dinâmicos em nossos bairros e em nossas cidades, devemos adquirir uma visão, trabalhar diligentemente para mudar nossas ideias sobre nosso estilo de vida, cultivar um espírito de serviço e sacrifício. ${ }^{1347}$

A propagação de pequenas comunidades tem sido comum entre os evangélicos, com cada denominação construindo a própria dinâmica e produzindo as adaptações. Damazio explica o conceito na perspectiva quadrangular, mostrando um duplo objetivo: o cuidado de uns com os outros, que passa pelo relacionamento; e a estratégia de missão a ser alcançada com essas células:

Quando preparamos nossas casas espirituais e praticamente para se tornarem centros de ministério, é certo que iremos ministrar estrategicamente à vizinhança. Nossos centros de ministério, chamados Células Urbanas, são grupos pequenos de crentes que se reúnem com um propósito definido. Nossas Células têm propósito duplo: Célula da Vida Urbana e Célula de Evangelização Urbana. A Célula da Vida Urbana é encontrada em seus relacionamentos, no cuidado de uns pelos outros. A Célula de Evangelização Urbana é nossa estratégia para alcançar os vizinhos, as áreas geograficamente definidas de cada célula. ${ }^{1348}$

Pode-se acrescentar aqui a perspectiva comblianina do assunto: "seria outro erro crer que a Igreja local está destinada a dissolver-se em pequenas comunidades fervorosas [...]". ${ }^{1349}$ Não se trata de resumir toda a atividade da igreja a essas pequenas comunidades, mas de se somar, na visão de Damazio, esse trabalho às atividades já praticadas nos templos: "deliberamos estabelecer cada célula como um centro de ministério oferecendo a vida de Cristo: graça, perdão, esperança e amor. A célula se torna uma casa entre outras casas onde a glória de Deus habita." 1350 É importante destacar o conceito quadrangular de "casas", que representa mais uma ponte com a perspectiva combliniana. $\mathrm{O}$ autor católico utiliza

\footnotetext{
${ }^{1347}$ DAMAZIO, F. Cruzando rios, tomando cidades, p. 194.

${ }^{1348}$ DAMAZIO, F. Cruzando Rios, Tomando Cidades, p. 193.

${ }^{1349}$ COMBLIN, J. Teologia da cidade, p. 256.

${ }^{1350}$ DAMAZIO, F. Cruzando Rios, Tomando Cidades, p. 193.
} 
o mesmo termo para designar seu conceito de alternativas à ação missionária: “tampouco é necessário que sejam uniformes todas as 'casas da Igreja'. Ao contrário, serão tanto mais complementares quanto mais variadas". ${ }^{1351}$

Não se afirma aqui que as duas vertentes referem-se ao mesmo modelo. Mas é inegável que se de um lado temos um missionário católico envolvido e articulador da missão, do outro vigoram a prática e a história de uma grande denominação pentecostal. Em comum entre as partes está justamente o esforço de tornar a missão mais dinâmica e eficaz. A prática em pequenos grupos ou comunidades tem sido executada por muitas denominações, entretanto chama a atenção o termo aplicado tanto ao conceito combliniano e quanto ao quadrangular, percebendo-se que ambas as partes objetivam propagar o modelo. Damazio diz: "o objetivo é estabelecer centenas e milhares de casas como centros de glória, lugares onde Deus habita de maneira poderosa". ${ }^{1352} \mathrm{O}$ modelo apresentado por Comblin difere da percepção dos quadrangulares, pois para Comblin as paróquias deveriam se tornar comunidades pequenas, convicto que estava de que o templo já não encontrava lugar no cristianismo, enquanto os quadrangulares, mais moderados, compreendem que essas casas dariam apoio e somariam ao templo, sem determinar sua extinção.

Comblin chega a levantar possibilidades de identificação após a transformação de tais paróquias: "quanto às nossas paróquias transformadas, poderíamos pensar em chamá-las comunidades". ${ }^{1353}$ O autor percebe que o termo "pequenas comunidades" pode dar a entender que se trata das CEBs Comunidades Eclesiais de Base, por isso opta por outro termo de identificação:

Mas esse nome parece já reservado ao uso das pequenas comunidades de base, às microestruturas. Por isso propomos chamá-las "irmandades", nome que designa instituições bastante semelhantes ao que podemos esperar da transformação de nossas paróquias e do que necessitará a Igreja do futuro. ${ }^{1354}$

$\mathrm{Na}$ perspectiva combliniana o conceito passa a chamar-se "irmandades", apontando para o sentido aproximado do proposto por essas novas pequenas estruturas. Já o conceito dos quadrangulares parece propor a utilização da casa do crente, tornada a estrutura do modelo. Damazio esclarece:

\footnotetext{
${ }^{1351}$ COMBLIN, J. Teologia da cidade, p. 260.

${ }^{1352}$ DAMAZIO, F. Cruzando Rios, Tomando Cidades, p. 193.

${ }^{1353}$ COMBLIN, J. Teologia da cidade, p. 261.

${ }^{1354}$ COMBLIN, J. Teologia da cidade, p. 261.
} 
Convide a presença do Senhor para saturar sua habitação; sua casa pode então tornar-se como a Arca da aliança, um lugar onde Deus irá encontrar-se e falar com você (veja Êxodo 25:22; Números 7:89). Quando Deus está na casa, há uma atmosfera de adoração, alegria e esperança. Deus na casa faz a diferença! Os seguintes versículos confirmam o fato de que quando Ele está na casa uma bênção deliberada repousa sobre ela: "A maldição do Senhor habita na casa do perverso, porém a morada dos justos ele abençoa" (Provérbios 3:33). "Os perversos serão derribados e já não são, mas a casa dos justos permanecerá" (Provérbios 12:7). "Na casa do justo há grande tesouro, mas na renda dos perversos há perturbação" (Provérbios 15:6). ${ }^{1355}$

Nota-se o esforço do autor de propor aos pentecostais as bênçãos de atender e abrir sua casa para essa missão. Brasil lembra: "algo bem comum nas cidades hoje em dia são os chamados grupos pequenos, células e outros, que basicamente têm a mesma função, correspondendo a determinada congregação, mas a metodologia aqui proposta não é essa". ${ }^{1356}$ O modelo pentecostal propõe a ampliação do templo para a casa do fiel. Comblin, ao propor as irmandades, reconhece, contudo, a impossibilidade de fechar a questão em um único modelo: "se as estruturas organizativas da comunidade pretendem uniformizar ou reduzir todos a um modelo único de ser e de agir, não há liberdade possível". ${ }^{1357} \mathrm{O}$ modelo quadrangular visa reforçar a missão em dois pontos, conduzindo ao templo orientando pequenos grupos como motor da evangelização, como afirma Damazio: "ao preparar nossa igreja para ministrar e penetrar a cidade com o evangelho, desenvolvemos tanto o poder da corporação como o do ministério em rede da célula, nossos pequenos grupos". ${ }^{1358}$

O conceito pode ser interessante, mas não deveria ter por produto final a condução ao templo. Brasil diz: "os modelos de que se dispõe nas cidades, já citados, têm por finalidade levar as pessoas ao templo". ${ }^{1359}$ É preciso ficar atento para não perder a centralidade da missão nos pequenos grupos, pois a ideia de partilhar comunhão e dinâmica, que pode ser desenvolvida com esse modelo, é bem-vinda à missão. Comblin diz: "o primeiro lugar da liberdade no Espírito Santo é a comunidade pequena, o núcleo básico em que se vive a fé". ${ }^{1360}$ Assim, para o autor, a comunhão pode ser exercida independentemente do modelo.

\footnotetext{
${ }^{1355}$ DAMAZIO, F. Cruzando Rios, Tomando Cidades, p. 192.

${ }^{1356}$ BRASIL, J, G. Missão e Urbanização no Século 21, p. 55.

${ }^{1357}$ COMBLIN, J. Vocação para liberdade, p. 298.

${ }^{1358}$ DAMAZIO, F. Cruzando Rios, Tomando Cidades, p. 170.

${ }^{1359}$ BRASIL, J, G. Missão e Urbanização no Século 21, p. 55.

${ }^{1360}$ COMBLIN, J. Vocação para liberdade, p. 298.
} 
Entretanto, reside no DNA pentecostal o ganhar, o conquistar, o que se constata na estratégia apresentada por Damazio: "nossas células estão sendo desenvolvidas a fim de implementar nossas estratégias para alcançar nossas cidades". ${ }^{1361}$

Em missão existem muitas possibilidades, por isso a diversidade é bemvinda. É necessário propor novas maneiras de ações missionárias. Comblin afirma: "a Igreja com Cristo é chamada a fazer a viagem que vai de Deus aos homens". ${ }^{1362}$ Isso passa pelo esforço de tentar criar ambientes de relacionamento. $\mathrm{Na}$ verdade é um conjunto ordenado que gera a missão, agregando-se a isso a hermenêutica bíblica, como lembra Lara: "Comblin acredita que o cristão deve ler a Bíblia a partir de um comprometimento de vida, com o espírito aberto para aprender, se deixar tocar e se transformar pelo próprio Deus que se revela na Palavra". ${ }^{1363}$ A partir da reflexão bíblica o processo hermenêutico pentecostal cria perspectivas envolventes. Essa ação missionária não envolve somente a vida do crente, mas também sua própria casa, seu lugar de privacidade. A casa do crente, agora uma célula, acaba por se tornar pública, pois a família perde parte do espaço privado para atender às atividades da igreja, num processo embasado biblicamente, como explica Damazio: “a corporação ou a reunião pública é absolutamente necessária e tem um propósito definido; mas sem as células a igreja não se tornará uma igreja do Novo Testamento, que se reúne tanto no templo como de casa em casa.". 1364

Ainda é preciso distinguir a proposta quadrangular da comblianiana, iniciadas com os mesmos questionamentos e preocupações, mas distantes na finalidade e no modo de operação, pois a versão quadrangular fortalece o templo, enquanto a combliniana o enfraquece ou mesmo suprime. Brasil comenta:

A proposta aqui apresentada é diferente: primeiro, por não se tratar da casa de alguém, o local é mesmo uma casa de igreja; segundo, nessas casas de igrejas não existem templos. Essas casas de igrejas, além de residências para missionários, também podem acolher outros, não se limitando a abrigar sacerdotes, mantendo-se ocupadas todo o tempo pela missão da igreja na cidade. ${ }^{1365}$

\footnotetext{
${ }^{1361}$ DAMAZIO, F. Cruzando Rios, Tomando Cidades, p. 170.

${ }^{1362}$ COMBLIN, J. Teologia da missão, p. 25.

1363 LARA, V. L. Hermenêutica Bíblica para Compreender Paulo em Comblin, p. 658.

${ }^{1364}$ DAMAZIO, F. Cruzando Rios, Tomando Cidades, p. 170-171.

${ }^{1365}$ BRASIL, J. G. Missão e Urbanização no Século 21, p. 55.
} 
No exemplo acima as casas de igrejas seriam um local específico para a missão, não uma casa particular. Comblin explica que a vida em um mundo predominantemente rural mantinha uma percepção comunitária, o que se perdeu num ambiente predominantemente urbano: "no mundo rural essa comunidade de base era a família grande, unindo três gerações. Hoje, na cultura urbana, essa família desapareceu e deixou de ser o centro religioso. Muitas famílias compõemse de membros que aderiram a várias religiões". ${ }^{1366}$ Cabe à igreja em missão reconhecer e buscar novas formas de apresentação do evangelho. A igreja deve cooperar, facilitando a missão, como afirma Damazio:

A igreja que dificulta a evangelização depende de seus especialistas, de sua equipe profissional, para cumprir o ministério, está violando tanto as intenções do seu cabeça, Cristo, como o padrão coerente da Primeira Igreja, como visto em Atos 17. Nosso coração deve pulsar biblicamente se quisermos ser igrejas que alcançam cidades. ${ }^{1367}$

Os passos para a mudança são necessários à sobrevivência da ação missionária, e se a igreja brasileira reconhecer essa necessidade e engajar-se na luta, contribuirá significativamente, amenizando a tensão que se tornou o desafio missionário. Comblin afirma: "desta maneira, a Igreja latino-americana será a primeira a reconhecer que a sociedade mudou tanto, sobretudo pela urbanização quase total da população, que as estruturas atuais já não funcionam como antes". ${ }^{1368}$ Com a atuação contextualizada da missão, a prática quadrangular percebe que as reuniões nesse tipo de ambiente podem fortalecer as igrejas. Damazio diz: "os períodos de reunião corporativa têm o propósito de conferir saúde e força espiritual às nossas congregações". ${ }^{1369} \mathrm{O}$ entendimento estabelecido no modelo dos quadrangulares aponta o fortalecimento espiritual e a estabilidade da estrutura, como nas aproximações entre católicos e pentecostais mediante o pentecostalismo da IEQ e da teologia de Comblin.

Enquanto nessa vertente do pentecostalismo a missão dos pequenos grupos fortalece os trabalhos no templo, em vez de descartá-lo. Já o catolicismo de Comblin convoca a sair dos templos: "trata-se de sair dos templos para se meter

\footnotetext{
${ }^{1366}$ COMBLIN, J. Vocação para liberdade, p. 298.

${ }^{1367}$ DAMAZIO, F. Cruzando Rios, Tomando Cidades, p. 171.

${ }^{1368}$ COMBLIN, J. O papel histórico de Aparecida, p. 883-884.

${ }^{1369}$ DAMAZIO, F. Cruzando Rios, Tomando Cidades, p. 172.
} 
no meio da sociedade". ${ }^{1370} \mathrm{O}$ autor convida a avançar e a se envolver na vida das pessoas. Ambas as partes se aproximam nesse diálogo quando o assunto é a proposta central que desafia todos à missão. Damazio esclarece: "o pulsar balanceado do coração da igreja que conquista cidades é uma reunião pública corporativa espiritualmente poderosa e um ministério de grupo pequeno espiritualmente saudável". 1371

É nítido o avanço dos quadrangulares, que igualmente compreendem a necessidade da abertura ao diálogo: "As igrejas devem reconhecer a necessidade do desenvolvimento de uma estrutura que irá incorporar oportunidades para construir e cultivar relacionamentos, isto é, relacionamentos com outros crentes e com incrédulos". ${ }^{1372}$ Voltando ao modelo proposto pela perspectiva combliniana, também aberta ao diálogo com vistas à construção de novas formas de missão, Brasil esclarece:

Claro que o modelo não está engessado, sendo sobretudo marcado pela flexibilidade, não prescindindo de outros lugares de culto e pregações, desde que estes não se destaquem nas cidades: lugares discretos que se prestem, por exemplo, a retiros, permitindo às pessoas momentos de comunhão, o que, na maioria das vezes não ocorre no mesmo lugar e muito menos em um templo. Trata-se de ambientes complementares que visam a dar fôlego e vida novos à comunidade. ${ }^{1373}$

De início foi possível notar que as partes nesse diálogo tinham ideias preconcebidas do modelo de operação dos seus respectivos grupos pequenos, mas o aprofundamento da questão levou à construção de modelos compartilhados de ação missionária mediante a flexibilidade e o diálogo. Damazio diz: "o ministériocélula da nossa igreja é parte integrante de nossa estratégia para conquistar a cidade. Casas, ou ministério baseados nas casas, podem ser o meio mais adequado para alcançar a geração pós-cristã com o evangelho". ${ }^{1374}$ Os quadrangulares, assim, estão conscientes do cenário que se apresenta à missão, para a qual é preciso reconhecer a urgência de mudança e flexibilidade, como afirma Shedd:

\footnotetext{
${ }^{1370}$ COMBLIN, J. O papel histórico de Aparecida, p. 883-884.

${ }^{1371}$ DAMAZIO, F. Cruzando Rios, Tomando Cidades, p. 174.

1372 DAMAZIO, F. Cruzando Rios, Tomando Cidades, p. 174.

${ }^{1373}$ BRASIL, J, G. Missão e Urbanização no Século 21, p. 55.

${ }^{1374}$ DAMAZIO, F. Cruzando Rios, Tomando Cidades, p. 174.
} 
“embora os métodos e os meios evangelísticos possam apresentar diferenças conforme a época e a cultura, a mensagem não pode sofrer alteração". ${ }^{1375}$

As casas ou células quadrangulares como propostas não se limitam à estrutura e à representação, mas abarcam também o fator pneumatológico e a cura divina. O modelo de missão da Cruzada Nacional de Evangelização tem centralidade pautada nas questões pneumatológicas com forte ênfase na cura divina. Por isso o modelo apontado por Damazio parece estar em sintonia com as tendas do auge da missão que originou a Igreja do Evangelho Quadrangular no Brasil: "o lar de cada crente ligado a uma igreja saudável doadora de vida irá se tornar um lar doador de vida. Esses lares podem vir a ser centros de atividade espiritual, lugares onde a cirurgia divina acontece na vida das pessoas". ${ }^{1376}$ Assim a casa do crente seriam as barracas ou tendas de cura divina contemporâneas, revivendo a missão quadrangular no pentecostalismo brasileiro.

Para Kirk, o tema pode ser interpretado como moda: "está na moda atualmente, em algumas partes da igreja ocidental, a igreja nos lares ou o modelo das comunidades eclesiais de base". ${ }^{1377}$ É verdade que esse modelo tem se popularizado nas últimas décadas, recebendo a adesão de muitas denominações. $\mathrm{Na}$ Quadrangular não tem sido diferente e Damazio explica a necessidade do conceito:

\begin{abstract}
A célula é um grupo de indivíduos que tomou o compromisso de se relacionar, entre si com cada vez maior profundidade, autenticidade, honestidade e vulnerabilidade. Abaixo se encontra minha definição para células, abrangendo o propósito, missão e função da nossa igreja: Conectar as pessoas em relacionamentos. Encorajar e preparar cada crente para ser um discípulo de Cristo. Libertar as pessoas dos poderes das trevas. Usar nossas casas como centros de ministério. Causar impacto em nossa área geográfica imediata por meio de um ministério estratégico e criativo. ${ }^{1378}$
\end{abstract}

Esse modelo de fato não tem sido aceito por todos, com críticas à sua vulnerabilidade. Kirk afirma que os entusiastas do modelo o enxergam como a solução para a missão da igreja e que os templos ou instituições burocratizam e estacionam a missão, e por conseguinte não dão liberdade ao Espírito:

\footnotetext{
${ }^{1375}$ SHEDD, Russell P. Evangelização: fundamentos bíblicos. São Paulo: Shedd Publicações, 2006. p. 9.

${ }^{1376}$ DAMAZIO, F. Cruzando Rios, Tomando Cidades, p. 174.

${ }^{1377}$ KIRK, J. A. O que é missão?, p. 252.

${ }^{1378}$ DAMAZIO, F. Cruzando Rios, Tomando Cidades, p. 174.
} 
As pessoas que acreditam que o "pequeno é bonito" e que o novo é melhor em relação ao antigo entendem que não existe mérito em sustentar instituições e estrutura que lhes parecem perpétuas e continuam a existir sob o peso da tradição ao invés de serem inspiradas pelo Espírito. ${ }^{1379}$

Testar ideias faz parte do fazer missionário, e é a partir de tentativas que surgem as alternativas. Assim, é pela prática aliada à reflexão que encontraremos caminhos para a missão. Brasil diz: "este tempo é bastante singular para a missão frente à lacuna da cidade. É um momento único para a reflexão do papel missionário no espaço urbano". ${ }^{1380}$ Sim, um possível caminho pode passar pelos pequenos grupos. A missão precisa ousar ser recuperada, e no caso da Quadrangular, trata-se de recuperar o conceito da Cruzada Nacional de Evangelização. Damazio diz: "assim como a igreja tem um coração que pulsa harmoniosamente, o coração do ministério de células também pulsa e deve pulsar da mesma forma". ${ }^{1381}$ O modelo Cruzada Nacional de Evangelização proporcionou comunhão e partilha de vida. As pessoas dividiam também suas dores, eram acolhidas pelos obreiros, em grande parte, leigos, e a recuperação desse modelo em uma nova realidade passa por grupos pequenos de comunhão. Continua:

\footnotetext{
A Célula Vida-da-Cidade descreve o pastoreio, o aspecto do ministério pastoral que cuida e presta serviço a cada pessoa mediante a célula durante sete dias da semana. Este é o espírito de comunidade visto em Atos 2:42-27, o espírito koinonia de comunhão, partilha, relacionamento, intimidade, responsabilidade, apoio e família extensa. ${ }^{1382}$
}

A realidade da ação missionária é a fé, e os quadrangulares tem por lema bíblico a imutalidade de Cristo e seu poder de operação de milagres. Para Shedd, a missão dos cristãos em geral passa por esse princípio, pois é a atualização do evangelho que diz: "a evangelização proclama a mensagem imutável de um Deus que não muda jamais. 'Jesus Cristo, ontem e hoje, e o mesmo e o será para sempre (Hb 13.8)" " ${ }^{1383}$ Constrói-se um modelo de evangelização como o já experimentado pela Cruzada Nacional de Evangelização, mas as casas agora substituem as tendas, como explica Damazio:

\footnotetext{
${ }^{1379}$ KIRK, J. A. O que é missão?, p. 252.

${ }^{1380}$ BRASIL, J, G. Missão e Urbanização no Século 21, p. 35.

${ }^{1381}$ DAMAZIO, F. Cruzando Rios, Tomando Cidades, p. 174.

${ }^{1382}$ DAMAZIO, F. Cruzando Rios, Tomando Cidades, p. 175.

${ }^{1383}$ SHEDD, R, P. Evangelização, p. 9.
} 
A Célula Evangelização-da-Cidade descreve o gene do evangelismo espiritual cultivado em cada célula. Este gene faz com que nos voltemos para fora e não para dentro, a fim de aplicar os princípios práticos de evangelização da nossa cidade pessoa por pessoa, casa por casa, bairro por bairro. ${ }^{1384}$

É bem clara a proposta estabelecida a partir desse conceito, uma estratégia de evangelização individual, chegando até as casas, espalhando-se pelo bairro e alcançando a cidade: "nossa suprema responsabilidade como líderes espirituais é transformar nossas igrejas para alcançar cidades". ${ }^{1385} \mathrm{Na}$ perspectiva católica de Amado, são indispensáveis os relacionamentos em pequenas comunidades, vitais ao cristianismo. Pesa ainda principalmente a individualidade da sociedade contemporânea, como explica Amado:

Uma experiência eclesial integrada implica necessariamente a vida de comunidade. O acesso a Deus passa pela mediação dos irmãos e irmãs e esta mediação tem que, também de modo indispensável, se concretizar em relacionamentos humanos primários. É por isso que a rede ou comunidade de pequenas comunidades, territoriais ou ambientais, é indispensável para a concretização do sujeito eclesial. $^{1386}$

A partir da formação do sujeito eclesial como mencionado por Amado, a igreja tem condições de se mover em missão, renovando em ação. $\mathrm{Na}$ visão do pentecostal Oliveira, a interação da igreja com a sociedade envolve sua marca profética: "para que a igreja possa interagir com a sociedade é preciso que ela se mostre ao mundo como uma comunidade com voz profética e propostas práticas que sejam contra a corrente da sociedade consumista e mercadológica". ${ }^{1387}$ Os pesquisadores comblinianos tendem a apontar caminhos mais radicais, em alguns aspectos, a exemplo de Souza:

Ora, a evangelização terá que resultar num outro rosto tanto do cristianismo como da Igreja. Para isto, consiste em dar testemunho, nos diversos ambientes urbanos, com base no conhecimento e na vivência concreta, de que o cristianismo é distante ou oposto à ideia preconcebida que dele se possa fazer. Sim, o testemunho desempenha um papel essencial. ${ }^{1388}$

\footnotetext{
${ }^{1384}$ DAMAZIO, F. Cruzando Rios, Tomando Cidades, p. 175.

${ }^{1385}$ DAMAZIO, F. Cruzando Rios, Tomando Cidades, p. 175.

${ }^{1386}$ AMADO, J, P. Leigos na linha de frente?, p. 406.

${ }^{1387}$ OLIVEIRA, D, M, d. Missão, cultura e transformação, p. 147.

${ }^{1388}$ SOUZA, A. R. A teologia da cidade segundo José Comblin, p. 593.
} 
A missão necessita sim, de um novo rosto que desperte interesse da sociedade, em que a igreja colabore como essência. Toda forma de missão é bemvinda, pois de Deus. Damazio afirma: "o Senhor prometeu que iria edificar a Igreja e nós somos seus auxiliares". ${ }^{1389} \mathrm{Na}$ tarefa missionária cabe à igreja a contextualização. É seu dever dar sequência à missão do Cristo, agora na vivência do Espírito. Para os pentecostais, segundo Oliveira, é preciso recuperar a missão em diaconia, sem a qual é inconcebível falar em missão: "o mestre uniu diaconia e missão em seu ministério, de tal forma que não é possível concebê-los separadamente no seguimento de Jesus. Não se trata de outro modelo de missão, mas do reconhecimento de que a completude da missão só é possível pela via diaconal". 1390

Quanto mais se avança na reflexão em busca de uma proposta de missão capaz de atender a realidade contemporânea, mais se retorna aos modelos das primeiras comunidades cristãs, mesmo em época tão distinta. $\mathrm{Na}$ visão dos quadrangulares essa diaconia passa pela evangelização, serviço do qual os crentes são convocados a participar. Damazio explica: "nossa cidadania celestial engloba o direito e a obrigação de adorarmos o Deus único e verdadeiro da cidade eterna. Temos sua autoridade e poder para soltar os que foram forçados pelo pecado a viver fora dos muros. Vamos trazê-los para dentro da cidade real". ${ }^{1391}$ Nessa vertente é perceptível o papel fundamental do crente e do leigo, pois a mensagem pentecostal convoca todos à missão. É característica da missão pentecostal, em geral, a renúncia; e é comum no ambiente do pentecostalismo a valorização da kenosis, em que o crente participa da missão de Deus, como afirma Oliveira: "para isso será necessário sofrer a kenosis até o fim. Kenosis é transformação. Toda a missio Dei está aí’ ${ }^{1392}$ A participação nessa missão cria um clima de cooperação na missão de Deus.

$\mathrm{Na}$ tentativa de dar concretude a essa cooperação na missão de Deus o crente assume em sua espiritualidade a kenosis. Damazio explica que o processo de participação do crente na evangelização passa pela célula: “o pulsar equilibrado de uma igreja sadia para alcançar cidades é o que chamo de corporação e

\footnotetext{
${ }^{1389}$ DAMAZIO, F. Cruzando Rios, Tomando Cidades, p. 175.

${ }^{1390}$ OLIVEIRA, David, Mesquiati de. Missão, cultura e transformação: desafios para a prática missionária comunicativa. São Leopoldo: Sinodal; Quito: CLAI, 2011, p. 146.

${ }^{1391}$ DAMAZIO, F. Cruzando Rios, Tomando Cidades, p. 175.

1392 OLIVEIRA, D, M, d. Missão, cultura e transformação, p.147.
} 
célula". ${ }^{1393}$ A estrutura em torno desse modelo de missão é chamado aqui de "corporação" porque tem objetivo orquestrado: "corporação, reunião da igreja inteira: celebração, pregação, direção, preparação, edificação."1394 Aqui podemos ver o passo a passo do modelo quadrangular para o desenvolvimento da sua missão em grupos pequenos. Para outros comentadores comblinianos, como Oliveira, o sucesso da missão passa pela vida comum: "para Comblin, 'o que constitui um povo é, em primeiro lugar, a vida comum, a vida sofrida e, assumida em comum". ${ }^{1395}$

Esse apontamento também ajuda a completar a percepção quadrangular da missão em grupos pequenos. A missão no viés dos grupos pequenos é, na verdade, a missão em comunidade. Réne afirma: "no léxico teológico evangélico, comunidade e missão são termos correlatos - isso porque sem comunidade não há missão, e sem esta não existe aquela. As duas se completam mutuamente, e cada uma depende em grande medida da outra" ${ }^{1396}$ Essa completude é bem aceita pelas partes em diálogo neste trabalho. Em geral a cristandade é comunidade. Brighenti concorda: "para o cristianismo, adesão a Jesus Cristo implica necessariamente adesão a uma comunidade". ${ }^{1397}$ A questão é de consenso, mas o desafio tem sido o modo de vida em comunidade, desafio que pede empenho e resposta. Damazio diz: "célula, reunião da igreja em pequenos grupos: infiltração, compartilhamento, discipulado encorajamento, expansão". ${ }^{1398}$ A atuação dessa alternativa missionária requer atenção para que o trabalho não se confunda com os modelos que apresentam objetivos contrários. Para Brighenti a contribuição que esse tipo de comunidade pode proporcionar ao cristianismo em geral é justamente a animação: “o importante é que tais momentos não se destinem, já na sua origem, ao consumo religioso, mas sim à animação da vida cristã em geral, à permanência na pequena comunidade e à missionariedade [...]”. ${ }^{1399}$

O propósito de qualquer modelo de comunidade pequena tem por marco a missão e é sempre isso que faz a igreja caminhar, seguir seu curso, participando

\footnotetext{
${ }^{1393}$ DAMAZIO, F. Cruzando Rios, Tomando Cidades, p. 169.

${ }^{1394}$ DAMAZIO, F. Cruzando Rios, Tomando Cidades, p. 170.

${ }^{1395}$ OLIVEIRA, A. F. d. Igreja dos Pobres e Imagens de Deus em José Comblin: convites à práxis cristã emergentes da Missão Ibiapina no semiárido nordestino, p. 75.

${ }^{1396}$ C. RENÉ, P. O que é missão integral?, p. 57.

1397 BRIGHENTI, Agenor (org). Pastoral Urbana: categorias de análise e interpelações Pastorais. Brasília: Edições CNBB. 2010, p. 86.

${ }^{1398}$ DAMAZIO, F., Cruzando Rios, Tomando Cidades, p. 170.

${ }^{1399}$ BRIGHENTI, A., Pastoral Urbana, p. 87.
} 
da missão de Deus no mundo. A instalação desse modelo pelos quadrangulares segue a marca tradicional de sua prática missionária, que avança por meio da missão leiga pneumatológica, com destaque para a atuação taumatúrgica. No sentido em que foi dado pela IEQ. Damazio afirma: "acreditamos que os dons do Espírito enumerados em 1 Coríntios 12:7-11 não se aplicam apenas ao momento presente, mas devem ser desejados, buscados e evidenciados em todas igrejas". ${ }^{1400}$ No quadro que se desenhou a sociedade mudou, os relacionamentos e certezas também, entretanto o evangelho continua presente. É em meio a esse cenário que se necessita de uma atuação missionária na esteira pneumatológica, priorizando tudo aquilo que abarca a temática, como afirma Oliveira: “a igreja-em-missão está hoje diante de um mundo fundamentalmente diferente de tudo que enfrentou antes. Esse fato, por si só, demanda uma nova compreensão de missão”. ${ }^{1401} \mathrm{Em}$ época de mudanças profundas é constante a renovação em todas as áreas da vida, e urgente que a missão se atualize. Entretanto, não se defende uma missão com função meramente responsiva às demandas da sociedade; ela precisa, antes, fazer parte dessas mudanças, como esclarece Comblin: "pois estamos num mundo novo. A grande maioria dos batizados já nem conhece o Pai-nosso e ignora tudo da Igreja. A vida é um corre-corre, correndo de uma atividade para outra, para sobreviver". 1402

Qual será o novo rumo da missão nesse cenário tão dinâmico e incerto de repentinas transformações? Talvez o único caminho possível seja a constante transformação, mas ela precisa também ser transformada no conceito de Bosch. Assim como a terra, as relações humanas também clamam por recuperação. René diz: "em segundo lugar, a obra de Deus em Cristo Jesus inclui a restauração de todas as relações da pessoa, que têm sido prejudicadas pelo pecado: a relação com Deus, com o próximo e com a criação". ${ }^{1403}$

Os quadrangulares tentam recuperar a dinâmica que os envolveu durante o tempo da Cruzada Nacional de Evangelização, quando evangelizavam em cooperação com outras denominações, num trabalho de características fortemente pneumatológicas, evidenciando a cura divina, como alerta Damazio: "se há um momento em que estes dons se fazem necessários, esse momento é o que estamos

\footnotetext{
${ }^{1400}$ DAMAZIO, F., Cruzando Rios, Tomando Cidades, p. 68.

${ }^{1401}$ OLIVEIRA, D, M, d., A Dimensão Comunicativa da Ação Missionária e as Culturas, p.79.

${ }^{1402}$ COMBLIN, J., As Grandes Incertezas na Igreja Atual, p. 39.

${ }^{1403}$ C. RENÉ, P. O que é missão integral?, p. 58.
} 
vivendo". ${ }^{1404}$ Desafios simultâneos mostram que a missão não terá uma única face, mas, pelo contrário, só será eficaz se for plural e completamente diversa. Comblin alerta para o atual quadro social: "a desorganização social é tal que as pessoas vivem como indivíduos solitários, isolados, sem confiança nos outros, sem relação humana firme". ${ }^{1405}$

É preciso lembrar que Comblin reflete a partir da realidade da sua missão, em meio aos desafios refletidos em sua teologia. E como Soares diz: "o ponto de partida de toda a sua reflexão é a análise e a crítica da realidade e das propostas com as quais diferentes grupos e tendências dela se aproximam para conhecê-la e nela interferir". ${ }^{1406}$ A discussão da temática se amplia à medida que muitos especialistas compreendem a importância da inserção de algum modelo de grupo pequeno. Brighenti alerta: "outro perigo refere-se à não inserção dos pequenos grupos, das pequenas comunidades, na caminhada maior da Igreja local". ${ }^{1407}$ Os quadrangulares interpretam a adesão aos grupos pequenos não somente pela sua estrutura, mas também por esse modelo oportunizar o exercício dos dons espirituais. Damazio conclui: "não cremos que esses dons foram destinados apenas à igreja embrionária dos primeiros cinco séculos, mas são parte integrante da igreja até que Cristo retorne para a sua noiva perfeita". ${ }^{408}$

Enfim, desde as primeiras práticas missionárias quadrangulares a evangelização esteve presente, com auspiciosos resultados, e o somatório desse esforço foi uma das maiores denominações pentecostais do Brasil e do mundo. Mas os desafios atuais requerem da missão quadrangular uma ágil recuperação. Em vez do antigo caminho das tendas, o que se propõe aqui é a evangelização em grupos pequenos, mas de acordo com os elementos centrais nas tendas da Cruzada, ou seja, forte ênfase na cura divina, manifestando a essência do pentecostalismo clássico: a missão do Espírito Santo.

\footnotetext{
${ }^{1404}$ DAMAZIO, F. Cruzando Rios, Tomando Cidades, p. 68.

${ }^{1405}$ COMBLIN, J. As Grandes Incertezas na Igreja Atual, p. 39.

${ }^{1406}$ SOARES, S. A. G. José Comblin, homem do Espírito, p. 52.

${ }^{1407}$ BRIGHENTI, A. Pastoral Urbana, p. 87.

${ }^{1408}$ DAMAZIO, F. Cruzando Rios, Tomando Cidades, p. 68.
} 


\subsection{2. \\ Contribuições para enriquecimento da perspectiva da Igreja do Evangelho Quadrangular à luz de Comblin e outras sugestões no contexto do diálogo entre pentecostais e católicos}

Diante da contribuição da Igreja do Evangelho Quadrangular ao pentecostalismo, cabe aqui também a investigação da contribuição dos quadrangulares ao diálogo, com temas relevantes para a missão, bem como para o cristianismo em geral. A pauta da missão repousa atualmente nas questões da cultura, da inculturação e da Missio Dei. Quanto à cultura, Oliveira afirma: "a questão da cultura afeta cada aspecto da missão. Ignorá-la é se permitir errar seriamente na interpretação das situações". ${ }^{1409}$ Temas como esse tornam-se desafiadores ao pentecostalismo em geral, todavia parece que o pentecostalismo foi, no último século, o movimento religioso cristão que melhor se adaptou à cultura. A inculturação tem chamado a atenção e despertado interesse em toda a cristandade, pois a missão clama por um caminho cultural. Bosch alerta: "mas a inculturação não constitui unicamente um evento local. Ela tem também uma manifestação regional ou macrocontextual". ${ }^{1410}$

São muitos os campos que precisam passar no processo e isso envolve questões que diferenciam Bíblia e palavra de Deus. Lara esclarece: "na verdade, não é exatamente a Bíblia que ocupa o centro da teologia de Comblin, mas é a Palavra de Deus o centro da fé cristã e, por isso, também é o centro da própria teologia". ${ }^{1411}$ A missão da Igreja do Evangelho Quadrangular tem avançado, mas ainda carece de reflexão. O pentecostalismo em geral passa por constante atualização e vem buscando o diálogo com as temáticas que envolvem e desafiam a missão. Bosch reflete: "nesse paradigma, não se trata tanto de a igreja ser expandida, mas de ela nascer de novo em cada novo contexto e cultura". ${ }^{1412}$

O ITQ - Instituto Teológico Quadrangular, encarregado dos estudos e da formação teológica dos quadrangulares, publicou, em uma de suas apostilas preparatórias, temas relativos aos novos paradigmas da missão. Fluck argumenta: “é sempre salutar lembrar os limites, que antes de obstáculos, se tornam sempre

\footnotetext{
${ }^{1409}$ OLIVEIRA, D. M. d. A Dimensão Comunicativa da Ação Missionária e as Culturas, p. 82.

${ }^{1410}$ BOSCH, D. J. Missão transformadora, p. 542.

1411 LARA, V. L. Hermenêutica Bíblica para Compreender Paulo em Comblin, p. 656.

${ }^{1412}$ BOSCH, D, J. Missão transformadora, p. 542.
} 
um desafio. O caráter de pioneiro no assunto e a inabilidade com os conceitos são apenas algumas referências que sinalizam no sentido de paciência e compreensão". ${ }^{1413} \mathrm{O}$ movimento pentecostal responde a alguns desafios da sociedade, e o êxito pentecostal está associado à sua mobilização do comum da cultura, pois o movimento se utiliza de características presentes nas sociedades e transformam a sua prática. Para Bosch, a inculturação é um processo natural na fusão do cristianismo com as culturas e por meio dele ambos se transformam: "a inculturação sugere um movimento duplo: há, simultaneamente, a inculturação do cristianismo e a cristianização da cultura". ${ }^{1414}$ Esse tema também ocupou a agenda de Comblin, como lembra Cabral: "a temática da inculturação foi, aliás, uma entre as tantas por ele antecipadas em suas vivências, tanto na condição de criador e animador/incentivador de múltiplas atividades pastorais, quanto na sua vasta produção de teólogo profícuo". 1415

Os quadrangulares percebem que a encarnação da cultura não pode ser apenas uma capa para a anunciação do evangelho. A inculturação precisa ser assumida em concretude de fato, como explica Fluck: "a encarnação/enculturação não pode acontecer como um passeio turístico. Em outras palavras a mensagem, ao ser proclamada dentro de novos pressupostos, precisa encarar isso como uma nova realidade de ser e não como uma opção meramente estratégica". ${ }^{1416} \mathrm{O}$ pentecostalismo em geral tem conseguido dinamizar sua relação com a cultura, entretanto o pentecostalismo clássico ou neoclássico, no qual se insere a Igreja do Evangelho Quadrangular, tem obtido maior sucesso, na maioria, entre os mais pobres da sociedade. Bosch diz: "a relação entre mensagem cristã e a cultura é criativa e dinâmica, repleta de surpresas. Não existe uma teologia eterna, uma teologia perennis que possa ser o árbitro de "teologias locais". ${ }^{1417}$

Os quadrangulares percebem que a anunciação do evangelho passa por sua integralidade e isso abarca tudo o que envolve a vida humana, inclusive a cultura na qual acontece a evangelização. Bezerra diz: "portanto, o Evangelho Integral significa total comprometimento com todas as demandas de Jesus Cristo, incluindo todos os requisitos éticos que são inerentes à mensagem do Evangelho.

\footnotetext{
${ }^{1413}$ FLUCK, M. R. Introdução à Missiologia, p. 63.

${ }^{1414}$ BOSCH, D, J. Missão transformadora, p. 543.

${ }^{1415}$ CABRAL, N. D, d, A.; MARQUES, Luiz Carlos Luz. Um Tufão Chamado José Comblin, p. 594.

${ }^{1416}$ FLUCK, M. R. Introdução à missiologia, p. 67.

${ }^{1417}$ BOSCH, D. J. Missão transformadora, p. 544.
} 
Logo, é viver de 'maneira digna do Evangelho de Cristo (F1 1.27)". ${ }^{1418}$ A missão se revela a partir de determinada cultura, a encarnação do Cristo acontece no âmbito da cultura e a inculturação proporciona a comunicação necessária à evangelização. Oliveira afirma: “a base da fé cristã é a auto-comunicação de Deus em Jesus Cristo. O fundamento teológico da missão só é possível se referir-se continuamente a essa base da fé". ${ }^{1419}$

Entretanto é preciso cuidado com os limites, pois a compreensão do nascimento da missão em uma dada cultura local não pode ser pretexto para o isolamento, como alerta Bosch: "a inculturação pressupõe, ademais, que as encarnações locais da fé não deveriam ser locais demais". ${ }^{1420}$ A diversidade do rosto da cristandade mostra-se na realidade diversa das culturas, gerando um cristianismo multiforme, porém as pontes precisam ser construídas, ainda que sobressaiam os limites de determinada cultura. Bosch continua: "por um lado, uma igreja do tipo 'unidade homogênea' pode tornar-se tão 'encravada' que lhe seja impossível a comunicação com outras igrejas, acreditando que sua perspectiva do evangelho seja legítima". ${ }^{1421}$

Com o avanço dos estudos em torno da missão, muitos conceitos e termos têm surgido. Os quadrangulares usam a palavra "aculturado" para tratar dos assuntos que envolvem a missão e sua atuação na cultura. Bezerra afirma: "assim como ele foi enviado pelo Pai, também nos envia. Jesus foi encarnado, humano, social aculturado, solidário, para vivenciar os valores do reino de Deus (justiça e paz) na história, tomando partido ao lado da verdade e dos pequeninos". ${ }^{1422}$ Os pesquisadores têm se esforçado para delimitar os desafios à missão e a relação entre cultura e missão tem preenchido a pauta de muitos deles, o que tornou recorrente a palavra "inculturação". Bosch explica: "a inculturação é um dos padrões em que o caráter pluriforme do cristianismo contemporâneo se manifesta. Inclusive o termo é novo". ${ }^{1423}$ Já o teólogo católico Amado utiliza a palavra "exculturação" ao alertar sobre um possível enfraquecimento do evangelho frente à cultura, com valores não mais pautados no evangelho: "exculturação significa o

\footnotetext{
${ }^{1418}$ BEZERRA, C. M. Missão integral da igreja, p. 15.

${ }^{1419}$ OLIVEIRA, D. M. d. A dimensão comunicativa da ação missionária e as culturas, p. 90.

${ }^{1420}$ BOSCH, D, J. Missão transformadora, p. 545.

${ }^{1421}$ BOSCH, D, J. Missão transformadora, p. 545.

1422 BEZERRA, C. M., Missão Integral da Igreja, p. 25.

${ }^{1423}$ BOSCH, D, J., Missão transformadora, p. 535.
} 
enfraquecimento na relação entre o Evangelho e a(s) cultura(s) de tal modo que as referências ético-existenciais destas mesmas culturas já não são marcadas pelos valores do Evangelho". ${ }^{1424}$ Também engajados na discussão dos desafios que envolvem missão e cultura, os quadrangulares acreditam que a missão já não é exequível com uma única face, sendo indispensável o diálogo, no qual a enculturação é decisiva. Fluck esclarece:

Dentro desta perspectiva surge a questão da enculturação como fator decisivo e motivador para o diálogo entre as religiões. Muito mais que entender e pensá-la, como sinônimo para contextualização ou uma nova saída semântica para esquivarse de tratar de forma séria e profunda o descompromisso com o outro, a perpetuação dos sistemas de dominação, do etnocentrismo, da imposição de um padrão universal de cultura, a enculturação nasce como necessidade plena e exige despojamento pleno. ${ }^{1425}$

A missão só pode existir na cultura e essa característica marca a face diversa do cristianismo, daí o grande espaço granjeado pela reflexão do tema na atualidade. Bosch afirma: “a fé cristã jamais existe senão como 'traduzida' para dentro de uma cultura. Essa circunstância [...] era um traço integrante do cristianismo [...]". ${ }^{1426}$ As muitas tentativas de dar fôlego à reflexão da missão continuam agregando termos ao campo da missiologia, a exemplo da palavra "contextualização", constante nos estudos da missão e referente à situação da missão no contexto atual. Bosch continua: "a palavra 'contextualização' foi cunhada pela primeira vez, no início da década de 1970, nos círculos do Fundo para Educação Teológica [...]". ${ }^{1427}$ No cenário da missão na América Latina, estabelece-se recorrentemente um embate com aqueles que compreendem que a missão deve se dedicar mais a questões espirituais.

Também tem lugar, nesse contexto, as teologias que têm voz na América Latina, a exemplo da Teologia da Libertação, de viés católico, e da Teologia da Missão Integral, de seguimento protestante. Constantemente elas também discutem a ação missionária, mas a centralidade da concepção de ambas não tem sido bem vista por alguns pensadores. Em certa medida, dois extremos têm se desenhado: de um lado, os mais espirituais, que não se envolvem muito com questões sociais; de outro, os que militam em questões sociais e políticas

\footnotetext{
${ }^{1424}$ AMADO, J, P,. Mudança de época e conversão pastoral,p. 305.

${ }^{1425}$ FLUCK, M. R., Introdução à Missiologia, p .63.

${ }^{1426}$ BOSCH, D, J., Missão transformadora, p. 535.

${ }^{1427}$ BOSCH, D, J. Missão transformadora, p. 503.
} 
concernentes às injustiças, entre outros temas. Na visão dos quadrangulares, a questão necessita de equilíbrio. Bezerra explica:

O primeiro restringe o Evangelho apenas às questões espirituais, esquecendo que o homem ainda vive no mundo; o segundo produz o chamado Evangelho Social, onde predomina a preocupação com as injustiças, a pobreza e os desníveis sociais, em detrimento da espiritualidade. É a tentativa de mobilizar a comunidade a lutar por seus direitos, dando-lhe uma dinâmica socialista. ${ }^{1428}$

As variadas faces da missão são muito bem-vindas, parecendo ser o único caminho possível à evangelização, pois desde a origem o cristianismo se apresenta de forma plural, adaptando-se à realidade da cultura em que se insere. Para os quadrangulares, a missão não precisa ser uniforme, mas diversa, de acordo com as primeiras ações missionárias. Fluck diz: "não deveríamos, entretanto, nos surpreender com o fato de o Novo Testamento não refletir uma concepção uniforme de missão, mas, antes, uma variedade de 'Teologias da Missão"”. ${ }^{1429} \mathrm{O}$ novo paradigma da missão venceu o conceito restrito à salvação das almas e ao crescimento da igreja. $\mathrm{Na}$ atualidade missão diz respeito a toda forma de vida e significa responsabilidade com o mundo. Bosch explica:

Onde se definia a missão quase exclusivamente em termos de salvação de almas ou de expansão eclesiástica, a missiologia só poderia mesmo constituir a ciência do missionário e para o missionário, uma disciplina prática (se não pragmática) que respondia à questão: "Como devemos executar nossa tarefa?" Uma vez, porém, que não se compreendia a igreja como sendo "missionária por sua própria natureza", a missão e, implicitamente, a missiologia, permaneciam um acessório prescindível. ${ }^{1430}$

Os quadrangulares percebem que a situação pede equilíbrio; na reflexão quadrangular, os novos desafios da missão estão constantemente em pauta e questão segue em duas direções, que vão de Deus ao próximo. Bezerra questiona: “alguém pode perguntar: ‘A tarefa principal da igreja não é a evangelização?' A resposta é afirmativa. Todavia, a atividade da igreja tem duas dimensões: vertical, para com Deus; e horizontal, para com o próximo". ${ }^{1431}$ A dupla missão - ou os dois compromissos da missão - aponta a integralidade que se inicia em Deus.

\footnotetext{
${ }^{1428}$ BEZERRA, C. M. Missão Integral da Igreja, p.16-17.

${ }^{1429}$ FLUCK, M. R. Introdução à Missiologia, p .14.

${ }^{1430}$ BOSCH, D. J. Missão transformadora, p. 588.

${ }^{1431}$ BEZERRA, C. M. Missão Integral da Igreja, p.17.
} 
Assim a evangelização responsável está compromissada com a vida. Bezerra afirma:

Os dois extremos estão errados. Pois a missão integral da igreja está na proclamação das boas novas de salvação, confrontando o pecado, as injustiças e toda forma de opressão. Portanto, quando o Evangelho de Cristo é aceito na íntegra, possui em si mesmo poder suficiente para transformar não somente o indivíduo, mas toda a sociedade. ${ }^{1432}$

A igreja é parceira na missão de Deus. Ela participa, faz parte da missio Dei, anunciando as Boas Novas. Bosch alerta: "dizer que a igreja é, em essência, missionária não significa que a missão esteja centrada na igreja. Ela é missio Dei. É trinitária. Está mediando o amor de Deus Pai, que é pai/mãe de todas as pessoas, quem quer que sejam e onde quer que estejam. Ela é epifania [...]". ${ }^{1433} \mathrm{O}$ status da missão na atualidade aponta que ela ultrapassou os limites da igreja, não podendo retornar à marginalidade frente à igreja. A dinâmica levou a missão a assumir seu papel em meio aos desafios, apresentando o evangelho ao mundo, como explica Bosch:

Não podemos mais volver à posição anterior em que a missão era periférica para a vida e o ser da igreja. É por causa de sua missão que a igreja foi eleita, por causa de sua vocação que ela se tornou "povo do próprio Deus" (1Pe 2.9; cf. Linz 1964:33). A missão, por conseguinte, não se pode definir unicamente em termos da igreja mesmo da igreja que é missão por sua própria natureza. A missão vai além da igreja. ${ }^{1434}$

Assim, já não é aceitável falar em missão da igreja, pois a igreja em missão percorre os passos de Cristo, compromissada com o mundo e com toda forma de vida. A missão, mais do que nunca, assume a responsabilidade por toda a criação e isso inclui o planeta. Os quadrangulares pensam dessa forma e Fluck afirma: “diante destes gemidos, a Igreja de Cristo não pode ficar passiva. Ela passa a aguardar a redenção completa, que significará também a restauração também do ecossistema: Deus fará surgir um novo céu e uma nova terra!". ${ }^{1435}$ A Missão Quadrangular passa por atualizações que são uma questão de sobrevivência, e a missão precisa ser repensada. O pentecostalismo quadrangular aceita bem o conceito da missio Dei, por isso estimula sua prática missionária, mantendo seu

\footnotetext{
${ }^{1432}$ BEZERRA, C. M. Missão Integral da Igreja, p.17.

${ }^{1433}$ BOSCH, D. J. Missão transformadora, p. 589.

${ }^{1434}$ BOSCH, D. J. Missão transformadora, p. 589.

${ }^{1435}$ FLUCK, M. R. Introdução à Missiologia, p. 16.
} 
envolvimento com a recuperação de todas as áreas da vida, incluindo a cura, como esclarece Fluck:

O importante é o reconhecimento de que a missão procede de Deus: o envio parte dele. A igreja envolve-se na missão porque ela quer obedecer à grande comissão recebida de Jesus. Na versão joanina da mesma, inclusive nos é apresentado o modelo para o exercício da missão: "como o Pai me enviou, assim eu vos envio". Como Cristo alimentou famintos, lavou pés, curou doentes, confortou os aflitos e restaurou a vida de pessoas, nós também somos enviados a servir. Cristo é o modelo a ser seguido. A comissão envolve, portanto, pregar e servir (amar o próximo). ${ }^{1436}$

A amplitude da missão destaca sua responsabilidade no mundo, portanto pensar em missão é pensar na ação evangelizadora, não se limitando, porém a esta, mas envolvendo todo o mundo, e a forma como essa pauta é cumprida às vezes foge dos limites estabelecidos, como diz Bosch: "portanto, a missão diz respeito também ao mundo que se encontra além dos limites da igreja. Trata-se do mundo que Deus ama e por cujo amor a comunidade cristã é conclamada a ser sal e luz". ${ }^{1437}$ Os textos quadrangulares mostram o esforço no avanço para uma missão contextualizada, sem perda de sua essência pentecostal. É verdade que grande parte do pentecostalismo prefere se ausentar do diálogo, situando-se na tradição do movimento, mas não avançar significa perder-se e isolar-se. Nesse sentido Bezerra diz:

Poderíamos chamar o Evangelho Integral de Evangelho "Pleno", que implica na salvação da alma humana sem negligenciar o cuidado ou atendimento das necessidades materiais daquele que é comprovadamente carente: escola, creche, clínicas, asilos, orfanatos, alimentação, vestuário etc. ${ }^{1438}$

O assunto pode parecer simples para a reflexão acadêmica, mas para o mundo pentecostal é um grande desafio, pois o novo tem suas tensões, como reflete Bosch: "inclusive o intento de arrolar algumas dimensões da missão, porém, está repleto de perigo, porque de novo sugere que nos é possível definir o que é infinito". ${ }^{1439}$ Ao analisar a estrutura geral e as bases que configuram o pentecostalismo, notam-se sinceridade e preocupação profundas com a salvação, mas em um panorama geral a questão causa estranheza, pois a estrutura da vida

\footnotetext{
${ }^{1436}$ FLUCK, M. R. Introdução à Missiologia, p. 15.

${ }^{1437}$ BOSCH, D. J. Missão transformadora, p. 589.

${ }^{1438}$ BEZERRA, C. M. Missão Integral da Igreja, p. 15.

${ }^{1439}$ BOSCH, D. J. Missão transformadora, p. 610.
} 
muitas vezes é desconsiderada. Bezerra alerta: "infelizmente, a falta de equilíbrio quanto à visão da missão integral da igreja tem gerado, através da história, dois extremos". ${ }^{1440}$ Toda a pluralidade e as transformações profundas têm marcado a sociedade, e manter a missão ativa tornou-se uma missão. Busca-se aqui expor toda a transformação social como motivo da missão, dinamizando sua atuação, descrevendo-se nesta tese alguns conceitos que julgamos importantes para as próximas agendas da missão dos quadrangulares. Por isso é recorrente nosso recurso ao texto de Bosch:

Quem quer que sejamos, espreita-nos a tentação de enclausurar a missio Dei nos estreitos confins de nossas próprias predileções, voltando, necessariamente, à unilateralidade e ao reducionismo. Deveríamos guardar-nos de qualquer tentativa no sentido de delinear a missão de uma forma demasiadamente nítida. ${ }^{1441}$

A questão tornou-se decisiva aos quadrangulares a ponto de perceberem que "sem ação missionária não há teologia cristã!". ${ }^{1442}$ A tendência é que, no âmbito do pentecostalismo em geral, cresça o interesse pela reflexão da prática missionária, como reforça Fluck: "os autores do Novo Testamento tinham menos interesse em definir corretamente os conceitos do que na existência de uma concreta ação missionária". ${ }^{1443}$ É notável no pentecostalismo a ligação entre o atual movimento e fatos do período neotestamentário, o que também define a concepção de missão, como afirma Bosch:

\begin{abstract}
Nossa missão precisa ser multidimensional, para que seja fidedigna e fiel a suas origens e seu caráter. Assim, visando a proporcionar uma ideia da natureza e qualidade dessa missão multidimensional, poderíamos recorrer a imagens, metáforas, eventos e quadros em vez de lançar mão da lógica ou da análise. Sugiro, pois, que uma maneira de oferecer um perfil do que a missão é e do que requer seja examiná-la em termos de seis "eventos salvíficos" relevantes descritos no Novo Testamento: a encarnação de Cristo, sua morte na cruz, sua ressurreição do terceiro dia, sua ascensão, o derramamento do Espírito Santo em Pentecostes e a parúsia. ${ }^{144}$
\end{abstract}

As muitas formas de expressão da missão são todas bem-vindas, pois a questão entre igreja e missão ganhou destaque na pauta missionária. Igreja é missão e as duas se completam continuamente: "é claro que tampouco se deve

\footnotetext{
${ }^{1440}$ BEZERRA, C. M. Missão Integral da Igreja, p. 16.

${ }^{1441}$ BOSCH, D. J. Missão transformadora, p. 610.

${ }^{1442}$ FLUCK, M. R. Introdução à Missiologia, p. 16.

${ }^{1443}$ FLUCK, M. R. Introdução à Missiologia, p. 16.

${ }^{1444}$ BOSCH, D, J. Missão transformadora, p. 610.
} 
divorciá-la completamente dele. Antes, missão é missio Dei, que procura englobar em si as missiones ecclesiae, os programas missionários da igreja. Não é a igreja que 'empreende' a missão; é a missio Dei que constitui a igreja". ${ }^{1445}$ A missão maior assume os problemas que degradam a vida e é voz profética que denuncia algo como incorreto ou injusto. Mas é preciso estabelecer limites quanto à responsabilidade que envolve a atuação missionária, sob o risco de perda em meio a tantas vozes. Para os quadrangulares:

Primeiro, devemos estar cientes de que os problemas da sociedade são, na sua maioria, resultados de políticas opressoras e escravizadoras, impostas por governos que não levam em conta o indivíduo nem prezam as famílias. Nós, como cristãos, não podemos fechar os olhos a essas situações nem ficar esperando iniciativas políticas. Se acompanharmos a filosofia política mundial, perceberemos que o Estado está se retirando das atividades públicas. ${ }^{1446}$

O modelo de missão quadrangular que tem se desenhado a partir do exame dos textos encontrados tenta recuperar a sintonia vista na ação da missão do Cristo, como define Fluck: "o nosso modelo missionário é a ação concreta vivida por Jesus Cristo. Ele evangelizou e engajou-se a favor do próximo". ${ }^{1447}$ Não cabe mais à missão deter-se num único modelo, pois a inovação faz parte das promessas, o novo é uma anunciação do evangelho e isso também se aplica muito bem à própria missão proclamadora das Boas Novas, que nesse ato também encontra um novo. Ao ser feita, a missão se renova, como esclarece Bezerra:

A missão da igreja precisa ser constantemente renovada e repensada. Missão não equivale a competição com outras religiões, não é atividade de conversão, de expansão da fé, de edificação do reino de Deus; tampouco é atividade social, econômica ou política. Existe, porém, mérito em todos esses projetos. ${ }^{1448}$

A hermenêutica quadrangular abarca sua atualização de missão, que parte de conceitos bíblicos para convocar o crente ao engajamento, como comenta Bezerra: "a Bíblia diz que a omissão da responsabilidade social é pecado. Portanto, toda igreja local deveria fazer filantropia". ${ }^{1449} \mathrm{O}$ chamamento às causas que estruturam a vida parece estar na pauta pentecostal da Igreja do Evangelho Quadrangular, que as trata como questões de urgência:

\footnotetext{
${ }^{1445}$ BOSCH, D, J. Missão transformadora, p. 618.

${ }^{1446}$ BEZERRA, C. M. Missão Integral da Igreja, p. 59.

${ }^{1447}$ FLUCK, M. R. Introdução à Missiologia, p .16.

${ }^{1448}$ BOSCH, D. J. Missão transformadora, p. 618.

${ }^{1449}$ BEZERRA, C. M. Missão Integral da Igreja, p. 17.
} 
Precisamos articular programas educacionais e de renda mínima, para evitar que os jovens caiam na marginalidade. Podemos criar projetos voltados para os grandes guetos, onde impera a delinquência. Cabe aos líderes de igrejas, pastores e responsáveis por ministérios pensarem em alternativas comunitárias, educativas e produtivas, para encaminhar pessoas que, naturalmente, têm menos oportunidade do que outras. ${ }^{1450}$

Descreveram-se temas que integram e desafiam a missão, retratando como desafiadora a prática missionária da Quadrangular. Cabem questões, no entanto, como a manutenção da dinâmica da pneumatologia pentecostal junto às demandas em torno da vida no planeta, assim como posicionamentos éticos e políticos, entre outras demandas. Como sintonizar uma forte espiritualidade com essa realidade? Percebeu-se também a caminhada dos quadrangulares por alguns temas em discussão.

Seguindo a proposta de somar contribuições ao enriquecimento da perspectiva da Igreja do Evangelho Quadrangular, cumpre refletir sobre diálogo e ecumenismo, abarcando a percepção dos quadrangulares nesse assunto. É fato que os pentecostais em geral resistem ao tema, mas Bosch alerta: “[...] manter missão $e$ unidade, verdade e unidade pressupõe tensão. Não uniformidade". ${ }^{1451}$ Quando se propõe ao pentecostal tratar de temas que reportam ao diálogo ou ao ecumenismo, pressupõe-se que o nivelamento ou abertura à fé do outro implicam renúncia a parte de sua convicção. É mais fácil, portanto, levantar um muro em torno da questão, o que infelizmente tem sido comum entre os pentecostais. Costa diz: "os grupos pentecostais, em geral, são avessos ao ecumenismo. A maioria deles veio de redutos evangélicos conservadores". ${ }^{1452}$ A Igreja Quadrangular não difere do pentecostalismo em geral, como lembra Bezerra:

Em nossa história, por décadas, a igreja brasileira se manteve afastada da missão integral. Fomos ensinados a nos manter isolados e não integrados à comunidade na qual estamos inseridos. Construímos uma cultura preconceituosa, que não nos permite conviver com "publicanos" e "pecadores", como fez Jesus. ${ }^{1453}$

A questão torna-se mais tensa quando o acirramento da discussão não colabora para a abertura como se percebe no trato da questão por Ottaviani:

\footnotetext{
${ }^{1450}$ BEZERRA, C. M. Missão Integral da Igreja, p. 59.

${ }^{1451}$ BOSCH, D. J. Missão transformadora, p. 554.

${ }^{1452}$ COSTA, Rovílio. O pentecostalismo e o culto do divino na atualidade. Teocomunicação, Porto Alegre, v. 37, n. 158, p. 586-600, dez. 2007. p. 597.

${ }^{1453}$ BEZERRA, C. M. Missão integral da igreja, p. 18.
} 
"embora elenque um rol de novas seitas extremistas (escatologistas ou excessivamente espirituais), como os adventistas, assembleias de Deus, pentecostais [...]" ${ }^{1454} \mathrm{O}$ pentecostalismo é marcado por extremismos, em alguns aspectos, mas destaca-se sua singularidade nas questões interpretativas da fé na vida e nas relações. As denominações não dialogam entre si, o que fragmenta o movimento pentecostal, incapaz de pensar a questão para além do pentecostalismo, o que constitui um desafio considerável, dada a ausência dessa prática, mesmo dentro do pentecostalismo. Costa explica: "para eles, a base da fé cristã e da ação de Deus é a conversão e a salvação do indivíduo como eventos, muitas vezes, isolados e momentâneos; a Bíblia, como a norma infalível e única fonte de fé, e sua interpretação acentuadamente legalista; posicionamento anticatólico". 1455

Se é nesse cenário que está a Igreja do Evangelho Quadrangular, qual o caminho para o diálogo? A ideia de ecumenismo no pentecostalismo não é bem vista, pois leva ao desconhecido. Para Comblin, é preciso celebrar a diversidade, que aponta para a liberdade: "a marca da Igreja do Novo Testamento é a diversidade, a pluralidade, sem a qual não há liberdade". ${ }^{1456}$ Já se veem entre pentecostais acadêmicos a busca do diálogo e o empenho em levar o pentecostalismo à reflexão ecumênica. A questão central é a falta de conhecimento do tema, motivo de conclusões erradas, infelizmente as que se popularizam no movimento. Poderíamos começar, por exemplo, pela afirmação de Bosch: "o propósito não é um nivelamento de diferenças, um reducionismo superficial, uma espécie de 'caldo' ecumênico. Nossas diferenças são genuínas e devem ser tratadas como tais". ${ }^{1457}$

Para o início da contextualização da prática quadrangular no diálogo ecumênico, é preciso deixar claro que uma das principais marcas do ecumenismo é justamente a diversidade, e isso é histórico no cristianismo, pois a fé cristã se manifesta na diversidade, o que não pode ser pretexto para o isolamento e a individualidade da fé. González afirma: "o cristianismo chegou a todas as nações; tem maior vitalidade e crescimento em umas que em outras, mas, sem dúvida, seu

\footnotetext{
${ }^{1454}$ OTTAVIANI, E. S.; FREZZATO, A. Teologia a marteladas, p. 615.

${ }^{1455}$ COSTA, Rovílio. O pentecostalismo e o culto do divino na atualidade. Teocomunicação, Porto Alegre, v. 37, n. 158, p. 586-600, dez. 2007. p. 597.

${ }^{1456}$ COMBLIN, J. Vocação para a liberdade, p. 299.

${ }^{1457}$ BOSCH, D. J. Missão transformadora, p. 554.
} 
rosto é diverso". ${ }^{1458}$ É verdade que as diferenças provocam certa tensão, mas também oportunizam o repensar, pois a missão necessita disso para avançar. Bosch argumenta:

Ao contrário, essa tensão nos convoca ao arrependimento. A missão em unidade e a unidade na missão são impossíveis sem uma atitude autocrítica, especialmente onde cristãos se encontram com outros, irmãos de fé ou não-crentes, que, por padrões humanos, deveriam ser inimigos. ${ }^{1459}$

Um possível caminho para o convite ao diálogo ecumênico é a reiteração da importância da identidade, e na percepção comblianiana essa é uma ação do Espírito e a cristandade é chamada a celebrar: "finalmente, se o Espírito age ocultamente no interior de cada homem, para que este homem seja ele mesmo e não outro, e não o executor da vontade de outro, daí resulta que a obra do Espírito é uma infinita multiplicidade e diversidade". ${ }^{1460}$ Qual seria o objetivo de propor o diálogo ecumênico ao pentecostalismo da Quadrangular? O que significa o conceito de ecumenismo? Propor respostas requer a compreensão das delimitações do tema. Cardoso explica:

Qual o conceito de ecumenismo? O modo de usar o termo pode variar desde a referência a um círculo mais estrito ou mais amplo. No sentido mais estrito, estaria se referindo aos cristãos que empreendem um movimento de aproximação ou maior unidade com outros cristãos de diferentes confissões ou denominações. Num sentido mais amplo, envolveria a aproximação e o diálogo entre pessoas de diferentes credos ou religiões. ${ }^{1461}$

A abertura ao diálogo passa por querer conhecer o outro, aceitar, superar as diferenças, não para igualar-se a ele, mas para superar barreiras e entender que a diferença é exatamente o que constitui o outro. A tensão no processo de aproximação é inevitável, mas pode haver unidade na diversidade, como Bosch descreve: “o ecumenismo só é possível onde as pessoas aceitam umas às outras a despeito de diferenças. Nossa meta não é uma comunhão isenta de conflito, mas uma comunhão caracterizada por unidade na diversidade reconciliada". ${ }^{1462}$

O resultado projetado com a missão que caminha rumo ao diálogo ecumênico é justamente a cooperação para a paz e a colaboração para a superação

\footnotetext{
${ }^{1458}$ L. GONZÁLEZ, J. História do movimento missionário, p. 531.

${ }^{1459}$ BOSCH, D. J. Missão transformadora, p. 555.

${ }^{1460}$ COMBLIN, José. Breve curso de teologia: o Espírito Santo e sua missão Tomo II, p. 329.

${ }^{1461}$ CARDOSO, M. T. F. Paulo e o Ecumenismo, p. 243.

${ }^{1462} \mathrm{BOSCH}, \mathrm{D}, \mathrm{J}$. Missão transformadora, p. 555.
} 
de desafios que envolvem tantos de mesma fé ou propósitos comuns. Cardoso explica o termo: "hoje, quando se fala de ecumenismo se deseja e se pretende um envolvimento que leve à paz e à cooperação entre todos nós. O termo 'ecumênico' tem sua origem em sentido universalista. 'Oikoumene' era toda a terra habitada, era o universo das pessoas". ${ }^{1463}$ A análise da questão a partir da hermenêutica bíblica pode ajudar a esclarecer a questão, admitindo requisitos prioritários em torno do diálogo ecumênico. Pode ser apontada como pecaminosa a desunião, dado o preceito de Cristo que nos dirige à unidade. E como Bosch diz: "por último, temos que confessar que a perda da unidade eclesial não constitui apenas uma vexação, mas um pecado. A unidade não é um acessório opcional. Ela já é, em Cristo, um fato, algo dado. Ao mesmo tempo, é um mandamento: 'Sejam um!". 1464

Comentadores de Comblin também enriquecem a discussão. Lara, ao comentar os critérios utilizados durante a escolha dos relatos para escrever sobre Comblin, revela que uma grande contribuição foi o conceito de provisório, de inconcluso:

Escolhi esses retalhos do livro do Comblin para atualizarmos nossa reflexão sobre a importância do provisório, e também para pensarmos na provisoriedade do que fazemos. Lembrando inclusive Paulo Freire, que costumava dizer: "eu não sou, estou sendo". A interiorização desses conceitos talvez nos ajude, na vida cotidiana, a evitar que nos aproximemos dos nossos irmãos dizendo ou pensando: "sabe com quem está falando? [...]" Pois somos todos imperfeitos, inconclusos [...] $]^{1465}$

Não deveríamos nos fechar em nossas convicções, pois estamos em continuidade e descontinuação. Eis aqui um alerta relevante, que descreve o processo de aprendizado para os dispostos a dialogar. Outro caminho é proposto por Comblin, para quem a diversidade é uma construção do Espírito, devendo ser a multiplicidade vista como algo bom: "o Espírito respeita e desenvolve a personalidade de cada pessoa humana. Desta forma, ele promove a variedade, a multiplicidade na Igreja e no mundo". ${ }^{1466}$

O diálogo inter-religioso não prevê ausência de tensões, entretanto, seguindo um plano maior de cristianismo situado além e uma cultura ou igreja

\footnotetext{
${ }^{1463}$ CARDOSO, M. T. F. Paulo e o Ecumenismo. Atualidade Teológica Ano XIII no 32, maio a agosto / 2009. p. 244.

${ }^{1464}$ BOSCH, D, J. Missão transformadora, p. 557.

${ }^{1465}$ LEITE, M. C. C. Comblin e a espiritualidade do provisório, p. 47.

${ }^{1466}$ COMBLIN, José. Breve curso de teologia: o Espírito Santo e sua missão Tomo II, p. 339.
} 
local, a missão abarca todo o mundo e a vida. Por isso, se pensamos em missão na perspectiva da missio Dei, é necessária a abertura antes da ação. Cardoso diz que não devemos buscar fronteiras, mas cruzá-las:

O diálogo inter-religioso não precisa esperar que a unidade dos cristãos seja perfeita, mas também pode se beneficiar de que os cristãos se apóiem mutuamente também na atitude de diálogo, e melhor, se sintam estimulados para a fraternidade que, segundo a fé cristã, não deve encontrar fronteiras. ${ }^{1467}$

Voltando um pouco na história do movimento pentecostal, percebe-se a existência de, pelo menos, três elementos diversos que podem ser discutidos: cura divina, fundamentalismo e ecumenismo, como Mendonça descreve, ao tratar desse período do pentecostalismo norte-americano: "o período se fecha com as igrejas tradicionais situadas perante três vias opostas a elas mesmas e entre si: o pentecostalismo de cura divina, o fundamentalismo e o ecumenismo incipiente". ${ }^{1468}$ A Quadrangular absorveu alguns desses elementos, e a cura divina foi mantida na Quadrangular brasileira, enquanto o ecumenismo existiu na fase de fundamentação no Brasil, embora mais tarde pareça ter sido sufocado. A situação carece de boa vontade e é preciso querer o diálogo. Quem se abre ao outro contribui na mesma medida em que é fortalecido, mostrando ao mundo a dimensão de sua missão, como lembra Cardoso:

Como falávamos, a unidade é um desejo que se abre mais universalmente do que o campo dos cristãos. Deseja-se alcançar uma unidade que abrace todas as pessoas. O diálogo se estende a quem desejar dialogar. Respeitem-se as convicções, mas haja uma atitude de boa vontade com o outro, de confiança na boa fé de cada um, de apreciação da riqueza também de cada qual. Isso para todas as pessoas, qualquer que seja a sua convicção religiosa. ${ }^{1469}$

O diálogo tem por obrigação gerar concretude em ações visíveis a todos. Comblin é categórico em afirmar: "o evangelho de Cristo não é discurso sobre Cristo, mas manifestação de Cristo feito escravo e crucificado". ${ }^{1470}$ Elementos do pentecostalismo o levam a testemunhar e isso proporcionou o crescimento do movimento, e agregar o tema do ecumenismo é o desafio a ser superado. Parece interessante propor à Quadrangular um diálogo a partir da percepção de Cardoso:

\footnotetext{
${ }^{1467}$ CARDOSO, M. T. F. Paulo e o Ecumenismo, p. 244.

${ }^{1468}$ MENDONÇA, A. G. O Protestantismo no Brasil e suas Encruzilhadas, p. 61.

${ }^{1469}$ CARDOSO, M. T. F. Paulo e o Ecumenismo, p. 244.

${ }^{1470}$ COMBLIN, J. O Espírito Santo e a libertação, p. 202.
} 
“o ecumenismo é uma atitude que vai ao encontro e dialoga, mas não anula o que acredita, não anula a própria identidade confessional". ${ }^{1471}$ A autora acena à cooperação, pois não são pequenos os desafios à missão cristã. É preciso vencer a tentação de acreditar que o diálogo ou a aproximação queiram nos padronizar. Comblin afirma: “o Espírito não age para uniformizar. Ao contrário, ao exaltar a personalidade de cada um, o Espírito se mostra fonte de uma variedade infinita". ${ }^{1472}$ Se o diálogo ecumênico é uma missão e a diversidade é obra do Espírito, o pentecostalismo tem muito trabalho pela frente. $\mathrm{O}$ ecumenismo não pode ser encarado como arena de embates, mas como cenário de respeito, interrelações e enriquecimento mútuo, agregando valor a ambos os dialogantes, como propõe Cardoso:

\begin{abstract}
Com isso tudo, o ecumenismo guarda o respeito da identidade, e, destarte, aquele que participa do ecumenismo pode guardar a própria confissão de fé, bem como ter sua prática de vida coerente com as opções fundamentais. É assim que cada um entrará em diálogo. Não para impor sua conviç̧ão, mas com o direito de guardá-la, professá-la e até apresentá-la para explicar o seu pensamento e a sua prática. É interessante também a crescente iluminação dessa identidade: ver que a fé cristã se pode tratar, e conhecer mais profunda e vivamente, e que no diálogo as convicções se revelam e, umas com as outras, muitas vezes se enriquecem. ${ }^{1473}$
\end{abstract}

O Cristo nos dá por missão ser um, e não ser igual. Segundo o exemplo bíblico, a unidade do corpo é justamente a soma da diversidade que o compõe. Comblin esclarece: "há uma infinidade de formas diversas de imitar a Cristo: o Espírito está na base de todas e ele não pede um modelo uniforme. Existem variações infinitas nas vocações cristãs". ${ }^{1474}$ A marca da mensagem do evangelho é o amor, iniciado por Deus ao dar seu filho por amor. Da mesma maneira Ele dá o Espírito, que por amor habita no cristão e o faz evangelizar e participar da missão de Deus. Mikuszka diz: "a mensagem do amor produz mudança no mundo, pois tende a mudar o ser humano, configurando uma ordem de justiça e de amor entre todos". ${ }^{1475}$ A diversidade não é obstáculo ao cristianismo, sendo o desafio manter a unidade na diversidade, que existe desde as primeiras comunidades, como afirma Amado:

\footnotetext{
${ }^{1471}$ CARDOSO, M. T. F. Paulo e o Ecumenismo, p. 247.

${ }^{1472}$ COMBLIN, José. Breve curso de teologia: o Espírito Santo e sua missão Tomo II, p. 329.

${ }^{1473}$ CARDOSO, M. T. F. Paulo e o Ecumenismo, p. 247.

${ }^{1474}$ COMBLIN, José. Breve curso de teologia: o Espírito Santo e sua missão, Tomo II, p. 340.

${ }^{1475}$ MIKUSZKA, G. L. A Reforma Protestante e a ação evangelizadora da Igreja católica, p. 67.
} 
Já as primeiras comunidades manifestavam essa diversidade. Os textos neotestamentários e os subsequentes mostram a preocupação em manter o essencial e respeitar a pluralidade. Essa preocupação diz respeito a se manter a identidade da Igreja, enquanto comunhão dos diversos. ${ }^{1476}$

A unidade pode ser vista como mover do Espírito, entretanto a manifestação dessa unidade não se empreende por caminhos humanos, por vezes confusos ao entender unidade como uniformidade. Comblin afirma: "embora seja verdade que o Espírito é uno e busca a unidade, não a busca por meios humanos, isto é, mediante a uniformidade e a submissão comum a uma simples lei. Não é uno pela redução da multiplicidade à unidade". ${ }^{1477}$ A questão é muito importante para o cristianismo em geral, pois trazer o pentecostalismo ao diálogo é conseguir a participação da ala cristã que mais cresceu no último século. Oliveira diz: "o modo de ser pentecostal funde a realidade social com a espiritualidade, gerando uma ressignificação do mundo e de suas relações". ${ }^{1478}$ A convocação à participação do diálogo e unidade é também princípio de vocação cristã, segundo Cardoso:

É a própria vocação cristã que exige de nós andar na unidade, a partir do Espírito. Ao propor a vocação cristã como caminho, e a necessária correspondência com essa vocação, entre outras exigências e virtudes, o autor de Ef. faz especial apelo à unidade: "Exorto-vos, pois, eu, o prisioneiro no Senhor, a andardes de modo digno da vocação a que fostes chamados: com toda humildade e mansidão, com longanimidade, suportando-vos uns aos outros com amor, procurando conservar a unidade do Espírito pelo vínculo da paz (Ef. 4,1-3)." Desse modo, é mantendo a unidade que se realiza a vocação cristã. ${ }^{1479}$

$\mathrm{Na}$ perspectiva de Oliveira é possível um caminho que integre o pentecostalismo ao diálogo: "a ênfase adequada é tratá-los na integralidade e indivisibilidade do paradigma. A característica predominante é o caráter ecumênico da missão e o conceito abrangente é o da missio Dei". ${ }^{1480}$ Para Comblin, a unidade passa pela ação do Espírito, e esse ambiente pneumatológico reforça a adesão do pentecostalismo: "mas o Espírito tem força para unir o que exteriormente parece mais diversificado, menos unido. A unidade se situa num

\footnotetext{
${ }^{1476}$ AMADO, J. P. O Documento de Aparecida e sua proposta para toda a Igreja, p. 86.

${ }^{1477}$ COMBLIN, José. Breve curso de teologia: o Espírito Santo e sua missão, Tomo II, p. 329.

1478 OLIVEIRA, D. M. d. Pentecostalidade da Missão Latino-Americana, p. 91.

${ }^{1479}$ CARDOSO, M. T. F. Paulo e o Ecumenismo, p. 249.

1480 OLIVEIRA, D. M. d. A Dimensão Comunicativa da Ação Missionária e as Culturas, p. 79.
} 
nível oculto, invisível”. ${ }^{1481}$ A unidade ultrapassa a concepção humana, portanto, e o ecumenismo pode se processar de forma muito sutil e mesmo invisível. $\mathrm{Na}$ percepção combliniana o Espírito é quem promove a unidade, num entendimento semelhante ao conceito de missão do autor, que vê o Espírito como promotor da missão contínua:

O Espírito cria diversidade e promove a unidade entre tudo o que é diferente. - A ação própria do Espírito consiste em multiplicar e estabelecer as diferenças. Para realizar a unidade ele não precisa da uniformidade, porque faz a unidade mediante o amor e a fraternidade, que são forças capazes de juntar o que é diverso e de unir os diferentes, mesmo deixando que permaneçam diferentes. ${ }^{1482}$

Os quadrangulares ensaiam certa reflexão sobre o tema e convidam a conhecer a manifestação de Deus no outro, pois na diversidade habita a glória de Deus, como diz Fluck:

Enfim, o que se põe como horizonte de reflexão, que a expressão do diálogo é, antes de qualquer coisa, uma expressão dos que se encontram. Não para descobrir no outro a nossa face, não para fazer do outro a nossa imagem e semelhança, para perceber nele a face maravilhosa diversa de Deus. ${ }^{1483}$

Isso proporciona a esperança cristã, embasada na concretização da missão, pois o que une os cristãos é mais forte do que aquilo que os separa. Cardoso diz: "certamente que essa esperança irmana os diversos cristãos e convida-os a um diálogo em mais confiança e mais solidariedade, em vista do que se propõe na mesma fé e do que se deseja e espera em comum". ${ }^{1484}$ A relação entre missão e diálogo nasce na visão includente que envolve também o diferente. Eis aí uma causa missionária aberta, que não figura como vertente absoluta da verdade, como expõe Oliveira:

A missão tem suas verdades e seus pontos de vistas. Entra em diálogo com os demais atores não com uma atitude exclusivista, mas como abertura para questionamentos e formulações locais. Contudo o referencial para a vida continua

\footnotetext{
${ }^{1481}$ COMBLIN, José. Breve curso de teologia: o Espírito Santo e sua missão Tomo II, p. 329-330.

${ }^{1482}$ COMBLIN, José. Breve curso de teologia: o Espírito Santo e sua missão Tomo II, p. 332.

${ }^{1483}$ FLUCK, M. R. Introdução à Missiologia, p. 70.

${ }^{1484}$ CARDOSO, M. T. F. No respeito e no Amor. Ensinamento de Bento XVI e Francisco sobre a Solicitude Ecumênica. Perspect. Teol., Belo Horizonte, v. 48, n. 2, p. 357-387, Mai./Ago. 2016, p. 374.
} 
sendo Jesus. É preciso pensar em uma comunidade includente, no modelo crítico. ${ }^{1485}$

Ainda na relação entre missão e ecumenismo, é preciso ampliar a dimensão de missão, que não se limita a determinada denominação, mas abarca todas. Pensar em missão numa perspectiva ampla dirige a Deus e envolve todos no Seu reino. E como pontua René, "se a missão da igreja é a missão do reino de Deus, ela deve ser ao mesmo tempo evangélica e ecumênica". ${ }^{1486}$ Agir que aponta para o reino de Deus, a missão tende a se cumprir na força do Espírito, criando a unidade pela sua manifestação. Comblin diz: "o Espírito e a multiplicidade na diversidade. - O Espírito realiza a unidade, não, porém, através de meios humanos. Não se trata de uma unidade puramente humana, tal como poderia proceder de fatores humanos". 1487

No entanto, isso não deve gerar acomodação ou deixar a tarefa a cargo do Espírito. Como parceiro na missão de Deus, todo cristão é convocado a participar. Segundo René, a missão é "evangélica porque anuncia a boa nova do estabelecimento de uma nova realidade na história de Jesus Cristo [...]" ${ }^{1488}$ Para Comblin, tanto a diversidade quanto a unidade (na perspectiva do Espírito, que não reduz à diversidade) compõem o plano divino e ambas são importantes:

\begin{abstract}
Por conseguinte, a unidade não prevalece sobre a multiplicidade. Ambas são igualmente divinas, porque a unidade não se realiza de modo humano. Neste mundo, e sobretudo nas coisas feitas pelos homens, não há unidade que não corresponda à redução da diversidade. Graças ao Espírito, não ocorre o mesmo na história da libertação. ${ }^{1489}$
\end{abstract}

Segundo René, a missão tende a ser ecumênica por revelar a universalidade da comunidade cristã: "ecumênica porque tem como horizonte a comunidade 'universal' por meio da qual Deus quer manifestar seu amor e justiça em todas as nações". ${ }^{1490}$ Há no pentecostalismo acadêmico uma organização que se ocupa de temas relacionados à pesquisa do ecumenismo e de temas gerais do pentecostalismo. Rosa diz:

\footnotetext{
${ }^{1485}$ OLIVEIRA, D. M. d. A Dimensão Comunicativa da Ação Missionária e as Culturas, p. 89.

${ }^{1486}$ C. René, P. O que é missão integral?, p. 132.

${ }^{1487}$ COMBLIN, José. Breve curso de teologia: o Espírito Santo e sua missão, Tomo II, p. 339.

${ }^{1488}$ C. René, P. O que é missão integral?, p. 132.

${ }^{1489}$ COMBLIN, José. Breve curso de teologia: o Espírito Santo e sua missão, Tomo II, p. 330.

${ }^{1490}$ C. René, P. O que é missão integral?, p. 132.
} 
Ainda uma outra iniciativa ecumênica de pentecostais latino-americanos é a Rede Latino Americana de Estudos Pentecostais (RELEP). Ela surgiu em 1996, através de pentecostais acadêmicos que pesquisavam o pentecostalismo latino-americano e tinham o desejo de formar um grupo de pentecostais, de maneira coordenada, para aprofundarem os estudos sobre o tema. ${ }^{1491}$

Os desafios da missão ultrapassam os temas do cotidiano da igreja, abrangendo assuntos relacionados ao direito humano, por exemplo, e pede empenho e uma missão de rosto ecumênico. Neto diz: "além disso, deve acentuarse o caráter ecumênico de toda pastoral sobre os direitos humanos, especialmente em trabalho conjunto com a Igreja Católica Romana, que surgiu de uma experiência vivida e que oferece a possibilidade de sistematizar as ações". ${ }^{1492}$ Questões que giram em torno da vida não se satisfazem com uma única resposta, pois é necessária a unidade em prol da vida. Por isso a atuação missionária pede empenho conjunto, criando força, como explica Cardoso:

O chamado do Evangelho para a vida é um chamado de interesse ecumênico. Todos os cristãos se identificam com essa aspiração e todos têm responsabilidade em atender ao Cristo. Por outro lado, também não se trata apenas da busca de unidade dos cristãos em torno a esse evangelho. Importa um diálogo maior. O interesse pela vida, e a responsabilidade perante a vida são para todos, ainda que de diferentes religiões ou de diferentes segmentos da sociedade. ${ }^{1493}$

Comblin compreende tanto a diversidade quanto a unidade como importantes: "acham que a unidade vem de Deus e a diversidade, dos homens. No entanto a diversidade também é de Deus, pois vem do Espírito. O Espírito criou os homens na diversidade e o Espírito orienta sua libertação também na diversidade". ${ }^{1494}$ Por último, os quadrangulares reconhecem que precisam avançar na construção de sua própria percepção da temática. Fluck diz:

Em torno do tema da diversidade religiosa, se agregam vários outros conceitos. Isso pressupõe mais que uma necessidade de elaboração literária. Diálogo, neste contexto, pressupõe compromisso em ouvir e aprender. Aprender para mudar, para retomar novas rotas ou reconstruir as atuais. ${ }^{1495}$

\footnotetext{
${ }^{1491}$ ROSA, André Luís da. Pentecostalismo e Ecumenismo: algumas observações. Reflexus - Ano XI, n. 18, 2017/2, p. 392.

${ }^{1492}$ LONGUINI NETO, L. O novo rosto da missão, p. 240.

${ }^{1493}$ CARDOSO, M. T. F. A perspectiva ecumênica do Documento de Aparecida. Encontros Teológicos n 57 Ano 25 / número 3 / 2010, p. 78.

${ }^{1494}$ COMBLIN, José. Breve curso de teologia: o Espírito Santo e sua missão, Tomo II, p. 339.

${ }^{1495}$ FLUCK, M. R. Introdução à Missiologia, p. 63.
} 
Concluímos esta seção percebendo que os quadrangulares estão receptíveis aos novos paradigmas que compõem a missão na atualidade, bem como a presença de reflexões em torno das questões apresentadas. Percebe-se com essa pesquisa uma possibilidade de diálogo sobre a missão. A perspectiva quadrangular pode se enriquecer com a visão libertadora mais ampla de Comblin. A perspectiva quadrangular também pode enriquecer a reflexão e a prática da missão com seu método de pequenos grupos e de ação dos leigos.

\subsection{3. \\ Contribuições da tese para a pastoral missionária de todos os cristãos, em especial, a missão dos leigos}

Iniciamos a pesquisa analisando a prática da missão da Igreja do Evangelho Quadrangular a partir da hipótese de que seu crescimento dentro do pentecostalismo está associado à missão do leigo. A própria Quadrangular vê a temática como elemento-chave no desafio da missão. Damazio confirma: "a identificação, preparo e encaminhamento do ministério leigo é uma chave para a construção da igreja que alcança cidades (veja Atos 6: 1-7)" ". 1496 O tema é relevante e tem despertado interesse, notando-se no pentecostalismo quadrangular a grande a participação do leigo, independentemente de faixa etária. A estrutura da denominação é dividida entre os chamados grupos missionários, que coordenam as atividades da igreja, num modelo que abre espaço à participação geral, seja na pregação durante os cultos ou em outra atividade.

Para Bosch, há diferença de participação do leigo entre as missões católica e protestante. Sobre o ambiente católico ele diz: "a participação deles no empreendimento missionário era, todavia, claramente auxiliar e se achava sob firme controle e jurisdição do clero. Nas missões protestantes, o cenário era mais auspicioso, especialmente à medida que crescia o "princípio voluntário". ${ }^{1497}$ Para Comblin, os leigos estão sobrecarregados com obrigações da paróquia e não têm destaque nela: "os leigos são objeto de obrigações: os leigos devem ir para a paróquia, devem obedecer e, sobretudo, sustentar financeiramente uma instituição

\footnotetext{
${ }^{1496}$ DAMAZIO, F. Cruzando Rios, Tomando Cidades, p. 170.

${ }^{1497}$ BOSCH, D. J. Missão transformadora, p. 561.
} 
na qual não têm poder nenhum". ${ }^{1498}$ Segundo Bosch, a estrutura das missões protestantes é marcada pela presença do leigo, passando pela formação das sociedades missionárias, que permitiam sua presença voluntária: “em verdade, já desde seu início, as missões protestantes eram, em grau significativo, um movimento leigo. As sociedades de voluntários não estavam limitadas a eclesiásticos". 1499

O pentecostalismo quadrangular apresentou ao Brasil uma face do cristianismo que cedeu lugar ao leigo, tornando-o participante da missão. Ao pentecostalismo sempre se atribui forte ênfase em questões pneumatológicas, mas não seria o leigo o elemento central do movimento? Cabe ainda outra pergunta: não é o leigo o responsável pela existência da forte espiritualidade pentecostal? Logo, poder-se-ia pensar que o pentecostalismo é, entre outras coisas, um movimento de maioria leiga que proporciona a experiência do Espírito. Costa afirma: "para os pentecostais, a experiência pentecostal é a redescoberta do cristianismo". 1500

Se os quadrangulares tivessem seguido o caminho convencional de preparação de pastores talvez sua missão não ganhasse destaque no pentecostalismo. O leigo é central na missão quadrangular e o poder de contextualização na missão leiga resulta de sua convivência entre as realidades da igreja e do mundo. Agrega-se a isso sua forte experiência espiritual, que acaba por moldar sua vida pessoal e levá-la até suas relações públicas. Oliveira explica:

Esse poder de penetração na sociedade é básico para uma missão contextualizada e relevante historicamente, aliado a um zelo evangelizador, que produz uma igreja militante. Sua missiologia é fortemente influenciada pela "Grande Comissão" (Mt 28. 19; Mc 16.15) e pela noção de experiência especial Espírito Santo para ser testemunha em todo o mundo (At 1.8). É tarefa urgente, considerando as mazelas deste mundo e a condição de "perdidos" dos não-cristãos. ${ }^{1501}$

É possível notar a clara participação e ativismo dos leigos na Missão Quadrangular desde a origem, entretanto também se percebe uma recuperação dos moldes da Cruzada Nacional de Evangelização, não pela estrutura em tendas, mas pela centralidade desse tipo de evangelização; ou seja, por uma missão de caráter

\footnotetext{
${ }^{1498}$ COMBLIN, J. As grandes incertezas na igreja atual, p. 38.

${ }^{1499}$ BOSCH, D. J. Missão transformadora, p. 561.

${ }^{1500}$ COSTA, R. O pentecostalismo e o culto do divino na atualidade, p. 594.

${ }^{1501}$ OLIVEIRA, D. M. d. Pentecostalidade da missão latino-americana, p. 95.
} 
pneumatológico com ênfase na cura divina com a atuação dos leigos. A atualização missionária dos quadrangulares, com sua distribuição em células e grupos pequenos manteria a centralidade iniciada no modelo das tendas de cura divina. Esse modelo também reserva espaço ao leigo. Damazio diz: "acrescentamos à nossa equipe de ministério pastores leigos juntamente com pastores da equipe". ${ }^{1502}$

A participação do leigo na missão tem sido repensada, e parece que o leigo é percebido como o caminho mais curto entre missão, cultura e sociedade. O leigo é a resposta da missão às grandes transformações sociais. Enquanto a igreja não acompanha as rápidas transformações e por isso não se comunica, o leigo participa das mudanças sociais, constituindo um instrumento de evangelização que atua de maneira aculturada. Se a igreja não dá conta de acompanhar as diversas e simultâneas transformações, o leigo faz parte desse contexto e se transforma junto. Bosch diz:

\begin{abstract}
Mesmo assim, está em andamento uma mudança inequívoca. As pessoas leigas não são mais apenas os escoteiros que, retornando do "mundo lá fora", como testemunho oculares e, talvez, com alguns cachos de uvas, apresentam-se à "base de operação"; elas são a base operacional donde emana a missio Dei. De fato, não são elas que devem "acompanhar" aqueles que são os portadores de "ofícios especiais" na missão deste mundo. Pelo contrário, são os portadores de ofícios que precisam acompanhar os leigos, o povo de Deus. ${ }^{1503}$
\end{abstract}

Comblin, ao comparar a preparação de sacerdotes católicos e protestantes, conclui que os pastores evangélicos em geral surgem em proporção muito maior: "quantos milhares de pastores evangélicos surgiram no Brasil ultimamente que se dedicam à pregação, à missão, com entusiasmo, sacrifício e dedicação!". ${ }^{1504}$ Segundo Bosch, os leigos alcançaram seu espaço na missão, e a atuação do leigo na Missão Quadrangular tem sido decisiva. Bosch lembra: "sua significação reside sobretudo no fato de que aqui as pessoas leigas chegaram à maioridade e se encontraram envolvidas na missão de maneira imaginativa". ${ }^{1505} \mathrm{O}$ pentecostalismo surge como movimento carente de mão de obra para a missão e foi atacado por denominações já estabelecidas. O caminho, então, foi utilizar os meios disponíveis, no caso o leigo. Costa afirma: "por isso, o pentecostalismo

\footnotetext{
${ }^{1502}$ DAMAZIO, F. Cruzando rios, tomando cidades, p. 170.

${ }^{1503}$ BOSCH, D. J. Missão transformadora, p. 563.

${ }^{1504}$ COMBLIN, J. As grandes incertezas na igreja atual, p. 48.

${ }^{1505}$ BOSCH, D. J. Missão transformadora, p. 565.
} 
representa a nova Reforma da Igreja, superior a todas as reformas e renovações até agora existentes na história da Igreja" ${ }^{1506}$ Para Amado, o laicato é considerado um fenômeno, mas no caso quadrangular a questão talvez seja diferente e não possa ser encarada assim, pois nessa denominação, desde o início, o leigo teve papel catalisador:

Diante do fenômeno de um laicato que crescentemente se organiza nas chamadas novas comunidades, cada uma com seu carisma, sua história e sua missão, o elemento comum haverá de ser, como, aliás, sempre foi, a eclesialidade, esta entendida também como abertura aos demais carismas e, portanto, como comunhão. ${ }^{1507}$

O cristianismo enfrenta um grande desafio, que também se traduz num momento único de mudanças na atuação missionária, que apontam para a atuação do leigo, como afirma González: "em resumo, as missões não acabaram. O cristianismo vive um momento espetacular, mas cheio de tensões e paradoxos que demandam fé, amor e esperança". ${ }^{1508}$ É preciso recompor a reflexão da missão leiga e fortalecer esse caminho, já percebido como possível solução missionária. Oliveira afirma:

Uma teologia pentecostal está dada pela relação intensa que desenvolve com o templo (alta frequência), com a Bíblia (paixão pelas Escrituras, mormente lida e aplicada literalmente), com a atualidade dos dons espirituais (capacitação e sacerdócio de todos os crentes), com a escatologia (esperança de novo céu e do encontro com Cristo) e com a missão (anunciam em qualquer lugar e a todos). ${ }^{1509}$

O modelo de missão proposto pela quadrangular em grupos pequenos traz em seus planos a atuação de pastores leigos. Parece que os quadrangulares compreenderam que o sucesso da missão no cenário atual depende da atuação leiga. Damazio confirma: “os pastores leigos são preparados para trabalhar em todos os aspectos do ministério. Eles supervisionam nossas células, pois esta é a estratégia que preparamos para alcançar todos os bairros da nossa cidade". ${ }^{1510}$ Comblin, afirma a necessidade de aceitação das mudanças sociais e a compreensão de que a evangelização não pode ser uma ação de força: "este é o desafio prático ainda não assumido coletivamente pela Igreja: reconhecer que não

\footnotetext{
${ }^{1506}$ COSTA, R. O pentecostalismo e o culto do divino na atualidade, p. 594-595.

1507 AMADO, J. P. Leigos na linha de frente?, p. 411.

${ }^{1508}$ L. GONZÁLEZ, J. História do movimento missionário, p. 531.

${ }^{1509}$ OLIVEIRA, D. M. d. Pentecostalidade da Missão Latino-Americana, p. 94.

${ }^{1510}$ DAMAZIO, F. Cruzando Rios, Tomando Cidades, p. 170.
} 
se pode mais evangelizar a partir de uma posição de poder, mas apenas numa relação de seres humanos com seres humanos iguais". ${ }^{1511}$

No trato da atuação dos cristãos leigos e leigas na sociedade, é importante notar o Documento 105 da CNBB, concernente ao tema. O papel do leigo na missão é decisivo porque ele é ponte entre igreja e sociedade, como destaca esse documento: “a Igreja não é uma ilha de perfeitos, mas uma comunidade missionária e de aprendizagem em seu modo de ser, organizar e agir como seguidora de Jesus Cristo". ${ }^{1512}$ O destaque da ação leiga na missão está justamente em sua coexistência no mundo, pois é no mundo que a missão acontece, encontrando nele audiência, ecoando a experiência da esperança sendo mundo o lugar das tarefas, para no mundo o cristão agir santamente e consagrar o próprio mundo a Deus:

Queremos recordar e insistir que o primeiro campo e âmbito da missão do cristão é o mundo. A vocação específica dos leigos é estar no meio do mundo, à frente de tarefas variadas da ordem temporal. Os cristãos leigos levam o Evangelho para dentro das estruturas do mundo, onde homens e mulheres vivem, agindo em toda parte santamente, e consagram a Deus o próprio mundo. ${ }^{1513}$

A missão da Igreja engloba todas as possibilidades, pois visa o Reino. Assim, avança diante dos desafios atuais, buscando caminhos de diálogos e de anunciação: "a Igreja direcionada e pautada pelo Reino de Deus caminha para frente, dentro da história, com lucidez e esperança, com paciência e misericórdia, com coragem e humildade". ${ }^{1514} \mathrm{O}$ cenário do mundo atual pede uma Igreja em ação, envolvida, participante e missionária, que anuncie sua mensagem em compaixão. O Documento 105 destaca: “a Igreja é comunhão no amor, seguidora de Cristo e servidora da humanidade. Por isso a essência da Igreja é a missão, a Igreja é toda ela missionária". ${ }^{1515}$

A missão do Cristo carrega uma cruz, pelas muitas lutas diante da Igreja. Entretanto, essa batalha requer uma espiritualidade somente possível pelo Espírito que leva a missão no caminho do Cristo, como destaca o documento: "uma espiritualidade encarnada caracteriza-se pelo seguimento de Jesus, pela vida no

\footnotetext{
${ }^{1511}$ COMBLIN, J. As Grandes Incertezas na Igreja Atual, p. 40.

${ }^{1512}$ CNBB, Doc. $105,7$.

${ }^{1513}$ CNBB, Doc. $105,4$.

${ }^{1514}$ CNBB, Doc. $105,7$.

${ }^{1515}$ CNBB, Doc. 105,14
} 
Espírito, pela comunhão fraterna e pela inserção no mundo. Não podemos querer um Cristo sem carne e sem cruz". ${ }^{1516}$ O Documento 105 faz apontamentos que possibilitam a atuação do leigo em vários segmentos da sociedade e sua inserção no mundo, reconhecendo o poder da missão leiga e sua contribuição como caminho de atualização missionária atual.

O Documento 105 da CNBB, o qual desborar alguns ideias do Documeto de Aparecida, CELAM, destaca a missão dos leigos e leigas. Amado considera que atividade leiga tem um papel fundamental na Igreja e no mundo. São os leigos e as leigas que tornam a ação missionária um dialogo com o mundo, com a vida de pessoas e povos. Ele explicita que "na vivência do duplo espaço Igreja e mundo, Os (as) leigos (as) têm diante de si uma grande riqueza pneumatologica, pois permitem á Igreja falar, se a sim se pode dizer, uma língua difente das cotidianas, porque é a língua da comunhão de vida". ${ }^{1517}$ Assim, os leigos e as leigas têm uma missão relacionada com o Espírito Santo para a evangelização, para a atuação na Igreja e no mundo e para a comunicação das pessoas e povos.

O tema do laicato pertence fortemente á agenda missionária de vez na agenda missionária, e consequentemente pensadores de várias plataformas têm contribuído para o enriquecimento dessa percepção. Ainda no ambiente católico, Amado afirma: "há no DNA da condição laica uma perspectiva missionária irrenunciável. Trata-se da capacidade de atuar na inculturação do Evangelho". ${ }^{1518}$ Católicos e pentecostais concordam neste ponto: o leigo está no lugar estratégico, fazendo parte da sociedade e de suas transformações. A prática pentecostal em geral atua por intermédio da ação evangelizadora pessoal e individual, compreendendo que seu chamado a participar da missão de Deus inclui levar outros ao caminho, com todas as suas possibilidades. Oliveira explica:

A igreja pentecostal entende a ekklesia literalmente. São chamados para fora do mundo (santificação) e para fora do seu grupo (evangelização). Por isso, abordam quem não pertence ao grupo com naturalidade, sendo acusados de proselitistas e conversionistas. A eficácia da evangelização depende, dentre outros fatores, da decisão do evangelizado em acolher ou não a proposta cristã. Os fiéis devem preocupar-se em anunciar com intrepidez o evangelho e vivê-lo de forma radical. ${ }^{1519}$

\footnotetext{
${ }^{1516}$ CNBB, Doc. $105,16$.

${ }^{1517}$ AMADO, J. P. Leigos na linha de frente?, p. 413.

${ }^{1518}$ AMADO, J. P. Leigos na linha de frente?, p. 412.

1519 OLIVEIRA, D. M. d. Pentecostalidade da Missão Latino-Americana, p. 95.
} 
Essa atuação pentecostal remete à prática missionária de Comblin, um grande exemplo de missionário, segundo a ótica pentecostalista. Ele inspirou muitos cristãos, rompendo com os limites do catolicismo. Sua missão e sua teologia tornaram-se exemplo para outras denominações, talvez pela simplicidade e coerência de sua vida em missão, como lembra Aragão: "Comblin foi um homem que não deixou de sonhar. Plantava jardins (foi sepultado nos jardins que plantou, junto do túmulo do Padre Ibiapina) e construía Escolas Missionárias (faleceu quando dava um curso). Escolas e jardins eram para os outros...". ${ }^{1520}$ Essa coerência na vida de Comblin é o tipo de atitude bastante valorizada no pentecostalismo, e bem presente nos chamados cultos de missão ou na literatura pentecostal que trata de exemplos de homens e mulheres dedicados à causa missionária no estilo combliniano, numa assimilação com o período bíblico, como afirma Duffield e Cleave: "o que quer que Jesus fosse para o pequeno grupo de discípulos, o Espírito Santo também seria". ${ }^{1521}$

O exercício do caminho missionário que anuncia a compaixão parece ser um novo antigo modelo de missão cristã, como aponta Cardoso e Rangel: "dado que o mundo carece e clama pela descoberta ou manifestação do amor, que precisa concretizar-se na misericórdia, o caminho da misericórdia/compaixão aparece como demanda urgente e única". ${ }^{1522}$ Essa perspectiva é coerente com o conceito de missão que envolve todas as áreas da vida, o sofrer com o outro, o participar da dor, ser companheiro, mas também anunciar a esperança. E como diz Cardoso: "os destinatários da boa nova são em especial pessoas que sofrem, às quais se anuncia libertação do sofrimento e, portanto, a alegria. Isso faz parte do tema da consolação."1523 A missão encontra sua essência profética quando luta pela vida, daí o posicionamento de Cardoso: "torna-se importante para a teologia sistemático-pastoral considerar o nosso tempo sofrido e desesperançado,

\footnotetext{
${ }^{1520}$ ARAGÃO, G. d. S. A sombra do Padre Cícero..., p. 356.

${ }^{1521}$ DUFFIELD, P. G.; CLEAVE, N. M. V. Fundamentos da teologia pentecostal, vol. II, p. 26.

1522 CARDOSO, M. T. F.; RANGEL, Luiz Fernando Lima. Compromisso para a misericórdia: tema do recente Jubileu para Diálogo e Ação. Encontros Teológicos, Florianópolis, V. 34, N. 3, Set.-Dez. 2019. p. 438.

${ }^{1523}$ CARDOSO, M. T. F. Opções preferenciais: Solicitude e desprendimento como temas de teologia e diálogo na perspectiva de Puebla, fundamentos bíblicos e ênfases do Papa Francisco. ATeo, Rio de Janeiro, v. 23, n. 62, p. 278-303, mai./ago.2019, p. 291.
} 
escutando os clamores das pessoas, em seus mais variados tipos de exclusões." A missão assume a tensão de posicionar-se ao lado dos sofridos, entretanto a face de uma missão de compaixão responde à fase inicial da missão cristã e à sua centralidade.

O modelo missionário empregado pelo Cristo é possibilitado pela presença do Espírito e só pode ser estabelecido por uma atuação do Espírito. Assim, agregam-se a essa missão suas manifestações, e como missão anunciada ela precisa ser sinal do reino de Deus, que também passam pela taumaturgia, segundo Comblin, um sinal de compaixão: "Jesus curava os doentes por compaixão, mostrando assim que a compaixão pelos doentes é realmente um dos sinais de Deus e do seu reino". ${ }^{1525}$ Talvez aqui tenhamos um dos indícios do sucesso da Missão Quadrangular, que tem por centralidade a cura divina. Não faz sentido que uma visão de missão se preocupe com o futuro e se ocupe das maravilhas do reino de Deus, assim como das agendes de injustiça e mazelas da sociedade, mas silencie diante da degradação do corpo. Comblin afirma:

A vitória de Jesus sobre a doença mostrava também que ele tinha poder sobre os demônios e era mais forte do que eles. Mostrava que era mais forte do que o pecado. Se há doenças, é porque o pecado entrou no mundo. Mas qualquer pessoa que cura os doentes mostra uma vitória sobre a morte e um anúncio do reino de Deus: é uma vitória sobre o pecado e a morte, sobre todas as forças de destruição que agem no mundo. ${ }^{1526}$

Esse modelo missionário aponta para a salvação, sinal do reino de Deus. E segundo os quadrangulares, tal maneira de agir se aproxima mais do modelo das primeiras comunidades cristãs, traduzindo-se, segundo Duffield e Cleave, em "uma paixão mais profunda pelas almas. Não se pode ler a história da primeira igreja, logo depois do Pentecostes, sem compreender como havia um desejo ardente de proclamar o caminho da salvação (At. 2:14-41; 4:19-20; 5:29-33; 6:8$10 ; 11: 22-24 ; 26: 28,29)$ ". ${ }^{1527}$ A percepção da atuação do Espírito na ação evangelizadora pode ser decisiva, agregando à mensagem elementos como a cura divina, entre outras ações pneumatológicas. Grupos católicos e protestantes

${ }^{1524}$ CARDOSO, M. T. F. Opções preferenciais: Solicitude e desprendimento como temas de teologia e diálogo na perspectiva de Puebla, fundamentos bíblicos e ênfases do Papa Francisco, p. 296.

${ }^{1525}$ COMBLIN, J. Breve curso de teologia: a sabedoria cristã, Tomo IV, p. 204.

${ }^{1526}$ COMBLIN, J. Breve curso de teologia: a sabedoria cristã, Tomo IV, p. 204.

${ }^{1527}$ DUFFIELD, P. G.; CLEAVE, N. M. V. Fundamentos da teologia pentecostal, vol. II, p. 85. 
pautam sua atuação missionária na perspectiva do Espírito, semelhantes em muitos aspectos, mas diferentes quanto à atuação. Costa explica: "carismáticos e pentecostais convergem na ênfase dada ao efeito e à experiência do Espírito Santo na vida do indivíduo e da Igreja, mas divergem na forma. O movimento carismático é menos dogmático e mais flexível que o movimento pentecostal". ${ }^{1528}$

A missão leiga pentecostal incorporou o poder do Espírito à sua prática, e de acordo com esse entendimento todo crente é um missionário na unção do Espírito. Nessa atuação missionária, os quadrangulares priorizaram a taumaturgia, outros grupos pentecostais preferem a glossolalia, e ainda outros enfatizam outros fatores. Para Comblin, a questão é apostólica e o dom de cura dos doentes é dado à comunidade, embora não a todos, como ele esclarece:

Jesus deu aos apóstolos o mesmo dom que tinha. Com certeza os apóstolos não exerceram de igual modo, nem sempre, esse dom. Temos poucas informações a esse respeito, nada mais do que os poucos sinais que referem os Atos dos Apóstolos. Além disso, S. Paulo refere que existe nas comunidades o dom de curar os doentes. Certas pessoas têm esse dom que não é dado a todos. ${ }^{1529}$

A missão que não ignora a fragilidade humana tem que ser levada a sério, não devendo a degradação e a limitação humanas ser vistas como oportunismo, mas com compaixão. Brasil alerta: "a missão da igreja dá voz a quem não tem, não usando tais problemas como oportunidade para proclamar sua mensagem, e sim por ter uma mensagem profética que concretiza essas obras". ${ }^{1530}$ A cura é relevante, tem a ver com a manifestação do poder de Cristo e a atuação do Espírito por meio de uma comunidade que testemunha ao mundo que Cristo comissiona, e é mediante essa unidade que o mundo reconhece a glória de Deus. O corpo é importante, por isso é pauta da missão do Cristo, do Espírito e da igreja em missão, como afirma Duffield e Cleave:

Ele ressuscitará o corpo dos crentes no último dia. "Se habita em vós o Espírito daquele que ressuscitou a Cristo Jesus dentre os mortos, vivificará os vossos corpos mortais, por meio do seu Espírito que em vós habita" (Rm 8:11). O corpo é uma parte definida e importante ao ser humano. Ele é incluído na redenção de Cristo $(\operatorname{Rm} 8: 23){ }^{1531}$

\footnotetext{
${ }^{1528}$ COSTA, R. O pentecostalismo e o culto do divino na atualidade, p. 594.

${ }^{1529}$ COMBLIN, J. Breve curso de teologia: a sabedoria crista Tomo IV, p. 205.

${ }^{1530}$ BRASIL, J. G. Missão e Urbanização no Século 21, p. 76.

${ }^{1531}$ DUFFIELD, P. G.; CLEAVE, N. M. V. Fundamentos da teologia pentecostal, vol. II, p. 25.
} 
Evangelizar a partir do leigo atuando na mensagem da cura divina é contextualizar o evangelho, pois se trata de linguagem comum. Dessa forma a missão encontra recepção e popularidade, como salienta Macedo: "podemos ressaltar, entretanto, que o fenômeno da cura divina, por exemplo, manifestado em cultos evangélicos, constitui em forte apelo para significativa parte da população". ${ }^{1532}$ A divergência quanto à taumaturgia e à sua propagação entre pentecostais e outros é grande, mas constitui um código de linguagem compreensível entre o evangelho e a massa, uma questão que pede atenção, como diz Amado:

Cientes de que, nestes tempos em que a complexidade da vida, a exclusão social e a aguda centralização sobre o próprio eu contribuem para que o fenômeno Jesus Cristo taumaturgo não seja exclusividade desta ou daquela confissão religiosa, mas desafio transconfessional, deparamo-nos, em termos de ação evangelizadora, com um sério desafio cristológico. ${ }^{1533}$

A taumaturgia é um desafio que envolve diretamente o sofrimento pessoal e requer comprometimento e seriedade. Brasil alerta: "a dor não pode ser somente a pauta de um projeto. A missão opera junto aos marginalizados, sem isentar-se de tal ação. Ela cuida porque é responsável por salvar coletivamente". ${ }^{1534} \mathrm{O}$ sofrimento clama pelo olhar de compaixão e amor, e em esperança o evangelho anunciado precisa apontar para a recuperação, independentemente das causas, como afirma Cardoso: "o sofrimento, nunca totalmente compreendido, e que deve ser tanto quanto possível aliviado e superado, é também percebido na fé junto com a busca de um sentido maior e uma esperança final que o ultrapasse". ${ }^{1535}$

Infelizmente, tal área de atuação tem se tornado objeto de oportunismo, como alerta Oliveira: "a missiologia pentecostal tem se movido nesse campo minado, entre oportunidades e perigos". ${ }^{1536}$ Tudo que está no mundo é causa de missão, e o novo paradigma da missão tem apontado para isso, mas ignorar esse alerta pode levar ao fracasso. René entende que "o mundo todo é um 'campo missionário' e cada necessidade humana é uma oportunidade de ação missionária". ${ }^{1537}$ Entre todas as possibilidades refletidas pelos pensadores da

\footnotetext{
${ }^{1532}$ MACEDO, E. U. Pentecostalismo e religiosidade brasileira, p. 179.

${ }^{1533}$ AMADO, J. P. Mudança de época e conversão pastoral, p. 308.

${ }^{1534}$ BRASIL, J. G. Missão e Urbanização no Século 21, p. 75-76.

${ }^{1535}$ CARDOSO, M. T. F. No sentido da vida. Em diálogo sobre a prevenção do suicídio, p. 321.

${ }^{1536}$ OLIVEIRA, D. M. d. Pentecostalidade da Missão Latino-Americana, p. 96.

${ }^{1537}$ C. René, P. O que é missão integral?, p. 20.
} 
missão, a taumaturgia é objeto constante de discussão, não por representar a solução ou a esperança para o sucesso missionário, mas por ser empregada em práticas missionárias de grande poder de comunicação. Dessa maneira ela pode indicar um caminho ou até mesmo a necessidade de repensar tal prática. Amado afirma: “[...] acabam por, na prática, desconhecer o fato de que os atuais mecanismos para a iniciação sociocultural não conduzem ao Jesus Cristo da Kénosis. Parecem tender muito mais para o Jesus Cristo taumaturgo". ${ }^{1538}$

A perspectiva proposta neste trabalho remonta à atuação do pentecostalismo quadrangular a partir da contribuição de Comblin e de outros pensadores no esforço de estruturar a missão leiga como elemento catalisador da Missão Quadrangular a partir da força do Espírito, com ênfase na cura divina. A proposta passa pelo plano de restituição que envolve a missio Dei, como explica Comblin:

Jesus cura os doentes para anunciar o poder que tem de regenerar a criação inteira. Pode perdoar os pecados, dar a vida eterna. A saúde que ele restitui significa, além da saúde, também a reconciliação com Deus, e reconciliação do mundo, um mundo novo vivendo na paz e na felicidade. A saúde restituída provisoriamente a este corpo mortal anuncia e significa a saúde restituída ao mundo para sempre. ${ }^{1539}$

A comprovação dos milagres é um campo para uma investigação que não integra este trabalho. O que se tem proposto aqui é o entendimento da estrutura que move a missão do pentecostalismo quadrangular e da missão cristã em geral. Sobre o pentecostalismo, Macedo esclarece: "acreditam fortemente em alguma salvação futura pelo advento de Jesus Cristo à Terra e na cura divina. A presença do Espírito Santo nos cultos é fator de consenso entre os pentecostais". ${ }^{1540}$ Os resultados muitas vezes são relatados durante os cultos e é comum que o crente fale do milagre que recebeu. Essa prática visa também incentivar a busca desses milagres e a propor aos crentes leigos que busquem atuar como instrumentos de milagres. Cardoso, ao tratar do tema do sofrimento humano, diz que se deve propor esperança: "o sofrimento, que não podemos compreender totalmente, e que se deve procurar aliviar, na fé é associado ao sofrimento redentor de Cristo". ${ }^{1541}$

O sofrimento é, sem dúvida, um assunto que envolve a missão em geral, não somente uma pauta da religião. E como diz Cardoso e Rangel: “abordagens

\footnotetext{
${ }^{1538}$ AMADO, J. P. Mudança de época e conversão pastoral, p. 310.

${ }^{1539}$ COMBLIN, J. Breve curso de teologia: a sabedoria crista Tomo IV, p. 204.

${ }^{1540}$ MACEDO, E. U. Pentecostalismo e religiosidade brasileira, p. 192.

${ }^{1541}$ CARDOSO, M. T. F. No sentido da vida. Em diálogo sobre a prevenção do suicídio, p. 322.
} 
filosóficas, abordagens religiosas, abordagens diversas tentaram ao longo da história abordar o problema do sofrimento ou indicar para as pessoas os possíveis passos". ${ }^{1542}$ A atenção à temática do sofrimento leva a reflexões, entretanto na perspectiva missionária a questão envolve estreitamento e compaixão em atitudes concretas, a exemplo das ações de Jesus. Cardoso explica:

No ministério de Jesus aparecem constantemente o seu amor compassivo e a solicitude benevolente para com todos os que sofrem, os "pobres" de todas as categorias de frágeis e necessitados: aos enfermos, Ele cura (Lc 4,40), aos possessos, liberta (Lc 4,35.41); consola a viúva que chora $(\operatorname{Lc} 7,13)$ e ressuscita o filho (Lc 7,14-15); atende ao estrangeiro ( $\mathrm{Lc} 7,2-10)$, acolhe os pequenos ( $\mathrm{Lc}$ 18,15-17), traz salvação aos pecadores, vai à casa deles (Lc 19,9-10). ${ }^{1543}$

Assim, o anúncio da mensagem é seguido por atos concretos que possibilitam transformação, em primeiro lugar, daquele que recebe; em segundo, de quem evangeliza. Cardoso continua: "evangelizar é anunciar o dom do amor salvífico de Deus e o estabelecimento do seu Reino, proporcionar sinais que manifestam esse amor e esse dom. Jesus proclama a Boa Nova do Reino e realiza os seus sinais". ${ }^{1544}$ A vivência da Boa Nova não se restringe à futuridade, mas acontece no presente, enquanto a mensagem é proclamada e concretizada.

Observa-se nesta pesquisa que a missão de cura ou de cuidado com os que sofrem se amplia em várias formas de ação libertadora. Assim foi a cura e a ação de Jesus. Como se disse, não se trata neste trabalho de comprovar a taumaturgia. De início, esta estava na perspectiva da missão na Igreja do Evangelho Quadrangular. Porém, para esta pesquisa, destaca-se que essa linha de ação está contida na mensagem evangelizadora e libertadora que a Igreja do Evangelho Quadrangular pretende anunciar e realizar.

Para os quadrangulares a questão está relacionada ao batismo no Espírito Santo, pois é dele que partem os sinais sobrenaturais da missão do crente. Ao cumprir a missão no poder do Espírito, o crente torna-se ousado o suficiente para orar, suplicando por alguém que sofra, isso implicando um gesto de compaixão,

\footnotetext{
${ }^{1542}$ CARDOSO, M. T. F.; RANGEL, L. F. L. Compromisso para a misericórdia: tema do recente Jubileu para Diálogo e Ação, p. 438.

${ }^{1543}$ CARDOSO, M. T. F. Opções preferenciais: Solicitude e desprendimento como temas de teologia e diálogo na perspectiva de Puebla, fundamentos bíblicos e ênfases do Papa Francisco, p. 291.

${ }^{1544}$ CARDOSO, M. T. F. Opções preferenciais: Solicitude e desprendimento como temas de teologia e diálogo na perspectiva de Puebla, fundamentos bíblicos e ênfases do Papa Francisco, p. 293.
} 
pois participar desse sofrimento propõe comunidade e testemunho. Duffield e Cleave dizem:

O que os discípulos fizeram ao serem cheios pela primeira vez, podemos esperar que todos os que sejam cheios nesse mesmo sentido também façam. Desde que o propósito da unção era dar poder para testemunhar, não é surpreendente que o sinal da experiência fosse manifestado em suas palavras. ${ }^{1545}$

Em todo campo de pesquisa existem contrapontos ou caminhos diferentes para o alcance de resultados. Kirk acredita que os milagres que geram maior impacto na sociedade são a cura dos males sociais: "os efeitos de cura de males sociais - como bebedeira, violência na família, e dependência mais séria de drogas - são testemunhos poderosos do poder que a mensagem pregada tem para transformação da vida". ${ }^{1546}$

As muitas faces da missão abrem espaço para esse caminho importantíssimo. É preciso recuperar perspectivas que remontem ao valor da vida, dos direitos, da justiça e da igualdade de oportunidades, entre outros benefícios relacionados com a Bíblia e requisitados em tempos desafiadores dos quais a missão é convidada a participar. Longuini lembra: "nas Sagradas Escrituras destaca-se com clareza que Deus reclama o respeito pelo pobre e pela vida. As leis que regulavam os empréstimos, ou a do jubileu, por exemplo, são amostras da afirmação do direito dos desvalidos". 1547

Tudo que degrada, limita e gera dor requer resposta e é preciso missionar em torno da vida. A missão adentra novos campos, mas sempre foi anunciada profeticamente. A missão que dá voz ao que sofre revela sua comunhão com Cristo, pois pratica as obras que Ele também fez. Cardoso alerta:

Entretanto, enquanto peso, limite, dor, enfermidade, o sofrimento é uma diminuição da plenitude de vida e deve ser eliminado e superado, pois é o serviço da vida que deve prevalecer, sanando-a ao máximo, e aliviando-a de toda dor. O amor o exige. ${ }^{1548}$

"Quando não se respeitavam tais direitos, Deus enviava os profetas para fazer denúncia". ${ }^{1549}$ A expectativa é que a missão se torne parte da vida, pois a

\footnotetext{
${ }^{1545}$ DUFFIELD, P. G.; CLEAVE, N. M. V. Fundamentos da teologia pentecostal, vol. II, p. 80-81.

${ }^{1546}$ KIRK, J. A. O que é missão?, p. 288.

${ }^{1547}$ LONGUINI NETO, L. O novo rosto da missão, p. 240.

${ }^{1548}$ CARDOSO, M. T. F. No sentido da vida. Em diálogo sobre a prevenção do suicídio, p. 321.

${ }^{1549}$ LOGINI NETO, L. O novo rosto da missão, p. 240.
} 
unidade e o compartilhamento são caminhos requeridos na atualidade, já que, como discutido antes, a missão não se fará a partir de uma única ótica. Kirk apela para a comunhão: "quando a Igreja tiver aprendido a compartilhar dessa maneira, ela verdadeiramente entenderá o que significa ser koinonia no Espírito Santo.”1550 Em tempos de mudanças repentinas surgem incertezas, entretanto na incerteza pode residir a concretude para o estabelecimento de outras certezas, quando as anteriores não mais respondem. Comblin questiona: "contudo parece que sempre houve tais dons no meio do povo cristão. De modo geral, juntam orações com meios naturais. Não sabemos como os resultados se produzem, mas não se pode negar tudo dos relatórios que se fazem". ${ }^{1551}$

Sobre a cura divina praticada pelos quadrangulares, ainda há incertezas quanto à sua concretude, todavia é inegável que, por algum motivo, ao longo de tantas décadas, os testemunhos de cura continuam a ser propagados. Na visão de Kirk, esse tipo de missão só tem audiência nas localidades desamparadas pela medicina tradicional: "esse ministério de cura, geralmente no contexto das campanhas evangelísticas, é feito em áreas onde existe pouco acesso à medicina convencional". ${ }^{1552}$ Os quadrangulares são redundantes ao associarem a missão ao poderio do Espírito, pois a missão é impulsionada por este, que a conduz, e por isso não faz diferença que um leigo a anuncie. A questão central é que os sinais necessitam acompanhar os que executam a missão; ou seja, não há plano específico para missionar, e é enquanto se missiona que se mostram os sinais. Duffield e Cleave afirmam:

Promessa feita: Seria de esperar que uma capacitação espiritual especial fosse provida a fim de que a igreja pudesse desempenhar a missão divina que lhe foi entregue pelo Senhor Jesus Cristo. Jesus instruiu seus seguidores para pregarem o evangelho, mas ordenou-lhes que primeiro esperassem a concessão de poder do alto (Lc 24:47-49). Com a Grande Comissão, Deus prometeu: "Estes sinais hão de acompanhar aqueles que crêem", sinais como: expulsão de demônios, falar em "novas" línguas e cura de doenças com imposição de mãos. ${ }^{1553}$

A agenda está aberta e a primeira regra é não existir uniformidade quanto à ação missionária. Assim como Deus criou o mundo e o diversificou pelo Seu poder, novamente Ele convida todos a participar da recriação pela missio Dei. É

\footnotetext{
${ }^{1550}$ KIRK, J. A. O que é missão?, p. 250.

${ }^{1551}$ COMBLIN, J. Breve curso de teologia: a sabedoria cristã, Tomo IV, p. 205.

1552 KIRK, J. A. O que é missão?, p. 288.

${ }^{1553}$ DUFFIELD, P. G.; CLEAVE, N. M. V. Fundamentos da teologia pentecostal, vol. II, p. 91.
} 
sob esse olhar que se abarcam todos os caminhos de missão cuja centralidade está no Cristo, na atualidade da missão do Espírito. Os anunciadores do evangelho precisam demostrar atos de fé, não em palavras, mas, sobretudo, em concretude, como diz Bosch: "não existe, contudo, uma única maneira de testemunhar Cristo. A palavra, portanto, jamais pode estar divorciada da ação, do exemplo, da 'presença cristã', do testemunho da vida". ${ }^{1554}$

Toda a criação é pauta de missão, todo o mundo, toda a natureza, entretanto o sofrimento é notório e a humanidade tem padecido de muitos males. Ferida a humanidade, a terra também é ferida. A agenda da missão de recuperação iniciase no humano. Brasil lembra: "Jesus sempre apregoou maior valor ao ser humano, mesmo quando muitos não compreendiam". ${ }^{1555}$ Sempre houve limitações, doenças e deficiências e estas também se apresentaram à missão do Cristo. Sua resposta foi a recuperação. Na maioria dos casos, houve quem não tornasse a enxergar, andar ou falar, mas a questão o evangelho está para além de um texto citado em determinado período da história. Isso implicaria, do ponto de vista humano, uma injustiça, pois qual seria o critério para aquele não ver ou não escutar? A superação é proposta pelo evangelho vivido e manifestado no poder. Por isso poderíamos pensar que o evangelho é sempre constituído quando a palavra é encarnada gerando concretude e alterando o curso natural da vida; ou seja, não se trata do anúncio do evangelho, mas da sua constituição, bem diferente. Onde se anuncia o evangelho existe salvação; onde se constitui o evangelho há transformação, e não somente da vida, mas também da própria missão. Bosch afirma: “é a 'palavra encarnada' que constitui evangelho. A ação sem palavras é muda; a palavra sem ação é vazia". ${ }^{1556}$

Nesse caminho de missão, as promessas do comissionamento de Cristo, iniciando em Pentecostes a abertura do novo, a rotina da missão sempre foi alterada por surpresas e manifestações não humanamente prescritas. Brasil afirma: "eis a nossa missão: anunciar e declarar o grande amor, que é Jesus." ${ }^{, 1557}$ Isso é a participação necessária, que torna a criação viva e dinâmica. E, enquanto ela estiver nessa condição de participação, Deus estará presente no mundo, pois o

\footnotetext{
${ }^{1554}$ BOSCH, D. J. Missão transformadora, p. 502.

1555 BRASIL, J. G. Ele se entregou... Eu também me entregarei. Vitória, ES: Foco Editora do Brasil, 2009, p. 73.

${ }^{1556}$ BOSCH, D. J. Missão transformadora, p. 502.

${ }^{1557}$ BRASIL, J. G. Ele se entregou... Eu também me entregarei, p. 73.
} 
Cristo encarnou, o Espírito veio, e quem se apresentar ao mundo em missão é também constituinte do evangelho, como explica Bosch: "participar da missão é participar do movimento de amor de Deus para com as pessoas, visto que Deus é uma fonte de amor que envia". ${ }^{1558}$ A missão não será a anunciação do evangelho, mas a sua constituição. Diante desta estrutura não será preciso escolher um caminho, pois a sua vivência e a encarnação geram nova realidade. Brasil diz: "a palavra da mensagem de Cristo pode ser pregada verbalmente, mas também pode ser vivida no serviço que aponta para o futuro do reino". 1559

Se ser cristão é ser parecido com o Cristo, é preciso aproximação com a sua proposta, e essa ação indica pontos importantes, como sofrimento, renúncia e serviço. Cardoso afirma: "em Cristo vemos um amor que se entrega totalmente, que inclusive passa pelo sofrimento, integrando tudo na doação do amor e proporcionando uma redenção que comunica vida em plenitude". ${ }^{1560}$ Pensar no curso da história em que o evangelho é constituído a todo tempo traduz-se no seguinte enunciado: "a igreja que ultrapassa a barreira verbal da pregação revela sua natureza profética ao dar voz a quem não tem, gerando justiça e revelando uma mensagem encarnada a fim de envolver todas as áreas da vida humana". ${ }^{1561}$

Propõe-se um constante repensar, já que as tensões e crises recriam essa necessidade; e é preciso avançar, acrescentar agora um elemento diferenciador: a responsabilidade. Durante algum tempo no pentecostalismo compreendeu-se o quadro geral do cristianismo como o sacrifício feito, o sofrimento das primeiras comunidades e o privilégio no Espírito ao aguardar os novos céus. A verdade é que essa perspectiva envolve pouca responsabilidade, ou seja, tudo aconteceu para nossa salvação e podemos contribuir em missão. Entretanto, uma releitura com base na constituição, em vez da anunciação do evangelho, o sacrifício volta a fazer parte da missão. Bosch diz: "nós, cristãos, somos apenas 'colaboradores de Deus’ em sua missão de redenção da criação. Esse é nosso grande privilégio e nossa grande responsabilidade". ${ }^{1562}$

Os desafios à missão pentecostal e ao cristianismo em geral são parte do mal presente no mundo, mas também está presente o bem a partir da Boa Notícia do

\footnotetext{
${ }^{1558}$ BOSCH, D. J. Missão transformadora, p. 468.

${ }^{1559}$ BRASIL, J. G. Missão e Urbanização no Século 21: o desafio missionário na cidade. São Paulo: Fonte Editorial. 2016, p. 76.

${ }^{1560}$ CARDOSO, M. T. F. No sentido da vida. Em diálogo sobre a prevenção do suicídio, p. 321.

${ }^{1561}$ BRASIL, J. G. Missão e Urbanização no Século 21, p. 76.

${ }^{1562}$ C. René, P. O que é missão integral?, p. 63.
} 
evangelho que se vivencia no cotidiano por muitos cristãos comprometidos, que assumem uma responsabilidade que não se resume ao anúncio, pois essa ideia não define a amplitude da concepção dessa missão. Bosch diz: "a história do mundo não constitui apenas uma história do mal, mas também de amor, uma história em que o reinado de Deus está sendo levado adiante pela obra do Espírito". ${ }^{1563}$

Esse caminho envolve sofrimento, numa época em que se foge de toda forma de sofrimento, todavia na história do cristianismo esse termo sempre conviveu com conceitos como milagres, poder, multiplicação, salvação e outros. Será também preciso recuperar o conceito de sofrimento para uma perspectiva de missão que não seja somente triunfalista? Barro afirma: "o sofrimento é a marca patente da igreja através de toda a história da missão. Aquele que seguir e proclamar Jesus deve aprender do seu sofrimento". ${ }^{1564}$

Parte do sofrimento de muitos diz respeito aos clamores da alma que levam a pessoa a não mais querer viver, e as causas prováveis ampliam o assunto e o estendem a diferentes áreas dos saberes. Esse sofrimento também preocupa a teologia e a missão. Cardoso alerta: "permanece um mistério e ao mesmo tempo irradia uma luz na fé a redenção cristã, que, assim por amor, embora passe pela cruz de Cristo, orienta para a esperança da vitória desse amor e a comunicação da plenitude da vida". ${ }^{1565}$ Assumir uma identidade de responsabilidade implica continuidade a partir dos exemplos propostos no período bíblico e descontinuidade da vida comum que não assume a renúncia e o sofrimento em missão.

O termo "integral" tem sido empregado na missiologia quadrangular para denotar a totalidade das questões que envolvem a vida. Sanches explica: "a Teologia da Missão Integral parte da concepção de que a igreja é comunidade apostólica no mundo, portanto, comissionada a missionar". ${ }^{1566}$ É no seguimento e na diversificação que a missão gera testemunho, abrindo espaço na vida contemporânea. Para Barro, é nas lacunas da sociedade que a missão deve fazer a

\footnotetext{
${ }^{1563}$ BOSCH, D. J. Missão transformadora, p. 469.

${ }^{1564}$ BARRO, J. H. De cidade em cidade, p. 74.

${ }^{1565}$ CARDOSO, M. T. F. No sentido da vida. Em diálogo sobre a prevenção do suicídio, p. 321.

${ }^{1566}$ FERNANDES SANCHES, Regina. Teologia da Missão Integral. São Paulo: Reflexão, 2009, p. 145.
} 
diferença: "assim é com as ações de misericórdia. A multiplicação de testemunhos ao alcance de cada cristão fará a diferença". ${ }^{1567}$

Não se pode pensar em missão sem tratar de cuidado. A missão está relacionada ao outro e não é feita para dentro, mas dirigida ao outro. $\mathrm{O}$ cuidado, assim, é ampliado a todo o mundo e ofertado ao outro. Hoffmann reflete: "a missão de Deus tem dimensão cuidadora da boa criação e uma dimensão curadora e restauradora das feridas e dos traumas das pessoas". ${ }^{1568}$ O cuidado desperta a missão à atenção e à afeição que se dedica ao outro, e marca presença nas relações. A desatenção e a falta de tempo para o outro, na nova conjuntura social em que se cumprem múltiplas tarefas, aumentaram a carência de tempo e fecharam as pessoas em si mesmas, sem a adequada percepção do próximo. Bezerra alerta:

A cada dia multiplicam-se os desafios. Estes clamam por uma ação efetiva, responsável, coerente e legitimada numa leitura libertadora da palavra de Deus e da realidade social, cultural e econômica das cidades, pois são elas que incorporam nossa existência. A maioria dos homens e mulheres contemporâneos mora nas cidades. ${ }^{1569}$

Uma ação em prol do cuidado mostra ao mundo a dimensão de Deus que se preocupa com a vida, que é cuidado. Hoffmann diz: "urge resgatar uma teologia da criação para defender o propósito do criador que proveu todo o necessário para o convívio harmonioso entre criaturas e criação". ${ }^{1570}$ A dimensão de cuidado pode ser multiplicada em muitos caminhos, a exemplo da proposta quadrangular mediante a cura divina, da dimensão libertadora de Comblin ou ainda da perspectiva do novo paradigma de Bosch. Enfim, o cuidado abarca uma imensa perspectiva de missão, permanecendo como marca a unidade, relacionada ao cuidado, como afirma Bosch:

Primeiro, a coordenação mútua de missão e unidade é inegociável. Ela não se deriva simplesmente de uma nova situação mundial ou de circunstâncias modificadas, mas da dádiva divina de unidade no corpo uno de Cristo. O povo de Deus é um só; o corpo de Cristo, idem. ${ }^{1571}$

\footnotetext{
${ }^{1567}$ BARRO, Jorge Henrique. De cidade em cidade. Londrina: Descoberta, 2006, p. 26.

${ }^{1568}$ HOFFMANN, Arzemiro. A cidade na missão de Deus: o desafio que a cidade representa a Bíblia e à missão de Deus. Curitiba: Encontro, 2007, p. 136.

${ }^{1569}$ BEZERRA, C. M. Missão Integral da Igreja, p. 56-57.

${ }^{1570}$ HOFFMANN, A. A cidade na missão de Deus, p. 136.

${ }^{1571}$ BOSCH, D. J. Missão transformadora, p. 554.
} 
O discurso, mas o que se evidencia como serviço cristão são as relações de cuidado, como assegura Mikuszka: "no entanto, o amor só se torna concreto pelas relações humanas com liberdade". ${ }^{1572}$

O tema levantado nesta pesquisa rompe a barreira reflexiva ao se referir à prática cotidiana da igreja e ao tratar de questões pertinentes a milhares de cristãos. Apontar ou sugerir uma atuação uniforme já seria prever fracassos. Os dados expostos mostram a frente missionária da Igreja do Evangelho Quadrangular, parte do pentecostalismo, que iniciou sua atividade missionária no Brasil a partir de um movimento ecumênico de pregação da cura divina em tendas itinerantes. Acrescenta-se a isso a teologia da missão e do Espírito de Comblin, que experimentou a missão como reflexão e como prática. Buscou-se aqui reunir as duas experiências, mesmo depois das primeiras tentativas de missão. Arrisca-se a dizer que as duas missões alcançaram sucesso, mas ao longo do tempo, questões e desafios cobram novas respostas. E os estudos em questão mostraram que a prática quadrangular precisa se compromissar com a vida cotidiana, algo que Comblin já havia declarado.

Nos estudos quadrangulares já se nota um novo encaminhamento das questões, como reflete Dugan: “a igreja, na sua missão de fazer discípulos, vai desenvolver uma missão 'integral', procurando atender, além das necessidades espirituais, as necessidades físicas, emocionais, econômicas e de justiça". ${ }^{1573}$ Percebeu-se que a missão precisa de comunicação, desafio considerável frente às repentinas transformações da sociedade. Para os quadrangulares a comunicação pressupõe amor em decisão, ou seja, é preciso decidir-se por um estilo de vida em missão. Lapa diz: "o amor se comunica, trata-se de uma disposição para agir em amor e não apenas de um sentimento. O amor é uma decisão". ${ }^{1574}$ Esse amor em decisão pode ser apreciado e imitado em Comblin, que decidiu viver como peregrino entre o Nordeste brasileiro e outros lugares, sempre demonstrando amor pela vida. Essa coerência o fez optar por uma vida simples entre os simples, vivendo um evangelho também simples, mas transformador. Por isso se propõe aqui sua aproximação à missão dos quadrangulares, na maioria leiga, pessoas

\footnotetext{
${ }_{1572}$ MIKUSZKA, G. L. A Reforma Protestante e a ação evangelizadora da Igreja católica, p. 67.

${ }^{1573}$ DUGAN, Patrick Bernard. Teologia Sistemática 3. ITQ Instituto Teológico Quadrangular. Curitiba: SGEC, 2012, p. 125.

1574 LAPA, Marco Antonio Teixeira. Teologia Sistemática 1. ITQ Instituto Teológico Quadrangular. Curitiba: SGEC, 2014, p. 59.
} 
simples, que, por sua vez, também desejam se aproximar. Lapa continua: "por isto a necessidade de nos organizamos e nos unirmos em torno de um propósito comum, superando obstáculos e preconceitos internos e denominacionais, priorizando as questões maiores da defesa do povo de Deus". ${ }^{1575}$

No material de ensino quadrangular constata-se um avanço significativo em sua nova proposta de atuação missionária, que também abrange temas concernentes à atualidade teológica, como a responsabilidade ambiental. Dugan afirma: "o estabelecimento de uma Nova Criação, a restauração das pessoas e a terra ao seu estado original. Podemos chamar este novo mandamento de o Mandamento Missionário". ${ }^{1576}$ Resulta da mistura entre pentecostalismo e catolicismo o direcionamento à missão encarnada, que reflete no cotidiano sua pregação, exemplificando em testemunho o evangelho. Bezerra afirma: "o caminho da encarnação é a via que a igreja tem para transformar a realidade. Como comunidade terapêutica, a igreja tem que ser sal e luz na sociedade". ${ }^{1577}$ Pensar em missão é assumir um compromisso que vai de Deus à humanidade inteira. Conti afirma: "ser mensageiro de Deus requer muita responsabilidade". ${ }^{1578}$ As muitas sugestões e possibilidades de missão passaram pela palavra, pois é a partir da Bíblia que se criam caminhos, como declara Lapa: “a Bíblia é a mensagem de Deus aos homens. Ela traz a Automanifestação de Deus". ${ }^{1579}$ Muitos dos novos paradigmas de missão apontam para a abertura em todos os sentidos, entretanto para os quadrangulares é essencial multiplicar os seguidores de Cristo. Sampaio afirma: "é importante salientar que é grandiosa a responsabilidade dos cristãos, quanto a fazer aumentar o número dos discípulos de Jesus, através da Evangelização de alcance mundial (Mt. 28:19,20)". ${ }^{1580}$ Os que querem ganhar as pessoas para Cristo têm sido elemento catalisador para a

${ }^{1575}$ LAPA, Marco Antonio Teixeira. Cidadania. ITQ Instituto Teológico Quadrangular. Curitiba: SGEC, 2010, p. 110.

${ }^{1576}$ DUGAN, Patrick Bernard. Teologia Sistemática 2. ITQ Instituto Teológico Quadrangular. Curitiba: SGEC, 2012, p. 27.

${ }^{1577}$ BEZERRA, Cícero. Teologia Pastoral Urbana. ITQ Instituto Teológico Quadrangular. Barra Funda - SP: SGEC, 2018, p. 63.

${ }^{1578}$ CONTI, Lécio. Hermenêutica. ITQ Instituto Teológico Quadrangular. Campos Elíseos - SP: SGEC, 2017, p. 13.

${ }^{1579}$ LAPA, Marco Antonio Teixeira. Bibliologia. ITQ Instituto Teológico Quadrangular. . Campos Elíseos - SP: SGEC, 2018, p. 13.

${ }_{1580}$ SAMPAIO, Regina Câmara; SOBREIRO, Adriana Câmara. Vida de Cristo e Espiritualidade. ITQ Instituto Teológico Quadrangular. Curitiba: SGEC, 2010, p. 103. 
motivação e o engajamento do crente no estilo de vida de missão, e nesse esforço, toda oportunidade de evangelização é valiosa.

É marca do pentecostalismo o grande número de reuniões na agenda. Em tempos de individualismo, essa prática revela o poder da comunhão proporcionada pelo evangelho. Santos diz: "A koinonia implica compartilhar tudo o que tenho e tudo o que sou; é andar lado a lado numa verdadeira parceria". ${ }^{1581}$ Isso não quer dizer que as comunidades sejam sinônimos de refúgio e perfeição fora do mundo. Friesen alerta: “onde há comunidade, há pessoas com problemas: brigas, depressão, drogas, crises, conflitos, problemas familiares, matrimoniais e outros. Mas, onde há comunidade, também existem pessoas tentando ajudar". ${ }^{1582}$

Certamente a missão em comunidade implica tais tensões, mas é em comunidade que se faz missão. Na perspectiva dos quadrangulares, a missão tende a vencer os desafios rumo ao crescimento. Vaciloski e Santos afirmam: "o crescimento da igreja e a evangelização do mundo continuarão até que o corpo de Cristo esteja completo". ${ }^{1583}$ O crescimento possível está associado ao engajamento do leigo e de todos os cristãos. Para os quadrangulares a posição social do crente não deve isentá-lo da missão, dado o comissionamento geral. Conti diz: “[...] A tarefa missionária pertence a toda a igreja de Cristo. Seja o crente rico ou pobre, influente ou não, de boa formação ou pouca cultura, cada um deve participar deste empreendimento". ${ }^{1584}$ Por fim, a missão encontrou nas novas sociedade um desafio que reune oportunidades e perigos, e isso possibilitou novas expectativas na ação missionária. O leigo é prioridade em todos os caminhos de missão, participando das transformações sociais e possibilitando maior comunicação. A capacitação do leigo no pentecostalismo quadrangular é uma ação do Espírito e, portanto, a anunciação do evangelho na atualidade é leiga, plural e comunitária, na manifestação do poder da missão do Espírito Santo.

\footnotetext{
${ }^{1581}$ SANTOS, Sinésio Carlos dos. Vivência Cristã. ITQ Instituto Teológico Quadrangular. Barra Funda - SP: SGEC, 2018, p. 56.

${ }_{1582}$ FRIESEN, Albert. Aconselhamento Pastoral. ITQ Instituto Teológico Quadrangular. Curitiba: SGEC, 2012, p. 9.

${ }^{1583}$ VASILOSKI, Gerlene Vidal; SANTOS, Sandra Morais Ribeiro dos. Escatologia Bíblica. ITQ Instituto Teológico Quadrangular. Curitiba: SGEC, 2012, p. 86.

${ }^{1584}$ CONTI, Lécio. Teologia Pastoral. ITQ Instituto Teológico Quadrangular. Curitiba: SGEC, 2011, p. 52.
} 


\section{5 \\ Conclusão}

$\mathrm{O}$ movimento pentecostal iniciado no século $\mathrm{XX}$ alterou significativamente alguns conceitos na cristandade, por sua capacidade de adaptação às transformações sociais. A atuação da missão pentecostal propõe à teologia um olhar atencioso, tendo em vista que muitas pessoas têm abandonado sua relação com a fé, enquanto no meio pentecostal se percebe o contrário, com o surgimento, nas últimas décadas, de várias denominações.

Assim, foi proposta aqui a pesquisa da missão da Igreja do Evangelho Quadrangular, componente da história do movimento pentecostal, com grande atuação entre os brasileiros. O segundo capítulo buscou recuperar a história e a origem da denominação, bem como sua estrutura de atuação, descrevendo as igrejas pentecostais em geral e situando a Quadrangular entre elas. O trabalho se propôs distinguir o início da denominação no Brasil, dissociando a Igreja do Evangelho Quadrangular da Cruzada Nacional de Evangelização, tendo em vista que, apesar da liderança do movimento por missionários de doutrina quadrangular, sua composição era interdenominacional, constituindo um movimento ecumênico entre pentecostais e protestantes. A Igreja da Igreja do Evangelho Quadrangular foi fundada oficialmente em 1958, enquanto a Cruzada já atuava desde 1953 e contava com pastores de várias denominações e com forte atuação leiga. Ainda na parte inicial a pesquisa buscou mostrar a relação da Cruzada Nacional de Evangelização com o pós-pentecostalismo, também conhecido como neopentencostalismo, mostraram-se as novidades do modelo da Cruzada Nacional de Evangelização, como a utilização de instrumentos musicais e a centralidade na cura divina, elementos absorvidos depois pelo neopentecostalsimo. Este outro grupo muito se afastou do pentecostalismo clássico ou neoclássico, assumindo características peculiares, ainda que conservasse elementos do pentecostalismo. Por isso, o termo utilizado na tese para esse outro grupo é de pós-pentecostalismo, pela natureza posterior, distante dos primeiros grupos pentecostais, inclusive na teologia. 
Tentou-se, no mesmo capítulo, recuperar o histórico das origens da Igreja do Evangelho Quadrangular a partir da biografia de McPherson, de suas primeiras experiências com o pentecostalismo norte-americano e de seu envolvimento com a cura divina, o que se tornaria central na missão dos quadrangulares. Foi visto que o conceito e a prática da missão quadrangular relacionam-se com as experiências pessoais de sua fundadora, que moldou o modelo de missão empregado na denominação a partir de sua experiência com a cura divina na China e tornou-se missionária utilizando-se deste elemento. Ela serviu-se da estrutura em tendas, algo já comum nos Estados Unidos para fins evangelísticos. Aimee cumpriu a missão de maneira ecumênica, contando com a parceria de várias denominações pentecostais e protestantes, até receber a revelação da visão quadrangular a partir do texto bíblico de Ezequiel, anunciada por ela a todo o público presente em uma das campanhas de avivamento. A partir daí, Aimee baseou sua doutrina nessa visão, construindo a sede internacional da denominação em Los Angeles, Califórnia.

$\mathrm{Na}$ parte final do segundo capítulo foi feito um estudo propondo compreender a estrutura organizacional da denominação, com base em uma análise dos estatutos da Igreja do Evangelho Quadrangular brasileira, percebendose a existência dessa denominação em terras brasileiras, diferente da International Church of the Foursquare Gospel. Elas se relacionam amistosamente, mas quanto à doutrina, a Quadrangular brasileira segue os parâmetros e a declaração de fé da fundadora, até mesmo no hino oficial. O que se notou de diferente nessa parte da pesquisa foi apenas a dissociação administrativa entre a igreja brasileira e a sede nos Estados Unidos. Como também se viu, a estrutura da doutrina dos quadrangulares sempre está relacionada ao número quatro, base das doutrinas cardeais da Quadrangular, cujos quatro pilares são Jesus Cristo, O Salvador; Jesus Cristo, Aquele que Batiza; Jesus Cristo, Aquele que Cura; e Jesus Cristo, O Rei que Virá. Tal concepção abarca ainda outros termos e significados.

O pentecostalismo sempre optou pela priorização da prática, sendo secundário o ato reflexivo teológico. A prática pautada pela cura ou pela taumaturgia tem uma dimensão libertadora. Além disso, o pentecostalismo anuncia Cristo e acentua a ação do Espírito Santo. Por esses moltivos, justificouse a escolha de José Comblin para o diálogo com o pentecostalismo quadrangular; 
o autor não somente refletiu sobre a missão e a pneumatologia, mas mostrou viver ambas, provando a missão na prática e nos desafios cotidianos. Nessa contribuição combliniana buscamos traçar o perfil geral do teólogo desde a formação, ainda na Bélgica, passando por sua vocação missionária para a América Latina e pela transformação diante da realidade do Brasil e de outros países latinoamericanos.

Percebeu-se principalmente sua aproximação com o povo nordestino como elemento definitivamente catalisador de sua transformação, tanto missionária quanto teológica, reestruturando até mesmo seus textos, que de longos estudos passaram a ser curtos e diretamente voltados ao povo.

No terceiro capítulo foram expostos alguns precedentes de Comblin que influenciaram sua teologia e sua prática missionária, destacando-se três nomes: o do teólogo dominicano francês Yves Congar, que lhe inspirou a possibilidade do diálogo com o pentecostalismo quadrangular; do Padre José Antonio Maria Ibiapina, uma das inspirações do estilo de vida missionário de Comblin entre o povo nordestino; e de Dom Hélder Câmara, no que tange à arquitetura de suas várias tentativas de missão, como as escolas de formação missionária, a Teologia da Enxada e outras práticas de missão no Nordeste brasileiro. Também sob o entusiasmo do Vaticano II surgiram muitas tentativas de propor uma maior dinâmica na atuação missionária, somando-se a isso sua experiência com as CEBs. O recorte proposto na pesquisa prioriza os estudos do curso histórico das experiências da missão de Comblin, percebendo-se que ele viveu um período de peregrinação entre perseguições, tendo sido expulso do Brasil, acolhido no Chile, de onde também foi expulso e retornou ao Brasil, para atuar definitivamente no Nordeste.

Na segunda seção do terceiro capítulo buscou-se identificar o conceito e a prática da missão em Comblin, e durante a análise, apontamentos sugeriram a vinculação da missão combliniana à pneumatologia, o que conduziu à investigação de sua aproximação da missão pentecostal. Para Comblin, a teologia ocidental dedica-se pouco ao Espírito, preferindo o evento Cristo, em detrimento da atenção ao evento Pentecostes. Na visão do autor, o momento atual pede uma missão do Espírito, e é em conformidade com essa força do Espírito que o autor sugere a integração da missão leiga e dos cristãos em geral. Encerrando os estudos da missão combliniana, destacou-se seu engajamento com o povo leigo 
nordestino, propondo meios de envolvê-lo em missão, já na vivência da realidade do lugar onde praticava sua missão.

O capítulo quatro propõe aproximações entre a Igreja Quadrangular e Comblin, encontrando em textos comblinianos referências ao pentecostalismo, mantendo a tese o entendimento de que a Igreja do Evangelho Quadrangular integra o movimento pentecostal surgido a partir do século XX. Dessa maneira a pesquisa encontrou em textos de Comblin suas perspectivas e intuições sobre o pentecostalismo em geral, inclusive no que toca aos quadrangulares. Em parte o trabalho mostrou a boa percepção do autor do movimento quanto à sua atuação missionária, revelada em seus textos na dinâmica da evangelização pentecostal utilizada para comparações com sua própria estrutura de fé. Assim, essa etapa do trabalho se propôs encontrar pontos em comum no conceito e nos métodos para a missão, percebendo-se a presença de referências bibliográficas de Comblin no material produzido e utilizado pela IEQ. É verdade que tais referências situam-se nos títulos que tratam da temática da missão.

Ainda na fase inicial do mesmo capítulo tratou-se das diferenças principais no conceito e nos métodos para a missão, e no aprofundamento da questão se percebeu que quadrangulares e Comblin reconhecem a necessidade de repensar a missão a partir de suas próprias estruturas. A crítica quadrangular dirige-se a um extremismo espiritual que tem deixado de atuar no cotidiano da missão, concernente às mazelas da sociedade. Já Comblin critica o modelo por ele estimado das comunidades de base, em que percebeu certo desconforto com a ausência de mística no modelo. Tal crítica é relevante, pois foge um pouco dos comentários de Comblin, na maioria das vezes dirigidos à estrutura católica. A tese compreendeu que os extremos expostos pelas partes poderiam compor uma única face de missão, indicando o equilíbrio. Os sucessos e limites da prática missionária da Igreja Quadrangular à luz da teologia desenharam um cenário de atuação pneumatológica, mas com forte ênfase na taumaturgia, elemento central desse segmento pentecostal. Segundo Comblin, se em algum momento do cristianismo esse dom se manifestou, ele também é possível atualmente.

No último bloco do quarto capítulo a pesquisa sugeriu aprofundamentos a partir das contribuições da IEQ para o enriquecimento da reflexão e a prática da missão, segundo a perspectiva de Comblin, retomando o modelo de evangelização do movimento ecumênico que originou a Quadrangular no Brasil. Diante do 
exposto, pareceu interessante a prática entre os brasileiros na fase que antecedeu a institucionalização da Quadrangular, mas o curso da pesquisa mostrou ser inviável o retorno da ação evangelizadora em tendas de cura divina. Entretanto, os estudos dos quadrangulares propuseram pequenos grupos ou células apontando esse modelo como opção de atuação evangelizadora, somando-se a isso a recuperação da centralidade da essência que estava nas tendas de cura divina. Essa parte do trabalho também agregou à reflexão o pensamento de Comblin, também simpatizante da atuação dos pequenos grupos como forma de atuação missionária, mas existem diferenças significativas entre as duas propostas. A primeira é que, para os quadrangulares, o modelo de pequeno grupo fortaleceria o templo. Já para Comblin, o templo se tornou desnecessário e as chamadas casas de igrejas poderiam substituí-lo. A tese concluiu que, mesmo em formatos diferentes, as concepções de ambas as correntes comungam da ideia de grupo pequeno.

Em outra tentativa de propor contribuições ao enriquecimento da perspectiva da Igreja do Evangelho Quadrangular à luz de Comblin, no contexto do diálogo entre pentecostais e católicos, constatou-se a pertinência da missão na atualidade, com temas relevantes como a relação entre missão e cultura, inculturação e a missio Dei. Cogitou-se também da possibilidade de diálogo ecumênico, encontrando no material de ensino e no preparo quadrangular reflexões sobre tais temas, o que anima à aproximação entre cristãos. Por último, buscou-se oferecer contribuições à pastoral missionária de todos os cristãos, em especial, dos leigos, compreendendo a missão evangelizadora como associada à atuação do leigo em comunidade, no poder do Espírito, reivindicando a manifestação da cura, componente da restituição e da boa notícia do evangelho. A hipótese inicial da pesquisa é que o crescimento da missão da Igreja do Evangelho Quadrangular estava associada à atuação do leigo, e foi possível perceber que o leigo sempre esteve em missão nessa denominação, assim como se encontrou em Comblin e em outros pensadores esse caminho de missão na atualidade.

Por fim, a análise da missão na Igreja do Evangelho Quadrangular enriqueceu o diálogo com o teólogo e missionário Comblin. O período de instalação da Igreja Quadrangular e de Comblin no Brasil proporcionou aproximações, mesmo que indiretas. Dessa forma, percebeu-se que os desafios da evangelização envolvem tanto católicos quanto pentecostais. E mesmo que haja diferenças entre as partes - e importa que as haja - perceberam-se afinidades. No 
final, por mais que se tente estabelecer fronteiras, percebe-se na missão unidade, não em uniformidade, mas em compromisso, superando as diferenças na busca da superação dos verdadeiros desafios, o que se configura como parte do comissionamento missionário.

A mensagem de cura da IEQ, em sua fase inicial de inserção no Brasil, era dirigida ao corpo, buscando uma libertação da dor e do sofrimento que oprimiam o indivíduo. A missão de cura da IEQ continua necessária, mas se ampliou: o planeta precisa de cura, de restauração, bem como as relações sociais, políticas e o próprio homem. 


\title{
6 \\ Referências bibliográficas
}

\begin{abstract}
ACHILlE, Atta Amichia. A Ação do Espírito Santo e a Missão da Igreja Frente ao Desafio do Pentecostalismo da Igreja Universal do Reino de Deus. Tese de Doutorado. PUC-SP. São Paulo 2012. Disponível em: < https://sapientia.pucsp.br/bitstream/handle/18311/1/Atta\%20Amichia\%20Achille. pdf>. Acesso em: 01 Mai. 2019.
\end{abstract}

AGUIAR, Jorge Roberto A. A. José Comblin e os sinais de Deus na profecia. Paralellus, Recife, v. 4, n. 7, p. 7-19, jan./jun. 2013. Disponível em: < http://www.unicap.br/ojs/index.php/paralellus/article/view/237/pdf > . Acesso em: 17 Mai. 2019.

AGUIAR, Jorge Roberto de Araújo. José Comblin: um intelectual orgânico em tempo de neoliberalismo. Paralellus, Recife, v. 6, n. 11, Especial José Comblin, p. $19-28, \quad 2015.2$ Disponível em: < http://www.unicap.br/ojs/index.php/paralellus/article/view/530/414>. Acesso em: 11 Jun. 2019.

ALEIXO, Vitor Corrêa. "Deus Faz, o Templo dos Anjos Mostra": perfil eclesial e adesão religiosa na Igreja do Evangelho Quadrangular em Belo Horizonte. Dissertação de Mestrado. UFMG. Belo Horizonte, 2014. Disponível em: < http://www.bibliotecadigital.ufmg.br/dspace/bitstream/handle/1843/BUOS9JLFQQ/vitor_aleixo__ppgs_ufmg_dissertacao_2014.pdf?sequence=1 >. Acesso em: 04 Ago. 2018.

AMADO, Joel Portella. Leigos na linha de frente? Uma reflexão a respeito do laicato no atual momento evangelizador. ATeo, Rio de Janeiro, v. 20, n. 53, p. 387-416, mai./ago.2016. Disponível em: < https://www.maxwell.vrac.pucrio.br/27085/27085.PDF>. Acesso em: 16 Set. 2019.

AMADO, Joel Portella. Mudança de época e conversão pastoral: Uma leitura das conclusões de Aparecida. Atualidade Teológica ano XII $\mathrm{n}^{\mathbf{0}} 30$, setembro/dezembro 2008. Disponível em: < https://www.maxwell.vrac.pucrio.br/18418/18418.PDF>. Acesso em: 16 Set. 2019.

AMADO, Joel Portella. O Documento de Aparecida e sua proposta para toda a Igreja. ATeo, Rio de Janeiro, v. 22, n. 58, p. 65-90, jan./abr.2018. Disponível em: < https://www.maxwell.vrac.puc-rio.br/32793/32793.PDF>. Acesso em: 16 Set. 2019.

AMARAL, Miguel De Salis. O Espírito Santo e a Igreja: respostas de Congar e do Concílio Vaticano II à questão "carisma e instituição". Teocomunicação, Porto Alegre, v. 41, n. 2, p. 200-220, jul./dez. 2011. Disponível em: < https://core.ac.uk/download/pdf/25529635.pdf>. Acesso em: 01 Mai. 2019. 
ANDRADE, Paulo Fernando Carneiro de. Sinais dos tempos: Igreja e seitas no Brasil. SDT.

ARAGÃO, Gilbraz de Souza. A sombra do Padre Cícero... Paralellus, Recife, v. 5, n. 10, p. 343-360, jul./dez. 2014. Disponível em: < www.unicap.br/ojs/index.php/paralellus/article/download/490/pdf490 >. Acesso em: 20 Ago. 2019.

BANDINI, Claudirene Aparecida de Paula. Religião e Política a Participação Política dos Pentecostais nas Eleições de 2002. Dissertação de Mestrado. UFSCAR. São Carlos, 2003. Disponível em: < https://repositorio.ufscar.br/bitstream/handle/ufscar/1457/236.pdf?sequence=1\&is Allowed=y >. Acesso em: 04 Ago. 2018.

BANDINI, Claudirene. Ministério Feminino na Igreja do Evangelho Quadrangular: autonomia além do espaço religioso Notas de uma pesquisa. Actas dos ateliers do $\mathrm{V}^{\mathrm{o}}$ Congresso Português de Sociologia Sociedades Contemporâneas: Reflexividade e Acção Atelier: Género. p.42-46, 2004. Disponível em: < https://aps.pt/wpcontent/uploads/2017/08/DPR4628d44b30f2c_1.pdf >. Acesso em: 04 Ago. 2018.

BARRO, Jorge Henrique. De cidade em cidade. Londrina: Descoberta, 2006.

BARROS, Marcelo. O Padre Comblin e a sua Teologia política. Paralellus, Recife, v. 6, n. 11, Especial José Comblin, p. 67-74, 2015. Disponível em: < http://www.unicap.br/ojs/index.php/paralellus/article/viewFile/535/419 >. Acesso em: 04 Jun. 2018.

BARROS, Onésimo de. Catecismo Quadrangular. São Paulo: Quadrangular, 2005.

BAYLÃO, Alexandre. A Pneumatologia no Pensamento de Yves Congar. Dissertação de Mestrado: PUC-SP. São Paulo, 2016. Disponível em: < https://tede.pucsp.br/bitstream/handle/18911/2/Alexandre\%20Bayl\%C3\%A3o.pdf >. Acesso em: 01 Mai. 2019.

BELLOTTI, Karina Kosicki. Delas é o Reino dos Céus: mídia evangélica infantil na cultura pós-moderna do Brasil (anos 1950 a 2000). Tese de Doutorado. Campinas, $\quad$ SP, 2007. Disponível em: < http://repositorio.unicamp.br/handle/REPOSIP/280290 >. Acesso em: 04 Ago. 2018.

BEZERRA, Cícero Manoel. Missão Integral da Igreja. Curitiba: SGEC; Igreja do Evangelho Quadrangular. 2010.

BEZERRA, Cícero. Teologia Pastoral Urbana. ITQ Instituto Teológico Quadrangular. Barra Funda - SP: SGEC, 2018.

BITUN, Ricardo. A "remasterização" do movimento pentecostal Igreja Mundial do Poder de Deus. Ciberteologia - Revista de Teologia \& Cultura - Ano III, n. 23. p.19-31. Maio/Junho 2009. Disponível em: < 
http://ciberteologia.paulinas.org.br/ciberteologia/wpcontent/uploads/2009/06/02remasterizacao.pdf >. Acesso em: 04 Ago. 2018.

BOSCH, David J. Missão transformadora: mudanças de paradigmas na teologia da missão. São Leopoldo, RS: EST, Sinodal, 2002.

BRASIL, Jefferson Grijo. Ele se entregou... Eu também me entregarei. Vitória, ES: Foco Editora do Brasil. 2009.

BRASIL, Jefferson Grijo. Missão e Urbanização no Século 21: o desafio missionário na cidade. São Paulo: Fonte Editorial. 2016.

BRIGHENTI, Agenor (org). Pastoral Urbana: categorias de análise e interpelações Pastorais. Brasília: Edições CNBB. 2010.

BRITO, José Artur Tavares de. "O que escutei do Padre Comblin...”. Paralellus - Recife, v. 4, n. 7, p. 33-41, jan./jun. 2013 Disponível em: < http://www.unicap.br/ojs/index.php/paralellus/article/view/248/236>. Acesso em: 11 Jun. 2019.

C. RENÉ, Padilla. O que é missão integral? Viçosa, MG: Ultimato, 2009.

CABRAL, Newton Darwin de Andrade; MARQUES, Luiz Carlos Luz. Um Tufão Chamado José Comblin. Paralellus, Recife, v. 9, n. 22, set./dez. 2018, p. 593-596. Disponível em: < https://www.teologianordeste.net/images/pdf/1356-4689-1PB.pdf>. Acesso em: 11 Jun. 2019.

CAMPOS, Leonildo Silveira. As origens norte-americanas do pentecostalismo brasileiro: observações sobre uma relação ainda pouco avaliada. REVISTA USP, São Paulo, n.67, p. 100-115, setembro/novembro 2005. Disponível em: < https://www.revistas.usp.br/revusp/article/view/13458/15276>. Acesso em: 25 Ago. 2019.

CAMPOS, Leonildo Silveira. Pentecostalismo e Protestantismo "Histórico" no Brasil: um século de conflitos, assimilação e mudanças. Horizonte, Belo Horizonte, v. 9, n. 22, p.504-533, jul./set. 2011. Disponível em: < http://periodicos.pucminas.br/index.php/horizonte/article/view/P.2175-

5841.2011v9n22p504/2909 >. Acesso em: 04 Ago. 2018.

CANOVA, Hermínio. José Comblin e a Igreja dos pobres. Paralellus, Recife, v. 4, n. 7, p. 21-32, jan./jun. 2013. Disponível em: < http://www.unicap.br/ojs/index.php/paralellus/article/view/238/pdf >. Acesso em: 08 Ago. 2018.

CAPPELLETTI, Paulo. Conceito de Conversão no Pensamento de José Comblin. Paralellus, Recife, v. 9, n. 22, set./dez. 2018, p. 635-651. Disponível em: < http://www.unicap.br/ojs/index.php/paralellus/article/view/1286/pdf > . Acesso em: 11 Jun. 2019.

CHARLES. Carlos Roberto de Oliveira. Comunidade segundo o Espírito: fraternidade e libertação. Uma aproximação pneumatológica entre Francisco de Assis e José Comblin. Tese de Doutorado. PUC-RIO. 2015. Disponível em: < https://www.maxwell.lambda.ele.puc-rio.br/25726/25726.PDF>. Acesso em: 08 Ago. 2018. 
CNBB, Cristãos leigos e leigas na sociedade. Brasília: Edições CNBB. (Doc. 105). Disponível em: $<$ http://www.diocesecachoeiro.org.br/arquivos/downloads/documento105cnbb.pdf>. Acesso em: 15 Jul. 2020.

COMBLIN, José. A Virada da Teologia Cristã. Mandrágora, v.20. n. 20, 2014, p. 85-100. Disponível em: < https://www.metodista.br/revistas/revistasims/index.php/MA/article/view/5174/4337>. Acesso em: 08 Ago. 2018.

COMBLIN, José. A maior esperança. Petrópolis: Vozes, 1974.

COMBLIN, José. As Grandes Incertezas na Igreja Atual. REB-Revista Eclesiástica Brasileira. v. 67, n. 265 (2007). Disponível em: < http://revistaeclesiasticabrasileira.itf.edu.br/reb/article/view/1539/1379>. Acesso em: 05 Jun. 2018.

COMBLIN, José. As estranhas acusações de Clodovis Boff. Revista Eclesiástica Brasileira. v. 69, n. 273 (2009). Disponível em: < http://revistaeclesiasticabrasileira.itf.edu.br/reb/article/view/1378/1230>. Acesso em: 06 Jun. 2019.

COMBLIN, José. Breve curso de teologia: a sabedoria crista Tomo IV. São Paulo: Paulinas, 1983.

COMBLIN, José. Breve curso de teologia: o Espírito Santo e sua missão. Tomo II. São Paulo: Ed. Paulinas, 1984.

COMBLIN, José. Evangelizar. Petrópolis: Vozes, 1980

COMBLIN, José. O Espírito Santo e a libertação. Petrópolis: Vozes, 1987.

COMBLIN, José. O Espírito Santo no Mundo. São Paulo: Paulus, 2009.

COMBLIN, José. O papel histórico de Aparecida. Revista Eclesiástica Brasileira. v. 67, n. 268 (2007). Disponível em: < http://revistaeclesiasticabrasileira.itf.edu.br/reb/article/view/1483/1325>. Acesso em: 06 Jun. 2019.

COMBLIN, José. O papel histórico de Aparecida. Revista Eclesiástica Brasileira. v. $67, \quad$ n. 268 (2007). Disponível em: < http://revistaeclesiasticabrasileira.itf.edu.br/reb/article/view/1483/1325>. Acesso em: 06 Jun. 2019.

COMBLIN, José. Olhando para o horizonte. Revista Eclesiástica Brasileira. v. 65, n. 260 (2005) Disponível em: < http://revistaeclesiasticabrasileira.itf.edu.br/reb/article/view/1627/1464>. Acesso em: 30 Set. 2019.

COMBLIN, José. Sinais dos Novos Tempo - 40 Anos do Vaticano II. Revista Eclesiástica Brasileira. v. 66, n. 263 (2006) Disponível em: < http://reb.itf.edu.br/reb/article/view/1567/1407>. Acesso em: 30 Set. 2019.

COMBLIN, José. Tempo da Ação. Petrópolis: Vozes, 1982. 
COMBLIN, José. Teologia da cidade. São Paulo: Edições Paulinas, 1991.

COMBLIN, José. Teologia da missão. Petrópolis: Vozes, 1983.

COMBLIN, José. Viver na cidade: pistas para a pastoral urbana. 2. ed. São Paulo: Paulus, 1996.

COMBLIN, José. Vocação para liberdade. São Paulo: Paulus, 1998.

CONCEIÇÃO. Douglas Rodrigues da. Aspectos Religiosos do Brasil Contemporâneo. Revista Estudos Amazônicos • vol. X, nº 1, pp. 86-117. 2014. Disponível em: http://www.ufpa.br/historia/Estudos\%20Amazonicos/2014/_Douglas_Conceicao. pdf >. Acesso em: 04 Ago. 2018.

CONTI, Lécio. Hermenêutica. ITQ Instituto Teológico Quadrangular. Campos Elíseos - SP: SGEC, 2017.

CONTI, Lécio. Teologia Pastoral. ITQ Instituto Teológico Quadrangular. Curitiba: SGEC, 2011.

COSTA, Rovílio. O pentecostalismo e o culto do divino na atualidade. Teocomunicação, Porto Alegre, v. 37, n. 158, p. 586-600, dez. 2007. Disponível em:

http://revistaseletronicas.pucrs.br/ojs/index.php/teo/article/view/2736/2085>.

Acesso em: 26 Ago. 2019.

COUTO, A. Sílvio. A Igreja peregrina à luz da Trindade na eclesiologia de Yves Congar. Didaskalia. Lisboa. ISSN 0253-1674. 34:2 (2004) 145-194. Disponível em: < https://repositorio.ucp.pt/bitstream/10400.14/20142/1/V03402-145194.pdf>. Acesso em: 01 Mai. 2019.

COX, R. L. Aimee: sua vida sua obra. São Paulo: Editora e Publicadora Quadrangular, 1992.

COX, R. L. O evangelho quadrangular: a visão de Aimee Semple McPherson. São Paulo: Quadrangular, 1991.

CÉSAR, Elben M. Lenz. História da evangelização do Brasil; dos jesuítas aos neopentecostais. Viçosa: Ultimato, 2000.

DAMAZIO, Frank. Cruzando Rios, Tomando Cidades. São Paulo: Editora Quadrangular. 2001.

DIAS, Agemir de Carvalho. A Implantação da Igreja do Evangelho Quadrangular em Curitiba: a evangelização através de tendas. Anais eletrônicos. Congresso de Teologia da PUC/PR. Curitiba, 2009. Disponível em: < www2.pucpr.br/reol/index.php/9CT?dd1=2758\&dd99=pdf>. Acesso em: 04 Ago. 2018.

DIAS, Júlio César Tavares. Comblin, mais uma vez Comblin. Paralellus, Recife, v. 6, n. 11, Especial José Comblin, p. 5-8, 2015. Disponível em: < http://www.unicap.br/ojs/index.php/paralellus/article/view/520/pdf >. Acesso em: 11 Jun. 2019. 
DINIZ, Priscila Ribeiro Jeronimo. A Construção do Conceito de Identidade a Partir da Análise Realizada na Igreja do Evangelho Quadrangular, em Juazeiro do Norte. Ciências da Religião - História e Sociedade v. 11 • n. 2 • p. 115-137. 2013. Disponível em:

http://editorarevistas.mackenzie.br/index.php/cr/article/view/6445/4552 Acesso em: 04 Ago. 2018.

DUFFIELD, P. Guy; CLEAVE, Nathaniel. M. Van. Fundamentos da teologia pentecostal. Vol I. São Paulo: Quadrangular, 1991.

DUFFIELD, P. Guy; CLEAVE, Nathaniel. M. Van. Fundamentos da teologia pentecostal. Vol II. São Paulo: Quadrangular, 1991.

DUGAN, Patrick Bernard. Teologia Sistemática 2. ITQ Instituto Teológico Quadrangular. Curitiba: SGEC, 2012.

DUGAN, Patrick Bernard. Teologia Sistemática 3. ITQ Instituto Teológico Quadrangular. Curitiba: SGEC, 2012.

ESCOBAR, Samuel. Desafios da igreja América Latina: história, estratégia e teologia de missões. Viçosa: Ultimato, 1997.

FAGUNDES, Claudiberto. A "Pneumatologia Cristológica" de Yves Congar e a Cristologia do "Pro-Seguimento com Espírito" de Jon Sobrino uma Proposta para um Mundo Desigual e Plural. Dissertação de Mestrado. PUCRS. Porto Alegre, 2006. Disponível em: < http://tede2.pucrs.br/tede2/bitstream/tede/5864/1/388159.pdf $>$. Acesso em: 01 Mai. 2019.

FERNANDES SANCHES, Regina. Teologia da Missão Integral. São Paulo: Reflexão 2009.

FILHO, Mariano Vicente da Silva. Dossiê: José Comblin. Paralellus - Recife, v. 4, n. 7, p. 3-6, jan./jun. 2013 Disponível em: < http://www.unicap.br/ojs/index.php/paralellus/article/view/251/pdf_1>. Acesso em: 11 Jun. 2019.

FLUCK, Marlon Ronald. Introdução à Missiologia. Curitiba: SGEC; Igreja do Evangelho Quadrangular. 2012.

FRIESEN, Albert. Aconselhamento Pastoral. ITQ Instituto Teológico Quadrangular. Curitiba: SGEC, 2012.

FRANCISCO, PP. Carta encíclica Laudato Si', sobre o cuidado da casa comum. Disponível em:

http://www.vatican.va/content/francesco/pt/encyclicals/documents/papafrancesco_20150524_enciclica-laudato-si.html>. Acesso em: 23 Fev. 2020.

FRANCISCO, PP. Exortação apostólica Evangelii Gaudium, sobre o anúncio do Evangelho no mundo atual. Disponível em: < http://www.vatican.va/content/francesco/pt/apost_exhortations/documents/papa- 
francesco_esortazione-ap_20131124_evangelii-gaudium.html>. Acesso em: 23 Fev. 2020.

FREITAS CARDOSO, Maria Teresa de. A perspectiva ecumênica do Documento de Aparecida. Encontros Teológicos n 57 Ano 25 / número 3 / 2010, p. 67-80. Disponível em: < https://facasc.emnuvens.com.br/ret/article/viewFile/255/243>. Acesso em: 14 Set. 2019.

FREITAS CARDOSO, Maria Teresa de. No respeito e no Amor. Ensinamento de Bento XVI e Francisco sobre a Solicitude Ecumênica. Perspect. Teol., Belo Horizonte, v. 48, n. 2, p. 357-387, Mai./Ago. 2016. Disponível em: < http://www.faje.edu.br/periodicos/index.php/perspectiva/article/view/3553/3639>. Acesso em: 16 Set. 2019.

FREITAS CARDOSO, Maria Teresa de. No sentido da vida. Em diálogo sobre a prevenção do suicídio. Atualidade Teológica Ano XV n 38, maio a agosto/2011. Disponível em: < https://www.maxwell.vrac.puc-rio.br/20327/20327.PDF>. Acesso em: 16 Set. 2019.

FREITAS CARDOSO, Maria Teresa de. Paulo e o Ecumenismo. Atualidade Teológica Ano XIII no 32, maio a agosto / 2009. Disponível em: < https://www.maxwell.vrac.puc-rio.br/18307/18307.PDF>. Acesso em: 16 Set. 2019.

FREITAS CARDOSO, Maria Teresa de. Opções preferenciais: Solicitude e desprendimento como temas de teologia e diálogo na perspectiva de Puebla, fundamentos bíblicos e ênfases do Papa Francisco. ATeo, Rio de Janeiro, v. 23, n. 62, p. 278-303, mai./ago.2019. Disponível em: < https://www.maxwell.vrac.pucrio.br/46110/46110.PDFXXvmi= >. Acesso em: 29 Dez. 2019.

FREITAS CARDOSO, Maria Teresa de; RANGEL, Luiz Fernando Lima. Compromisso para a misericórdia: tema do recente Jubileu para Diálogo e Ação. Encontros Teológicos, Florianópolis, V.34, N.3, Set.-Dez. 2019. Disponível em: $<$ https://facasc.emnuvens.com.br/ret/article/view/1578/1245>. Acesso em: 29 Dez. 2019.

GINI, Sérgio. Conflitos no Campo Protestante: o movimento carismático e o surgimento da Igreja Presbiteriana Renovada (1965-1975). Revista Brasileira de História das Religiões. ANPUH, Ano III, n. 8, p.121-164. Set. 2010. Disponível em: < http://www.dhi.uem.br/gtreligiao/pdf7/08.pdf >. Acesso em: 04 Ago. 2018.

GOÇALVES, Alonso S. Desafios pastorais para uma eclesiologia aberta. Ciberteologia - Revista de Teologia \& Cultura ISSN 1809-2888 - Ano XI, n. 50. 2015.

Disponível em: 
https://www.academia.edu/14350589/Desafios_pastorais_para_uma_eclesiologia_ aberta >. Acesso em: 04 Jun. 2018.

GREEN, Michael. Evangelização na Igreja primitiva. São Paulo: Vida Nova, 2000.

HOFFMANN, Arzemiro. A cidade na missão de Deus: o desafio que a cidade representa a Bíblia e à missão de Deus. Curitiba: Encontro, 2007.

HOORNAERT, Eduardo. O Apocalipse como fonte inspiradora da Cristologia de José Comblin. Paralellus, Recife, v. 6, n. 11, Especial José Comblin, p. 59-66, 2015.

Disponível em:

http://www.unicap.br/ojs/index.php/paralellus/article/view/534/418>. Acesso em: 11 Jun. 2019.

HOORNAERT, Eduardo. O tema da transformação no pensamento de José Comblin. Disponível em: < http://www.unicap.br/ojs/index.php/paralellus/article/view/531/415>. Acesso em: 11 Jun. 2019.

IBGE - Censo Demográfico. Disponível em: < https://sidra.ibge.gov.br/tabela/137\#resultado15273 >. Acesso em: 7 nov. 2020.

IGREJA DO EVANGELHO QUADRANGULAR. Uma Igreja em 60 Anos: igreja do Evangelho Quadrangular em fotos. São Paulo, 2011.

IV Simpósio do GT História das Religiões e Religiosidades - ANPUH/ Regional (Santa Catarina, Paraná e Rio Grande do Sul) "Religiões, Religiosidades E Patrimônio Cultural" 14,15 e 16 de Outubro de 2015. Disponível em: < http://www.academia.edu/22355749/ANAIS_DO_GT_HIST\%C3\%93RIA_DAS_ RELIGI\%C3\%95ES_E_RELIGIOSIDADES-

_ANPUH_REGIONAL_SUL._JOINVILLE_OUTUBRO_DE_2015>. Acesso em: 05 Ago. 2018.

JESUS. Marli de. George Faulkner: série memórias quadrangular. São Paulo: Editora Quadrangular. 1999.

JESUS. Marli de. Onésimo de Barros: série memórias quadrangular. São Paulo: Editora Quadrangular. 2003.

KIRK, J. Andrew. O que é missão? Londrina: Descoberta, 2006.

L. GONZÁlEZ, Justo; ORLAND, Carlos Cardoza. História do movimento missionário. São Paulo: Hagnos, 2008.

LAPA, Marco Antonio Teixeira. Bibliologia. ITQ Instituto Teológico Quadrangular. . Campos Elíseos - SP: SGEC, 2018.

LAPA, Marco Antonio Teixeira. Cidadania. ITQ Instituto Teológico Quadrangular. Curitiba: SGEC, 2010.

LAPA, Marco Antonio Teixeira. Teologia Sistemática 1. ITQ Instituto Teológico Quadrangular. Curitiba: SGEC, 2014. 
LARA, Valter Luiz. Hermenêutica Bíblica para Compreender Paulo em Comblin. Paralellus, Recife, v. 9, n. 22, set./dez. 2018, p. 653-666. Disponível em: < http://www.unicap.br/ojs/index.php/paralellus/article/view/1287/pdf > . Acesso em: 11 Jun. 2019.

LEITE, Maria Celina Correia. Comblin e a espiritualidade do provisório. Paralellus, Recife, v. 6, n. 11, Especial José Comblin, p. 43-50, 2015. Disponível em: < http://www.unicap.br/ojs/index.php/paralellus/article/view/532/pdf>. Acesso em: 11 Jun. 2019.

LIBÂNIO, João Batista. O Espírito Santo e a tradição de Jesus. Paralellus, Recife, v. 4, n. 7, p. 121-125, jan./jun. 2013. Disponível em: < http://www.unicap.br/ojs/index.php/paralellus/article/view/232/pdf >. Acesso em: 03 Jun. 2019.

LIMA, Josadak; BEZERRA, Cícero Manoel. História e Teologia da Igreja do Evangelho Quadrangular. Curitiba: Intersaberes, 2017.

LIMA, José Hélio de. Manoel de Mello: expoente na radiodifusão religiosa ao anonimato na historiografia brasileira. Relegens Thréskeia estudos e pesquisa em religião V. $01-\mathrm{n} .02-\mathrm{p} .32-39.2012$. Disponível em: < https://revistas.ufpr.br/relegens/article/view/31083/19957 >. Acesso em: 05 Ago. 2018.

LONGUINI NETO, LUIZ. O novo rosto da missão: os movimentos ecumênico e evangelical no protestantismo latino-americano. Viçosa: Ultimato, 2002.

LOPES, Marcelo. O legado de uma Pioneira: Aimee Semple McPherson, a cura divina e seus desdobramentos no subcampo religioso pentecostal brasileiro. PLURA, Revista de Estudos de Religião, ISSN 2179-0019, vol. 6, nº 1, p. 74-99, $2015 . \quad$ Disponível em:

http://www.abhr.org.br/plura/ojs/index.php/plura/article/viewFile/795/pdf_115 >. Acesso em: 05 Ago. 2018.

LOPES, Marcelo. Pentecostalismo no Brasil e a Cura Divina: um olhar histórico e Fenomenológico. Sacrilegens, Juiz de Fora, v.11, n.1, p. 89-110, jan-jun/2014. Disponível em: < http://www.ufjf.br/sacrilegens/files/2015/02/11-1-7.pdf >. Acesso em: 05 Ago. 2018.

MACEDO, Emiliano Unzer. Pentecostalismo e religiosidade brasileira. Tese de Doutorado, USP. São Paulo, SP, 2007. Disponível em: < http://www.teses.usp.br/teses/disponiveis/8/8138/tde-23102007-140542/ptbr.php>. Acesso em: 26 Ago. 2019.

MAgalhães, Cicero Edvam. Religiosidade e Teologia Popular à Luz da Eclesiologia de José Comblin. Dissertação de Mestrado. FAJE - Belo Horizonte, 2012. Disponível em: < http://www.faculdadejesuita.edu.br/documentos/0705131mx4ImtR2CnHA.pdf>. Acesso em: 08 Ago. 2018.

MARIANO, Ricardo. Crescimento Pentecostal no Brasil: fatores internos. Revista de Estudos da Religião dezembro / ISSN 1677-1222 / pp. 68-95, 2008. Disponível em: < http://www.pucsp.br/rever/rv4_2008/t_mariano.pdf $>$. Acesso em: 06 Ago. 2018. 
MATOS, Alderi Souza de. O Movimento Pentecostal: reflexões a propósito do seu primeiro centenário. FIDES REFORMATA XI, No 2, p. 23-50, 2006. Disponível em: http://mackenzie.br/fileadmin/Mantenedora/CPAJ/revista/VOLUME_XI_2006_ _2/Alderi.pdf >. Acesso em: 18 Jul. 2018.

MAÇANEIRO, Marcial. Uma aproximação ao diálogo internacional católicopentecostal. Revista de Cultura Teológica 13 Ano XXI No 82 p. 11-31.Jul/Dez. 2013. Disponível em: https://revistas.pucsp.br/index.php/culturateo/article/view/17378/12896 $>$. Acesso em: 05 Ago. 2018.

MENDONÇA, Antonio Gouvêa. O Protestantismo no Brasil e suas Encruzilhadas. REVISTA USP, São Paulo, n.67, p. 48-67, set/nov, 2005. Disponível em: < http://www.revistas.usp.br/revusp/article/view/13455/15273 >. Acesso em: 06 Ago. 2018.

MIKUSZKA, Gelson Luiz. A Reforma Protestante e a ação evangelizadora da Igreja católica. REB, Petrópolis, volume 77, número 305, p. 55-73, Jan./Mar. 2017. Disponível em:

http://revistaeclesiasticabrasileira.itf.edu.br/reb/article/view/113/105>. Acesso em: 20 Ago. 2019.

MIKUSZKA, Gelson Luiz. O Discípulo Missionário na Perspectiva de José Comblin. Implicações para uma paróquia missionária. Tese de Doutorado. FAJE. Belo Horizonte, 2016. Disponível em: $<$ http://www.faculdadejesuita.faje.edu.br/teses-teologia-227/o-discipulomissionario-na-perspectiva-de-jose-comblin-implicacoes-para-uma-paroquiamissionaria-04092017-224410>. Acesso em: 08 Ago. 2018.

MUGGLER, Monica Maria. Padre José Comblin: Uma vida guiada pelo Espírito. São Bernardo do Campo : Nhanduti Editora, 2012. Disponível em: < http://www.nhanduti.com/NH_2013/Padre\%20Jose\%20Comblin/Comblin.B.Miol o.paweb.pdf >. Acesso em: 08 Ago. 2018.

McPHERSON, Aimee Semple. Aimee Semple McPherson. A história de uma vida. São Paulo: Publicadora Quadrangular, 1991.

OLIVEIRA, Anastácio Ferreira de. Igreja dos Pobres e Imagens de Deus em José Comblin: convites à práxis cristã emergentes da Missão Ibiapina no semiárido nordestino. Dissertação de Mestrado em Teologia FAJE - Faculdade Jesuíta de Filosofia e Teologia Belo Horizonte 2013. Disponível em: < https://www.faculdadejesuita.edu.br/documentos/101014-WiAUnlhA9nApy.pdf >. Acesso em: 03 Jun. 2019.

OLIVEIRA, David Mesquiati de. A Dimensão Comunicativa da Ação Missionária e as Culturas. Revista Reflexus v. 3, n. 3 (2009). Disponível em: < http://revista.faculdadeunida.com.br/index.php/reflexus/article/view/110/82>.

Acesso em: 16 Set. 2019.

OLIVEIRA, David Mesquiati de. A pneumatologia de Lutero: uma aproximação. REFLEXUS - Ano XI, n. 17, 2017/1. Disponível em: < 
http://revista.faculdadeunida.com.br/index.php/reflexus/article/view/474/418>. Acesso em: 16 Set. 2019.

OLIVEIRA, David Mesquiati de. Pentecostalidade da Missão Latino-Americana: uma nova reforma na igreja? Revista Reflexus v. 5, n. 6 p. 89-98, (2011). Disponível em: http://revista.faculdadeunida.com.br/index.php/reflexus/article/view/32/88>. Acesso em: 14 Set. 2019.

OLIVEIRA, David, Mesquiati de. Missão, cultura e transformação: desafios para a prática missionária comunicativa. São Leopoldo: Sinodal; Quito: CLAI, 2011.

OLIVEIRA, Myckon Alves de. Pentecostais: história, contexto e caminhos para teologizar. INTEGRATIO, v. 1, n. 2, jul. - dez. p. 67-77. 2016. Disponível em: < http://fnbonline.com.br/revista/integratio/index.php/INT/article/view/20/23 >. Acesso em: 06 Ago. 2018.

OLIVEIRA, Myckon de. Igreja do Evangelho Quadrangular: história, teologia e contribuições ao pentecostalismo. Campinas: Editora Saber Criativo, 2018.

OTTAVIANI, Edelcio Serafim; FREZZATO, Anderson. Teologia a Marteladas. Paralellus, Recife, v. 9, n. 22, set./dez. 2018, p. 597-619. Disponível em: < http://www.unicap.br/ojs/index.php/paralellus/article/view/1281/pdf > . Acesso em: 11 Jun. 2019.

PASSOS, Mauro; ROCHA, Daniel. Em tempos de pós-pentecostalismo: repensando a contribuição de Paulo Siepierski para o estudo do pentecostalismo brasileiro. Angelus Novus, (3), 261 - 290. Disponível em: < http://www.revistas.usp.br/ran/article/view/98999>. Acesso em: 26 Ago. 2019.

PAULO VI, PP. Exortação Apostólica Evangelli Nuntiandi do Papa Paulo VI ao Episcopado, ao Clero aos Fiéis de Toda a Igreja Sobre a Evangelização no Mundo Contemporâneo. Disponível em: < http://www.vatican.va/content/paulvi/pt/apost_exhortations/documents/hf_p-vi_exh_19751208_evangeliinuntiandi.html>. Acesso em: 23 Fev. 2020.

PAULA, Vitor Aparecido Santos de. Religião e Política no Vale do Paranapanema: a Igreja do Evangelho Quadrangular em Assis-SP (1996-2008). Dissertação de Mestrado. ASSIS, 2012. Disponível em: < https://repositorio.unesp.br/bitstream/handle/11449/93391/paula_vas_me_assis.pd f?sequence=1\&isAllowed=y >. Acesso em: 06 Ago. 2018 .

PAULY, Evaldo L. Modernidade e Pastoral Urbana: Um Depoimento Teórico e Pessoal. Estudo Teológicos ISSN 2237-6461 v. 34, n. 1 (1994). Disponível em: <http://periodicos.est.edu.br/index.php/estudos_teologicos/article/view/874/836 Acesso em: 11 Jun. 2019.

PEDDE, Valdir. A inserção dos pentecostais na política: uma ameaça à democracia? História Unisinos. Vol. 13 No 3 - p.285-296. Set /dez, 2009. 
Disponível em: < http://revistas.unisinos.br/index.php/historia/article/view/5099 >. Acesso em: 06 Ago. 2018.

PEREIRA, Paulo César. Transitando entre diferentes esferas da vida: uma abordagem sobre a multifacetada caminhada de José Comblin II. Paralellus, Recife, v. 4, n. 7, p. 59-78, jan./jun. 2013 Disponível em: < http://www.unicap.br/ojs/index.php/paralellus/article/view/249/pdf >. Acesso em: 11 Jun. 2019.

POMMRENING, Claiton Ivan. Fragmentos de uma Teologia do Espírito para o Pentecostalismo Clássico. Congresso Internacional da Faculdades. EST, 2., 2014, São Leopoldo. Disponível em: < anais.est.edu.br/index.php/congresso/article/download/249/214>. Acesso em: 11 Jun. 2019.

QUADRANGULAR. Declaração de fé da Igreja do Evangelho Quadrangular: edição especial comentada. São Paulo: Quadrangular, 2018.

QUADRANGULAR. Estatuto e regimento interno da Igreja do Evangelho Quadrangular: São Paulo: Quadrangular, 2011.

ROSA, André Luís da. Pentecostalismo e Ecumenismo: algumas observações. REFLEXUS - Ano XI, n. 18, 2017/2. Disponível em: < http://revista.faculdadeunida.com.br/index.php/reflexus/article/view/518/462>. Acesso em: 16 Set. 2019.

ROSA, Júlio O. O evangelho quadrangular no Brasil. Belo Horizonte: Betânia, 1977.

SAMPAIO, Regina Câmara; SOBREIRO, Adriana Câmara. Vida de Cristo e Espiritualidade. ITQ Instituto Teológico Quadrangular. Curitiba: SGEC, 2010.

SANTANA, Neusa Tolentino. Mover do Espírito Santo na Virada do Milênio - Pentecostais e Carismáticos em Goiânia. Dissertação de Mestrado. Universidade Católica de Goiás. Goiânia, 2001. Disponível em: < http://tede2.pucgoias.edu.br:8080/bitstream/tede/999/1/Neusa\%20Tolentino\%20S antana.pdf >. Acesso em: 07 Ago. 2018.

SANTOS, Sinésio Carlos dos. Vivência Cristã. ITQ Instituto Teológico Quadrangular. Barra Funda - SP: SGEC, 2018.

SANTOS, Valdevino Rodrigues dos. Tempos de exaltação: um estudo sobre a música e a glossolalia na Igreja do Evangelho Quadrangular. São Paulo: Annablume, 2002.

SCOTTI, Ignez T. R. Quadrangular: há 65 anos sendo a luz que resplandece neste mundo! São Paulo: Quadrangular, 2016.

SCOTTI, Ignez Terezinha. Evangelho quadrangular: teologia confessional. Curitiba: SGEC, 2010.

SHEDD, Russell P. Evangelização: fundamentos bíblicos. São Paulo: Shedd Publicações, 2006. 
SIEPIERSKI, Paulo D. Pós-Pentecostalismo e Política no Brasil. Estudos Teológicos, v. 37, n. 1, p. 47-61, 1997. Disponível em: < http://periodicos.est.edu.br/index.php/estudos_teologicos/article/download/776/71 1 >. Acesso em: 07 Ago. 2018.

SILVA, Mariane de Almeida. Dom Paulo de Tarso Campos e a Vinda do Padre José Comblin ao Brasil. Paralellus, Recife, v. 9, n. 22, set./dez. 2018, p. 621-633. Disponível em: http://www.unicap.br/ojs/index.php/paralellus/article/view/1282/pdf_1>. Acesso em: 11 Jun. 2019.

SOARES, Sebastião Armando Gameleira. José Comblin, homem do Espírito. Paralellus, Recife, v. 6, n. 11, Especial José Comblin, p. 51-58, 2015. Disponível em: < Disponível em: < http://www.unicap.br/ojs/index.php/paralellus/article/view/533/417>. Acesso em: 11 Jun. 2019.

SOUSA, Alzirinha Rocha de. A prática de Comblin: a Igreja do chão da realidade. Horizonte, Belo Horizonte, v. 15, n. 45, p. 239-255, jan./mar. 2017 - ISSN 21755841. Disponível em: < https://dialnet.unirioja.es/descarga/articulo/5908814.pdf >. Acesso em: 08 Ago. 2018.

SOUSA, Alzirinha Rocha de. Formação de "missionários profetas": a centralidade das narrativas no método de formação das EFM do Nordeste do Brasil. Teoliterária V. 8 - N. 15 - 2018. DOI - 10.19143/2236-9937.2018v8n15p65-91 ISSN 2236-9937. Disponível em: < https://revistas.pucsp.br/index.php/teoliteraria/article/view/37096/26001>. Acesso em: 08 Ago. 2018.

SOUZA, Alzirinha Rocha de. A teologia da cidade segundo José Comblin. REB, Petrópolis, Ano 74, Número 295, p. 564-598, Jul./Set. 2014. Disponível em: < http://reb.itf.edu.br/reb/article/view/481/415 >. Acesso em: 20 Ago. 2019.

SOUZA, Alzirinha Rocha de. Análise da ação humana a partir do pensamento de José Comblin. Paralellus, Recife, v. 5, n. 10, p. 9-18, jul./dez. 2014. Disponível em: <http://www.unicap.br/ojs/index.php/paralellus/article/view/529/pdf >. Acesso em: 30 Set. 2019.

SOUZA, Alzirinha; ARAGÃO, Gilbraz. Fazer a Igreja Católica se Mover: a pertinência do Evangelho no Mundo Contemporâneo. Paralellus, Recife, v. 9, n. 22, set./dez. 2018, p. 667-697 Disponível em: < http://www.unicap.br/ojs/index.php/paralellus/article/view/1324/pdf >. Acesso em: 11 Jun. 2019.

SOUZA. Alzirinha Rocha de. O Vaticano II no cotidiano do Nordeste brasileiro: a contribuição de D. Hélder Câmara e José Comblin à renovação da Igreja de Recife (1965-1972). Paralellus, Recife, v. 4, n. 8, p. 275-289, jul./dez. 2013. Disponível em: < http://www.unicap.br/ojs/index.php/paralellus/article/view/260/pdf>. Acesso em: 03 Jun. 2019.

SUESS, Paulo. Missionário migrante - teólogo militante José Comblin: O retorno do enviado do Pai. Paralellus, Recife, v. 6, n. 11, Especial José Comblin, p. 7580 , 2015. Disponível em: 
http://www.unicap.br/ojs/index.php/paralellus/article/view/536/420>. Acesso em: 11 Jun. 2019.

THOMÉ, Adriana. A Arte de Educação Popular e o Processo de Libertação no Pensamento de Comblin. Dissertação de Mestrado. UMESP. São Bernardo do Campo. 2012. Disponível em: < http://tede.metodista.br/jspui/bitstream/tede/260/1/Adriana\%20Thome.pdf >. Acesso em: 08 Ago. 2018.

TRACCO, Celso Luiz. As CEBs em Aparecida. A retomada de um modelo de evangelização? Revista de Cultura Teológica, Ano XXII No 84 Jul/Dez 2014. Disponível em: < http://revistas.pucsp.br/culturateo/article/view/21639/15890 >. Acesso em: 04 Jun. 2018.

TURECK, Andre. Cuidando da Comunicação em Família: uma reflexão sobre a interação entre cônjuges na primeira igreja do Evangelho Quadrangular em Curitiba. Dissertação de Mestrado. Escola Superior de Teologia. São Leopoldo, 2009. Disponível em: < http://dspace.est.edu.br:8080/xmlui/bitstream/handle/BRSIFE/104/tureck_a_tmp98.pdf?sequence=1\&isAllowed=y >. Acesso em: 07 Ago. 2018.

VASILOSKI, Gerlene Vidal; SANTOS, Sandra Morais Ribeiro dos. Escatologia Bíblica. ITQ Instituto Teológico Quadrangular. Curitiba: SGEC, 2012.

WALKER, Wiliston. História da Igreja Cristã. São Paulo: ASTE, 2006.

WRIGHT, Chistopher J. H. A missão do povo de Deus: uma teologia bíblica da missão da igreja. São Paulo: Vida Nova: Instituto Betel Brasileiro, 2012.

WULFHORST, Ingo. O Pentecostalismo no Brasil. Estudos Teológicos, 35 (1) p.7-20, $1995 . \quad$ Disponível em: http://ism.edu.br/periodicos/index.php/estudos_teologicos/article/download/838/7 67 >. Acesso em: 07 Ago. 2018.

ZWETSCH, Roberto Ervino. Missão Como Com-Paixão por uma Teologia da Missão em Perspectiva Latino-Americana. Tese de Doutorado. São Leopoldo, 2007. Disponível em: < http://dspace.est.edu.br:8080/xmlui/bitstream/handle/BRSIFE/465/zwetsch_re_td66.pdf?sequence=1\&isAllowed=y >. Acesso em: 07 Ago. 2018. 